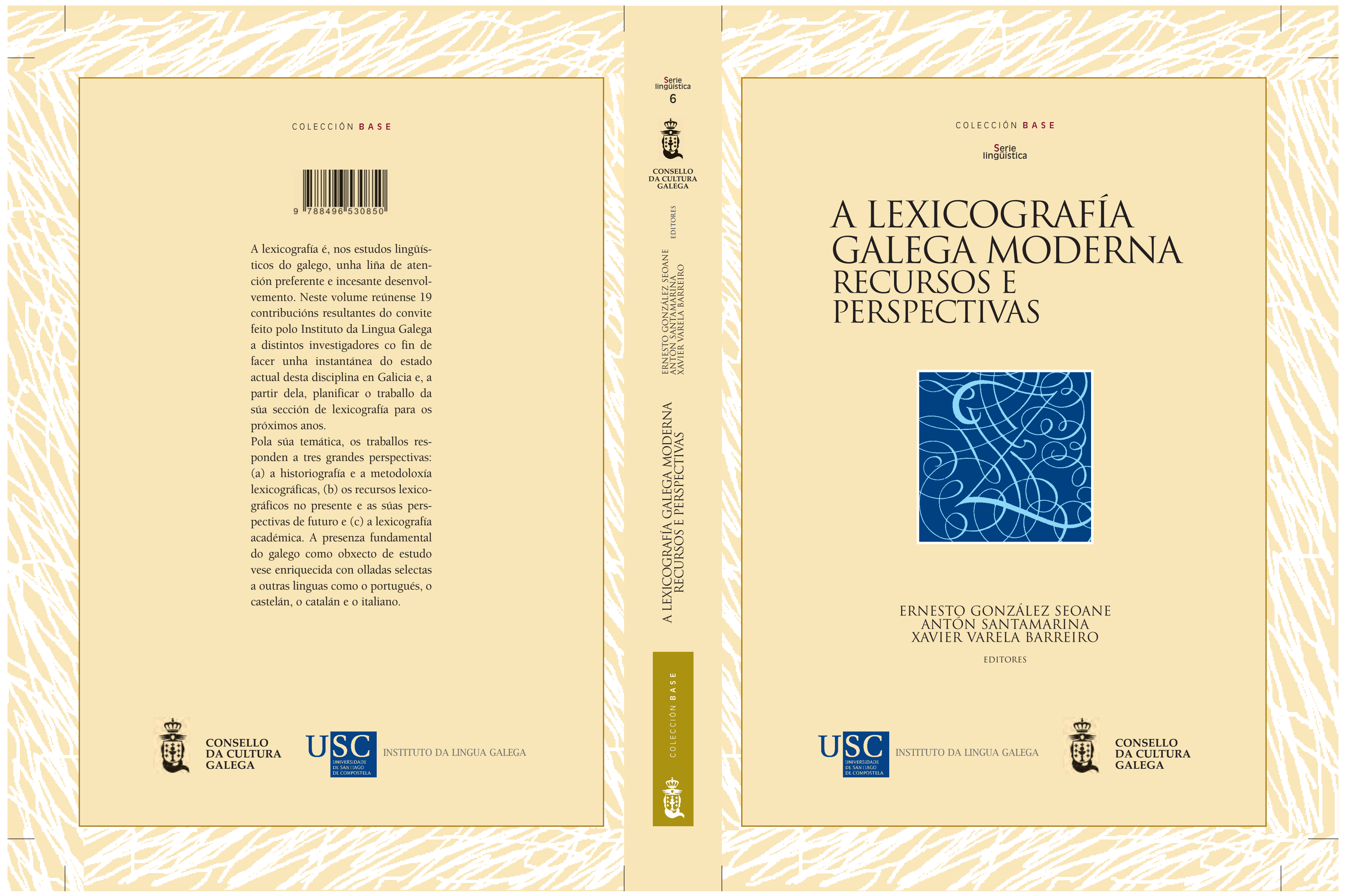


A LEXICOGRAFÍA GALEGA MODERNA

RECURSOS E PERSPECTIVAS 
A lexicografia galega moderna: recursos e perspectivas /

Ernesto González Seoane, Antón Santamarina, Xavier Varela Barreiro

(editores).- Santiago de Compostela: Consello da Cultura Galega: Instituto da Lingua Galega, 2008.- 425 p. ; 22 cm.

(Colección Base. Serie Lingüística; 6)

D.L. VG 1648-2008.- ISBN: 978-84-96530-85-0

1. Lingua Galega-Lexicografía. I. González Seoane, Ernesto. II. Santamarina, Antón. III. Varela Barreiro, Xavier. IV. Consello da Cultura Galega, ed. V. Instituto da Lingua Galega, ed.

(c) CONSELLO DA CULTURA GALEGA

Pazo de Raxoi, $2^{\circ}$ andar

Praza do Obradoiro, s/n

15705 Santiago de Compostela

Tel. 981957202 Fax 981957205

correo@consellodacultura.org

Proxecto gráfico

Agalip

Deseño de cubertas

Manuel Janeiro

ISBN 978-84-96530-85-0

Depósito legal VG-1648-2008

Imprime: C/A gráfica (c) INSTITUTO DA LINGUA GALEGA

Praza da Universidade, 4

15782 Santiago de Compostela

Tel. 981563100 Fax 981572770

ilgsec@usc.es 


\title{
A LEXICOGRAFÍA GALEGA MODERNA RECURSOS E PERSPECTIVAS
}

\author{
Ernesto González Seoane \\ Antón Santamarina \\ Xavier Varela Barreiro (eds.)
}





\section{ÍNDICE}

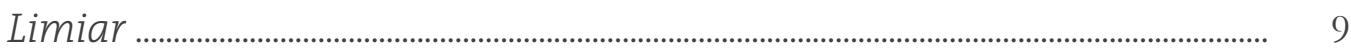

\section{HISTORIOGRAFÍA E METODOLOXÍA}

Manuel Alvar Ezquerra

Problemas teóricos y prácticos en la redacción del NTLE

Dieter Messner

Os dicionários como fonte lexicográfica

Xosé-Álvaro Porto Dapena

A información gramatical nos dicionarios

Telmo Verdelho

Lexicografia portuguesa. Perspectiva crítica

II. RECURSOS E PROXECTOS

Maria Xesús Bugarín López

O galego fundamental: dicionario de frecuencias

Eva $M^{a}$ Domínguez Noya

O Corpus de Referencia do Galego Actual (CORGA): presente e futuro 
Francisco Fernández Rei / Carme Hermida Gulias

O Arquivo do Galego Oral e o seu aproveitamento lexicográfico 153

Xesús Ferro Ruibal

A fraseoloxía como fonte lexicográfica

Ana Belén Crespo Bastos / Xosé María Gómez Clemente

Novos criterios para a elaboración dun dicionario de neoloxismos

Xavier Gómez Guinovart

A investigación en lexicografía e terminoloxía no Corpus

Lingüístico da Universidade de Vigo (CLUVI) e no Corpus Técnico

do Galego (CTG)

Paulo Martínez Lema

Un corpus para o estudo do galego medieval: O TMILG (Tesouro

Medieval Informatizado da Lingua Galega)

Xusto Rodríguez Río

bUSCatermos: banco de datos terminolóxico multilingüe

Maria Francisca Xavier

O Dicionário do Português Medieval. Fontes, concepção e

metodologia

\section{A LEXICOGRAFÍA ACADÉMICA}

Manuel González González

O novo dicionario da Real Academia Galega 257

Joaquim Rafel i Fontanals

La actividad lexicográfica del Institut d’Estudis Catalans.

Pasado, presente y futuro.

João Malaca Casteleiro

Actividades lexicográficas da Academia das Ciências de Lisboa 
Guillermo Rojo

Pasado, presente e futuro nos traballos lexicográficos da Real

Academia Española

Pär Larson

O Tesoro della Lingua Italiana delle Origini: o futuro do italiano antigo?

Antón Santamarina

Os dicionarios históricos. Trazos dun dicionario histórico

galego e consideracións sobre a súa viabilidade 343

Bibliografía citada 393 



\section{LIMIAR}

Recentemente o Instituto da Lingua Galega quixo facer unha instantánea do estado actual da lexicografía galega co fin de, a partir dela, propiciar unha reflexión e planificar o traballo da súa sección de lexicografía para os próximos anos. Con tal motivo convidou a participar a distintos especialistas, da casa e de fóra, e encargoulles a realización de traballos orixinais nos que desen conta dalgún aspecto da súa propia investigación que fose relevante neste eido e, deste xeito, contribuísen a fixar as áreas temáticas preferentes e delimitar mellor, dentro delas, as vías polas que haxa que encamiñar no futuro os esforzos lexicográficos.

Neste volume reúnense 19 contribucións, mais poderían figurar algunhas máis que, estando previstas no chamamento inicial, non chegaron a termo. A uns e a outros contribuíntes exprésalles o Instituto da Lingua Galega o seu agradecemento pola colaboración prestada.

A idea inicial foi abordar de forma proporcional tres grandes perspectivas: (a) a historiografía e a metodoloxía lexicográficas, (b) os recursos lexicográficos no presente e as súas perspectivas de futuro e (c) a lexicografía académica. Ao cabo as seccións non resultaron exactamente proporcionais mais nas tres comparecen traballos representativos e de innegable valor.

Abre a sección de metodoloxía o traballo de Manuel Alvar Ezquerra (Universidad Complutense de Madrid). Nel dá noticia pormenorizada dos aspectos máis cotiáns e íntimos do proceso de construción do monumental-11 volumes e 10.522 páxinas-e recentemente aparecido (2007) Nuevo tesoro lexicográfico del español (s. XIV-1726) (NTLE), feito en colaboración con Lidio Nieto Jiménez. Este capítulo é un bo exemplo de "caderno de 
bitácora" da fabricación dun dicionario de dicionarios. Nel non faltan as alusións aos problemas do lexicógrafo cunha informática balbuciente (finais dos 80 e comezos dos 90), ao compromiso de seleccionar os materiais nunha longa lista de fontes, ao intenso esforzo de lematización de textos dunha elevadísima variación gráfica e, tamén, á continxencia de ter que enfrontar unha reforma ortográfica na metade do camiño (RAE 2000). No segundo capitulo, Dieter Messner (Paris-Lodron-Universität Salzburg) explora no seu tamén monumental e aínda en curso de publicación Dicionário dos dicionários portugueses (1994- ) (20 volumes e 12.000 páxinas) o aproveitamento, non sempre -ou case nunca- recoñecido, da información lexicográfica dos dicionarios na produción dicionarística portuguesa ata 1858. Nela sobresaen como fontes lexicográficas, en distintas épocas, os propios dicionarios portugueses (nun lugar destacado o Bluteau (17121728), os españois (moi especialmente o Tesoro de la lengua castellana o española de Covarrubias (1611) e o Diccionario de Autoridades da RAE (17261739) e, en menor medida, os franceses (a Encyclopédie (1752). D. Messner é especialmente crítico co abuso deste procedemento no Diccionario da Lingoa Portugueza publicado pela Academia Real das Sciencias de Lisboa (1793), que considera un exemplo reprobable dos "dicionários que copiavam por inteiro o que está em outros dicionários" (neste caso o Diccionario de Autoridades). Xosé-Álvaro Porto Dapena (Universidade da Coruña) ofrece no terceiro capítulo o seu punto de vista sobre o papel e o lugar da información gramatical nos dicionarios xerais e comúns. Desde a súa longa experiencia como lexicógrafo e gramático e moi especialmente desde a praxe actual da elaboración, como director, do Diccionario "Coruña" de la lengua española actual (DCLEA), de futura aparición, revisa os aspectos teóricos da distinción entre Léxico e Gramática e o espiñento cometido de establecer na información gramatical os límites entre o que é obxecto da gramática e o que é obxecto do dicionario. Pasa revista a practicamente todos os valores gramaticais susceptibles de figuraren nun dicionario, tanto na macroestrutura como na microestrutura. Por último, Telmo Verdelho (Universidade de Aveiro) fai no seu capítulo unha historia crítica da lexicografía portuguesa ata 1900, desprovista cronicamente do amparo das institucións políticas nacionais. Entre as súas características menciona unha aparición tardía -comparativamente con outras: italiana, española, francesa- e a orixinalidade de iniciarse, en dicionarios bilingües, tomando como punto de partida o vernáculo e non o latín. Destaca nela, como fíos condutores sucesivos, a liña de obras nacidas como resposta ao encontro interlingüístico con Asia e América (o Brasil) -na que foi verdadeira pioneira e na que tiveron un papel destacadísimo os Xesuitas (ata 
1750)-, e como resposta ao confronto moderno do portugués coas linguas de Europa. A nivel de autores salienta a figura do Rafael Bluteau e o seu monumental Vocabulario Portuguez... (1712-1728).

O segundo bloque de contribucións reúne traballos dedicados á presentación de proxectos e recursos de aproveitamento lexicográfico desenvolvidos no ámbito do galego, co engadido dalgún do portugués. Un deles, o capítulo 5, de María Xesús Bugarín (ILG), ten carácter individual e preséntase como investigación concluída. Nel explica a autora a elaboración da súa obra O galego fundamental. Dicionario de frecuencias (2007), referida ao galego moderno. Detense na indicación das utilidades varias dunha obra deste tipo -é, neste dominio, a primeira e única publicación sobre o galego- e, sobre todo, relata con abundancia de exemplos ilustrativos o proceso de elaboración (construción do corpus, tratamento dos materiais e obtención de resultados).

Nos outros capítulos deste segundo bloque dáse noticia de proxectos, recursos e investigacións lexicográficas en curso, realizados colectivamente por equipos de investigación de carácter universitario ou institucional. Coinciden todos eles en presentaren experiencias, propostas e logros na lingüística de corpus ou na fabricación de bases de datos de orientación lexicográfica. No capítulo 6 describe Eva Domínguez o Corpus de Referencia do Galego Actual (CORGA) do Centro “Ramón Piñeiro" para a Investigación en Humanidades. Centra a atención, sobre todo, no etiquetador e lematizador do corpus, do que forman parte o sistema de etiquetas ou tagset, o lexicón, o preprocesador (sen resolución de ambigüidades) e o etiquetador (resolución de ambigüidades). No capítulo 7 expoñen Francisco Fernández Rei e Carme Hermida Gulías (ILG) a estrutura e composición do Arquivo do Galego Oral (AGO) do Instituto da Lingua Galega (seis subarquivos, máis de 2.500 horas de gravacións, voces de 7.000 informantes e 315 concellos de Galicia + 38 da Galicia exterior + mostras dos concellos cacereños do Val de Xálima) e ilustran cun caso práctico o aproveitamento léxico dos seus materiais. No capítulo 8 Xesús Ferro Ruibal, director do proxecto Fraseoloxía Galega do Centro "Ramón Piñeiro", rescata das compilacións paremiolóxicas de Vicente Llópiz (1954a e 1954b) e de Francisco Vázquez Saco (1962) unha manchea de valores semánticos, variantes gramaticais infrecuentes, voces xa pouco frecuentes ou hibernadas e mesmo voces íntegras que non aparecen rexistrados nas obras lexicográficas compiladas no Diccionario de diccionarios de Antón Santamarina (2003b), o que demostra que "a fraseoloxía [...] aínda é unha despensa léxica" e que hai que tela máis presente. No capítulo 9 Ana Belén Crespo Bastos e Xosé María Gómez Clemente (Universidade de Vigo) presentan os novos criterios de identificación de 
neoloxismos empregados nos traballos do Observatorio de Neoloxía da Universidade de Vigo. Inciden, unha vez máis, na necesidade de revisión do concepto de "neoloxismo", na importancia de establecer con coherencia as marcas dos dicionarios de neoloxismos (marcas temporais, marcas de frecuencia absoluta e dispersións temporal e marcas lingüísticas) e na importancia das tecnoloxías informáticas como ferramenta auxiliar (extractores semiautomáticos de neoloxismos...). Xavier Gómez Guinovart, director do Seminario de Lingüística Informática (SLI) da Universidade de Vigo, ocúpase no capítulo 10 dos logros lexicográficos e terminolóxicos obtidos a partir dos córpora da Universidade de Vigo creados polo SLI e o OdN. Explica as características dos córpora Corpus Lingüístico da Universidade de Vigo (CLUVI) e Corpus Técnico do Galego (CTG), e, como produtos propiamente lexicográficos, presenta o Dicionario CLUVI Inglés-Galego e o Banco de Datos Terminolóxico da Universidade de Vigo. Detense nos proxectos que o grupo ten en perspectiva e entre eles destaca a colaboración co Instituto da Lingua Galega en distintas empresas científicas. No seguinte capítulo, o 11, Paulo Martínez Lema (ILG) amosa a nova versión do Tesouro Medieval Informatizado da Lingua Galega (2007), o corpus lingüístico medieval do Instituto da Lingua Galega (USC). Explica a súa estrutura e características (tipoloxía textual, cronoloxía e glotoloxía, microestrutura do corpus) e indica as expectativas que ten abertas como banco de datos doutros proxectos lexicográficos (Dicionario Medieval Galego-Portugués, Dicionario Histórico Galego e Inventario Toponímico da Galicia Medieval). No capítulo 13 Xusto Rodríguez Río (USC) describe o bUSCatermos e mais o Banco de Datos Terminolóxico (BDT), dúas instancias dun mesmo recurso terminolóxico do Servizo de Normalización Lingüistica da Universidade de Santiago de Compostela. Explica moi sucintamente a composición das fontes empregadas (propias e alleas) e o proceso de reelaboración do material recollido (aplicación do enfoque onomasiolóxico, arrequentamento da información das fontes e análise valorativa das propostas alleas). No capítulo 13, Maria Francisca Xavier (Centro de Linguística da Universidade Nova de Lisboa) ofrece, como directora, unha panorámica de dous proxectos de investigación lexicográfica do portugués medieval: o Dicionário do Português Medieval (DPM) e o Corpus Informatizado do Português Medieval (CIPM). En relación co primeiro, presenta as publicacións derivadas, explica o sistema de traballo (preparación dos datos, identificación das unidades léxicas e análise delas) e explicita a estrutura da ficha lexicográfica (vedetta, clasificación das palabras, etimoloxía, acepcións, aboamentos e remisións). En relación co corpus, ofrece a listaxe de obras procesadas. 
O terceiro bloque acolle os seis traballos recibidos de representantes autorizados de Academias e institucións investidas de potestade na fixación do estándar lingüístico das súas respectivas comunidades ou altamente representativas delas. Algúns, seguindo as indicacións dos editores deste volume, preferiron ofrecer unha visión histórica da actividade lexicográfica da institución representada, outros optaron por ocuparse dun aspecto ou obra concreta e outros decidiron conxugar as dúas solucións anteriores. No nome da Real Academia Galega e como Secretario dela, Manuel González presenta no capítulo 14 a actividade dicionarística do Seminario de Lexicografía desta institución -do que é director- nos últimos vinte anos. Despois de pasar unha rápida revista ao Diccionario da lingua galega (ILG/RAG 1990) e ao Diccionario da Real Academia Galega (RAG 1997), expón as características da futura versión da segunda das obras mencionadas, que conterá 50.000 entradas. Detense nas fontes empregadas (obras lexicográficas anteriores, corpus representativo da lingua escrita do galego moderno e corpus representativo da lingua oral actual), na macroestrutura da obra e na súa microestrutura. Joaquim Rafel i Fontanals comparece, no capítulo 15, na representación do Institut d' Estudis Catalans. No plano xeral, ofrece unha visión da historia, das funcións e da estruturación en seccións do Institut. En referencia aos traballos lexicográficos da Sección Filolóxica, dá noticia dos dicionarios de 1995 e 2001 e detense na elaboración do Diccionari del català contemporani (DCC). Preséntao como produto in fieri da realización, en dúas fases, de proxectos previos: o Corpus Textual Informatitzat de la Llengua Catalana (CTILC) e a Base de Dades Lexicogràfica (BDLex). Partindo da información contida nestes dous recursos e contando cunha excelente "estación de traballo lexicográfica", estase a realizar na actualidade este dicionario descritivo, "que tiene por objeto la definición de las unidades léxicas de la lengua desde el punto de vista de su contenido y de su utilización real, sin restricciones basadas en criterios prescriptivos". No capítulo 16, João Malaca Casteleiro (Academia das Ciências de Lisboa) fai unha síntese da historia dos dicionarios da Academia desde o ano 1793, no que aparece o Diccionario da lingoa portugueza, ata a actualidade, cando xa está concluído, aínda que inédito -desde o 2005-, o Novo Dicionário da Língua Portuguesa. Ao seu antecedente, o Dicionário da Língua Portuguesa Contemporânea (2001), dedícalle boa parte do capítulo. Explica o ámbito cronolóxico (séculos XIX e XX), o volume da súa información (70.000 entradas e 170.000 significados e acepcións) e o seu carácter panluso (presenza notable de brasileirismos, africanismos e asiaticismos). Por parte da Real Academia Española e como Secretario dela, Guillermo Rojo (USC) fai no capítulo 17 
un balance histórico da actividade lexicográfica da RAE. Correspondendo co pasado, explica as características básicas das sucesivas edicións do DRAE anteriores á de 2001. Como actividades presentes da Academia destaca a realización dos córpora moderno (CREA) e diacrónico (CORDE), culminada coa publicación, en 2001, do Diccionario de la lengua española (edición en CD-ROM en 2003). De cara ao futuro sinala, como filosofía de traballo, a importancia da colaboración entre todas as Academias e, no terreo das obras lexicográficas, a posta en marcha do Nuevo diccionario histórico de la lengua española, do Diccionario académico de americanismos e a próxima publicación dun novo DRAE (2013?) no que xa non se inclúa a información diacrónica e diatópica correspondente aos dous dicionarios mencionados. No capítulo 18 e na representación da Opera del Vocabolario Italiano (OVI), Pär Larson describe o marco institucional e filolóxico de OVI (representa a continuación da Accademia della Crusca) e céntrase no Tesoro della Lingua Italiana delle Origini (TLIO). Realiza unha "visita guiada" a este dicionario do italiano antigo, incluíndo referencias mínimas ao corpus no que se fundamenta. Pasa revista aos oito -en realidade nove- apartados que compoñen a estrutura das entradas (lema -o moderno-, variantes gráficas, etimoloxía, atestacións, observacións lingüisticas, anotacións, valores semánticos estruturados e información sobre os redactores) e destaca tres opcións deste recurso on-line: a posibilidade de recuperación de explicacións semánticas nos propios textos (opción Gloss.), a indicación do grao de fiabilidade e representatividade lingüistica das fontes textuais e a posibilidade de recuperación conxunta das unidades polirremáticas.

No capítulo que clausura o volume, Antón Santamarina (director da Sección de Lexicografía do Instituto da Lingua Galega-USC e membro numerario da Real Academia Galega) contribúe cun extenso texto preparatorio do Dicionario Histórico da Lingua Galega. Nas súas páxinas condensa a experiencia e o esforzo de varias décadas de traballo lexicográfico orientado á realización desta vasta obra que situará o galego no restrito grupo de linguas románicas que conten cun dicionario histórico. Por varias veces refírese a estes dicionarios como monumentos imprescindibles das culturas nacionais, pero ao que con máis énfase lle atribúe esta cualidade é ao Oxford English Dictionary (OED), que chega a cualificar como "un dos principais monumentos da cultura mundial do século XX". Nunha primeira parte de carácter historiográfico bota unha ollada aos máis importantes dicionarios históricos. Cita algúns antecedentes antigos e detense máis demoradamente nos dicionarios de linguas da Europa occidental, moi maioritariamente de linguas xermánicas (alemán, 
inglés, holandés, afrikaans, sueco, danés, noruegués), aínda que tamén dalgunha lingua románica (francés e, moi sinaladamente, catalán). Na segunda parte vai debullando os trazos constitutivos do futuro DHG: o alcance cronolóxico ou profundidade histórica, as fontes textuais (córpora e dicionarios), as características da macroestrutura e a organización da microestrutura (información fonética, variantes gráficas, etimoloxía, información léxico-semántica). Por último valora a viabilidade da empresa atendendo a cinco parámetros: (a) quen debe levala a cabo, (b) en que institución, (c) canto tempo vaia levar, (d) custo das actividades e (e) como se vaia facer (tecnoloxías informáticas).

No nome do Instituto da Lingua Galega queremos deixar constancia do agradecemento a distintas institucións e organismos polas axudas recibidas. A Real Academia Galega patrocinou, ofreceu axuda económica e deu acollida na súa sede a algúns actos. O Ministerio de Educación e Ciencia contribuíu con axuda económica. A Facultade de Filoloxía (USC) deu, como sempre, acollida á maior parte dos actos e eventos a que deu lugar esta iniciativa (realización dun simposio en novembro de 2006). Mención especial merece o Consello da Cultura Galega, que estende o seu patrocinio ao ILG desde o ano 2001, no que inaugurou esta prestixiosa Serie Lingüística, dentro da Colección Base, editada en formato papel e electrónico (http://www.consellodacultura.org), este último cunha difusión extraordinaria. Quedamos en débeda tamén cos compañeiros do Instituto da Lingua Galega polo apoio constante ofrecido aos editores durante este tempo, moi especialmente a Paulo Martínez Lema, que, ademais de participar como contribuinte, colaborou eficazmente nas actividades organizativas. Finalmente reiteramos o noso recoñecemento aos autores dos traballos incluídos neste libro, na seguranza de que a súa difusión e lectura fomentará a perseverancia dos lexicógrafos actuais e a incorporación de novos investigadores que aseguren a continuidade no cultivo da lexicografía. 

I. HISTORIOGRAFÍA E METODOLOXÍA 



\title{
PROBLEMAS TEÓRICOS Y PRÁCTICOS EN LA REDACCIÓN DEL NTLE*
}

\author{
Manuel Alvar Ezquerra \\ Universidad Complutense de Madrid
}

Cuando los organizadores de este volumen me propusieron que escribiera sobre los problemas en la redacción de diccionarios generales de la lengua, me alegró porque me hacía recordar pasados retos e imaginaba los que pueden presentarse a la actividad diccionarística en los próximos años. Sin embargo, no me atreví a sostener el envite porque en estos momentos mis preocupaciones se hallan orientadas en otras direcciones. Mirando hacia el quehacer actual que absorbe la mayor parte de mi tiempo fue cuando les propuse tratar de las dificultades que surgen, que nos han surgido, en la elaboración de un tesoro lexicográfico, el Nuevo tesoro lexicográfico del español (s. XIV-1726) (NTLE) ${ }^{1}$, que, por otra parte, no deja de ser un diccionario de carácter general, si bien muy diferente de lo que concebimos habitualmente como un diccionario general de la lengua, de carácter descriptivo y sincrónico. Por otro lado, el NTLE se encuentra más cerca, porque lo es, de los repertorios de carácter acumulativo e histórico, y muchos de los problemas que se nos presentaron son comunes a los que aparecen en cualquier otro proyecto de lexicografía histórica. No son, pues, problemas nuevos, sino viejos conocidos -como siempre, unos más que otros- que reaparecen al emprender una nueva obra.

Una de las principales dificultades con las que se encuentra cualquiera que desee redactar un diccionario, del tipo que sea, es la informatización, pues, como resulta conocido de todos, hoy ya no se acomete una empresa lexicográfica sin acudir a los ordenadores, no puede ser de otro modo. No creo necesario recordar aquí que fueron los estudios lexicológicos y lexicográficos de los primeros en beneficiarse de los avances

* Este trabajo se encuadra dentro de los llevados a cabo para el proyecto Nuevo Tesoro Lexicográfico del Español (s. XIV-1726), que goza de una ayuda del Ministerio de Ciencia y Tecnología (HUM2004-05344).

1. A propósito de la obra, véanse Alvar Ezquerra (2003a, 2003b, 2004 y 2006a). Además, Nieto Jiménez / Alvar Ezquerra (2004) y Alvar Ezquerra / Nieto Jiménez (2006). 
tecnológicos, como ha ocurrido siempre, por lo menos desde que la imprenta irrumpió en nuestro mundo. El uso de los ordenadores en nuestros ámbitos ya no es una novedad: han transcurrido más de treinta años desde que comenzaron a hacerse los primeros trabajos de informatización aplicada al léxico y a los diccionarios del español. Por supuesto, los medios, técnicas, procedimientos, rapidez, volumen de datos tratados, complejidad de las consultas, etc., etc., han cambiado de forma sustancial, y lo que hoy podemos hacer en nuestra casa en unos minutos con un ordenador personal y un programa comercial, entonces requería de un gran esfuerzo personal y material, y de unas cuantas semanas, si no meses, de trabajo.

Por lo que respecta al NTLE, los inconvenientes en su informatización han surgido por cualquier parte cuando menos los esperábamos, y hemos tenido que acudir a múltiples frentes para ir solucionando los problemas que se planteaban cada vez que deseábamos avanzar un paso en el trabajo.

En primer lugar, para tratar informáticamente los datos contenidos en los diccionarios que deseábamos recopilar resultaba necesario darles un formato electrónico, como es obvio. Para ello había que disponer de ordenadores, pero ¿de qué tipo? En el inicio de las tareas, una parte del equipo se encontraba en Madrid, y otra en Málaga, así que debíamos buscar la máxima compatibilidad posible, para evitar problemas en el envío de datos de un lado a otro. Nos pareció lo más apropiado emplear ordenadores personales en lugar de grandes equipos, decisión que venía avalada por mi experiencia anterior durante la redacción del Diccionario general ilustrado de la lengua española (DGILE 1987), en la que la utilización de grandes equipos informáticos nos proporcionó más de un sobresalto, y siempre debido a motivos ajenos a la propia redacción lexicográfica. Es más, cuando la editorial Biblograf s. a. decidió crear en Málaga el CELEX (Centro de Lexicografía Vox), se optó por los ordenadores personales, pues eran la mejor solución para facilitar el trabajo en equipo con sedes diferentes, y para el envío de materiales entre Málaga y Barcelona.

La segunda parte del problema informático inicial consistía en la recuperación de la información contenida en las fuentes que iban a servir para la elaboración del NTLE. El trabajo que pretendíamos llevar a cabo se nos presentaba inmenso: agrupar decenas y más decenas de diccionarios y otras obras con contenido léxico. La primera idea que acude a cualquiera que se vea en la misma tesitura es la de escanear los repertorios. Sin embargo, apenas la consideramos, entreviendo la multitud de inconvenientes que nos iban a surgir, derivados de los tipos de materiales tan heterogéneos que íbamos a manejar. 
De entrada, quedaba descartado el escaneo de los manuscritos, pues los medios técnicos a nuestro alcance no pueden recuperar su información, máxime habida cuenta del pésimo estado en que se encuentra la mayor parte de los que hemos utilizado, y que no son pocos, pues del centenar y medio de fuentes manejadas 23 son manuscritos que hemos tenido que leer nosotros mismos, y dos más de los que se dispone de transcripciones fiables, junto con los tres glosarios medievales editados por Américo Castro. Por otra parte, tampoco era posible el escaneo de los repertorios impresos, pues resulta evidente que, de ningún modo, se nos facilitarían los originales para tal tarea, por lo que hubiéramos debido partir de las fotocopias de que hemos dispuesto, en las que los problemas se acentúan, debido a la falta de limpieza que tienen para poder realizar un escaneo con unas mínimas garantías. Es cierto que disponemos de ediciones facsimilares de algunas obras, de los dos diccionarios grandes de Nebrija $(1492,1495$ ?) y de sus Introductiones latinæ (Nebrija 1481), del de Cristóbal de las Casas (1570), del de John Minsheu (1599), del de Hadrianus Junius (1567), de los dos anónimos ingleses de 1554 (Anónimo 1554a y Anónimo 1554b), del Vocabulario del humanista de Lorenzo Palmireno (1569), del Vitruvio de Miguel de Urrea (1582), de la Instrucción náutica de Diego García de Palacio (1587), del tratado de Bernardo de Aldrete (1606), así como de otras obras de gran envergadura de las que queríamos extraer datos, como el Dioscórides de Andrés Laguna (1555) o el tratado de las aves de Francisco Marcuello (1617). Poca cosa ante el panorama que se nos presentaba, máxime cuando las ediciones facsimilares, en algunos casos, tampoco presentan la limpieza que se necesita en estas ocasiones, y parten de reproducciones de baja calidad. En cualquier caso, fuesen originales, facsímiles o fotocopias, el escaneado no parecía la mejor solución debido a múltiples causas que se comprenden con facilidad:

- la diversidad tipográfica, que hubiera obligado a instruir al programa en cada caso particular, si es que llegaba a reconocer el tipo de letra. Piénsese en las diferencias entre los impresos de finales del siglo XV y los del siglo XVIII, o en el empleo de tipografía gótica, mantenida durante varios siglos en los textos en alemán y flamenco junto a otros tipos para las otras lenguas de los mismos repertorios.

- las manchas de tinta debidas a una impresión no excesivamente cuidada (acrecentadas en las fotocopias), que hubieran dificultado la interpretación de las letras.

- la escasa calidad de los papeles empleados para la impresión, que aportan otras manchas que dificultan la lectura, en el caso en que 
el contraste hubiese sido suficiente entre el papel y la tinta, debido al deterioro de aquél.

- la variedad de lenguas utilizadas en los repertorios, y alfabetos distintos: latino, griego, hebreo, árabe.

- el empleo de frecuentes abreviaturas, no sistemáticas, y, esporádicamente, de algunos signos no alfabéticos.

- las numerosas erratas y errores debidos a que una buena cantidad de los repertorios fueron impresos fuera de nuestras fronteras, por impresores que no conocían bien nuestra lengua.

Téngase en cuenta, además, que los diccionarios eran obras de carácter didáctico, de consulta, por lo que los papeles empleados en ellos no eran los mejores, y su impresión no resultaba todo lo cuidada que hubiéramos deseado, y, por supuesto, de una calidad inferior a la de otros libros, por no pensar en el desgaste por el uso en manos de estudiantes, comerciantes y otras personas, lo que no necesariamente afecta a todos los ejemplares conservados.

Si nos hubiésemos decidido por el escaneo, las tareas de lectura y corrección hubiesen sido muy superiores a lo tolerable para que la solución fuese razonable en términos de tiempo, de trabajo y de gasto.

Aunque poco deseable, y menos apetecible, la única solución que nos quedaba era teclear, uno a uno, todos los diccionarios que debían constituir el cuerpo del NTLE, labor a la que nos hemos dedicado varias personas durante unos cuantos años. Pero no se trataba de comenzar el tecleado a ciegas, sin haber imaginado el resultado final. ¿Para qué iban a servir los datos codificados? Sin duda, como en tantos otros diccionarios, tendríamos que montar una base de datos para los tratamientos y consultas que fuese necesario realizar antes de alcanzar la meta propuesta. Mi decisión estaba tomada de antemano: trabajaríamos con Access de Microsoft, pese a que se barajó la posibilidad de emplear otra base de datos para ordenadores personales. Ello era así porque conocía el funcionamiento y prestaciones de esa base de datos, gracias a la experiencia con ella en otro tesoro lexicográfico, bien es cierto que de un carácter diferente del que estábamos acometiendo, terminado ya cuando habíamos comenzado el NTLE, el Tesoro léxico de las hablas andaluzas (Alvar Ezquerra 2000), en cuya realización me surgieron no pocos problemas, de los que he dado cuenta en otros lugares ${ }^{2}$, y que alumbraron nuestros primeros pasos. Sin embargo, debido a la heterogeneidad del equipo, de la diversidad de per-

2. Véase el propio prólogo de la obra, así como Alvar Ezquerra (1996). 
sonas que iban a trabajar y de la disponibilidad de equipos informáticos de todas ellas, así como por la falta de conocimientos en herramientas informáticas, y otros inconvenientes menores, no resultaba aconsejable pasar directamente los datos a la base de datos. Fue éste el motivo por el que se optó por teclear los diccionarios en un programa de tratamiento de textos, disponible en todos los equipos, en un formato RTF, con el fin de que no surgieran los problemas de compatibilidad que se nos presentaron en varias ocasiones con el Tesoro léxico de las hablas andaluzas.

Esa resolución conllevaba, como es lógico, que todos los colaboradores trabajasen del mismo modo, por lo que fue necesario redactar unas normas de tecleado en las que se especificaban las instrucciones que debían seguirse, los signos que se debían emplear, formatos, tamaños de archivos, etc., etc. Como es fácil de imaginar, estas normas fueron modificándose durante los primeros tiempos a medida que avanzaba el trabajo, pues no fue posible prever todas las contingencias desde los inicios. Algunas de esas modificaciones nos obligaron a volver atrás y rehacer parte de lo que ya teníamos hecho, lo cual no siempre fue bien entendido por los colaboradores, aunque lo perseguido era dar consistencia al conjunto de los materiales. Bien es cierto que ahora vemos lo acertado de las decisiones, pues la base de datos nos permite avanzar con una rapidez que, de otro modo, no hubiese sido posible. El ulterior paso desde las informaciones codificadas en el tratamiento de textos a la base de datos, entre otras cosas, obligaba a marcar la separación entre algunos campos para que la carga en ella no plantease otras dificultades sobrevenidas. Pero también ello obligaba a tener en cuenta otros aspectos. Por ejemplo, la base de datos no permite los cambios de tipo de letra, por lo que no era posible el empleo de cursivas y negritas, para lo cual seguimos el mismo procedimiento que en el Tesoro léxico de las hablas andaluzas: poner unas marcas de apertura y de cierre, de modo que los cambios fuesen fácilmente detectables en cualquier momento y para cualquier necesidad que pudiese surgir en el futuro, como así sucedió. Tampoco eran posibles los cambios de tamaños de letra, o el empleo del alfabeto griego o el hebreo, pues todos esos signos desaparecían al cargar la base; igualmente, no era posible el empleo de algunos signos especiales, como cruces y otros símbolos que encontramos en algunos de los originales, bien es cierto que de forma muy esporádica. Para todo se fueron adoptando soluciones, que obligarían a cambios más adelante en el trabajo.

Al tiempo que se realizaba el tecleado, se marcaban las supresiones de texto innecesario, los blancos, las ausencias, los rotos en el papel, los cortes que impedían la lectura, etc., etc. Pero esos no eran los únicos as- 
pectos formales que se iban solucionando. En los textos manejados han aparecido numerosísimos errores y erratas debidos al poco escrúpulo con que se componían los diccionarios, a la escasa formación de algunos tipógrafos, o sus pocos conocimientos de español cuando las impresiones se realizaban fuera de nuestras fronteras, o a que no interpretaban adecuadamente los manuscritos que les llegaban. No resulta extraño encontrar confusiones de $u$ por $n$ o a la inversa, de $c$ por $c$, numerosos casos de seseo y algunos de ceceo, etc. Se efectuaron las correcciones de errores y erratas poniendo entre corchetes nuestra interpretación, añadiendo unas interrogaciones a aquellas de las que no nos hallábamos muy seguros, hasta una comprobación posterior. Por el contrario, las lecturas que resultan sorprendentes, o para las que no tenemos una solución satisfactoria, van seguidas de unas interrogaciones entre corchetes, o de un sic, con el fin de que el usuario no tenga dudas sobre lo que lee. Hemos optado por ofrecer a continuación de la palabra su reconstrucción íntegra entre corchetes, y no poner sólo la letra o signo cambiado en su interior, de modo que si en algún momento se realiza una consulta automática de una cadena de caracteres no se nos escamoteen las soluciones porque no se haya tenido en cuenta un corchete que no puede estar previsto en la cadena buscada. Esta solución es tanto más necesaria cuando lo modificado es la palabra que figura como entrada del diccionario: hemos respetado el original, pero en el NTLE aparece como lema la solución correcta.

Como se ve, los textos no se han tecleado tal cual figuran en los originales. Se han modificado la puntuación y la acentuación, para adecuarlas a las reglas y usos actuales en español, no así en las otras lenguas, lo cual hubiera requerido un esfuerzo para el que no estábamos capacitados, ni para el que teníamos medios personales y materiales, aunque en determinadas ocasiones, y para facilitar la lectura, se ha cambiado la puntuación o la acentuación, o se han introducido correcciones entre corchetes, pero, repito, sólo de manera muy esporádica. Por eso, el lector encontrará en lo escrito en lenguas diferentes al español unas tildes o unos signos de puntuación que resultan chocantes (por ejemplo, tildes en algunos textos latinos, empleos de diacríticos que no se corresponden con los actuales en italiano o en francés, etc., por no hablar de los signos de puntuación). Esta tarea, que parecía fácil, se nos vino a complicar con la aparición de las nuevas normas ortográficas de la Academia (RAE 2000). Tuvimos que plantearnos si volver atrás en todo lo que teníamos realizado hasta entonces, que era mucho, o seguir adelante con los mismos criterios. Optamos por esta última posibilidad para no estar tejiendo y destejiendo de modo continuo, lo que a la postre, iría en contra del desarrollo del trabajo, 
y nos alejaría el puerto al que queríamos llegar, todavía lejano. Además, el mantenimiento de la ortografía anterior no suponía un atentado demasiado grande contra la lengua, de ninguna manera impediría la lectura de la obra, ya que los usuarios, al menos los actuales, están acostumbrados al sistema conservado, y sabrían comprender lo sucedido.

En este proceso también se comprobaban las remisiones que hacían los autores a otras partes de sus diccionarios, señalándose aquellos casos en que se trataba de pistas perdidas, cuando no era un simple error, habiéndose corregido como los demás.

También se desarrollaron las abreviaturas españolas para hacer fácilmente comprensible el texto, excepto las que son habituales hoy, como S., Sr., etc. A la vez, se fueron incluyendo remisiones cuando en el interior del texto reproducido se definía otra palabra, o había una referencia a ella digna de ser tenida en cuenta, o se utilizaban varios equivalentes españoles para una forma extranjera, o la entrada española contenía varias voces, y tantas otras posibilidades más. Se ha puesto especial cuidado para que estas remisiones no se confundan con las que se ponían los propios autores para guiar al usuario en la consulta de su obra; éstas aparecen con la misma tipografía empleada para el texto de los diccionarios, mientras que las nuestras van con un tipo de letra diferenciado.

En definitiva, hemos seguido unos criterios que resultan habituales en la edición de textos, y que no sorprenderán al lector experimentado. En este sentido, quiero dejar claro que las erratas muy evidentes se han corregido sin más, aunque en pocos casos. Además de todo ello, durante el proceso de tecleado se sustituía el signo tironiano de acuerdo con la norma en la lengua correspondiente, excepto en inglés, por el uso que sigue teniendo.

El tecleado resultó verdaderamente complicado con el Vocabulista aráuigo en letra castellana de fray Pedro de Alcalá (1505). La ventaja inicial que presentaba esta obra, al hallarse las voces árabes transliteradas en nuestro alfabeto, se vio desvanecida inmediatamente, ya que el autor empleó unos signos especiales para determinados sonidos, que no se encuentran en la tabla de signos ASCII que hemos manejado, la más reducida, para, como siempre, evitar problemas. La solución que adoptamos fue el empleo de unas combinaciones de signos que sustituyeran a los del autor, que han sido, a su vez, cambiados por los correctos en el tratamiento final del NTLE, antes de su envío a la imprenta. Tuvimos la suerte de contar con una hispanista marroquí para el tecleado de esa obra, con lo que las dudas e inconvenientes que podría haber tenido cualquiera de nuestros colaboradores se solucionaron en el acto. Creo que éste es el mo- 
mento oportuno para decir que ha sido la única ocasión en que durante el proceso de tecleado hemos debido acudir, fuera de nuestro equipo, a un especialista en lenguas que no fuesen la nuestra. Nuestros colaboradores, afortunadamente, poseen unos conocimientos sobrados de otros idiomas para las tareas realizadas, y solamente el flamenco ha ofrecido alguna resistencia, no demasiada, pues, para nuestra sorpresa, una de nuestras colaboradoras se había iniciado en el conocimiento de esa lengua, y varios miembros del equipo dominaban a la perfección el alemán. Por lo demás, el latín, el griego, el francés, el inglés, el catalán, el gallego o el portugués no han presentado especiales dificultades, y sólo las pocas palabras en hebreo que hay en el Tesoro de Covarrubias (1611), y las escasas del Minsheu (1617) o del manuscrito de Bartolomé Valverde (1760?) nos han llevado a consultas externas.

A la vez que se realizaba el proceso de codificación, se avanzaba ya algún paso en la redacción del NTLE, como fue el ir efectuando una incipiente lematización, para la que se reservó un campo especial: los sustantivos y adjetivos irían en singular, estos últimos bajo la forma masculina, con la terminación femenina si fuese el caso, las formas de los paradigmas verbales se lematizaban en infinitivo, etc. Como no es difícil de sospechar, las unidades fraseológicas han presentado no pocas dificultades. Se ha procurado lematizarlas bajo la entrada que tenía el autor, salvo en aquellas ocasiones en que aparecían bajo un elemento de relación, en cuyo caso se han llevado a la palabra que soportara la mayor carga semántica de la expresión. Cuando hemos detectado que una construcción de este tipo aparece bajo entradas diferentes, porque así lo hacían los autores, hemos procurado poner unas referencias cruzadas, con el fin de que no se pierdan las informaciones. En general, hemos marcado los refranes y frases proverbiales entre unas comillas de valor, no así las frases hechas y las locuciones, máxime cuando el DRAE las registra como tales. Tampoco llevan una señal especial las numerosas frases y ejemplos que figuran en algunos repertorios como meros modelos de uso. En este sentido, he de decir que se han detectado algunos refranes y frases proverbiales que se presentaban truncados, y que también se han marcado, para mantener una cierta coherencia con los que no están truncados en los mismos artículos del Tesoro.

De modo simultáneo al tecleado, se iban incorporando unas referencias internas que nos ayudasen más adelante en la agrupación de variantes, o para que sirviesen de llamadas de atención. Esas referencias se han revisado en la corrección final, para mantener únicamente como remisiones internas aquellas que fuesen necesarias y eliminar las que 
sólo sirvieron para el desarrollo interno de nuestro trabajo, que no debían trascender el ámbito de la redacción. Una vez finalizado todo el proceso de corrección, en la Universidad Politécnica de Madrid nos han preparado un nuevo programa que efectúa una comprobación de todas las remisiones que hemos dejado, para que remitan al artículo correspondiente, y no a una variante que se haya lematizado bajo una entrada diferente $o$ tenga un error de cualquier tipo, realizando los cambios correspondientes. Además, incorpora remisiones desde todas las variantes documentadas en cada autor, de modo que el usuario se encuentre siempre asistido en sus búsquedas. Por otra parte, genera un informe indicando aquellos artículos en cuyo interior hay más de tres remisiones a un mismo lugar, que hemos empleado en la revisión final para prescindir de aquellas que figuraban en cinco o más autores, sustituyéndolas por una genérica al final del artículo. Esto mismo se ha hecho en aquellos artículos con menos remisiones pero que contaban con un número reducido de fuentes, o que enviaban a lugares con pocas autoridades. Sin embargo, cuando se remitía desde un artículo con muchas fuentes, o a uno de esas mismas características, se han mantenido en cada autor, para no obligar al usuario a una tediosa búsqueda.

Los diccionarios, poco a poco, iban siendo tecleados, pero eso no era sino el comienzo de un proceso, que ya en sus inicios era pesado. Una vez finalizada la codificación electrónica de cada obra, los responsables del proyecto procedíamos a su lectura y corrección sobre papel, que devolvíamos a los colaboradores para que efectuasen las modificaciones señaladas. Cuando se concluía este proceso, se archivaba una copia, y se procedía a una alfabetización del contenido, que sufría un nuevo tratamiento, para unificar bajo una sola entrada toda la información del diccionario, y para eliminar las repeticiones innecesarias, más frecuentes en los repertorios de carácter temático que en los estrictamente alfabéticos. Después, se ponían las marcas de identificación del texto y se guardaba una copia de esta versión, que se convertía a un formato TXT, también guardado por separado, que era el empleado para ir cargando la base de datos.

Ya avanzada esta fase del proceso tuvimos un gran tropiezo imprevisto, que supusimos debido a nuestra propia inexperiencia: comprobamos que las informaciones de la base de datos no eran las mismas que había en la versión del tratamiento de textos, pues el contenido de algunos campos estaba truncado. No sabíamos a qué se debían las diferencias, y lo achacamos a algún error cometido inadvertidamente, por lo que reiniciamos una nueva carga de datos. Hicimos los controles pertinentes, y vimos que los errores detectados no se habían producido. Pero el alivio 
duró poco y sonó otra alarma. En el nuevo proceso de carga volvía a suceder lo mismo, desaparecían los errores, pero se presentaban otros que no había antes. Ya no quedaba duda, el programa realizaba unos cortes aleatorios, probablemente debidos a la cantidad de información trasvasada. Recurrimos entonces al Grupo de Estructura de Datos de la Universidad de Las Palmas de Gran Canaria, que ya me había ayudado en las tareas informáticas del Tesoro léxico de las hablas andaluzas, y nuestras sospechas fueron confirmadas. A partir de ese instante la colaboración ha sido intensa, y las herramientas de que hemos ido disponiendo son resultado de su generosa asistencia, aunque en los últimos meses hemos recurrido a informáticos de la UPM, como he dicho, por la comodidad de la proximidad, y la necesidad del contacto directo y continuo. Fueron aquellos quienes nos propusieron la solución adoptada, y la importación de datos, desde entonces, no se ha hecho directamente empleando los recursos de Access, sino mediante un programa diseñado ad hoc, que es el que lleva la información desde el tratamiento de textos a la base de datos, con el fin de que no se pierda nada, y, para mayor seguridad, a continuación realiza una comparación para comprobar que lo que ha llegado a la base de datos sea igual a lo que se deseaba trasvasar. El proceso es extraordinariamente rápido y, sobre todo, nos proporciona una seguridad en nuestros medios que habíamos comenzado a perder. Pasado el tiempo he constatado que los errores no eran culpa nuestra, ni se debían a códigos mal empleados, pues otras personas que han llevado a cabo procesos similares en otras empresas lexicográficas se han tropezado con idénticos inconvenientes. Tal vez se trate de un defecto en el diseño del programa, cuestión sobre la que no he querido indagar más, una vez que los problemas sobrevenidos estaban ya resueltos.

En el momento en que consideramos que disponíamos de una cantidad significativa de obras en la base de datos, procedimos a generar un informe para ir viendo los resultados parciales, y animarnos en nuestro quehacer. Así, a finales de 1999 (tras varios años de intensos trabajos) elaboramos el primer borrador del NTLE, pasando todo el contenido de la base de datos a un tratamiento de textos, Word de Microsoft. Los cientos y cientos de páginas producidos nos causó asombro, pero también nos mostraba que el camino que quedaba por recorrer aún era largo.

Cuatro años más de esfuerzos nos llevaron a realizar un nuevo ensayo del resultado final, y vimos, nuevamente, cómo se producían errores en la carga de la base de datos, si bien esta vez ya no eran imputables a fallos en los programas informáticos, sino a nosotros mismos: se habían producido durante el proceso de tecleado. Esta alerta se produjo cuando 
las marcas para separar campos no coincidían con los de la base de datos. Se trataba de un mero problema formal fácilmente subsanable. Pero, a la vez, nos percatamos también de la presencia de otras faltas formales, como equivocaciones en las secuencias de signos y otros errores de consistencia. Afortunadamente, se podían sistematizar, y, por tanto, corregir de una forma automatizada. El grupo informático de Las Palmas se dispuso a prepararnos un nuevo programa que comprobara si los separadores de campos estaban bien puestos, y otro que comprobara si las marcas sistemáticas que habíamos ido utilizando habían sido tecleadas correctamente. A partir de ese momento, comenzamos a buscar y detectar otros errores formales que pudiesen ser corregidos de una manera automática, o con la asistencia de sistemas informáticos, lo que nos llevó a solicitar nuevos programas. En realidad, es un solo programa que va realizando múltiples tareas encadenadas, y en un orden estricto para que unas instrucciones no puedan afectar a los cambios realizados por otras. De este modo, se incrementó el programa para detectar que siempre que se abra un paréntesis, un corchete, un signo de interrogación o de exclamación, unas comillas, etc., estén cerrados en el mismo campo, que los diferentes campos terminen de la misma manera, en especial que al finalizar el texto de cada artículo aparezca un punto, que no surjan espacios en blanco delante de los signos de puntuación, y que haya uno tras ellos (menos para el punto final), que no aparezcan dos espacios en blanco consecutivos, que los puntos suspensivos sean tres, etc., etc. Son pequeños detalles cuya corrección, en el conjunto del NTLE, hubiera requerido una gran dedicación de haberla realizado manualmente, y, lo que es peor, sin la garantía del resultado final. De este modo, hemos podido disponer de un corrector formal que se ha ido perfeccionando continuamente, hasta en doce versiones diferentes, algunas de las cuales suponían una marcha atrás, pues, a veces, los requerimientos para una corrección concreta afectaban a otros lugares, produciéndose cambios en exceso, o se introducían elementos que no debían aparecer. En definitiva, se trataba de ir afinando la herramienta y puliendo los errores en su diseño o en la apreciación de las tareas que se requerían.

La utilidad de este sistema es innegable, y desde los primeros instantes nos produjo una gran fascinación por las ventajas que presentaba, no sólo porque nos exoneraba de una gran cantidad de trabajo, a la vez que nos proporcionaba una considerable seguridad sobre el contenido formal de los originales, lo que nos permitió en la posterior fase de corrección manual centrar nuestra atención en otros aspectos. Por otra parte, la rapidez del mecanismo resultaba asombrosa, pues la corrección de cual- 
quier diccionario no le ocupaba más de un minuto, además de generar un informe con las correcciones realizadas para que nos cerciorásemos de lo que había hecho, al tiempo que señalaba lugares en que no se habían realizado modificaciones aunque eran posibles, y marcaba otros que se debían comprobar y corregir manualmente. Esta otra tarea, en cambio, requería un tiempo considerable, infinito en comparación con la rapidez de la comprobación automática.

La alegría que nos proporcionaba el funcionamiento de esa herramienta iba siempre acompañada de un poco de amargura, pues pese a los esfuerzos realizados, al cuidado con que se efectuaba el trabajo, en cada texto que se hacía pasar por el programa se descubrían numerosos errores e inconsistencias, que, cuando el repertorio era extenso, resultaban ser varios cientos. Aquello que creíamos bien hecho, sometido a varias correcciones por distintas personas, nunca alcanzaba la perfección deseada, y nuestra euforia por ver cerca el final del tratamiento de cada diccionario se veía atemperada siempre que nos sometíamos al juicio informático, inexorable. De todos modos, no podíamos renunciar a tan valiosa ayuda para que el contenido de las obras que iban pasando a la base de datos fuese el deseado, y cumpliese, al menos, unos estrictos requisitos formales. Era la única manera de ir avanzando con un pie firme sin necesidad de mirar continuamente hacia atrás.

Los problemas formales, de organización y de informatización, como los descritos hasta ahora, con ser importantes y afectar de manera directa a la marcha del trabajo, evidentemente, no han sido los únicos con los que nos hemos ido encontrando durante la elaboración del NTLE, pues los ha habido de otra índole que también han incidido en la organización del trabajo, el general y el cotidiano.

Una de las decisiones que se nos antojaba fácil era la de qué repertorios habrían de formar parte del Tesoro. Por el carácter del proyecto, y lo ambicioso de nuestro objetivo, que ha continuado siéndolo hasta el final, la respuesta era inmediata: todos los anteriores a la publicación del Diccionario de Autoridades (1726-1739), así de sencillo. Sin embargo, como siempre sucede, esa simplicidad era solamente aparente. Resultaba necesario precisar, y elaborar una lista de obras para trabajar sobre ella. El elenco de lo manejado por Gili Gaya (1960) para su Tesoro podía constituir un buen punto de arranque, si bien pronto apreciamos los defectos que encerraba aquella nómina que nos parecía extensa. Por un lado, algunas obras estaban confundidas, otras no eran las primeras ediciones, de unas pocas había manejado varias ediciones, otras estaban en la relación pero no las encontrábamos citadas en el interior de los artículos... Había más. 
No se recogían todos los diccionarios del periodo abarcado, y faltaban algunos anteriores, como pusieron de manifiesto quienes se encargaron de hacer reseñas del Tesoro cuando fue publicado (por ejemplo, Alonso 1951, Colón 1956 y Pottier 1962). Además, aquella era una lista de diccionarios en la que también figuraban obras que no eran de carácter lexicográfico, ni mucho menos, por más que su interés para la historia de nuestro léxico resultaba incuestionable, por lo que su incorporación, fuera de otras consideraciones, estaba sobradamente justificada desde el punto de vista lexicológico.

Ante todo ello, se imponía elaborar nuestra propia lista de obras, tarea a la que nos dedicamos de inmediato, y que no hemos abandonado sino en el último instante, al concluir el proceso de redacción, tal ha sido nuestro empeño por ser consecuentes con nuestras decisiones, y por proporcionar al usuario la mayor cantidad posible de materiales, siempre que no se entorpeciera el manejo de la obra y que no se acumulasen informaciones de manera farragosa hasta ocultar las informaciones verdaderamente interesantes. Éste es el motivo por el que no damos cuenta de algunas nomenclaturas que, en la parte española, no hacen sino repetir cabalmente lo que ya figura en los repertorios que toman como fuente, con escasísimos o nulos cambios, además, en un léxico, que, por la naturaleza de las obras, es el más cotidiano, por lo que aparece abundantemente documentado en la lexicografía y en la historia de la lengua.

En otros lugares he descrito cómo se ha ido configurando el conjunto de obras que ha terminado por ser el cuerpo del NTLE'. Si don Samuel había dado cabida a textos no lexicográficos, y, como he dicho, su presencia en su Tesoro quedaba justificada, nosotros no sólo mantuvimos aquella decisión, sino que la extendimos, de modo que retomamos los mismos textos y añadimos alguno más. De este modo, si había razones para recoger el léxico del Dioscórides de Andrés Laguna (1555)4 ya que incluye unas tablas en varias lenguas de los nombres registrados en su interior (entre ellas, por supuesto, de los españoles), no tenía sentido prescindir de los términos españoles que puso Antonio de Nebrija (1518) en la edición del Dioscórides impresa en 1518 por Guillén Arnao de Brocar, partiendo de la edición de Ruelio, publicada poco antes en París. Y ello nos llevó a incorporar también las voces españolas que Amato Lusitano (1553) había incluido en su versión de la obra, aparecida sólo dos años antes que la de Laguna. Los motivos que amparaban la inclusión de las palabras españolas con-

3. Véanse los trabajos que cito en la primera nota.

4. Gili Gaya empleó la edición de 1570, y no la primera, de 1555, como hemos hecho nosotros. 
tenidas en esas obras son los mismos que autorizan la de las que hay en la obra de Conrad Gesner (1551-1587) (cfr. Alvar Ezquerra, 2002-2004), o en la Historia de las yeruas y plantas de Juan Jarava $(1557)^{5}$, o en el anterior Modus faciendi cum ordine medicandi de fray Bernardino de Laredo (1527) -la primera farmacopea escrita en español-, que también tienen índices de las palabras españolas registradas en su interior. Y desde ellas llegamos al Tesoro de medicinas para todas enfermedades de Gregorio López $(1672)^{6}$. De esta manera, en el interior de nuestro NTLE se halla un tesoro léxico de la medicina de la época, que, sin duda, presenta un notable interés y puede ser de gran utilidad a quienes se interesan por esa parcela del léxico. Como nos ha sucedido con otros grupos de obras, han sido más las consultadas, pero no han pasado a engrosar las páginas del NTLE por no ser de carácter lexicográfico y no presentar un índice de voces que avalase su incorporación, pese a que el vocabulario contenido en ellas sea de interés, como por ejemplo, el Tractado de las drogas y medicinas de las Indias Orientales de Cristóbal Acosta (1578) (cfr. Alvar Ezquerra 2006b).

Ciertamente, ese grupo de obras constituye un conjunto homogéneo de fuentes para un ámbito de léxico específico, pero no es el único que hay en nuestro NTLE, aunque sí el más rico. No carece de importancia el dedicado a la terminología marinera, tanto es así que Lidio Nieto (2002) dio un avance de esa parte en su Tesoro lexicográfico del español marinero anterior a 1726, aunque después se ha añadido alguna obra más. En otros ámbitos, como el del derecho, las bellas artes o las ciencias exactas, la riqueza no es tan grande, y no por falta de empeño por nuestra parte. Los repertorios de léxico técnico se desarrollan después del periodo abarcado en el NTLE, y son muy pocos los elencos de que hemos podido disponer. Es lo mismo que sucede con las listas de palabras de uso regional, pues antes de 1726 solamente aparece la de Gerónimo de Blancas (1641)7, mientras que sí hay algún elenco de voces anticuadas, así como de carácter etimológico -según se entendía la etimología en la época-, aunque una buena porción de ellos sólo se han conservado manuscritos, pese a su trascendencia, como sucedió con el repertorio de voces de origen ára-

5. Disponemos de una edición moderna de $M^{a}$ Jesús Mancho Duque (2005), con varios estudios preliminares donde se desentrañan los problemas relativos a la obra y su contenido.

6. De 1672, aunque redactado a finales del siglo anterior. El manuscrito hológrafo ha sido editado por Francisco Guerra (1982).

7. Son las voces aragonesas que se encuentran en el "Índice donde se declaran algunos vocablos aragoneses antiguos [...]”, que puso en las Coronaciones de los sereníssimos reyes de Aragón, publicadas en 1641, si bien fueron escritas en 1583 . 
be del P. Guadix $(1593)^{8}$ o las etimologías de Bartolomé Valverde $(1760 \text { ? })^{9}$ o Francisco del Rosal $(1601)^{10}$, por no señalar nada más que un par de ellos.

Por supuesto, en el NTLE están recogidos los diccionarios monolingües anteriores al Diccionario de Autoridades (1726-1739), no solamente los específicos, sino los más extensos, así como los bilingües y plurilingües que contienen el español, sean alfabéticos, sean temáticos. La cantidad de obras recogidas es un centenar y medio, aunque son más las consultadas. De ello se da cuenta en las páginas preliminares del NTLE.

La lista de obras que iban a configurar el contenido del NTLE quedó esbozada en un primer momento, pero no cerrada. Las consultas de fondos bibliográficos, de repertorios de toda índole, de catálogos de la imprenta en España y en otros países, de variados trabajos científicos, no solamente de lexicología y lexicografía, sino también de historiografía lingüística, de historia de la ciencia, etc., etc., así como las investigaciones que desarrollan nuestros colaboradores para sus tesis doctorales y otros trabajos de investigación, nos han hecho descubrir de forma continua obras cuyo examen era necesario para decidir si su contenido debía verterse en el Tesoro o no, con lo que han quedado por el camino muchos esfuerzos, y algún que otro libro. De unos ni siquiera se mantiene un rastro en el NTLE, de otros se da una somera explicación de los motivos por los que no se han tenido en consideración. De todos modos, alguna que otra obra de las que no han pasado al interior del NTLE ha sido objeto de estudio por parte de los miembros del equipo, por lo que, con los trabajos que ya se van derivando de nuestra empresa, no se ha perdido del todo el léxico de esas otras obras no incorporadas, y nuestros esfuerzos han dado frutos, aunque no en el interior del NTLE; es lo ocurrido, por ejemplo, con la breve lista de palabras que aparece en The Key of the Spanish Tongve de Lewis Owen $(1605)^{11}$, que es solamente inglés-español, con la Janua linguarum (1611) de Salamanca (cfr. Alvar Ezquerra 1992), latín-español, o con el vocabulario francés-español que aparece en la gramática de Monsieur de Maunory (1701). Este continuo desvelo por las fuentes ha hecho que la nómina de obras no se haya cerrado hasta el último instante, cuando la corrección final de los datos se hallaba muy avanzada, con la incorporación

8. Recopilación de algunos nombres arábigos [...], ms. 59-I-24 de la Biblioteca Colombina (Sevilla), manejado por los lexicógrafos posteriores.

9. De la obra se conservan, al menos, dos copias más manuscritas.

10. Origen y etimología de todos los vocablos originales de la lengua castellana, ms. 6929-T.127 de la Biblioteca Nacional, Madrid. También hay más copias de él. Hay una edición moderna con estudio de Enrique Gómez Aguado (1992) y reproducción del manuscrito citado.

11. Sobre ella, véase Nieto Jiménez / Alvar Ezquerra (2002). 
de un pequeño repertorio multilingüe de la primera mitad del siglo XVI, el Quinque linguarum (1534), cuya copia tardó en llegar, por lo que habíamos introducido una edición posterior, en seis lenguas, de 1541, con escasas diferencias en la parte española (Vocabulario de seis linguaies 1541) ${ }^{12}$.

Con la lista de obras esbozada comenzó una nueva complicación, la de conseguir reproducciones sobre las que trabajar. En unos casos, no muchos, había reproducciones facsimilares sobre las que podríamos trabajar, o ediciones modernas, por más que su grado de fiabilidad no fuese muy elevado, como nos ha sucedido con la citada de Francisco Guerra (1982) del Tesoro de medicinas para todas enfermedades de Gregorio López (1672). Pero no siempre hemos empleado las ediciones modernas, pues unas veces hemos acudido a los originales, como en el Tesoro de Covarrubias (1611), ya que teníamos a mano un ejemplar de la primera edición, si bien hemos consultado la edición de Martín de Riquer en caso de duda; diferente ha sido el caso de los Diez previlegios para mugeres preñadas de Juan Alonso y de los Ruyzes de Fontecha (1606), pues, una vez realizado nuestro tecleado, ha aparecido una edición moderna (Zabía Lasala 1999), que nos ha servido de guía en el proceso de corrección posterior.

Por otra parte, teníamos fotocopias de otras obras, tampoco muchas, que conservábamos de trabajos nuestros anteriores, o que habíamos ido acumulando por diversos motivos. Con éstas, y las ediciones de que acabo de hablar, era suficiente para iniciar el tecleado de los contenidos, aunque fuese de una manera desordenada, pues siempre que nos ha sido factible, hemos avanzado de manera cronológica, entre otras razones, para que aquellas obras que fueron utilizadas como fuente por otras posteriores nos sirviesen de guía o facilitasen el trabajo.

Del resto del elenco comenzamos a buscar ejemplares en las bibliotecas públicas. Primero acudíamos a las madrileñas, por ser las más cercanas y ricas en fondos. Si no encontrábamos en ellas la obra en cuestión, rastreábamos su presencia en otras bibliotecas españolas, y, en caso negativo, nuestras pesquisas se dirigían al extranjero. Incluso en alguna ocasión hemos entrado en bibliotecas particulares, españolas y extranjeras, tal ha sido la intensidad de la búsqueda, para la que nos han ayudado grandemente los repertorios bibliográficos que han ido apareciendo durante los últimos años, y los ficheros on-line de las principales bibliotecas, aunque no siempre ha sido ésa la manera de llegar hasta el ejemplar deseado.

12. Es preciso advertir que tanto la versión en cinco lenguas como la de seis coinciden en su primera parte con el Quinque linguarum (1526), aunque no en la segunda, que presenta diferencias, por lo que la hemos trasladado al NTLE, donde el lector podrá comprobar los cambios. 
Con la localización de ejemplares tampoco se terminaba el proceso de búsqueda, salvo, evidentemente, de los manuscritos. Era preciso conocer el estado de los libros para que no faltasen páginas y para que el texto no estuviese mutilado. Por ello, no han sido pocas las veces en que, tras comprobar la reproducción que nos llegaba, y cerciorarnos del estado del original, hemos tenido que reiniciar el proceso de búsqueda. En otras ocasiones, las reproducciones estaban mal hechas, con los márgenes cortados, hojas sin reproducir, texto desenfocado o con tantas manchas que resultaba ilegible, y con cuantas complicaciones que ni nosotros mismos éramos capaces de imaginar. Entonces teníamos que volver a la biblioteca para reclamar, con el malestar de todos, como es fácil de suponer. Aunque estos problemas causaban trastornos, especialmente porque debíamos adaptar el ritmo de las tareas a las circunstancias, era tal la cantidad de obras que teníamos entre manos, y la cantidad de correcciones y filtros que se efectuaban, que nunca se constituyeron en un gran inconveniente para el progreso de los quehaceres.

Pese a que los servicios de información y de reproducción de las bibliotecas funcionan razonablemente bien, la obtención de fotocopias ha llegado a constituir un verdadero conjunto de adversidades. En este sentido, nunca se nos olvidarán las acaecidas con el Diccionario español-francés de fr. Pierre Seguin, que a punto estuvieron de hacernos abandonar y de provocar que su contenido no figurase en el NTLE, pero nuestro tesón estaba hecho a toda prueba, por difíciles que se planteasen las contrariedades. Se trata de un manuscrito de la Biblioteca Nacional de Francia, empleado por Gili Gaya en su Tesoro. Solicitamos su reproducción tanto directamente como con la ayuda de nuestra Biblioteca Nacional, y fueron nuestros colaboradores a París en varias ocasiones, sin que lo consiguiéramos; por fin, y tras una reclamación a la dirección de la biblioteca al cabo de los años, pudimos saber que había cambiado la signatura de la obra, con lo que volvimos a iniciar el proceso, pero la reproducción que nos enviaron no tenía nada que ver con nuestro manuscrito. Vuelta a las quejas, y admitieron haber cometido un error en la signatura que nos comunicaron. Para poder seguir adelante tuvimos que devolver las fotocopias recibidas, pero las nuevas no llegaban, pese a las promesas, así que aproveché un viaje a París para averiguar lo sucedido; me dijeron que el envío se había efectuado unos días antes, pero en Madrid no recibía nada. Nuevas quejas, y cada vez más serias, hasta conseguir las dichosas fotocopias. Habían transcurrido unos cuantos años desde la primera solicitud. En honor a la verdad, y en defensa de las bibliotecas y de sus trabajadores, he de decir que ésta no ha sido la tónica general, aunque nunca nos han llegado las copias con 
la rapidez deseada, con algunas excepciones, como la de la Real Academia Española. Si el funcionamiento de las bibliotecas no hubiese sido el adecuado, nuestro trabajo no hubiera podido llevarse a cabo, o lo hubiéramos hecho de manera más lenta y penosa, y no hubiéramos podido contar con reproducciones de ejemplares conservados en bibliotecas tanto españolas como extranjeras. Las bibliotecas españolas han sido fundamentalmente madrileñas (principalmente la Biblioteca Nacional, la de la Real Academia Española y la Biblioteca Histórica Marqués de Valdecilla de la Universidad Complutense de Madrid, pero también la Biblioteca de Palacio, la de la Real Academia de la Historia, Biblioteca General de Humanidades del CSIC, Biblioteca del Instituto de Filología del CSIC, Biblioteca Histórica Municipal, la del Museo Naval, la de la Fundación Universitaria Española, la del Monasterio de El Escorial), aunque también de otros lugares de nuestra geografía (Biblioteca Universitaria de Salamanca, Biblioteca Universitaria de Granada, Biblioteca de la Universidad de Barcelona, Biblioteca Pública de Málaga, Biblioteca Colombina de Sevilla, Biblioteca Valenciana de Valencia). Una buena parte de las bibliotecas extranjeras han sido de Francia (Bibliothèque Nationale de France, Bibliothèque de l'Arsenal, Bibliothèque Mazarine, Bibliothèque Sainte Geneviève, en París, así como la Bibliothèque Municipale de Rouen y la Bibliothèque Municipale de Montauban), pero también hemos acudido a las de Alemania (Bayerische Staatsbibliothek de Munich, Herzog August Bibliothek de Wölfenbüttel, Stadtbibliothek de Nürnberg, Universitäts Bibliothek de Augsburgo), de Bélgica (Universidad de Amberes, Rijks Universiteit de Gante), de Italia (Biblioteca Nazionale Centrale de Roma, Biblioteca Nazionale Marciana de Venecia), de Portugal (Biblioteca Nacional de Lisboa), de Gran Bretaña (British Library), de Austria (Österreichische Nationalbibliothek de Viena), de Argentina (Biblioteca Nacional de Buenos Aires), y de Estados Unidos (The Hispanic Society of America), así como alguna más particular en España y en Francia. Además, a muchas de las bibliotecas reseñadas, tanto españolas como extranjeras (en Europa y en Estados Unidos) hemos acudido personalmente para comprobar los ejemplares, o para cotejar nuestras lecturas.

En todos los casos, hemos utilizado reproducciones de las primeras ediciones de las obras, dejando de lado otras ediciones, cuando las hubo, ya que en una buena parte de ellas los cambios introducidos no eran muchos, y, de todas maneras, no se trataba de realizar ediciones críticas para saber la evolución de la obra, por más que el NTLE sea la base fundamental para realizarlas. Únicamente se ha hecho una excepción con el diccionario nebrisense, por su importancia para la lexicografía posterior, en que, además de la primera edición, hemos incorporado las variantes 
(sólo las variantes) de la edición de 1520, última hecha en vida del autor y corregida por él, que coincide, sustancialmente, con la de 1516, también corregida por Nebrija ${ }^{13}$.

Aunque se ha introducido todo el contenido de los repertorios seleccionados, como se dijo antes, en ocasiones se ha suprimido texto (especialmente en las obras no lexicográficas), cuando resultaba irrelevante para el conocimiento de la palabra. Como el NTLE es un repertorio léxico, no han pasado a él los numerosos nombres propios que aparecen en las fuentes, sean geográficos, de personas, de seres mitológicos, de animales fantásticos, de constelaciones y cuerpos celestes, etc., salvo, evidentemente, cuando están lexicalizados, o cuando constituyen parte de una expresión pluriverbal fijada.

Por lo que se refiere a los diccionarios bilingües y plurilingües, únicamente hemos tenido en consideración la parte español-otra lengua, no la parte en la que nuestra lengua es a la que se vierten las palabras. No se nos oculta que en esa otra parte de los diccionarios hay léxico de enorme interés para la historia de nuestra lengua, pero no es menos cierto que la información, en bastantes ocasiones, hubiese sido muy repetitiva, alargando en exceso el NTLE, y, además, nuestros recursos tanto humanos como económicos resultaban limitados para acometer esa tarea, que queda para fases posteriores del proyecto, si es que retomamos energías para continuarlo. De todos modos, son muchas las excepciones que se han hecho a este principio, ya que hemos llevado al NTLE las voces españolas de todos los repertorios anteriores a 1500, independientemente de su posición en la obra (como entrada o como lengua meta). Igualmente se ha hecho excepción de algunos repertorios posteriores, entre ellos todos los de Nebrija, que no sólo son sus dos diccionarios grandes -los más conocidos, por otra parte-, y los diccionarios que iniciaban la lexicografía bilingüe del español con otra lengua. El lugar que ocupa el español no se ha planteado para las nomenclaturas, ya que en ellas lo importante no es la posición de la lengua, sino el modo de ordenar las informaciones, que, al pasar al NTLE, se muestran según el orden alfabético.

En el momento en que se tuvieron seleccionadas todas las obras, y se hubieron tecleado, se comenzó el proceso de lematización definitiva, esbozado cuando se pasaban los textos a formato electrónico. La diferencia es que entonces se realizaba aisladamente para cada una de las obras manejadas, mientras que ahora se procedía de una manera conjunta, y

13. De esta última hay una edición debida a Gerald J. Macdonald (1981). El contenido léxico de esta salida ha sido analizado por María Lourdes García Macho (1993, 1995 y 2005). 
definitiva. El problema con que nos hemos encontrado en esta fase ha sido el de las numerosas variantes gráficas que constan en los repertorios. Para facilitar la consulta del NTLE, las hemos agrupado todas bajo una sola entrada, remitiendo a ella desde el lugar alfabético que les correspondía a cada una de ellas. Es cierto que son numerosos los reenvíos, pero no lo es menos que de otra manera hubiéramos tenido una inmanejable red de referencias cruzadas que habrían dificultado la consulta de la obra, y habrían enfadado no poco al usuario. Como hizo Gili Gaya, podríamos haber dejado cada forma en el lugar que le hubiese correspondido por el orden del abecedario, pero así la información hubiese aparecido desperdigada en mil lugares de la obra, inconexos entre sí, tanto más cuanto más distantes eran las formas. Pero no nos pareció una forma adecuada de ofrecer los materiales.

La solución adoptada permite ver la historia lexicográfica de la palabra, además de presentar agrupadas las variantes tras la forma de la entrada. Para esta tarea se ha desarrollado otro programa informático en la Universidad Politécnica de Madrid que, además, resalta la forma coincidente con el lema -lo que permite, con un simple vistazo, saber si figura en las fuentes utilizadas-, o pone un asterisco tras él cuando no coincide con ninguna de las variantes registradas, lo cual puede ser de interés para los estudiosos que acudan a consultar el NTLE.

Gracias al sistema informático empleado, la información contenida en los diversos textos ha aparecido ordenada de manera cronológica, para lo cual cada obra va acompañada de una clave con la que se ordena. Si dos o más obras pertenecen a la misma fecha, esa clave, que no figura en la versión impresa, va acompañada de un dígito diferenciador. De esta manera, se ofrecen los datos en una secuencia histórica que vale para conocer no sólo la evolución formal de la palabra en cuestión, o su tratamiento lexicográfico, sino también para ver la filiación y deudas de unas obras con otras.

Cuando se hubo procedido a la lematización del conjunto de las informaciones, que en total han sobrepasado largamente los 600000 registros en la base de datos, se procedió a una impresión en papel, con un formato similar al que tiene la versión impresa, sobre la que se ha efectuado un doble proceso de corrección, para asegurarnos de la calidad del contenido, lo cual, por otro lado, es obvio. Esta tarea ha llevado más tiempo del previsto, por los errores detectados, lo que nos ha obligado a una tercera lectura, cuando creíamos que ya estaba el trabajo culminado. Sin dudas, los yerros e inconsistencias serán menores de este modo, aunque quedarán todavía, pues ninguna obra humana es perfecta. 
Con todos los datos unificados, nos ha sido posible corregir errores que habían pasado desapercibidos al tratar las obras aisladamente, o que no habíamos podido solucionar a falta de mayor información. Ha sido también éste el momento en que hemos podido solventar muchas de las dudas que habían quedado durante el proceso de tecleado. Pero también nos ha obligado a unificar la puntuación en aquellos lugares en que lo contenido es similar, y que, al ser tratado independientemente, se había codificado según el criterio de cada colaborador.

Sabíamos de la dependencia de unas obras de otras, que, ahora, queda bien patente, pero también, al reunir todos los datos, hemos podido comprobar nuevas filiaciones y deudas. Queda, a partir de estos momentos, una enorme labor de estudio, pues antes no se habían entrevisto muchas de las concomitancias que se muestran con nitidez al presentar todos los diccionarios agrupados y ordenados, como se puede apreciar en la larga lexicografía con el inglés (cfr. Nieto Jiménez / Alvar Ezquerra 2006). En otras ocasiones se aprecia cómo se han repetido afirmaciones que no tenían consistencia, o que deben ser precisadas, como la deuda de Stevens respecto a Minsheu (cfr. Alvar Ezquerra / Nieto Jiménez 2003), o la de Pedro de Alcalá con respecto a Nebrija (cfr. Alvar Ezquerra, 2006c). "Disponer de un modo conjunto de todas las informaciones nos proporciona un excelente panorama de la historia de nuestro léxico y de la representación de cada una de las palabras a través de los diccionarios, pero además se convierte en un instrumento de primera magnitud para ver la filiación y la interdependencia de los diccionarios, y eso que únicamente hemos recogido las primeras ediciones de las obras, excepción hecha, como he comentado, de Nebrija, aunque en una sola de sus obras. Es más, las posibilidades que nos brinda una base de datos nos permite comparaciones entre obras, entre series de obras, entre repertorios de una misma época, o la búsqueda de soluciones para una voz de otra lengua en diversos elencos, e, incluso, rastrear la actividad de un lexicógrafo cuando es autor de varios repertorios, etc." (Alvar Ezquerra 2006a: 55).

Ha sido ciertamente revelador comprobar cómo los errores y erratas se transmitían de un elenco a otro. En este sentido, el NTLE se convierte en un excelente instrumento para averiguar las fuentes empleadas por determinados autores, o para seguir la presencia de un lexicógrafo en los diccionarios posteriores, o para conocer qué edición de una obra pudieron manejar sus seguidores. En este sentido, cabe hablar de la fidelidad de los diccionarios ingleses con respecto a los anteriores, pese a las innovaciones que hay en todos ellos. En ocasiones, nuestro trabajo nos ha llevado a consultar no sólo varias ediciones de un mismo repertorio, sino 
hasta diversos ejemplares de una misma edición, lo que nos ha permitido descubrir emisiones distintas, como las que detecté para la Bibliotheca hispanica de Richard Percivale (cfr. Alvar Ezquerra 2002: 175-176).

El trabajo está finalizado. Han sido muchos años de dedicación y de renuncias. Me gusta recordar las palabras del humanista Juan Lorenzo Palmireno en la nota "Al lector" que hay después del octavo abecedario del Vocabvlario del hvmanista:

\footnotetext{
Mi propófito fue poner nueue abecedarios, tratando en el v́ltimo las antiguallas que al principio prometo: pero quien tiene familia que fuftentar en años tan caros, y fin Mecenate, que ayude al papel, por fuerça ha de boluer a tras; contemplando que pone fus ojos, falud, fama, y dinero a votos del vulgo: el qual con fu acoftumbrada ingratitud dize, que vendo muy caro efte librico: en el qual, allende de los pefcadores y caçadores que he eftrenado, y combidado, para ver cómo quadraba lo que yo facaua de los libros con lo que ellos experimentan. En fólo Hippólito Saluiano, y los otros autores que de peces efcriuen gafté veynte y cinco ducados: y por no dexar agrauiado al lector de lo que aquí efperaua, hafta que yo tenga dinero, para facar a parte lo que le he prometido, lea entre tanto lo que fe figue (Lorenzo Palmireno 1569: II, 114).
}

Con otras apariencias, bajo otras formas, en otros tiempos, las dificultades y los problemas continúan siendo los mismos. Dicho con la desesperación y el estoicismo del autor del Eclesiastés (1,9), y como advertencia, y alivio, para quienes en el futuro intenten abrirse paso en este mundo: nihil novum sub Sole.

Esperamos que los esfuerzos no sean baldíos y sirvan para el mejor conocimiento de nuestro léxico, de nuestros diccionarios y de nuestra lengua. Indocti discant, et ament meminisse periti ("que los que no saben aprendan, y los instruidos gocen al recordar"), que cuentan decían los edictos romanos. 


\title{
OS DICIONÁRIOS COMO FONTE LEXICOGRÁFICA ${ }^{1}$
}

\author{
Dieter Messner
}

Paris-Lodron-Universität Salzburg

Rafael Bluteau publicou a partir de 1712 o Vocabulário Portuguez e Latino que, em grande parte, já foi redigido antes de 1700; nele há duas entradas: uma Santiago, e a outra Compostela:

\begin{tabular}{|c|c|}
\hline Bluteau (1712-1728) & Covarrubias (1611) \\
\hline $\begin{array}{l}\text { Compostella, ou San-Thiago de Galiza. } \\
\text { Cidade, \& Arcebispado de Galiça em } \\
\text { Hespanha. } \\
\text { Covarrubias, curioso investigador de } \\
\text { Etymologias, confessa, que lhe não foy } \\
\text { possível achar a deste nome; \& sospei- } \\
\text { ta, que Compostella se disse de alguma } \\
\text { estrella, que assinalasse o lugar, donde } \\
\text { estava o corpo do Santo Apostolo. [...] } \\
\text { V. San-Tiago. }\end{array}$ & $\begin{array}{l}\text { Compostella }[\ldots] \text { La etimologia de } \\
\text { Compostela no la sé con certidumbre; } \\
\text { pudo haberse dicho de alguna estrella o } \\
\text { cometa, que señalase el lugar donde esta- } \\
\text { ba el cuerpo santo del Apóstol. }\end{array}$ \\
\hline $\begin{array}{l}\text { Santiago. Cidade de Hespanha, no Re- } \\
\text { yno de Galliza. Tem Arcebispo, \& Uni- } \\
\text { versidade. } \\
\text { He celebre pelo grande concurso dos pe- } \\
\text { regrinos, que vão visitar na Igreja Metro- } \\
\text { politana o corpo do Apostolo Santiago. } \\
\text { Chama-se por outro nome Compostella, } \\
\text { que segundo alguns he o Brigantium de } \\
\text { Antonino, Dion, \& Osório [...]. V. Com- } \\
\text { postella. }\end{array}$ & $\begin{array}{l}\text { Santiago. Ciudad populosa y memorada } \\
\text { en toda la cristiandad, pues de todas par- } \\
\text { tes della vienen en peregrinación a visitar } \\
\text { el cuerpo del apóstol Santiago }[\ldots] .\end{array}$ \\
\hline
\end{tabular}

1. No ano 1986, com motivo dum colóquio de lexicografia (cfr. Ramón Lorenzo 1988), reunira-se na cidade de Santiago de Compostela um grupo de importantes lexicógrafos das línguas românicas. Alguns, infelizmente, já desapareceram. Para que a memória deles continue, reproduzo uma foto em anexo. 
Bluteau menciona expressis verbis a fonte, o lexicógrafo espanhol Sebastián de Covarrubias Horozco, o autor do Tesoro de la lengua castellana o española, deixando ver um comportamento que muitos lexicógrafos antigos e modernos não mostram tão frequentemente, ocultando as fontes.

Se compararmos as citações sacadas dos dois dicionários, podemos constatar uma semelhança bastante alta. É provável que Bluteau não só tenha copiado a etimologia proposta pelo Covarrubias -ele o confessa-, mas sim também outros troços da microestrutura do modelo espanhol, que sublinhei no texto. E com este exemplo já estamos no centro da minha contribuição.

Fui convidado para tratar dos dicionários como fonte lexicográfica, e concentrar-me em dicionários portugueses, por isso não me vou ocupar de dicionários espanhóis, os quais, ao contrário do que aconteceu com os portugueses, já foram analisados sob este ponto de vista. De cada dicionário espanhol com certa importância já se conhece a genealogia, por exemplo do Universal Vocabulario de Alfonso de Palencia (1490)-dizem- uma fonte foi o Elementarium Doctrinae rudimentum de Papias, do Tesoro de Covarrubias (1611) uma fonte foi o Calepino, etc., etc. (cfr. Azorín Fernández 2000). Não conheço o número exacto de estudos, são muitíssimos, que se fizeram sobre os dicionários que copiavam as várias edições do Diccionario de la lengua española (DRAE). E não só os lexicógrafos espanhóis copiaram o DRAE, mas sim também os autores de dicionários galegos, como mostrou Santamarina, que chamou a atenção sobre a forma como Sobreira copiou o DRAE de 1780: "se se cotexan as papeletas de Sobreira co diccionario da RAE 1780 o asunto resulta case escandaloso" (Santamarina 2003b: 54). E para a língua catalã consta: "El diccionari de l’Academia española serà guia universal dels de la nostra llengua" (Rico / Solà 1995: 127).

A minha presença aqui justifica-se por ser responsável de um projecto de grande envergadura que se chama Dicionário dos dicionários portugueses. Publiquei já 20 volumes, com um total de 12.000 páginas (Messner 1994- ).

Para o espanhol existe uma obra semelhante, o Tesoro lexicográfico 1492-1726, de Samuel Gili Gaya (1947-1957); infelizmente ficou inacabado. Mas teremos dentro de pouco um Nuevo Tesoro, o NTLE, redigido por Manuel Alvar e Lidio Nieto.

Com a ajuda da obra de Gili Gaya foi possível esclarecer a história de palavras espanholas, e a genealogia dos dicionários. Só quero mencionar o exemplo da palavra aferes à que Nebrija atribuíu o significado 'nugae', quer dizer 'coisas sem importância', um significado errado que se conservou em todos os dicionários seguintes, durante mais de dois séculos, até ao ano de 1726. Só o Diccionario de Autoridades corrige este significado. 
Descobrir a genealogia de palavras pode fazer-se agora também para a língua galega com o Diccionario de diccionarios, um CD-Rom editado por Antón Santamarina (2003b). E também já está pronto o Tresor lexicográfic valencià (Guardiola Savall 2006).

O Dicionário dos dicionários portugueses reúne uns 40 dicionários e obras de interesse lexicográfico, publicados entre 1554 e 1858. Comecei, claro, com muitos mais dicionários; mas muitos são cópias de dicionários anteriores, por isso, tirei-os da minha lista actual (cfr. http://www.sbg. ac.at/rom/people/prof/messner/dddport.htm).

As entradas portuguesas do dicionário português-latim de Bento Pereira (1697) foram copiadas, pela maior parte, por um lexicógrafo desconhecido em 1701, para o primeiro dicionário bilingue português-inglês (A. J. 1701), e por Alewyn em 1714, para o primeiro dicionário portuguêsflamengo (Alewyn / Collé 1714).

\begin{tabular}{|c|c|c|}
\hline Pereira (1697) & A.J. (1701) & Alewyn / Collé (1714) \\
\hline $\begin{array}{l}\text { abano, ou avano. Flabe- } \\
\text { llum, i. }\end{array}$ & abano: A fan. & $\begin{array}{l}\text { abano, or, avano. Een } \\
\text { waajer. }\end{array}$ \\
\hline $\begin{array}{l}\text { abano de enxotar mos- } \\
\text { cas. Muscarium, i. }\end{array}$ & $\begin{array}{l}\text { abano de enxotar mos- } \\
\text { cas: A flie flap. }\end{array}$ & $\begin{array}{l}\text { abano de enxotar mos- } \\
\text { cas. Eeen waajer, on vlie- } \\
\text { gen te verjaagen. }\end{array}$ \\
\hline abanos. Collaria, ium. & abanos: Collars. & $\begin{array}{l}\text { abanos: halsbanden, } \\
\text { kraagen. }\end{array}$ \\
\hline $\begin{array}{l}\text { abanos da camisa. Pata- } \\
\text { giata, ae... }\end{array}$ & $\begin{array}{l}\text { abanos de camisa: The } \\
\text { gathering of the neck... }\end{array}$ & $\begin{array}{l}\text { abanos de camisa. } \\
\text { Hemds banden... }\end{array}$ \\
\hline
\end{tabular}

Bluteau (1712-1728) foi a fonte de Folqman (1755), de Marquês (17581764), autor do primeiro dicionário português-francês, e de Transtagano (1773), autor do segundo dicionário português-inglês. 


\begin{tabular}{|c|c|c|c|}
\hline Bluteau (1712-1728) & Folqman (1755) & Marques (1758-1764) & Transtagano (1773) \\
\hline $\begin{array}{l}\text { abanar. Agitar, \& } \\
\text { causar vento }[. . .] \text { ven- } \\
\text { tilare... }\end{array}$ & $\begin{array}{l}\text { abanar (causar vento), } \\
\text { ventilare... }\end{array}$ & $\begin{array}{l}\text { abanar (causar vento), } \\
\text { ventilare.... }\end{array}$ & abanar, v. a. to fan. \\
\hline $\begin{array}{l}\text { abanar o fogo: ignem } \\
\text { flabello excitare... }\end{array}$ & $\begin{array}{l}\text { abanar o fogo, ignem } \\
\text { ventilare... }\end{array}$ & $\begin{array}{l}\text { abanar o fogo, ignem } \\
\text { ventilare... }\end{array}$ & $\begin{array}{l}\text { abanar o lume, ou } \\
\text { o fogo, to kindle the } \\
\text { fire... }\end{array}$ \\
\hline $\begin{array}{l}\text { abanar hum arvore: } \\
\text { arborem quatere... }\end{array}$ & $\begin{array}{l}\text { abanar hum arvore, } \\
\text { arborem quatere... }\end{array}$ & $\begin{array}{l}\text { abanar huma arvore, } \\
\text { arborem quatere... }\end{array}$ & $\begin{array}{l}\text { abanar as arvores, to } \\
\text { shake the trees... }\end{array}$ \\
\hline $\begin{array}{l}\text { abanar moscas. Vid. } \\
\text { enxotar. }\end{array}$ & $\begin{array}{l}\text { abanar as moscas, } \\
\text { muscas abigere. }\end{array}$ & $\begin{array}{l}\text { abanar as moscas, } \\
\text { muscas abigere. }\end{array}$ & $\begin{array}{l}\text { abanar as moscas, to } \\
\text { drive the flies away... }\end{array}$ \\
\hline $\begin{array}{l}\text { abanarse. Auram fla- } \\
\text { bello colligere. }\end{array}$ & $\begin{array}{l}\text { abanar-se, aurem fla- } \\
\text { bello colligere... }\end{array}$ & $\begin{array}{l}\text { abanar-se, auram fla- } \\
\text { bello colligere... }\end{array}$ & $\begin{array}{l}\text { abanar-se, to coll } \\
\text { one's self with a fan. }\end{array}$ \\
\hline $\begin{array}{l}\text { abanar as orelhas: } \\
{[\ldots] \text { Surdum simulare. }}\end{array}$ & $\begin{array}{l}\text { abanar as orelhas } \\
{[\ldots] \text {, surdum simulare. }}\end{array}$ & $\begin{array}{l}\text { abanar as orelhas } \\
{[\ldots] \text {, surdum simulare. }}\end{array}$ & $\begin{array}{l}\text { abanar as orelhas, to } \\
\text { give a negative answer. }\end{array}$ \\
\hline
\end{tabular}

Entre os muitos dicionários portugueses que consultei antes de começar o meu projecto existe mesmo um dedicado às ciências naturais, que descreve, entre outros, também os animais. É provável que o autor não tenha tomado obras científicas como base, mas, sim, o dicionário de Bluteau.

É o Diccionario Portuguez das plantas, arbustos, matas, arvores, animaes quadrúpedes, e reptis, aves, peixes, mariscos, insectos, gomas, metaes, terras, mineraes, \&. [...] escrito por José Monteiro de Carvalho (Carvalho 1765). 


\begin{tabular}{|c|c|}
\hline Bluteau (1712-1728) & Carvalho (1765) \\
\hline 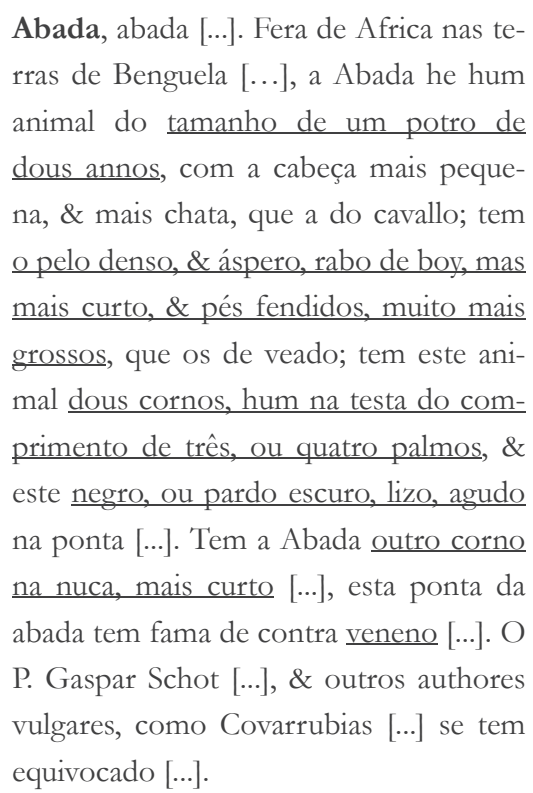 & $\begin{array}{l}\text { Abada. Animal quadrúpede, e feroz, que } \\
\text { se cria nas terras de Africa: tem a grande- } \\
\text { za de hum potro de dous annos, o pello } \\
\text { denso, e áspero, rabo de Boi, porém cur- } \\
\text { to, os pés fendidos, e grossos, com duas } \\
\text { pontas: huma na testa de quatro palmos } \\
\text { de comprido, negra, liza, e aguda; outra } \\
\text { na nuca de menor grandeza: qualquer } \\
\text { dellas he singular antídoto para todo o } \\
\text { género de veneno. }\end{array}$ \\
\hline
\end{tabular}

Uma breve anotação entre parêntese: Bluteau é uma das raras excepções à pouca presença portuguesa na dicionarística espanhola.

No primeiro dicionário da Academia espanhola, publicado entre 1726 e 1739, o que chamamos hoje Diccionario de Autoridades, encontramos também Rafael Bluteau. Nos volumes publicados a partir de 1734 achamos citações do dicionário de Bluteau (Gómez-Pablos 2004):

Galardon: El premio, recompensa ò retribucion de los méritos, servicios y beneficios. Bluteau en

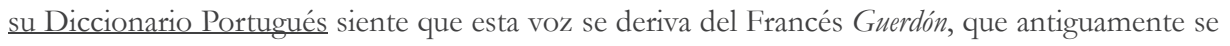
decía Guerredon, esto es don o premio de guerra [segundo Corominas: origen germánico].

Roque: Pieza grande en el juego del Axedrez, que se coloca en la esquinas del tablero. Camina por línea recta, y puede andar de una vez todas sus casas, si las halla desembarazadas de otras piezas. Covarr. dice que significa la fortaleza que se suele hacer al frente de los enemigos: y assi algunos le dan la etymologia de Roca: y Bluteau en su Diccionario Portugues previene, que algunos se la dan de la voz Persa Rokh, que significa caballero errante o aventurero [Corominas: árabe].

Acredito que o Dicionário dos dicionários portugueses vai ser útil muito tempo, porque nem no Brasil nem em Portugal existe algo semelhante ao Corpus diacrónico del español (CORDE) da RAE em Madrid. Existem muitas tentativas de criar corpora, todos pequenos, nenhum projecto de grande envergadura. Se compararmos os resultados já publicados do Corpus informatizado do português medieval (CIPM) da Universidade Nova 
de Lisboa com o Vocabulário do Português medieval, um CD-Rom de António Geraldo da Cunha (2002), constatamos lacunas:

\begin{tabular}{|c|c|c|}
\hline \multicolumn{2}{|c|}{ CIPM (consulta 1.11.2006) } & Cunha (2002) \\
\hline \multirow{2}{*}{\multicolumn{2}{|c|}{$\begin{array}{l}\text { DULDAR cf. DUVIDAR } \\
\text { Ocorrências: } \mathbf{3}\end{array}$}} & \multirow{5}{*}{$\begin{array}{l}\text { duldar (4) vb. Duvidar: sXIII Fuero } \\
\text { Real III.820; S XIV Gen.Estoria 23,1; } \\
\text { Crónica Gen.Gallega 897,50; Hist.Tro- } \\
\text { yana 33.33.; } \\
\text { dultar. (7) vb. Duvidar: sXIII CSM 50.3, } \\
\text { sXIV Crónica Gen.Gallega 98.43; San- } \\
\text { toGraal 119b7; Miragres 225,9; Tristan } \\
\text { 79.3; Hist.Troiana 104.4 Crón.Troyana } \\
\text { 1. 156.6. }\end{array}$} \\
\hline & & \\
\hline C6 & duldariã 1 (Foro real) & \\
\hline $\mathrm{CP} 3$ & dulte 1 (CantigasEsc.Mald.) & \\
\hline PP f.s. & dultada 1 (CEM) & \\
\hline
\end{tabular}

Temos que falar tanto de dicionários portugueses em tanto que fonte de dicionários portugueses, como também de dicionários escritos em outras línguas, a espanhola, sobretudo, e a francesa também, que os lexicógrafos portugueses usaram para redigir as suas obras.

Também temos que distinguir entre dicionários receptores que copiaram inteiramente as entradas do seu modelo, e os outros que só tiraram uma parte do modelo, ou a transformaram.

Com a citação da entrada Compostela, tomada de Bluteau, mostrei que o Covarrubias (1611), chamado por Bluteau "curioso investigador de etimologias", era uma fonte importante para explicar a etimologia de palavras portuguesas em 1700, mas nem sempre Bluteau aceitou cegamente o que escreveu Covarrubias. Por isso reproduço uma parte da entrada Abada:

O P. Gaspar Schot [...], \& outros authores vulgares, como Covarrubias [...] se tem equivocado.

Covarrubias foi também a fonte para difundir as explicações etimológicas em Portugal que o Padre Guadix já redigiu antes de 1593 (Guadix 1593; cfr. Messner 2007a).

O seguinte exemplo, que ilustra a prolongada influência de Covarrubias em Portugal, provém do Dicionário da Academia Portuguesa, publicado em 1793: 


\begin{tabular}{|c|c|}
\hline Academia das Ciências (1793) & Covarrubias (1611) \\
\hline $\begin{array}{l}\text { Alquitira. s. f. Certo arbusto de flores } \\
\text { polypetalas, e da familia das leguminosas. } \\
\text { He denominada por Linneo Astragalus } \\
\text { tragacantha. He hum arbusto pequeno, } \\
\text { espinhoso, que nasce frequentemente na } \\
\text { Asia, nas vizinhanças de Alepo, em Can- } \\
\text { dia, e outras mais partes [...]. } \\
\text { He voz puramente Arabiga, segundo } \\
\text { Covarrubias, que traz as origens, que lhe } \\
\text { assignão Diogo de Urréa e o P. Guadix. } \\
\text { A. da Cruz, Recop. } 2,8 \text { Fação este cole- } \\
\text { rio. R. Sarcaiola nutrida [...] alquitira, \&c. } \\
\text { Azev. Correcç. 2,2,121 Alquitira e gom- } \\
\text { ma arabiga. Morat. Pratic. 1,30,1 Gomma } \\
\text { alcatira, amendoas doces, de cada hum } \\
\text { meia onça. }\end{array}$ & $\begin{array}{l}\text { Alquitira. Es cierto género de goma que } \\
\text { distila una planta dicha [...] tragacantha, } \\
\text { id est, hircispinae; nace ordinariamente } \\
\text { en Arcádia y en Creta y en el Peloponeso; } \\
\text { descríbela Dioscórides, lib. 3, cap. 21; y } \\
\text { por esta razón Ant. Neb. vuelve dragan- } \\
\text { tum. Los médicos la llaman gummi dragan- } \\
\text { tina, los arábigos alquitira; y dice Diego de } \\
\text { Urrea que se dijo así del verbo cathare, } \\
\text { que sinifica distilar, porque es gota que } \\
\text { se distila del dicho árbol. Paréceme que } \\
\text { le da la mesma raiz que dio a alquitara. } \\
\text { El padre Guadix dice haberse dicho al- } \\
\text { quitara de quitir, que vale mucho, porque } \\
\text { echada en agua poça cantidad della se } \\
\text { extiende y se hace mucho. }\end{array}$ \\
\hline
\end{tabular}

Quando encontrei esta palavra no dicionário português de 1793 perguntei-me, por quê é que, pouco antes do ano de 1800, os lexicógrafos académicos copiaram o resumo que Covarrubias fez das duas etimologias propostas, uma pelo Padre Guadix, do que o livro recebeu a licença em 1593, quer dizer já 200 anos antes da publicação do dicionário português de 1793, e a outra por Diego de Urrea, uma autoridade -parece- ao redor de 1600, porque é nomeado por Covarrubias no prólogo ao leitor assim: "Yo he consultado a Diego de Urrea, intérprete del rey nuestro señor".

Os dicionários portugueses posteriores são mais explícitos:

Alquitira ou Alcatira, s. f. (do Arab. alcatira, derivado do verbo cátara, pingar, destillar, gottejar, porque a gomma alcatira ou tragacantho transsuda da planta), a gomma tragacantho; it. a planta que a dá (astragalus tragacantha) (Constâncio 1836).

Ponho ao lado do dicionário de 1845 a entrada do de 1793: 


\begin{tabular}{|c|c|}
\hline Diccionario Universal (1845) & Academia das Ciências (1793) \\
\hline $\begin{array}{l}\text { Alquetira, (ant.) V. Alquitira. } \\
\text { Alquitira, s. f. (bot.) Arbusto de flores } \\
\text { polypétalas, e da familia das legumino- } \\
\text { sas, denominada por Linneo astragalus } \\
\text { tragacantha. É pequeno e espinhoso; dá } \\
\text { umas flores purpurinas, ás quaes succe- } \\
\underline{\text { dem bainhas villosas, inchadas, e cheias }} \\
\underline{\text { de pequenos grãos da figura de um rim. }} \\
\underline{\text { Do tronco e ramos d'esta planta, corre }} \\
\underline{\text { naturalmente, ou por incisões que se fa- }} \\
\underline{\text { zem, um succo gommoso (draganthum }} \\
\text { gummi) branco ou cinzento, luzidio, } \\
\underline{\text { leve, sem gosto nem cheiro, que tambem }} \\
\underline{\text { se chama alquitira. Quando se lança de }} \\
\text { infusão em agua, incha muito, e parece } \\
\underline{\text { uma especie de creme gelado. Esta mu- }} \\
\underline{\text { cilagem de gomma alquitira emprega-se }} \\
\underline{\text { na pharmacia, e serve para outros usos. } S} \\
\text { arab. alcatira; do v. cátara, pingar, distillar, } \\
\text { gottejar; porque a gomma alcatira, ou tra- } \\
\text { gacantho transsuda da planta. }\end{array}$ & $\begin{array}{l}\text { Alquitira. s. f. } \\
\text { Certo arbusto de flores polypetalas, e da } \\
\underline{\text { familia das leguminosas. He denomina- }} \\
\underline{\text { da por Linneo Astragalus tragacantha. He }} \\
\text { hum arbusto pequeno, espinhoso [...]. As } \\
\text { flores são pequenas, leguminosas, e quasi } \\
\text { purpurinas. Ás flores succedem bainhas } \\
\text { villosas, inchadas, e chêas de pequenos } \\
\text { grãos da figura de hum rim. Nos prin- } \\
\text { cipios de Junho, e mezes seguintes corre, } \\
\underline{\text { ou naturalmente, ou por incisões feitas no }} \\
\underline{\text { tronco ou ramos deste arbusto, em ma- }} \\
\text { neira de fio, ou fita mais ou menos com- } \\
\text { prida, enrolada, crespa, ou em grumos, } \\
\underline{\text { hum succo gommoso, branco, ou cinzen- }} \\
\underline{\text { to, luzidio, leve, sem gosto, ou cheiro, que }} \\
\underline{\text { se chama tambem gomma alquitira, ou só }} \\
\underline{\text { alquitira. Quando se lança de infusão em }} \\
\underline{\text { agoa se incha muito, e parece huma es- }} \\
\text { pecie de creme gelado. Esta mucilagem } \\
\underline{\text { da gomma alquitira serve na Pharmacia, }} \\
\text { e outros usos. He voz puramente Ara- } \\
\text { biga, segundo Covarrubias, que traz as } \\
\text { origens, que lhe assignão Diogo de Urréa } \\
\text { e o P. Guadix. A. da Cruz, Recop. } 2,8 \\
\text { Fação este colerio. R. Sarcaiola nutrida } \\
\text { [...] alquitira, \&c. Azev. Correcç. } 2,2,121 \\
\text { Alquitira e gomma arabiga. Morat. Pratic. } \\
1,30,1 \text { Gomma alcatira, amendoas doces, } \\
\text { de cada hum meia onça. }\end{array}$ \\
\hline
\end{tabular}

Alquitíra, s. f. (do Arab. alcatira) Herva, e juntamente gomma medicinal. (Dragacanthum gummi). Morat. Prat. 1. 30. 1. S. Alguns dizem alquetiro (Morais 1858 ${ }^{\circ}$ ).

Alquitira, s. f. (Do árabe alcatira) O mesmo que Alcatira [...] (Vieira 1871-1874).

Alcatira s. f. ant. (Do árabe alcatira; do verbo catara, pingar, distillar.) Arbusto de flores polypétalas, da família das leguminosas. Produz um succo gommoso, branco, cinzento, inodoro e insípido; é uma mucilagem empregada na Pharmacia [...] (Vieira 1871-1874).

Constâncio deve ter conhecido também o dicionário de Covarrubias, porque o seu texto se parece muito ao de Covarrubias. Foi copiado pelos lexicógrafos do Diccionario Universal (1845), no qual o resto da microestrutura provém do dicionário académico de 1793 (isso fez também Domingos Vieira). 
Os académicos portugueses de 1793 foram prudentes. Fizeram bem porque algumas explicações são extravagantes. Guadix, por exemplo, deduz o nome da capital da Áustria, Viena, de elementos árabes. Os académicos portugueses não transcrevem as duas propostas etimológicas de Covarrubias, porque não souberam qual a melhor entre as duas. Já tiveram entre mãos uma obra, os Vestígios da Língua Arábica em Portugal, ou lexicon etymologico das palavras, e nomes portuguezes, que tem origem arábica (Sousa 1789). Muitas vezes aproveitam dela, mas na edição de 1789 a palavra alquitira ainda não está; por isso foram forçados a recorrer a Covarrubias, sem meterse nas explicações divergentes entre Urrea e Guadix.

De onde é que vem então a frase "derivado do verbo cátara 'pingar, distillar"'? Constâncio (1836) copiou a explicação etimológica da palavra alcatrão que está em Sousa (1789), porque este deduz alcatrão do verbo árabe cátara; verbo que está em Covarrubias e que provém de Urrea:

Alcatrão [...] Alcatrán. Espécie de bitume liquido. Deriva-se do verbo cátara pingar, distillar, cahir ás pingas; porque o pez se colhe das gotas da resina, que o pinheiro de si distilla (Sousa 1789).

Na nova edição do mesmo livro sobre Vestígios arábigos, feita em Lisboa em 1830, já está alquitira com o étimo:

Alquitira [...] Arab. Alcatira. He nome de certo arbusto, ou da goma de certa raiz (Sousa / Moura 1830).

Por isso, os redactores do Morais (1858 $)$ cópiam esta explicação e não reproduzem aquela do Diccionario Universal (1845).

Vemos então, graças a estes exemplos que são muitos os dicionários espanhóis que serviam de fonte aos antigos dicionários portugueses.

É interessante constatar que ainda hoje, os dicionários portugueses modernos recorrem a fontes espanholas para explicações etimológicas de palavras portuguesas.

Comparei os comentários etimológicos sobre a palavra chinela em sete dicionários portugueses modernos (Messner 2007b), e constatei que existe uma semelhança textual bastante grande entre as explicações etimológicas dos dicionários citados.

A solução do enigma é que todos os lexicógrafos portugueses citados copiaram o que foi escrito, bastantes anos antes, pelo lexicógrafo espanhol Joan Corominas (1954-1957) no Diccionario crítico etimológico de la lengua castellana, texto retomado letra por letra na edição de 1980. 
Como já disse antes, a minha especialidade é a dicionarística histórica da língua portuguesa: por isso vou servir-me de exemplos tirados do meu Dicionário dos dicionários portugueses, para ilustrar a minha contribuição.

Já mencionei o facto de existirem dicionários que copiavam por inteiro o que está em outros dicionários. Um exemplo: um dos dicionários portugueses que contem microestruturas que diferem de maneira vistosa das definições contidas em dicionários anteriores é o Diccionario da Lingoa Portugueza publicado pela Academia Real das Sciencias de Lisboa (Academia das Ciências 1793), que só contém a letra A, um dicionário já mencionado antes, quando falei do arabista espanhol Guadix.

Por um lado encontramos no dicionário académico muitas descripções científicas de plantas e animais (já o vimos na entrada alquitira, onde aparece uma informação moderníssima, a do botânico Linneo, ao lado de uma etimologia proposta 200 anos antes):

\footnotetext{
agoa [...]. As agoas naturaes destilladas sáo tambem do numero das artificiaes, estas, e as da chuva sáo as mais puras, que se conhecem, e no seu pezo especifico sáo para a agoa do mar :: 10000 : 10263; sáo para o ouro :: $1: 19114$ e sáo para o ar :: $800: 1$; estando o barometro em 28 pollegadas, e o thermometro de Reaumur em 14112 gráos [...].
}

Pelo outro lado há definições de palavras triviais, que diferem das dos dicionários anteriores, e em terceiro lugar há microestruturas não acompanhadas de textos reais.

Esta falta de ilustrações contrasta com uma frase do prólogo, onde podemos ler:

O Diccionario [...] deverá conter os vocabulos puramente Portuguezes em todas as suas significações [...] inteiramente com o uso regular [...] fixado tudo pelos exemplos dos Autores Classicos.

A discrepância entre a metodologia proposta no prólogo e a realidade tal qual a encontramos nas entradas conduz-me a comparar o dicionário académico português com obras estrangeiras, também com a da Academia espanhola, o chamado Diccionario usual (RAE 1780).

Não é dificil ver que nas microestruturas de muitas entradas as definições portuguesas e espanholas são semelhantes, o que não pode ser um puro acaso. 


\begin{tabular}{|c|c|}
\hline RAE (1780) & Academia das Ciências (1793) \\
\hline $\begin{array}{l}\text { Ala. Mil. La parte de tropa que cubre el } \\
\text { centro del exército por qualquiera de los } \\
\text { dos costados (p. } 36 \text { ). }\end{array}$ & $\begin{array}{l}\text { Ala Milic. A parte da tropa, que cobre o } \\
\text { centro do exercito por qualquer dos dous } \\
\text { costados (p. 178). }\end{array}$ \\
\hline $\begin{array}{l}\text { Alcanzadura s. f. Alb. La hinchazon que } \\
\text { suele hacerse a las caballerías de algun } \\
\text { golpe de hierro, ó piedra en la parte trase- } \\
\text { ra del pie junto á la uña, ó casco. Llámase } \\
\text { tambien así la contusión, ó herida que se } \\
\text { les hace topándose el pie con la mano } \\
{[\ldots] \text { (p. 44) [= Diccionario de Autoridades, }} \\
\left.1770^{2}, 148\right] .\end{array}$ & $\begin{array}{l}\text { Alcançadura, s. f. Alveit. Inchação, que } \\
\text { se costuma fazer nas cavalgaduras por al- } \\
\text { gum golpe de ferro o de pedra na parte } \\
\text { posterior do pé junto á unha ou casco; ou } \\
\text { tambem a contusão ou ferida, que ellas } \\
\text { mesmas se fazem a si, tocandose com a } \\
\text { ferradura do pé na mão [...] (p. 190). }\end{array}$ \\
\hline $\begin{array}{l}\text { Algo s. m. ant. Bienes, hacienda, caudal; } \\
\text { en este sentido se usó también antigua- } \\
\text { mente en número plural (p. } 50 \text { ) }\end{array}$ & $\begin{array}{l}\text { Algo s. m. antiq. Fazenda, haver, cabedal, } \\
\text { bens. Tambem se usa neste sentido no } \\
\text { plural (p. 212). }\end{array}$ \\
\hline
\end{tabular}

Alguns colegas atribuem certa importância ao primeiro e único volume de este dicionário:

Em suma, verifica-se que o $1 .^{\circ}$ Dicionário da Academia é ainda hoje um modelo de técnica lexicográfica, elaborado com o maior rigor científico [...] (Casteleiro 1993: XXII).

Eu acho que este dicionário, visto sob uma perspectiva moderna, não merece estes elógios.

De vez em quando os três lexicógrafos citam de maneira explícita o dicionário castelhano da RAE.

$\mathrm{Na}$ entrada alcorque podemos ler:

\begin{tabular}{|c|c|c|}
\hline $\begin{array}{c}\text { Academia das Ciências } \\
\text { (1793) }\end{array}$ & $\begin{array}{l}\text { Diccionario de Autori- } \\
\text { dades (1770) }\end{array}$ & RAE (1780) \\
\hline $\begin{array}{l}\text { Alcorque. s. m. ant. Certo } \\
\text { calçado antigo, que tinha a } \\
\text { sola de cortiça. No Diccion. } \\
\text { Castelhano se diz, que pare- } \\
\text { ce vir do Arabigo córque, } \\
\text { que significa o mesmo, } \\
\text { accrescentado o articulo } \\
\text { al [...]. }\end{array}$ & $\begin{array}{l}\text { Alcorque, s. m. antiq. Za- } \\
\text { pato ú outro calzado, que } \\
\text { tenia la suela de corcho. } \\
\text { Parece viene del árabe } \\
\text { corque, que significa lo } \\
\text { mismo añadido el artículo } \\
\text { al }[\ldots] \text {. }\end{array}$ & $\begin{array}{l}\text { Alcorque, s. m. antiq. Za- } \\
\text { pato, ú outro calzado, que } \\
\text { tenía la suela de corcho. } \\
\text { Parece viene del árabe } \\
\text { corque, que significa lo } \\
\text { mismo añadido el artículo } \\
\text { al [...]. }\end{array}$ \\
\hline
\end{tabular}


O mesmo dicionário da Academia Portuguesa serviu-se também de uma obra fundamental francesa, a Encyclopédie (1752), traduzindo-a e reorganizando a estrutura interna das entradas, sem indicar, claro, a fonte, que foi, naquela época, proibida em Portugal. A numeração é minha:

Encyclopédie 1752, vol. I. 363ss.

Ammoniac, sel Ammoniac ou Armoniac, sal ammoniacus seu armeniacus (Hist. nat.)

[1] Nous ne connoissons le sel ammoniac des anciens que par les descriptions quils en ont laissé: autant que nous pouvons en juger aujourdhui, il paroît que ce sel étoit assez semblable à notre sel gemme.

[2] Les anciens lui ont donné le nom de sel ammoniac, parce qu'on le trouvait en Libye aux environs du temple de JupiterAmon.

[3] Quelques-uns l'ont appellé sel armoniac, ou armeniac, peut-être à cause du voisinage de l'Armenie ...

[4] Nous connoissons aujourd'hui deux sortes de sel ammoniac, le naturel \& le factice. Le sel ammoniac naturel se tire des soufrieres de Pouzzol, dans cette grande fosse...

Il y a des fentes dans quelques endroits, d'où l'on voit sortir la fumée le jour \& des flammes la nuit. On entasse sur ces fentes des monceaux de pierres; les évaporations salines qui sont continuellement élevées pare les feux soûterrains, passent à travers ces monceaux, \& laissent sur les pierres une suie blanche, qui forme après quelques jours une croûte de sel ...

[5] M. d'Herbelot rapporte dans sa

Bibliothéque orientale que dans le petit pays de Boton en Asie, ... ... que les habitans du pays appellent nuschader.

[6] ... Le Sel ammoniac, si l'on en croit l'illustre Boerhaave, garantit toutes les substances animales de la corruption....
Dicionário português 1793, 276.

Ammoniaco adj. (Sal) Certa especie de Sal.

[2] He denominado pelos antigos sal almoniaceum ou armoneacum, e armenium, ou porque se achava nas vizinhanças do templo de Jupiter Ammon na Lybia,

[3] ou porque os lugares, em que se encontrava erão proximos a Armenia.

[1] As descripções, que os Antigos nos deixarão, deste sal o fazem semelhante ao nosso sal gemma.

[4] Presentemente distinguem-se duas especies de sal ammoniaco, natural, e artificial. O natural se extrahe, principalmente das minas de enxofre do Pouzzol, aonde

sobre as fendas, de que de dia se vê sahir fumo, e de noite chammas, se atravessão pedaços de pedras, por entre as quaes passando as evaporaçôes salinas das minas, deixão em cima das pedras huma ferrugem branca, que alguns dias depois fórma humas crustas de sal, ...

[5] Segundo Herbelot hao tambem no paiz de Botom na Asia,...

... Os naturaes the chamão Muschader ...

[6] ... Boerhaave o julga accommodado para preservar todas as substancias animaes de corrupção ... 
Mais interessante e provavelmente não conhecida é a influência espanhola sobre os dicionários posteriores em Portugal, no século XIX, no que as grandes línguas europeias criaram os seus dicionários.

Os três lexicógrafos académicos de 1793 não foram os únicos em traduzir dicionários espanhóis, sem declará-lo. Em 1806 publicou-se o Novo Diccionario da Lingua Portugueza, composto sobre os que até ao presente se tem dado ao prelo, e Accrescentado de varios vocabulos extrahidos dos Classicos Antigos, e dos Modernos de melhor nota, que se achaõ universalmente recibidos (Novo Diccionario 1806).

É notória a inserção de muitos neologismos recuperados -dizem- no título de autores portugueses antigos e modernos. A verdade é por completo outra: encontrei as palavras também no Diccionario castellano con las voces de ciencias y artes y sus correspondientes en las tres lenguas Francesa, Latina é Italiana, de Esteban de Terreros y Pando (Terreros 1786).

\begin{tabular}{|c|l|l|}
\hline Terreros (1786) & \multicolumn{1}{|c|}{$\begin{array}{c}\text { Novo Diccionario } \\
\text { (1806) }\end{array}$} & $\begin{array}{c}\text { Diccionario Universal } \\
\text { (1845) }\end{array}$ \\
\hline $\begin{array}{l}\text { Alioth, termino de As- } \\
\text { tronomia, nombre de una } \\
\text { estrella que está en la cola } \\
\text { de la Osa mayor; sirve para } \\
\text { conocer la altura del Polo. }\end{array}$ & $\begin{array}{l}\text { Allioth, s. m. Estrella da } \\
\text { cauda da ursa maior. }\end{array}$ & $\begin{array}{l}\text { Allioth, s. m. (ast.) Estre- } \\
\text { lla na cauda da ursa-maior, } \\
\text { que se observa no mar } \\
\text { para se conhecer a altura } \\
\text { do polo. }\end{array}$ \\
\hline
\end{tabular}

É possível que os redactores do dicionário universal de 1845 tenham copiado também o Terreros y Pando, visto a semelhança textual:

\begin{tabular}{|l|l|l|}
\hline \multicolumn{1}{|c|}{ Terreros (1786) } & $\begin{array}{c}\text { Novo Diccionario } \\
\text { (1806) }\end{array}$ & $\begin{array}{c}\text { Diccionario Universal } \\
\text { (1845) }\end{array}$ \\
\hline $\begin{array}{l}\text { Alibanias, ciertas telas } \\
\text { de algodon, que trahen } \\
\text { de las Indias Orientales á } \\
\text { Holanda. }\end{array}$ & $\begin{array}{l}\text { Alibania s. f. Estofo das } \\
\text { Indias Orientaes. }\end{array}$ & $\begin{array}{l}\text { Alibania, s. f. (Com.) Pan- } \\
\text { no de algodão da India. }\end{array}$ \\
\hline
\end{tabular}

É possível que os redactores do dicionário de 1818 copiassem também o Terreros y Pando, visto a palavra algodão.

Também o Morais copiou de uma obra, do Viterbo (1798-1799). Na segunda edição de Morais, de 1813, aparecem os mais raros arcaísmos, alguns deles hapaxlegomena em dicionários portugueses do século XIX, se 
bem que Morais argumenta, no "Prólogo do autor à primeira impressão", de 1813: "Os Autores, com que autorizei os Artigos addidos, são Portuguezes castiços [...]”. Um exemplo:

Ousám. Atrevimento, insolencia, desaforo. Vem do Latino Audeo (Viterbo 1798-1799).

Ousão, s. m. antiq. Atrevimento. Elucidar (Morais 1813).

Ousão, s. f. (ant.) Atrevimento (Diccionario Geral 1818).

Ousão, s. m. antiq. Atrevimento. Elucidar (Morais 1831).

Ousão s. obsol. V. Atrevimento, Ousadia (Constâncio 1836).

Ousão, s.m.ant. Atrevimento. Eluc. (Morais 1858).

Ousão, s. m. Termo antiquado. Audacia, arrojo, atrevimento (Vieira 1871-1874).

É uma palavra para a qual nem Viterbo reproduz o documento, mas com a entrada no Morais de 1813 e a sua autoridade obteve direito à vida e perpetuou-se em todos os dicionários seguintes.

Ter-me-ia sido possível enumerar muitos mais exemplos para indicar a dependência de dicionários portugueses de outros, portugueses e estrangeiros, que lhes antecedem, mas, acredito, os exemplos com o que ilustrei a minha contribuição são suficientes. 


\section{ANEXO}

1. Coloquio de Lexicografía (Instituto da Lingua Galega, Santiago de Compostela, 27 de febreiro - 1 de marzo de 1986).

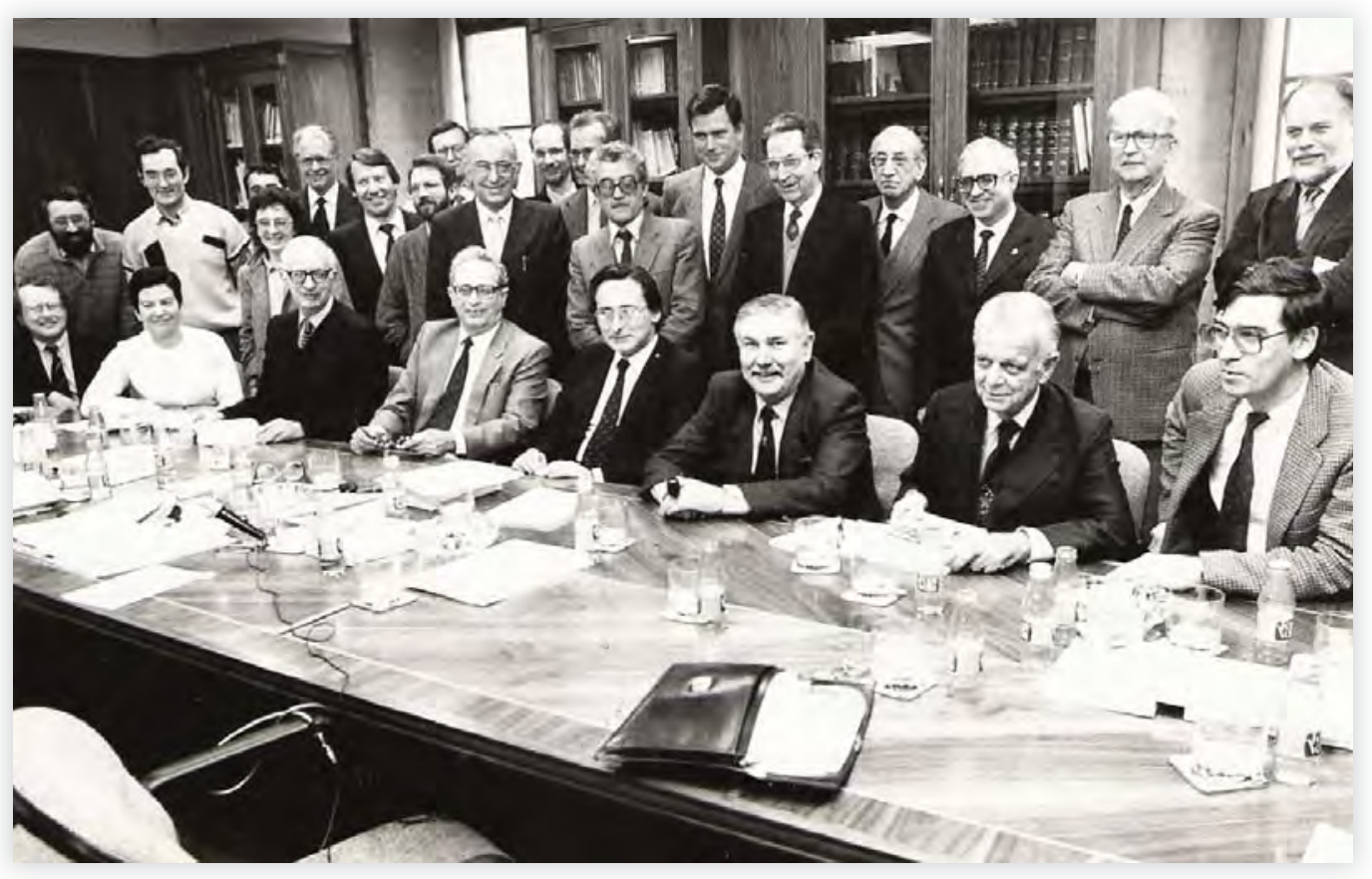





\title{
A INFORMACIÓN GRAMATICAL NOS DICIONARIOS
}

\author{
Xosé-Álvaro Porto Dapena
}

Universidade da Coruña

\section{O. INTRODUCIÓN}

Cando nos preguntamos pola información gramatical nos dicionarios, estamos a partir en realidade da existencia dunha dicotomía -a de gramática / dicionario-, na que certamente cada día se cre menos, aínda que, por outro lado, veña sendo mantida tradicionalmente mesmo dende moito antes de que Saussure fundase a lingüística sobre as súas famosas antinomías. Estou seguro de que a inmensa maioría dos que aquí nos atopamos seguimos pensando que posuír unha lingua non consiste basicamente noutra cousa que, por unha banda, en coñecer o seu vocabulario e, por outra, en dominar as regras gramaticais que nos permiten xerar ou producir, a partir daquel, un indefinido número de enunciados. Pero non é menos certo, ao mesmo tempo, que todos estamos absolutamente convencidos de que en materia de linguaxe -e, polo tanto, tamén na lingüística-non hai compartimentos estancos, de maneira que nunca se poden facer delimitacións exactas e, conseguintemente, os límites que intentemos establecer serán sempre imprecisos e necesariamente difusos.

No que aos terreos da Lexicografía e da Gramática se refire, esta indefinición púxoa recentemente moi ben de manifesto Ignacio Bosque (2004: LXXIX e ss.) na introdución do seu REDES, dicionario dedicado, como é sabido, ao aspecto combinatorio do léxico, por certo nunca tratado anteriormente en ningunha lingua. Segundo observa, cando informaba das particulares características da súa obra, aínda en elaboración, aos colegas, había discrepancias entre eles no sentido de que, se eran gramáticos, lle dicían que o que estaba a facer era lexicografía, mentres que, tratándose de lexicógrafos, se inclinaban a pensar que a súa investigación correspondía, pola contra, ao ámbito do gramatical. E certamente nin el mesmo -que, segundo confesa, non é lexicógrafo, senón gramático- parece estar moi 
seguro de que a súa obra, malia o seu título, sexa un verdadeiro dicionario, cousa que eu -que si son lexicógrafo-xamais puxen en dúbida, nin sequera antes de ser publicada, nas miñas conversas co propio Bosque.

Para empezar, sinalemos que opoñer Gramática e Dicionario implica ante todo ter unha idea clara e á vez particular -aínda que só sexa teoricamente- dos respectivos dominios destas dúas disciplinas, dominios que aínda non foron fixados dun modo unánime. Sen entrar na dificultade -posta de manifesto hai algúns anos por Alvar Ezquerra (1993: 59 e ss.)-á hora de definir o concepto de 'dicionario', abonde con fixarnos na variedade de concepcións sobre o verdadeiro contido e extensión da Gramática, concepcións que, por certo, non sempre permiten manter a súa oposición fronte ao Dicionario. Pensemos, se non, no caso dos xenerativistas cando a interpretan no seu sentido máis amplo, equivalente a Lingüistica, e segundo o cal o Dicionario ou Lexicón non viría a ser máis que unha das súas partes ou compoñentes.

É evidente que, se nos preguntamos pola presenza de información gramatical nos dicionarios, é porque estamos a entender a Gramática no seu sentido máis tradicional e xeneralizado, é dicir, como a suma de Morfoloxía e Sintaxe, entendida a primeira, grosso modo, como "estudo da forma das palabras" e a segunda como "estudo da combinatoria destas para formar unidades sintagmáticas de orde máis complexa, isto é, frases ou oracións". Porque neste sentido, efectivamente, os dicionarios -aínda sen saír dos máis comúns e correntes, isto é, os de carácter xeral, alfabético e sobre todo didáctico- abundan en informacións de tipo morfolóxico e sintáctico, mesmo máis alá do que, ás veces, poidan mostrar as puras aparencias. E sendo isto así, un dicionario típico, isto é, de carácter semasiolóxico, non consiste -contra o que talvez tende a pensarse- nun puro estudo semántico do léxico, exclusivamente encamiñado a informar dos significados ou acepcións das palabras, senón que, como non podería ser doutro xeito, nos informa ademais doutros moitos aspectos, entre os que cabe destacar, por ser o tema deste traballo, o morfolóxico e, sobre todo, o sintáctico.

\section{ALGUNHAS CUESTIÓNS PREVIAS}

\subsection{Contido do dicionario}

O Dicionario, segundo iso, preséntasenos como un estudo híbrido, isto é, a cabalo entre o estritamente lexical, que constituiría o seu primordial 
e xenuíno ámbito, e o gramatical, chegando a abranguer mesmo outros moitos campos que nalgúns casos superan o terreo estritamente lingüistico, para incluír tamén o que non é máis que saber enciclopédico. Non fai falta insistir en que, efectivamente, nun dicionario podemos atopar, por exemplo, información etimolóxica, terminolóxica, pragmática, sociolingüistica, dialectal, fonético-fonolóxica, ortográfica e un longo etcétera, dependendo -claro está- do tipo específico de dicionario.

Pero volvendo á cuestión da información gramatical, aínda que de feito non se pode negar a existencia de certo solapamento entre Dicionario e Gramática, de sorte que nun e noutra atopamos ás veces estudadas as mesmas cuestións (pensemos, por exemplo, no tratamento das preposicións e, en xeral, das chamadas palabras gramaticais), non é menos certo que, en non poucas ocasións, se lle nega lexitimidade ao Dicionario para ocuparse de cuestións de natureza morfolóxica ou sintáctica, porque -penso que erroneamente- se consideran todas elas patrimonio exclusivo da Gramática. A mesma denominación que ás veces utilizamos -eu o primeiro (véxase, por exemplo, Porto Dapena 2002a: 64)- de dicionarios gramaticais para referirnos a aqueles cuxas entradas se elixen atendendo precisamente a certas peculiaridades morfosintácticas, pon ben ás claras a vixencia de semellante opinión.

É, non obstante, un erro negar que, por exemplo, un dicionario non debe dar conta de que un verbo ha de construírse cun determinado tipo de complemento, de que un adxectivo pode xuntarse soamente a certos substantivos ou de que unha determinada palabra pode funcionar como adverbio e preposición ou ofrece, por outro lado, algunha particularidade na súa conformación morfonolóxica. E é un erro porque tales cuestións, lonxe de pertenceren á Gramática -tal como a entendemos normalmente-, corresponden só e exclusivamente ao Dicionario.

E chegados a este punto, véxome na necesidade de observar que Morfoloxía e Sintaxe non son -contra o que comunmente tende a pensarsedisciplinas exclusivamente gramaticais, senón tamén léxicas, de sorte que entre elas, por unha parte, e entre Gramática e Dicionario, por outra, se dá unha relación de cruzamento, tal como se pode esquematizar no seguinte gráfico: 


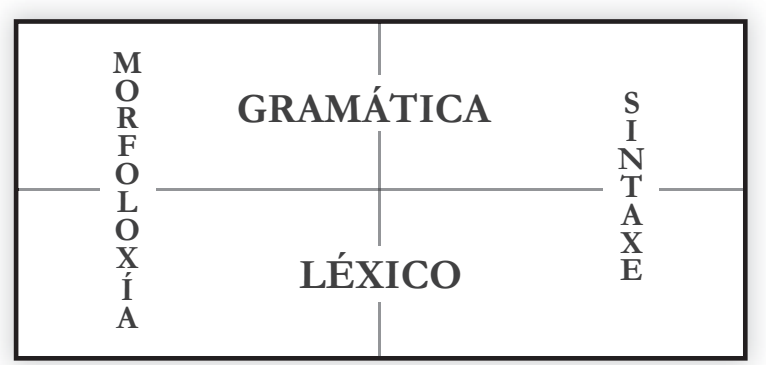

Aínda que -insisto- a delimitación entre os membros de cada un destes dous pares de disciplinas sexa na práctica relativamente difusa, non cabe a máis mínima dúbida de que así como na Gramática existen unha morfoloxía e unha sintaxe, tamén no estudo do léxico -e por ende na Lexicografía- haberá que facer a mesma distinción. Hai que falar, como se fai con frecuencia, dunha morfoloxía léxica xunto a unha morfoloxía gramatical, preocupada esta última fundamentalmente polos aspectos flexivos; pero tamén dunha sintaxe léxica, referida ao nivel máis concreto da palabra, fronte a unha sintaxe gramatical, enfocada máis ben ao estudo da oración e as súas partes ou funcións.

\subsection{Delimitando o noso obxecto de estudo}

Aínda que resulte un pouco contraditorio co que acabo de observar, cando se me suxeriu que me ocupase da información gramatical nos dicionarios, entendín inmediatamente que o que se me estaba a propoñer era que tratase fundamentalmente de cuestións de morfoloxía e, sobre todo, de sintaxe léxicas rexistradas nos dicionarios xerais e comúns. Por iso é nelas -moi especialmente nas sintácticas- no que vou centrar o obxecto da miña exposición. Non hai que perder de vista, non obstante, que van quedar fóra outros aspectos -neste caso máis estritamente gramaticais e sen dúbida interesantes-, como pode ser, por exemplo, o tratamento nos mesmos dicionarios de palabras gramaticais, de cuestións relacionadas coa flexión e categorización das palabras ou, en fin, o estudo da terminoloxía gramatical e con el da propia Gramática.

Respecto a isto último, xa dicía Gili Gaya (1945) que un dicionario non debe ser unha gramática estruturada en artigos dispostos por orde alfabética, aínda cando é aceptable que, sobre todo tratándose de dicionarios de tipo escolar, se empregue certa manga ancha neste aspecto, incluíndo, entre outras cousas, explicacións e informacións de tipo gramatical, como poden ser paradigmas flexionais, formas irregulares e mesmo algunhas regras sintácticas elementais. Dende logo, todos nos temos beneficiado algunha vez da presenza destas cuestións gramaticais nos nosos peque- 
nos dicionarios bilingües cando eramos estudantes. Pero non hai que acudir exclusivamente aos dicionarios escolares para constatar este feito, pois tamén os dicionarios comúns e correntes de tipo máis ou menos descritivo e normativo - pensemos, para o español, no DRAE ou no DUE de María Moliner- tenden a incluír así mesmo este tipo de información en atención a que están destinados a un público non particularmente versado en materia gramatical.

En calquera das dúas estruturas que caracterizan un dicionario pode detectarse a información morfosintáctica. En primeiro lugar, na macroestrutura, isto é, atendendo ao lemario ou conxunto de entradas, e en segundo termo, na microestrutura ou interior do artigo lexicográfico. No primeiro caso cabe aínda referirnos a dous aspectos: o que atende aos tipos de léxico rexistrado, ao incluír, entre outras cousas, palabras ou morfemas gramaticais así como elementos morfolóxicos -por exemplo, prefixos e sufixos derivativos-, e, por outra banda, o que se refire máis ben á forma da entrada, a cal, ademais de informar sobre a súa propia ortografía, pode facelo así mesmo sobre as súas particularidades morfolóxicas, e ata ás veces fonético-fonolóxicas.

Dende logo todos os dicionarios de tipo xeral rexistran as chamadas palabras gramaticais, isto é, pronomes, preposicións e conxuncións, de modo que aquí atopamos o primeiro solapamento entre Gramática -que é máis propiamente a que debe estudar estes elementos- e o Dicionario, o cal, por outro lado, cando é de tipo xeral, non se limita a recoller as unidades léxicas, senón todo tipo de vocábulos indo mesmo máis alá destes: por exemplo, a rexistrar así mesmo certos afixos ou, sen ir máis lonxe, as letras do abecedario (véxase a este respecto Porto Dapena 2000-2001) e ata ás veces elementos que non pertencen propiamente á lingua, como é o caso do DUE de María Moliner cando recolle mesmo certos clics (jchsss!, $\mathrm{mmm}$, etc.).

Pero falando de elementos de tipo gramatical incluídos na nomenclatura do Dicionario, cabe aínda -seguindo unha feliz distinción de Eugenio Coseriu (1977: 107-109) entre linguaxe primaria e metalinguaxe-separar entre entradas gramaticais, as representadas por pronomes, preposicións, formas irregulares, etc., que pertencen, obviamente, á linguaxe primaria, e, por outro lado, entradas de gramática, isto é, terminoloxía gramatical, pertencente ao léxico especializado da Gramática -ou, máis ben, da Lingüística-, estudado ás veces enciclopedicamente non só, por suposto, nos dicionarios e vocabularios especializados, senón mesmo ás veces -se ben iso non se xustifique doadamente- nos dicionarios xerais e comúns. Exemplificando co mesmo DUE de María Moliner, os artigos que esta au- 
tora chama "de desarrollo gramatical" corresponden precisamente a este último tipo de entradas.

Aínda se atendemos á lematización ou forma en que aparecen rexistradas as entradas no Dicionario, este pode ofrecer de feito información gramatical. Se, ante todo, incluímos dentro desta a de tipo ortográfico, ¿quen non usou algunha vez o dicionario para descubrir, en caso de dúbida, como se escribe unha palabra? Pero, referíndonos máis especificamente ao aspecto morfolóxico, non é infrecuente no enunciado das entradas que, ao lado do lema, isto é, a forma básica que se toma en conta para a orde alfabética, aparezan outras formas ou ben de tipo flexional (por exemplo, a forma feminina xunto á masculina nos artigos de adxectivos e de certos substantivos) ou ben variantes de tipo morfonolóxico, dando así lugar a enunciados polimórficos.

A pesar de todo isto, a maior -e talvez máis importante-información tanto morfolóxica como, sobre todo, sintáctica nos dicionarios vén dada na microestrutura, xa sexa directamente, isto é, mediante explicacións ad hoc ou por medio da correspondente marcación gramatical, para indicar neste caso, en abreviatura, a categoría ou subcategoría (por exemplo, adxectivo, transitivo, masculino, plural), xa sexa indirectamente, como algo que se desprende doadamente das propias definicións ou dos contextos de que estas forman parte. Así, non é infrecuente nos dicionarios correntes sinalar o tipo de conxugación propia dos verbos irregulares ou indicar as peculiaridades prosódicas e mesmo ás veces de pronuncia cando se trata dunha palabra - polo regular un empréstito- cuxa ortografía non se adapta ás regras xerais de equivalencia entre grafía e pronuncia. Moitos dicionarios sinalan tamén certas posibilidades de construción; por exemplo, cando se di dun verbo que tamén se usa como pronominal ou que rexe unha determinada preposición, que vai acompañado dun complemento especial, etc.

É xeralmente neste último punto de vista no que os dicionarios comúns e correntes adoitan ser menos explícitos, confiando na maior parte dos casos na competencia e intuición lingüística dos usuarios, que se ven obrigados a descubriren indirectamente as peculiaridades sintácticas ou combinatorias da palabra en cada unha das súas acepcións. Precisamente é neste último tipo de información -ao tratarse sen dúbida do aspecto menos evidente e coñecido e, por iso, máis interesante- no que vou centrar o resto da miña exposición, pois o tema deste traballo é tan amplo que nos sería imposible abranguelo aquí en todos os aspectos que acabo de sinalar moi esquematicamente. 
Así pois, vou referirme concretamente á información sintáctica contida-case sempre implicitamente-nas definicións lexicográficas, ou nos contextos de que estas forman parte dentro das respectivas acepcións. Os exemplos que vou utilizar corresponden todos eles a dicionarios do español, concretamente ao DRAE, ao DUE e ao DEA de Manuel Seco, Olimpia Andrés e Gabino Ramos, por ser a lexicografía española o ámbito no que máis traballei e, polo tanto, mellor me movo.

\section{A INFORMACIÓN GRAMATICAL NA MACROESTRUCTURA}

De acordo, pois, co esquema que acabo de trazar, voume fixar antes de nada na información gramatical contida na macroestrutura dos dicionarios. E neste punto, atendendo en primeiro lugar ao tipo de léxico estudado, cabe sinalar, como vimos antes, a presenza de, por unha parte, palabras ou elementos de significación exclusivamente gramatical, como as partículas e os pronomes, xunto a voces pertencentes ao que poderiamos chamar metaléxico, é dicir, referentes a realidades gramaticais ou lingüísticas en xeral. Pero así mesmo, independentemente do significado ou referencia das entradas, o modo como estas aparecen rexistradas no dicionario pode nalgunha medida informar acerca dalgunha ou dalgunhas das súas peculiaridades gramaticais.

\subsection{Con atención ao tipo de léxico rexistrado}

Non é este, dende logo, o momento de entrar na discusión acerca do nivel ou niveis de unidades lingüísticas que deben ou non formar parte da nomenclatura dun dicionario. Todos estamos de acordo en que as entradas están constituídas basicamente por palabras; palabras ortográficas, claro está, posto que nos estamos a referir a unha obra de carácter escrito. Iso non obsta, sen embargo, para que, á súa vez, formen parte da nomenclatura elementos menores que a palabra, como é o caso de certos sufixos ou prefixos utilizados na formación de palabras, e mesmo outros -como é o caso das letras do abecedario ou dos clics- que non son nin sequera unidades lingüísticas propiamente falando.

A presenza na nomenclatura dos dicionarios das chamadas palabras gramaticais constitúe sen dúbida o máis claro expoñente de interferencia entre gramática e dicionario. Realmente o punto de vista adoptado na descrición das conxuncións e preposicións, por exemplo, non varía substancialmente dun dicionario a un tratado gramatical, a non ser talvez 
no carácter polo xeral máis minucioso daquel: comparemos, sen ir máis lonxe, o tratamento, de apenas dúas páxinas, que se dá á preposición entre na Gramática descriptiva de la lengua española dirixida por Bosque e Demonte (De Bruyne 1999: 674-676) co correspondente artigo, redactado por min mesmo, do $D C R$, que ocupa máis de vinte páxinas a dobre columna. As diferenzas entre dicionarios e gramáticas son talvez maiores no que se refire ao tratamento dos pronomes, debido, entre outras razóns, á necesidade de ter que adaptarse naqueles á estruturación alfabética, o que fai que formas dun mesmo paradigma gramatical -como poden ser, por exemplo, en galego, eu, me ou comigo, ou as correspondentes formas yo, me, conmigo do español- aparezan espalladas en lugares moi distintos da macroestrutura dun dicionario.

O tratamento, por certo, que na simple nomenclatura reciben os pronomes ou o artigo, xunto cos hoxe chamados determinantes, pode ser índice das bases teóricas que, con respecto á concepción do pronome, subxacen no propio dicionario. Así, por exemplo, pode ser significativo que, como acontece no DGILE, se rexistren como entradas independentes os demostrativos en función adxectiva e en función substantiva, o que significa que o autor ou autores do dicionario opoñen -como, por outra parte, se veu facendo frecuentemente- os adxectivos demostrativos aos seus correspondentes pronomes, reducidos á función substantiva. De todos os xeitos, como estudei nun artigo sobre o tema (Porto Dapena 2003-2004), os dicionarios mostran unha gran vacilación á hora de rexistrar na súa nomenclatura as formas pronominais, que tenden, como acabo de observar, á dispersión, ao figurar cada forma na súa correspondente posición alfabética. Por iso, quizais, pode dicirse que os pronomes en xeral aparecen, dende logo, mellor tratados nas gramáticas que nos dicionarios.

Algo parecido ao que acabo de dicir dos pronomes se pode afirmar de palabras, sobre todo verbos, con flexión irregular. Neste caso, efectivamente, non será imposible, sobre todo en dicionarios de aprendizaxe, rexistrar como entradas independentes as formas irregulares, remitindo -claro está- en cada unha delas á forma baixo a cal se describe o correspondente vocábulo e onde se informa, entre outras cousas, das correspondentes irregularidades.

Evidentemente, este modo de proceder explícase sobre todo nos chamados dicionarios pedagóxicos ou de aprendizaxe, posto que van destinados a un público cun baixo nivel de coñecementos en materia gramatical. A mesma explicación pode valer, por certo, para xustificar a presenza na nomenclatura dos dicionarios xerais da terminoloxía gramatical ou lingüística, isto é, do metaléxico utilizado na descrición das linguas, cir- 
cunstancia que se aproveita ás veces para ofrecer na correspondente microestrutura todo un estudo de tipo gramatical, entrando así o Dicionario no que xa habería que considerar saber enciclopédico. Considérese a este propósito, por exemplo, o longo artigo, de máis de corenta páxinas, que a propósito da palabra verbo aparece na primeira edición do DUE de María Moliner, o cal constitúe un amplo e detallado capítulo digno de figurar nun tratado de gramática descritiva.

De todos os xeitos, habemos de coincidir con Gili Gaya en que un dicionario, como xa queda sinalado, non debe ser nunca unha gramática estruturada en capítulos dispostos por orde alfabética, que é realmente o que María Moliner fixo cos artigos "de desarrollo gramatical" e que, precisamente por esa razón, os encargados de preparar a segunda edición do $D U E$, eliminaron da nomenclatura, pasándoos a formar un longo apéndice ao final da obra. É inevitable, con todo, que un dicionario común trate o léxico metalingüistico, aínda que, evidentemente, sen chegar ao grao de especialización dun dicionario de lingüística ou sobre terminoloxía gramatical, nin, por suposto -simplemente porque cadra de camiño-, tomar como pretexto ese vocabulario para desenvolver toda unha teoría lingüística ou un estudo detallado da gramática da lingua en cuestión.

Isto último suporía unha confusión -por certo bastante frecuente nos dicionarios comúns-entre o lingüístico e a realidade (aínda que neste caso esteamos a falar á vez dunha realidade lingüística), pois unha cousa, loxicamente, será definir a palabra verbo, que é o que atinxe ao dicionario, e outra ocuparse -como fai María Moliner-da realidade chamada verbo. Ás veces a confusión é tan forte que se chegan a incluír na nomenclatura dos dicionarios elementos que, aínda sendo realidades lingüísticas, non constitúen verdadeiras unidades léxicas, como é o caso, por exemplo, das letras, segundo puxen de manifesto hai algún tempo nun artigo sobre o tema (Porto Dapena 2000-2001). Realmente unha entrada como B, por exemplo, non é unha palabra (fronte ao substantivo be), senón a letra mesma, a cal, malia ser unha realidade gráfica -e, polo tanto, lingüística-, non debería figurar como entrada en ningún dicionario e só, en todo caso, nunha enciclopedia. Cando, efectivamente, o DRAE nos define

\footnotetext{
b 1. $f$. Segunda letra del abecedario español y del orden latino internacional, que representa un fonema consonántico labial y sonoro. Su nombre es be, be alta o be larga.
}

non nos está a dar o significado dunha palabra $b$ inexistente, senón que nos está a caracterizar a letra mesma, o signo ortográfico; por iso non ten ningún sentido a marcación $f$. (feminino) que fai desta entrada. 
Situación moi distinta é a correspondente aos afixos derivativos, pois, malia non ser palabras, constitúen unidades lingüísticas cun significado e unha evidente potencialidade combinatoria para constituír novos vocábulos ou facer posible a análise doutros xa existentes. De aí que os dicionarios sexan cada día máis proclives a aceptar estes elementos morfolóxicos na súa nomenclatura, facendo así innecesario o rexistro de, por exemplo, aumentativos e diminutivos nos substantivos, ou superlativos nos adxectivos, que tanto inflaron noutro tempo a macroestrutura do $D R A E$. En realidade estas formas -así como outros tipos de derivados (por exemplo, os deverbais) - deberían ser tratados na microestrutura, quero dicir, nos artigos correspondentes ás palabras de que derivan, a non ser, loxicamente, cando presentan significados non previsibles, isto é, non derivables dos seus elementos morfolóxicos compoñentes.

\subsection{Con atención á lematización ou forma das entradas}

Pero, como xa queda dito, a información gramatical na macroestrutura non só vén dada polo tipo de entradas que a constitúen, senón tamén pola forma en que estas aparecen rexistradas no dicionario. É dicir, a lematización representa sen dúbida -sexa directa ou indirectamente- un aspecto importante para determinar algunhas características gramaticais das palabras tomadas como entradas. Concretamente, as relacionadas en primeiro lugar coa súa ortografía e pronuncia, e, en segundo termo, as que atinxen, por exemplo, ás súas características flexionais, morfonolóxicas ou gráficas.

Máis arriba, en efecto, xa me referín ao feito -en absoluto infrecuente- de que os dicionarios comúns son consultados coa especifica finalidade de descubrir a ortografía dun vocábulo concreto. Trátase -claro estádun tipo de información indirecta, por canto que a entrada, ao vir dada na súa representación gráfica, fai supoñer que tal representación ha de ser a correcta. Nalgúns dicionarios, non obstante, ao lado do lema -isto é, a forma do enunciado do artigo sometida á orde alfabética- poden aparecer como sublemas outras formas ortográficas posibles, como é o caso, por exemplo, do enunciado de

\footnotetext{
guion o guión. [...] 1. m. Escrito en que breve y ordenadamente se han apuntado algunas ideas o cosas con objeto de que sirva de guía para determinado fin.
}

que atopamos na última edición do DRAE. Dende logo nos dicionarios históricos, ao detectárense ás veces múltiples grafías dunha mesma palabra, é moi frecuente atoparnos con enunciados deste tipo. 
Achámonos neste último caso ante enunciados polimórficos, os cales non só poden informar da existencia de variantes ortográficas, senón moitas veces tamén morfonolóxicas, como sería o caso, por exemplo, dun dicionario que rexistrase como entradas as formas amueblar ou amoblar, carnicería ou carnecería, espabilar ou despabilar, etc. Mesmo -por exemplo, na primeira edición do DUE de María Moliner- dentro dun mesmo enunciado pode aparecer toda unha familia morfolóxica, con remisión á entrada á que se subordinan; é o caso, por exemplo, de

perfección; perfeccionador, -a; perfeccionamiento; perfeccionar; perfeccionarse; perfectamente; perfectibilidad; perfectible; perfectivo, -a. V. bajo "PERFECTO".

Evidentemente, no caso do español, que ten, como o galego, unha ortografía doadamente transcodificable en elementos sonoros, o simple enunciado da entrada en forma escrita proporciona tamén información -aínda que así mesmo indirecta- acerca da pronuncia, ao se poder interpretar como representación desta. Non acontece, en troques, o mesmo con certos extranxeirismos que, como leasing, lead ou pizza, se escriben como na lingua orixinal sen que, por outro lado, exista a correspondencia gráfico-fonética propia do español. Neste caso, como procede o DRAE na súa última edición, tal inequivalencia vén marcada polo tipo de letra -a cursiva- utilizado na lematización, mentres que a pronuncia, cando se dá, se expresa directamente na microestrutura, é dicir, dentro do artigo lexicográfico. Así, por exemplo, considérese no DRAE:

leasing. (Voz ingl.) 1. m. Econ. Arrendamiento con opción de compra del objeto arrendado.

E no DEA:

lead (ing; pronunc corriente, /lid/; pl normal, -s) m En un periódico: Entradilla.

En canto a aspectos relacionados coa pronuncia dados na macroestrutura, cabe engadir que algúns dicionarios -por exemplo, o GDUEA de SGEL- presentan as entradas con separación silábica, dando así información-cremos que innecesaria e ás veces ata discutible-acerca deste particular. Así, des.a.gra.de.ci.do, em.plas.to, ma.nual.men.te.

Agora ben, a información máis estritamente gramatical ofrecida pola forma en que se rexistran as entradas é, evidentemente, a que atinxe ao carácter flexivo, isto é, gramaticalmente variable -ou, pola contra, invariable- das palabras. En primeiro lugar, como é sabido, os substantivos e 
adxectivos que posúen variación de xénero rexístranse na cabeceira do artigo baixo a forma masculina acompañada da terminación feminina, e, no caso dos verbos, que se presentan só nunha forma, o infinitivo, a terminación -ar, -er ou -ir é suficiente para determinar a conxugación -e polo tanto o modelo de flexión- a que corresponde. Só no caso de que se trate dun verbo irregular se fai necesario indicar esa particularidade na microestrutura, remitindo, como fai o DRAE ou o DEA de Manuel Seco, ao modelo de conxugación ou ás formas concretas de carácter irregular. Así, por exemplo, no DRAE:

\section{retraer [...] \ MORF. conjug. actual c. traer.}

\section{A INFORMACIÓN GRAMATICAL NA MICROESTRUCTURA}

É, con todo, na microestrutura onde os dicionarios comúns ofrecen unha maior cantidade de información gramatical, información que, dada dun xeito explícito ou implícito, directo ou indirecto, é sen dúbida superior ao que habitualmente se cre, aínda cando -iso si- presenta deficiencias evidentes, en comparación sobre todo con dicionarios especiais, como os de valencias, de construción e réxime, e os combinatorios ou de colocacións. De feito, no interior dun artigo é posible atopar todo tipo de información gramatical: nel pode darse conta, entre outras cousas, tamén da pronuncia, ortografía, etimoloxía e particularidades de flexión, así como da categorización ou subcategorización da entrada e -o que é máis importante e, polo tanto, ao que aquí vou prestar especial atención- do seu comportamento sintagmático.

\subsection{Indicacións sobre pronuncia, ortografía, etimoloxía e flexión}

Non vou insistir aquí sobre as indicacións - por outro lado evidentes, dado o seu carácter explícito e directo-que aparecen con frecuencia nos dicionarios ao uso sobre a pronuncia, etimoloxía ou propiedades de orde ortográfica ou flexiva. Son indicacións, por certo, que adoitan aparecer no que poderiamos chamar periferia do artigo, é dicir, na parte inicial, despois da entrada, ou final deste, para non se confundiren con ningunha das acepcións en particular. E así é frecuente que a etimoloxía -e o mesmo as particularidades fonético-ortográficas- aparezan, como acontece, por exemplo, no DRAE, inmediatamente despois da entrada, entre parénteses, ou que as particularidades de flexión se indiquen nunha especie de apéndice ao final de artigo. 
Dende logo, como xa sinalou A. Quilis (1982), nun dicionario de español a indicación da pronuncia non ten demasiada xustificación, dada a normal e case exacta correspondencia entre letras e fonemas. A lectura do español (e tamén do galego) non ofrece, efectivamente, ningunha dificultade -sobre todo aos falantes nativos- coñecendo, claro está, esas equivalencias, que, ademais, non son absolutamente idénticas para todos os hispanofalantes (e galegofalantes), o que dificultaría ás veces a súa transcrición fonética'. Só excepcionalmente, no caso de empréstitos tomados doutras linguas na súa orixinal grafía, poden presentarse dificultades neste sentido e, polo tanto, resulta necesario e conveniente realizar algunha observación ao respecto, sempre, naturalmente, que a pronuncia contradiga dalgún xeito as correspondencias letra /son de español ou galego. Considérese, como exemplo, o caso de sándwich tal como aparece na primeira edición do DUE:

sandwich (pronunc. aproximadamente "sanuich"; y a la española, vulgarmente, "sambich"). Pa-

labra inglesa con que se designa [...].

A dificultade deste tipo de indicacións radica, naturalmente, no feito de que o dicionario, ao ir destinado a un público descoñecedor da fonética, non pode utilizar senón os grafemas ordinarios e, polo tanto, dar unha pronuncia tan só aproximada, como acontece no caso anterior. O DEA, penso que acertadamente, dá, non obstante, a transcrición fonolóxica.

Polo que se refire á indicación da etimoloxía, os dicionarios comúns conténtanse normalmente con sinalar, entre parénteses, o étimo precedido da indicación da lingua a que este pertence xunto con, a continuación do étimo, o significado orixinal. Non se engade ningún comentario acerca da evolución fonética e semántica, nin se aborda ningunha discusión de carácter crítico sobre outras posibles hipóteses.

De todas estas informacións a máis destacable é sen dúbida a referente a aspectos flexionais, como é o caso da conxugación dos verbos. Polo xeral, os dicionarios tan só fan referencia aos casos de irregularidade, sinalando as correspondentes formas irregulares ou ben indicando o tipo de conxugación, contida nun apéndice da obra onde se ofrecen os paradigmas prototípicos completos. Este último é, por exemplo, o procedemento seguido polo DEA de Manuel Seco. Máis completo, dende logo, é

1. Resulta, polo tanto, redundante o procedemento seguido polo GDLE, que inclúe invariablemente a pronuncia -segundo a norma española- de todas as súas entradas, as cales aparecen en transcrición fonética: así, ha.ber [aßér] 
o método seguido polo $D R A E$, que na súa versión electrónica ofrece a posibilidade de despregar a conxugación completa de cada verbo, picando simplemente o botón azul que aparece ao lado da entrada. En calquera caso, velaquí un punto máis onde Gramática -no seu sentido máis estrito- e Dicionario interfiren claramente.

\subsection{A marcación gramatical}

Outro caso, por certo, de interferencia que adoita sinalarse á hora de establecer a separación entre Dicionario e Gramática é o representado pola indicación das categorías e subcategorías, habida conta de que estas corresponden de cheo ao terreo gramatical. Teñamos en conta, non obstante, a este respecto que os dicionarios non se ocupan propiamente das categorías gramaticais do mesmo xeito que o fai a Gramática, que as estuda en xeral, como "partes da oración", é dicir, atendendo ao seu comportamento ou funcións dentro da unidade sintáctica por antonomasia. O Dicionario, en cambio, limítase a tomalas como criterio de clasificación das palabras concretas, as cales, de acordo coa devandita clasificación, posuirán un determinado contido categorial, asociado -iso si- a unhas posibilidades combinatorias ou sintácticas.

A categorización nos dicionarios vén dada sempre por marcas, consistentes en abreviaturas, como $a d x$. (adxectivo), adv. (adverbio), $m$. ou $f$. (masculino ou feminino), tr. (transitivo), amb. (ambiguo), etc. Algún dicionario, non obstante, como é o caso do DUE de María Moliner na súa primeira edición (p.XXIII), prescinde desta marcación, habida conta de que a categoría e subcategoría dunha palabra é doadamente deducible da correspondente definición: un substantivo, en efecto, non pode ser definido máis que mediante outro substantivo ou sintagma equivalente, un verbo por medio doutro verbo e así sucesivamente. A falta de categorización nun artigo lexicográfico pode crear problemas, como cando se trata de palabras que poden ser obxecto de recategorización; por exemplo, un adxectivo que pode substantivarse ou funcionar adverbialmente, etc. Por outro lado, nos verbos, non sempre son deducibles da definición os carácteres de transitivo ou intransitivo, etc. De aí que na súa segunda edición o DUE rexistre tamén a categoría ou subcategoría, que de ningún xeito deben tomarse como información redundante, senón absolutamente necesaria.

Como dixen noutro lugar (Porto Dapena 2002a: 253), a indicación da categoría e subcategoría nos dicionarios responde ante todo ao obxectivo fundamental de determinar o comportamento gramatical -tanto paradigmático como sintagmático- das entradas. De todos os xeitos, como 
sinalou recentemente Ignacio Bosque (2006), é certo que os dicionarios deberían incrementar a marcación gramatical, incluíndo subcategorizacións como animado / non animado, contable / non contable nos substantivos, ou, por exemplo, perfectivo / imperfectivo, incoativo / cursivo / terminativo nos verbos, posto que estas características -semanticamente clasemas- tamén inflúen no comportamento morfosintáctico das palabras en cuestión.

Trátase, en todo caso, de trazos que, polo menos nalgunhas ocasións, son dalgún xeito deducibles das respectivas definicións, como penso mostrar nun próximo traballo sobre este tema. Para non me alongar agora demasiado, contentareime con presentar dous ou tres casos: por exemplo, os verbos cuxas definicións están constituídas pola frase verbal facer (esp. hacer) + oración substantiva son verbos factitivos:

acosar. tr. Hacer correr al caballo.

anticipar. $t$ r. Hacer que algo suceda antes del tiempo señalado o esperable, o antes que otra cosa.

Os que, pola súa banda, se definen por empezar, comezar ou poñerse a + infinitivo serán incoativos:

adormecerse. prnl. Empezar a dormirse, o ir poco a poco rindiéndose al sueño.

templar. intr. Dicho de una cosa: Perder el frío, empezar a calentarse.

Terán, pola súa banda, carácter terminativo desinente aqueles que se definen mediante deixar (esp. dejar) de + infinitivo, como

callar. intr. Dicho del mar, del viento, de un volcán, etc.: Dejar de hacer ruido.

morir. intr. Dejar de vivir.

etcétera.

\subsection{A información gramatical nas definicións: o contorno}

Pero falando da definición lexicográfica como fonte de información gramatical, convén non esquecer que esta non consiste -contra o que doadamente se puidese pensar- nunha mera descrición do significado ou contido semántico dunha palabra ou unidade léxica, senón que moitas veces informa tamén, implícita ou explicitamente, acerca do seu comportamento sintagmático. Isto quere dicir que nunha definición poden distinguirse con frecuencia dous elementos: o que propuxen chamar 
enunciado parafrástico, que repite o contido semántico do definido e, polo tanto, en principio, pode substituír a este en calquera contexto, xunto ao que, despois dun memorable traballo de Manuel Seco, deu en denominarse contorno definicional, no que se expresan as condicións contextuais de uso (cfr. Seco 1979; Porto Dapena 1997 e 2002a: 307-328, e Rafel 2006). Así, por poñer un exemplo sinxelo, na definición

comprar. tr. Adquirir algo por dinero

o que aparece subliñado é o contorno, posto que funcionará tamén como complemento directo do definido, fronte ao resto do definiens, que reproduce o contido interno de comprar, pois pode substituír a este, por exemplo, en

Pedro compró una moto $=$ Pedro adquirió por dinero una moto.

Notemos de paso que ás veces a maior parte dos compoñentes dunha definición non analizan -contra o que sería de esperar- o significado do definido, senón que informan máis ben do seu comportamento sintáctico, como é o caso en

confluir. intr. Juntarse dos o más ríos u otras corrientes de agua en un mismo lugar

que vén a ser máis ben unha definición sinonímica, dado que o enunciado parafrástico está representado por unha soa palabra; pero onde se nos informa acerca das características do suxeito (ten que ser unha corrente de auga) e da necesidade dun complemento de lugar.

Non foron estudadas aínda en profundidade as circunstancias en que unha definición ha de ofrecer o seu contorno. Dende logo este non debe faltar, obviamente, cando os elementos que o compoñen teñan que cumprir unhas determinadas condicións semánticas e, polo tanto, exista un condicionamento por parte do definido, representado xeralmente por un verbo ou, se acaso, un adxectivo. Pola contra, non é necesario-e polo tanto non debe aparecer-cando é doadamente deducible do contexto parafrástico. De aí, por exemplo, que esta definición tomada do DRAE:

anglófono. adj. Dicho de una persona o de un país: Que tiene el inglés como lengua nativa

presente un contorno en certo modo redundante, posto que ter unha lingua como nativa tan só pode atribuirse a persoas ou, por metonimia, ao país onde viven. Pero, desgraciadamente, tamén acontece o contrario 
nos dicionarios: ás veces as definicións non son o suficientemente explícitas porque lles falta o contorno, como esta outra, tomada así mesmo do DRAE,

abanicar. $\operatorname{tr}$ Hacer aire con el abanico

onde, evidentemente, falta "a alguien", que é o complemento directo do verbo definido.

De acordo con estas observacións, existen, por unha parte, contornos explícitos e contornos non explícitos, aínda que doadamente deducibles do contexto definicional, como, por exemplo,

sabiondo. adj. coloq. Que presume de sabio sin serlo.

Non fai falta sinalar que se di unicamente de persoas. Por outra ban$\mathrm{da}$, os contornos explícitos poden ser integrados, cando -como é o típicoforman parte do enunciado definicional, e non integrados, se aparecen fóra del; así, en

transcurrir. intr. Dicho generalmente del tiempo: Pasar, correr

o contorno é externo ou non integrado.

Dende logo, o ideal é que o contorno sexa integrado e, ademais, desempeñe no definiens as mesmas funcións sintácticas que ha de desempeñar cando se constrúe co definido, como acontece, por exemplo, nestes casos:

\footnotetext{
contener. tr. Llevar o encerrar dentro de sí una cosa a otra.

trasladar. tr. Llevar a alguien o algo de un lugar a otro.

apto, ta. adj. Idóneo, hábil, a propósito para hacer algo.

digno, na. adj. Merecedor de algo.
}

Non fai falta subliñar, efectivamente, que un contorno deste tipo, ao que chamamos homoxéneo, é altamente informativo dende o punto de vista gramatical, pois non só pon de manifesto o número e características semánticas dos actantes ou valencias, senón tamén as súas respectivas funcións sintácticas.

Lamentablemente, non sempre resulta posible utilizar contornos homoxéneos, e entón bótase man de contornos heteroxéneos, é dicir, aqueles en que nos temos que contentar con explicitar os argumentos ou actan- 
tes do verbo definido, pero con funcións sintácticas distintas ás que lles corresponden cando se constrúen con el.É o caso, entre outros, de

rizar. tr. Formar en el pelo artificialmente anillos o sortijas, bucles, tirabuzones, etc.

onde pelo actúa como complemento circunstancial no definiens, mentres que co definido sería o complento directo; así mesmo, en

resucitar. $t$. Volver la vida a un muerto.

o complemento indirecto sería, non obstante, o directo do definido. Notemos que, nestas circunstancias, o poder informativo -sintacticamente falando- do contorno queda bastante minguado, o que levou a algúns autores de dicionarios -é o caso, por exemplo, do DEA ou do DS e antes, aínda que tan só parcialmente, do DUE- a sinalar por diversos procedementos formais as funcións sintácticas que os elementos do contorno han de desempeñar cando aparecen co definido. Considérese, como exemplo, esta definición do DEA:

retirar. tr. Hacer que [alguien o algo $(c d)$ ] deje de estar [en un lugar (complDE)]

onde, como é sabido, os elementos entre corchetes pertencen ao contorno, os cales, ao desempeñaren funcións sintácticas distintas que co definido, van seguidos da indicación de función entre parénteses.

Como sinalei no seu día nun artigo sobre o contorno (Porto Dapena 1997: 221-222), o poder informativo do dicionario podería potenciarse aínda máis, sinalando na definición, por exemplo, o réxime preposicional, o carácter obrigatorio ou non dun complemento, a súa condición de complemento interno, etc., simplemente utilizando distintos tipos de parénteses: concretamente, propoñía entón usar corchetes ([ ]) para indicar o carácter obrigatorio, parénteses angulares $(\langle\rangle)$ para os complementos non obrigatorios, e, finalmente, parénteses normais para os complementos internos, ademais dunha serie de subíndices encargados de sinalar a función (cando non coincidise coa do definiens) ou o réxime preposicional. Así, resultaría o seguinte:

\footnotetext{
abanicar. tr. Hacer aire ${ }_{\text {od }}[\mathrm{a}$ alguien] (con un abanico u otro objeto a modo de abanico).
}

abastecer. tr. Dar o vender ${ }_{\text {od }}[\text { a alguien }]_{\mathrm{cpde} \text {, con }}<$ todo lo que se necesita $>$. 
Sistema semellante a este, aínda que máis sinxelo, foi o adoptado despois polo $D S$.

De todos os xeitos, habida conta de que toda esta parafernalia de parénteses e subíndices resultan bastante enguedellantes á hora de consultar o dicionario, eu avogaría hoxe por separar nas acepcións os elementos contextuais ou contorno, dos propiamente definicionais ou parafrásticos, rexistrando en primeiro lugar o contexto e logo a definición, que así quedará bastante despoxada de elementos externos. É, por certo, unha práctica que estou a adoptar -penso que con éxito- no meu futuro Diccionario "Coruña" de la lengua española actual (DCLEA) e que, ao meu xuízo, fará deste dicionario, sendo xeral, un dos máis informativos dende o punto de vista sintáctico. Proporei tan só un caso a xeito de simple mostra:

beber $v$. 1. tr. $[\sim$ un animal o persona (suj.) <una cosa líquida $><$ p. e. agua $>$ (od.) $]$. Ingerirla o meterla en la boca haciéndola pasar al tubo digestivo.

Yo nunca bebo soda. Cuando tengo sed, mejor bebo agua. (Santiago, El sueño de América, 21 [CREA])

a) intr. Sin obj. directo puede significar particularmente 'consumir bebidas alcohólicas'. $\vee$ En este caso puede ir acompañado de los advs. de cantidad mucho, demasiado o poco, o también con la expresión como un cosaco. Si no lleva ningún adv., se entiende siempre mucho o demasiado y, por lo tanto, el verbo adquiere más particularmente el significado de 'ser alcohólico o tener el vicio de tomar bebidas alcohólicas'. Finalmente, en frase negativa equivale siempre a 'ser abstemio, no probar el alcohol': "Domingo no bebe, pero su hijo sî".

$\mathrm{Y}$ el español bebe sobre todo fuera de casa y raras veces bebe en solitario. (Domingo, El sabor de España, 40 [CREA])

Vivía en una pensión y bebía como un cosaco. (Leguineche, La tierra, 151 [CREA])

No fuma, no bebe y habla con el desparpajo y la insolencia propias de su edad. (El País [CREA], 02/08/87 [CREA])

b) $[\sim$ alguien (suj.) por algo o alguien (cp.)]. Tomar una copa — p. e. después de un brindis— para celebrar o desear algo positivo a favor de la persona o cosa que se expresa.

Vamos a beber por los buenos consejos. (Loriga, Héroes, 130 [CREA])

Contra sus hábitos, la madre pidió que le sirvieran vino y bebió por su esposo y sus hijos, mencionando cada nombre con tal énfasis (luego comentarían) que quizá quiso despedirse de esta manera. (Otero, Temporada de ángeles, 130 [CREA])

Trátase, como pode verse, da primeira acepción do verbo beber: o contexto aparece entre corchetes, as parénteses angulares serven para indicar a non obrigatoriedade do elemento que acoutan, e nas definicións aparecen só aqueles elementos do contorno (en cursiva) que resultan sintacticamente imprescindibles para facer viable o enunciado definicional. 


\subsection{Información gramatical e separación de acepcións}

No tocante ás informacións gramaticais contidas nas definicións lexicográficas -ou que se poden doadamente deducir delas-, quero referirme agora a unha cuestión que, no que a min se me alcanza, non foi ata agora abordada por ninguén, porque atinxe ao aspecto sen dúbida máis problemático e á vez espiñento da Lexicografía, como é a delimitación ou separación de acepcións. Concretamente, a cuestión que quero formular aquí é ata que punto as acepcións en que se dividen os artigos lexicográficos corresponden -tal como se adoita crer- a significados diversos da palabra-entrada ou, máis ben, a distintos comportamentos sintácticos desta e, polo tanto, proporcionan unicamente información gramatical.

De todos é sabido que, para a separación de acepcións, non existen uns criterios universalmente aceptados polos lexicógrafos, o que explica a gran disparidade con que os dicionarios -agás nos casos, non infrecuentes, de plaxio- describen dende este punto de vista unha mesma palabra, atribuíndolle un maior ou menor número de acepcións, por outra parte non sempre coincidentes. Por regra xeral, confúndense nesta operación características de moi distintas ordes: semánticas, gramaticais, pragmáticas, enciclopédicas... O lexicógrafo, guiado pola súa intuición, limítase a constatar os diversos sentidos que vai detectando nos textos proporcionados polo corpus, sen distinguir normalmente se se trata realmente de significados distintos ou máis ben de puras variantes dun mesmo significado. É o que acontece, como é lóxico, nos dicionarios que, como o $D R A E$, non rexistran máis que acepcións; pero aínda nos que separan acepcións e subacepcions -así no DUE e no DEA-tampouco se seguen uns criterios homoxéneos e, dende logo, obxectivos ${ }^{2}$.

A pregunta que se fan todos os que por primeira vez se teñen que enfrontar coa redacción de artigos é sempre a mesma: que debemos separar en primeiro lugar, os significados ou as construcións? O que en realidade equivale a cuestionar se na separación de acepcións debe primar o sintáctico sobre o semántico ou, pola contra, o semántico sobre o sintáctico.

2. En realidade non existe unha idea clara na lexicografía tradicional acerca do que ha de ser unha acepción e unha subacepción, e, polo tanto, tal distinción obedece así mesmo a criterios meramente subxectivos. Na miña opinión, non obstante, os dous termos deberían empregarse, respectivamente, para referirse aos significados e ás variantes de significado: debe entenderse que dous sentidos dun vocábulo corresponden a significados ou acepcións distintas cando en ambos a devandita palabra forma parte de paradigmas léxico-semánticos diferentes, mentres que, de pertenceren ao mesmo paradigma, acharémonos ante variantes ou subacepcións dun mesmo significado (véxase Porto Dapena (2002a: 199). Sobre os problemas do establecemento de acepcións ocupáronse recentemente J. A. Pascual Rodríguez e R. García Pérez (2007: 117 ess.). 
Dende logo eu non teño ningunha dúbida -como non a tivo tampouco Cuervo no seu $D C R$ - de que a separación de acepcións debe consistir basicamente en distinguir significados ou, por mellor dicir, sentidos, aínda cando cada un destes vaia moitas veces asociado a un determinado comportamento sintáctico. Pero non todo o mundo segue este procedemento: sen ir máis lonxe, o DEA, que representa nestes momentos sen dúbida o mellor dicionario do español actual, parte, como é sabido, dunha separación sintáctica, ao estudar separadamente nos artigos dos verbos as construcións transitiva, intransitiva e pronominal, cousa que o leva, por certo, a repetir en moitos casos o mesmo significado en cada unha desas construcións, duplicando ou triplicando así o número de acepcións. Considérese, por poñer un exemplo sinxelo, o seguinte artigo do DEA:

enfermar A intr 1 Ponerse enfermo [1]. Tb. $(r e g) \operatorname{pr}(\sim \mathrm{se})$. A veces con un compl. DE.

B $\operatorname{tr} 2$ Poner enfermo [1 y 2] [a alguien o algo]. A veces con un compl DE o, raro, CON.

onde se establecen dúas acepcións, que en realidade non son máis que unha, aínda que en construcións sintácticas distintas: as diferenzas veñen aquí dadas pola configuración sintáctica dos actantes, pois o suxeito de 1 é o complemento directo de 2, onde á vez se incrementa un novo actante, un causante ou instigador.

Cando unha mesma acepción dun verbo é susceptible de expresarse mediante construcións distintas o máis frecuente nos dicionarios -porque este é o proceder preferido polo DRAE- é utilizar unha soa definición de acordo cunha desas construcións (a que se considera máis xenuína) e engadir, mediante abreviaturas, na mesma acepción, expresións como "u. t. c. tr. (intr. ou prnl.)", é dicir, "usado tamén como transitivo (intransitivo ou pronominal)". Así,

derrumbar [...].2. tr. Derribar, demoler una construcción o parte de ella. U. t. c. prnl.

A información sintáctica resulta correcta, pero sen dúbida insuficiente, posto que non se explica a modificación funcional de que serán obxecto os actantes.

Estes mesmos dicionarios, non obstante, non seguen un criterio homoxéneo nesta cuestión, posto que, ao lado desta solución, atopamos tamén, o mesmo que no exemplo que acabamos de ver do DEA, unha diversificación de acepcións, que -repito- non presentan máis que unha pura variación na configuración sintáctica dos actantes. Considérese, por exemplo, o seguinte artigo tomado do propio DRAE: 
empapar. 1. tr. Humedecer algo de modo que quede enteramente penetrado de un líquido. Empapar una sopa en vino. U. t. c. prnl. El pan se empapa en el vino. 2. tr. Dicho de una cosa: Absorber dentro de sus poros o huecos algún líquido. La tierra empapa el agua. U. t. c. prnl. La tierra se empapa de agua. 3. tr. Absorber un líquido con un cuerpo esponjoso o poroso. Empapar con un trapo el agua vertida. 4. tr. Dicho de un líquido: Penetrar los poros o huecos de un cuerpo. La llwvia empapa los vestidos. U. t. c. prnl. La lluvia se empapa en la tierra.

cuxas catro acepcións son en realidade unha soa, pero con distintas funcións sintácticas dos mesmos actantes e que poderiamos resumir nas seguintes frases:
1. Juan empapó la esponja en agua.
2. La esponja empapó el agua.
3. Juan empapó el agua con una esponja.
4. El agua empapó la esponja.

onde, como se ve, utilizamos os mesmos argumentos ou actantes, é dicir, $\mathrm{A} 1$ = Juan, A2 = esponja, e A3 = agua (cfr. Porto Dapena 2002b).

\subsection{Información sobre o réxime e as colocacións}

Con ser as definicións, xa sexa, como acabamos de ver, a través dos contornos ou na súa relación con outras acepcións dentro do mesmo artigo lexicográfico, unha importantísima e indiscutible fonte de información gramatical nos dicionarios comúns, non cabe dúbida de que estes, ao mesmo tempo, presentan indubidables deficiencias á hora de precisar o comportamento sintáctico ou combinatorio das palabras. De acordo co que sinalou recentemente Ignacio Bosque (2004: CVII), das definicións de sumo, por exemplo, que tomo do DEA abreviado,

sumo ${ }^{1}$, -ma [...] adj 1. Máximo, o superior a todos los de su especie. 2. Muy grande en calidad o intensidad.

non se deduce -senón máis ben ao contrario- que non sexan aceptables, entre outras, expresións como *Tenía suma hambre ou *Esta lámpara es suma, fronte, en cambio, a Lo haré con sumo gusto, Hay que tener sumo cuidado, que serían perfectamente aceptables. Nos dicionarios, efectivamente, case nunca se precisa con que palabra ou palabras concretas adoita construírse de feito un vocábulo; é dicir, non se rexistra o que hoxe coñecemos co nome de colocacións, así como en moitísimos casos tampouco se mostra o réxime preposicional das 
palabras, segundo acontece, por exemplo, neste artigo, que tomamos do DRAE:

comparar. 1. tr. Fijar la atención en dos o más objetos para descubrir sus relaciones o estimar sus diferencias o semejanza.|| 2. tr. cotejar.

Non se precisa, en efecto, que dos obxectos comparados un deles haberá de actuar como complemento preposicional precedido de con.

Non é, dende logo, agora o momento de entrar na discusión do que debemos entender exactamente por colocación, noción, como se sabe, dabondo controvertida (véxase, entre outros, Alonso Ramos 1994-1995 e Koike 2001) e que eu aplicaría, por razóns prácticas, a toda combinación fixa de palabras -establecida polo uso- que se repite sen que entre elas exista solidariedade nin que, por outro lado, posúa significado idiomático. É dicir, a presenza dunha non esixe necesariamente a da outra -non existe condicionamento ou selección semántica-e, dende o punto de vista do seu contido, cada unha conserva o seu correspondente significado. Así, a expresión frecuente durmir profundamente ou pracidamente será unha colocación, pois nin durmir esixe a profundamente ou pracidamente, nin ningún destes adverbios a durmir, e, ademais, ambas as dúas palabras conservan o seu significado individual. Pero notemos que a semellante combinación non se fai a máis mínima alusión en ningún dicionario xeral da lingua galega (nin da española verbo do comportamento parello de dormir).

En relación, por certo, co español dormir, en todos os dicionarios atopamos rexistradas expresións como dormir a pierna suelta ou dormir como un lirón, que, ao meu modo de ver, seguen sendo tamén colocacións, agora constituídas por dormir e as locucións a pierna suelta e como un lirón. Neste caso penso que tal rexistro se debe á interpretación -sen dúbida errónea- desas combinacións como locucións verbais aínda que, evidentemente, o carácter locucional corresponde unicamente ás correspondentes expresións adverbiais.

Non é este, naturalmente, o único caso en que os dicionarios comúns rexistran colocacións. Obsérvese, por exemplo, o seguinte exemplo tomado do DRAE:

tomar $[\ldots]$ 28. tr. Ponerse a ejecutar la acción o la labor para la cual sirve un determinado instru-

mento. Tomar la pluma, ponerse a escribir. Tomar la aguja, ponerse a coser. 
onde é evidente que tomar la pluma e tomar la aguja son así mesmo colocacións. O rexistro, con todo, deste tipo de construcións é sempre esporádico e, dende logo, nada sistemático.

E outro tanto cabe dicir do réxime preposicional, cando este non é deducible do enunciado definicional, como no caso de comparar, a que me referín antes. Só algúns dicionarios -por exemplo, o DEA e, na maioría dos casos, o DUE- ofrecen realmente esa información. E así, no artigo correspondente á mesma palabra comparar, o DEA di o seguinte:

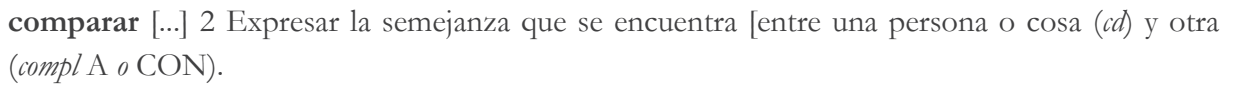

E no DUE de María Moliner:

comparar [...]1 («con») tr. *Examinar alternativamente dos o más cosas para apreciar sus semejanzas y diferencias.

onde, como é sabido e pode aquí observarse, o réxime preposicional se indica mediante unha paréntese diante da definición, aínda que non se precisa que elemento ha de levar a preposición. Son, con todo, sempre casos excepcionais e case sempre esporádicos.

\section{CONCLUSIÓN}

E, xa para concluír, direi que, dende logo, os dicionarios comúns -de tipo xeral e semasiolóxico ou alfabético-, aos que aquí me vin referindo, non informan sobre aspectos morfolóxicos e, sobre todo, sintácticos coa mesma intensidade e detalle con que o fan os dicionarios especializados ou dicionarios gramaticais, é dicir, entre outros, os de valencias, de construción e réxime, combinatorios, de colocacións, etc. Se así non fose, é obvio que a existencia destes últimos carecería de toda xustificación. Non obstante, como creo quedou suficientemente demostrado ao longo desta breve exposición, os dicionarios comúns -aínda sen pretendelo moitas veces-informan sobre eses e outros aspectos en maior medida do que quizais podería pensarse á primeira vista. Isto, por outra banda, non significa que o dicionario se extralimite nas súas funcións de informar sobre o léxico da lingua, entrando nun terreo que non lle corresponde e reservado unicamente á gramática. Realmente, aínda que é verdade que existe certa imbricación entre Dicionario e Gramática, como, por exem- 
plo, acontece -segundo vimos-co tratamento de palabras gramaticais ou formas irregulares de flexión por parte daquel, non é menos certo que os aspectos valenciais e combinatorios en xeral das palabras concretas son aspectos que atinxen só e exclusivamente ao Dicionario, o cal de ningún xeito se pode limitar a informar sobre os significados ou, en xeral, os trazos estritamente paradigmáticos do léxico. En realidade, como moi ben se demostra na análise das definicións lexicográficas, sería imposible delimitar o significado dunha palabra sen ter en conta ao mesmo tempo a súa proxección sintagmática, isto é, o contexto ou contextos en que ese significado pode aparecer; digamos que entre o paradigmático e o sintagmático existe unha interdependencia e, polo tanto, sería imposible o estudo dun prescindindo absolutamente do outro. O único que, en todo caso, cabe lamentar é que os dicionarios comúns non exploten en maior medida as posibilidades que, sen apenas custo, teñen de informar máis e mellor acerca do comportamento morfosintáctico das palabras, como, dende logo, hai que lamentar á vez que os usuarios do dicionario carezan na maior parte dos casos das debidas destrezas como para sacalle todo o rendemento que cabe sacar ás consultas lexicográficas. A verdade é que se usa pouco e mal o dicionario. 



\title{
LEXICOGRAFIA PORTUGUESA. PERSPECTIVA CRÍTICA
}

\author{
Telmo Verdelho
}

Universidade de Aveiro

1. O bibliónimo Dictionarium foi pela primeira vez publicado em Portugal em 1551 no título de um pequeno manual escolar, Hieronymi Cardosi Dictionarium Iuventuti studiosae admodum frugiferum (Cardoso 1551)', destinado ao ensino do latim a estudantes portugueses. Trata-se de um abreviado vocabulário latim-português, com 3.300 entradas, distribuídas por grupos temáticos, sem qualquer ordem alfabética e com valorização de um universo de referência profano, com alargado espaço para a terminologia da medicina.

A primeira dicionarização efectiva do português, com alfabetação do conjunto do corpus lexical, teve lugar em 1562, com a publicação de um dicionário de português-latim (Cardoso 1562-1563). Regista cerca de 12.000 entradas e oferece uma boa documentação do vocabulário comum, tradicional e não erudito da língua. Todavia, apresenta já alguns indícios da renovação latinizante que se encontrava crescentemente exercitada nos textos dos humanistas e nos versos de poetas como Camões.

A lexicografia portuguesa, prolongando a herança latina, nasceu um pouco mais tarde do que a de outras línguas europeias, e teve um percurso menos abundante, em obras publicadas, mas não deixou de preencher um espaço interessante, pela sua dimensão linguística e cultural, e ainda por uma certa originalidade, no panorama amplo da elaboração dicionarística das línguas modernas.

Poderemos salientar, entre vários aspectos observáveis no percurso histórico da lexicografia portuguesa, um conjunto de traços mais caracterizadores, que particularmente a distinguem de outras experiências lexicográficas suas contemporâneas, e que marcam a sua especificidade. Nomeadamente:

1. Não se conhece actualmente nenhum exemplar da edição princeps. 
- herança residual no que respeita à produção glossarística da Idade Média,

- estreita e continuada vinculação à tradição europeia, particularmente italiana, espanhola e francesa,

- surgimento relativamente tardio,

- produção de uma precoce e original lexicografia transeuropeia ligada à missionação,

- destacado predomínio da lexicografia escolar dos Jesuítas, até 1750 ,

- emergência singular duma obra monumental: o Vocabulário de Rafael Bluteau (1712-1728),

- período áureo de produção lexicográfica na segunda metade do século XVIII, correspondente ao início de uma dicionarística verdadeiramente moderna,

- recepção dos dicionários no Brasil e interacção francesa,

- democratização do dicionário prático na primeira metade do século XIX,

- inexistência de uma política da língua e desamparo institucional em relação à elaboração e produção lexicográfica, em contraste com o contributo gracioso proveniente do espaço não lusófono.

Estas observações não compendiam toda a história dos dicionários portugueses. Muitos outros factos assinalaram o seu percurso e condicionaram a sua produção e interacção no horizonte linguístico e cultural português. Os dicionários para além de inesperadas peripécias bibliográficas, que muitas vezes acompanharam a sua publicação, integraram-se na vida das línguas e dos povos como um objecto de civilização. Constituem agora, pela acumulação de alguns séculos, um património documental onde se encontram repercutidas, de maneira muito sensível, a sociedade e as suas vicissitudes, neles transparecem os recursos técnicos e económicos, a vida literária, e até o trânsito político e as ondas ideológicas. Os dicionários portugueses são, sob este ponto de vista, proveitosamente instrutivos. Tiveram um processo de emergência e de divulgação, que lhes permitiu acompanhar, com uma discreta inocência testemunhal, sobretudo os últimos duzentos anos da história nacional. Alguns foram objecto de edições sequenciadas em genealogias mais ou menos "generosas" e mais ou menos prolongadas. O caudal do léxico foi-se acumulando e transmitindo de maneira quase automática, com algumas raras interferências de vigilância crítica. 
Perspectivando um roteiro da lexicografia portuguesa poderiamos anotar uma linhagem sucessória em que se distinguem os nomes de Jerónimo Cardoso (1510?-1569) Bento Pereira (1605-1681), Rafael Bluteau (1638-1734), António de Morais Silva (1755-1824), Joaquim José da Costa e Sá (1740-1803), Pedro José da Fonseca (1751-1816), Francisco Solano Constâncio (1772?-1846), José da Fonseca (1788-1866), Inácio Roquete (1801-1870), Domingos Vieira (?-1854), Caldas Aulete (1823-1878), António Lopes Santos Valente (1839-1896), Candido de Figueiredo (1846-1925), Augusto Moreno (1870-1955), Cardoso Júnior (1884-1969), Francisco Torrinha (1879-1955), José Pedro Machado (1914-2005), Almeida Costa, Sampaio e Melo, e no Brasil, entre outros, Antenor Nascentes (1886-1972), Aurélio Buarque de Holanda Ferreira (1910-1989), Geraldo da Cunha (1924-1999) e António Houaiss (1915-1999).

O contributo destes autores fluiu, transfundiu-se e transcendeu o âmbito do legado pessoal, para ser continuado em edições póstumas "actualizadas", "revistas", "corrigidas", "renovadas", "emendadas", "acrescentadas", "melhoradas", "enriquecidas", "reformadas", "ampliadas", "adicionadas", numa herança de intercolaboração de gerações, que faz de quase todos os dicionários textos característicos de autoria colectiva.

Na tradição portuguesa, a mais ilustre e prolongada linhagem é a de António de Morais Silva que, por sua vez, retoma o testemunho do Vocabulário de Bluteau que ele próprio quis repercutido no título da edição inicial. Começou em 1789 com a publicação do Diccionario da lingua portugueza / composto pelo padre D. Rafael Bluteau; reformado e accrescentado por Antonio de Moraes Silva (Morais 1789), e foi reeditado, sempre em dois volumes, em 1813, 1823, 1831, 1844, 1858, 1877-78, 1889, 1891, e finalmente retomado para uma edição monumental (12 volumes), com o título Grande dicionário da língua portuguesa / António de Morais Silva; $10^{\mathrm{a}}$ ed / revista, corrigida muito aumentada e actualizada segundo as regras do acordo ortográfico luso - brasileiro de 10 de Agosto de 1945 por Augusto Moreno, Cardoso Júnior e José Pedro Machado (Morais 1949-1959). Geralmente mencionado, desde as primeiras edições, pela designação metonímica de "o Morais", este dicionário é citado e aludido, sobretudo a partir dos meados do século XIX, por gramáticos e grandes escritores, entre eles, Camilo Castelo Branco, como a mais importante referência normativa para autorizar e esclarecer o léxico português (cfr. Verdelho 2002). 
2. A reflexão lexicográfica participa da história da língua, é uma condição do seu ordenamento normativo e, de certo modo, acompanha a língua escrita antes do aparecimento dos dicionários. O dicionário é um instrumento metalinguístico tardio, que veio fazer parceria com a gramática, no apoio ao ensino e ao uso da língua. A gramática surgiu na antiguidade clássica, na sequência da reflexão linguística dos filósofos e sofistas gregos e dos filólogos helenistas, mas o dicionário é uma "arte" moderna, criada para o estudo e uso do latim, no âmbito do humanismo renascentista, e depois desenvolvida, até aos nossos dias, com o apoio da técnica tipográfica, no percurso progrediente da generalização da escrita por parte das línguas modernas.

Em todo o caso, os dicionários latinos, que começaram a ser publicados no final do século XV, não surgiram "ex nihilo", foram precedidos por alguns textos medievais pré-dicionarísticos -v.g. Elementarium de Papias (1050) (cfr. de Angelis 1977-1980 e Shaw 1997) e Catholicon de Balbo (1286) (cfr. Shaw 1997)- e sobretudo por uma considerável produção glossarística, que facilitava o acesso aos textos latinos e apoiava o ensino do latim. Desse património de glossários medievais, que é relativamente abundante para algumas línguas europeias, guarda-se para o português apenas um modesto e delido manuscrito alcobacense, dos séculos XIII ou XIV, com uma lista alfabética de verbos latinos (cerca de 3.000) a que foram acrescentadas as equivalências portuguesas (1.130 formas diferentes -muitos verbos portugueses são várias vezes repetidos e utilizados para traduzirem os verbos latinos correspondentes que foram agenciados de modo mais copioso por uma longa tradição de escrita $)^{2}$. Houve provavelmente mais glossários de latim-português, mas são hoje herança perdida.

A escrita portuguesa desse tempo repercute o espírito pré-dicionarístico da cultura literária medieval, especialmente nos textos dedicados ao relacionamento jurídico, que retomam as formas latinas e as traduzem quanto à letra e quanto ao sentido (cfr. José de Azevedo Ferreira 1980 e 1987, e ainda Miranda Menéndez 2004).

Também nos textos de Avis são frequentes as transcrições de sequências glossarísticas e os enunciados redundantes, que procuram com insistência garantir o acesso à significação das palavras. Nestas obras, com objectivos bem distantes da reflexão discursiva, salienta-se a informação

2. Descrito no Inventário dos códices alcobacenses com o n CDIV/286: "Pequeno dicionário de verbos latinos com a correspondente significação em português. No fim algumas notas sobre versificação... letra gótica cursiva, miúda, dos meados do século XIV" (p. 257); ver Carter (1953). Cfr. Verdelho (1995: 195 e 515). 
metalinguística, sobretudo orientada para o esclarecimento lexical e filológico, e a preocupação de traduzir o latim para linguagem³.

A escrita "em linguagem", na Idade Média, pela sua insistente redundância, acusa bem a ausência dos dicionários, que a partir do século XVI vão libertar os autores para um certo aligeiramento da intransparência semântica, para a inovação lexical, e também para uma fácil intertextualização do latim em citações eruditas e de ornamento estilístico. Com o advento da produção lexicográfica, termina também a tradição glossarística. As gramáticas latinas, que começaram a ser impressas em grande número e distribuídas individualmente pelos estudantes, e os pequenos dicionários escolares, organizados por grupos temáticos de palavras, permitiam a aprendizagem sistemática, dos verbos e nomes anómalos e do vocabulário em geral.

3. Em Portugal a renovação deste horizonte metalinguístico foi feita no âmbito duma estreita e continuada vinculação à tradição europeia.

A língua portuguesa, desde o início da sua memória escrita, recebeu informação metalexicográfica, proveniente de um convívio interlinguístico em que, juntamente com o latim, se ia cultivando uma relação com os vernáculos, particularmente com o espanhol, o provençal, o italiano e o francês, e sobretudo com a produção lexicográfica latina originada no espaço central da Europa.

A prosa não historiográfica produzida em língua portuguesa durante a Idade Média retomava e traduzia, geralmente a partir do latim, como já notámos, textos e fragmentos avulsos de súmulas e enciclopédias que transmitiam o legado do saber europeu, elaborado desde a antiguidade. Esses textos pré-dicionarísticos continuaram a ser usados depois do século $\mathrm{XV}$, juntamente com os dicionários humanistas, já impressos, provenientes de Espanha, Itália e França. No espólio acumulado das bibliotecas portuguesas e ainda no mercado do livro antigo, encontram-se exemplares, não raros, desses monumentos inaugurais da elaboração lexicográfica.

Para além de testemunhos manuscritos ainda conservados (um fragmento do Catholicon e os códices alcobacenses das Derivationes de Hugúcio e do Elementarium de Papias, este em três preciosos volumes), temos

Servem-nos de ilustração estes exemplos do Livro da Montaria: "E con este escolhimento representa a outra virtude a que dizem vontade e, se se acorda con aquillo que o entender boo acorda, entom lhe dizem bom entendimento porque se ajunta a esta palavra de duas virtudes, de entender e de vontade, a que dizem mente. Tomando estas duas palavras, 'entender' e 'mente', vem a fazer aquella concordia daquellas virtudes e chamam-lhe entendimento" (1.1). "E porque ha hi huma palavra en latin que comprehende a muytas partes, demais aos que as obran, que diz assi: Omnis laus in fine canitur, que quer dizer, todo louvor está en fin das cousas quando bem feitas son, ca, das cousas que bem feitas non son, non pode en ellas caber louvor" (1.23). 
notícia da utilização de textos impressos, alguns dos quais se encontram ainda hoje entre o espólio remanescente nas bibliotecas portuguesas. $\mathrm{Na}$ livraria, assaz modesta, da Universidade de Lisboa, por altura da sua transferência para Coimbra, foi inventariado um "vaqabulairo de marmotreto" 4

Estão referenciadas também algumas edições incunabulares e renascentistas do Catholicon e de textos paralexicográficos como o enigmático Suda ou suidas lexicon graecum, publicado por Demetrios Chalkondyles (Milão, 1499)5 , a Cornucopia de Nicolaus Perottus, a versão latina do Onomasticon de Julius Pollux e vários outros (Verdelho 1995: 496-499).

Nos primeiros decénios da pedagogia e da cultura humanista em Portugal, foi sobretudo a obra lexicográfica de Nebrija, mais do que todas as anteriores, que teve curso em Portugal e que tutelou a escolarização e o uso literário do latim. Houve mesmo uma edição do seu conjunto dicionarístico (Nebrija 1545), impressa na Bélgica, expressamente destinada ao público português (composto pelos dicionários de latim-castelhano -em que foi integrado um dicionário de termos de medicina com a colaboração do português Luís Nunes-, castelhano-latim e um dicionário de nomes próprios). Foi ainda o dicionário de latim-espanhol deste autor que serviu de matriz para o primeiro dicionário latim-português publicado em 1569 por Jerónimo Cardoso. Os dicionários espanhóis devem ter acompanhado a formação de quase todos os humanistas portugueses e contribuíram para o convívio interlinguístico e interliterário peninsular. Foram certamente utilizadores de Nebrija os cerca de 1.800 portugueses que escreveram em castelhano até alguns anos depois de 1640.

Além dos manuais do humanista espanhol, a produção europeia foi correspondendo à procura lexicográfica portuguesa, mesmo depois do aparecimento dos primeiros dicionarios portugueses, na segunda metade do século XVI. A importação alargou-se aos dicionários históricos e de especialidade, que preencheram o espaço português com bastante afluência e, poderemos acrescentar, com satisfatório proveito. Alguns foram mesmo impressos em Portugal, como o dicionário de nomes próprios publicado por Stochkammer'; e o dicionário de vozes eclesiáticas de Ximenes Arias (1490-1578?) (Ximenez Arias 1566)․

Propriorum nominum... Trata-se de um texto quase integralmente retomado directa ou indirectamente do Dictionarium poeticum, geralmente designado "Elucidário", de Hermannus Torrentinus (1450-1520). Foi integrado no conjunto dicionarístico de Cardoso a partir de 1569 e repetido nas edições seguintes até ao final do século XVII.

7. Teve a primeira edição em 1566 em Salamanca e foi duas vezes impresso em Portugal (Braga, 1569 e Lisboa, 1588). 
Foram bem conhecidas e muito manuseadas as recolhas lexicais ciceronianas de Mário Nizolio (1488-1567) e de Pedro Juan Núñez de Valencia (1522-1602), e vários outros dicionários literários, de epítetos e de citações, particularmente as obras de Ravísio Textor (1480-1524) (Officina, Cornucopia e Epithetorum opus). A obra de Textor, sobretudo a Officina, é reiteradamente citada em textos portugueses. Heitor Pinto na Imagem da Vida Cristã refere-se-lhe 14 vezes; Barros cita Ravísio no Espelho de Casados (1540); Jorge Ferreira de Vasconcelos recolheu, na obra de Textor, os nomes das suas personagens e numerosas outras informações históricas e mitológicas; e Camões, muito provavelmente, socorreu-se dos epítetos recolhidos por Textor, para o provimento de grande parte da alatinada adjectivação que ornamenta a sua obra, além de outros elementos poéticos, como a designação para o fabuloso e oportuno mito do Adamastor.

Os grandes dicionários latinos do século XVI e XVII, especialmente o Thesaurus Linguae Latinae de Robert Estienne (1503-1559), o Calepino de Ambrósio Calepino (1435-1511) e a Amalthea de Giuseppe Laurenzi (1573?1647) tiveram recepção ampla e diuturnamente recorrida entre os humanistas e pedagogos portugueses.

O Thesaurus Linguae Latinae (Estienne 1531), nos seus três volumes "in folio", foi conhecido e muito utilizado. A sua difusão pode ter sido condicionada pelo facto de Robert Estienne ser um autor "damnatus", pela adesão ao calvinismo; em todo o caso, temos notícia certa de que o Thesaurus circulou com muito desimpedimento e foi citado pelos estudiosos em Portugal, ao longo dos séculos XVI, XVII e XVIII. Conservam-se, nas bibliotecas portuguesas, vários exemplares, ainda que alguns se encontrem riscados e mutilados, pelo mau uso dos leitores ou pelas injúrias censórias. Amaro Reboredo deve ter recolhido no Thesaurus as séries de locuções, de listas coocorrentes e de grupos de significantes sinonímicos ou analógicos que alargam inesperadamente um bom número de artigos.

O dicionário de Ambrósio Calepino (1502) foi, entre toda a lexicografia europeia, a obra que mais se difundiu e utilizou em Portugal, e é ainda hoje o título dicionarístico importado que se encontra com mais abundância no fundo bibliográfico português, público e privado, e teve o privilégio de ser levado pelos Missionários portugueses até ao Japão em 1595 (Verdelho 1999-2000).

No século XVII, a Amalthea onomastica de Laurenzi (1640) motivou o modesto vocabulário escolar de Frei Tomás da Luz (1633-1713) a Amalthea sive hortus onomasticus (Luz 1673) (cfr. Telmo Verdelho 2006) e serviu de fonte copiosíssima (cerca de 7.300 citações) para a revisão da Prosódia de Bento Pereira, levada a cabo em 1697. 
A abertura do espaço linguístico português para o acolhimento da lexicografia europeia vai alargar-se com a participação de lexicógrafos e editores estrangeiros como Rafael Bluteau (1638-1734) e de vários impressores franceses que, a partir da segunda metade do século XVIII e durante mais de um século, sediados em Portugal e em França, estimularam e sustentaram a publicação da maior parte dos dicionários portugueses e suscitaram a interacção dos modelos estrangeiros.

4. A dicionarização e alfabetação da língua portuguesa aconteceu relativamente tarde, tendo em conta a cronologia da emergência lexicográfica em outras línguas europeias. Em 1562, o italiano, o espanhol, o francês e o inglês (para citar apenas as grandes línguas mais próximas) tinham já, no seu conjunto, vários títulos, reproduzidos em muitas dezenas de edições, em que as nomenclaturas desses vernáculos preenchiam as entradas que recebiam a equivalência do latim.

A originalidade do português esteve em começar pelo portuguêslatim, supondo um trabalho de agenciamento e inventariação do léxico sem poder contar com alfabetações anteriores e sem ter a possibilidade de recorrer a um dicionário de latim-português, como fonte ampla e privilegiada do fundo lexical. Outras línguas, como por exemplo o espanhol, puderam socorrer-se dos respectivos dicionários de latim-vernáculo, fazendo uma espécie de reversão do "corpus" lexical.

A alfabetação do léxico de uma língua constitui hoje uma técnica elementar de execução fácil, com os recursos da informática. Mas não foi assim no início da dicionarização das línguas. As primeiras tentativas confrontavam-se com o número, a variedade e a fluidez das palavras, e sentiram certamente muitas dificuldades para procederem à recolha sistemática e à identificação de um “corpus" o mais possível abrangente, que pudesse corresponder ao propósito de roteirar a língua, até aos limites de uma tendencial exaustividade. Por outro lado, as condições materiais da escrita, nos séculos XV e XVI, não facilitavam a ordenação alfabética dos elementos acumulados. Não havia ainda o recurso da ficha lexicográfica (o professor Quemada, nos seminários leccionados na École des Hautes Etudes, em Paris, atribuía a invenção a Diderot (1713-1784)) e a elaboração de um dicionário exigia uma repetida reescrita, com reintegração e reordenação alfabética de todas as entradas, em sucessivos manuscritos, com a forma de grandes cadernos.

Jerónimo Cardoso pode ter contado com a colaboração dos seus discípulos, que eram diligentes e numerosos (e possivelmente também com o apoio das filhas), para compor uma primeira alfabetação da língua portuguesa e dá-la à imprensa, oito anos antes da publicação do primeiro dicio- 
nário de latim-português, que ele próprio também preparou, certamente com a ajuda dos mesmos colaboradores.

De modo diferente, a primeira alfabetação sistemática do espanhol foi publicada por Nebrija, alguns anos depois de ter composto e publicado o Lexicon hoc est dictionarium ex sermone latino in hispaniense (Nebrija 1492), e é muito provável que tenha aproveitado o "corpus" vernáculo desta obra para preencher as entradas do Dictionarium ex hispaniense in latinum sermonem (Nebrija 1495?). Também para o francês, segundo o estema genético proposto por Wooldridge (1977:18), teríamos, nas origens da sua lexicografia, a seguinte linhagem de dicionários: Latinae linguae thesaurus (1531-36) $\rightarrow$ Dictionarium latinogallicum (1538) $\rightarrow$ Dictionaire françois-latin (1539).

A nomenclatura do Dictionarium ex Lusitanico in Latinum Sermonem (Cardoso 1562-1563), continuou, depois da sua primeira publicação, a ser objecto de pesquisa e de recolha, com o mesmo espírito de agenciamento em relação a um vocabulário difuso, e foi desse modo alargada com mais 728 novas entradas na $2^{a}$ edição em 1569-1570, perfazendo no seu todo 12.787 lemas. Muitas destas palavras não se encontram no conjunto dos restantes dicionarios (de latim-português) de Jerónimo Cardoso, confirmando assim uma elaboração original e sem recurso a um processo de reversão sobre os dicionários de latim-português.

O vocabulário coligido por Cardoso tornou-se uma referência instituidora, uma espécie de matriz alfabética, retomada e continuada na tradição lexicográfica da língua portuguesa.

Foi essa nomenclatura que serviu de base para um primeiro encontro interlinguístico entre a Europa e a China, num Dicionário PortuguêsChinês, redigido pelos missionários jesuítas (com destaque para o Padre Matteo Ricci, S.J., 1552-1610) aproximadamente entre 1583 e 1588 e transmitido manuscrito até aos nossos dias.

5. Este dicionário de português-chinês faz parte de um conjunto bastante amplo de estudos e ensaios linguísticos, realizados no quadro dos descobrimentos e da expansão ultramarina portugueses, motivados sobretudo pelo desejo de comunicar a mensagem cristã.

Sob a urgência do impulso missionário foram elaborados "vocabularios, e artes de mão..." configurados pelos modelos dos manuais escolares humanistas e emparceirando frequentemente o latim, pela primeira vez, com as línguas exóticas.

Ao lado da motivação apostólica, surgiram também textos menores, de tipo paralexicográfico, suscitados pelas necessidades do império, pelo relacionamento pessoal e comercial e pelo interesse científico. O exem- 
plo mais interessante será o pequeno glossário (138 termos) conservado em anexo do manuscrito do Roteiro de Alvaro Velho na primeira viagem de Vasco da Gama (1497) $)^{8}$. De muito interesse histórico e científico são as recolhas de designações botânicas e de drogas farmacêuticas, como as que se encontram na Suma Oriental de Tomé Pires (1465?-1540?) (Cortesão 1978) e na obra de Garcia da Orta (1501-1568), Colóquio dos simples e drogas e coisas medicinais da Índia, impresso em Goa em 1563 e difundido em versões latinas por toda a Europa (Orta 1563).

No que respeita ao Brasil, embora com menos proximidade em relação aos modelos lexicográficos, conhecem-se hoje vários títulos que dão testemunho do confronto com as palavras das línguas indígenas. Bluteau transcreve, em muitas centenas de citações, nomes "brasílicos" recolhidos especialmente nas obras do jesuíta Simão de Vasconcelos (1597-1671) e de Francisco de Britto Freire (1623-1692).

Os vocabulários coligidos no âmbito da aculturação missionária, destinados a superar o "detrimento da língua" no apoio à actividade escolar e catequética, são obras de um raro interesse lexicográfico, linguístico e etnocultural. Dão testemunho de uma aguda sensibilidade perante a expressão vária da comunicação verbal, e mobilizam uma formação metalinguística iluminada pela tradição teórica gramatical e filológica grecolatina. Ilucidativo a este propósito é o texto de João de Lucena, quando relata a iniciativa de São Francisco Xavier que estimula e orienta os confrades para o estudo da língua malabar:

\footnotetext{
Desejando habilitar ainda nesta parte os instrumentos da diuina palaura, quanto fosse possivel, ordenou ao padre Francisco Anriquez, a que sentio mais aplicaçam, \& talento reduzisse a arte, a lingoa Malabar, como anda a latina, com suas declinações de nomes, \& pronomes, conjugações de verbos, generos, preteritos, \& todas as mais regras de grammatica [...]. O padre Francisco Anriquez aprendeo em menos de seis meses a fallar, \& a ler, \& escreuer as proprias letras \& caracteres da terra, \& em breue tempo sahio com a arte, \& vocabulario da lingoa com espanto dos naturais (Lucena 1600: 367) $)^{9}$.
}

A necessidade de vocabulários no apoio à missionação vem igualmente documentada no "Prologo" do Vocabulario da lingoa de Iapam; nele se declara que "ja ha annos auia alguns Vocabularios, \& Artes de mão" (Rodrigues Tçuzu et al. 1603-1604).

Na sua maior parte, esses vocabulários eram transmitidos de forma manuscrita porque não havia meios, nem teriam qualidade suficiente-

8. Foi objecto de várias edições; cfr. Marques (1999). Ver ainda Messner (1998) e Losada Soler (2006).

9. Barbosa Machado (1741-1758: II, 449-450) atribui a autoria da arte de gramática da língua malabar e deste vocabulário ao P. Henrique Henriques (c. 1520-1600), que partiu para a Índia em 1546 e teria pronto o Vocabulário em 1550. 
mente revista para acederem à publicação impressa. Temos notícia de que um dos autores de "Vocabulários" da língua japonesa (os Jesuítas chegaram ao Japão em 1549) foi o P. Duarte da Silva, que ali faleceu em 1564.

A intercomunicação com as línguas não europeias tem suscitado ultimamente algum interesse entre os estudiosos da cultura e da historiografia linguística, mas não temos ainda informação suficiente para fundamentar um levantamento sistemático do encontro do português com o universo das línguas exóticas descobertas.

Pode fazer-se uma ideia aproximada dessa produção retomando as informações coligidas por David Lopes (1867-1942), (com as anotações de Luís de Matos (1911-1995) na $2^{a}$ edição) (Lopes 1936) e por Maria Leonor Buescu (1983). Merecem oportuna lembrança os nomes duma boa dúzia de lexicógrafos, entre os "Authores que escreverão em linguas Ultramarinas", citados na Biblioteca Lusitana de Barbosa Machado (1741-1758):

- Álvaro Semedo (1585-1658), lingua chinense (I, 114)

- António Barbosa (1 $1^{a}$ metade do séc. XVII), anamitica (I, 215)

- Boaventura de Santo António († 1697), brasilica (IV, 80)

- Diogo Ribeiro († 1633), canarina (I, 691)

- Duarte da Silva († 1564), japonica (I, 745)

- Francisco de Pina (1588-1625), anamitica (II, 221)

- Gaspar do Amaral († 1645), anamitica (II, 332)

- Gaspar Ferreira (1574-1649), chinense (II, 351)

- Henrique Henriques (1520-1600), malabarica (II, 450)

- Manuel Dias (1574-1659), chinense (III, 246-247) (?)

- Manuel Ferreira (1630-c. 1699), anamitica (III, 265)

- Miguel de Almeida (c. 1604-1683), canarina (III, 462).

Também se encontram alguns nomes na obra do Pe. Francisco Rodrigues (1917):

- Antão de Proença († 1666), tamúlico-português (publ. 1679) (346)

- António Saldanha (1598-1663), concaní (353)

- Gaspar Luís (1ª metade do séc. XVII), anamita (360)

- João Fernandes († 1567), japonês (371)

- João Rodrigues († 1633), japonês (370)

- Manuel Barreto († 1620), japonês (374)

- Manuel Viegas († 1608), língua dos maramomis (381)

- Miguel de Almeida († 1681), concaní (354). 
Esta lexicografia das origens teve uma renovada emergência, a partir do final do século XIX, especialmente em relação a algumas línguas africanas. Trata-se todavia de uma produção de modestas proporções que mal se pode comparar com as dimensões, a importância e a originalidade do património antigo. Entre os textos mais remotos que chegaram até nós, salientam-se, com justo relevo, os já citados Dicionário Português-Chinês e o Vocabulario da lingoa de Iapam (Rodrigues Tçuzu et al. 1603-1604), e além destes, o Dictionarivm latino lvsitanicvm, ac iaponicvm ex Ambrosii Calepini (1595), o Vocabulario da lingoa canarina (Diogo Ribeiro? 1626), o Diccionario Portuguez e Brasiliano e Brasiliano-Portuguez (1795/1934) ${ }^{10}$, os dicionários da Lingua Bunda ou Angolense e da Lingua Congueza do missionário capuchinho italiano Bernardo Maria de Cannecatim (1804 e 1805).

A interlexicografia portuguesa com línguas orientais teve ainda uma interessante realização na obra do oratoriano Jácome Gonçalves (16761742), natural de Divar (Goa). Segundo o testemunho de Barbosa Machado (1966: II, 472-474), o padre oratoriano compilou um conjunto de dicionários: Vocabulário cingalês-lusitano (1730), Vocabulário lusitano-cingalês, Vocabulário lusitano, tamul e cingalês. Deste último conhecem-se cópias manuscritas feitas pelo oratoriano Eusébio do Rosário em 1772 (cfr. Edmund Peiris 1943).

A herança interlexicográfica do português com as línguas não europeias é um testemunho primordial na história da dicionarística moderna que distingue a língua portuguesa, no panorama da lexicografia interlinguística. Trata-se de uma importante comunicação transeuropeia que levou ao novo mundo da América, à Africa e ao Oriente remoto, o alfabeto latino e uma ciência metalinguística acumulada e exercitada desde a antiguidade clássica. Para a história da língua portuguesa constitui uma preciosa fonte de informação porque documenta o confronto do vocabulário português com outros sistemas linguísticos que dão o nome a civilizações distantes, que organizam o mosaico semântico do mundo de modo muito diferente do universo lexical europeu.

6. Os dicionários elaborados nas terras de missão são o resultado de uma competência lexicográfica adquirida e parcialmente exercitada na tradição europeia e na experiência escolar. A lexicografia transeuropeia com participação portuguesa foi, na sua maior parte, promovida pelos padres da Companhia de Jesus, que ocuparam também um lugar muito destacado na história da lexicografia vernácula portuguesa, especial-

10. Átila Almeida (1988: 285) atribui este dicionário a José Mariano da Conceição Veloso A.A. 
mente no âmbito da lexicografia escolar, publicada até à sua compulsiva extradição em 1759.

Deixaram-nos uma produção vultosa e amplamente difundida, dedicada ao latim e ao português, orientada para o apoio aos mestres e para a habilitação literária dos discípulos portugueses, que estudavam o latim e a arte oratória nos colégios da Companhia e em outras instituições de ensino.

O nome que mais avulta entre os autores desta lexicografia latino portuguesa é o de Bento Pereira (1605-1681) que foi um operoso pedagogo, filólogo e dicionarista, mas mais autores podem ser referenciados: Fernando Pires (c. 1530-1597), António Velez (1545-1609), Manuel de Gouveia, Manuel Barreto (1561-1620), Matias de S. Germano, António Franco (16621732), Manuel de Azevedo (1713-1796), José Caeiro, e outros mais que ficaram no anonimato de um trabalho de colaboração. A feitura de vocabulários era uma actividade propícia ao trabalho participado, e os Jesuítas tinham um enquadramento pedagógico favorável, valorizavam o contributo dos alunos, criavam espaços funcionais, suscitavam a intercomunicação, validavam os manuais na exercitação escolar e podiam garantir o seu sucesso editorial.

A simples observação dos títulos produzidos e publicados entre 1599 e 1754 deixa transparecer a abrangência e a importância desta lexicografia que se conserva ainda hoje como um património de referência para a história da língua e da cultura portuguesas.

Principais títulos da lexicografia latino-portuguesa elaborada pelos Jesuítas:

1. António Velez (1599?): Index totius artis (Emmanuelis Aluari e Societate Iesu De institutione grammatica libri tres). Évora.

2. Manuel Barreto (1607): Vocabulario Lusitanico Latino composto na Provincia de Japão. 3 vols. manuscritos (Academia das Ciências de Lisboa).

3.1. Bento Pereira (1634): Prosodia in Vocabularium Trilingue, Latinum, Lusitanicum, \& Hispanicum digesta, in qua dictionum significatio, et sylabarum quantitas expenditur. Évora [reeds. em Lisboa, 1653; Lisboa, 1661; Lisboa, 1669; Lisboa, 1674; Lisboa, 1683 (cfr. infra Pereira 1697)].

4.1. Bento Pereira (1647): Thesouro da Lingoa Portuguesa. Lisboa. Publicado sempre juntamente com a Prosodia a partir de 1661.

5.1. Bento Pereira (1655): Florilegio dos modos de fallar, e adagios da lingoa portuguesa: dividido em duas partes, em a primeira das quaes se poem pella ordem do Alphabeto as Frases Portuguesas, a 
que correspondem as mais puras, \& elegantes Latinas: na segunda se poem os principaes adagios Portugueses, com seu Latim proverbial correspondente. Pera se ajuntar a Prosodia, \& Thesouro Portugues, como appendiz, ou complemento. Lisboa. Publicado sempre juntamente com a Prosodia e o Thesouro a partir de 1661.

3.2. Prosodia in vocabularium bilingue, Latinum, et Lusitanum digesta...

4.2. Thesouro da lingua portugueza.

5.2. Primeira parte das frases portuguezas, a que correspondem as mais puras, \& elegantes latinas como tiradas de Marco Tullio, \& outros authores de primeira classe.

5.3. Segunda parte dos principaes adagios portuguezes, com seu latim proverbial corespondente.

5.4. Bento Pereira (1697): Tertia pars selectissimarum descriptionum, quas idem auctor vel olim á se compositas, vel à probatissimis scriptoribus emendicatas alphabetico ordine digessit. Ubi quae sine ullo auctore proponuntur, auctor ipse Florilegii composuit, reliquas collegit. Évora [reed. em Évora, 1710; Évora, 1723; Évora, 1732; Évora, 1741; Évora, 1750].

6. António Franco (1716): Indiculo universal: contém distinctos em suas classes os nomes de quasi todas as couzas que ha no mundo. Évora [reed. em 1754, 1804].

7. Francisco Pomey / Manuel de Azevedo (1736): Pomarium latinitatis elegantiori consitum cultu, longeque paritiori descriptum manu in quo locutiones synonymae bene multae...editio postrema ac nova lusitano ordine translata. Coimbra.

Neste elenco bibliográfico, o Index totius artis, o Indiculo universal e o Pomarium latinitatis são textos específicamente escolares. O primeiro teve um percurso regular e assíduo no espaço escolar português, porque foi sempre publicado como anexo da gramática latina de Manuel Álvares. Na última edição (Évora, 1755), compunha-se de 300 páginas $8^{\circ}$, e oferecia cerca de 3.600 entradas latinas, às quais correspondia um "corpus" lexical português bastante mais amplo.

O Indiculo Universal servia como vocabulário enciclopédico, organizado pelo universo de saber escolarizado naquele tempo. Prolongava a tradição do Onomasticon de Julius Pollux, que valorizava a memorização do vocabulário como instrumento do conhecimento erudito. Foi composto sem qualquer preocupação com a ordem alfabética. A versão portuguesa, bastante diferenciada do original francês, foi coordenada pelo P. António Franco com uma apreciada e motivada colaboração dos alunos. 
O Pomarium Latinitatis deve ter surgido quase exclusivamente como uma exercitação escolar orientada para a escrita latina e particularmente para a elaboração literária. Foi um título com escassa recepção.

Os textos mais importantes encontram-se no conjunto dicionarístico composto pela Prosódia, pelo Tesouro da lingua portuguesa e pelo Florilégio, geralmente referenciado unicamente pelo título Prosodia. Este conjunto configurava um grande volume "in-folio", com cerca de 1.400 páginas, impressas em tipo miúdo, e deveria ser entre os livros indispensáveis e de uso frequente aquele que mais avultava nas estantes das escolas. Foi reeditado mais de uma dezena de vezes, preencheu, aproximadamente durante uma sesquicentúria, o espaço editorial, e serviu aos mestres, aos estudantes e aos estudiosos e letrados como principal apoio e instrumento de referência para a intercomunicação latina e para a leitura e a escrita em latim e em português.

A Prosodia (entenda-se todo o manual) ocupou de maneira predominante um período instituidor da história da lexicografia, tornou-se um título quotidiano, quase popular, no panorama escolar e cultural dos séculos XVII e XVIII, e influenciou, como nenhum outro dicionário, o percurso diacrónico da língua portuguesa.

Os manuais escolares dos Jesuítas incluindo os dicionários, foram severamente proibidos e mandados queimar pelo Marquês de Pombal (Verdelho 1982). Todavia, a influência e a repercussão desta lexicografia não se extinguiu com a proibição e com a expulsão dos Jesuitas. A obra de Bento Pereira, especialmente o Tesouro, no que respeita à nomenclatura portuguesa, foi quase integralmente retomado por Bluteau e, por esta via, entrou na tradição lexicográfica subsequente. Por sua vez, a Prosodia, com a revisão e as correcções que lhe foram acrescentadas ainda pelos Jesuítas, foi continuada no Magnum Lexicon (que teve publicação autorizada apenas depois de terminado o consulado pombalino) pelo franciscano Manuel de Pina Cabral (1746-c. 1810) (Cabral 1780).

A nomenclatura do Tesouro foi integralmente retomada num dicionário de português-inglês publicado em Londres em 1701 (A. J. 1701), e num dicionário de português-flamengo, publicado em Amsterdam em 1714 (Alewyn / Collé 1714).

7. A lexicografia escolar dos Jesuítas era sobretudo latino-portuguesa. Repercutiu-se certamente com muita influência na história da língua, mas o seu objectivo principal não era a dicionarização do português. Neste âmbito, o Tesouro de Bento Pereira coligiu e inventariou um vocabulário muito amplo e, nos textos introdutórios da primeira edição (elididos 
nas seguintes), acrescenta mesmo um primeiro elenco de autores portugueses procurados e valorizados como fontes de referência para o registo e testemunho do bom uso das palavras do vernáculo, mas as entradas desse dicionário de português-latim, para além das equivalências latinas, não têm enquadramento de glosas, com definição ou contextuação e explicação semântica em português.

O primeiro tratamento lexicográfico da língua portuguesa foi elaborado por Rafael Bluteau, no Vocabulario Portuguez e Latino, publicado em oito volumes "in folio", com mais dois outros de suplemento, entre 1712 e 1728 (Bluteau 1712-1728). Trata-se de uma realização monumental, não tanto pela sua dimensão, pela feitura tipográfica, pela encadernação e pelo cuidado tratamento bibliofílico (que são, em todo o caso, notáveis), mas sobretudo pela abundância dicionarística, pela memória da língua acumulada, pela erudição enciclopédica (englobando os saberes modernos e a sabedoria antiga) e, finalmente, também pelos seus méritos literários.

Rafael Bluteau foi um padre teatino cosmopolita e poliglota, que nasceu de uma família francesa, em Londres, onde aprendeu o inglês e o francês; estudou depois em Itália (doutorou-se em Roma), e aos 30 anos, ao serviço da religião, veio para Lisboa, onde se familiarizou rapidamente com o português, começando desde logo a usá-lo na oratória e na escrita. Interessou-se pelo estudo do vernáculo e preocupou-se com a normalização lexical e ortográfica. Confrontando-se com a modéstia dos recursos dicionarísticos empreendeu, com grande generosidade e com sentido de serviço a elaboração desse "magnum opus" que tão faustosamente haveria de avultar na história da lexicografia portuguesa.

Os paratextos introdutórios e posfaciais, a informação bibliográfica e o conjunto de vocabulários especiais coligidos no suplemento fazem da obra de Bluteau uma importante referência da reflexão lexicográfica e metalinguística na história da língua portuguesa ${ }^{11}$.

Em anexo ao tomo VIII do Vocabulario encontra-se um Diccionario castelhano y portuguez de 189 páginas, "magno in quarto", com cerca de 22.000 entradas, registando a equivalência portuguesa apenas quando não há coincidência ou semelhança lexical entre as duas línguas (cerca de 11.000 formas contrastantes). Este dicionário é precedido por um vocabulário básico de português-castelhano com cerca de 1.200 entradas (Salas Quesada 2003).

11. Nas Prosas portuguesas Bluteau retomou a reflexão sobre a norma linguística -"Decisoens Academicas de Palavras Portuguezas" (Bluteau 1714-1728: I, 1) - e sobre a ortografia, especialmente na "Prosa grammatonomica" (Bluteau 1714-1728: II, 186). 
O Vocabulário foi modelado pelo ideal de dicionário autorizado e locupletíssimo, procurou coligir toda a memória lexical disponível, incluindo as variedades regionais, diacrónicas e as terminologias do universo técnico e erudito, com seleccionada exclusão no que respeita aos nomes próprios da geografia e da história. Acumulou um "corpus lexical" considerável para a época, muito superior aos registos até então efectuados e, sobretudo textualizou, pela primeira vez, de modo sistemático, em cerca de 36.000 entradas, a interpretação e as definições das palavras portuguesas, tornando-se uma fonte imprescindível para toda a lexicografia subsequente. Os artigos lexicográficos de Bluteau desprendem-se do constrangimento dicionarístico e aproximam-se da exercitação literária, oferecendo-se, ainda hoje, como um exemplo de leitura aprazivel do património clássico.

José Caetano (1690-post 1757) elaborou um Complemento do Vocabulario portuguez de Bluteau, aproveitando ainda alguns apontamentos deixados pelo autor, que começou a ser impresso justamente antes do terramoto de Lisboa de 1755. A destruição e o incêndio que se seguiram provocaram o seu total desaparecimento. Sorte diferente, menos aniquiladora, sofreu a compilação efectuada pelo P. Carlos Folqman (1704-?). O seu Diccionario Portuguez e Latino, no qual as dicções e phrases da lingua portugueza [...] se acham clara e distinctamente vertidas na latina, e authorisadas com exemplos dos auctores classicos. [...] Compilado do Vocabulario do Reverendo Padre D. Rafael Bluteau (Folqman 1755), publicado imediatamente antes do terramoto, foi igualmente destruído pelo fogo, mas resgataram-se alguns exemplares que nos servem para confronto e que nos permitem apreciar a recepção e o percurso de evolução e de actualidade do Vocabulário ${ }^{12}$.

A mais importante sequência do Vocabulário de Bluteau foi empreendida por António de Morais Silva, acima citado, que o transformou no primeiro dicionário moderno e funcional da língua portuguesa. A partir de 1789, todos os dicionários monolingues do português participaram no processo de herança e de actualização desse monumento instituidor da lexicografia portuguesa. Recentemente foi retomado no projecto do "Corpus Lexicográfico do Português", da Universidade de Aveiro, e foi objecto de uma tese de doutoramento (Silvestre 2004).

O texto integral do Vocabulário encontra-se já disponivel em memória digital, transcrito em modo texto, e está em preparação uma edição

12. O dicionário de Folqman e as origens da lexicografia monolingue do português: edição e estudo é o título do projecto de doutoramento de Paula Cristina Barbosa Araújo (bolseira da FCT, na Universidade de Aveiro). 
com registo e manutenção da informação original, e com revisão e uma prótese de remissões que permitem a redicionarização ortográfica da nomenclatura e a integração do suplemento.

8. A segunda metade do século XVIII foi um período áureo da lexicografia portuguesa. Nele se deu início a uma dicionarística moderna, bilingue e monolingue, inovadora, original e às vezes também com alguma "excêntrica erudição", próxima do jocoso e do recreativo (Ramalho Ortigão 1945: II, 251 ss.). Entre 1750, data da última edição da Prosodia de Bento Pereira, e 1806, ano em que foi publicado o primeiro dicionário prático monolingue do português, foram feitas, contando com as reimpressões de vários títulos, cerca de uma centena de publicações de tipo dicionarístico; entre elas salientam-se algumas das mais úteis e perduráveis elaborações lexicográficas portuguesas.

A cronologia desses títulos é bem esclarecedora:

1750 Bento Pereira (1605-1681) / Matias de S. Germano (1667-1699): Prosodia in vocabularium bilingue, Latinum, et Lusitanum digesta. Eborae: ex Typographia Academiae.

1754 [Francisco Pomey / Antonio Franco (1662-1732)]: Indiculo universal: contém distinctos em suas classes os nomes de quasi todas as couzas que ba no mundo. Evora: Off. da Universidade.

António Pereira de Figueiredo (1725-1797): Colecção de palavras familiares assim portuguêsas como latinas. Lisboa: Miguel Rodrigues [várias reeds.].

1755 Carlos Folqman: Diccionario Portuguez, e Latino [...], Compilado do Vocabulario do Reverendo Padre D. Rafael Bluteau. Lisboa: Miguel Manescal da Costa.

1758-64 José Marques: Nouveau dictionnaire des langues françoise et portugaise: Novo diccionario das linguas portugueza e franceza. 2 vols. Lisboa: Imp. de José da Costa Coimbra / Of. Patr. de Francisco Luiz Ameno.

1760 António Pereira de Figueiredo (1725-1797): Breve diccionario da latinidade pura e impura, com a significação portugueza. Lisboa: Of. Patr. de Francisco Luiz Ameno.

1762 Carlos Folqman: Nomenclatura portugueza, e latina [...] com hum pequeno vocabulario de verbos portuguezes. Lisboa: Miguel Rodrigues.

Pedro José da Fonseca (1737-1816): Parvum lexicon latinum Lusitana interpretatione adjunta. Lisboa: Miguel Manescal da Costa [várias reeds.].

1764 José Marques: Novo Diccionario das linguas portugueza, e franceza. Lisboa: Of. Patr. de Francisco Luiz Ameno. 
Bartolomeu Alvares da Silva: Colleç̧ão de palavras familiares portuguezas, francezas, latinas $e$ britanicas. Coimbra: $\mathrm{Na}$ Real Officina da Universidade.

1765 José Monteiro de Carvalho: Diccionario Portuguez das plantas, arbustos, matas, arvores, animaes quadrupedes, e reptis, aves, peixes, mariscos, insectos, gomas, metaes, pedras, terras, mineraes \&. Lisboa: Officina de Miguel Manescal da Costa.

Francisco José Freire (Cândido Lusitano) (1719-1773): Diccionario poetico. Lisboa: Na Of. Patr. de Francisco Luiz Ameno [reeds. em 1794, 1820].

1766 Diccionario abbreviado da Bíblia traduzido do francez. Lisboa: Antonio Rodrigues Galhardo, 17942.

1767 Fr. Luis do Monte Carmelo (1715-1785): Compêndio de orthografia, com sufficientes catalogos. Lisboa: Antonio Rodrigues Galhardo.

1771 Pedro José da Fonseca (1737?-1816): Diccionario portuguez̧, e latino. Lisboa: Regia Officina Typografica [várias reeds.].

1773 Antonio Vieira Transtagano: A Dictionary of the Portuguese and English Languages, in two parts. Londres: J. Nourse [várias reeds.].

1773-74 Joaquim José da Costa e Sá (1740-1803): Diccionario italiano e portuguez: 2 vols. Lisboa: Régia Oficina Tipográfica.

1775-76? José Marques: Nouveau Dictionnaire des langues françoise et portugaise. Lisboa: Imp. Royale [ $3^{\mathrm{a}}$ ed.].

1778 Miguel Tibério Pedegache Brandão Ivo (1730?-1794): Novo Diccionario francez e portuguez. Lisboa [4a . ed. Falta notícia das eds. anteriores; teve depois várias reeds.].

1779 Vicente de Bastos Teixeira: Dictionnaire moderne françois expliqué en portugais Tome premier. Lisbonne: Imp. Louisiane [1 vol. até à lettra C].

Pierre Chompré / Pedro José da Fonseca (1737-1816) (trad.): Diccionario abbreviado da fabula. Lisboa: Na Regia Officina Typografica [várias reeds.].

1780 Manuel de Pina Cabral: Magnum lexicon latinum et lusitanum. Olysipone: Typii Regiae Officinae [várias reeds.].

António José Teixeira (?) (trad.): Noticia da mythologia. Lisboa: Na Typ. Rollandiana [reed. em 1803].

1781 [Francisco Luís Ameno (1713-1793)]: Diccionário exegético. Lisboa: Of.. Patr. de Francisco de Luiz Ameno.

João de Moraes Madureyra Feyjó (1688-1741): Orthographia, ou arte de escrever, e pronunciar com acerto a lingua portugueza. Lisboa: $\mathrm{Na}$ Regia Officina Typografica [ $3^{\mathrm{a}}$ impr.]. 
1783 Bernardo de Lima e Melo Bacelar: Diccionario da lingua portugueza... Lisboa: Of. de Jozé de Aquino Bulhoens.

1784 Bernardo de Lima e Melo Bacelar: Arte, e diccionario do commercio, e economía portugueza. Lisboa: Of. de Domingos Gonsalves.

Miguel do Couto Guerreiro (c. 1720-1793): Tratado da versificaçaõ portugueza [...]. Diccionario de Consoantes. Lisboa: Na Of. Patr. de Francisco Luiz Ameno.

Luís Álvares Pinto: Diccionario pueril para uso dos meninos. Lisboa: Of. Patr. de Francisco Luiz Ameno.

1784-86 Manuel de Sousa / Joaquim José da Costa e Sá (1740-1803): Nouveau dictionnaire FrancoisPortugais. 2 vols. Lisboa: Simão Thaddeo Ferreira.

1785 Fr. Francisco de Jesus Maria Sarmento (?): Thesouro biblico ou diccionario bistorico, e etymologico dos nomes proprios. Lisboa: Na Of. de Simão Thaddeo Ferreira.

1788 Pedro de Mariz de Sousa Sarmento: Elementos de construçãa e diccionario francez e portuguez, de todas as pessas de... navios... Lisboa: Of. Patr. de Francisco Luiz Ameno.

Domingos Vandelli: Diccionario dos termos technicos de Historia Natural extrabidos das obras de Linnéo. Coimbra: Real Officina da Universidade.

Pedro de Mariz de Sousa Sarmento: Preceitos de construç̧ão de navios e da sua mastrição e nomenclatura portugueza dos termos technicos da mastrição e diccionario delles em francez. e portuguez: Lisboa: Of. de António Rodrigues Galhardo.

António de Morais Silva (1755-1824): Diccionario da lingua portugueza composto pelo padre D. Rafael Bluteau; reformado e accrescentado por... Lisboa: Of. de Simão Thaddeo Ferreira [reeds. em 1813, 1823, 1831, 1844, 1858, 1877-78, 1889, 1891, 1922, 1949-1959].

João de Sousa (1730?-1812): Vestigios da lingua arabica em Portugal, on lexicon etymologico das palavras, e nomes portuguezes, que tem origem arabica. Lisboa: Academia Real das Sciencias [reeds. em 1830, 1981].

1790 Manuel Rodrigues Maia: Diccionário das elypses, que mais frequentemente se encontram nos auctores clássicos: interpretadas. Lisboa: Of. de António Gomes.

1793 [Academia das Ciências]: Diccionario da lingoa portugueza publicado pela Academia Real das Sciencias de Lisboa. Lisboa: Officina da mesma Academia.

Diccionario universal das moedas: assim metallicas, como ficticias, imaginarias, ou de conta, e das de fructos, conchas, \&r. que se conhecem na Europa, Asia, Africa, e América. A que se ajunta buma noticia das Moedas dos Judeos, Gregos, e Romanos; e dois Mappas dos pêzos das principaes Cidades de Commercio; das Medidas d'extensão reduzidas a palmos, covados, e varas; e das de capacidade, assim para secos como para molhados. Recopilado por***. Lisboa: Of. de Simão Thaddeo Ferreira. 
1794 Joaquim José da Costa e Sá (1740-1803): Diccionario portuguez-francez-e-latino. 2 vols. Lisboa: Na Officina de Simão Thaddeo Ferreira.

Antonio Vieira Transtagano: A Dictionary of the Portuguese and English. Diccionario abbreviado da Bíblia traduzido do francez... Lisboa: Typ. Rollandiana [2 $2^{\mathrm{a}}$ ed.].

Joaquim do Rosário: Compendio do Diccionario dos Casos de Consciencia de Pontas. 8 vols. Lisboa: Simão Thaddeo Ferreira.

1795 Diccionario portuguez e brasiliano. Lisboa: Oficina Patriarcal.

1798-99 Frei Joaquim de Santa Rosa de Viterbo (1744-1822): Elucidario das palavras, termos, e frases, que em Portugal antigamente se usárão e que hoje regularmente se ignoram.... 2 vols. Lisboa: Of. de Simão Thaddeo Ferreira [reeds. em 1865, 1966].

1804 Fr. João de Deus (1732-179?): Diccionario bistorico, juridico, e theologico. Porto: Typ. de Antonio Alvarez Ribeiro.

Fr. Bernardo Maria da Cannecattim: Diccionario da lingua bunda ou angolense, explicada na portugueza, e latina composto por... Lisboa: Impressão Regia.

1804-06 Francisco Soares Franco (1772-1844): Diccionario de agricultura. 5 vols. Coimbra: Real Imprensa da Universidade.

1805

Fr. Bernardo Maria da Cannecattim: Colleç̧ão de observaçoes grammaticaes sobre a lingua bunda ou angolense, a que se ajunta dicionario abreviado da língua conguesa. Lisboa: Imp. Regia.

1806

Novo diccionario da lingua portugueza. Lisboa: Typ. Rollandiana.

Nesta sequência de títulos avultam cinco aspectos essenciais que haveriam de caracterizar de maneira estruturante a história dos dicionários portugueses ao longo dos últimos dois séculos:

(a) a renovação da lexicografia latino-portuguesa (Folqman 1755, Figueiredo 1754 e 1760, Fonseca 1762 e 1771, Pina Cabral 1780);

(b) a emergência da interlexicografia do português com as línguas europeias (francês: Marques 1758 e 1764, Silva 1764, Ivo 17784, Sousa / Sá 1784-86, Teixeira 1779, Sá 1794; italiano: Sá 1773-74; inglês: Vieira Transtagano 1773);

(c) o despontar de dicionários especializados em domínios científicos e técnicos, sobre a economia, o comércio, as ciências naturais, a agricultura, as ciências jurídicas e a teologia (Carvalho 1765, Bacelar 1784, Francisco Sarmento 1785, Pedro Sarmento 
1788-89, Vandelli 1788, Diccionario universal das moedas 1793, João de Deus 1804);

(d) a criação da lexicografia monolingue do português com dicionários gerais e práticos (Bacelar 1783, Morais Silva 1789, Academia das Ciências 1793, Novo diccionario 1806);

(e) o aparecimento de uma lexicografia de especialização metalinguística, com relevo para a ortografia (Feijó 1781³, Carmelo 1767), a história da língua (Frei João de Sousa 1789, Viterbo 179899) e a escrita literária (Cândido Lusitano 1765, Francisco Luís Ameno 1781, Couto Guerreiro 1784).

A elaboração dicionarística pluralizou-se e desenvolveu domínios de produção relativamente autónomos, de acordo com estes vectores de referência. Para a lexicografia portuguesa poderemos considerar muito relevante e instituidora a experiência deste período, no que respeita particularmente à tradição interlinguística e ao património lexicográfico monolingue.

O convívio com as línguas europeias vai intensificar-se e marcar uma nova sociedade escolarizada e cada vez mais interdependente do espaço cultural e económico europeu, com predomínio do relacionamento com a França e o Reino Unido. Esta relação interlinguística sustentou e promoveu os dicionários bilingues, suscitando uma produção cada vez mais abundante e, nem sempre, mais qualificada. Não deixou também de ter alguma repercussão nos dicionários monolingues, em todo o caso, a lexicografia da língua portuguesa, mesmo quando, composta em França e sob a influência dos modelos estrangeiros, nunca se desprendeu da ligação matricial ao século XVIII.

No âmbito da lexicografia de apoio à escrita literária e à informação diacrónica, o dicionário de rimas (então com o nome mais tradicional de "consoantes") de Couto Guerreiro (1784), o Dicionario poético de Francisco José Freire (de nome arcádico Cândido Lusitano) (1765), o vocabulário com a informação etimológica de origem árabe, recolhido e estudado por Frei João de Sousa (1789), e o Elucidário dito de Frei Joaquim de Santa Rosa de Viterbo (1798-1799) (em grande parte coligido por Fr. Bernardo da Encarnação), subsistiram e mantêm-se em grande medida insuperados, mesmo quando escassamente reeditados.

Mais importante ainda, na história da lexicografia monolingue portuguesa, foi o legado de António de Morais Silva (1789) e a adequação ao uso prático e funcional que teve início com o Novo dicionário (1806). Estas duas obras definitivamente modernas abriram caminho para os dois modelos básicos de dicionários da língua vernácula que preencheram o 
percurso subsequente da lexicografia portuguesa. O dicionário de Morais foi reeditado de década em década até ao século XX e retomado e transfigurado (1949-1959) como grande dicionário autorizado. O Novo Dicionário inspirou e serviu de exemplo para uma preenchida linhagem de dicionários práticos, que se prolongou até à actualidade, de uso fácil e acessível, na escola e no espaço familiar.

A tentativa infindada (e que se revelaria até hoje infindável) do dicionário da Academia Real das Ciências (Academia das Ciências 1793) ${ }^{13}$ não foi certamente uma experiência perdida. O contributo propriamente lexicográfico foi modesto, ficou-se pela letra A, não conseguiu estabelecer um modelo de dicionário autorizado com viabilidade de realização prática, no quadro da instituição académica, e foi escassamente gerador de exemplaridade metalexicográfica. O verbo "azurrar", lugar de chegada e limite final no seu percurso inacabado, suscitou humoradas alusões entre os escritores e intelectuais do século XIX. Em todo o caso, o trabalho do diligente dicionarista Pedro José da Fonseca, já citado, e dos dois académicos que o coadjuvaram, Bartolomeu Inácio Jorge e Agostinho José da Costa de Macedo, deixou uma referência fundamental na história da lexicografia. Os textos introdutórios (a "Planta para se formar o Diccionario", as "Memorias e Louvores da Lingoa Portugueza", o "Catalogo dos Autores") e o grande volume "in folio" constituem um documento culturalmente muito estimável e uma fonte de informação lexicográfica auferível, que aguarda ainda uma leitura e um estudo que facilitem a sua entrada na memória activa da língua ${ }^{14}$.

Herança louvável foi a valorização do património escrito, como referência do vernáculo. $\mathrm{O}$ dicionário da Academia foi uma instância privilegiada para a reflexão sobre o cânone autoral do português. Além da lista de autores que integra o volume, suscitou uma segunda e mais ampla indexação dos autores, num "Catalogo dos livros que se haõ de ler para a continuaçaõ do Diccionario da Lingua Portugueza, mandado publicar pela Academia Real das Sciencias de Lisboa", em 1799.

Entre alguns factos sempre lembrados na história deste período, destaca-se, de modo promontoriante, como um dos episódios "jocosos" da lexicografia portuguesa, a publicação da obra de Bernardo de Lima e Melo Bacelar (1783), Dicionário da língua portuguesa. O título ocupa lugar inaugural, visto que nunca antes se tinha utilizado como epígrafe esta precisa designação. Trata-se, na realidade, da primeira publicação em absoluto

13. O Dicionário da Língua Partuguesa Contemporânea, publicado em 2001 com a chancela da Academia (Academia das Ciências 2001), não corresponde ao projecto anunciado e ensaiado em 1793.

14. O dicionário da Academia (1793) foi objecto de uma reprodução facsimilada, em 1993, assinalando o segundo centenário da sua publicação. 
de um dicionário geral monolingue da língua portuguesa ${ }^{15}$. Deve todavia observar-se que não é obra muito digna dessa primazia. Com efeito, a sua realização, sob o ponto de vista lexicográfico e metalinguístico é disforme, incoerente, mal fundamentada e praticamente inútil. A apreciação incomplecente de Inocêncio, no seu registo bibliográfico, não é muito esclarecedora quanto às características dicionarísticas, mas é um indicador da sua pouca qualidade e um desimpedido testemunho sobre o modo como foi recebida pelo público:

\footnotetext{
Esta tentativa, anterior de alguns annos, como se vê pela data, á publicação da primeira edição do Diccionario de Antonio de Moraes Silva, faz por certo honra aos bons e patrioticos sentimentos do auctor, cujo zelo inconsiderado o levou a tentar uma empresa na verdade superior as suas forças e para a qual lhe faleciam os elementos e especies necessarias. Á força de querer ser conciso e systematico em demasia, tornou-se escuro, e por vezes ridiculo; e nas suas extravagantes investigações etymologicas adoptou opiniões insustentaveis, e só proprias de um espirito irreflexivo, que deixando se dominar por idéas antecipadas, vê tudo a travez do prisma de uma imaginação preoccupada. A obra, logo que sahiu a luz, começou a servir de alvo aos apodos e sarcasmos dos criticos; e ha quem diga que a auctoridade publica interviera, mandando retirar da circulação os exemplares, que por isso chegaram a tornar-se raros, e valeram conseguintemente preços mais elevados (Silva 1858-1958: I, 378-379).
}

9. A recepção dos dicionários no Brasil e a interacção dos centros de produção franceses são aspectos preponderantes na história da lexicografia portuguesa.

Em 1807, a transferência da Corte portuguesa para o Brasil marca o início de uma acentuada transumância linguística. O português ganha um novo espaço e uma identidade regional, amplia o consumo da leitura e suscita o crescimento do mercado livreiro, com especial solicitação no que se refere aos manuais escolares e aos textos de apoio ao uso da língua, gramáticas e dicionários.

António de Morais Silva, o grande dicionarista da língua portuguesa moderna, é, a este respeito, uma figura emblemática. Nasceu no Rio de Janeiro, estudou e escreveu na Europa (Portugal, Inglaterra e França) e, depois de regressar ao Brasil, continuou a trabalhar na revisão do dicionário, produzindo acrescentos e correcções que foram retomados até à $4^{\text {a }}$ edição.

Neste âmbito, merece também referência Manuel Joaquim Henriques de Paiva (1752-1829), provável companheiro e incentivador de Morais Silva. É-lhe atribuído o trabalho de revisão e mesmo uma possível colaboração autoral na publicação ou numa das reedições do primeiro dicionário prá-

15. O Dicionário poético (Cândido Lusitano 1764) era já um dicionário monolingue, mas era pouco mais do que um vocabulário de epítetos. 
tico bilingue publicado em Lisboa, o Novo dicionário francês e português (Ivo / Paiva 1786), objecto de sucessivas edições no final do século XVIII e princípio do século XIX. Henriques de Paiva nasceu e estudou em Portugal e foi no Brasil (embora na condição de degredado, por insubmissão intelectual) um médico estudioso e um devotado intérprete da intercomunicação de Portugal com o Brasil. Traduziu várias obras do francês e do inglês e, ainda no âmbito lexicográfico, compôs uma farmacopeia e um dicionário de Botânica (Bahia, 1819) (cfr. Silva 1858-1958: VI, 12-18).

A procura de dicionários, no Brasil, estimulou de tal modo o trabalho de edição que, perante a incapacidade de resposta do parque gráfico em Portugal, motivou o surgimento de um centro editorial português em França, em grande parte dedicado à produção de dicionários.

Ao longo de todo o século XIX imprimiram-se em França, com tiragens de muitos milhares de exemplares, várias dezenas de dicionários portugueses, monolingues e bilingues, que eram transportados de barco para Portugal e para o Brasil.

Alguns dicionaristas portugueses acompanharam a deslocação do centro editorial, viveram em França e, sob a influência dos modelos europeus, especialmente franceses, elaboraram as suas obras. Entre outros, tiveram copiosa divulgação no Brasil os dicionários de Solano Constâncio (c. 1772-1846), José da Fonseca (c. 1788-1866) e José Inácio Roquete (18011870), todos impressos em França (cfr. Ramos 1972).

Estes dicionários, na sua maior parte, e bem assim outros manuais escolares, traziam no rosto uma dedicatória formal: eram "oferecidos à mocidade estudiosa de Portugal e do Brasil", ou à "estudiosa mocidade portugueza e brasileira".

A partir dos meados do século XIX estabeleceram-se linhas regulares de circulação entre a Europa e o Brasil, com recurso parcial à navegação a vapor, os livros (particularmente os dicionários) beneficiaram dessa melhoria e ocuparam, durante algum tempo, um segmento muito significativo nas exportações para o Brasil. A difusão dos dicionários portugueses no Brasil (impressos em França) acentuou-se justamente a partir desses anos.

Correspondendo a essa solicitação do mercado, em 1858, Eduardo Faria (1823-1860) lançou no Brasil uma edição do Diccionario da Lingua Portugueza (Faria 1859) e, na reedição revista deste dicionário, feita em Lisboa, por D. José de Lacerda (1803-1877), além de se referir no próprio título a integração de um "vocabulario da lingua Tupy", invocava-se expressamente o público do Brasil como parceiro destinatário: Diccionario da lingua portugueza: para uso dos portuguezes e brazileiros (Faria 1858-1859) 
confirmando a importância comercial crescente desse espaço de escrita e leitura e de estudo da língua portuguesa.

Um dos dicionários mais divulgados no Brasil foi o de António de Morais Silva, sobretudo a partir da $7^{\mathrm{a}}$ edição (1877), "consideravelmente aumentada”. No prefácio pode ler-se uma informação esclarecedora, a este respeito:

Do grande numero de termos novos accrescentados, uma parte consideravel respeita ao Brasil, onde o Diccionario de Moraes é tão consultado.

A procura e o uso deste dicionário devem ter-se intensificado no Brasil, por iniciativa da Editora Empresa Literária Fluminense de A. A. da Silva Lobo, que tinha sede no Rio de Janeiro e que promoveu também a $8^{a}$ edição em 1889. Diz o editor, na nota introdutória desta "Nova edição revista e melhorada":

\footnotetext{
Fômos nós que ha onze annos, ao começarmos a nossa casa no Brazil, ahi levámos o Moraes, collocando cinco sextas partes do total da $7^{\mathrm{a}}$ edição, que um nosso amigo fazia em Lisboa a esse tempo.
}

10. Acompanhando a democratização da escrita e da leitura, os dicionários foram alargando o seu espaço de recepção e de difusão até se tornarem hoje um instrumento de uso quotidiano, indispensável no relacionamento das sociedades. São uma condição de civilização.

O primeiro dicionário prático português, procurado pelo público e muito divulgado, foi um dicionário bilingue de francês-português, acima referido (Ivo / Paiva 1786). Era um volume manual in $8^{\circ}$ que terá começado a publicar-se pelos anos de 1770 e que teve um assinalado sucesso editorial, com tiragens "numerosas", no dizer dos editores. Teve uma edição, que se dizia sétima, em $1803^{16}$. Oferecia-se com a aparência de um livro funcional, graficamente aligeirado, utilitário e certamente menos dispendioso do que outros de volume semelhante. Transcreve-se a portada da edição de 1786, que se dizia $5^{a}$ :

Novo Diccionario Francez e Portugues, composto segundo os mais célebres diccionarios e enriquecido de muitos termos de medicina, de anatomia, de cirurgia, de farmacia, de quimicia [sic], de historia natural, de botanica, de

16. "Os applausos com que o público tem recebido, e approvado este Diccionario todas as vezes que tem sahido á luz, a grande estimação que delle fez, a brevidade com que seis edições tão numerosas se consummirão, tudo isto prova bem evidentemente a sua bondade e merecimento" ("Aviso", texto introdutório da $7^{\mathrm{a}}$ ed.). 
mathematica, de marinha, e de todas as outras artes e sciencias, notavelmente corrigido, emendado, e addicionado com hum sem numero de termos, e locuçoes, e algumas fražes em ambos os idiomas. Quinta Edição. Lisboa: Na Officina de Filipe da Silva e Azevedo. Anno M.DCC.LXXXVI.

Não se indica, nesta edição, o nome do autor, mas o Novo Dicionario Francês e Português, publicado pelo menos até 1817, é geralmente atribuído a Miguel Tibério Pedegache Brandão Ivo (1730?-1794) e é também referido como responsável pela sua revisão e melhoria, o já citado Manuel Joaquim Henriques de Paiva (1755-1829) ${ }^{17}$. O número de entradas do léxico francês aproxima-se, neste dicionário, das 34.000. Trata-se de um valor quantitativo apreciável correspondente a um registo muito elevado do domínio lexical da língua, tendo em conta os níveis médios das nomenclaturas dos dicionários monolingues da época. Neste Novo Diccionario, convergiam já as principais características dos dicionários de fácil e frequente utilização, que se tornaram instrumentos imprescindíveis no trânsito escolar e na interacção discursiva da vida moderna, cada vez mais ocupada pela escrita e pela comunicação alargada. Mas havia ainda margem para reduzir o vulto e a cópia dos dicionários práticos. A adequação a um público de novos leitores e à solicitação escolar haveria de torná-los mais pequenos, mais maleáveis e fáceis de manusear e de consultar, e mais adequados para acompanharem a mobilidade dos utilizadores.

Este e outros dicionários de francês-português, numerosamente publicados desde o final do século XVIII, correspondiam certamente ao impulsionamento do uso e do ensino do francês em Portugal e no Brasil, mas podemos tomá-los também como um indicador do início de um processo de vulgarização dos dicionários.

A lexicografia teve início bilingue, com os dicionários de latim-vernáculo, e foi ainda a procura bilingue que suscitou, no espaço da língua portuguesa, a democratização do dicionário, começando e crescendo com o progrediente desenvolvimento do ensino do francês e (com menos solicitação, e um pouco mais tarde) também do inglês.

O dicionário monolingue veio um pouco depois. A sua divulgação e uso generalizado podem tomar como referência cronológica inaugural o ano de 1806, com a publicação de um dicionário prático da língua portuguesa (já acima citado), por iniciativa do operoso tipógrafo francês, instalado em Lisboa, Francisco Rolland (1743-1814) (Novo diccionario 1806).

17. A notícia biliográfica desta mesma edição que se encontra em catálogos internacionais apresenta algumas diferenças; provavelmente foram feitas diferentes tiragens com a mesma referência de edição. Num desses registos bibliográficos menciona-se João Henriques de Paiva, como eventual responsável pela melhoria da edição, mas não se conhece documentação que possa confirmar esse dado, que poderá ser um lapso do catalogador. 
Trata-se de um volume in $4^{\circ}$ pequeno, com 864 páginas (não numeradas), que oferece cerca de 30.000 entradas, distribuídas, com grande legibilidade, em duas colunas. Foi publicado anónimo e não temos ainda hoje informação provável sobre a sua autoria, para além de uma muito previsível implicação do próprio editor. Foi objecto de reedição "correcta e augmentada" em 1817 e 1835. Começa com um parafraseado exergo, na página de rosto, adiantando algumas informações sobre a doutrina lexicográfica e linguística que terá orientado a sua publicação:

Novo Diccionario da Lingua Portugeza, composto sobre os que até o presente se tem dado ao prelo, accrescentado de varios Vocabulos extrabidos dos Classicos Antigos, e dos Modernos de melhor nota, que se achão universalmente recebidos. Lisboa, na Typografia Rollandiana. 1806. Com Licença da Meza do Desembargo do Paço.

A valorização da memória patrimonial da língua e a aceitação de uma norma do bom uso são os aspectos lembrados como indicadores da qualidade da obra. A invocação dos autores clássicos é sobretudo ornamental e encontra-se muito ocasionalmente repercutida no texto do dicionário. Diz-se no "Prólogo" que foram omitidas "as numerosas citações e allegações" porque ocupariam uma boa parte do volume. A criteriosa selecção da nomenclatura recolhida nos dicionários de António de Morais Silva (1789) e de Joaquim José da Costa e Sá (1794), e a síntese dos artigos recolhidos nas mesmas fontes dispensaram o autor de recorrer aos clássicos para "extrair" os vocábulos dicionarizados. Assim mesmo, e pelo mérito das fontes, o Novo dicionário marca um momento de referência na história dos dicionários portugueses.

A lexicografia prática monolingue prosseguiria, logo no início do século XIX, com os dicionários "portáteis" ainda mais pequenos, em tamanho de bolso, e mais numerosos, despertando a concorrência de autores e editores. Foram produzidos, na sua maior parte, em prelos franceses.

Entre os vários dicionários práticos da língua portuguesa publicados durante o século XIX, o que mais se distingue é o Diccionario da Lingua Portugueza de José da Fonseca, feito inteiramente de novo e consideravelmente augmentado por José Inácio Roquete, publicado pela primeira vez em Paris, pelos editores Guillard/Aillaud, em 1848, juntamente com o Diccionario dos Synonimos, Poetico e de Epithethos da Lingua Portugueza, pelos mesmos autores (Fonseca / Roquete 1848a e b). Este conjunto de dicionários teve sucessivas edições até ao final do século, e foi provavelmente a elaboração lexicográfica mais difundida e com maior volume de vendas em toda a históra da dicionarística portuguesa. Segundo o testemunho de Alberto de Oliveira (s. d.: 44-46) foi este um dos dicionários usados por Eça 
de Queirós, este, certamente entre outros, porque o talentoso romancista foi um frequentador assíduo de dicionários e a eles se refere em vários locais da sua obra ${ }^{18}$. Serve-nos o seu exemplo também para documentar uma implicada reciprocidade entre os dicionários e a elaboração literária, potenciada, neste caso com a parceria do Diccionario dos Synonimos ${ }^{19}$. É certo que os dicionários de apoio à composição literária tinham já uma tradição que remontava ao século XVI, mas a sua utilização foi fortemente incentivada com o alargamento do consumo literário no século XIX. Almeida Garrett, numa nota à primeira edição do poema Camões (1825), notava a necessidade e as vantagens dessa elaboração lexicográfica:

Direi sempre que sem um bom Dicionário de Sinónimos e outro de origens ou etimológico, nunca chegaremos a falar uma língua perfeita e de nação civilizada (Garrett 1966: II, 429).

A utilização geral e individualizada dos dicionários, a democratização que transparece claramente em títulos como "dicionário popular", "elementar", "escolar", coalesce com a expansão da literatura de ficção romanesca e da actividade jornalística, ao longo do século XIX, estabelecendo vínculos e interdependências sinérgicas que se repercutem na história das línguas.

No século XIX, intensifica-se a ligação entre o espaço da literatura e os dicionários, que se tornam ingrediente oculto mas vital para a produção literária e, de um modo mesmo mais amplo, para todo o discurso do universo cultural.

11. A lexicografia portuguesa preencheu a sua história geralmente confrontada com um certo desamparo institucional, e sem o apoio de uma política da língua, responsável e esclarecida. Os ideais de "defesa", "estudo" e "ilustração" da língua vernácula, que ardorosamente estimularam escritores e filólogos portugueses, motivaram também algumas vezes o discurso político, mas raramente se repercutiram em acções concretas.

Não existe em Portugal uma academia da língua, nem outro qualquer instituto do estado que lhe seja dedicado de modo exclusivo. A

18. Entre outras citações, menciona em Os Maias, O Crime do Padre Amaro e A Ilustre Casa de Ramires "dicionários de rimas" e "dicionários de sinónimos", com subtil ironia, deixando implícita a ideia de que a sua utilização torna artificial e falseia a criação literária, mas é claro que ele os conhecia e podemos supor que poderia muito bem utilizá-los.

19. Extinta a parceria editorial entre os dois dicionários, no final do sec. XIX, o percurso do dicionário de sinónimos prosseguiu ao longo do século XX com muitas reedições na Editora Lello \& Irmão, Porto. 
Academia Real das Ciências (hoje Academia das Ciências de Lisboa), fundada em Dezembro de 1779, incluía no seu programa a publicação de uma gramática e de um dicionário, mas "os fins" da Academia abrangiam, para além dos saberes linguísticos, todo o espectro amplo das ciências e por isso, ela era corporizada por uma diversidade escolhida de sábios que não tinham que privilegiar as iniciativas literárias e filológicas. A história do Dicionário da Academia é um concludente exemplo, se não da sua inoperância, pelo menos da dificuldade em implementar o projecto fundacional.

Apesar de tudo, a Academia foi uma das poucas instituições públicas a assegurar alguma referência normativa, promovendo a publicação de trabalhos metalinguísticos ${ }^{20}$, apoiando a codificação e a legislação ortográfica, e assumindo a elaboração do Vocabulário Ortográfico da Língua Portuguesa (Academia das Ciências 1940), depois redimensionado no Vocabulário ortográfico resumido da língua portuguesa (Academia das Ciências 1947 e 1970), e, finalmente, tentando sempre a elaboração de um "Dicionário Académico". Na estrutura da Academia foi integrado um Instituto de Lexicologia e Lexicografia da Língua Portuguesa que apoiou já a publicação do Dicionário da Língua Portuguesa Contemporânea (Academia das Ciências 2001) ${ }^{21}$.

Os empreendimentos de pesquisa e de elaboração lexicográfica em Portugal foram realizados, na sua maior parte, sem o apoio do estado ou de instituições públicas, sobretudo até aos últimos decénios do século XX, quando começou a poder contar-se com o trabalho de investigadores ligados às universidades e, em especial, ao Centro de Estudos Filológicos, actualmente Centro de Linguística da Universidade de Lisboa (CLUL).

O projecto do Português Fundamental (Bacelar do Nascimento et al. 1984 e 1987), aqui iniciado em 1970, foi o primeiro contributo institucio-

20. Além da Gramática de Jerónimo Soares Barbosa (1822), poderão mencionar-se, entre outros, alguns textos mais orientados para o estudo do vocabulário, como os ensaios de António das Neves Pereira, António Pereira de Figueiredo e Francisco Dias Gomes; os estudos lexicográficos de Fr. João de Sousa e do Cardeal Saraiva, e as Reflexões sobre a lingua portugueza por Francisco José Freire (1842).

21. De acordo com os Estatutos actualmente em vigor, entre as "finalidades da Academia", destacam-se as seguintes disposições referentes à língua portuguesa: "Estimular o enriquecimento e o estudo do pensamento, da literatura, da língua e demais formas de cultura nacional" (art. $4^{\circ}$ b); "A Academia é o órgão consultivo do Governo Português em matéria linguística" (art. $5^{\circ}$ ); "No que respeita à unidade e expansão da língua portuguesa, a Academia procura coordenar a sua acção com a Academia Brasileira de Letras e com as instituições culturais dos outros países de língua portuguesa e dos núcleos portugueses no estrangeiro. À Academia compete propor ao Governo ou a quaisquer instituições científicas e serviços culturais as medidas que considerar convenientes para assegurar e promover a unidade e expansão do idioma português" (art. $6^{\circ}$ ). 
nal para o agenciamento e estudo estatístico do léxico português em uso activo.

A iniciativa deu origem a uma base de dados actualizável, que se prolongou e que se encontra reconfigurada, a partir de 1988, no Corpus de Referência do Português Contemporâneo (CRPC). Nele se acumulam presentemente cerca de 334 milhões de palavras, recolhidas num alargado leque de tipos de discurso e de variedades regionais de todo o espaço lusófono, com um alcance diacrónico dos meados do século XIX até à actualidade.

O estudo e a pesquisa nos domínios da lexicografia, são hoje objecto de linhas de investigação e de projectos em desenvolvimento, em várias Universidades e em alguns Centros da Fundação para a Ciência e a Tecnologia, com destaque para o Instituto de Linguística Teórica e Computacional (ILTEC), criado em 1988, para dar apoio a um projecto europeu de tradução automática (EUROTRA), manteve-se depois, ligado às Universidades de Lisboa, privilegiando, entre os seus objectivos, a execução de projectos orientados para a a construção e a informatização de léxicos e terminologias.

Assinalável referência merece também o projecto do Corpus Lexicográfico do Português (CLP) empreendido no Centro de Línguas e Culturas na Universidade de Aveiro, iniciado em 2003, com financiamento da FCT. Tem por objecto a recuperação da memória lexical portuguesa, dicionarizada desde o século XVI. Foi já efectuada a leitura crítica e o tratamento computacional do texto da maior parte dos dicionários antigos, facultando-se o acesso a todas as formas portuguesas neles registadas e à respectiva concordância, através de um motor de busca DICIWEB (Verdelho / Silvestre 2007).

Além da abundante pesquisa desenvolvida no Brasil, onde a dicionarística da língua portuguesa tem actualmente os centros mais dinâmicos da sua realização, a lexicografia portuguesa tem podido contar ainda com a colaboração generosa de estudiosos lusitanistas ligados a centros de investigação fora de Portugal. A maior parte dessa colaboração encontra-se em dicionários bilingues, mas foram produzidos também textos de muito mérito no âmbito da lexicografia monolingue portuguesa. Entre outros, devem citar-se o Dicionário inverso da língua portuguesa, publicado em Moscovo, em 1971, pela saudosa Professora Elena Wolf (1971); e o compendioso Dicionário dos dicionários portugueses, publicado com diligente persistência pelo Professor Dieter Messner, a partir de 1994, numa sequência que vai já em 20 volumes (Messner 1994- ).

Ainda fora do espaço lusófono, o reconhecimento e estudo do vocabulário português tem sido beneficiado também por projectos de inves- 
tigação que recorrem à tecnologia computacional e que oferecem na Internet a informação elaborada. Entre outros, merecem boa lembrança, o Corpus do Português (Davies/Ferreira 2006) que dá acesso a uma base de dados com mais de 45 milhões de palavras, permitindo acesso fácil a todas as formas contextuadas com as respectivas concordâncias ${ }^{22}$.

Especial menção é devida ao Tesouro Medieval Informatizado da Lingua Galega (TMILG), promovido pelo Instituto da Lingua Galega (Santiago de Compostela) e dirigido pelo Prof. Xavier Varela Barreiro. Trata-se de um trabalho filológico feito com rara sistematicidade e com recorrida acribia. Além da fruição literária dos textos, acrescenta um tratamento computacional que faculta acesso a todas as formas ocorrentes oferecendo-se como o mais importante recurso paralexicográfico, presentemente disponível, para o estudo do português antigo.

22. Transcreve-se a informação fornecida pelos autores: "O Corpus do português foi generosamente patrocinado pela US National Endowment for the Humanities (2004-06). O projeto do corpus foi concluído no verão de 2006, mas a interface, a anotação/etiquetagem e a arquitetura do corpus ainda estão sendo modificados. Também recebemos um apoio muito generoso de nossas respectivas universidades: Brigham Young University (Mark Davies) e Georgetown University (Michael J. Ferreira)." 
II. RECURSOS E PROXECTOS 



\title{
O GALEGO FUNDAMENTAL: DICIONARIO DE FRECUENCIAS
}

\author{
María Xesús Bugarín López
}

Instituto da Lingua Galega

\section{O. INTRODUCIÓN}

O galego fundamental: dicionario de frecuencias é o título da miña tese de doutoramento presentada na Universidade de Santiago de Compostela (Bugarín 2007) ${ }^{1}$. Aínda que o obxectivo inicial era o establecemento do léxico galego fundamental, a magnitude do traballo, as limitacións humanas, cronolóxicas, tecnolóxicas, etc. levaron a acoutar o campo de traballo ao léxico galego de frecuencia, un dos dous elementos base para a construción do léxico fundamental.

A denominación de Dicionario de frecuencias vén dada pola presentación das formas obtidas do corpus, xa que foron agrupadas baixo o seu lema correspondente.

\section{LÉXICO, LÉXICO FUNDAMENTAL E LÉXICO DE FRECUENCIAS. QUUE SON?}

Unha das acepcións recollidas no DRAG di que léxico é "o conxunto de palabras dunha lingua". Se falamos dunha lingua viva, este conxunto caracterízase por ser aberto, susceptible de cambios. As palabras nacen, cambian no seu uso (amplían os seus significados, perden algunhas das acepcións...), deixan de ser usadas, etc.

Así a todo, a tendencia xeral que se observa en todas as linguas é que a maioría dos seus usuarios, a pesar da súa maior ou menor riqueza de vocabulario, fan uso unicamente dunha pequena parte dos seus recursos léxicos. Ese sería o léxico fundamental: un núcleo de palabras que todo

1. Agradézolle ao Dr. Manuel González González a oportunidade que me brindou ao darme a coñecer esta liña de investigación, os seus ánimos e a dirección da tese. 
membro dunha comunidade debe coñecer para establecer unha comunicación elemental.

Pero, como se chega ao establecemento do léxico fundamental dunha lingua? Xeralmente na construción do léxico fundamental adoitase recorrer á combinación do léxico de frecuencias e do léxico de dispoñibilidade. Do primeiro extráense as formas máis usadas polos falantes mentres que o segundo proporciona aquelas palabras que os falantes actualizan de modo máis espontáneo a través de estímulos axeitados, aínda que non alcancen unha determinada frecuencia.

\section{UTILIDADE DOS VOCABULARIOS E DICIONARIOS DE FRECUENCIAS}

Coñecer a frecuencia do léxico dunha lingua é moi útil e o seu establecemento resulta un material básico para o desenvolvemento de novos estudos ou de aplicacións en campos tan diversos como os seis seguintes, por poñer algúns exemplos:

(1) O ensino de lingua para estranxeiros. Nesta área xurdiron as primeiras listas de frecuencias, coas que se buscaba o vocabulario que debían coñecer as persoas que se achegaban a unha lingua distinta á súa establecendo unha gradación para a súa posterior aprendizaxe.

Os estudos de frecuencia coinciden en sinalar que son as palabras gramaticais as que aparecen sempre nos máis altos índices de frecuencia, como tamén en que hai un número moi reducido de palabras que se repiten ao longo de todo o corpus cunha determinada frecuencia, mentres que as formas denominadas hápax son as maioritarias. Estes coñecementos son os que permiten o establecemento dunha gradación: elemental ou introdutorio, medio e superior.

(2) Relacionado co campo anterior está a elaboración do material escolar, en lingua galega no noso caso, dun xeito racionalizado, gradual e progresivo. Cal é o léxico que deben aprender e fixar os cativos en cada unha das distintas etapas de escolarización debe ser algo previo ao deseño editorial.

(3) Este traballo tamén é útil na elaboración e corrección de dicionarios. As formas que integra calquera dicionario están expostas a unha serie de procesos que van desde a aparición do termo, a ampliación de significados, a restrición dos mesmos, ata a completa caída en desuso. Todos eses aspectos deben ser tidos en conta á hora da actualización das obras lexicográficas. Outro factor importante son as diferenzas internas entre os vocábulos que conforman o léxico dunha lingua. Algúns termos son 
moi frecuentes por posuíren moitas acepcións mentres que outros son raros por apareceren en contextos de uso demasiado especializados ou técnicos. Ónde establezamos o corte fará que o dicionario sexa de tipo básico ou escolar, por exemplo, onde deben estar recollidas as formas máis usuais, fronte a outro concibido coma un tesouro da lingua, xa no outro extremo, onde se pretende recoller todo o léxico desa lingua.

(4) Outro campo de aplicación é o da recuperación de pacientes con perda ou problemas de fala. Cando tratamos de dicir unha palabra que sae do noso campo de léxico habitual e frecuente adoitamos atoparnos con certas dificultades chegando a tela... 'na punta da lingua'. Ese fenómeno, aínda que máis agravado, afecta a persoas afásicas. Neste grupo tamén poderiamos incluír as persoas con dificultades na lectoescritura.

(5) O galego, como o resto das linguas, debe incorporarse ao mundo das novas tecnoloxías para poder ser útil aos seus falantes. Entre as súas múltiples aplicacións centrémonos, por un instante, no desenvolvemento de recoñecedores de fala. Hoxe en día o home pode establecer diálogos coas máquinas para que así elas leven a cabo as tarefas para as que foron concibidas. Así e todo, as comunicacións adoitan producirse en medios que non están exentos de ruídos e interferencias. Se a máquina dispón de ferramentas como listaxes de léxico acompañadas de datos estatísticos de frecuencia de uso pode chegar a recompoñer aquelas mensaxes dubidosas grazas á lóxica matemática.

(6) Se seguimos dentro do campo informático, o deseño de xogos tamén necesita dunha ferramenta de apoio que indique os distintos niveis de frecuencia e, coa mesma, de proximidade ou afastamento do xogadorfalante fronte aos vocábulos-xogo. Un clásico Aforcado en soporte electrónico, por exemplo, ten que posuír distintos niveis de dificultade e non errar neles se quere ter éxito e non perder o xogador xa no nivel principiante por exceso de dificultade.

\section{LÉXICO DE FRECUENCIA DA LINGUA GALEGA}

\section{3.o. Antecedentes}

Para a lingua galega en 1986 fíxose un traballo deste tipo que nunca chegou a ver a luz e do que souben por un dos seus autores. Trátase do Vocabulario de frecuencias da lingua oral, elaborado por Dolores Sánchez Palomino e Manuel González González. Esta obra, froito dun proxecto de investigación financiado pola Xunta de Galicia, consistiu na creación dun 
corpus de 300.000 palabras que permitiu a elaboración dunha lista coas 1.000 máis frecuentes.

\subsection{Elaboración do Dicionario de frecuencias da lingua galega}

\subsubsection{Deseño e creación do corpus}

A elaboración do vocabulario de frecuencias requiría primeiramente a creación dun corpus-mostra como punto de partida ou base da nosa investigación.

En primeiro lugar consultáronse e analizáronse distintas obras relacionadas co noso ámbito de traballo. Esas obras versaban maioritariamente sobre linguas románicas -castelán, catalán, francés, italiano, portugués...-, xa que os problemas que o galego podería presentar serían máis facilmente predicibles. Logo procedemos ao deseño do corpus e á posterior recompilación do material que o integraría e que pretendería ser unha representación da lingua galega actual en todas as súas manifestacións. De cara a conseguir o obxectivo proposto, creamos un corpus de carácter textual, con documentos completos, subdividido en dous subcórpora: un de lingua escrita (65\%) e outro de lingua oral (35\%). O subcorpus de lingua escrita estaba formado por obras literarias (novela, teatro, poesía), científico-técnicas, divulgativas e ensaísticas, en distintas proporcións. Á súa vez, o subcorpus de lingua oral recollía exemplos de intervencións formais (no ámbito do Parlamento ou na Universidade) e non formais (conversas, contos, etc.). Os materiais lingüísticos que o integraban pertencían ao período cronolóxico comprendido entre os anos 1975 e 1999, é dicir, aos últimos 25 anos do pasado século XX.

Na elaboración do corpus ideal hai moitos atrancos, algúns difíciles de resolver, aos que o investigador se debe enfrontar e que converten esta tarefa, segundo os estudosos, nunha utopía. Referímonos a dificultades como o nivel de lingua en que basear o traballo -lingua estándar, lingua común, lingua corrente, dialectos...-, o distinto valor e a porcentaxe dos materiais lingüísticos que se utilizan -escrito/oral, prosa/verso...-, os problemas técnicos -adquisición do material, uso de programas...-, e por qué non, a inexperiencia do deseñador, etc. A precaución ante tales avisos levounos a tentar contrarrestar os previsibles erros de selección de material cun tamaño global do corpus o suficientemente grande para que, dalgún xeito, conseguise facelos mínimos. O noso labor, individual e sen apoio informático, fixo que situaramos o límite ao redor dos 2 millóns de ocorrencias. 
Na escolla do material empregado, das proporcións establecidas e do período temporal pesaron, grosso modo, tres razóns:

(1) A través das distintas porcentaxes tentamos solucionar unha serie de problemas que podían interferir na 'calidade' dos materiais recollidos.

A linguaxe literaria está fortemente influída por dúas variables: (a) a cultura castelá dos escritores (ben sexa a simple escolarización recibida en territorio galego, ben a realización de estadías en universidades de fóra de Galicia, por exemplo), e (b) a acción dos correctores nas editoriais, acción que explicarei un pouco máis adiante.

Do mesmo xeito pode verse afectada a expresión oral formal, en ocasións froito dunha tradución simultánea desde un pensamento formulado orixinariamente en castelán (por exemplo, a lingua dalgúns parlamentarios).

Para contrarrestar a posible 'desviación' e empobrecemento lexical, os textos de recolla oral de rexistro non-formal permiten o acceso a un léxico máis propio e variado, xa que non podemos deixar de lado que a cultura rural foi a gran depositaria durante séculos da lingua galega.

(2) A selección cronolóxica veu dada en primeiro lugar pola intención de 'actualidade'. A primeira característica que buscou sempre esta investigación foi a súa practicidade e posterior aplicabilidade aos problemas que sofre a lingua galega como entidade minoritaria. En segundo lugar, preferiuse que a selección de textos fose dun período non excesivamente entrado no mundo das novas tecnoloxías editoriais. Así, aínda que os materiais chegan ao ano 1999, a maioría son anteriores a 1990. E isto para evitar a excesiva corrección lingüística provocada polo lema "o que non está recollido en dicionarios e correctores non é válido, non existe", que está ocasionando tan graves eivas no noso patrimonio lingüístico.

(3) Finalmente, e debido á amplitude do corpus que perseguiamos, foinos de esencial axuda valernos de material recompilado noutros proxectos $^{2}$ (xa en formato electrónico), aínda que debeu ser completado ata conseguir o deseño global do noso 'universo lingüístico' ideal (idea de representatividade).

2. Quixera agradecer o apoio prestado polo Dr. Antón Santamarina, con quen tiven a sorte de traballar durante seis anos no seu equipo de Lexicografía, no Instituto da Lingua Galega. Unha parte importante dos textos manexados neste corpus proceden do seu proxecto Base de datos lexicográfica do galego moderno. 


\subsubsection{Tratamento do material do corpus}

O respecto á lingua dos textos na súa substancia fonética, morfosintáctica e léxica foi a norma xeral básica. Así e todo, houbo que sometelos a unha serie de adaptacións de cara a unificalos e a poder procesalos despois mediante aplicacións informáticas. Basicamente as modificacións efectuadas afectaron á corrección de erros tipográficos; á eliminación de topónimos, antropónimos, estranxeirismos, etc. a efectos de cómputo; á uniformización no uso das grafías $b / v, h / \varnothing, i / y$, seguindo criterios etimolóxicos; á representación dos pronomes enclíticos ou ás segundas formas do artigo unidas a eles; á eliminación do uso do guión en formas compostas cando iso era factible ou á súa substitución por un guión baixo que soldaba as partes integrantes como unha única entidade; á unión, tamén con guión baixo, de palabras formantes dun lema único, etc.

Unha vez que foron uniformizados todos os materiais lingüísticos foi posible o emprego de programas informáticos para extraer o léxico do corpus. Primeiro, con axuda de WordSmith Tools elaborouse a lista de todas as formas gráficas distintas aparecidas no corpus coa ferramenta WordList.

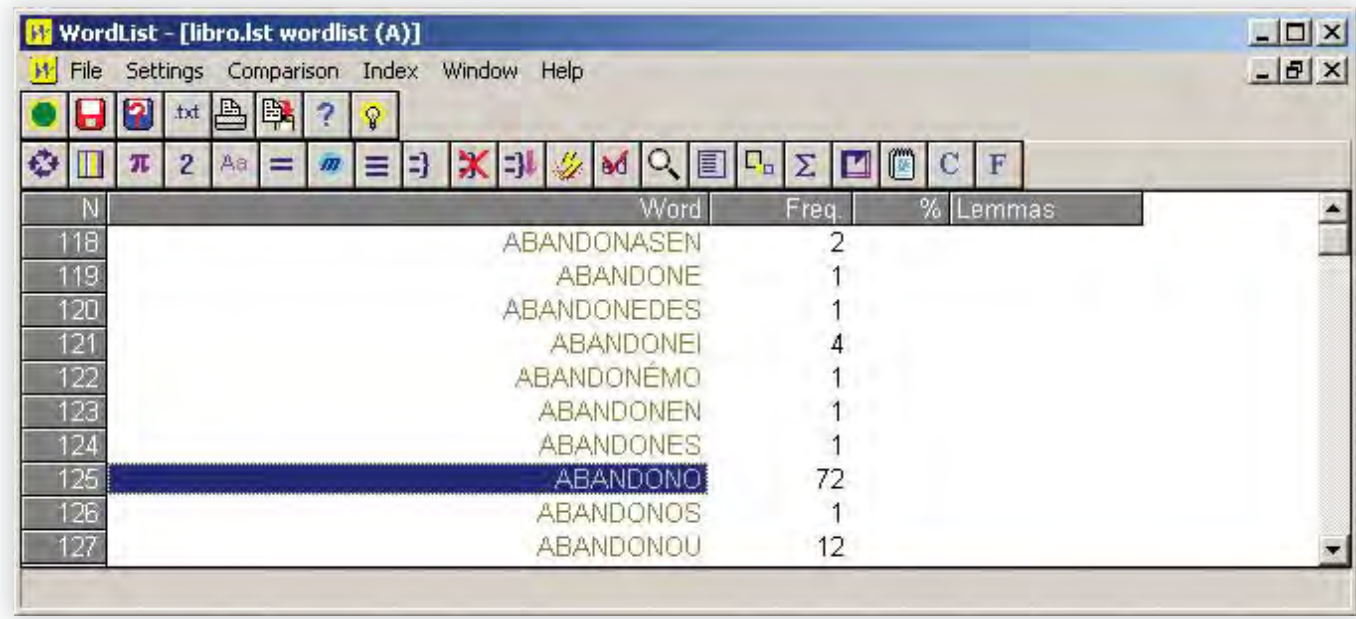

Despois, coa ferramenta Concord, extraéronse todas as concordancias de cada unha desas formas. Coas concordancias obtivéronse os contextos de uso, fundamentais para a posterior desambiguación. 


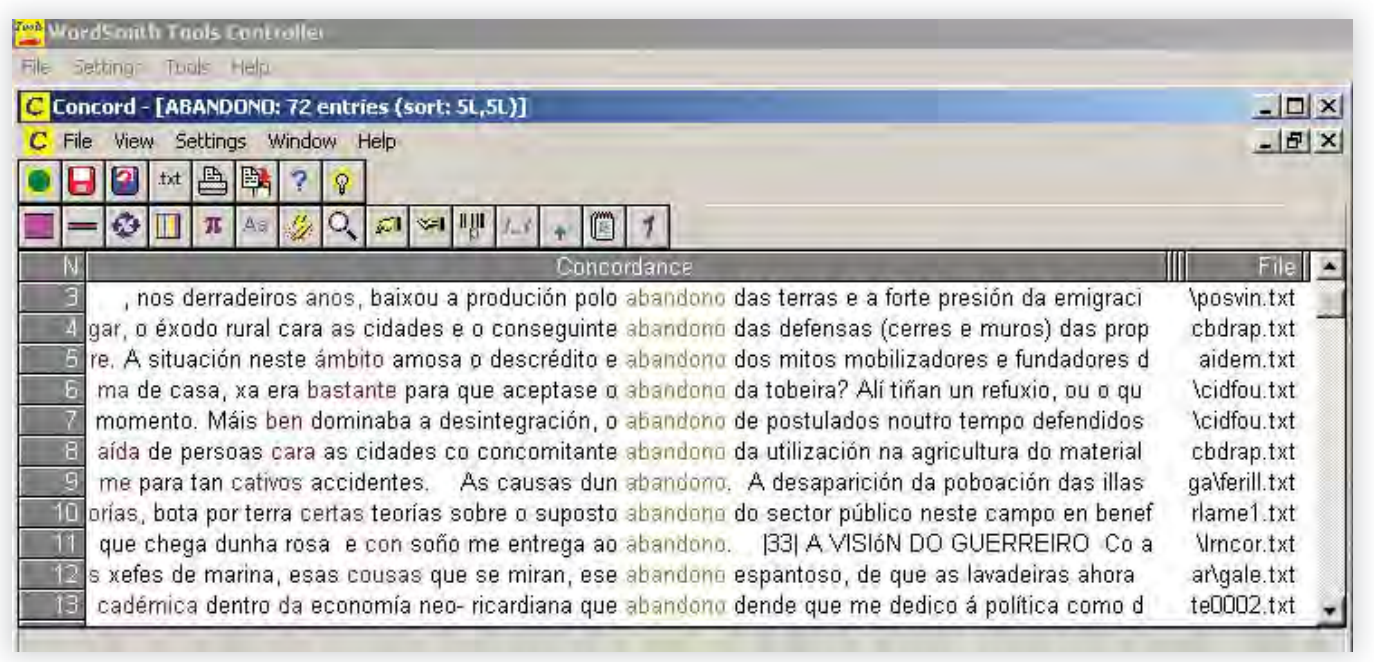

De seguido, toda esa información foi adaptada e introducida nunha base de datos do programa Microsoft Access. Nas diferentes táboas de traballo establecéronse os seguintes campos: contexto anterior, forma, contexto posterior, lema, categoría gramatical, tipo de lingua (escrita/oral), rexistro (coloquial/formal/científico, etc.) e fonte (documento orixe da forma). Unha vez que se revisou e corrixiu a transferencia da información de Wordsmith a Access, xa todo estaba preparado para comezar o proceso de lematización manual coa introdución dos datos referentes a lema e a categoría nos campos correspondentes.

\begin{tabular}{|c|c|c|c|c|c|c|c|}
\hline 2. Microsoft Access - [abandono: Tabla] & & & & & & & $-\mid ㅁ ㅣ$ \\
\hline 国 Archivo Édición ver Insertar Farmato Begist & tros Herrami & entas ventana? & & & & & $-|0| x \mid$ \\
\hline 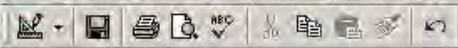 & A $\mid$ A t & 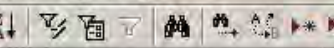 & 謇 & ?. & & & \\
\hline contexto1 & forma & contexto2 & Iema & cate & lingua & rexisi & font- \\
\hline - derradeiros anos, baixou a produción polo & abandono & das terras e a forte presión da & & & escrita & divulg; & posvin. \\
\hline I o rural cara as cidades e o conseguinte & abandono & das defensas (cerres e murosi ic & & & escrita & divulg: & cbdrap \\
\hline I ación neste ámbito amosa o descrédito e & abandono & dos mitos mobilizadores e fund: & & & escrita & literari & maider \\
\hline I sa, xa era bastante para que aceptase 0 & abandono & da tobeira? Ali tiñan un refuxi & & & escrita & literari & cidfou: \\
\hline 1. Máis ben dominaba a desintegración, o & abandono & de postulados noutro tempo defi & & & escrita & literari & cidfou. \\
\hline I persoas cara as cidades co concomitante & abandono & da utilización na agricultura d & & & escrita & divulg: & cbdrap \\
\hline I an cativos accidentes. As causas dun & abandono & A desaparición da poboación $\mathrm{c}$ & & & escrita & divulg: & ferill.tx \\
\hline or terra certas teorias sobre o suposto & abandono & do sector público neste campo I & & & oral & formal & parlam \\
\hline ga dunha rosa e con soño me entrega ao & abandono & |33| A VISlóN DO GUERREIF & & & escrita & literari & Irncort \\
\hline e marina, esas cousas que se miran, ese & abandono & espantoso, de que as lavadeiras & & & oral & coloqi & gale.t $x$ \\
\hline ca dentro da economía neoricardiana que & abandono & dende que me dedico á política & & & escrita & xornal & te0002 - \\
\hline $1+|\boldsymbol{H}| \mathbf{k} * \mid$ de 72 & & 11 & & & & & \pm \\
\hline Vista Hoja de datos & & & & & & & \\
\hline
\end{tabular}

O proceso de lematización, ou adxudicación dun lema ou forma léxica única a cada unha das ocorrencias aparecidas no corpus, foi o último paso da elaboración do corpus, xunto coa adxudicación dunha categoría gramatical. Para iso seguimos a tendencia maioritaria neste tipo de traballos e tomamos a palabra, ou elemento que aparece separado por espazos en branco, como a unidade de traballo. Para enfrontármonos aos problemas derivados de fenómenos coma a polisemia e homografía, a división e agrupación de cadeas gráficas, e a asignación de palabras a clases debe- 
mos establecer previamente unha serie de criterios básicos que guiasen a asignación das ocorrencias aos seus respectivos lemas. A desambiguación viuse facilitada por ser este un traballo totalmente manual. A consulta de todo tipo de obras lexicográficas, principalmente en linguas románicas, axudou na resolución dalgunhas situacións problemáticas.

\begin{tabular}{|c|c|c|c|c|c|c|}
\hline \multicolumn{6}{|l|}{ Microsoft Access - [abandono : Tabla] } & \multirow{2}{*}{$\begin{array}{l}-|0| x|x| x \mid \\
-|0| x \mid\end{array}$} \\
\hline \multicolumn{6}{|c|}{ 疄 Archivo Edición Ver Insertar Formato Registros Herramientas Ventana? } & \\
\hline \multicolumn{7}{|l|}{ 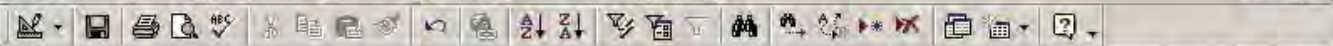 } \\
\hline contexto1 & forma & contexto2 & lema & cate & lingua & \begin{tabular}{|l|l|} 
rexist & font \\
\end{tabular} \\
\hline I derradeiros anos, baixou a produción polo & abandono & das terras $\mathrm{e}$ a forte presión $\mathrm{da}$ & ABANDONO & s.m. & escrita & divulg: poswin. \\
\hline 1 o rural cara as cidades e o conseguinte & abandono & das defensas (cerres e muros) c & C ABANDONO & s.m. & escrita & divulg: cbdrap \\
\hline ación neste ámbito amosa o descrédito e & abandono & dos mitos mobilizadores e funds & ABANDONO & s.m. & escrita & literari maider \\
\hline I sa, xa era bastante para que aceptase 0 & abandono & da tobeira? Ali tiñan un refuxi & ABANDONO & s.m. & escrita & literari cidfou: \\
\hline 1. Măis ben dominaba a desintegración, 0 & abandono & de postulados noutro tempo defi & ABANDONO & s.m. & escrita & literari cidfou. \\
\hline I persoas cara as cidades co concomitante & abandono & da utilización na agricultura d & ABANDONO & s.m. & escrita & divulg: cbdrap \\
\hline I an cativos accidentes. As causas dun & abandono & A desaparición da poboación $\mathrm{c}$ & ABANDONO & s.m. & escrita & divulg: ferill $t x$ \\
\hline or terra certas teorias sobre o suposto & abandono & do sector público neste campo & ABANDONO & s.m. & oral & formal parlam \\
\hline ga dunha rosa e con soño me entrega ao & abandono & |33|A VISIóN DO GUERREIF & ABANDONO & s.m. & escrita & literari Irncor.t \\
\hline e marina, esas cousas que se miran, ese & abandono & espantoso, de que as lavadeiras & ABANDONO & s.m. & oral & cologi gale tx \\
\hline ca dentro da economía neoricardiana que & abandono & dende que me dedico á política & ABANDONAR & & escrita & xomal te0002 \\
\hline 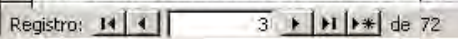 & & 4 & & & & + \\
\hline 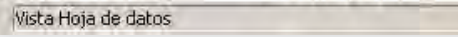 & & & & & & \\
\hline
\end{tabular}

\subsection{Resultados}

\subsubsection{Introdución}

Un corpus informatizado coma este permite distintas vías de consulta:

(a) polo lema:

\begin{tabular}{|l|l|r|}
\hline \multicolumn{2}{|c|}{ ABANDONO } \\
\hline s.m. & abandono & 66 \\
\hline s.m. & abandonos & 1 \\
\hline s.m. & abandoo & 2 \\
\hline \multicolumn{2}{|c|}{ suma: 69 } \\
\hline
\end{tabular}

(b) pola forma:

\begin{tabular}{|l|l|r|}
\hline \multicolumn{2}{|c|}{ ABANDONO } \\
\hline s.m. & abandono & 66 \\
\hline v. & abandono & 6 \\
\hline & & suma: 72 \\
\hline
\end{tabular}


(c) pola categoría: listas de substantivos, de adxectivos, de verbos etc.

(d) outras posibilidades: pódense obter listas froito do cruzamento das distintas variables establecidas no corpus.

\subsubsection{O dicionario de frecuencias}

A información preséntase ao posible usuario a través de dúas vías distintas:

(1) Unha lista na que por frecuencia decrecente aparecen os lemas resultantes do proceso de lematización. Cando existe máis dun lema coa mesma frecuencia hai unha ordenación secundaria de carácter alfabético.

\begin{tabular}{|l|l|l|}
\hline $6,28 \%$ O (art.) & $1,45 \%$ NON & $0,59 \%$ SEU \\
$3,76 \%$ E & $1,28 \%$ O & $0,58 \%$ HABER \\
$3,74 \%$ DE & $1,19 \%$ A (prep.) & $0,56 \%$ ESTAR \\
$3,09 \%$ DO & $0,94 \%$ EN & $0,54 \%$ DICIR \\
$2,19 \%$ QUE (pron.) & $0,83 \%$ TER & $0,53 \%$ FACER \\
$1,94 \%$ SER (v.) & $0,78 \%$ PARA & $0,53 \%$ ME \\
$1,89 \%$ UN & $0,71 \%$ POR & $0,52 \%$ MOITO \\
$1,77 \%$ QUE (con $x)$. & $0,69 \%$ O (pron.) & $0,51 \%$ MÁIS (adv.) \\
$1,56 \%$ NO & $0,64 \%$ LLE & $0,51 \%$ TODO \\
$1,48 \%$ SE (pron.) & $0,63 \%$ IR & $0,50 \%$ OU (con $x$. $)$ \\
\hline
\end{tabular}

(2) Outra lista que inclúe, seguindo unha orde alfabética, o lema coas súas ocorrencias, así como a(s) categoría(s) diferenciada(s) xunto coas cifras tanto da(s) ocorrencia(s) como do total de formas agrupadas baixo ese lema. 


\begin{tabular}{|l|l|r|}
\hline \multicolumn{2}{|c|}{ CARO } & 23 \\
\hline adx. & cara & 11 \\
\hline adx. & caras & 1 \\
\hline adx. & carísemo & 1 \\
\hline adx. & carísimas & 1 \\
\hline adx. & carísimo & 1 \\
\hline adx. & carísimos & 54 \\
\hline adx. & caro & 11 \\
\hline adx. & caros & suma: 72 \\
\hline
\end{tabular}

\subsubsection{Outras aproximacións}

A pesar de que neste punto remataría a elaboración do vocabulario de frecuencias ou, neste caso, dicionario de frecuencias, o feito de traballar sobre un corpus destas características permite múltiples posibilidades de estudo do léxico galego. A continuación, imos facer unha breve demostración dalgunhas aproximacións de carácter inicial aos datos que poden parecer máis relevantes desde o punto de vista da frecuencia:

(1) Abordar os datos de carácter xeral que se extraeron do corpus, é dicir, o número de ocorrencias totais, das formas gráficas distintas, dos lemas resultantes, dos hápax, etc.

(2) Extraer os cen lemas máis frecuentes e comentar algúns aspectos desprendidos da súa observación e da súa comparación cos cen lemas máis frecuentes noutras linguas románicas.

(3) Facer unha aproximación segundo a categoría gramatical. Para exemplificalo imos traballar coas categorías substantivo, adxectivo, verbo e adverbio. Procederemos a elaborar a lista dos cen lemas máis frecuentes de cada categoría, acompañada dalgúns comentarios xerais.

(4) Facer, por exemplo, unha cala dentro dos substantivos buscando lemas relacionados con algúns campos léxicos. 


\subsubsection{Algúns datos de carácter xeral}

Un primeiro achegamento aos datos estatísticos totais proporcionou a seguinte información:

- As 2.064.847 ocorrencias que integran o corpus corresponden a 87.273 formas gráficas distintas.

- Despois de lematizadas esas 87.273 formas gráficas distintas, obtivéronse un total de 32.529 lemas diferentes.

- O número de hápax, ou lemas cunha única ocorrencia, ascende a 10.117, ou sexa, un $31,1 \%$, o que indicaría que case un terzo dos lemas ten carácter ocasional.

- A suma das ocorrencias correspondentes aos 53 primeiros lemas en orde de frecuencia representa un 49,98\%, o que vén ser case a metade das ocorrencias do corpus.

- Os 1.000 lemas máis frecuentes cobren coas súas ocorrencias o $80,32 \%$ do corpus.

\subsubsection{Os cen primeiros lemas}

$\begin{array}{lc}\text { O (art.) } & 129.256 \\ \text { E } & 77.624 \\ \text { DE } & 77.220 \\ \text { DO } & 63.735 \\ \text { QUE (pr.) } & 45.200 \\ \text { SER }(v .) & 40.150 \\ \text { UN } & 38.985 \\ \text { QUE (cx.) } & 36.553 \\ \text { NO } & 32.311 \\ \text { SE (pr.) } & 30.487 \\ \text { NON } & 30.026 \\ \text { Ó } & 26.402 \\ \text { A (pp.) } & 24.503 \\ \text { EN } & 19.339 \\ \text { TER } & 17.199 \\ \text { PARA } & 16.017 \\ \text { POR } & 14.573 \\ \text { O (pr.) } & 14.247 \\ \text { LLE } & 13.319 \\ \text { IR } & 13.109 \\ \text { SEU } & 12.245 \\ \text { HABER } & 12.061 \\ \text { ESTAR } & 11.636 \\ \text { DICIR } & 11.065 \\ \text { FACER } & 11.022 \\ \text { ME } & 10.918 \\ \text { MOITO } & 10.655 \\ \text { MÁIS (av.) } & 10.562 \\ \text { TODO } & 10.438 \\ \text { OU (cx.) } & 10.418 \\ \text { COMO } & 10.268 \\ \text { POLO } & 9807 \\ \text { CON } & 9673 \\ & \end{array}$

$\begin{array}{ll}\text { ESTE } & 9189 \\ \text { CO } & 9090 \\ \text { PERO } & 8561 \\ \text { EU } & 7631 \\ \text { XA } & 7584 \\ \text { PODER (v.) } & 7539 \\ \text { OUTRO } & 7228 \\ \text { SE (cX.) } & 6967 \\ \text { ESE } & 6955 \\ \text { DAR } & 6683 \\ \text { EL } & 6395 \\ \text { DUN } & 5693 \\ \text { MEU } & 5436 \\ \text { TAMÉN } & 5310 \\ \text { VIR } & 5250 \\ \text { CANDO } & 5235 \\ \text { SABER } & 5220 \\ \text { VER } & 5123 \\ \text { PORQUE } & 4906 \\ \text { BEN } & 4814 \\ \text { MESMO } & 4463 \\ \text { ANO 'tp' } & 4441 \\ \text { DESSPIS } & 4425 \\ \text { ASÍ } & 4406 \\ \text { QUERER } & 4216 \\ \text { POIS } & 3990 \\ \text { NUN } & 3924 \\ \text { DOUS } & 3882 \\ \text { NOS } & 3772 \\ \text { VEZ } & 3714 \\ \text { DÍA } & 3660 \\ \text { LEVAR } & 3633 \\ \text { SEN } & 3548 \\ & \end{array}$

$\begin{array}{ll}\text { BO } & 3493 \\ \text { AQUÍ } & 3435 \\ \text { AGORA } & 3410 \\ \text { PÓR } & 3292 \\ \text { ONDE } & 3213 \\ \text { PASAR } & 3183 \\ \text { CHE } & 3173 \\ \text { CASA } & 3155 \\ \text { POUCO } & 3044 \\ \text { COMA } & 3042 \\ \text { CHEGAR } & 3023 \\ \text { TEMPO } & 3011 \\ \text { GALEGO } & 2996 \\ \text { ENTRE } & 2958 \\ \text { ALÍ } & 2929 \\ \text { AQUEL } & 2878 \\ \text { SI (aV.) } & 2854 \\ \text { NIN } & 2806 \\ \text { DESTE } & 2718 \\ \text { AÍNDA } & 2700 \\ \text { PRIMEIRO } & 2692 \\ \text { SOBRE ( } p p .) & 2680 \\ \text { SEÑOR } & 2668 \\ \text { CHAMAR } & 2658 \\ \text { GRANDE } & 2623 \\ \text { FALAR } & 2608 \\ \text { TANTO } & 2587 \\ \text { COUSA } & 2543 \\ \text { ATA } & 2520 \\ \text { CUN } & 2509 \\ \text { PARTE } & 2507 \\ \text { DEIXAR } & 2502 \\ \text { HOME } & 2501 \\ \text { NOSO } & 2470\end{array}$

Da observación dos cen lemas máis frecuentes no idioma galego pódense tirar, entre outras, as seguintes conclusións: 
- Os lemas máis usuais en lingua galega son formas curtas, na súa maioría bisílabas.

- Os lemas máis frecuentes correspóndense coas denominadas palabras gramaticais: o artigo determinado, a conxunción copulativa e, e as preposicións de e $a$, etc.

- As primeiras palabras léxicas son verbos: ser, ter, ir, haber, estar, dicir, facer...

- O primeiro substantivo que aparece é ano 'intervalo de tempo'. Outros substantivos frecuentes son: día, casa, tempo, señor, vez, cousa, home e parte.

- Os adxectivos máis frecuentes son grande, galego e bo.

- Os adverbios están a medio camiño entre as formas gramaticais e as léxicas. Os máis frecuentes en orde decrecente son: non, máis, xa, moito, tamén, ben, así, aquí, despois, agora, onde, ali, si, sempre, ai, ainda $a^{3}$.

A elaboración desta lista permitiunos confrontar os datos referidos ao idioma galego con outros idiomas da Romania. En 1994 Henri Guiter publicaba o traballo "Rang et dispersion des fréquences lexicales romanes" (Guiter 1994). Nese artigo atópase unha táboa, a número 1, na que, en orde decrecente, aparecen os cen termos máis frecuentes de portugués, castelán, catalán, francés, provenzal, italiano e romanés. Para a correcta comparación foi necesario someter a lista galega a unha 'corrección': as contraccións e amálgamas foron desdobradas nos seus formantes orixinarios e computáronse con cada un dos lemas base correspondentes.

\begin{tabular}{|l|l|l|l|l|l|l|l|l|}
\hline & gal. & port. & cast. & cat. & fr. & prov. & \multicolumn{1}{c|}{ it. } & rom. \\
\hline 1 & o (art.) & o- a & el - la & el - la & le - la & lou - la & il -la & de \\
2 & de & de & de & de & de & de & di + da & şi (conx.) \\
3 & e & que & y & i & un & que & e & (pron.) \\
4 & en & e & que & a & être & e & a & avea \\
5 & un & ser & en & un & et & à & essere & în (prep.) \\
6 & a (prep.) & um & a & que & à & un & un \\
7 & que & se & él & se & avoir & èstre & un & fi \\
\hline
\end{tabular}

3. É interesante comprobar que os adverbios máis habituais fan referencia á situación cronolóxica ou locativa. Esas referencias revélanse como un motivo habitual en calquera produción lingüistica reflexo dunha necesidade de concreción situacional no tempo ou no espazo. 


\begin{tabular}{|c|c|c|c|c|c|c|c|c|}
\hline & gal. & port. & cast. & cat. & fr. & prov. & it. & rom. \\
\hline 8 & $\operatorname{ser}(v)$. & não & ser & ser & il & soun & si & se (pron.) \\
\hline 9 & $\begin{array}{l}\text { que } \\
\text { (conx.) }\end{array}$ & a (prep.) & $\mathrm{su}$ & anar & ne & $\begin{array}{l}\text { se } \\
\text { (pron.) }\end{array}$ & in & să (conx.) \\
\hline 10 & se (pron.) & com & haber & haver & $\begin{array}{l}\text { que } \\
\text { (conx.) }\end{array}$ & avé & non & nu (adv.) \\
\hline 11 & non & lhe & con & no & je & dins & avere & la (prep.) \\
\hline 12 & por & ter & un & que (pron.) & ce (adx.) & pèr & con & pe (pron.) \\
\hline 13 & con & seu & por & per & se & en & per & al (art.) \\
\hline 14 & para & $\mathrm{em}$ & yo & en & qui & faire & lo & $\begin{array}{l}\text { care } \\
\text { (pron.) }\end{array}$ \\
\hline 15 & ter & para & este & $\mathrm{amb}$ & pas (adv.) & lou (pron.) & $\mathrm{mi}$ & mai (adv.) \\
\hline 16 & o (pron.) & me & no & fer & ce (pron.) & tout & suo & $\operatorname{din}$ \\
\hline 17 & lle & dizer & todo & com & en (prep.) & mai & quello & ca (conx.) \\
\hline 18 & este & por & como & me & dans & coume & gli & $\mathrm{eu}$ \\
\hline 19 & ir & $\mathrm{eu}$ & más & seu & son & sus & fare & ce (pron.) \\
\hline 20 & seu & mais & para & dir & vous & emé & tutto & că (conx.) \\
\hline 21 & haber & mas & estar & li & pour & mai & $\mathrm{ma}$ & acest \\
\hline 22 & estar & como & tener & més & on & me & dire & putea \\
\hline 23 & me & estar & ir & hi & plus & vèire & sù & tu \\
\hline 24 & dicir & ir & ese & tot & nous & dire & piu & cel, cea \\
\hline 25 & facer & haver & hacer & tenir & par & moun & io & face \\
\hline 26 & moito & meu & otro & ell & me & ié (pron.) & mio & pentru \\
\hline 27 & $\begin{array}{l}\text { máis } \\
\text { (adv.) }\end{array}$ & ele & poder & ne (pron.) & mais & veni & questo & cînd (adv.) \\
\hline 28 & todo & ver & pero & si (conx.) & sur & ana & altre & noi \\
\hline 29 & ou & fazer & decir & però & tout & bèu & come & dar (conx.) \\
\hline 30 & como & muito & $\mathrm{O}$ & aquest & le (pron.) & en & egli & între \\
\hline 31 & ese & todo & ver & poder & pouvoir & toun & ne & a \\
\hline 32 & pero & ja & $\mathrm{mi}$ & estar & faire & se (conx.) & potere & tot \\
\hline 33 & outro & dar & $\sin$ & altre & dire & aquéu & vedere & voi \\
\hline 34 & el & saber & aquel & aquell & mon & vous & lui & da \\
\hline 35 & eu & querer & hombre & ja & comme & quand & vi & vedea \\
\hline 36 & xa & outro & ya & veure & avec & pas & volere & prin (prep.) \\
\hline 37 & poder (v.) & sem & vida & ho & bien & te & $\mathrm{O}$ & om \\
\hline 38 & se $(\operatorname{con} x)$. & poder & dar & saber & lui & ié (adv.) & se & $\begin{array}{l}\text { cum } \\
(\operatorname{conx} .)\end{array}$ \\
\hline 39 & dar & homem & sobre & voler & en (pron.) & éu & sapere & mare \\
\hline 40 & meu & este & si & quan & tu & iéu & poco & veni \\
\hline 41 & tamén & esse & cuando & perquè & $\mathrm{y}$ & noun & stare & aşa (adv.) \\
\hline
\end{tabular}




\begin{tabular}{|c|c|c|c|c|c|c|c|c|}
\hline & gal. & port. & cast. & cat. & fr. & prov. & it. & rom. \\
\hline 42 & vir & quem & mismo & jo & ou & nous & cosa & $\begin{array}{l}\text { numai } \\
\text { (adv.) }\end{array}$ \\
\hline 43 & cando & aquele & dos & o & si & grand & andare & $\begin{array}{l}\text { nici } \\
\text { (conx.) }\end{array}$ \\
\hline 44 & saber & casa & nuestro & donar & leur & ounte & venire & $\begin{array}{l}\text { după } \\
\text { (prep.) }\end{array}$ \\
\hline 45 & ver & vir & vez & home & voir & $\tan t$ & anche & zice \\
\hline 46 & porque & bem & mucho & què & cela & voulè & perchè & spune \\
\hline 47 & ben & nem & grande & cosa & où & poudé & me & şti \\
\hline 48 & mesmo & lá & tu & molt & sans & bon & ci & dacă \\
\hline 49 & $\begin{array}{l}\text { ano } \\
\text { 'tempo' }\end{array}$ & então & entre & passar & savoir & autre & $\operatorname{cosi}$ & trebui \\
\hline 50 & despois & palavra & día & senyor & monsieur & entre & quale & său \\
\hline 51 & así & olho & querer & bé & deux & tu & senza & decît \\
\hline 52 & querer & quando & poco & te & moi & bèn & ti & doi \\
\hline 53 & pois & onde & muy & ara & notre & teni & tanto & meu \\
\hline 54 & nos & algum & $\tan$ & tornar & même & acò & due & $\begin{array}{l}\text { unul } \\
\text { (pron.) }\end{array}$ \\
\hline 55 & aquel & ficar & porque & $\begin{array}{l}\text { fins } \\
\text { (prep.) }\end{array}$ & vouloir & sant & dovere & iar \\
\hline 56 & dous & mesmo & usted & ni & non & nostre & parlare & tot \\
\hline 57 & che & vida & ni & mà & grand & o & giorno & lua \\
\hline 58 & vez & até & uno & sense & tout & tèms & parere & acel \\
\hline 59 & día & ou & creer & dia & venir & diéu & ora & zi \\
\hline 60 & levar & vez & primer & meu & très & amour & trovare & ochi \\
\hline 61 & sen & assim & llegar & casa & encore & falé & qualche & nostru \\
\hline 62 & bo & deixar & tiempo & $\tan$ & petit & long & quando & $\begin{array}{l}\text { acum } \\
\text { (adv.) }\end{array}$ \\
\hline 63 & aquí & entrar & mujer & deixar & là & cop & dare & parte \\
\hline 64 & agora & isso & año & venir & homme & dous & sentire & domn \\
\hline 65 & pór & tão & algún & dos & quelque & plus & tu & unde \\
\hline 66 & onde & primeiro & parecer & mateix & peu & pièi & uomo & însă \\
\hline 67 & pasar & so & hasta & trobar & devoir & canta & mai & sau \\
\hline 68 & casa & também & español & semblar & falloir & jour & cui & mînă \\
\hline 69 & pouco & tu & mundo & any & jour & ome & ancora & apoi (adv.) \\
\hline 70 & coma & coisa & vivir & arribar & donner & souto & occhio & $\begin{array}{l}\text { spre } \\
\text { (prep.) }\end{array}$ \\
\hline 71 & chegar & conhecer & pasar & gran & aussi & léu & guardar & bine (adv.) \\
\hline 72 & tempo & dia & casa & bo & autre & aquí & mano & trece \\
\hline 73 & galego & dois & después & pensar & dont & $\operatorname{man}$ & parola & loc \\
\hline
\end{tabular}




\begin{tabular}{|c|c|c|c|c|c|c|c|c|}
\hline & gal. & port. & cast. & cat. & fr. & prov. & it. & rom. \\
\hline 74 & entre & ouvir & saber & $\operatorname{mig}$ & te & crida & chi & $\begin{array}{l}\text { a(i)-ci } \\
\text { (adv.) }\end{array}$ \\
\hline 75 & alí & pai & siempre & nos & aller & mèstre & grande & $\begin{array}{l}\text { atunci } \\
\text { (adv.) }\end{array}$ \\
\hline 76 & algún & pensar & $\cos a$ & encara & oui & vièi & amare & pînă (prep.) \\
\hline 77 & si (adv.) & sentir & hablar & ull & rien & quau & mettere & cap \\
\hline 78 & $\operatorname{nin}$ & passar & desde & mai & quand & jouine & parte & an \\
\hline 79 & aínda & tempo & $\operatorname{sino}$ & parlar & si (adv.) & rèi & poi & $\begin{array}{l}\text { sub(t) } \\
\text { (prep.) }\end{array}$ \\
\hline 80 & primeiro & coração & donde & tot (adv.) & premier & soulèu & quanto & bun \\
\hline 81 & $\begin{array}{l}\text { sobre } \\
\text { (prep.) }\end{array}$ & mão & nuevo & això & même & vostre & sempre & rămine \\
\hline 82 & señor & olhar & también & sentir & trouver & car & vecchio & sta \\
\hline 83 & chamar & te & sólo & entrar & heure & tres & ogni & $\begin{array}{l}\text { altul } \\
\text { (pron.) }\end{array}$ \\
\hline 84 & grande & velho & pueblo & pas (adv.) & croire & vers & tempo & vreme \\
\hline 85 & falar & ainda & ahora & $\operatorname{tant}$ & prendre & encaro & prendere & mult \\
\hline 86 & tanto & ano & mano & sortir & votre & saupre & dio & pune \\
\hline 87 & cousa & hora & mil & hora & moins & rèn & signore & $\begin{array}{l}\text { singur } \\
(\operatorname{adx} .)\end{array}$ \\
\hline 88 & ata & nada & tres & on & bon & sènse & vita & urmă \\
\hline 89 & parte & pouco & llevar & obrir & celui & blanc & pensare & începe \\
\hline 90 & deixar & sobre & bien & vegada & temps & ne & primo & lăsa \\
\hline 91 & home & noite & dejar & posar & chose & uei & tuo & cit \\
\hline 92 & noso & paixão & ojo & algun & tout $^{4}$ & paure & certo & părea \\
\hline 93 & só & pois & encontrar & sempre & alors & plen & solo & viață \\
\hline 94 & nada & senhor & salir & vida & vie & passa & molto & $\begin{array}{l}\text { peste } \\
\text { (prep.) }\end{array}$ \\
\hline 95 & te & grande & quien & així & toujours & toumba & nè & pămînt \\
\hline 96 & quedar & porta & nada & damunt & femme & ansin & voi & uita \\
\hline 97 & ti & $\operatorname{sim}$ & pensar & mirar & parler & ni & allora & trei \\
\hline 98 & sempre & alí & aquí & temps & donc & terro & amore & mult \\
\hline 99 & medio & aquí & poner & sobre & entre & courre & bene & tot \\
\hline 100 & andar & parecer & sentir & entre & jamais & aigo & casa & vorbă \\
\hline
\end{tabular}

Da análise das distintas listas pódense tirar as seguintes conclusións:

- Canto máis frecuente é un lema máis posibilidades hai de coincidencia entre as distintas linguas románicas comparadas.

4. O artigo manexado inclúe tres veces a forma tout na columna francesa nas posicións 29, 58 e 92 . 
- Os lemas máis frecuentes son palabras gramaticais. Salientan de xeito especial os artigos o e un, a conxunción copulativa e e as preposicións de e $a$.

- As primeiras palabras léxicas en aparecer son verbos. Os máis frecuentes son ser, haber, ter e estar, xusto os máis desemantizados.

- Os substantivos comúns ás oito linguas comparadas son: día, tempo e home. Os dous primeiros lemas responden á necesidade humana dunha referencia situacional no tempo ou no espazo na súa produción lingüística (a forma ano rexístrase en seis das linguas comparadas). O terceiro lema aglutina distintas acepcións que van desde a máis xenérica 'ser humano' ata a máis específica 'ser humano adulto de xénero masculino' ou 'cónxuxe de xénero masculino'.

\subsubsection{Os cen primeiros lemas por categoría}

(a) Os cen substantivos máis frecuentes:

\begin{tabular}{|c|c|c|c|c|c|c|c|c|}
\hline & & & & & & 67 & PALABRA & 705 \\
\hline 1 & AN̦O 'tp' & 4441 & 34 & ESTADO & 1018 & 68 & VECIÑo & 700 \\
\hline 2 & DÍA & 3540 & 35 & EXEMPLO & 1001 & 69 & VACA & 696 \\
\hline 3 & CASA & 3152 & 36 & LEI & 997 & 70 & SITUACIÓN & 696 \\
\hline 4 & TEMPO & 2889 & 37 & ZONA & 979 & 71 & AMIGO & 689 \\
\hline 5 & SEÑOR & 2665 & 38 & DEUS & 970 & 72 & LINGUA & 668 \\
\hline 6 & VEZ & 2552 & 39 & RAPAZ & 951 & 73 & ESPECIE & 661 \\
\hline 7 & COUSA & 2543 & 40 & SOCIEDADE & 941 & 74 & HISTORIA & 652 \\
\hline 8 & HOME & 2478 & 41 & MES & 936 & 75 & LIBRO & 627 \\
\hline 9 & PARTE & 2281 & 42 & NOME & 934 & 76 & VERDADE & 625 \\
\hline 10 & CASO & 1822 & 43 & PORTA & 920 & 77 & LUZ & 624 \\
\hline 11 & AUGA & 1772 & 44 & CONTA & 902 & 78 & LIÑA & 624 \\
\hline 12 & MULLER & 1698 & 45 & ILLA & 884 & 79 & AMOR & 621 \\
\hline 13 & TERRA & 1639 & 46 & MOMENTO & 881 & 80 & PÉ & 617 \\
\hline 14 & NOITE & 1625 & 47 & OBRA & 879 & 81 & IRMÁN & 616 \\
\hline 15 & MAN & 1624 & 48 & HORA & 877 & 82 & CAMPO & 615 \\
\hline 16 & VIDA & 1602 & 49 & CABEZA & 867 & 83 & SISTEMA & 607 \\
\hline 17 & XENTE & 1545 & 50 & PAI & 866 & 84 & RELACIÓN & 605 \\
\hline 18 & TRABALLO & 1490 & 51 & PUNTO & 854 & 85 & RAZÓN & 604 \\
\hline 19 & LUGAR & 1451 & 52 & PROBLEMA & 848 & 86 & PESETA & 599 \\
\hline 20 & VIÑo & 1448 & 53 & DON 'trat.' & 830 & 87 & NAI & 598 \\
\hline 21 & FORMA & 1325 & 54 & РОВО & 829 & 88 & CIDADE & 594 \\
\hline 22 & FILLO & 1246 & 55 & CORPO & 829 & 89 & SITIO & 593 \\
\hline 23 & MEDIO & 1238 & 56 & MANEIRA & 828 & 90 & EMPRESA & 589 \\
\hline 24 & OLLO & 1230 & 57 & SÉCULO & 824 & 91 & VOLTA & 585 \\
\hline 25 & XEITO & 1189 & 58 & LADO & 812 & 92 & PAN & 576 \\
\hline 26 & NENO & 1180 & 59 & PEDRA & 808 & 93 & GALEGO & 570 \\
\hline 27 & MAR & 1162 & 60 & PERSOA & 796 & 94 & MEDO & 568 \\
\hline 28 & MUNDO & 1156 & 61 & FESTA & 790 & 95 & ALETA & 564 \\
\hline 29 & MOZO & 1129 & 62 & PRODUCIÓN & 774 & 96 & A 'letra' & 563 \\
\hline 30 & PAÍS & 1070 & 63 & NÚMERO & 763 & 97 & Tío & 558 \\
\hline 31 & CAMIÑo & 1070 & 64 & VELLO & 758 & 98 & IGREXA & 557 \\
\hline 32 & TIPO & 1069 & 65 & MONTE & 715 & 99 & POUCO & 550 \\
\hline 33 & GRUPO & 1024 & 66 & GOBERNO & 713 & 100 & FEITO & 549 \\
\hline
\end{tabular}

Se nos achegamos aos datos desde o punto de vista semántico é posible establecer unha serie de grupos atendendo a campos nocionais ${ }^{5}$ :

5. En ocasións algún dos lemas pode aparecer en máis dun grupo xa que a ampla frecuencia está en relación directa coa posibilidade de posuír varias acepcións. 
- Tempo cronolóxico: ano, día, tempo, vez, noite, mes, momento, hora, século.

- Ser humano: señor, home, muller, xente, neno, mozo, grupo, rapaz, sociedade, don, persoa, vello, veciño, amigo.

- Familia. Este campo está moi relacionado co anterior e case funcionando coma un subcampo: fillo, pai, irmán, nai, tío. Hai que incluír aquí tamén home 'esposo', muller 'esposa', neno 'fillo', mozo 'noivo', rapaz 'fillo' e vello 'avó'.

- Espazo e medio físico: casa, parte, auga, terra, lugar, mar, mundo, camiño, zona, illa, lado, monte, situación, campo, cidade, sitio.

- Outros campos que ocupan un lugar importante nesta listaxe son os referidos ao corpo humano (ollo, cabeza, corpo, lingua), aos alimentos (auga, viño, pan), ás relacións laborais (traballo, obra, produción, sistema, empresa), á política (país, estado, lei, pobo, goberno), aos sentimentos (verdade, amor, medo), á relixión (deus, igrexa).

Os campos nocionais documentados permiten afirmar que o mundo xira ao redor do ser humano, que se describe a si mesmo física e psicoloxicamente, que se sitúa no espazo e no tempo, e que se organiza socialmente.

(b) Os cen adxectivos máis frecuentes:

\begin{tabular}{|c|c|c|c|c|c|c|c|c|}
\hline & & & & & & 67 & EUROPEO & 287 \\
\hline 1 & GRANDE & 2623 & 34 & NEGRO & 456 & 68 & PRINCIPAL & 276 \\
\hline 2 & GALEGO & 2150 & 35 & PÚBLICO & 452 & 69 & PRÓXIMO & 268 \\
\hline 3 & BO & 2096 & 36 & ACTUAL & 449 & 70 & COÑECIDO & 268 \\
\hline 4 & Novo & 1715 & 37 & FORTE & 429 & 71 & DURO & 267 \\
\hline 5 & PEQUENO & 1590 & 38 & NATURAL & 423 & 72 & LOCAL & 264 \\
\hline 6 & PROPIO & 1260 & 39 & SUPERIOR & 418 & 73 & AGRARIO & 263 \\
\hline 7 & VELLO & 979 & 40 & NECESARIO & 407 & 74 & NORMAL & 259 \\
\hline 8 & MAIOR & 892 & 41 & CERTO & 399 & 75 & MÍNIMO & 259 \\
\hline 9 & SOCIAL & 877 & 42 & CHEO & 396 & 76 & LIBRE & 257 \\
\hline 10 & ECONÓMICO & 847 & 43 & ESPAÑOL & 383 & 77 & MODERNO & 256 \\
\hline 11 & POLÍTICO & 843 & 44 & DETERMINADO & 368 & 78 & DEREITO & 253 \\
\hline 12 & IMPORTANTE & 831 & 45 & SECO & 360 & 79 & RICO & 253 \\
\hline 13 & MEDIO & 776 & 46 & DORSAL & 349 & 80 & TRADICIONAL & 252 \\
\hline 14 & ALTO & 763 & 47 & MORTO & 348 & 81 & XUNTO & 252 \\
\hline 15 & SANTO & 721 & 48 & COMÚN & 345 & 82 & URBANO & 249 \\
\hline 16 & BRANCO & 720 & 49 & INDUSTRIAL & 339 & 83 & FUNDAMENTAL & 248 \\
\hline 17 & MALO & 691 & 50 & SEMELLANTE & 339 & 84 & MENOR & 248 \\
\hline 18 & MELLOR & 670 & 51 & IGUAL & 322 & 85 & TOTAL & 247 \\
\hline 19 & SEGUINTE & 661 & 52 & PRESENTE & 316 & 86 & CURTO & 236 \\
\hline 20 & ÚLTIMO & 652 & 53 & REAL 'res' & 314 & 87 & CONCRETO & 232 \\
\hline 21 & XERAL & 651 & 54 & DIFÍCIL & 314 & 88 & FAMILIAR & 232 \\
\hline 22 & ÚNICO & 639 & 55 & DIFERENTE & 313 & 89 & PARLAMENTARIO & 230 \\
\hline 23 & LONGO & 618 & 56 & VIVO & 310 & 90 & DOADO & 228 \\
\hline 24 & RURAL & 614 & 57 & ESCURO & 307 & 91 & MÁXIMO & 222 \\
\hline 25 & só & 580 & 58 & INFERIOR & 307 & 92 & POSTERIOR & 220 \\
\hline 26 & POPULAR & 571 & 59 & CULTURAL & 305 & 93 & PASADO & 220 \\
\hline 27 & CLARO & 547 & 60 & HUMANO & 303 & 94 & FRÍO & 219 \\
\hline 28 & ANTIGO & 544 & 61 & DERRADEIRO & 301 & 95 & ABSOLUTO & 211 \\
\hline 29 & DISTINTO & 524 & 62 & VERDADEIRO & 297 & 96 & CAPAZ & 209 \\
\hline 30 & POSIBLE & 522 & 63 & CIVIL & 294 & 97 & PRIVADO & 208 \\
\hline 31 & ANTERIOR & 509 & 64 & VERDE & 291 & 98 & FINO & 205 \\
\hline 32 & BAIXO & 484 & 65 & ESPECIAL & 291 & 99 & ENTEIRO & 204 \\
\hline 33 & POBRE & 479 & 66 & HISTÓRICO & 291 & 100 & CENTRAL & 203 \\
\hline
\end{tabular}


Despois de observar os cen adxectivos máis frecuentes pódense facer as seguintes observacións:

- Os adxectivos que teñen moción xenérica son o $61,58 \%$. Os únicos que non responden ao modelo masculino -o / feminino - a son: bo, só e español (fem. + -a).

- Os adxectivos sintéticos poden ser positivos, comparativos ou superlativos. Na relación obsérvase que, ao igual que aparecen as formas positivas bo, grande e pequeno, entre as máis frecuentes tamén están a ese nivel as súas correspondentes comparativas: mellor, maior e menor.

- Importante é tamén o número de adxectivos que atopan na mesma lista outro(s) lema(s) co(s) que poden establecer distintos tipos de relación semántica: grande/pequeno; bo/malo; novo/vello; maior/menor; alto/baixo; branco/negro/verde; longo/curto; rural/ urbano; claro/escuro; antigo/moderno; distinto/igual; anterior/ posterior; pobre/rico; público/privado; actual/histórico; superior/ inferior; morto/vivo; industrial/agrario; semellante/diferente; difícil/doado; galego/español.

(c) Os cen verbos máis frecuentes:

\begin{tabular}{|c|c|c|c|c|c|c|c|c|}
\hline & & & & & & 67 & BAILAR & 681 \\
\hline 1 & SER & 39.901 & 34 & METER & 1291 & 68 & VENDER & 681 \\
\hline 2 & TER & 17.199 & 35 & CONTAR & 1176 & 69 & DURMIR & 672 \\
\hline 3 & IR & 13.109 & 36 & TRABALLAR : & 1144 & 70 & ESCRIBIR & 669 \\
\hline 4 & HABER & 12.057 & 37 & MORRER & 1113 & 71 & NACER & 664 \\
\hline 5 & ESTAR & 11.636 & 38 & TRAER & 1107 & 72 & MANTER & 661 \\
\hline 6 & DICIR & 11.047 & 39 & VIVIR & 1082 & 73 & MATAR & 657 \\
\hline 7 & FACER & 11.022 & 40 & EMPEZAR & 1052 & 74 & MARCHAR & 657 \\
\hline 8 & PODER & 7477 & 41 & ENTRAR & 1043 & 75 & RESULTAR & 651 \\
\hline 9 & DAR & 6683 & 42 & COÑECER & 972 & 76 & SUPOR & 638 \\
\hline 10 & VIR & 5250 & 43 & TRATAR & 927 & 77 & MANDAR & 633 \\
\hline 11 & SABER & 5137 & 44 & RIR & 927 & 78 & CONSIDERAR & 631 \\
\hline 12 & VER & 5123 & 45 & EXISTIR & 917 & 79 & PAGAR & 626 \\
\hline 13 & QUERER & 4201 & 46 & CRER & 914 & 80 & VALER & 624 \\
\hline 14 & LEVAR & 3633 & 47 & ACABAR & 907 & 81 & SUBIR & 617 \\
\hline 15 & PÓR & 3292 & 48 & TIRAR & 904 & 82 & PREGUNTAR & 615 \\
\hline 16 & PASAR & 3183 & 49 & ABRIR & 880 & 83 & LER & 603 \\
\hline 17 & CHEGAR & 3023 & 50 & TOMAR & 869 & 84 & COMEZAR & 600 \\
\hline 18 & CHAMAR & 2658 & 51 & CASAR & 869 & 85 & CORRER & 599 \\
\hline 19 & FALAR & 2592 & 52 & TOCAR & 854 & 86 & ACORDAR & 587 \\
\hline 20 & DEIXAR & 2502 & 53 & CAER & 840 & 87 & GUSTAR & 584 \\
\hline 21 & QUEDAR & 2355 & 54 & APARECER & 830 & 88 & UTILIZAR & 567 \\
\hline 22 & ANDAR & 2207 & 55 & SENTIR & 822 & 89 & PERMITIR & 560 \\
\hline 23 & DEBER & 2050 & 56 & PRESENTAR & 813 & 90 & OÍR & 556 \\
\hline 24 & BOTAR & 1879 & 57 & FORMAR & 802 & 91 & SERVIR & 554 \\
\hline 25 & SAIR & 1853 & 58 & CANTAR & 800 & 92 & RECOLLER & 548 \\
\hline 26 & MIRAR & 1844 & 59 & REMATAR & 797 & 93 & BAIXAR & 542 \\
\hline 27 & PARECER & 1752 & 60 & PERDER & 796 & 94 & ESCOITAR & 499 \\
\hline 28 & COMER & 1662 & 61 & PEDIR & 764 & 95 & REFERIR & 499 \\
\hline 29 & VOLVER & 1542 & 62 & BUSCAR & 762 & 96 & BEBER & 498 \\
\hline 30 & COLLER & 1455 & 63 & ENTENDER & 762 & 97 & SENTAR & 486 \\
\hline 31 & SEGUIR & 1447 & 64 & SACAR & 729 & 98 & EMPREGAR & 471 \\
\hline 32 & PENSAR & 1420 & 65 & PRODUCIR & 708 & 99 & COMPRAR & 464 \\
\hline 33 & ATOPAR & 1304 & 66 & CUMPRIR & 685 & 100 & LEMBRAR & 457 \\
\hline
\end{tabular}


Unha vez examinada a lista de frecuencia pódense tirar as seguintes observacións:

- O verbo copulativo ser ocupa a primeira posición. A pouca distancia sitúase o verbo estar.

- Nas primeiras posicións están aqueles verbos que teñen, entre as súas posibles funcións, a de poder desempeñar o papel de verbo auxiliar en perifrases: ser, ter, ir, haber, estar, poder, dar, vir, querer, levar, chegar, deixar, andar, deber, botar, volver, seguir, empezar comezar, acabar. Nas ocorrencias do verbo ser inflúe ademais a voz pasiva.

- Moitos dos verbos da listaxe manteñen entre si relacións semánticas de oposición, de complementariedade, etc.: ir/vir; sair/entrar; vender/comprar; levar/traer; quedar/marchar; nacer/vivir/morrer; coller/deixar; subir/baixar; empezar comezar/rematar acabar; buscar/atopar; meter/pór/sacar; preguntar/dicir; etc.

(d) Os cen adverbios ${ }^{6}$ máis frecuentes:

\begin{tabular}{|c|c|c|c|c|c|c|c|c|}
\hline & & & & & & 67 & MAÑÁ & 181 \\
\hline 1 & NON & 29809 & 34 & ALÁ & 660 & 68 & NAMAIS & 177 \\
\hline 2 & MÁIS & 10431 & 35 & FÓRA & 615 & 69 & ESPECIALMENTE & 169 \\
\hline 3 & $\mathbf{X A}$ & 6998 & 36 & SOAMENTE & 602 & 70 & PERFECTAMENTE & 164 \\
\hline 4 & MOITO & 6702 & 37 & ARRIBA & 590 & 71 & ABSOLUTAMENTE & 163 \\
\hline 5 & TAMÉN & 5310 & 38 & MAL & 554 & 72 & SIMPLEMENTE & 160 \\
\hline 6 & BEN & 3941 & 39 & TAMPOUCO & 540 & 73 & CEDO & 159 \\
\hline 7 & ASÍ & 3551 & 40 & ALó & 527 & 74 & EVIDENTEMENTE & 156 \\
\hline 8 & AQUÍ & 3435 & 41 & ADEMAIS & 488 & 75 & NATURALMENTE & 152 \\
\hline 9 & DESPOIS & 3403 & 42 & ABAIXO & 488 & 76 & ENRIBA & 141 \\
\hline 10 & AGORA & 3312 & 43 & CANDO & 459 & 77 & SEICA & 136 \\
\hline 11 & ONDE & 3213 & 44 & TANTO & 457 & 78 & PRACTICAMENTE & 136 \\
\hline 12 & ALí & 2929 & 45 & LONXE & 440 & 79 & DISQUE & 131 \\
\hline 13 & SI & 2844 & 46 & ADIANTE & 437 & 80 & CAL & 131 \\
\hline 14 & SEMPRE & 2231 & 47 & ALGO & 411 & 81 & UNICAMENTE & 129 \\
\hline 15 & AÍ & 2158 & 48 & IGUAL & 386 & 82 & FINALMENTE & 127 \\
\hline 16 & AÍNDA & 1888 & 49 & BASTANTE & 349 & 83 & SEGURAMENTE & 124 \\
\hline 17 & só & 1837 & 50 & PRECISA + & 331 & 84 & FUNDAMENTAL+ & 124 \\
\hline 18 & сомо & 1613 & 51 & INCLUSO & 323 & 85 & XERALMENTE & 123 \\
\hline 19 & HOXE & 1557 & 52 & DIANTE & 321 & 86 & DEMASIADO & 117 \\
\hline 20 & ENTONCES & 1472 & 53 & SEQUERA & 304 & 87 & TALVEZ & 113 \\
\hline 21 & TAN & 1369 & 54 & PRIMEIRO & 278 & 88 & PROBABLEMENTE & 112 \\
\hline 22 & NUNCA & 1246 & 55 & ATA & 277 & 89 & XAMAIS & 106 \\
\hline 23 & CASE & 1243 & 56 & QUIZAIS & 266 & 90 & CERTAMENTE & 105 \\
\hline 24 & LOGO & 1161 & 57 & ATRÁS & 245 & 91 & PRONTO, & 104 \\
\hline 25 & ANTES & 1090 & 58 & REALMENTE & 242 & 92 & VELAQUí & 103 \\
\hline 26 & MESMO & 1072 & 59 & TARDE & 237 & 93 & EXACTAMENTE & 103 \\
\hline 27 & MENOS & 1046 & 60 & EFECTIVA+ & 234 & 94 & CLARAMENTE & 101 \\
\hline 28 & DENTRO & 1008 & 61 & BAIXO & 223 & 95 & VELAí & 97 \\
\hline 29 & INDA & 876 & 62 & TOTAL+ & 208 & 96 & PRINCIPALMENTE & 96 \\
\hline 30 & ENTÓN & 771 & 63 & AXIÑA & 207 & 97 & EXCLUSIVAMENTE & 95 \\
\hline 31 & DAQUELA & 714 & 64 & NORMAL + & 194 & 98 & ABONDO & 91 \\
\hline 32 & MELLOR & 681 & 65 & DIRECTA+ & 182 & 99 & MEDIO & 91 \\
\hline 33 & POUCO & 668 & 66 & ONTE & 181 & 100 & XUSTAMENTE & 90 \\
\hline
\end{tabular}

6. Na lista dos cen adverbios a aparición do símbolo (+) indica que a palabra remata en-mente. Esta solución veu motivada por razóns de espazo. 
Dos adverbios da lista pódense facer algunhas observacións:

- O adverbio máis frecuente é non. As súas ocorrencias supoñen un $23,27 \%$ sobre os cen adverbios máis frecuentes, e o $21,89 \%$ sobre o total do corpus.

- Contrasta fortemente a alta porcentaxe de aparición do adverbio de negación non (29.809) en relación ao adverbio afirmativo si (2.844). Si e non poden actuar como adverbios substitutivos dun enunciado completo: Vés canda min? -Si (ou -Non). Con todo, mentres que se utiliza o adverbio non para indicar o carácter negativo dun predicado (o neno non come ben) ou de calquera dos elementos (unha vida non fácil), non se utiliza si para indicar o carácter afirmativo.

- O segundo adverbio da lista que destaca sobre o resto polas ocorrencias no corpus é o de cantidade máis. Ao seu alto índice de aparición contribúe sen dúbida o feito de ser o procedemento habitual de formación do grao comparativo de superioridade.

- Dentro dos adverbios con frecuencia superior a 1.000, o grupo máis numeroso é o formado polos adverbios de tempo: $x a$, despois, agora, sempre, aínda, hoxe, entonces, nunca, logo, antes.

- Dentro dos adverbios de lugar os predominantes son os que pertencen á serie rematada en -í: aquí, alí e aí, nesta orde. Das series en -á (acá, alá), en -ó (acó, aló), só se rexistran entre os cen primeiros lemas as formas correspondentes á $3^{a}$ persoa: alá, aló, pero non as que indican un maior grao de proximidade: acá, acó.

- Dos cen lemas máis frecuentes 26 corresponden a adverbios rematados en -mente. O primeiro en aparecer é soamente.

- Se eliminamos os adverbios que rematan en -mente entrarían na lista os seguintes lemas: endexamais, peor, nada, tras, cerca, dabondo, embaixo, denantes, canto, detrás, acolá, quizabes, cecais, seguro, acaso, xusto, total, acó, alomenos, preto, recén, decote, amais, debaixo, encima, lexos?. 


\subsubsection{Algúns campos léxicos}

Un corpus deste tipo permite tamén o estudo de campos léxicos. Ao falar dos substantivos despuntaron xa os relacionados co tempo cronolóxico, co ser humano e a familia, co espazo e o medio físico. Vexamos, por exemplo, o léxico que xorde, con máis de 100 ocorrencias, ao traballar os seguintes campos: os animais e os alimentos.

- Os animais: vaca, peixe, besta, can, burro, animal, cabalo, lobo, gando, paxaro, ovella, gato, ave, raposo, porco, boi, galo, galiña, egua, gaivota, becerro, corvo, sardiña, cabra, pito. Neste apartado habería que ter en conta as variantes dialectais de etimoloxía distinta (golpe, cuxo, xato, etc.) con frecuencias inferiores e sumalas para coñecer a realidade.

- Os alimentos: auga, viño, pan, peixe, leite, carne, millo, uva, ovo, pataca, [froito], comida, café, aceite, gran, augardente, azucre, castaña, sal, caldo, trigo, fariña, sardiña, pera, mazá. Neste campo tamén sería conveniente incluír algúns dos elementos do campo anterior (ave, porco, galo, galiña ou becerro).

Unha vez extraídos os datos, depurados e ordenados despois de engadir as variantes dialectais con étimos distintos, poderase establecer a maior ou menor frecuencia de uso. Unha lista con esa información serviría de base para a elaboración, por exemplo, de exercicios de aprendizaxe de léxico segundo campos semánticos.

\section{CONCLUSIÓN}

A través desta breve exposición quixemos dar a coñecer o Galego fundamental. Dicionario de frecuencias, sen deixar de lado o corpus-base e a información que del se pode extraer. Cando afrontamos o traballo de investigación o obxectivo que se perseguía era, en suma, contribuír ao mellor coñecemento da vitalidade do léxico da lingua galega, así como poder establecer un punto de partida sólido sobre o que basear a elaboración de material didáctico nos distintos niveis educativos, a extracción de datos útiles para o desenvolvemento de ferramentas de enxeñaría lingüística e de tecnoloxías da fala, etc. Se o conseguimos, aínda que só fose por encetar novos camiños, dariamos por bo o presente labor. 



\title{
O CORPUS DE REFERENCIA DO GALEGO ACTUAL (CORGA): PRESENTE E FUTURO
}

\author{
Eva $M^{a}$ Domínguez Noya \\ Centro Ramón Piñeiro para a Investigación en Humanidades
}

As posibilidades de recuperación de información nun corpus dado increméntanse notablemente en consonancia co seu grao de codificación. Canto máis estruturado e codificado estea este máis información extraemos das buscas. Pénsese que se os textos están marcados exhaustivamente sempre podemos decidir, como usuarios, se nos interesa toda a información resultante da busca executada ou se pola contra nos limitamos a estudar as diferentes ocorrencias da busca obxecto de estudo. Se o texto non presenta marcas de ningún tipo ou estas son mínimas teremos que cinguirnos a buscas moi simples e a información que desexamos ou non a podemos obter ou precisaremos dar moitas voltas para conseguila. Por exemplo, se os textos que integran un corpus non teñen asignada unha área temática que os caracterice será tarefa ardua delimitar os ámbitos nos que unha palabra ou expresión se emprega.

Como saben todos os que nalgún momento consultaron o Corpus de Referencia do Galego Actual (CORGA), este é un corpus documental que en novembro de 2006 consta duns 13 millóns de formas, integrado por distintos tipos de textos -xornais, semanarios, revistas, ensaios e textos de ficción (novela, relato curto e teatro)-, que abrangue temporalmente dende o ano 1975 ata a actualidade e que están codificados no estándar XML (eXtensible Markup Language). E aquí, cando falamos de codificación, referímonos principalmente á información bibliográfica e á estruturación do documento. Exemplificando cun texto xornalístico, o XML permítenos considerar un xornal como un único documento que está organizado en noticias, as cales, á súa vez, conteñen obrigatoriamente un corpo e opcionalmente un titular, resumo e/ou pé de foto. A maiores, cada un destes elementos está constituído por parágrafos (texto comprendido entre dous puntos e á parte) e estes son segmentados en oracións (secuencia textual separada do resto do texto por un punto, punto e coma, dous pun- 
tos, etc.). Esta disposición detallada habilita a posibilidade de realizar consultas sobre a totalidade do documento (noticia) ou sobre unha unidade estrutural concreta (titular, resumo, pé de foto ou corpo). A codificación inclúe ademais a marcación de fragmentos que aparecen nunha lingua distinta do galego -así evitamos indexar eses fragmentos e impedimos que engorden os datos totais do corpus no referente a número de palabras e tamén que se poidan realizar buscas sobre eles-, os poemas, as entrevistas, as táboas, as fórmulas, etc.

Sobre este conxunto de formas gráficas é posible facer buscas de palabras ou expresións en xeral, por tipos de texto, épocas, áreas temáticas ou calquera combinación dos parámetros anteriores. Proximamente contamos con poñer na rede unha nova versión do CORGA que, ademais de chegar aos case 20.000.000 de formas, engade un novo sistema de consulta da nómina de autores e obras que permite buscar que obras ou autores están no corpus, saber que número de palabras totais e documentos corresponde á busca realizada ou que cantidade de palabras contén o CORGA nunha certa área temática, período de tempo, etc.

Por exemplo, se buscamos unha forma como "abreconcertos" nos xornais que teñan como área temática principal economía e política, nos resultados da consulta, cando se nos ofrece o número de oracións e documentos atopados de todo o corpus, podemos visualizar o número de palabras e documentos que cumpren as condicións esixidas na consulta inicial.

Somos conscientes, sen embargo, de que para facer buscas máis avanzadas é imprescindible que os textos do CORGA estean lematizados e etiquetados, e levamos xa algúns anos traballando nesta dirección, e aquí, cando falamos de etiquetación, debemos aclarar que entendemos esta como o proceso mediante o cal a cada unidade léxica se lle asigna un lema e unha etiqueta. En concreto, no Centro Ramón Piñeiro para a Investigación en Humanidades desenvólvese paralelamente á construción do CORGA un proxecto denominado Etiquetador e lematizador do galego actual destinado precisamente a lematizar e etiquetar os textos de CORGA, ao que internamente coñecemos como XIADA, e sobre o que imos centrar este traballo tal como nos solicitaron os organizadores deste volume.

Á hora de abordar a construción dun analizador e etiquetador cómpre atender as seguintes frontes:

(1) Determinación dun sistema de etiquetas.

(2) Deseño da estrutura do lexicón e construción deste.

(3) O preprocesador.

(4) O etiquetador. 


\section{DETERMINACIÓN DUN SISTEMA DE ETIOQUETAS}

Se queremos asignarlle ás formas de CORGA unha etiqueta, primeiro deberemos decidir que etiquetas imos empregar, que clases morfolóxicas imos distinguir e que atributos as van caracterizar, e para iso é imprescindible delimitar un etiquetario ou tagset.

O etiquetario para o galego foi desenvolvido no marco do proxecto Construción, etiquetación e lematización do Corpus de Referencia do Galego Actual como unha ferramenta para a análise computacional e a anotación automática dos textos do CORGA. Para a elaboración desta etiquetaxe seguíronse as recomendacións de EAGLES (Leech / Wilson 1996) e os textos básicos da lingüística galega. Así, o sistema de etiquetación de XIADA presenta unha estrutura xerárquica na que no primeiro nivel se identifica a categoría morfolóxica e nun segundo os atributos gramaticais pertinentes que constitúen o conxunto básico de atributos para cada categoría. Esta división en dous niveis percíbese claramente no formato: a letra que identifica a clase de palabra á que pertence o elemento vai en maiúscula e o valor dos atributos represéntase con minúsculas.

$\mathrm{Na}$ construción do tagset primamos a descrición morfolóxica e reducimos a información sintáctica á caracterización de determinadas categorías cuxos elementos integrantes poden funcionar como determinantes ou non determinantes. Delimitamos, en primeiro lugar, as clases de palabras existentes e a continuación establecemos os atributos gramaticais pertinentes que permitisen o recoñecemento morfolóxico de calquera palabra: 


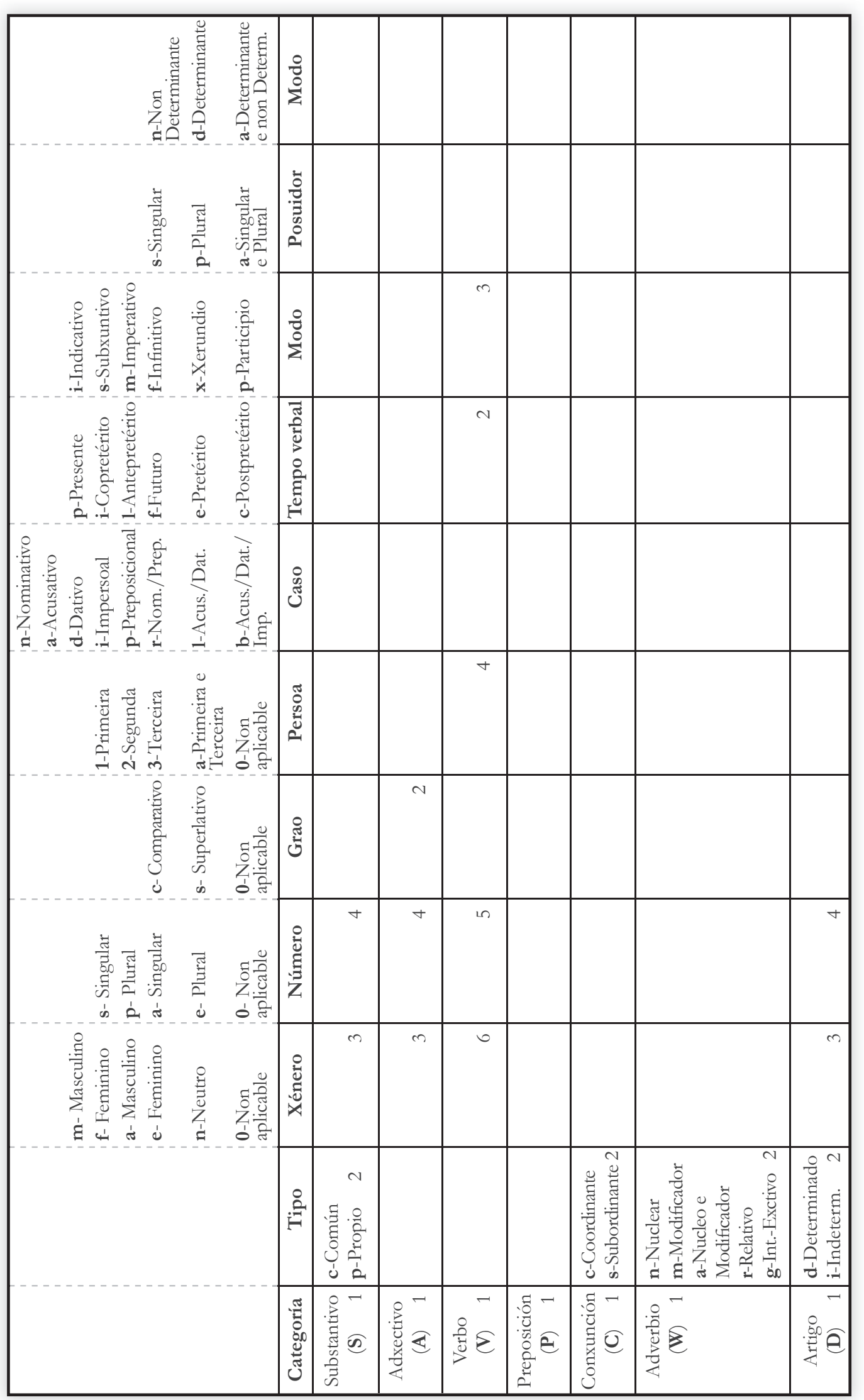




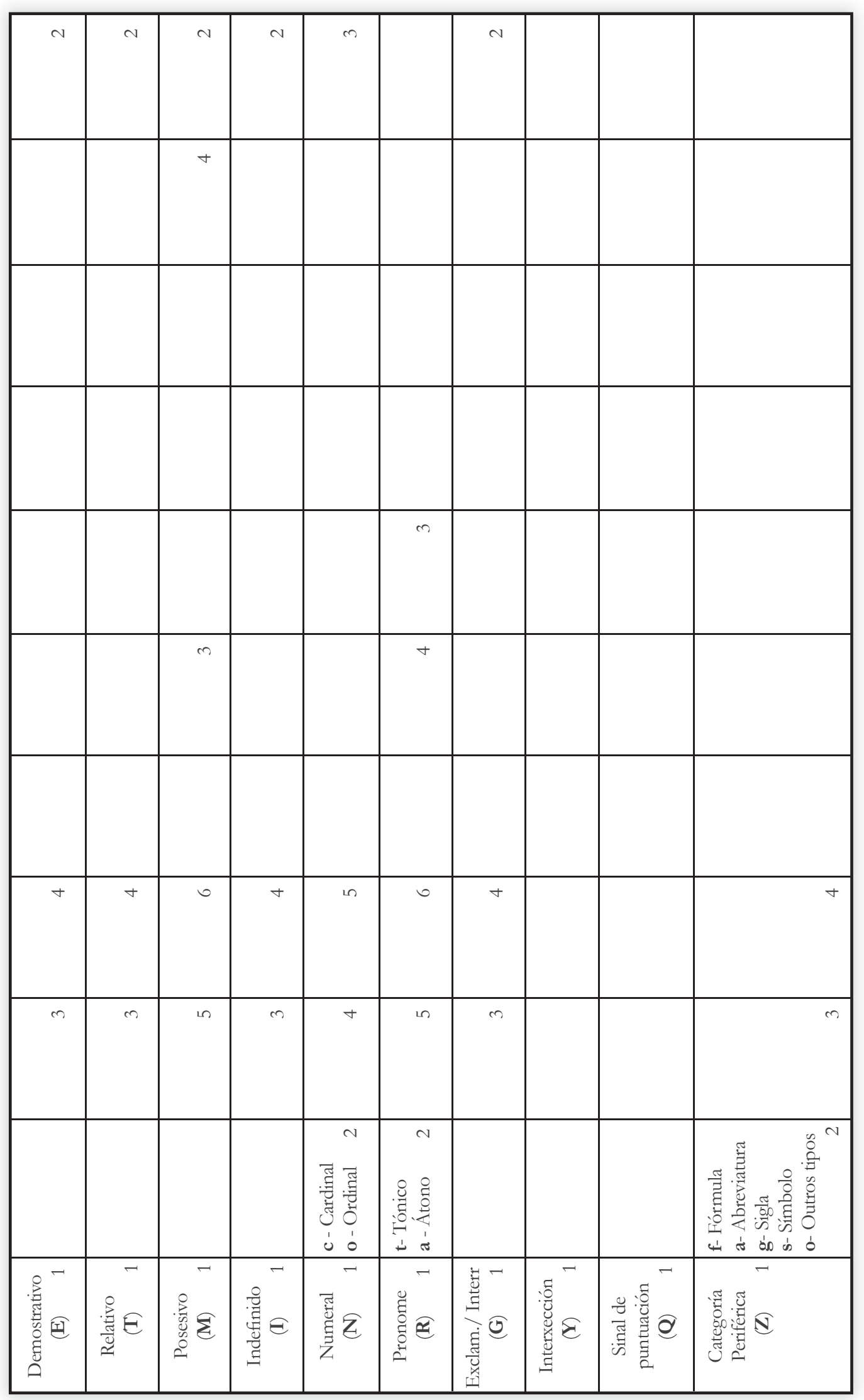


Como se pode observar no tagset de XIADA que acabamos de reproducir (dispoñible en http://corpus.cirp.es/xiada), na primeira columna recóllense as categorías gramaticais e as letras coas cales as denominamos:

- Adverbio

- Adxectivo

A

- Artigo

$\mathrm{D}$

- Conxunción

C

- Demostrativo

E

- Exclamativo-Interrogativo G

- Indefinido

- Interxección

- Locución

L

- Numeral

- Posesivo

$M$

- Preposición

$\mathrm{P}$

- Pronome

- Relativo

- Sinal de Puntuación

- Substantivo

- Verbo

- Categoría Periférica

Nas seguintes columnas recóllense os atributos e os valores destes e, por último, nas filas incorpórase un número que indica a posición que o atributo, se é pertinente, ocupa dentro da etiqueta final.

A distribución dos atributos dentro de cada categoría é simétrica, de tal xeito que todos os elementos pertencentes a unha categoría dada posúen o mesmo número de atributos e os seus valores ocupan a mesma posición dentro da cadea resultante.

Hai, sen embargo, etiquetas nas que en relación co grao de especificación ao que queiramos chegar, ou ben porque a atribución dun valor inequívoco sexa imposible, podemos neutralizar o valor dalgún ou de varios atributos. Por exemplo, nun texto de prensa, atopámonos coa expresión perigos e incertezas existentes, onde non sabemos se o adxectivo concorda co substantivo masculino perigos, co feminino incertezas ou cos dous. Nestes casos é necesario manter a ambigüidade, polo que a palabra existentes se etiqueta como "Adxectivo grao non aplica masculino ou feminino plural” (A0ap). En XIADA marcamos esta ambigüidade co 
valor "a", que representará o xénero, número, persoa, posuidor ou valor dependendo da clase de palabra e da posición que ocupe na cadea de etiquetaxe.

Por outra banda, non todos os elementos pertencentes a unha mesma categoría morfolóxica responden positivamente aos atributos que a caracterizan. Así, na categoría verbal, o atributo xénero só é un trazo pertinente para a caracterización do participio. Para o resto de elementos do paradigma verbal a aplicación do atributo xénero non é pertinente. Por este motivo creamos un valor "0" co significado de "Non aplica".

Consideráronse como atributos primordiais os seguintes: tipo, subtipo, xénero, número, grao, persoa, caso, tempo verbal, modo, posuidor e valor. Combinando as clases gramaticais delimitadas e os atributos que as caracterizan, o noso sistema de etiquetación presenta un total de 409 etiquetas posibles.

Poderiamos explicar detalladamente a escolla dos valores de cada un destes atributos e como afectan á clase implicada pero o espazo de que dispoñemos non é moito e cremos que outras fases do proxecto resultan tan interesantes ou máis.

\section{DESEÑO DA ESTRUTURA DO LEXICÓN E CONSTRUCIÓN DESTE}

Normalmente os etiquetadores necesitan un lexicón onde almacenar a información de etiqueta e lema que lle corresponde a cada palabra. Ademais, aínda que os etiquetadores intentan adiviñar a etiqueta dunha forma que non estea presente no lexicón, canto maior sexa este, máis posibilidades de acerto hai.

Á hora de afrontar a elaboración dun recurso léxico e gramatical calquera destinado a un uso computacional é fundamental que o deseño deste cubra todas as necesidades actuais e, ao tempo, contemple as futuras.

Por unha banda, dado que a introdución e xestión dos datos debe ser cómoda, consideramos que calquera entrada do lexicón debe ser caracterizada morfoloxicamente desagregándoa en lema ${ }^{1}$, raíz ${ }^{2}$, subetiqueta ${ }^{3}$ e

1. Xeralmente correspóndese coa entrada dun dicionario. Por exemplo "neno".

2. Segmento inicial do lema sen desinencia se esta é recorrente. Por exemplo "nen".

3. Definición e caracterización morfolóxica da forma obxecto de análise sempre e cando estea completa e non a enviemos a ningún grupo derivacional. 
grupo de derivación $n^{4}$. Esta estrutura esixiu un estudo formal detallado dos integrantes de cada unha das clases gramaticais variables para agrupalos en modelos e deste xeito construír a gramática formal que nos permitise analizar e tamén xerar as formas flexionadas e conxugadas do galego moderno. Evitamos así, por exemplo, introducir manualmente as 65 formas pertencentes a calquera verbo e incluímos só as raíces, asignándolles a subetiqueta Verbo e enviándoos ao grupo de derivación que corresponda.

Por outra banda, o noso lexicón non só é unha base de datos na que constan os lemas coas respectivas indicacións morfolóxicas de clase gramatical, xénero, número, tempo, modo, etc., senón que tamén nos proporciona máis información sobre cada unha das entradas, información non só morfolóxica senón tamén lingüística.

Así, en primeiro lugar, o recoñecemento e caracterización das formas existentes nos textos reais contemporáneos galegos esixe que o lexicón estea integrado por lemas normativos e non normativos. Se a construción do lexicón se realizase con suxeición á actual normativa ortográfica e morfolóxica da lingua galega, a etiquetación e análise dos textos dun corpus representativo do galego actual como o CORGA non sería de utilidade para os investigadores posto que quedarían numerosas formas sen recoñecer automaticamente. Pareceunos interesante, en consecuencia, rexistrar na estrutura do lexicón o parámetro da normatividade ou non dos lemas e das formas. Por que, ademais, das formas? Basicamente, porque a normatividade do lema non implica a normatividade da forma. Por exemplo, fosemos, forma totalmente correcta ata xullo de 2003 en que entrou en vigor a actual normativa, remítese ao lema "ser" ou "ir", normativos, sen embargo, per se, é un token que responde negativamente á normativa actual.

A economía lingüística e a reiteración impóñennos a obriga de aplicar este parámetro a algunhas desinencias xa que caracterizan formas dialectais recorrentes nos textos. É bastante frecuente, por poñer un exemplo, para a $3^{\mathrm{a}}$ persoa do pretérito de indicativo dos verbos da $2^{\mathrm{a}}$ conxugación, a aparición de formas coa vogal temática "i" no sitio da normativa "e". Coa

Conxuntos de desinencias para as que se proporcionan uns valores. Por exemplo o grupo G1 consta de:

o: masculino singular

a: feminino singular

os: masculino plural

as: feminino plural

Deste xeito, para todos os substantivos e adxectivos que rematan en "-o", fan o feminino en "-a" e forman o plural engadindo “-s", tipo "neno", introducimos só o lema e a raíz correspondente, sen necesidade de ter que incluír completas as formas masculina e feminina cos respectivos plurais. 
estrutura que empregamos en XIADA a opción máis rendible é a de caracterizar "-iu" no seu valor de "ei3s0" ${ }^{5}$ como non normativa no grupo V2 segundo o que se conxugan todos os verbos regulares da $2^{a}$ conxugación.

Outro exemplo: os grupos G2 e G3 foron creados para flexionar os substantivos e adxectivos cuxo masculino singular remataba en -án e facían o feminino en -á e -ana respectivamente. A aplicación da normativa oficial reduce considerablemente o número de elementos que van ao grupo G3 incrementando o $\mathrm{G} 2^{6}$. Ao igual que sucedía cos lemas, debemos manter as características dos dous grupos para que o analizador recoñeza e caracterice as formas existentes nos textos anteriores á normativa oficial actual pero tamén temos que introducir as modificacións precisas para que as novas formas normativas sexan recoñecidas e analizadas. A opción máis intelixente parece ser a caracterización das desinencias -ana no G2 e -á no G3, cos respectivos plurais, como non normativas.

É interesante e sobre todo útil, desde o punto de vista lingüístico, diferenciar na estrutura do lexicón módulos segundo o tipo de léxico que conteñan e con que poidan ser combinados. Para iso dispuxemos no deseño da estrutura, e obviamente implementamos na construción do lexicón, dun campo máis no que se caracteriza o lema como pertencente ao léxico común ou ao técnico-científico, especificando neste último o ámbito no que se clasifica: administración, economía, medicina, etc.

Relacionado co punto anterior está a inclusión na estrutura do lexicón dun indicador que nos marca a procedencia de cada un dos lemas. Nos textos actuais preséntanse formas que non aparecen nos dicionariosvocabularios preceptivos da lingua galega -DRAG (1997) e o máis recente VOLG (2004)-, ben porque son termos técnicos para os que se acaba de propoñer unha denominación, ben porque se documentan cun uso categorial distinto. Non obstante, a súa introdución no lexicón é imprescindible para o recoñecemento e caracterización dos textos. Coa indicación da

5. Pretérito de Indicativo, $3^{\circ}$ persoa do singular, non aplica xénero.

6. Na normativa oficial anterior seguían o esquema -án / -ana (as raíces e lemas destas formas remitíanse en XIADA ao grupo de derivación G3), mentres que na actual se acomodan ao esquema -án / -á (debemos remitir as raíces e lemas ao grupo de derivación G2) as formas seguintes: afgán, alazán, alemán, barregán, bosquimán, capitán, catalán, ermitán, escribán, gardián, musulmán, rufián, sancristán, sultán e truán. O G2 consta das seguintes terminacións, que caracterizamos formalmente como: án: masculino singular áns: masculino plural á: feminino singular ás: feminino plural ana: feminino singular $\left(^{*}\right)$ anas: feminino plural $\left({ }^{*}\right)$ 
fonte achegamos datos concretos sobre a localización do lema e a fiabilidade da forma.

Finalmente, polo que respecta aos parámetros de tipo de léxico e fonte, consideraremos que o VOLG (2004), como texto sancionador máis recente e posuidor dun número de entradas aceptable, definirá os lemas pertencentes ao léxico común ou principal do lexicón de XIADA.

Para que a estrutura do lexicón sexa permeable e máis accesible á identificación e asignación dos distintos modelos formais que o integran, inserimos no deseño da estrutura un representante de grupo que serve de modelo para cada un dos grupos existentes en XIADA. Así, o representante de grupo do grupo derivacional G1 é neno.

Recapitulando, o lexicón de XIADA, ademais de conter a información morfolóxica que permite a identificación e caracterización morfolóxica plena de calquera palabra galega, responde aos parámetros seguintes: indicación sobre a normativa oficial, ámbito léxico e procedencia da forma.

Unha vez deseñada a estrutura do lexicón, implementámolo coas entradas do VOLG (2004) e coas 70.000 formas máis frecuentes de CORGA, o que vén sendo algo máis de 51.000 lemas. Na seguinte táboa podemos ver o número de lemas e raíces das categorías principais do lemario de Xiada:

\begin{tabular}{|l|c|c|c|}
\hline $\begin{array}{c}\text { CLASE } \\
\text { GRAMATICAL }\end{array}$ & LEMAS & RAÍCES & FORMAS \\
\hline Adverbio & 1.906 & 1.916 & 1.916 \\
\hline Adxectivo & 13.574 & 13.625 & 44.899 \\
\hline Substantivo & 28.806 & 28.943 & 62.074 \\
\hline Verbo & 6.690 & 9.113 & 367.220 \\
\hline
\end{tabular}

Un lexicón non ten por que estar destinado unicamente a etiquetar e lematizar un texto. Se é o suficientemente detallado e complexo pode servir de punto de partida para outras utilidades como a construción dun corrector ortográfico ou un conxugador de verbos.

\section{PREPROCESADOR}

Lingüisticamente, unha vez elaborados os modelos formais que van acoller as raíces e grupos de derivación e implementado o lexicón computacional, estamos en disposición de etiquetar automaticamente calquera texto galego contemporáneo. Trátase "simplemente" de executar o 
programa que o equipo informático do proxecto está desenvolvendo para traballar con arquivos codificados en XML (cfr. http://corpus.cirp.es/xiada), porque ese é o formato no que están os textos de CORGA.

Un preprocesador, en xeral, delimita as distintas unidades léxicas que hai nun texto. Pode parecer sinxelo pero non é tarefa banal segmentar formas verbais con pronomes enclíticos ou separar os formantes dunha contracción. Seguimos traballando para que cometa menos erros pero é inevitable que nalgúns casos de ambigüidades falle de vez en cando. É un traballo informático pero no que o equipo lingüístico participa coa construción de regras que gobernan o comportamento do preprocesador. Por exemplo, cando estabamos comprobando o funcionamento das formas verbais con clíticos, hai xa bastante tempo, atopámonos con que para o token "semana" propoñía unha etiqueta na que o segmentaba en "se" (raíz verbal), "ma" (contracción dos pronomes me máis a) e o último constituínte formábao o alomorfo do pronome acusativo de terceira persoa na. Vimos entón a necesidade de construír unha regra que impedise análises coma esta, polo que creamos unha na que indicabamos que na mesma secuencia non pode haber dous clíticos de acusativo e, ademais, no, na, nos, nas, pronome átono acusativo de terceira persoa, só será unha etiqueta posible se vai enclítico a unha forma verbal rematada en ditongo e en ningún outro caso.

O preprocesador, no noso caso, ademais, despois de delimitar as unidades, asígnalle a cada unha os lemas e etiquetas posibles.

Así, a saída do documento preprocesado proporcionaranos o texto analizado contendo para cada palabra gráfica ou token todas as posibles análises morfolóxicas.

Por exemplo, o preprocesador ante un token como "polos", no que non só hai ambigüidade morfolóxica senón que tamén a segmentación da forma en constituíntes varía, proporciona as seguintes análises:

(1) Unha alternativa na que o clasifica como substantivo común masculino plural cuxo lema é polo:

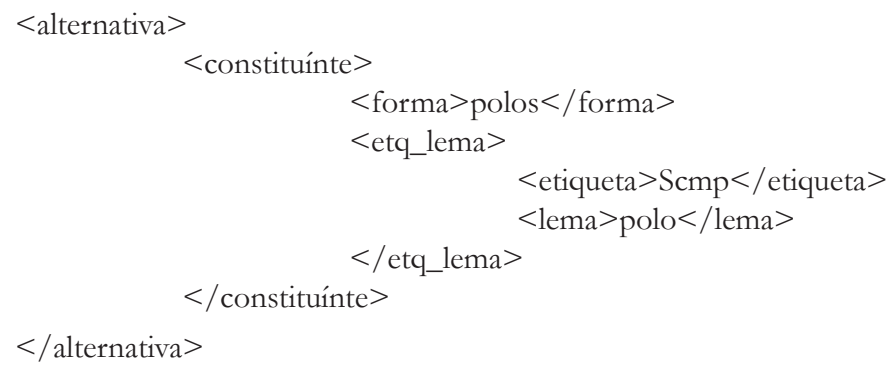


(2) Noutra alternativa segméntao en dous constituíntes definindo o primeiro como a preposición por e o segundo como o artigo determinado masculino plural cuxo lema é o:

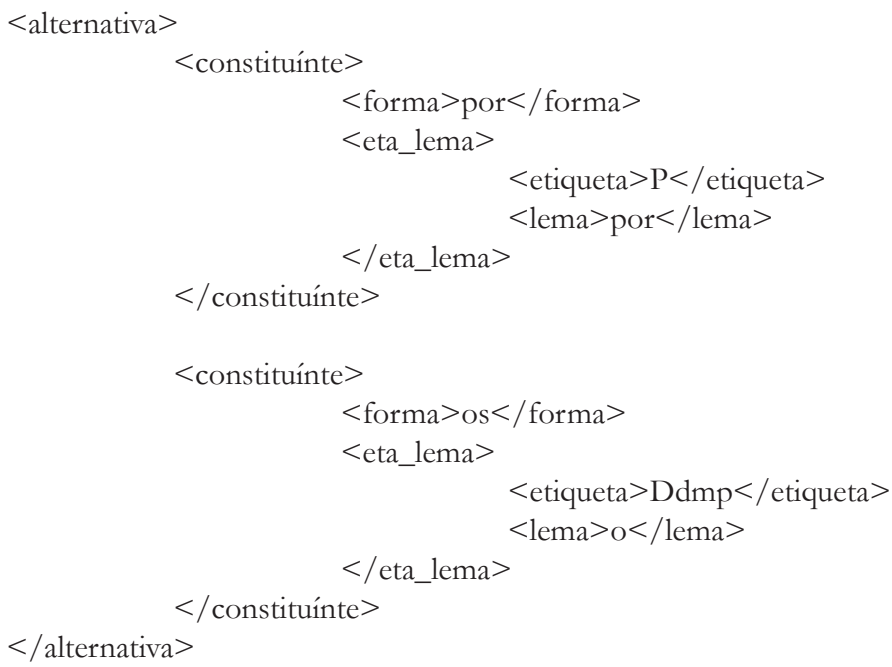

(3) Na última alternativa segméntao en pos, $2^{\mathrm{a}}$ persoa do presente de indicativo dos verbos pór e poñer e mais o pronome átono de acusativo de terceira persoa masculino plural cuxo lema é o:

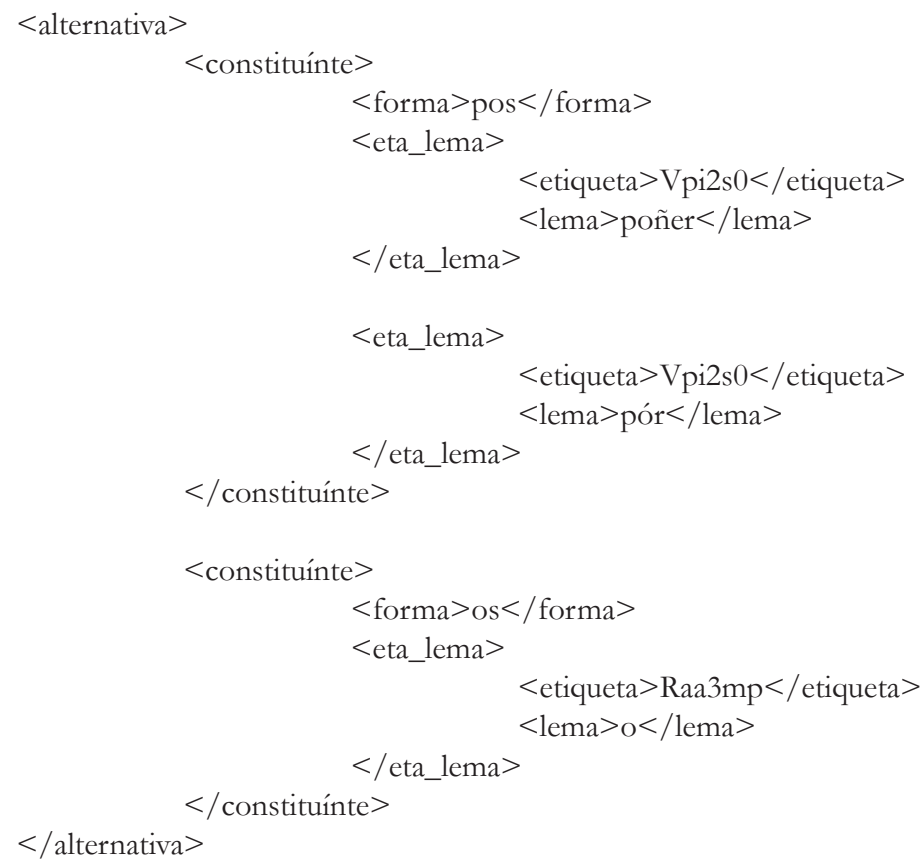


Neste punto teriamos o documento coas etiquetas e lemas posibles. Dado que para poder facer as buscas nel necesitamos ter a etiqueta correcta da palabra e non todas as posibles, temos dúas opcións:

(1) Determinar manualmente cal é a correcta.

(2) Que un sistema automático decida cal é a correcta.

É aquí onde entra en xogo o punto seguinte, o etiquetador, que "simplemente" escolle a etiqueta e o lema correctos para cada unha das palabras.

\section{ETIOQUETADOR}

Antes de que se poida empregar un etiquetador automático estatístico, como é o caso, é necesario adestralo desambiguando manualmente un subconxunto de textos. Obviamente canto maior sexa o volume de textos que se desambigüen á man máis probabilidades hai de que acerte o etiquetador. O noso obxectivo, ademais, é que, fronte ao 95/96\% de acerto que presentan os etiquetadores existentes para o inglés -para o galego non hai estatísticas-, o noso etiquetador alcance un acerto do $99 \%$.

A utilización do preprocesador e do etiquetador automático vainos resultar útil para atender dúas frontes: por unha banda, revisar as análises obtidas automaticamente e, pola outra, tomar nota das formas descoñecidas para mellorar o seu funcionamento e incrementar o lexicón computacional.

Esperamos que proximamente sexa posible consultar tanto o lematizador e o etiquetador en rede como un subcorpus de CORGA lematizado e etiquetado. 



\title{
O AROUIVO DO GALEGO ORAL E O SEU APRÖVEITAMENTO LEXICOGRÁFICO
}

\author{
Francisco Fernández Rei / Carme Hermida Gulias
}

Instituto da Lingua Galega (USC)

Desde a súa creación en 1971, unha das principais liñas de investigación do Instituto da Lingua Galega (ILG) da Universidade de Santiago de Compostela foi a recolleita sistemática do galego oral tanto na Galicia administrativa como nas comarcas estremeiras do Eo-Navia (Asturias), O Bierzo (León) e As Portelas (Zamora), onde o galego tamén é lingua propia.

Ese material usouse para redactar monografías léxicas ou gramaticais ou para ser cartografado, como ben se pode ver nos volumes editados do Atlas Lingüístico Galego (ALGa), nos de morfoloxía e fonética dos anos 90 e nos volumes léxicos que desde o 2003 se comezaron e publicar e que en conxunto constituirán unha excelente achega para redactores de dicionarios e doutras obras lexicográficas.

Cando aínda estaba inédito, moito deste material oral utilizouse nas diversas propostas de codificación morfolóxica e léxica realizadas desde mediados dos anos 70 polo ILG, en solitario ou en colaboración con outras entidades, particularmente coa Real Academia Galega. Os paradigmas verbais da normativa vixente ou os nomes dos días da semana e dos meses do ano, por poñer só uns exemplos, son como son en boa parte mercé ó revelado e posterior interpretación de fotos do galego oral realizadas por investigadores do ILG.

Ademais, especialmente desde 1974, diversos membros do Instituto rexistraron ininterrompidamente etnotextos na práctica totalidade do dominio lingüístico galego, á vez que dirixiron traballos académicos de moi diverso tipo onde o material estudado eran mostras orais con unha ou con máis dunha persoa informante. Estas gravacións, algunhas con máis de 30 anos de vida, xunto con moitas outras fornecidas por xente que non é do ILG, pero que as depositou alí para que estean a disposición dos investigadores, constitúen o esencial do Arquivo do Galego Oral 
$(A G O)$. Na xénese deste Arquivo está o labor pioneiro de Constantino García, fundador do ILG, e tamén o de Antón Santamarina, que nos animaron a moitos, cando eramos estudantes universitarios, a recoller e traballar o galego oral.

Nesta presentación trataremos en primeiro lugar o estado xeral do $A G O$ e dos traballos e publicacións que del derivaron; e a seguir daremos unha mostra do aproveitamento léxico dese material.

\section{ESTADO DO AROUUIVO DO GALEGO ORAL}

O AGO contaba a finais do 2006 con máis de 2.000 horas de gravacións, con voces duns 7.000 informantes rexistradas na maioría dos 315 concellos de Galicia e tamén en boa parte dos 38 concellos de fala galega de Asturias, León e Zamora. Tamén conta con mostras dos concellos cacereños do Val de Xálima (ou Val do Ellas) onde se emprega un "falar também essencialmente galego", en palabras de Lindley Cintra (1959: 536).

Dun xeito moi aproximado podemos dicir que un terzo de todo o material do $A G O$, se cadra algo máis, está transcrito e clasificado por temas; outro terzo está simplemente oído e clasificado tematicamente, mentres que do terzo restante só hai rexistro das gravacións, e aínda non de todas.

O AGO confórmano actualmente cinco subarquivos: tres de etnotextos, clasificados cronoloxicamente, un de música popular e outro de textos nun rexistro formal. Imos describir con máis detalle o estado dos subarquivos de etnotextos, por seren os de maior interese para o aproveitamento lexicográfico ${ }^{1}$.

\subsection{Subarquivo de etnotextos do Atlas Lingüístico Galego}

Existe un subarquivo de etnotextos do $A L G a$, gravados entre novembro de 1974 e maio de 1977 polos investigadores de campo do atlas (Rosario Álvarez Blanco, Francisco Fernández Rei e Manuel González González). O ideal era facer algunha gravación en cada un dos 167 puntos enquisados, e de xeito especial nas áreas onde se usaban marcadores sociolingüísticos como a gheada e o seseo para ter unha mostra oral deses fenómenos; pero en bastantes sitios non foi posible obter unha mostra oral por seren reticentes os informantes a deixárense gravar.

Hai que ter en conta que daquela -mediados dos 70- o desprestixio social do galego a nivel popular era practicamente total e a situación so-

1. Unha descrición detallada de cada un dos subarquivos do AGO pode verse en Fernández Rei (2004a). 
ciopolítica (derradeiras boqueadas do franquismo e pánico no poder a que a revolución portuguesa do 25 de abril do 74 se propagase a España) non invitaba a xente a deixarse gravar por descoñecidos, aínda que fose para falar do entroido ou da mata do porco. Outra cousa era falar e contestar preguntas, sobre todo léxicas, sen que quedase constancia gravada. E aínda así, rexistráronse algún etnotextos excelentes temática e lingüisticamente.

A este subarquivo pertencen tamén gravacións complementarias dos puntos enquisados para o ALGa, realizadas entre 1979 e 1983 en lugares da Terra Chá, do tramo medio do Lérez e do tramo final do río Miño, todas elas de grande interese etnográfico e socioeconómico, á parte do lingüístico. A maior parte destas gravacións realizáronas a comezos dos 80 Rosario Álvarez e Francisco Fernández Rei.

Os textos do subarquivo do ALGa están transcritos, informatizados e concordados. Nestes momentos, as dúas persoas que presentamos este traballo estamos ultimando a preparación da edición deses textos, á vez que estamos a redactar un glosario con todo o material léxico.

As gravacións do $A L G a$ son as mostras orais máis antigas que se conservan no ILG. Con todo, hai algúns etnotextos anteriores, mesmo de cando non existía oficialmente o Instituto, uns editados na revista Verba e outros inéditos, pero deles non se conserva a gravación.

Todos estes textos constitúen un documento único para coñecer o estado do galego oral nunha fase en que non existía ningún tipo de oficialización e ningunha variedade estandarizada e socialmente implantada que puidese influír no galego popular. A xente falaba, e facíao como lle transmitiran o idioma, coa súa enxebre fonética, enxebre gramática e enxebre fraseoloxía, e tamén con moi diversas interferencias do castelán, sobre todo léxicas.

\subsection{Subarquivo de etnotextos dos anos 80}

Son unhas 350-400 horas rexistradas entre 1979 e 1991, sobre todo no período 1979-1985. A finais dos 70 e comezos dos 80, antes de que se implantase e xeneralizase a lingua galega como materia obrigatoria no ensino non universitario, o Instituto de Ciencias da Educación da USC encargoulle ó ILG a organización e impartición de cursos de galego para o profesorado de Ensino Xeral Básico. No nivel superior, ademais de traballar con textos literarios e da prensa diaria, acordouse facelo con mostras orais de diferentes áreas lingüísticas tiradas dos etnotextos do ALGa, en papel e en soporte oral. Logo a persoa que impartía o curso facía que mes- 
tras e mestres traballasen en grupos con material recolleito na comarca onde exercían, co fin de analizar a fala da zona.

Moitas desas gravacións depositáronse no ILG, igual que se depositaron moitas outras feitas entre 1980 e 1985 por alumnado de diferentes titulacións de Filoloxía que cursaban a materia de Lingüística Románica I impartida por Francisco Fernández Rei, que no seu día supervisou cada unha das transcricións. Eran uns anos en que só existía unha subsección de Filoloxía Galega-Portuguesa e non había unha licenciatura de Galego, e os que ían ser profesores de galego no ensino medio só tiñan unha materia de Lingua Galega no $3^{\circ}$ ano (logo implantaríase en $4^{\circ}$ e $5^{\circ}$ ), polo que se considerou que era un excelente exercicio que o alumnado fixese algún tipo de análise do galego oral popular para estudar tanto as características do galego como as diversas interferencias.

Xeralmente os textos dos anos 80 son gravacións dunha soa persoa informante, moitas veces da primeira xeración, con gran riqueza temática. Só unha pequena parte deste material está informatizado.

\subsection{Subarquivo de etnotextos dos anos 90}

Nos anos 90 constituíuse no ILG un amplo subarquivo de textos orais, mercé á concesión de dous proxectos: un do Ministerio de Educación e Ciencia para a creación dun Arquivo Dialectal da Lingua Galega no período 1992-95; e outro da Xunta de Galicia para implementar ese Arquivo no período 1996-98. A este material engadiuse outro depositado por xente allea ó ILG, particularmente o recollido por estudantes das Facultades de Filoloxía e Ciencias da Comunicación da USC para traballos sobre galego oral.

En 1992 os membros do proxecto inicial realizamos unha planificación do traballo de campo co moi utópico obxectivo de obtermos en tres anos unha mostra da maioría das 3.768 parroquias galegas, á parte de mostras do galego das comarcas estremeiras. Tamén queriamos, na medida do posible, ter rexistros de varias xeracións dun mesmo lugar.

En xaneiro do 1999 o subarquivo de etnotextos dos 90 contiña unhas 1.200 horas de gravacións, coas voces de 4.434 informantes de diversas xeracións, pertencentes a 271 concellos de Galicia e das comarcas estremeiras de fala galega, a 1.312 parroquias e a máis de 2.000 lugares. A provincia de Pontevedra é a mellor representada, cun varrido parroquia por parroquia en diversas comarcas, sobre todo centro-meridionais.

Parte deste material oral dos anos 90 empregouse especialmente para redactar memorias de licenciatura sobre unha parroquia (Hí-Cangas, Loureiro-Cotobade, Viceso-Brion) ou sobre un concello (Forcarei, Frades, 
San Cosme de Barreiros...) ou para redactar traballos de cursos de doutoramento en que se analizaban aspectos da oralidade das parroquias dun concello (O Grove, A Estrada, Padrón, Vilardevós). Son investigacións xeralmente cunha ampla escolma de textos orais transcritos, sempre con mostras de diversas xeracións acompañados dun glosario ou dun estudo fonético e/ou morfolóxico ou das interferencias.

Aproximadamente un terzo deste inxente material está transcrito e/ ou comprobado acusticamente para fichalo tematicamente, pero só unha parte das transcricións se informatizaron. E este subarquivo dos 90, aínda que de xeito intermitente, seguiu aumentando con etnotextos rexistrados nos comezos deste milenio.

\subsection{Subarquivo de música popular}

Está depositada no ILG unha copia de todo o material sonoro dos sete volumes do Cancioneiro Popular Galego de Dorothé Schubarth e Antón Santamarina, que entre 1984 e 1995 editou a Fundación Pedro Barrié de la Maza.

Son unhas 350 horas de gravación recollidas en 82 concellos de Galicia e en 13 concellos da franxa estremeira de Asturias, León e Zamora. A maior parte do material recolleuno Schubarth entre 1978 e 1983; pero hai material de diversa procedencia, como cantigas rexistradas por Santamarina en 1968 na Fonsagrada ou cantigas e romances de 1975 procedentes de gravacións do ALGa.

Schubarth transcribiu as melodías, mentres que Santamarina fixou a transcrición lingüística dos textos, reflectindo do xeito máis fiel posible a oralidade, con seseos e gheadas, con rotacismos e contraccións e coas interferencias do castelán (e dos galeguismos en cantigas neste idioma), o que fai que este Cancioneiro sexa un inestimable documento lingüístico, á parte do innegable valor de recolleita musical.

\subsection{Subarquivo de textos en rexistro formal}

Empezouse a formar no ano 1996 e conta actualmente con máis de 100 horas de gravacións. Trátase especialmente de conferencias sobre temas relacionados coa realidade sociocultural de Galicia, así como presentacións de libros e diversos actos, moitos deles realizados en Santiago de Compostela.

Unha parte destas gravacións, as que corresponden ás conferencias e mesas redondas do I Congreso Internacional: A Lingua Galega, Historia e Actualidade organizado polo ILG en setembro do 1996, fornecéunola o Ar- 
quivo Sonoro de Galicia do Consello da Cultura Galega; pero a maior parte do material gravámolo os autores deste traballo. Ademais, este subarquivo contén algunas gravacións de emisoras locais de radio que emiten en galego, dalgunhas televisións locais e algúns programas da TVG de grande interese lingüístico e etnográfico.

\subsection{Arquivo Oral das Linguas Minorizadas}

O AGO compleméntase cun Arquivo Oral das Linguas Minorizadas (AOLM), cunhas 150 horas de gravacións en diferentes idiomas (entre eles o galego) sobre aspectos da problemática da estandarización e da vitalidade etnolingüística das linguas e variedades minorizadas, especialmente do ámbito románico, así como textos en diversos rexistros destas linguas, particularmente do sardo.

A maioría son gravacións feitas por Francisco Fernández Rei desde 1996 en moi diferentes territorios da Romania europea, entre as que cómpre salientar conferencias sobre a situación do aragonés, mirandés, occitano, esloveno do Friul, friulano e sardo. Algunhas son entrevistas ou ben lecturas de textos escritos en linguas románicas minorizadas a cargo de falantes nativos.

Tamén hai gravacións tiradas da radio, especialmente de finais da década de 1980 relativas á problemática do galego de Asturias, xunto con CDs e casetes comercializados con etnotextos ou ben con música de raíz e doutro tipo de diferentes linguas románicas minorizadas. Este arquivo foise creando coa finalidade de xuntar material sonoro de apoio para as clases das materias Variedades Románicas Minorizadas e Sociolingüística Románica de titulacións de Filoloxía da USC.

\subsection{Resultados e publicacións do AGO}

Ata o momento tirouse relativamente pouco froito do inxente material do $A G O$, tendo en conta o moito traballo investido na recolleita por todo o dominio galego e, sobre todo, o moito traballo de calada e fatigosa transcrición.

Na década de 1990 fíxose unha ampla escolma de textos transcritos de diversas áreas dos tres bloques lingüísticos do galego, que se usou para diversos traballos académicos e que Antón Santamarina introduciu no Tesouro Informatizado da Lingua Galega (TILG), de igual xeito que incorporou diversas coleccións de etnotextos dos 90, polo que léxico do $A G O$ navega entre o inmenso caudal léxico literario e científico do TILG. 
Con material dos anos 90 realizáronse diversos traballos de investigación dirixidos por membros do proxecto do $A G O$, tal como máis arriba se dixo, á vez que profesorado do ILG utiliza etnotextos (éditos e inéditos) e gravacións en rexistro formal para as prácticas de galego oral nas clases con alumnado de titulacións de Filoloxía e de Ciencias da Comunicación; e algúns artigos publicados recentemente derivan, en maior ou menor medida, de material de etnotextos do AGO, como son Fernández Rei / Hermida Gulías / Tato Plaza (2004) e Fernández Rei (2004b, 2005, 2007).

Ademais, o material usouse para moi diversas finalidades: hai anos algunha actriz do Centro Dramático Galego acudía ó ILG para escoitar gravacións de falas occidentais con gheada e seseo para preparar a súa personaxe, de igual xeito que alumnado universitario acode a consultar material para traballos academicamente dirixidos ben lingüísticos, ben etnográficos, como foi neste caso un sobre as costureiras presentado no 2006 na Facultade de Ciencias da Comunicación.

A publicación máis salientable (e ata o momento a de maior utilidade e difusión) feita con material dos tres subarquivos de etnotextos do AGO foi o audio-libro A nosa fala. Bloques e áreas lingüísticas do galego, edición preparada polos autores deste traballo para o Arquivo Sonoro de Galicia do Consello da Cultura Galega (Fernández Rei / Hermida Gulías 1996), do que, ademais de distribuírse en librarías, se fixo unha edición que se lles regalou ás 700 persoas que participaron no congreso dos 25 anos do ILG en setembro do 1996. Na $2^{\text {a }}$ edición, de 2003, as tres casetes con tres horas de gravación foron substituídas por tres CDs; e no 2004 fíxose unha versión electrónica do libro e dos textos orais para consultar libremente en Internet (www.consellodacultura.org/arquivos/asg/anosafala.php), que no 2005 tivo máis de 15.000 consultas.

Nesa obra figuran textos de diversas épocas e diversas xeracións nos que se pode apreciar a variedade dialectal do galego e á vez se dá unha mostra de como somos e de como estamos no mundo nós outros, os galegos. Como dicía Filgueira Valverde no limiar dese audio-libro, os textos “teñen non só interese como documento lingüístico senón tamén como testemuños da vida mesma: tráxicos unhas veces, festivos outras, intranscendentes outras, pero sempre engaiolantes" (Fernández Rei / Hermida Gulías 1996: 7).

$\mathrm{Na}$ transcrición das gravacións de A nosa fala procurouse un compromiso entre a claridade necesaria para que un non lingüista poida ler os textos e o rigor preciso para fornecerlle a un lingüista a maior información fonética e fonolóxica posible. Tomouse como base a normativa vixente da lingua galega que elaboraron o ILG e a RAG, pero cunha serie 
de particularidades relativas á abertura das vogais de grao medio, á representación da gheada e do seseo e outros fenómenos relevantes do galego oral (Fernández Rei / Hermida Gulías 1996: 11-15).

\section{APROVEITAMENTO LÉXICO DO AROQUIVO DO GALEGO ORAL}

Para exemplificar o valor e a importancia dos datos contidos no AGO centrarémonos nunha comparación entre a información proporcionada polos textos do subarquivo do $A L G a$, unha vez concordados e lematizados e definido o seu léxico, coa proporcionada polos dicionarios máis comúns. Aínda que esta información se podería confrontar coa incluída en calquera obra lexicográfica actual, consideramos que, para que houbera unha certa nivelación, o termo da comparación só podería ser un dicionario que tivese vocación xeneralizadora, que pretendese recoller a totalidade do léxico do idioma con tódalas acepcións que este poida ter.

$\mathrm{Na}$ actualidade existen editadas catro obras destas características: o Dicionário da língua galega de Isaac Alonso Estravís, publicado pola editorial Sotelo Blanco (Estravís 1995); o Gran Diccionario Xerais da Lingua, coordinado por Xosé María Carballeira Anllo e publicado por Edicións Xerais de Galicia (GDXL 2000); o Dicionario de galego coordinado por Xesús Domínguez Dono, Anxo Xosé Rajó Pazó e Beatriz Varangas González, da editorial Ir Indo (Ir Indo 2004); e o Gran Dicionario Século 21 da lingua galega, dirixido por Xosé Antonio Pena para as editoriais Galaxia e $\mathrm{Cu}-$ mio (GDS XXI 2005).

Dos catro diccionarios, Ir Indo (2004) e GDS XXI (2005) non serven na súa totalidade para o noso propósito, porque se trata de obras que seleccionan só léxico estándar e prescinden do usado noutros modelos de lingua. O Estravís (1995), aínda sendo acumulativo, está realizado cunha concepción lingüística do que é o galego que non concorda coa que rexe este traballo, polo que tampouco resulta lóxico o seu emprego como obra de referencia primaria. Daquela, a comparación realizarase co GDXL, aínda que no relativo á información gramatical, ás acepcións e á fraseoloxía tamén teremos en conta as outras tres obras nomeadas.

A confrontación da información obtida dos textos do ALGa coa proporcionada polo GDXL farémola sobre catro puntos básicos do artigo lexicográfico: a entrada ou lema, a información gramatical, o significado e a fraseoloxía. Nos exemplos usamos exclusivamente os termos léxicos contidos nunha letra de tamaño medio, o R, e prescindimos de palabras gramaticais como determinantes, preposicións e conxuncións. 


\subsection{Entradas}

En función da súa relación co léxico considerado estándar, fundamentalmente o contido no VOLG, as palabras dos textos que non se inclúen no GDXL poden ser variantes ou derivadas dunha forma común ou ben lemas totalmente novos.

Entre as variantes fonéticas ou morfolóxicas dunha forma común podemos salientar voces como rastear (<rastrear), rosucitar (<resucitar), rótolo (<rótulo), robanda (<rebanda), remudo (<remuda), resido (<resío), a relentín (<a ralenti), rair ${ }^{2}$ (<raer).

Ausentes do GDXL tamén están formas derivadas doutras comúns, que si teñen o seu espazo nesta obra de referencia. Mostras de voces derivadas son a rebolazos, roulada ou rumbante:

rebolazos, a loc. adv. De rebolos, dando voltas: "por a escaleir' abaixo, un pouco de pê, outro pouc' a rebolazos" (Calvos-Calvos de Randín ${ }^{3}$ ).

roulada s.f. Grupo cunhas características semellantes: "andaban todos na roulada" (AmeneiroTeo).

rumbante $a d x$. Rumboso, espléndido, pomposo: "non vin fèsta tan rumbante coma ela" (Campobecerros-Castrelo do $\mathrm{Val})$.

Tamén anotamos palabras que non gardan relación con ningún dos outros lemas do dicionario e, xa que logo, son totalmente novas:

raspita s.f. Aparello do cerco, máis pequeno có do cerco de xareta, que se emprega na pesca de baixura en lugares onde hai pouca auga: “á raspita tômanse moitos muxes” (Fefiñáns-Cambados).

rebisca s.f. Cebo para coller peixes que se atopa no propio río debaixo das pedras: "pa pesca-lo peixe, hai a rebisca" (Friol).

rechinchudo,-a $a d x$. Repoludo, gordo e ancho por demais: "i-èra gorda i rechinchuda, de gorda xa regañou” (Calvos-Calvos de Randín).

relento,-a $a d x$. Pousado, lento: “o corazón sièmpre, relento, triste” (Mourelle-A Pastoriza).

represar v.t. Reprender, recriminar: "quedaron amigos, el non represou a mullèr" (A Gudiña).

No caso de requeté (s.m. Barco de motor pequeno que anda ó cerco da xareta: "hai os requetês, que son os barcos más pequenos") (FefiñánsCambados), dubidamos se consideralo entrada totalmente nova ou ben

2. Neste caso a forma de referencia, raer, non contén o significado que nos textos ten raír 'tensar o aparello para metelo a bordo': "raír chamámoñe nôs metélo a bòrdo, o aparello" (Cambados).

3. Indicamos o lugar e o concello da gravación, agás cando ambos teñan a mesma denominación. 
unha extensión de significado, que se produciría no caso de o nome do barco estar motivado pola designación do grupo armado de combatentes de ideoloxía carlista que loitou en diferentes enfrontamentos armados dos séculos XIX e XX.

\subsection{Usos gramaticais}

Entre a nova información gramatical proporcionada polos etnotextos do ALGa pódense salientar os usos adverbiais dos adxectivos rápido, raro e regular ${ }^{4}$ e o uso intransitivo de receitar ${ }^{5}$ e retirar:

rápido, -a $a d v$. 2. Rapidamente, con celeridade: “queríamos que viñèr’ ò cura rápido” (Redondela). raro,-a $a d v$. 4. Raramente, poucas veces: "vèllos, sarráns, muxes ás veses, è alkhún sentolo raro, tod' o qu' encontra" (Fefiñáns-Cambados).

regular $a d v$. 2. Regular, nin ben nin mal: "veño... regular, nada más què regular" (CabreirosXermade).

receitar v.i. Facer receitas: "O mêdico cansado de receitar, non sabía nin que ll' había facer" (Friamonde-A Estrada).

retirar vi. 2. Retirar, coller dun fondo: "había anos que a xente retiraba máis, outros anos retiraba menos" (Lubián). 3. Parar nunha actividade: "ás sète ast’as dèz ou ás once; logo retiramos" (Caselas-O Rosal).

\subsection{Significados}

No campo do significado é onde a contribución dos textos é máis salientable. Entre as novas acepcións detectadas aparecen as seguintes:

rabuñar v.i. 1. Tocar un obxecto facendo un ruído semellante ó que se realiza ó espetar con forza as uñas: "xa don Climente taba rabuñando á pòrta" (Friamonde-A Estrada).

raiar v.i. 2. Limitar: "están aí raiando aí con Portugal” (Lubián) ${ }^{6}$.

rebumbio s.f. Importancia, dimensión: "vend' o rebumbio qu' a cousa iba tomando" (FriamondeA Estrada).

recaer v.i. Pasar por, acudir a: "Vaite mirar a ver se recaeron por alí teus irmáns" (Ameneiro- Teo).

recibir v.i. Comungar, recibir a hostia: "fasían unha vía cruses è resibía, había comunión” (Fefiñáns-Cambados).

recío s.m. Rosada, orballo: “o orballo dese, vamos, qu' hai pola mañá, tá ese recío qu’ hai asî”

4. No Estravís (1995) e no Ir Indo (2004) aparece o uso adverbial de rápido e regular.

5. No Estravís (1995) está recollido este uso.

6. No GDS XXI (2005) recóllese este significado. 
(Lubián) ${ }^{7}$.

reliquia s.f. Obxecto relacionado co culto a un santo ou lugar sagrado que se garda en lembranza dunha visita: "unhos santos feitos de masa, pòs levaban como reliquias de San Andrês" (Chímparra-Cedeira).

remendar v.t. 2. fig. Curar unha ferida sen moitos coñecementos: 'alí un remendeiro, qu' asta n' o levaron ó mêdico; remendoull’ a cabeza” (Cabreiros-Xermade).

remendeiro s.m. Curandeiro, menciñeiro: "levárono non sei pa donde, alí un remendeiro, qu' asta n’ o levaron ó mêdico" (Cabreiros-Xermade).

renunciar v.i. Renegar, abxurar: "que renunciaban da relighión catôlica” (Cerdedo) ${ }^{8}$.

repoñerse v.p. Compoñerse, amañarse: "è quedou así todo arruinado. Pèro aora foise repoñendo un algo" (Cabreiros-Xermade).

resaca s.f. Mar picado e o seu efecto ó escachar no peirao ou nas pedras do mar ou ó chocaren dúas ondas: “àndisía è mas a resaca chamámosñe nôs ó mar, cand’ ê mar picado" (FefiñánsCambados).

responso $s . m$. Recitado similar ás oracións nos oficios de defuntos: "o responso ese que tiña entre San Antonio" (Lubián) $)^{9}$.

retraer v.t. Reter, gardar na memoria: "a miña memoria vai pasada, non retraio nada xa" (Salcidos-A Guarda).

revisar v.t. Inspeccionar: "anque non foran cazadores è revisáronllelas" (O Buriz-Guitiriz).

revolver v.t. 2. Toldar: "que revòlv' o río todo" (Caldelas-Tui).

rodeo s.m. Roda, círculo, curro: "truxèmos o inghinièro aquí. Fixèmosll' un rodeo" (San Xián-O Rosal).

romeu s.m. 2. Barba de raposo, alga mariña: "pois nôs o romeu chamabámosñ' ònha planta, òn esterco" (Fefiñáns-Cambados).

rosario s.m. 3. p. ext. Conxunto de cousas iguais que se presentan enfiadas semellando ese obxecto de culto: "rosarios de castañas, cocíamos castañas sin pelare è lògo despois cunh' àgulla iè fío formaban un rosario" (O Buriz-Guitiriz) $)^{10}$.

ruín $a d x$. 2. Pobre: "o puèblo ê ruín; ê ruín pèro somos poucos veciños" (Sabuguido-Vilariño de Conso).

rula s.f. 1. Aparello eléctrico para poxar o peixe: "aparatiño èlêtrico que hai, que, chámanlle precisamente a rula" (Rinlo-Ribadeo). 2. Lonxa: "da rula non teño más nada que decir" (RinloRibadeo).

rumbar $v . i$. Ruxir, facer ruído: "os picos tocaron un no outro, è rumbaron” (Lindín-Mondoñedo).

Nalgúns casos non se trata propiamente de novas acepcións, senón de variacións que non quedan perfectamente recollidas no GDXL:

7. No Estravís (1995) e no GDS XXI (2005) inclúese esta acepción.

8. No Estravís (1995) inclúese este significado.

9. No Estravís (1995) recóllese este significado.

10. No Estravís (1995) documéntase esta acepción. 
rabioso,-a $a d x$. Moi picante: "xa hai algúns que pican, xa hai quen os mète mui grandes, que se faen rabiosos" (Caselas-O Rosal) [fronte a "que provoca unha sensación desagradable moi intensa"].

rapar v.t. Cortárlle-las crinas ás bestas bravas: "márcanas tódolos anos, è na i-anca, è rápanas" (Cerdedo) [fronte a "cortarlle a la ou o pelo a un animal”].

recría s.f. Alimentación e coidado dun animal comprado aínda cría: "ta comprando khaulas metálicas pa, pá recría de coello" (Caselas-O Rosal) [fronte 'acción e efecto de recriar'; recriar = "continuar criando un animal, proporcionándolle a alimentación adecuada, para o seu total desenvolvemento"] ${ }^{11}$.

rega s.f. 2. fig. Chuvia en tempo de sol continuado: "aquí o que faía falta, que viñèra unha règhiña, porqu' isti é un calor espantoso" (Fornelos-O Rosal) [fronte a "acción e efecto de regar" ou "acción e efecto de mollar ou mollarse" $]^{12}$.

\subsection{Fraseoloxía}

Tocante á fraseoloxía pódese salientar, entre outras, a ausencia no GDXL de dar resultado, nin de risas nin de veras, polo regular ${ }^{13}$ e retorcer o pescozo.

\subsection{Informacións varias}

Tres novos casos -moito máis complexos- inciden na importancia de continuar examinando os textos orais para o arrequentamento das obras lexicográficas. Trátase de raio, redondo e resultar.

No primeiro dos casos, o de raio, compróbase que faltan no GDXL, e tamén nos restantes dicionarios, tres usos diferentes e dúas expresións fixas:

raio s.m. 1. Lugar dotado con instrumental para someter un corpo a unha radiación: "tiña que pasar ó... ós raios, a face-la placa" (A Chan-Cotobade). 2. Seguido da preposición de e dun nome, pondera a este positiva ou negativamente: "aquil raio daquel armario empezou a rubir" (CalvosCalvos de Randín). 3. Precedido do interrogativo que e seguido dun verbo, intensifica o significado do verbo: “¿que raio quererá decir eso da Zocata?” (San Xoán de Tabagón-O Rosal). Malo raio + partir, expresión para maldicir: "malo raio part' ós rátor da condición dar formighas" (Abelán-Salvaterra). Coma raios, intensificador da rapidez ou velocidade dunha acción: "os señores albañiles, se axustan alghunha òbra andan listos coma raios non hai oficial que os colla" (Friamonde-A Estrada).

11. No Ir Indo (2004) recóllese totalmente esta acepción.

12. No Estravís (1995) inclúese unha acepción definida como 'popular' equivalente a "baño, molla, chúvia".

13. Esta locución aparece no GDS XXI (2005) como equivalente de "común ou regularmente" (s.v. regular). 
Tocante a redondo obsérvase a ausencia dunha das acepcións que ten como adxectivo e a falta do uso como adverbio e dunha locución adverbial ${ }^{14}$ :

redondo,-a $a d x$. 3. Que non é aguzado e ten forma de semicírculo: “porque tèn a popa, tèn' àsí redonda" (Cambados). // adv. 4. Totalmente, completamente: "nada, fallou redondo" (BonxeOuteiro de Rei). En redondo loc. adv. 1) ó redor: "ó mellor un quilómetro ou máis en redondo" (San Xoán de Tabagón-O Rosal); 2) en forma circular: "facendo coro, todo en redondo" (Deixebre-Oroso).

Verbo de resultar cómpre indicar que en ningún dos dicionarios analizados se fai mención da existencia do complexo resulta que, que se emprega no comezo ou continuación das narracións como fórmula focalizadora:

“resulta qu’ o óutor día estab’ àquí cun amigho” (A Chan-Cotobade).

O máis próximo que documentamos é a indicación que aparece na última acepción de resultar do GDS XXI (2005) sobre o uso impersoal co valor de "ocorrer algo de repente, de modo imprevisto".

Desde a década de 1980 avanzouse moito na elaboración de obras lexicográficas e os dicionarios actuais de uso xeral teñen un alto nivel de calidade ${ }^{15}$; porén, os exemplos que acabamos de presentar, que son unha pequena escolma, demostran que hai léxico, usos gramaticais, expresións fixas e significados que, mesmo sendo de uso xeral e común, aínda non chegaron ós diccionarios do galego moderno.

Xa que logo, a recompilación de léxico do galego oral como o sinalado, coas súas acepcións, preséntase como un labor necesario para o perfeccionamento de calquera estudo sobre o idioma, pero moi especialmente das obras lexicográficas vindeiras.

\section{REMATE}

O Arquivo do Galego Oral existe mercé á xenerosidade de milleiros de galegofalantes que doaron as súas voces e á xenerosidade de moi diversas persoas que percorreron o dominio lingüístico galego para facer gravacións in situ e que algunhas, ademais, realizaron o traballo, moitas veces ingrato, de transcribilas. 
O obxectivo xeral do proxecto Arquivo do Galego Oral do Instituto da Lengua Galega da USC é construír un corpus de interese multidisciplinar para estudar a situación da lingua oral, particularmente as variedades sociais e xeracionais, e á vez contribuír a un mellor coñecemento da sociedade galega a través de moi diversas mostras do patrimonio inmaterial. As metas fundamentais dese proxecto son:

(1) Inventariar e catalogar todo o material dos subarquivos que o conforman.

(2) Poñer en Internet coleccións de etnotextos agrupados tematicamente e atendendo á súa distribución en áreas lingüísticas.

(3) Redactar unha base de datos léxica do galego oral baseada, fundamentalmente, en etnotextos, que tamén se colocará en Internet.

(4) Actualizar e completar as coleccións de textos e outras gravacións do $A G O$.

(5) Poñer na rede o corpus a través dun motor de buscas axeitado ás peculiaridades da lingua oral.

Con este corpus pretendemos que se poidan redactar, entre outros traballos, vocabularios comarcais, léxicos de frecuencias ou estudos sobre a adquisición do estándar desde o punto de vista xeracional. Ademais, queremos fornecer material a lingüistas que traballen a gramática ou a pragmática do galego, pero tamén a outros investigadores alleos á lingüistica, particularmente etnógrafos, antropólogos, historiadores e sociólogos, dada a gran diversidade temática dos textos do AGO. Proba desta diversidade son os 18 grandes bloques temáticos (algúns con moi diferentes subtemas) con que clasificamos o material dos anos 90 .

Pretendemos, en fin, irlle devolvendo á sociedade galega, da maneira máis elaborada posible, un caudal oral que ela xenerosamente nos foi doando. 


\title{
A FRASEOLOXÍA COMO FONTE LEXICOGRÁFICA
}

\author{
Xesús Ferro Ruibal \\ Centro Ramón Piñeiro para a Investigación en Humanidades
}

Dende os inicios da lexicografía xa houbo repertorios fraseolóxicos autónomos. Aínda así, os dicionarios comúns sempre incluíron cantidades variables de fraseoloxismos que exemplificaban valores semánticos das palabras que definían. E, para moitos usuarios, os fraseoloxismos que adornaban os dicionarios foron a primeira experiencia de fraseoloxía definida. Ora ben, se entendémo-la lexicografía como repertorio de voces e dos valores semánticos desas voces, o acomodo nela dos fraseoloxismos presenta algúns problemas de lindeiros.

Non representan problema ningún para un lexicógrafo as palabras únicas que só aparecen en combinación fraseolóxica (jVaites, vaites!) ou en contextos pluriverbais (tralalalá en cantigas coma Teu pai non-o ten, / túa nai non cho dá; /¿de donde che vén? /-Do tralalalá). Pero xa teñen a súa dificultade aquelas palabras comúns que na combinación fraseolóxica collen un valor semántico específico desa combinación. Un caso moi simple é o da palabra beira. Defínese normalmente como "s.f. Orilla" (Rodríguez 1863) e dese substantivo nacen as locucións aa veira "junto ó pegado", andúvolle aas veiras "le anduvo al rededor ó cerca, etc." (Cuveiro 1876). Pero noutras locucións xa aparece unha metáfora: facer as beiras "rondar, dar vueltas al rededor de alguno o siguiéndole continuamente para conseguir de él alguna cosa: hacer el oso, hacer la rosca del gallo" (DRAG 1913-1928), facerlle as beiras a unha cousa "desearla con ansia y hacer indirectamente los medios para conseguirla" ou facerlle as beiras a unha rapaza "rondarla, cortejarla, galantearla, hacerle el amor" (Eladio Rodríguez 1958-1961). Como se ve, este novo valor non é valor da palabra senón do conxunto fraseolóxico. E nos fraseoloxismos idiomáticos o significado global xa non resulta da suma dos significados dos seus compoñentes senón que é un valor novo que unicamente se activa no uso conxunto e fraseolóxico das palabras que o forman. Isto impide establecer cal das palabras é a por- 
tadora da nova carga semántica, a cal dos elementos do conxunto se lle debe asigna-lo núcleo semántico do fraseoloxismo.

En consecuencia, o fraseoloxismo non vale sempre para exemplifica-los usos que o dicionario recolle para esa voz, porque non sempre é doado. E, aínda que os lexicógrafos utilizan certas convencións razoables para alfabetizaren esas unidades, o acomodo da fraseoloxía nun dicionario convencional non sempre é satisfactorio. Así que, pouco e pouco, a fraseografía vaise independizando da lexicografía e multiplícanse nas librerías os dicionarios fraseolóxicos, exclusivamente fraseolóxicos, que responden a un corpus diferente e tamén a pautas de dicionarización específicas.

Pero neste traballo eu non vou tratar de fraseografía nin de idiomaticidade. Vou facer algo moi simple que saben tódolos lexicógrafos: só vou lembrar algúns refráns que poñen á mostra valores semánticos, variantes ou mesmo palabras que non aparecen nos dicionarios; ou que manteñen vivas palabras enxebres que o contacto de linguas vai substituíndo polas simétricas coas de linguas poderosas. Isto é o que quero comentar: que a fraseoloxía, entendida en sentido amplo, aínda é unha despensa léxica; e que algúns paremiólogos fixeron tamén de lexicógrafos. Como ven, todo é cousa sabida.

Cando falo de dicionarios (galegos), limitareime ós dicionarios incluídos no Diccionario de diccionarios de Antón Santamarina (2003b), esa marabillosa ferramenta, insuficientemente loada pero masivamente usada, que nos permite consultar vinteseis obras lexicográficas de maneira instantánea, cómoda e comparativa. E cando falo de refraneiros, refírome a dous refraneiros de mediados do século XX, un felizmente xa público (Francisco Vázquez Saco 1962) e outro aínda inédito (Vicente Llópiz 1954a e 1954b), de dous homes que adoitaban preguntarlles ós seus informantes o significado daquelas palabras que a eles lles resultaban pouco transparentes. As definicións deles reprodúzoas entre comiñas e na maior parte dos casos anotarei a localización tal e como eles a anotan.

O material non é escaso e voume limitar nesta ocasión ás palabras que empezan polas letras comprendidas entre o A e o L.

\section{ALGÚNS VALORES SEMÁNTICOS OQUE NON VEXO NO DICIONARIO DE DICIONARIOS OU QUE SON MOI INFRECUENTES}

Raro é o cazador de fraseoloxismos que non se sorprende cunha palabra ou coa acepción dunha palabra que non lle é transparente. Raro 
é o que, nesa situación, non pregunta ó seu informante e non anota a información que dá transparencia ó refrán ou á locución e que converte ese fraseoloxismo en ocasión dunha nota lexicográfica. Un home así era o comandante Vicente Llópiz Méndez, que encheu o seu refraneiro de notas lexicográficas, máis ou menos canónicas, pero abundantísimas. Poñamos un caso: ó refrán Ben coñez Cristo as pousas dos seus amigos, engádelle o comentario: "Pousas': moradas, aposentos”, definición que non é exactamente a mesma que ofrecen Pintos (1865) (“Quinta, granja, lugar; pr. la casa murada") ou Valladares (1884) ("Quinta, ó casa de campo y recreo. Guimarans è linda pousa; / mais Jimonde, sin disputa, / e mais qu'entrambas ainda / Santa Crus de Ribadulla) ou Leiras (ca. 1906) ("descanso"), conceptos que repiten dun xeito ou doutro os posteriores. Para Llópiz é simplemente "casa", maiormente se o equivalente latino que ofrece é tecta (Iesus Christus amicorum co[g]nosci[t] tecta suorum). Isto quere dicir que moitas coleccións fraseolóxicas atesouran nas notas ós refráns ou locucións un certo caudal lexicográfico que ofrece acepcións pouco coñecidas de certas palabras, converténdose en cita valiosa para documentar un determinado valor semántico minoritario. Vexamos algúns exemplos.

abafado. Mal abafado "mal de origen venéreo e inconfesable". Non [b]ai mal abafado que por muller non veña (Llópiz 1954a: 535,439). Ata o DRAG (1913-1928) non aparece o valor de "El que tiene mal color, inficionado, emponzoñado. Se dice que una mano, un pié, ú otra parte del cuerpo esta abafada, cuando se halla inflamada por haber tocado en algún reptil ó insecto venenoso". Eladio Rodríguez (1958-1961) é o que matiza "Corrido, avergonzado, insultado", pero o significado de "venéreo" non o menciona ninguén.

abeirarse. Refregarse [unha vaca] coas outras cando está en celo e mesmo montar nelas. Cando a vaca anda maronda, toda se abeira coas outras (Llópiz 1954a: 1,137). Nos dicionarios aparece esta palabra como 1. "Guarecerse; resguardarse de la lluvia o nieve (Acevedo 1932); 2. "v. r. Acercarse, aproximarse, irse hacia la orilla” (Eladio Rodríguez 1958-1961), pero non co significado que ten no refrán.

adoar. "Pasar la palma de la mano suavemente". Ao que dá esmola Dios ca man o adoa (Llópiz 1954a: Dios, 674,15). Adoar aparece en numerosos dicionarios como 1. "Afilar instrumentos cortantes" (Sobreira), 2. "Llevar la piel la navaja, cortar bien" (Pintos 1865), 3. "Perfecionar, alisar, pulir, redondear los cortes toscamente hechos en la madera" (Valladares 1884), formas que repiten os posteriores. Pero o significado que parece ter nese refrán non figura nos dicionarios.

argabazo. Bólas de bosta pegadas ó pelo das coxas das vacas e das ovellas. A máis boa meleciña para tira-lo argabazo, auga, freganzo e xabón por enriba e por embaixo (Llópiz 1954a: 2,450). Para esta palabra os dicionarios só repiten unha vaga definición de Sobreira: "Cada uno de los fragmentos que hacen la suciedad algo gruesa”, pero o significado que ten no refrán é máis específico.

arolar. Xaxuar. Cando o médico arola, o crego chora. Llópiz comenta: "No desayuna el médico, cuando por gran sanidad en su distrito, gana poco. Y habiendo mucha salud, tampoco hay muchos entierros, rogativas y votos por las dolencias". T. Saavedra, Paradela de Abeleda, Porquera, ref. 1210 (Llópiz 1954a: 508,230). 
arolas. Xaxún. Pan en arolas con romeu en frol, volverante a cara a boa color. Llópiz explica que pan en arolas é "pan en ayunas" e localízao en Muras de Eume (Llópiz 1954a: 515,300). Nos dicionarios arola é cuncha de marisco e mesmo existe a fórmula ;Vaite á arola!, que "equivale a vete a paseo, déjame en paz, no me molestes" (Eladio Rodríguez 1958-1961) e que, como moito, pódenos lembra-la época na que estar mantido a ostras era "ter cara de fame".

arrazada. [Vaca] recastada de vaca do país cun boi de raza selecta. Vaquiña arrazada, filla de casa pra gasallala (Llópiz 1954a: 1,155). Nos dicionarios aparece arraz̧ar só co valor de "escampar, parar de chover".

asesego. Pausadamente, sosegadamente. Asesego gánase o ceo (var. Con paciencia gánase o ceo) (Llópiz 1954a: Culto religioso, 577,55). Este uso como adverbio non o recolle dicionario ningún.

axe. Ocasión propicia, para mercar ou vender, na feira do gando. O que deixa pasa-lo axe, non se teña por bo feirante (Llópiz 1954a: 2,15). Os dicionarios dan estes valores: 1. "Eixo" (Porto 1900-1908); 2. "Insulto, desprecio, bochorno, desaire, injuria" (Filgueira et al. 1926); 3. "interj. (Gro.) voz que se emplea para meter a las gallinas en el gallinero y al cerdo en la cuadra” (García González 1985).

baceira. Bazo. Cando ó corpo lle engorda a baceira, cousa boa non lle espera (Llópiz 1954a: 2,453). A definición que dan os dicionarios é a da enfermidade do bazo.

bórea. "Pláceme, felicitación". Parto suado, agarda as bóreas. Dr. A. Vila (Llópiz 1954a: 517,308). O DRAG (1913-1928) define bórea como "Vocablo que a continuación de la frase vaite â, significa: vete a paseo, vete al diablo, vete enhoramala. El vaite â bórea, úsase mucho en Santiago y su comarca. Var: BÓRIA en su tercera acep.", e boria como 1 "s. f. Holgorio, algazara, diversión". 2. "s. f. Bolsa en la que los cerrajeros llevan sus herramientas". Borear é aínda hoxe palabra moi viva en Ferrol co significado de "armar barullo". Non me parece posible que Llópiz, que viviu a adolescencia en Ferrol, fose marrar nesta definición.

bragada. Parte baixa do ventre, entre as pernas e a cara interna destas. A vaca farta, do seu rabo fai bragada (Llópiz 1954a: 1,132).

brexeiro. Crego canaveiro teno por brexeiro. Llópiz define canaveiro como "escuálido, magro" e brexeiro como “tunante” (Llópiz 1954a: Frailes, curas, 97). Brexeiro só aparece en Carré (1928-1931) como “adj. Lugar bajo, pantanoso y lleno de zarzas y matorral”.

cachapa. Recipiente metálico. Mais tolino que unha cachapa de grilos. Llópiz (1954b: 10668) defíneo aquí como "bote de hojalata con agujeros". Aparella-la cachapa antes de merca-la vaca "facer preparativos para algo que aínda non é seguro que vaia suceder". Cachapa parece ter aquí o significado de "caldeiro de muxir", aínda que non se podería excluí-la acepción que dan maioritariamente os dicionarios: "s. f. Vaso aplanado de madera que llevan los segadores a la cintura, y que contiene agua y una piedra para afilar la hoz. En algunas comarcas se utiliza un cuerno de buey o vaca para el mismo objeto". Só Elixio Rivas (1978) recolle outro valor: “caxato".

cachazo. Pescozo da vaca. Aplícase tamén, en sentido vulgar e burlesco, á xente cando o ten groso de máis. Carne de vaca vella, bon cachazo saca (Llópiz 1954a). Este valor aparece tamén na Mezquita e en Ponteareas.

cacholudo. [Boi] de cornos grandes. O boi, cacholudo; e o faco, cascudo (Llópiz 1954a: 1,146).

cagalleira. Diarrea contumaz. Courizas e cagalleiras acaban cas vellas. Couriza sería a defluxión nasal (Llópiz 1954a: Medicina, 55. Dr. Llopiz Ferrer, Repertorio médico). O que din os dicionarios resúmese na proposta de Eladio Rodríguez (1958-1961): "s. f. Sitio en donde hay muchas cagallas de ganado lanar y cabrío; CAGALLADA. / Conjunto de cagajones que una caballería suelta en cada vez".

camarzo. "Achaque de jaqueca". Cabeza de home sano pouco sabe de camarzo (Llópiz 1954a. S. Vicente de Lobeira). A palabra figura nos dicionarios pero non co significado que lle dá Llópiz senón 
co de "Chasco, burla o engaño. Suceso contrario a lo que se esperaba" (Valladares 1896). "Levar camarzo, agotarse la cosecha, llevar una buena baja. Dícese también de una persona. Dar un bon camarzo a unba leira, cavando o sachándola casi toda. Levóu un bon camarzo o fruto de unha leira, estrago a causa del tiempo o del ganado, en Pena de Cabras. Logo lle das bon camarzo, a una cosa, a golpes, en Mestre" (Aníbal Otero 1977).

canivés. [Bovino] acanaveirado, fraco coma unha cana. Ó boi canivés a corna lle creq (Llópiz 1954a: 1,128). Nos dicionarios aparece como "s. m. Cerdo desmedrado que no crece ni engorda por mucho que coma" pero nunca se refire a un bovino.

carouquexa. "Especie de aftas o granulaciones en el paladar o lengua de los niños". Carouquexas dos nenos, cúranse ao solpór co biquiño no fontenlo. V. Risco. Notas para un refranero (Ourense, 1953) (Llópiz 1954a: Medicina, 53). Só en Eladio Rodríguez (1958-1961), Franco Grande (1968), Carré (1928-1931): “s. f. Especie de afta o llaguita blanca que se presenta en la mucosa bucal, y especialmente en la lengua de los niños" (Eladio Rodríguez 1958-1961).

carracho. [Boi] ruín, fraco, suxo. Ó boi carracho non lle falta argabazo. Os dicionarios só se refiren ó insecto que vive maiormente nos bovinos e nos cans e, figuradamente, á persoa "pequeña, molesta, importuna; miserable etc". Pero que un boi sexa carracho non o di máis ca este refrán.

carrán. Llópiz dá boi carrán como sinónimo de boi carracho do refrán anterior (Llópiz 1954a).

chisgar. Enfraquecer por esgotamento. Cada día tres ou catro, chisgan ó almallo (Llópiz 1954a: 1,137). Llópiz explica que o refrán alude ó exceso de cubricións a que se obriga a un boi do posto; que tamén se aplica figuradamente ó home mullereiro e acabado por este exceso. Recólleo de E. Borrás no Seixo, onda Ferrol. O verbo chisgar só aparece nos dicionarios co valor de "beber viño" ou "pechar un ollo" (e mesmo "quedar torto"). Pero dalgún xeito no ms. de Rodríguez (1855) xa se ve implícito ese valor no part. chisgado que ten o valor de "flaco, consumido, enjuto, seco, etc." que despois repiten case todos.

choca. Bóla de bosta pegada ó pelo da vaca. Á vaca fraca non lle faltan chocas e raña (Llópiz 1954a: 1,132).

chorar. Florear. Liño chorado, medio medrado. En S. Simón de la Cuesta, chorimas = flores y chorado $=$ floreado. Vázquez Saco di que a palabra chorado, en este sentido, "está ausente de muchos diccionarios" (Vázquez Saco 1962: 1599). Parece intuílo Carré (1928-1931) ("Plantear. Trazar o esbozar en líneas generales un asunto"), pero o valor de "echar flor el lino" non aparece ata Rivas (1978): "Florecer, echar la flor (Fondo de Vila): Xa chora o liño, ya empieza a echar la flor el lino. Este verbo, que sólo se usaba ya en relación con el lino, ha dejado de oírse desde que dejó de sembrarse el lino por el año 1965. En la Edad Media: chor, flor"). Tamén o recolle o Glosario de Constantino García González (1985) en Novefontes (“echar flor el lino”).

cibeira. Presebe. Por santa Cecilia, o boi á cibeira (Llópiz 1954a: 1,151). Santa Icía é o 22 de novembro e nese tempo xa van feitos os traballos agrícolas que precisan bois e estes xa levan un tempo descansando por gándaras e montes; os fríos sucesivos poden facerlle mal ó gando e por iso se aconsella recollelo na corte, onda o presebe (cibeira). Este valor de lugar onde se ceba o animal só parece coñecelo Carré (1928-1931). Nótese que cibo e ciballo son nomes da comida do gando.

cobro. Llópiz define o cobro como "simple hematoma o una tumidez maligna con obstrucción de los vasos sanguineos. Puede ser 'branca' o herpes, 'rubia' escarlatina, 'rosa' erisipela, y 'negra' pústula maligna”. O cobro, con que o matarás? Con unto sin sal e cinza do lar. / var. lixo do lar en vez de cinza y en este caso se refiere a las barreduras del fogón”) (Llópiz 1954a: Medicina, 58. El Brujo de Sedes). Só recolle esta acepción como segunda Carré (1972) “s. m. Cobro, cobranza. / Enfermedad, afección de la piel”. Con todo, Llópiz no comentario posterior a un ensalmo terapéutico (59) di que “también se le llama 'cobro' o ‘cobrón' en algunos lugares (Forcarey, Moaña, etc.) a las inflamaciones producidas por la picadura de bichos venenosos". 
coita. "Coitas e rábeas, manchas que salen en la piel a causa de disgustos recibidos". Coitas e rábeas, sal na auga, n'unha cunquiña de bidueiro e limparás o pelexo. El Brujo de Sedes Abon. por M. Abizanda y San Martín, ref. 6 (Llópiz 1954a: 463,63). Hai unha patoloxía non identificada que consiste nun "tumor do gando vacún que se forma no peito" que primeiro anotou Filgueira (1926) e que algúns identifican con carbuncho; pero o refrán fala claramente dunha erupción cutánea.

confiscante. Que acaba con todo o patrimonio. Fillo de comerciante, paseante; e do paseante, confiscante (Vázquez Saco 1962: 16744). A palabra non aparece en ningún dicionario pero pode deducirse sen problemas do valor de confiscar que recollen Eladio Rodríguez (1958-1961) (“v. a. Confiscar, privar, despojar de sus bienes al reo y aplicarlos al fisco o venderlos judicialmente") e García González (1985) (“v. (Cod.) sacarle los bienes a uno por no pagar los impuestos”), porque ó final o fisco intervén cando a segunda xeración xa non ten con qué pagar.

cóxegas. "Calambres, también llamados brecas, cuando son muy agudos; rodela, rótula de la rodilla (xollo, sollo, xoela o xionllo)". "Cóxegas collo nesta rodela deste meu xollo. Brecas traio, deixo brecas, diste men cóbado, diste men xollo. Retahila de los compostores algebristas para curar los calambres agudos, Moraña, Pontevedra" (Llópiz 1954a. Dr. Castro Meizoso: Algunas denominaciones). A breca aparece como "calambre" por primeira vez no DRAG (1913-1928).

culabrela. Certa ave de rapina que se mantén de réptiles. Culabrela, culabrela, pon o ollo na portela; pastorciños gardai ben que abi ven o come res, que nos come a todos tres. ¿Que ave é? Só Franco Grande (1968) e o Carré inédito din que culabrela é o nome da aguia nalgunhas comarcas. Lembremos, en cambio, o refrán que Vázquez Saco recolle na Gudiña (Se o corvo corvexa, o lobo rastrexa; corvo calado, lobo de lado) e que nos fai pensar noutra ave, o corvo, de quen di que acompaña o lobo nas súas correrías para aproveitarse das reses que este mata; de aí que a presenza do corvo avise os pastores da proximidade do lobo ou come res (Vázquez Saco 1962: 977).

dapexado. Pexado, animal trabado coa pexa ou acabramo que non lle deixa facer movementos rápidos nin continuados. Boi dapexado, non se sal do prado (Llópiz 1954a: 1,133). Curiosamente algúns dicionarios inclúen esta palabra pero co significado contrario de "libre, expedito".

debullar. Remoer, segundo Llópiz, en terras de Bande e Lobeira. Non lle tápe-la boca ó boi que debulla (Llópiz 1954a: 1,145). O que máis se achega é unha das acepcións de Eladio Rodríguez (19581961): "Consumir ávidamente los manjares de una comida".

escornada. Cornada. Ó boi escorneador nunca lle faltou a súa escornada (Llópiz 1954a). Só García González (1985) trae esta voz pero co significado de "adj. (Caa. Cab. Val. Ped.) dícese de la vaca a la que le falta un cuerno" (VGR, Llópiz 1954a).

esgorriar. Turrar, cornear. jMalas vacas te esgorrien! é antiga expresión de desagrado en Betanzos segundo Llópiz (1,505). O can ladra e o gato rabuña, a vaca esgorría e o furaño fura (Llópiz 1954a).

fuciñeira. Vetillo. Ó boi que macha/ malla non lle poñas fuciñeira (Llópiz 1954a).

gaita. Lavativa. Convencionalismos de ant. menciñeiros. Cinco gaitas valen o que unha purga Camilo Carbelle, Colec. de ref. ant. - Remoiño, Valle de Arnoya (Llópiz 1954a: 520,335). Este valor non aparece en ningún dicionario. Algunhas veces teño pensado que a este significado negativo, e non ó instrumento musical, poden estar aludindo os usos negativos da palabra gaita coma os que recolle Eladio Rodríguez (1958-1961): estar de mala gaita ("estar de mal talante"); é unba gaita ("dícese de lo que constituye un inconveniente o una dificultad”); iQué gaita me tras! (“'icon qué encomienda me vienes!").

gatuñeira. O boi vello a gatuñeira tira dos regos (Llópiz 1954a: 1,147). Só Rivas (1988) recolle esta palabra como "s. f. Sitio de gatuñas ou uñagatos (Fondo de Vila)". É a Ononis spinosa, tamén chamada detén-bois que corresponde ó castelán detiene buey, quiebraarados; portugués resta-boi; catalán afrontacavadors, que algúns científicos denominaron remora aratri, polas súas raíces profundas e resistentes. A Enciclopedia Espasa comenta o equivalente refrán castelán da seguinte maneira: "Aconseja no despreciar sistemáticamente las cosas antiguas, que á veces son mejores que las modernas". 
guapa. [Vaca] ben feita. Llópiz recolle Guapes son les vaques como desdén feminino a un piropo.

íngoa / íncoa. "Postema que sale en la región inguinal. Muchas veces se confunde con la fígoa que es llaga purulenta”. Llópiz recóllea en Muras de Eume. Íngoa branca, Deus te desfaga; ingoa negra, Deus te deteña; ingoa rúbea, Deus te consuma (rezuma). / I Íncoa forca foi a (en) Roma; forca veu e íncoa non. íncoa forca! e define íncoa como "incordio, adenitis" (Llópiz 1954a: Medicina, 171). Os dicionarios definen estas palabras como unha simple rexión corporal.

ixola. Habilidade do feirante para mercar barato, vender caro e desfacerse das maulas. A ixola é a nai do choio (Llópiz 1954a: 2,14).

larchán. Tratante de gando. Ao máis larchán / latarego, máis logo danll'un pego (Llópiz 1954a: 2,4). Podería ser que este valor semántico que anota Llópiz fose unha derivación feita polos criadores de gando (sempre rivais dos tratantes de gando) a partir dos significados que para esta palabra son máis comúns: "folgazán” e "tragador de bienes de otros" que recolle Aníbal Otero.

latrica. Plática, sermón. Pregaria nun deserto, latrica perdida. Recollido do sacerdote Nicanor Durán (Llópiz 1954a: Culto religioso, 582,132).

lomba. Lombo. Boi cadeirudo e de lomba ancha, ao seu dono saca da lama (Llópiz 1954a). A palabra lomba aparece nos dicionarios como "corcova, lombo cando ten prominencias" pero refírese sempre a persoas, non ós bovinos que, non sendo de raza Holstein, teñen diversas prominencias.

\section{VARIANTES GRAMATICAIS INFRECUENTES}

A fraseoloxía fai ver que a lingua é máis versátil e maleable do que en abstracto parece. No corpus fraseolóxico batemos frecuentemente con variantes gramaticais que non figuran nos dicionarios. En Home refraneiro, pouco diñeiro o substantivo refraneiro converteuse en adxectivo co valor de "persoa que cre profundamente na verdade dos refráns e que se guía por eles", concepto que tamén expresa o xa citado Home lueiro non é bon *cosecheiro, que ten esta variante: Home moi luneiro, nin moita meda nin moito palleiro.

A fraseoloxía deixa ver non só variacións no vocalismo átono (fígoa) e fenómenos de prótese (afartado, afarto, alapa, apexado, bochar - abochar), senón tamén usos peculiares do número (arroace, aveño), do xénero (galipoto), do seseo (albarás, gradisela) e de sufixos (cadeirudo, cadriludo, catapoia, entrudio, esquinenza, frontudo, galiqueira, lagartola). A necesidade de consegui-la rima autoriza a crear variantes novas (deluvín, lucidio) e a propia categoría gramatical admite metamorfoses varias: entre a natureza substantiva e adxectiva (verémolo en amarelle, carranco), entre verbo e adxectivo (encho) e posiblemente entre verbo e substantivo (dizma).

afartado. [Boi] que deixou de comer ou por farto ou por inapetente. O boi afartado fai cama do rabo (Llópiz 1954a: 1,145). Só Porto (1900-1908) o define como “adj. ant. Harto, farto, mantenido".

Esta palabra e as dúas seguintes son máis comúns sen ese $a$ inicial que parece protético. 
afarto. V. afartado. O boi afarto, déitase no prado (Llópiz 1954a: 1,145). Porto (1900-1908) recolle esta palabra como "adv. c. ant. Asaz, harto, bastante".

alapar. Comer devorando. Deixa que mexe o boi que dos berros alapou (Llópiz 1954a: 1,139). Esta palabra aparece en varios dicionarios pero co valor de "Esconder, ocultar"; só se lle aproxima algo García González (1985) cando o define como “v. (Lax.) gruñir el cerdo cuando tiene hambre”. E a variante alampar aparece por primeira vez en Franco Grande (1968) co valor de "Devorar, engullir (con avidez)", valor que ten como común a forma lapar xa dende Sarmiento.

albarás. Llópiz dá este refrán: Gafeira, albarás e mal de san Antón, tres verbas para un mesme horror. E engade "gafeira, 'lepra'; albarás, 'albarazo o lepra tuberculosa'. Mal de san Antón o gangrena” (Llópiz 1954a: Medicina, 150). En Sarmiento aparece albaraz como "Clase de uvas en Pontevedra". Pero albarazo xa aparece no DRAG (1913-1928) como "s. m. Albarazo. Empeine, postilla, mancha blanca que sale en el cutis de las personas y en la piel de las caballerías. Especie de lepra". E Eladio Rodríguez (1958-1961) di: “s. m. Lepra tuberculosa. / Especie de empeines que forman en la piel manchas blancas. // adj. Uva blanca, grande en ramo y racimo, y no muy temprana”.

amarelle. Os amarelles, é dicir, os narcisos, si que aparecen nos dicionarios pero non vexo o valor de adxectivo, que aparece no substantivo composto anga amarelle co significado de "flores de narciso en infusión". O pan de bróa con anga amarella, fortalez a cervilla e as tripas enche. Cervilla sería a parte cervical do espiñazo humano (Llópiz 1954a: 535,443).

arroace. Arroace na ría, moita sardiña. Vázquez Saco (1962: 18019) di: “Arroace, variante de arroás (M. Valladares) y arroáz (C[arré]. Alvarellos), no registrada en nuestros diccionarios. / Arroace es el delfín, cuya presencia temen nuestros pescadores porque sus saltos son indicio seguro de tormenta y porque ahuyenta la sardina, a la que es muy aficionado. Var. arroaz (Carré, Voc. Irm[andades].; Ibáñez, D.E. [Eladio Rodríguez (1958-1961)]); arroás (Vall[adares]., D.E.) y arruaz. (D.E.) Se le llama también golfiño (D.E.), golfin (D.E.)".

aveño. Calquera instrumento de labranza. Pró ruín traballador non hai aveño que lle veña ben (Vázquez Saco 1962: 22140). Esta forma singular só figura nalgúns dicionarios co valor de "Palo algo labrado para bastón"; pero o significado que lle dá este refrán parece que o reservan para a forma exclusivamente plural e como palabra de varias comarcas de Lugo.

apexado. Pexado. Boi apexado non pasa o valado (Llópiz 1954a: 1,136). Nos dicionarios só aparece como participio de apexar con estes valores: "1. Atravesar el río en barca o barco con el auxilio de una vara o palo que no sea remo. 2. Tratar de agarrar, atarazar, morder o asir con los dientes".

bochar - abochar. "Romper a brotar los árboles. Falta en nuestros diccionarios, como bocho = capullo. Sin: abotoar, abrochar, abotoar, abrollar, abromar, abortar, abrumar, etc." O salgueiro bochou, a primavera entrou (Vázquez Saco 1962: 19913). Pero, se ben se mira, Aníbal Otero recolleu bocho e bochare en Parrochas.

cadeirudo. [Boi] ancho do tercio posterior. Boi cadeirudo e boas illargas, saca ó sen dono da lama (Llópiz 1954a: 1,133). Boi cadeirudo e de lomba ancha ao seu dono saca da lama (Llópiz 1954a: 1,133). Llópiz explica que sacar da lama significa sacar a alguén dunha situación comprometida. Recólleo en Campos de Vila (Quiroga).

cadriludo. V. cadeirudo. Boi cadriludo e de costas anchas ao seu dono saca da lama (Llópiz 1954a: 1,133). O refrán recolle o feito de que o aumento do volume torácico proporciona unha maior resistencia ante calquera esforzo.

carcaixía. "Carcaixía, en Puentedeume, de donde es el refrán, es niebla oscura, húmeda y espesa. Falta en los diccionarios gallegos”. Carcaixía, norte ou nordeste cría (Vázquez Saco 1962: 12844). Carcaixia, norte pía (Vázquez Saco 1962: 12845). Nos dicionarios aparece a forma carcaxía: o propio DRAG (1913-1928) recolle esa forma e ese mesmo refrán (Carcaxía norte cría) que outros posteriores repiten. 
carranco. Llópiz define os carrancos como "Reumáticos que andan arrastrando los pies o piernas, derrengados, nefríticos". Xa se van os carrancos do balneario, sin saúde e sin cartos "Contos de Garibaldi, aludiendo a los agüistas del Balneario de Cortegada, a los que anualmente servía” (Llópiz 1954a: 473,103). Nos dicionarios non aparece esta palabra, aínda que si aparecen carrancudo e carrancholas.

catapoia. Pílula. Catapoia dourada, non por iso millorada (Llópiz 1954a: Medicina, 53). Cuveiro (1876) e Porto (1900-1908) teñen catapocia "píldora". En latín catapotium xa era a "píldora que se envía sen mastigar" mentres que pilula era varias cousas: "pelotiña, bola, píldora e mesmo cagalla".

deluvín. Deluvin é palabra modificada no seu morfema final para consegui-la rima nun fraseoloxismo. Si me encontro no salto, ben me salvo; si vou ó saltarei, inda me salvarei; pero si vou ó delwín, non teñades mentes por min. ¿Que é ese deluvín? Vázquez Saco explica que "deluvar en la zona de Sarria es frotar la ropa para lavarla; y en la comarca de Lalín se aplica a la operación de sacar la vaina, habas, garbanzos, etc., lo que retiene también la idea de frotamiento". E engade este comentario: "Curiosa descripción que hace la pulga de los peligros que corre cuando se intenta cazarla. Se siente perdida si va ô deluvín, palabra procedente de deluvar = 'frotar suavemente, como los niños frotan los ojos al despertarse', ou 'Frotar la ropa cuando se lava, estregar el lino para quitarle las arestas etc.”' (Vázquez Saco 1962: 20471).

dizma. Dizma para a igrexa, anque non quede pelexa. "Dizma lo mismo que desma, diezmo de la Iglesia” (Llópiz 1954a: 578,75). Desma aparece en Carré (1928-1931) pero dižma, substantivo (como parece consideralo Llópiz), non aparece en ningún dicionario. Pero ben podería ser imperativo do verbo dizmar, que, ese si, aparece nos dicionarios.

encho. Soalleiras, mágoas e ceas teñen as covas enchas. Llópiz rexístrao en Forcarei (Llópiz 1954a: 528,385). Este inusual adxectivo aparece en Cuveiro (1876), Porto (1900-1908) e Filgueira (1926), pero só como substantivo co valor de "s.f. Enmienda, compensación, resarcimiento".

entrudio $=$ antroido. Entrudio (antroido) lacazán come a carne e deixa o pan (Vázquez Saco 1962: 7198).

esquinenza. Llópiz defíneo como "anginas, glándulas infartadas". Brétema a rente o chan, esquinenzas dan. Achanda a brétema? Centinelas con esquinenzas. (Dicen en los cuarteles de Galicia que los centinelas en las noches de niebla baja acaban con anginas). Os días de brétema cóllense as esquinenz̧as (Llópiz 1954a: Medicina, 164). Valladares (1884) é o primeiro que rexistra esquinència como "com. Angina en los animales, especialmente caballerías". Despois del recollen todos a forma esquinencia, pero só Aníbal Otero (1977) matiza algo máis cando di: "f. fig. y fam. Parece unha esquinencia, un niño raquítico. Está coma unha esquinencia, un viejo seco”.

estrame. Estrume. Na corte, estrame nova e viño á cova (Llópiz 1954a).

estreveira. Parte da corte onde se moxe a vaca. A vaca de boa teta véndese na estreveira (Llópiz 1954a: 1,156). A vaca de boa teta vese na estreveira (Llópiz 1954a: 1,157). Sendo estreveira o lugar da corte onde se moxen as vacas, a vaca que é boa encherá alí a canada do leite.

fígoa. Chaga infectada. Boi con lagartiña, manta queimada na fígoa (Llópiz 1954a: 1,155). A fígoa designa xenericamente unha chaga infectada, dado que este refrán a refire á lagartiña (enfermidade que carcome a pezuña da vaca) e dado que Valladares (1884) (e outros posteriores a el) a describen como "Especie de heridas, ó llagas, que se forman en la piel, al tiempo de salir las viruelas locas, mas grandes que las de estas, que dan mas trabajo y desaparecen tambien mas tarde". Comentando a palabra ingoa, Llópiz matiza que a fígoa é "llaga purulenta".

frontudo. [Boi] de grandes cornos. Boi, frontudo; e cabalo, cascudo. Indica as cualidades que se prefiren nos animais dunha e da outra especie (Llópiz 1954a) (Eladio Rodríguez 1958-1961: boi).

galipoto. "Cualquier mal venéreo". Galipoto malo, sualo (Llópiz 1954a: Medicina, 489,161). O que traen algúns dicionarios é galipota ("Mal gálico, enfermedad venérea" dende Filgueira 1926) pero temos que prescindir da acepción de "alquitrán", que só recolle Leiras (ca. 1906) e que nos fai 
lembra-lo galipote con que na Costa da Morte denominaban os mariñeiros o chapapote do Prestige do 2002. En calquera caso galipoto aquí é claramente masculino.

galiqueira. "Dolencia venérea". Non [b]ai galiqueira que non veña por bragueta. Dr. Arechaga (Llópiz 1954a: 535,439). Esta denominación do mal gálico non aparece nos dicionarios. Lémbrese no apartado anterior a palabra galipoto.

gradisela. Cando a gaivota anda á gradisela, mal pra nós e fame pra ela (Vázquez Saco 1962: 12610). Pode se-la gradicela que Aníbal Otero recolle en Marín e García González (1985) no Grove co significado de "estrela de mar", se temos en conta que son zonas de seseo. Vázquez Saco (1962) comenta que "Ni gradisela, ni gravisela figuran en nuestros diccionarios" pero gravisela figura en Franco Grande (1968) e Carré (1972) como “semilla en germinación”.

lagartola. Enfermidade que carcome a pezuña da vaca. Vaca con lagartola, tarrón queimado á taxoula (Llópiz 1954a: 1,155). García González (1985) recolle lagartina e lagartixa. Llópiz explica que outro remedio dos albéitares para as chagas dos cascos consistía en aplicar un terrón con céspede fresco e as súas raíces sobre a chaga enconada. É sabido que outro tratamento tradicional para as infeccións e feridas da pezuña (necrobacilose podal) consistía en cortar todo arredor da pata enferma un terrón de herba que logo poñían a secar: segundo ía secando a herba, ía curando a pata.

latarengo. Ladrón de gando. Llópiz (1956) recólleo como adxectivo: xente latarenga. Llópiz recolle as voces latarego e latarengo co significado xeral de "tratante" en Sarria; noutro momento, recolle de Noriega Varela xente latarenga, co mesmo significado: "feriantes, chalanes". Pero cando explica o refrán O que vacas non ten e vende xatiños, de algures lle vén, matiza o concepto de latarengo como "ladrón de ganado" (e faino equivaler ó cast. cuatrero). Lence Santar (1938-1941: 37) escribe, sen dar máis explicacións, que "en Riotorto chaman lataregos ós veciños d'Espasande de Abaixo" e é sabido que Espasande de Baixo é unha das parroquias de Riotorto. Con todo, inicialmente a vOz debía ter un significado neutro, porque en Ribarteme Llópiz recolleu Latarego son que merco e vendo, nin gano nin perdo (Llópiz 1954a: 2,10). Xente latarenga, sexa pobre sexa rica, atópase de feira en feira (Llópiz 1956: 313,689). O ms. de Rodríguez (1855) xa dicía que latarego era "Voz corrompida de Laitariegos, montaña de Asturias donde viven los ganaderos”. É ben posible que haxa aquí unha evolución semántica de tipo metonímico.

lucidío. [Boi] de boa calidade. V. lucido. Boi lucidío, nunca ten fastío (Llópiz 1954a: 1,134). Posiblemente sexa unha creación pedida pola rima, porque a mesma fonte cita Boi lucido, non coñez fastío.

\section{PALABRAS OUUE NON ENCONTRO NO DICIONARIO DE DICIONARIOS}

ababol. "Ababoles, flores o simientes de amapola u otra pap[aver]ácea. Tambien se emplean las hojas como emoliente". Collizo e freumón, pónese [sic] mol con auga d'ababol. Auga d'ababol "cocimiento de simiente de amapola o adormidera” (Llópiz 1954a: Medicina, 65. Ma Pouso. La Vega del Bollo). Cando o collizo te colla, ferve ababoles y enxanga (Ababoles "flores o simientes de amapola u otra pap[aver]ácea. Tambien se emplean las hojas como emoliente”) (Llópiz 1954a Ibidem; Dr. Llópiz Ferrer Repertorio médico).

abregoar. Expulsa-las secundinas. Nove follas de edreira fan abregoar ás femias (Llópiz 1954a: 2,516). Llópiz explica que as fregas se deben dar coa infusión das hedras no ventre. Ignoro se esta palabra terá algo que ver co adxectivo abregada que unicamente recolle Aníbal Otero con esta definición "Defendida, hablando del agua de riego. Trago a i-auga abregada naquela lameira; tem anga pra andar abregada todo o ano (porque la fuente es de él y nadie se la quita). Vale de Matos.

arguía. "Cornezuelo del centeno que entre varias de sus virtudes terapéuticas tiene la de secante". Unto de porco e po d'arguías o fogo negral mailo vermello tira (Llópiz 1954a: Medicina, 156). 
asobardo. Comida excesiva. Repúdeo traino o asobardo (Llópiz 1954a: 522,349). Ata Eladio Rodríguez (1958-1961) non figura sobardar ("Rebasar. Rebordar, salirse alguna cosa de los limites que la contienen. Sobrepasar”).

barbonda. "Especie de reuma articular propia de comarcas muy húmedas. Porque es muy difícil de curar o mitigar la reuma crónica o aguda. En las regiones húmedas existe la barbonda o reuma articular de transición, que se cura cambiando de clima". Dor de barbonda, chuvia á porta. Pra tira-la barbonda, unto das cobras. Derreira vella, a morte a leva (Llópiz 1954a: 472,103). Llópiz recolle esta palabra en Negreira e tamén do Dr. Casares Gil (1882) de quen parece tira-la noticia de que "el unto de cobra (culebra) no faltaba en el botiquín de los menciñeiros, boticas rurales y antros de meigos y hasta se vendía publicamente en las ferias".

benefe. "Violeta o alhelí blanco, también conocido en Gal. por "herba goubeiras y gayos"”. Parece localizalo na Gudiña. O que se cura con "benefes" xa non vai ao méstre (Llópiz 1954a: 505,218).

boeira (estrela). Planeta Venus, segundo Llópiz, por terras de Lourenzá. Estrela boeira, vaite deitar que os vosos boeiros vanse cear (Llópiz 1954a: 1,142). Supoño que a relación cos bois (ou cos pastores: boieiros) está no feito de se-la primeira estrela que se ve ó solpor e a última que desaparece ó mencer (Llópiz 1954a).

couriza. Defluxión nasal. Courizas e cagalleiras acaban cas vellas (Llópiz 1954a: Medicina, 55. Dr. Llopiz Ferrer, Repertorio médico).

culebrón. "Persona mala”. O que mata un culebrón, ten cen anos de perdón (Vázquez Saco 1962: 821).

endriña. "Endriñas falta en nuestos diccionarios, aunque registran endrino". Ano de moitas endriñas, ano de poucas fariñas (Vázquez Saco 1962: 1084). É o froito do endriño (Prunus spinosa).

defrouxeira. Correnza, diarrea. "Si es de pujos se llama defrouxeira; si con cámaras, reeira, correnza y colica. Vulgarmente se le llama cagalleira cagalleira y a la infantil lixo y codo. Correnzas por maio, saúde pra todo o ano. Froita verde pola correnza se perde. Se negra é a defrouxeira, inda máis é a cagalleira. Llópiz comenta neste caso: diferencia entre la diarrea común y la aguda o colerina, furria, furrica, cagalleira (Llópiz 1954a: Medicina, 76) .

escurrutar. Trucar, embestir. O que anda cos bois, a escurrutar deprende (Llópiz 1954a: 1,148). O máis parecido é escurruxar que figura no Apéndice de Eladio Rodríguez (1958-1961) como "v. Espantar, ahuyentar (Lemos)".

esmancarse. Desconxuntarse [unha articulación]. A quen co demo anda, o boi se lle esmanca (Vázquez Saco 1962). O ruin boi na corte folgando s'esmanca (Llópiz 1954a: 1,150).

falamenta. Cháchara mercantil do feirante. Non se fai boa feira sin cartos nin falamenta (Llópiz 1954a: $2,13)^{1}$.

farturado. Suficientemente alimentado. No inverno mormente o gado ha de estar ben alimentado / farto / farturado (Llópiz 1954a: 2,89). Pouco gado e ben farturado (Llópiz 1954a: 2,94). Lémbrense paralelos coma No inverno o gando ha de estar ben mantido (Zamora Mosquera 1972: 149), No inverno sobre todo o gando ha de estar ben comido (Carré Aldao 1926: 35.7, Vázquez Saco 1962).

feirada. Conxunto das operacións económicas realizadas por unha persoa nunha feira. Unha boa feirada cobre moitas malas (Llópiz 1954a: 2,17).

feirado. Feira. Si vas a feirado, ou vai enganar ou volve enganado (Llópiz 1954a: 2,21).

fogo negral. Absceso producido por un hematoma supuroso. Unto de porco e po d'arguías o fogo negral mailo vermello tira (Llópiz 1954a: Medicina, 158).

fogo vermello / aburante. Escarlatina. Unto de porco e po d'arguías o fogo negral mailo vermello tira

1. Llópiz: Non faise bóa feira. 
(Llópiz 1954a: Medicina, 156). Carré (1928-1931): Fogo ardente "Erupción cutánea”. Eladio Rodríguez (1958-1961) fala do Fogo ardente, el fogo de San Antón. Fogo de San Antón, "enfermedad epidémica que hizo grandes estragos en los siglos XI al XVI y que consistía en un ardor cutáneo abrasador y en dolores intolerables, acompañados de una especie de gangrena generalmente mortal. A veces ennegrecía, secaba la piel, extendíase por todo el cuerpo y terminaba por hacer desprenderse las carnes y los huesos". Repíteo sintetizando Franco Grande (1968).

herbado. "Prado". Cal é o herbado, tal é o gado (Llópiz 1954a: 2,95). Llópiz recólleo de C. Agrasar (Agrarismos, Herbón).

larpelo. "Larpelo es en la comarca de Samos, lonja delgada de tocino. Falta en nuestros Diccionarios”. Larpelo cocido, larpelo comido (Vázquez Saco 1962: 10597). Aínda que parece evoca-lo lardo, este é normalmente a parte gorda do touciño, mentres que o larpelo é a delgada.

lourado. "Color de piel melado". Boi marelo lourado, primeiro morto que ampeado. Aplícase á pelaxe do gando vacún (Llópiz 1954a: 1,134).

luareiro. "Que anda con las fases de la luna”. Home luareiro, nin boa palla nin bon palleiro (Vázquez Saco 1962: 11219).

lueiro. "El que anda siempre mirando a la luna para guiarse por sus fases". Home lueiro non é bon

*cosecheiro (Vázquez Saco 1962: 11220). V. na epígrafe 3 a entrada luareiro.

\section{PALABRAS XA POUCO FRECUENTES OU HIBERNADAS}

O refraneiro, como se ve, mantén activas algunhas palabras que xa son pouco frecuentes no uso e mesmo nos dicionarios. Ben mirado, o feito de que un paremiógrafo anote a definición dunha palabra xa indica que el sospeita que pode haber lectores que descoñezan o significado da tal palabra, e que de aí resulte que para eles o refrán sexa opaco. Pero neste apartado quero comentar algunhas palabras que simplemente van quedando desprazadas por outras que resultan simétricas do castelán ou doutras linguas, porque a homologación terminolóxica non sempre privilexia as formas diverxentes, nin sempre ten a debida preocupación por protexe-la variedade.

anazar. Llópiz explica que anazar é bater, axitar, no folklore de Lourenzá. O que anaźa a leite, n'anga a converte (Llópiz 1954a: 1,148). Sol e anga, tempo da anazada. Anazada é o leite callado ou requeixo na fala dos vaqueiros de Alzada (Llópiz 1954a: 2,86). Xa Sarmiento dicía que anaz̧ar é "mover y revolver [un] a cosa para que se condense o trabe, y también para que se liquide o disuelva, o para que se incorporen cuando son muchas cosas, como Bater ou anazar obos".

aprovecer. Noutros casos o fraseoloxismo parece insuflarlle nova vida a unha palabra que si recollen os dicionarios pero que xa parecía un fósil. Tal é o caso do verbo aprovecer. Para Cuveiro era "Aprovechar, hacer progresos"; para Porto (1900-1908), “1. Hacer progresos, adelantar, medrar, aprovechar, crecer, elevarse, desarrollarse. 2. ant. Propagarse, extenderse, multiplicarse, difundirse”; para Carré (1928-1931), “v. n. Adelantar, hacer progresos. Véase arrequecer”; para Acevedo (1932) “Cast. ant.: Aprovechar, hacer progresos. Ús. por los viejos de la montaña del Navia al Eo y en gall. F.”; para Eladio Rodríguez (1958-1961) “1. Aprovecer, aprovechar, 
adelantar, hacer progresos. 2. Cundir, propagarse, difundirse", no Apéndice do Eladio Rodríguez (1958-1961), “v. Aparecer súbitamente (Caurel)”. Os posteriores ou non o recollen xa ou repiten o dito. Ben, pois Llópiz recolle a locución aprovecer como a leite fervendo (Llópiz 1954a: 1,112).

arnelas. "Raigones fuertes de antiguas muelas". Mais val arnelas que móas podremias. L. F. Rev. A.N.T. Cir, 1909 (Llópiz 1954a: 471,99).

aviseda. "Umbría". Na abiseda o zuruxán medra. Este refrán contraponse a aqueloutro que di que Onde entra o sol non entra o médico. Llópiz recólleo en Monforte (Llópiz 1954a: 533,413). Aparece por primeira vez en Eladio Rodríguez (1958-1961).

barandal. "Terraza abalconada". Barandal ao mendía, abóa a vida. Pérez Lama, ref. 1566 (Llópiz 1954a: 536,452).

bochechar. "Enjuagarse la boca, buchear". Bochecha a boca co asento fervido e o dór de móas remargarido (Llópiz 1954a: 471,99).

cegallo. "Cegarrita, persona con poca vista”. Fel do barbo, cúralle a vista aos cegallos (Llópiz 1954a: 514,282).

cercenar. Florea-lo pan. Coma espendoar. Cando o pan cercena, *ablanda a masa na artesa. Cercena: "el hecho de florecer el pan en la tierra”. Variante de cenceno (ver valor) (Vázquez Saco 1962: 17691). "Variante de cenceno que Carré y Dicc. Enc. [Eladio Rodríguez (1958-1961)] sólo aplican a la flor del maíz”. 'Florecer el maíz’ é tamén o significado que o Glosario de Constantino García (1985) recolle en catro lugares da provincia da Coruña. Vázquez Saco (1962) explica que "En esa época [cando o millo florea] hay que dejar la masa un poco dura, porque ablanda".

citra. "Lacra o cicatriz". Cura a fígoa, mais deixa a citra. (Llópiz 1954a: 468,86). Valladares (1884) definía como "Especie de marca, señal, ó abolladura, que hace un objeto en otro y aun la mano del hombre”. A palabra chega a Carré (1928-1931) pero xa non a García González (1985).

cobra. Acción de cobrar. Fun ás cobras e salíronme lagartos. "Fuí a cobrar mis cuentas y no logré mi propósito”. Xoga coa polisemia da palabra cobras (Vázquez Saco 1962: 5986). Aparece por primeira vez en Eladio Rodríguez (1958-1961).

cochicha / cochincha. "Estomatitis, gengivitis, especie de aftas benignas que se presentan a los niños en la lactancia. Recibe además los nombres de boubas, buas, carouxeiras y sársaro. Se hacía respirar a los enfermos, sobre agua previamente pasada por el pío o pilón de los cerdos". "Cochicha, cochicha, vaite d'eiqui que o pórco e a pórca comen de tí. / / Cochincha cocbincha, vaite de aqui que pórcos e pórcas comen de ti (Celanova). Cochincha cochincha, vaite de ehi que os nenos do barrio non son para tí (El habla en Cadones, Bande). Enxunlla de galina tira as cuchichas. Cuchichas en el Valle de Monterrey son las perótidas inflamadas" (Llópiz 1954a: 60). Só Carré (1972) recolle a acepción de 'papera, parótida'.

coitas. "Manchas oscuras en la piel, producidas por disgustos". A pernina (o braciño, o corpiño) de (F. de T.) moi lastimosiña está, de coitas e rábeas e nacidas bravas. Si eres branca Dios te parta, si eres negra Dios te fenda, si eres rubia, Dios te confunda. Salmio, Reiriz - Orense (Llópiz 1954a: 463,63).

coto. De coto escribiu Sarmiento isto cando definiu cadabullo: "Lo último que queda de un tizón (por otro nombre coto) y en general significa un garabullo, un zoquete, un cabo de palo, y creo, del que sirve para alumbrar y quemar". En Valladares (1896) dise "Adición: Pedazo de cigarro, o pitillo. Pedazo inservible de madera". Non volve aparecer ata Carré (1972), que cita Llópiz "cabo de vela" explicando un refrán que recolle dunha fábrica de cera: Con moitos cotos faise un brandón (Llópiz 1954a: Culto religioso, 577,54).

cotoluvía. "Variante de cotovía, cogujada". Cotoluvía, vía, vía, canto máis alta, máis asubía. "El refrán imita el canto del ave. Cotulivía” (Vázquez Saco 1962: 14269). Aparece por primeira vez en Rivas (1978): "f. Calandria, cogujada, ave canora parecida a la alondra (Fondo de Vila y Estevesiños). En 
Fondo de Vila se dice más cotovía. En Estevesiños se dice: Canta a cotoluvía, rompe o día, que alude a sus hábitos mañaneros; en Mayo se oye su canto aéreo casi imperceptible, ya por las cuatro y media. A este hábito aluden también otras lenguas, como el I.: To rise with the lark. En realidad, es una variedad de laverca, pero que habita más por los sembrados, y la laverca por el monte de carrasco rastrero, que en Fondo de Vila llaman carpaz̧a o carpazo".

cuxiga. "Contraveneno, antídoto, triaca". Contra a pezoña malina, cuxiga. Pezoña malina "pústula de aspecto poco confiable; picadura de alimaña venenosa". Dr. R. Segade, Mellid (Llópiz 1954a: $519,324)$.

defumeira. "Fumigación, sahumerio, desinfección por ahumamiento". Defumeira pide o ban onde morreu a enferma. Gómez Durán, "Pract. médico pop.” (Llópiz 1954a: 469,92).

derreira 1. Amalar da derreira "enfermar del riñón". Si non queres amalar da derreira non conteñas a mexarreira (Llópiz 1954a: 511,260).

derreira 2. "Reuma crónica o aguda. Porque es muy difícil de curar o mitigar la reuma crónica o aguda. En las regiones húmedas existe la barbonda o reuma articular de transición, que se cura cambiando de clima". Derreira vella, a morte a leva (Llópiz 1954a: 472,103).

derreo. Mal do derreo "nefritis o reuma". Pra-o mal do derreo, caldo de cogumelos. M. Saavedra Ascariz, Santiago, ref. 1212 (Llópiz 1954a: 473,103). Dor derreado "nefrite". Door derreado trai a morte no rabo. Dr. Blak, Coruña, Folklore de medicina).

enfigoar. "Afistolarse una llaga". Man piedosa, a chaga enfigoa. Escusado en hacer daño al paciente, la llaga no es tratada con la debida energía”. Dr. García Durán, Pract. med. pop. (Llópiz 1954a: 468,87).

escornón. Corneador. Boi escornón recibe cornadas. Acevedo (1932) é o único que recolle a palabra escornón e defínea como "Que tiene condición de topar" (Llópiz 1954a) .

esfarnar. "Florear, purgarse de la flor, expulsar el pendón"; espendoar, en Aguada. Própan esfarnar, o cabelo temblar (Vázquez Saco 1962: 1890).

esforricar. Defecar. Ó solpor esforrical cágase o boi na teiró (Llópiz 1954a: 1,130).

esmechadela. "Descalabradura. Es término irónico". Despois da esmechadela, untal-a cabeza. Asieumedre, L. F., Tio Marcos da Portela 1916 (Llópiz 1954a: 473,104).

esmexarse. "Evacuar orina sin sentirlo". A que caga raleiro e sin querer s'esmexa, por prene se teña. Rafaela Gutierrez, prof. partos - Vigo (Llópiz 1954a: 520,333).

faramalla. A lei de Dios non quer faramallas. "Faramalla: trampa, enredo" (Llópiz 1954a: Dios: 674,8). Se lle habemos facer caso ás fontes escritas, esta ten tódalas trazas de ser unha palabra hibernada. Llópiz recolle o refrán de Bernardino Armesto e dátao en 1834 pero nos dicionarios non aparece ata Aníbal Otero (1977), que o define como "Charla artificial, encaminada a engañar”, e en Eladio Rodríguez (1958-1961), que o define así: "s. f. 1. Faramalla, charla artificiosa encaminada a engañar a uno. 2. Fachenda, bambolla, boato excesivo de más apariencia que realidad. 3. Trapisonda, embrollo, confusión, maraña. En esta acep. también se dice faramallada”. Repíteno despois Franco Grande (1968) e Carré (1928-1931). É curiosa a información que ofrece o TILG: só aparece 11 veces, das que dúas son textos de $1823^{2}$ e de 1853 e outras tres dos últimos once anos; dos últimos

2. Facer vínculos e casas. Recordade, que inda é tempo, Non vos metades en chanzas, que os valentes e o bon viño, Como dicen, logo acaban. ¿Qué ha de darvos ese crego? ¿Qué caudillo é o que vos manda? ¿Un escribano? vergonza E que haxa quen tras del vaia. Pode que teña valor, Como tamén faramalla, Pero ó fin é un escribano Sin opinión e sin fama. De esta xente solo salen Enredos, preitos e trampas. Foron a peste da terra E os ladrós da xente honrada. ¿Queredes saber por qué Contra as leises se levanta? Porque antes a escribanía De Burón daba ganancias. (Poema ós insurrectos de Burón (23.1.1823)). 
vinte anos o TILG ofrécenos tres citas e o CORGA, do CIRP, ofrécenos outras tres. Isto fainos pensar nunha palabra que esmorecía pero que está recuperando a literatura actual.

farón. Preguiceiro, que traballa pouco. Ó boi farón, pouco lle presta o ferrón (Llópiz 1954a: 1,129). Nótese que farona é un dos varios nomes populares da preguiza.

feira franca. Feira boa. O mintir non paga e fai feira franca (Llópiz 1954a: 2,15). Parece ser refrán de Noia. Haberá que lembrar aquí a $6^{a}$ acepción que de franco dá Eladio Rodríguez (1958-1961): "Aplícase a las cosas exceptuadas de derechos y contribuciones, y a los lugares y puertos que gozan de esa exención".

ferradela. Mordida. Ferradela de lozarra, percura a campa. Ferradela de sorropión, percura o queixón. Lozarra "alacrau, escáncere. Rio Caldo, Orense. Son especies distintas aunque ambos nombres lozarra y soropion entran en la misma leyenda. Segun el portugués Alvaro de Acevedo, el sorropion parece ser la cecilia o víbora de los prados. El alacrán, arácnido scorpio, por otros nombres vulgares, besta dos penedos, cancaro, cáncere, escacer, lacrau, lacraio, lescáncere, rabo torto, rapapedras, rascalzo y zábaro, sorropión" (Llópiz 1954a: Zoología, 1006,1).

fianza (venta a). Venda con pago aprazado. Venta ao contado, diñeiro gardo; venta a fianža, diñeiro â balanza (Llópiz 1954a: 2,23). É refrán de Ourense. Só Eladio Rodríguez (1958-1961) recolle indirectamente esta acepción: "2. Obligación que uno hace para seguridad de un pago o contrato. 3. Fianza, prenda que asegura el cumplimiento de una obligación, especialmente si es dinero, que se deposita y consigna".

freumón. "Nombre genérico del flemón de encías, pero más vulgarmente llamado collizoo y colleitizo y boloardo cuando es de gran tamaño; niva se llamaba en el s. XVII". Cocemento de ababois, bóos son pra os freumós (Llópiz 1954a: Medicina, 65. Dr. Andrade Herborística gall.). Collizo flemón en las encías. Auga d'ababol cocimiento de simiente de amapola o adormidera" (Llópiz 1954a: Medicina 65. Ma Pouso. La Vega del Bollo). Collizo e freumón, póñese [sic] mol con auga d'ababol. Auga d'ababol V. 2. s.v. ababol. Boloardo xa aparece en Rodríguez (1863). Freumón é unha interesante evolución semiculta do latín phlegmon, -ōnis, relacionado co grego $\varphi \lambda \varepsilon \gamma \mu \alpha$ e $\varphi \lambda \varepsilon \gamma \mu o w \eta$ que queda varrida polo cultismo normativo flegmón que ninguén di.

galero. Sombreiro. Home de capa e galero é o que eu quero. "La voz galero en el sentido expresado ha casi desaparecido del habla vulgar. La usan de vez en cuando los ancianos. Se pone en boca de las mozas casaderas. Era el hombre a quien tenían por noble y formal, cuyo matrimonio era por lo tanto conveniente" (Vázquez Saco 1962: 11180). Probablemente desapareceu por pensarse que, rematando en -ero, era un castelanismo, cando, se ben se mira, é a palabra latina galerum que xa significaba precisamente "sombreiro". Só a traen Valladares (1884), Filgueira (1926), Carré (1928-1931) e Ibáñez (1950).

gallardo. Lucido e de bo aspecto. Si queres ao boi gallardo, lévao ao lameiro entre febreiro e maio (Llópiz 1954a: 1,153). Fronte ós anteriores lexicógrafos que dan a gallardo o significado de "Que tiene los cuernos largos o a lo alto", Eladio Rodríguez (1958-1961) define como "Airoso, gentil. Bravo, bizarro, valiente".

gandarón. Monte con vexetación pobre ou devesa con monte sen moita costa. Acabada a labor, bois ó gandarón (Llópiz 1954a: 1,142). Franco Grande (1968), Carré (1928-1931) e Ibáñez (1950) reúnen estes significados para gandarón: "s. m. 1. Monte alto que se eleva al final de una gándara. 2. Cumbre que a veces separa dos parroquias".

landra. "Anginas malignas, crup, garrotillo, difteria". Morre o vello cas caimbras e os novos cas landras (Llópiz 1954a: Medicina, 64. O.L. Boado, Méd. Orense). Cuveiro (1876) é o primeiro que trae unha acepción parecida pero que sitúa noutra parte do corpo "Tumor del tamaño de una bellota que se forma en las glándulas, los sobacos, etc.”, que non reaparece ata Eladio Rodríguez (19581961) ("Glándula o quiste del tamaño de una bellota, que suele formarse en el cuello, los sobacos, 
las ingles, etc.”), que reproduce Franco Grande (1968); Carré (1972) di simplemente “Glándula, órgano que sirve para la secreción de humores. Var. Glanda” e reaparece en García González (1985): "Feás: 2. ganglio inflamado en la base del cuello".

lázaro. "Lepra febril". Lázaro, fogo salvaxe, eiqui te pillo, eiqui te mato. Fórmula ensalmista de Mondoñedo. Fogo salvaxe "sarpullido pernicioso" (Llópiz 1954a: 523,354).

lecer. "Buen humor". Deitarse cedo e cedo derguer, dá saúde, forza e lecer."Prevenciones medicas", Dr. Llopiz Ferrer, ref. 758 (Llópiz 1954a: 469,93).

louba. Loa, honor. Aparece na loc. en louva de / na louva de. En louba de san Lois, abogado da teriza, Padre Noso, Ave María. Dr. C. Pelliteiro, El curanderismo (Llópiz 1954a: 529,394). Na louba de san Lois, que me tire ista teriz, e non deixe nada eiquí. H. Gallego Arceste, Carballiño (Llópiz 1954a: 529,394). Na louba de san Gonzalo, pra que torne o pe ao seu estado. Invocación a san Gonzalo de Amarante, "curador" de pes abertos ou desfiados (Llópiz 1954a: 518,320). Na louba de san Tomé, desadormenta o meu pé. "Lo dicen las madres a los niños cuando se les duerme un pie. Castromil de Orense" (Llópiz 1954a: 518,320). En louba de San Silvestre pra que toda meiciña empreste. Sofisma médico farmacéutico. Abon. Dr. Punín (Llópiz 1954a: 507,221). 


\title{
NOVOS CRITERIOS PARA A ELABORACIÓN DUN DICIONARIO DE NEOLOXISMOS
}

\author{
Ana Belén Crespo Bastos / Xosé María Gómez Clemente
}

Observatorio de Neoloxía (Universidade de Vigo)

\section{O. INTRODUCIÓN}

Froito dos traballos do Observatorio de Neoloxía da Universidade de Vigo', en 2005 publicamos unha obra lexicográfica que denominamos Novas palabras galegas (López Fernández et alii 2005) e que reflectía a "vitalidade" (Cabré 2000, Gómez Clemente / Rodríguez Guerra 2003a) na creación de palabras que tiña a lingua galega. Nun anterior artigo fixemos unha pequena descrición desta obra (Gestido de la Torre / Gómez Clemente 2003). Recollíanse nela creacións léxicas que non estaban nos dicionarios galegos e que cumprían, polo tanto, un criterio de exclusión lexicográfica. Os criterios utilizados naquela obra deben ser revisados e ampliados e a información fornecida completada. Nesta contribución pretendemos:

(a) matizar os criterios de identificación de neoloxismos utilizados nos traballos do Observatorio de Neoloxía,

(b) describir unha serie de "marcas", algunhas derivadas do criterio de identificación e outras complementarias, que deberán ser empregadas en futuras edicións do devandito dicionarioº ${ }^{2}$ e

1. Este proxecto comezou en 1998. Nestes momentos faise unha avaliación dunha serie de fontes en Internet: www.vieiros.com; www.galicia-hoxe.com; www.canalciencia.com; www.anosaterra.com. En setembro de 2006, comezouse a analizar un blog, concretamente o chamado Brétemas de Manuel Bragado. Na base de datos, neste momento, están almacenados un total de 12.000 neoloxismos revisados.

2. Compróbense as marcas nos dicionarios de novas palabras do catalán (Observatori de Neologia 1998) e do italiano (Adamo / Della Valle 2003). O primeiro utiliza principalmente marcas lexicográficas (sobre o corpus de exclusión). O segundo inclúe tamén información morfolóxica e sintáctica sobre os procedementos de formación e identifica os formantes. 
(c) salientar a importancia que teñen as novas tecnoloxías para a elaboración de produtos lexicográficos, concretamente os extractores semiautomáticos de neoloxismos para a redacción de dicionarios de novas palabras.

\section{O CONCEPTO DE NEOLOXISMO E A SÚA IDENTIFICACIÓN}

As definicións de neoloxismo poden ser variadas, pero todas están centradas no feito de unha unidade ser considerada como "nova" nun sistema lingüístico determinado. Cabré (1993: 444) afirma que "o neoloxismo se pode definir como unha unidade léxica de formación recente, unha acepción nova dun termo xa existente ou, finalmente, un termo emprestado hai pouco dun sistema lingüístico estranxeiro"; Rey (1976: 4) defíneo como "une unité nouvelle, de nature lexicale, dans un code linguistique défini", e Boulanger (1989: 40) entende que "[o neoloxismo é o] resultado tanxible da operación de producción lingüística inédita [...], é dicir, a unidade nova capaz de encher cada baleiro detectado introducíndose no uso corrente ou socioprofesional". A novidade á que nos referiamos establécese basicamente con respecto a un criterio temporal (unha unidade é nova se apareceu recentemente nunha lingua), aínda que tamén pode referirse á ausencia desa palabra nun grupo de dicionarios ou á opinión sobre esa novidade que teñen os falantes.

Estas tres consideracións dan lugar a distintos criterios de identificación de neoloxismos:

\section{O criterio lexicográfico}

O criterio lexicográfico de identificación está baseado na comprobación sistemática da aparición da unidade léxica nunha serie de dicionarios: as que non se rexistran neles son consideradas como "neoloxismos lexicográficos". Este criterio, que á vez define o carácter do concepto neoloxismo, presenta certos problemas. Xa Corbeil (1971: 135-136) afirmaba que un dicionario nunca pode recoller todas as palabras dunha lingua ${ }^{3}$ e polo tanto o carácter neolóxico dunha unidade establecido con este criterio pode ser posto en dúbida 4 . Ademais, os lexicógrafos, cando elaboran as súas obras,

3. Este feito agrávase pola relativa limitación no número de entradas dos dicionarios utilizados no corpus de exclusión: VOLG (45.000), GDXL (95.000) e GDS XXI (80.000).

4. É significativo ver como os dicionarios, especialmente os académicos, son pouco permeables á introdución de palabras de uso frecuente. As gramáticas rexistran aínda con menor frecuencia novos formantes que poderían ser repertoriados nunha determinada lingua. Véxase Freixa / Solé (2003), que nos fornece datos moi significativos sobre a relación da neoloxía catalá cos dicionarios normativos nesa lingua. 
réxense por unha serie de normas que son máis ou menos permeables ás novas creacións léxicas, dependendo do tipo de dicionario que se elabore, da ideoloxía, da tradición, etc. Malia constatarmos estes feitos, o criterio de exclusión lexicográfica ten unha vantaxe, que é a da obxectividade na obtención dos datos e, dende logo, a facilidade de aplicación.

2. O criterio temporal, a frecuencia e o criterio psicolóxico-pragmático

Estes tres criterios deben ser considerados conxuntamente porque están estreitamente relacionados.

a) Criterio temporal e criterio da frecuencia

O criterio temporal baséase na constatación de que unha unidade léxica leva pouco tempo instalada nunha determinada lingua (velaquí a cerna do concepto de "neoloxismo"). Compróbase coas datas de aparición dunha palabra nun dicionario ou nun corpus textual para a atribución dunha teórica primeira ocorrencia nunha determinada lingua. Con respecto a isto temos que dicir que:

- Os dicionarios galegos non inclúen ningunha referencia a unha posible datación da palabra na lingua.

- As datas que se poden extraer dos corpora textuais galegos, CORGA e TILG, e da base de datos do Observatorio de Neoloxía deben ser utilizadas da seguinte maneira para establecer o criterio de novidade:

- Data da primeira ocorrencia. Neste sentido é máis útil o TILG por comezar os seus rexistros en 1612. O CORGA comeza a recoller os de 1975 e a base de datos do Observatorio comeza en 1998. Se consignamos esta primeira data, temos un dato obxectivo, pero hai que recoñecer que non é tarefa doada interpretar cando unha unidade léxica deixa de ser un neoloxismo, cantos anos teñen que pasar para que unha palabra xa non sexa considerada nova (estamos a falar de unidades léxicas non rexistradas en dicionarios). Quizais non haxa unha fronteira obxectiva, aínda que podemos entender que descentralizador, por exemplo, rexistrada en 1977 no CORGA xa non é un neoloxismo. Pero, unha palabra moi utilizada como represaliar, que se rexistra en 2001 tamén nesa base de datos, non nos dicionarios, é ou non é un neoloxismo 
despois de 5 anos? Quizais o único razoable sexa deixar a data da primeira ocorrencia para que sexa o usuario do dicionario de neoloxismos quen a interprete.

- Frecuencia e dispersión temporal. A análise destes parámetros leva a considerar que unha unidade, mesmo que se rexistre en data moi recuada, terá un maior carácter neolóxico (a) se ten unha baixa frecuencia, e (b) se, mesmo tendo unha frecuencia relativamente alta, a súa dispersión temporal é limitada. A baixa frecuencia dunha unidade contribúe en certa maneira a aumentar o seu carácter neolóxico porque a pouca difusión pode ser un indicador de que non tivo aceptación entre os falantes. Tamén poida que unha unidade tivese unha frecuencia alta durante un tempo pero despois desaparecese. Isto indica que pode ter un maior carácter neolóxico para os falantes que a volven recuperar pasado un tempo.

b) Criterio psicolóxico-pragmático

Falamos antes da dependencia que ten o criterio temporal da percepción sobre a novidade dunha palabra que teñen os usuarios da lingua. Alain Rey, cando fala do neoloxismo ${ }^{5}$, di que é imposible consideralo in abstracto como un elemento novo dentro dun sistema, independente do funcionamento concreto da lingua. Os neoloxismos defínense en relación cun modelo de comunicación determinado e, polo tanto, unha forma funcional limitada na súa función a un subsistema (dialecto, sociolecto) pode pasar a outro subsistema, no que será percibido como neoloxismo. É dicir, un neoloxismo tamén pode ser aquela unidade que ben por moda, por unha intervención institucional ou por outras causas pasa dun grupo de falantes a outro, ou dun rexistro de lingua a outro, independentemente da súa novidade obxectiva.

Para este autor, basear a neoloxía en criterios cronolóxicos ou lexicográficos presupón unha visión parcial dos fenómenos neolóxicos; daque-

5. Rey (1976: 17) defíneo así: "Le néologisme est une unité du lexique, mot, lexie ou syntagme, dont la forme signifiante ou la relation signifiant-signifié, caractérisée para un fonctionnement effectif dans un modèle de communication déterminé [novidade funcional], n'était pas réalisée au stade inmédiatement antérieur du code de la langue [sincronía]. Cette nouveauté, qui doit être appréciée par rapport à une définition précise et empirique du code [novidade pragmática], correspond en général à un sentiment spécifique chez les locuteurs [xuízo colectivo]. Selon le modèle de code choisi, on distinguira donc des néologismes en synchronie large et étroite, des néologismes pour la langue dans son ensemble ou pour un usage déterminé, des néologismes dans un contexte thématique spécialisé (technique et science) ou non spécialisé". 
la, fala do concepto de "impresión neolóxica", ou percepción da neoloxía por parte dos falantes, que debe estar baseada nun xuízo colectivo que supere os diferentes niveis de competencia que teñen os falantes. Este concepto de impresión neolóxica, difícil de cuantificar, é o que condiciona o criterio temporal, como antes dixemos ${ }^{6}$.

c) O concepto de "calidade neolóxica"

Á parte dos criterios citados, é necesario tamén falar da "calidade neolóxica" ( $\mathrm{CN}$ ) dunha unidade léxica, un concepto gradual que nos permite comprobar a novidade dunha palabra nun sistema lingüístico determinado, baseado principalmente no proceso polo cal se converteu en neoloxismo (Cabré et al. 2004). Neste traballo utilizamos a metodoloxía empregada polos autores do artigo citado para establecermos, cos nosos datos, os graos de calidade neolóxica que deberían logo ser reflectidos nunha obra lexicográfica dedicada ás novas palabras. Basicamente, a $\mathrm{CN}$ está baseada en criterios morfolóxicos, na análise dos compoñentes dunha palabra e na súa relación coas gramáticas e os dicionarios.

Presentamos os principais procesos de creación de novas palabras e a CN asociada a cada un deles.

a) Derivación por prefixación

- Se a base e mais o prefixo están repertoriados no corpus lexicográfico de exclusión e nas gramáticas: $\mathrm{CN} 0$.

- Se existe o prefixo e non a base: $+C N 1$.

- Se non se rexistra o prefixo e si a base: $+\mathrm{CN} 2$.

- Se non se rexistra nin o prefixo nin a base: $+\mathrm{CN} 3$.

- Se se altera algunha regra gramatical: $+C N 4$.

b) Derivación por sufixación

- A base e o sufixo están repertoriadas no corpus de exclusión e nas gramáticas: $\mathrm{CN} 0$.

- A base non está repertoriada e o sufixo si: $+C N 1$.

- A base está repertoriada e o sufixo non: $+C N 2$.

- Nin a base nin o sufixo están repertoriados: +CN 3.

6. Véxase tamén Gardin et al. (1974) e obsérvese a súa metodoloxía baseada en enquisas a un número determinado de falantes. 
c) Composición patrimonial ${ }^{7}$

- Se os dous elementos que forman o composto están repertoriados no corpus de exclusión: $\mathrm{CN} 0$.

- Se só aparece unha das bases que forman o composto: +CN 1 .

- Se non aparece ningún elemento repertoriado: +CN 2.

d) Composición culta ${ }^{8}$

- Os dous formantes están repertoriados: $\mathrm{CN} 0$.

- Un dos formantes non está repertoriado: +CN 1.

- Ningún dos formantes está repertoriado: +CN 2.

e) Composición híbrida9

- Se aparecen repertoriadas as bases e mais os formantes: $\mathrm{CN} 0$.

- Se non aparecen repertoriadas as bases: +CN 1 .

- Se non aparecen repertoriados os formantes: $+C \mathrm{CN} 2$.

- Se non aparecen nin as bases nin os formantes: $+\mathrm{CN} 3$.

f) Empréstitos ${ }^{10}$

- Se un empréstito está adaptado (A), a CN é menor porque se entende que leva máis tempo na lingua: $\mathrm{CN} 0$.

- Se un préstamo está sen adaptar (SA): +CN 1 .

- Se o empréstito non está repertoriado na lingua orixinal (LO): + CN 2 .

7. Na composición patrimonial integramos aquelas palabras que están formadas por unión de lexemas simples autónomos da lingua e que manteñen distinto grao de autonomía.

8. Entendemos por composición culta o procedemento polo cal se unen dous formantes de orixe grecolatina. Os exemplos rexistrados corresponden a neoloxía terminolóxica. Non hai unha relación exhaustiva de formantes cultos nos dicionarios e gramáticas galegas. Isto leva a que se consideren neoloxismos lexicográficos unidades que poida que estean recollidas en dicionarios especializados que non forman parte do noso corpus de exclusión e en obras dedicadas ao estudo teórico-práctico da terminoloxía.

9. Por composición híbrida entendemos a combinación de temas grecolatinos, ou truncacións de palabras modernas, cunha palabra moderna.

10. Véxanse os traballos de Rodríguez Río $(1998,2003)$ para unha completa relación dos procedementos de adaptación de empréstitos ao galego. 


\section{MARCAS NOS DICIONARIOS DE NEOLOXISMOS}

Entendemos que nunha obra lexicográfica que se poida definir como un repertorio de "novas palabras" deben incluírse unha serie de marcas que lle permitan ao usuario avaliar o grao de "neoloxicidade" das unidades léxicas extraídas cun criterio lexicográfico. Describiremos primeiro as marcas utilizadas no dicionario de Novas palabras galegas; a seguir, falaremos das novas marcas que serían necesarias en obras desta clase.

\subsection{O Dicionario de novas palabras (2005)}

O criterio utilizado para facer a escolla das entradas desta obra foi, como se dixo, o lexicográfico: incluíronse as palabras que non estaban no corpo de exclusión descrito. As marcas utilizadas foron as seguintes:

a) Lexicográficas

(1) O corpus de exclusión lexicográfica utilizado ata o ano 2000 foi o seguinte:

- VOLG (versión provisional 1989 // Corrixe 1.0-1.2).- É realmente o documento máis importante de todo o corpus de exclusión. Establece o léxico normativo e está realizado por unha institución que ten autoridade lingüística, derivada da Academia. Non serve para a análise da neoloxía semántica.

- DRAG (1997).- Non ten un número elevado de entradas (aproximadamente 25.000), pero ten a vantaxe de ser a única obra lexicográfica que ten un carácter normativo recoñecido e serve para analizar a neoloxía semántica.

(2) A partir do ano 2000 utilizouse o GDXL, que recolle un número moi elevado de entradas (95.000).

b) Textuais.- Fixéronse comprobacións adicionais en Internet para avaliar a difusión das entradas que aparecían na base de datos.

c) Temporais.- Indicáronse as datacións máis antigas rexistradas no CORGA e na nosa base de datos de neoloxismos.

Das 1.166 entradas que aparecían neste dicionario, 199 estaban presentes no GDXL, que se utilizou como parte do corpus de exclusión, aínda que tar- 
diamente. A marca GX00 apareceu en cada unha desas entradas para indicar que estaban nese dicionario. En 2005 incorporamos ao corpus de exclusión lexicográfica o GDS XXI. O emprego desta obra cando redactamos o dicionario de neoloxismos implicaría excluír 550 das súas entradas. Este dato mostra que a última obra citada se elaborou cun criterio aberto á aceptación de novas unidades léxicas que non tiveran entrada noutros dicionarios.

\subsection{Novas marcas nos dicionarios de neoloxismos}

Na redacción dun novo dicionario de neoloxismos cremos que se debería incluír unha serie de informacións complementarias que teñen que ver coa pequena revisión do noso concepto de neoloxismo que comentamos ao principio deste traballo.

Propoñemos a inclusión das seguintes marcas que dependen dos criterios descritos anteriormente ${ }^{11}$.

\section{(a) Marcas temporais}

En realidade, como comentamos, xa incluímos unha marca temporal no dicionario de 2005, pero agora propoñemos a súa comprobación sistemática en calquera fonte posible. Este criterio é o que máis se achega á definición que dan os autores que tratan sobre o concepto de neoloxismo. Enténdese, en principio, que unha unidade é neolóxica se aparece nunha época recente; non o é se é antiga. Consideramos que a única marca que se pode incluír é a da data da primeira documentación porque non podemos poñer un límite a partir do cal unha unidade deixa de ser neoloxismo (agás que entre nun dicionario).

Fixemos unha datación das unidades que estaban rexistradas no CORGA. Este corpus permite obter unha data aproximada da primeira ocorrencia da unidade que analizamos. Das 841 unidades rexistradas, 462 aparecen datadas neste corpus textual. A datación máis antiga é 1975 para a palabra centro-esquerda e a máis nova é para a palabra situacionismo de 2003. Entre estas dúas datas aparecen, entre outros, os seguintes exemplos:

[1975-1980] fraguismo, elitista, seguidista, castelán-falante, apartidista, atomización, reapropiación, minorizar, globalizador, departamental.

11. Para exemplificar esta información fixemos unha comprobación sobre 841 candidatos a neoloxismos do ano 2005, non rexistrados no corpus de exclusión lexicográfico, con 1334 ocorrencias. 
[1980-1990] on-line, modelización, privacidade, submundo, gay, profesionalización, sociopedagóxico, arbitrismo, impasse, corresponsabilidade.

[1990-2000] peonalización, xenocida, microrrede, aeroxerador, compós, e-mail, chat, recompilatorio, plurinacionalidade, risoterapia.

[2000-2003] alterglobalización, xogabilidade, jazzístico, pangaleguismo, eurobarómetro, punch, supervendas, router, teledermatoloxía, e-learning.

Como exemplos tirados da base de datos do Observatorio de Neoloxía podemos citar as de datación máis antiga:

[1997] deconstruccion, mercadeo, intramuros, medio ambiente.

(b) Marcas de frecuencia absoluta e dispersión temporal

(1) En principio, entendemos que se unha unidade é frecuente, o seu carácter neolóxico é menos evidente por repetida e, teoricamente, coñecida. Se a unidade é moi pouco frecuente, sucede á inversa:

\section{- Frecuencia alta:}

competencial 91, corresponsabilidade 64 , departamental 58, planeamento 54, vertebración 52, perigosidade 40, fraguismo 36 .

\section{- Frecuencia baixa:}

antiobreiro -a 2, apartidista 2, seguidista 5, potenciador -a 4, antinacionalista 17.

(2) Se unha unidade ten unha dispersión temporal ampla, o seu carácter neolóxico é menor. Se as ocorrencias están moi concentradas nuns determinados anos, pódese considerar que é máis "neolóxica":

- Ocorrencias dispersas:

planeamento 54: [1975-1984] 15; [1985-1994] 3; [1995-2004] 36.

- Ocorrencias concentradas:

departamental 58: [1975-1984] 1; [1985-1994] 3; [1995-2004] 54.

perigosidade 40: [1975-1984] 1; [1985-1994] 7; [1995-2004] 32.

plurinacional 51: [1975-1984] 8; [1985-1994] 5; [1995-2004] 38. 
Departamental aparece en 1977 pero rexistra 54 das súas ocorrencias a partir de 1995. O seu carácter neolóxico é evidente porque a meirande parte dos seus rexistros se dan nos últimos 10 anos. Perigosidade, da mesma maneira, aparece por primeira vez en 1977, pero concentra as súas ocorrencias a partir de 1995. No caso de plurinacional rexístranse 8 casos entre 1975 e 1979 e o seguinte rexistro xa é de 1993. Entre 1993 e 2004 rexístranse 43 das 51 ocorrencias.

(c) Marcas lingüísticas

Á parte das anteriores marcas, deberemos establecer que graos de novidade, ou calidade neolóxica $(\mathrm{CN})$, teñen as palabras segundo sexa o procedemento utilizado para formalas. A calidade neolóxica, como indicamos, establécese en relación coas gramáticas e dicionarios. Analizamos os seguintes casos:

- Derivación por prefixación:

- 0 [pref + base]. O prefixo e mais a base están repertoriados no corpus de exclusión e nas gramáticas. A súa CN é baixa. Así ocorre en multirreincidencia, deslocalización, precampaña, codecisión, teleformación, telecaza, dedocracia, mafiocracia.

- 1 [pref $+\varnothing]$. O prefixo está repertoriado; a base non. Maior grao de $\mathrm{CN}$ : antiviral, contraopa, insostibilidade, reubicación ${ }^{12}$.

- 2 [ $\varnothing$ + base]. O prefixo non está repertoriado; a base si. Grao de CN maior, xa que a aparición dun novo prefixo nunha lingua é un fenómeno neolóxico importante. Incluímos aquí os casos de neo-, que decidimos considerar prefixo pola súa ampla rendibilidade. Ex. neocolonia, neoconservador, neoliberal, neolicenciado.

- $3[\varnothing+\varnothing]$. Nin a base nin o prefixo están repertoriados. Grao de CN maior (non hai casos).

- 4 Alteración de regras gramaticais: [pref + substantivo = adxectivo]: [O alcalde nacionalista é cualificado de] antiobreiro, programa anticontaminación, mina antipersoa. Neste caso anti- non se comporta coma os outros prefixos xa que produce transcategorización. 
- Derivación por sufixación:

- 0 [base + suf]. A base e o sufixo están repertoriados. En principio, a CN da unidade é baixa porque, aínda que a impresión inicial sexa de novidade, os falantes poden identificar cada un dos compoñentes da nova palabra: anecdotario, conservacionista, comunicacional, condutual, conceptualidade, parabenizar.

- $1[\varnothing+$ suf]. A base non está repertoriada e o sufixo si. A CN é maior. Rexístranse casos con bases que son nomes propios, de marcas comerciais, préstamos e tamén de verbos, non rexistrados, derivados de substantivos. Ex.: mundialización, acebeiro, nominación, toyotismo, titulización, chateo, frontepopulista, blogueiro.

- $2[$ base $+\varnothing]$. A base está repertoriada e o sufixo non. Poden aparecer casos como a terminación -ing do inglés que nalgúns casos funciona como sufixo. Non rexistramos ocorrencias en 2005.

- $3[\varnothing+\varnothing]$. Nin a base nin o sufixo están repertoriados. Non se rexistran exemplos.

- Composición patrimonial:

- 0 [base + base]. As dúas bases están repertoriadas. A CN é baixa. Videochamada, videoconferencia, vídeoconsola, videocreación, escoitacontos, poema-imaxe, cd-libro.

- $1[\varnothing+$ base] ou [base $+\varnothing]$. Unha das bases non está repertoriada. Os exemplos que rexistramos teñen un elemento emprestado do inglés: blogmillo, blognovelado, netartista.

- $2[\varnothing+\varnothing]$. Non se rexistran exemplos.

- Composición culta ${ }^{13}$ :

- 0 [fprex + fsuf]. Rexístranse os dous formantes cultos: homofóbico.

13. Lémbrese o comentado antes sobre a presenza de neoloxismos terminolóxicos na nosa base que deberían ser tratados dunha forma diferente pola súa escasa aparición nos dicionarios. Ademais, as gramáticas tampouco recollen exhaustivamente os formantes cultos que funcionan na creación de unidades de valor especializado. 
- 1 [fprex $+\varnothing][\varnothing+$ fsuf]. Un dos formantes non está recollido no corpus de exclusión: dislipemia, cloroquina.

- $2[\varnothing+\varnothing]$. Non se rexistran exemplos.

- Composición híbrida:

- 0 [fprex + base] ou [base + fsuf]. Os dous elementos compositivos están repertoriados: aeroxerador, agrogandeiro, chupóptero, ecoeconomía, eurocidadán, euroconstitución, feminicidio, metrosexual, teleoperador.

- 1 [fpref $+\varnothing]$ ou $[\varnothing+$ fsuf]. Non está repertoriada a base, normalmente un préstamo adaptado ou sen adaptar: audioblog, ultrabiónico.

- $2[\varnothing+$ base $]$ ou [base $+\varnothing]$. Non se rexistra a forma prefixada ou sufixada no corpus: alterglobalización, cibercafé, cibersociedade, e-administración, e-ciencia, e-comercio, e-DNI .

- $3[\varnothing+\varnothing]$. Ningún elemento compositivo está repertoriado. Porén, o caso que rexistramos, altermundialización, produce unha impresión neolóxica baixa pola presenza de mundo, mundial.

- Préstamos:

- 0 (A). Como comentamos, os préstamos adaptados por importación ou calco, teñen, en principio, unha CN baixa: privacidade, párking, ránking, computerizar, compós.

- 1 (SA). Os préstamos sen adaptar teñen unha CN maior, aínda que moitos deles xa están na lingua cotiá de moitos falantes e, xa que logo, producen unha impresión neolóxica baixa: boom, hacker, driver.

- 2 (LO). Non se rexistran na lingua orixinal, onde funcionan como neoloxismos puros: godcasting, imode, blog, cromakey, book-crossing.

\section{CONCLUSIÓNS}

O criterio lexicográfico fornécenos dunha maneira sistemática candidatos a neoloxismos. A consideración dunha palabra como neoloxismo lexicográfico debe ser matizada coa aplicación doutros criterios. Os dicio- 
narios de neoloxismos deben presentarlle ao usuario a maior información posible sobre a cronoloxía, a frecuencia (a absoluta e a dispersión temporal) e os procedementos de formación das novas unidades, de maneira que poidan estes datos servirlle para formar o seu "xuízo" sobre a "calidade neolóxica" dunha palabra. En futuras ampliacións da nosa obra de 2005 introduciremos esta información e esperamos que sexa útil para a comprensión do concepto de neoloxismo. 



\title{
A INVESTIGACIÓN EN LEXICOGRAFÍA E TERMINOLOXÍA NO CORPUS LINGÜÍSTICO DA UNIVERSIDADE DE VIGO (CLUVI) E NO CORPUS TÉCNICO DO GALEGO (CTG)*
}

\author{
Xavier Gómez Guinovart \\ Seminario de Lingüística Informática (Universidade de Vigo)
}

\section{INTRODUCIÓN}

Neste artigo presentamos os traballos en lexicografía e terminoloxía a partir de córpora que se están a desenvolver na Universidade de Vigo por parte dos equipos de investigación do Seminario de Lingüística Informática e do Observatorio de Neoloxía, que realizan un labor conxunto orientado á creación de recursos para a lingua galega no marco do grupo TALG (Tecnoloxías e Aplicacións da Lingua Galega). Neste traballo explicaremos as características dos córpora CLUVI e CTG, que constitúen a fonte destes traballos, a metodoloxía seguida para a elaboración do Dicionario CLUVI Inglés-Galego e do Banco de Datos Terminolóxico da Universidade de Vigo, así como os resultados obtidos ata o momento e as tarefas que estamos a realizar e que temos en perspectiva.

\section{CORPUS LINGÜÍSTICO DA UNIVERSIDADE DE VIGO}

o Corpus Lingüístico da Universidade de Vigo (CLUVI) é un conxunto de córpora textuais de traducións en ámbitos específicos da lingua galega contemporánea, accesibles para consulta na web desde setembro de 2003 no enderezo http://sli.uvigo.es/CLUVI/. Cunha extensión actual total superior aos 20 millóns de palabras, o CLUVI está formado por seis

\footnotetext{
Este traballo foi financiado polo Ministerio de Educación y Ciencia e o Fondo Europeo de Desenvolvemento Rexional (FEDER), dentro do proxecto "Deseño e implementacion dun servidor de recursos integrados para o desenvolvemento de tecnoloxías da lingua galega (RILG)" do Plan Nacional de I+D+I, 2006-2009 (ref. HUM2006-11125-C02-01/FILO), proxecto coordinado da Universidade de Vigo (Seminario de Lingüística Informática e Observatorio de Neoloxía) e da Universidade de Santiago de Compostela (Instituto da Lingua Galega).
} 
córpora paralelos principais pertencentes a catro rexistros especializados (dos ámbitos xurídico-administrativo, literario, da informática e de divulgación científica) e a cinco combinacións lingüísticas diferentes (bilingüe galego-español, bilingüe inglés-galego, bilingüe francés-galego, tetralingüe inglés-galego-francés-español e tetralingüe español-galego-cataláneuskara). Estes seis córpora, cos datos actuais sobre a súa extensión, son o Corpus Lega de textos xurídico-administrativos galego-español (6.329.655 palabras), o Corpus Unesco de divulgación científica inglés-galego-francésespañol (3.724.620 palabras), o Corpus Logaliza de localización de software inglés-galego (1.979.687 palabras), o Corpus Tectra de textos literarios inglés-galego (1.476.020 palabras), o Corpus Fega de textos literarios francésgalego (1.267.119 palabras) e o Corpus Consumer español-galego-cataláneuskara de información sobre consumo (5.586.431 palabras) (figura 1).

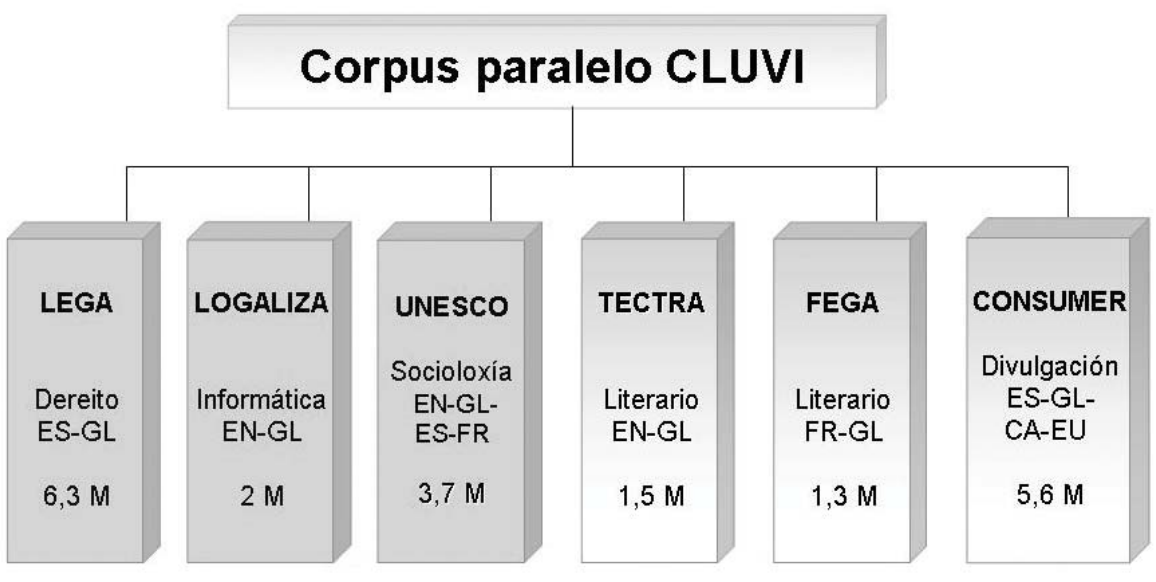

Figura 1. Composición do Corpus CLUVI

O corpus xurídico Lega galego-español contén material textual bilingüe de dous ámbitos especializados da linguaxe xurídica moi próximos, mais ben diferenciados: por unha banda, o ámbito administrativo, representado por 30 exemplares do Diario Oficial de Galicia publicados entre 2000 e 2005; e pola outra banda, o ámbito lexislativo, representado por un conxunto de 62 textos publicados entre 1978 e 2007 con lexislación diversa de ámbito estatal (publicada no Boletín Oficial del Estado) e supraestatal (Constitución Europea). Máis concretamente, as leis e regulamentos publicados no $B O E$ pertencen a distintos eidos dentro do ámbito lexislativo: ao eido xudicial, ao ámbito da Constitución e dos Estatutos, ao eido económico, ao eido social, ao Dereito ambiental, ao Dereito informático e ao ámbito relacionado con sectores específicos (universidades, pesca, circulación, etc.). Os textos que proveñen do DOG suman un 
total de 2.394.407 palabras, mentres que os textos lexislativos, procedentes maioritariamente do BOE, representan un total de 3.935.248 palabras. Por outra parte, o Corpus Logaliza de localización de software inglés-galego contén a localización ao galego do paquete ofimático OpenOffice, do sistema operativo Windows XP de Microsoft e do escritorio Gnome para Linux. O Corpus Unesco inglés-galego-francés-español de divulgación científica está constituído por 32 exemplares íntegros da revista mensual The Unesco Courier / O Correo da Unesco / El Correo de la Unesco / Le Courier de l'Unesco publicados entre 1998 e 2001. O Corpus Consumer español-galego-catalán-euskara de información sobre consumo inclúe 1.036 artigos da revista Consumer Eroski publicados entre 1998 e 2005. Finalmente, o corpus literario Tectra inglés-galego recompila 36 textos literarios en lingua inglesa coas súas traducións para o galego; e o corpus literario Fega francés-galego, 24 textos literarios en lingua francesa coas súas traducións para o galego. Os córpora Tectra inglés-portugués (735.529 palabras), e inglés-español (122.251 palabras), aínda en desenvolvemento, inclúen os textos literarios bilingües do Tectra inglés-galego na súa tradución ao portugués e ao español.

O CLUVI inclúe tamén outros cinco córpora paralelos en distintas fases de elaboración: o Corpus Egal de economía galego-español (718.642 palabras), o Corpus Palop de literatura poscolonial portugués-español (566.590 palabras), o Corpus literario Dega alemán-galego (76.364 palabras), o Corpus Veiga de subtitulación inglés-galego (71.618 palabras) e o Corpus Turigal de turismo portugués-inglés (373.126 palabras), este último aínda non dispoñible publicamente na web. Cómpre salientar que a través da interface do CLUVI se pode acceder tamén á consulta do Corpus Lege-Bi euskara-español de textos xurídico-administrativos (2.384.053 palabras) desenvolvido polo grupo DELi da Universidade de Deusto.

O aliñamento dos textos paralelos almacénase no CLUVI nunha adaptación do formato TMX (Translation Memory eXchange), o estándar para a codificación en XML de memorias de tradución, independentemente da aplicación utilizada. O concepto de memoria de tradución está relacionado coa tradución asistida por ordenador e, máis concretamente, cos escritorios de tradución como Trados, DéjàVu, SDLX, Transit ou Passolo (este último orientado á localización de software). Estes asistentes informáticos para a tradución integran nun único produto un procesador de textos especialmente deseñado para traducir, un conxunto de dicionarios bilingües, ferramentas para a xestión terminolóxica (creación e mantemento de glosarios, consulta automática de glosarios durante a tradución, extracción automática de terminoloxía...), e unha utilidade de memoria 
de tradución. A memoria de tradución é unha base de datos onde se almacenan a versión orixinal e traducida de cada unha das frases que se traducen no marco da aplicación. Cando se está a traducir unha frase, o programa detecta automaticamente se esa mesma frase ou outra similar xa foi traducida con anterioridade, co obxecto de que se poida reutilizar a tradución sen necesidade de reescribila completamente, facendo as modificacións que se consideren máis axeitadas. En 1997 a industria creou e impulsou o estándar TMX para permitir o intercambio de memorias de tradución entre os distintos programas de tradución asistida. Con certas diferenzas, un corpus paralelo aliñado equivale a unha memoria de tradución e, na práctica, existe un número considerable de córpora paralelos aliñados codificados en TMX, coa vantaxe adicional de que os córpora así etiquetados poden ser empregados como memorias de tradución para alimentar os programas de tradución asistida. A xeito de ilustración das características xerais deste formato, amósase a seguir o aliñamento inglés-galego en TMX simplificado das tres primeiras frases de A Perla de Steinbeck, no orixinal inglés e mais na súa tradución ao galego. Obsérvese que, no formato TMX, tanto o orixinal, coma a súa tradución, coma a información sobre os aliñamentos, está todo incluído nun único ficheiro. Nos ficheiros TMX, os segmentos orixinais e traducidos discorren literalmente en paralelo, rodeados por etiquetas que explicitan a súa adscrición lingüística e as súas equivalencias.

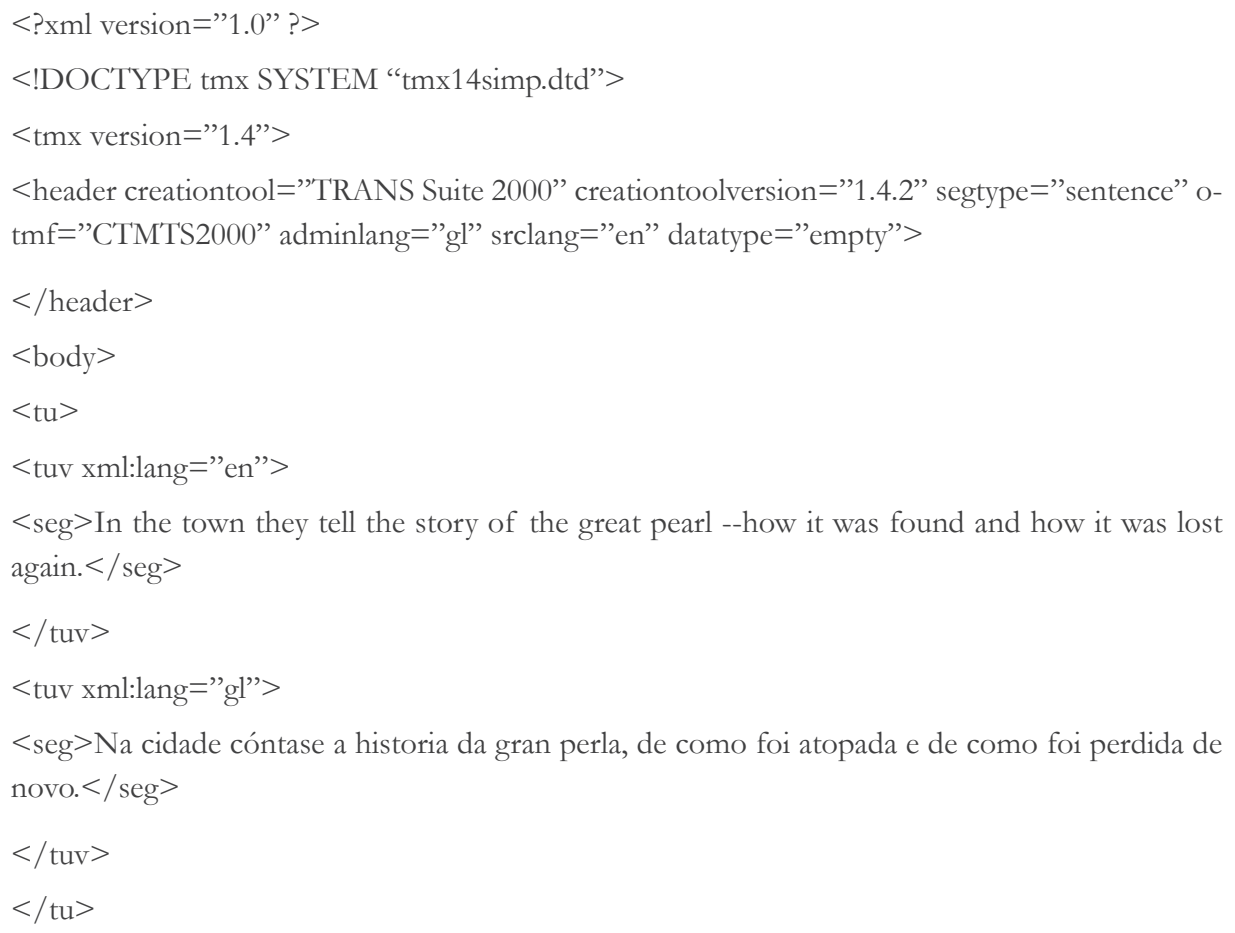




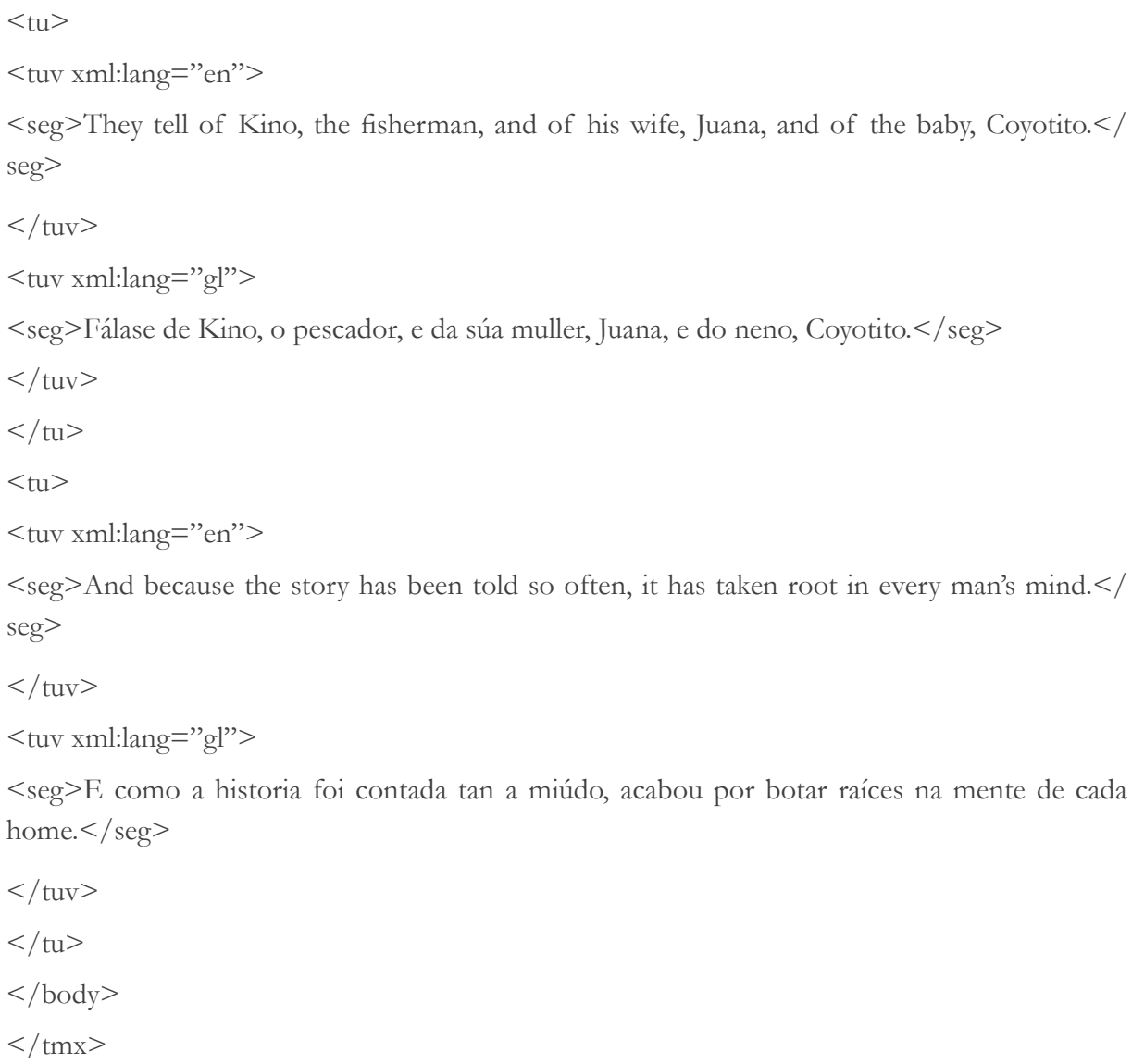

A unidade básica de segmentación para o aliñamento dos bitextos do corpus CLUVI é a frase ortográfica do texto orixinal. Xa que logo, a correspondencia entre o texto orixinal e a tradución vai ser sempre do tipo 1:n. Con frecuencia, a unha frase do orixinal correspóndelle unha frase da tradución (1:1). Porén, danse tamén casos nos que unha frase do orixinal non se traduce (1:0), ou nos que a unha frase do orixinal lle corresponde na tradución media frase $(1: 1 / 2)$ ou dúas frases $(1: 2)$, ou mesmo nos que unha frase da tradución non se corresponde con ningunha frase do orixinal (0:1). Alén diso, a tradución implica ás veces desprazamentos de frases enteiras, ou movementos de fragmentos de frases do orixinal a outras frases na tradución. Estes movementos reordénanse na sección de textos traducidos dos corpus paralelos do CLUVI para cumprir o requisito do aliñamento 1:n, que preserva a integridade e a orde das unidades de tradución do texto orixinal. Este criterio é crucial cando se aplica ao procesamento de córpora plurilingües de máis de dúas linguas, debido a que as frases do orixinal son as que, actuando a modo de intermediarias, nos permiten estabelecer as correspondencias entre as frases equivalentes das distintas linguas. A especificación TMX non ten en conta a 
codificación destes aspectos das traducións, xa que foi deseñada para o almacenamento e intercambio de memorias de tradución, e non para a representación de segmentos equivalentes en córpora paralelos. O sistema de codificación do CLUVI está baseado no TMX, e utiliza unha versión adaptada dalgunhas das etiquetas que forman parte da especificación TMX 1.4b (Savourel 2005) para representar as correspondencias que non son 1:1 (por omisión ou por adición) e os reordenamentos codificados no corpus paralelo.

A ferramenta de busca e visualización a través dunha interface web de consulta, deseñada na linguaxe de programación PHP polo SLI, está concibida para realizar buscas bilingües en textos etiquetados conformes co formato TMX, incluídas as especificacións usadas no CLUVI para as omisións, as insercións e os reordenamentos. Esta aplicación PHP permite facer buscas simples e complexas (con comodíns) de palabras illadas ou de secuencias de palabras, e observar as equivalencias bilingües dos termos pescudados nos seus contextos de uso en traducións reais e documentadas. Os termos buscados poden corresponder a calquera das dúas linguas da tradución, sendo posible tamén realizar consultas autenticamente bilingües, isto é, consultas a partir de dous termos, un de cada lingua, ou mesmo consultas tetralingües, nos casos do corpus Unesco e do corpus Consumer.

\section{DICIONARIO CLUVI INGLÉS-GALEGO}

O Dicionario CLUVI Inglés-Galego (CLIG) é un dicionario baseado na colección de textos ingleses traducidos ao galego que forma parte do Corpus CLUVI e constitúe, ao noso entender, o primeiro dicionario baseado en córpora da lexicografía galega. Todas as palabras inglesas que aparecen nas súas entradas están documentadas nos textos en inglés traducidos ao galego recompilados no CLUVI. Alén diso, todas as traducións galegas recollidas no dicionario para esas palabras son traducións reais identificadas nas versións galegas dos textos ingleses do corpus. Finalmente, para cada tradución identificada, o dicionario fornece un exemplo real do seu uso tal como está documentado no corpus.

Desde o ano 2005 está dispoñible na web, no enderezo http://sli.uvigo. es/CLIG/, a primeira edición deste dicionario, que na súa versión 1.5 (2006) alcanza as 6.677 entradas e 10.807 traducións. Aínda que as entradas desta primeira edición están redactadas só na dirección de tradución inglés-galego, o sistema de busca implementado permite recuperar tamén as entra- 
das a partir das súas traducións ao galego. Nestes momentos, o SLI esta a completar a segunda edición do dicionario, cuxa publicación está prevista para o último cuarto de 2008. Esta segunda edición no prelo incorpora ao dicionario un maior número de entradas e equivalencias tiradas do corpus (ao redor de 20.000 entradas e 40.000 traducións), ao tempo que amplía os datos lexicográficos contidos nas entradas con información sobre os americanismos do inglés e con notas de interese gramatical, tradutolóxico e normativo, co obxectivo de que a ferramenta resultante poida ser realmente útil tanto na docencia do inglés como na tradución inglés-galego.

A extracción de léxico bilingüe a partir do corpus Tectra, que serviu de base á xeración do dicionario tivo lugar en catro fases: anotación do corpus coas equivalencias de tradución entre frases, preparación do corpus para a extracción (fase de preedición), extracción léxica bilingüe automática, e edición manual dos resultados da extracción (fase de postedición). O problema central da extracción automática de léxico bilingüe consiste en converter un corpus paralelo anotado cos aliñamentos a nivel de oración (isto é, coas equivalencias oracionais de tradución) nun corpus etiquetado paralelo cos aliñamentos a nivel de palabra (isto é, coas equivalencias léxicas de tradución). Para acadar esta tarefa, existen diversos algoritmos baseados principalmente en medidas estatísticas relacionadas coa asociación mutua ou coa coaparición dos elementos léxicos nas frases bilingües aliñadas (Och / Ney 2003). Todos estes algoritmos presentan unha marxe de erro considerable nos resultados (Tiedemann 2003) por mor da natureza intrinsecamente "non literal" da tradución e doutras dificultades relacionadas coas características dos córpora, como a distancia lingüística entre as linguas implicadas, o tipo de textos ou o estilo da tradución. Para tentar superar as limitacións da extracción léxica baseada unicamente nos aliñamentos oracionais, codificamos no corpus paralelo a información tradutolóxica sobre asimetrías de tradución (aliñamentos non biunívocos e alteracións de orde na tradución), e preeditamos o corpus mediante a eliminación de diversos elementos que posúen unha incidencia directa nos erros da extracción (segmentos de texto marcados como omisións ou adicións, signos de puntuación agás os guións de unión de palabras compostas, díxitos e palabras gramaticais cun alto índice de frecuencia). A partir da versión preeditada do corpus paralelo, realizouse a extracción léxica bilingüe automática utilizando como ferramenta o programa de aliñamento léxico NATools (Simões / Almeida 2003). Este programa calcula o índice de correlación entre as coaparicións dos elementos léxicos nas oracións bilingües aliñadas e ofrece como saída da extracción un dicionario probabilístico inglés-galego consistente nunha lista bilingüe de todas 
as palabras distintas que aparecen nos textos en inglés do corpus, cada unha delas acompañada da súa frecuencia absoluta no corpus e de ata oito palabras en galego consideradas polo aliñador como traducións máis probables. Para cada palabra galega do léxico bilingüe xerado indícase un índice estimativo da correlación entre a súa presenza nunha frase e a presenza da palabra inglesa orixinal na frase aliñada correspondente, é dicir, un estimativo da probabilidade de coaparición dos dous elementos léxicos (o inglés e o galego) nunha mesma unidade oracional de tradución. Por último, e coa finalidade de mellorar a calidade dos resultados do programa, elaboramos un "filtro de fiabilidade" para eliminar do dicionario bilingüe probabilístico xerado os candidatos de tradución menos fiables. Os estatísticos que se comproban na peneira do dicionario posterior á extracción léxica son a frecuencia absoluta do lema e a probabilidade da súa tradución máis probable. O valor concreto destes dous estatísticos é un heurístico calculado a partir da avaliación dos resultados en bruto do programa (Gómez Guinovart / Sacau 2005).

O dicionario probabilístico resultante da aplicación do filtro de fiabilidade á extracción léxica automática ten que ser editado manualmente co obxectivo de mellorar a súa precisión, eliminando as traducións erróneas que pasaran o primeiro filtrado automático, e engadindo correspondencias correctas documentadas no CLUVI, pero que non aparecen no dicionario xerado, ben por non formar parte do conxunto de traducións elixido (isto é, das seleccionadas polo aliñador NATools como primeira ou segunda opción), ben por seren palabras gramaticais frecuentes eliminadas no proceso de preedición do corpus. Nesta fase de postedición do dicionario, engadíronse as categorías gramaticais correspondentes á palabra de orixe, así como un exemplo para cada tradución coa súa referencia tirada do CLUVI. A primeira versión da primeira edición do Dicionario CLIG (a versión 1.0), que recollía un total de 5.324 entradas e 7.998 traducións, publicouse na web en maio de 2005. Nas versións posteriores a esta primeira edición, fóronse engadindo paulatinamente os lemas documentados nos textos paralelos inglés-galego do CLUVI (principalmente, nos córpora Tectra e Unesco, pero tamén nos córpora Logaliza e Veiga) que constaban en diversos vocabularios básicos da lingua inglesa mais que, por diversas razóns, non aparecían aínda recollidos como entradas do dicionario, ata chegar á listaxe da segunda edición (2008, no prelo) que alcanza as 20.000 entradas e 40.000 traducións.

O Dicionario CLIG está almacenado nun formato interno codificado en $\mathrm{XML}$, consonte o cal cada entrada do dicionario inclúe ademais do lema en inglés un conxunto de informacións tradutolóxicas agrupadas en función 
das posibles categorías gramaticais do lema. Cada un destes conxuntos (denominados super_cat na codificación utilizada) pode conter unha ou máis acepcións, dependendo da polisemia de cada lema en cada categoría gramatical. A información agrupada en cada acepción inclúe a tradución ao galego, un exemplo de uso documentado no CLUVI e, opcionalmente, a expresión plurilexemática da que forma parte o lema cando é o caso. Por último, cada exemplo consta dun fragmento textual do corpus Tectra en inglés, a súa tradución ao galego e a referencia da obra na que se documenta o exemplo. De maneira opcional, as entradas poden incluír información sobre os americanismos do inglés e notas á entrada; e as acepcións poden conter notas normativas ou de tradución. Deste xeito, cada entrada do dicionario pode incluír unha ou máis categorías gramaticais cunha tradución ou máis, sendo codificada internamente en XML, como se ilustra a seguir mediante un exemplo:

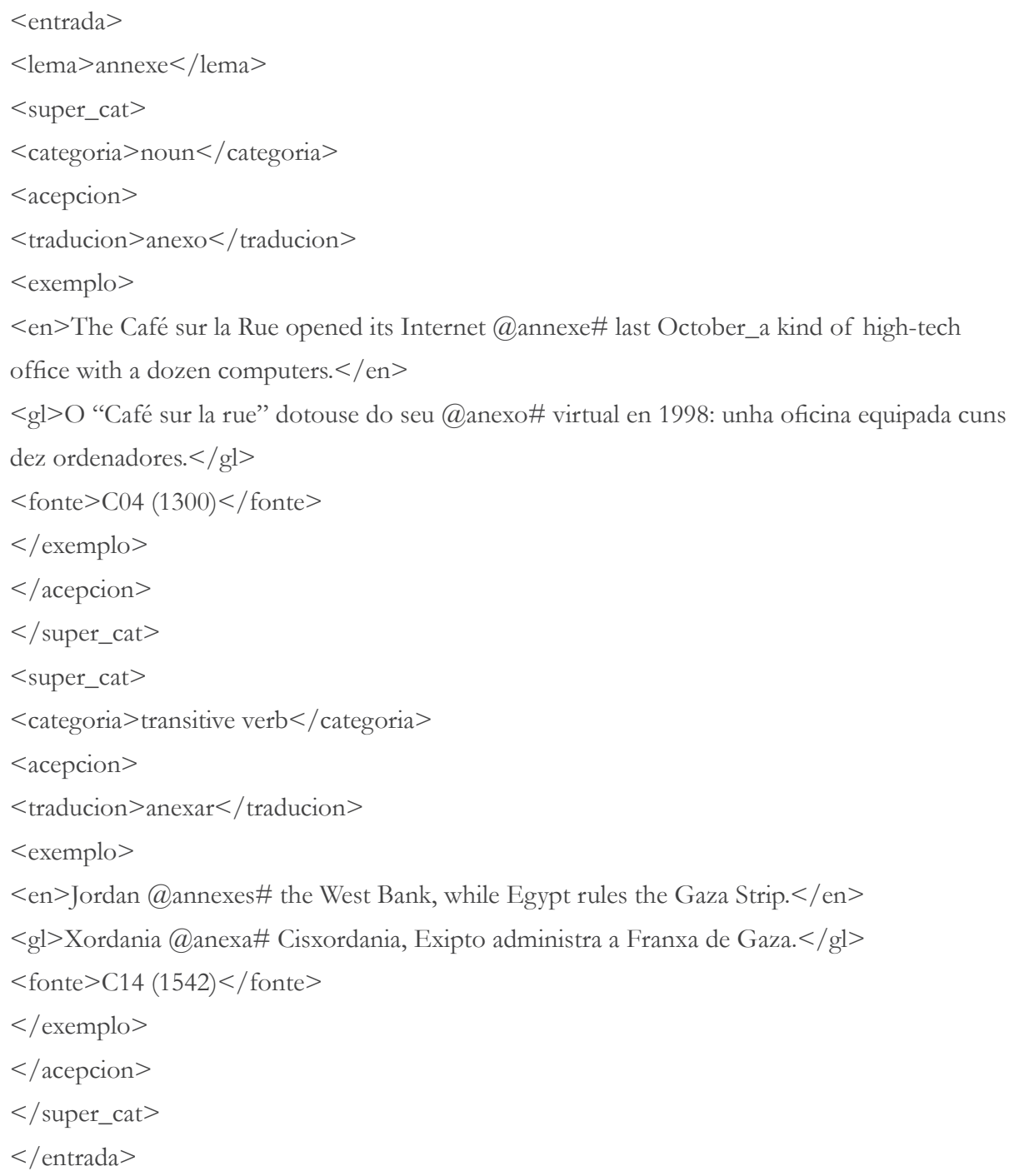


Este formato interno pódese consultar e converter a distintos formatos de presentación de acordo cos requisitos lexicográficos precisos en cada caso. Así, na versión para a web do dicionario, o dicionario en XML é procesado mediante un programa en PHP que permite a consulta interactiva do dicionario e a presentación dinámica dos resultados xerados en HTML para a súa visualización, como se pode comprobar realizando a consulta da calquera palabra inglesa na web do dicionario (http://sli.uvigo.es/CLIG/). Tamén se poden xerar presentacións das entradas aplicando follas de estilo XSL directamente sobre o formato XML, con resultados como o que se mostra a continuación:

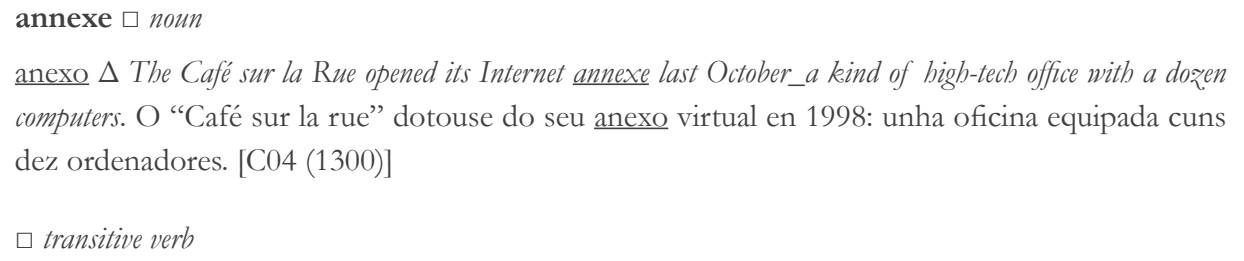

Neste exemplo de presentación impresa, as distintas categorías dunha entrada introdúcense mediante o cadrado, as acepcións inician parágrafo e van subliñadas, mentres que os exemplos van precedidos dun triángulo e, nun corpo de letra máis pequeno, conteñen a frase en inglés en cursiva, a súa tradución ao galego en redonda, e levan ao final entre corchetes a referencia bibliográfica abreviada da fonte (obra e número de frase). Nos restantes exemplos, ilustramos diferentes tipos de información lexicográfica codificada no dicionario: fraseoloxía, americanismos, notas ás entradas e notas ás acepcións. Todos os exemplos forman parte da segunda edición do dicionario:

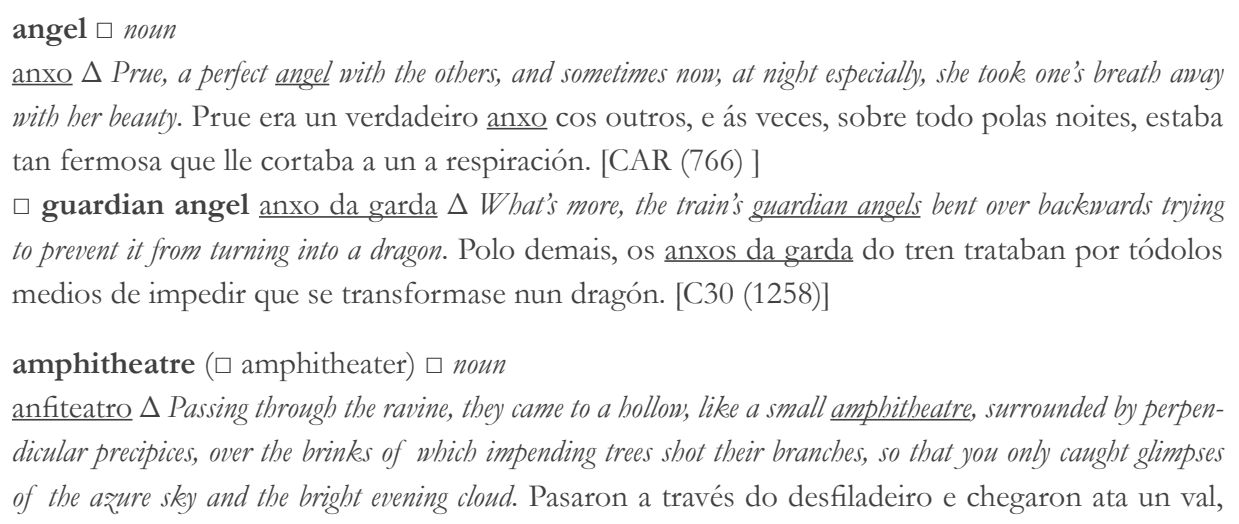


que era coma un pequeno anfiteatro, rodeado de precipicios verticais, con árbores próximas ó bordo, que proxectaban as súas pólas, polo que a penas se podía albisca-lo azul do ceo e as nubes brillantes da noitiña. [RIP (81)]

actual $\square$ adverb $\square$ O inglés actual nunca debe traducirse polo galego actual. Para este significado, o inglés emprega ou ben current ou present.

real $\Delta$ And yet was he to accuse Miss Daisy Miller of actual or potential inconduite, as they said at Geneva? E sen embargo, cía el acusar a Miss Daisy Miller de inconduite real ou potencial, como dicían en Xenebra? [DAI (216) ]

auténtico $\Delta$ At most, by an alms given to a beggar whose blessing he fled from, he might hope wearily to win for bimself some measure of actual grace. Todo o máis, ao dar unha esmola a un mendigo de cuxa benzón fuxira, podería agardar, con canseira, conseguir certa medida de auténtica gracia. [RET (2146) ] verdadeiro $\Delta$ The tortures endured, however, were indubitably quite equal for the time, to those of actual sepulture. Con todo, as torturas sufridas naqueles momentos foran indubidablemente iguais ás dun verdadeiro enterro. [BUR (249)]

ache $\square$ noun

dor $\square$ A diferenza entre ache e pain consiste en que a primeira refírese a unha dor intensa e xeralizada (a cabeza, a espalda, as moas) mentres que a segunda supón unha dor máis localizada, p.ex., nun brazo. $\Delta$ He felt only an ache of soul and body, his whole being, memory, will, understanding, flesh, benumbed and weary. Sentía soamente dor de corpo e alma: todo o seu ser, memoria, vontade, intelecto, carne, atordoado e canso. [ RET (2751) ]

pena $\Delta$ They sat with bowed heads, dead to all things but the ache at their hearts. Estaban sentados coa cabeza gacha, insensibles a todo agás á pena dos seus corazóns. [LEG (668)]

$\square$ intransitive verb

doer $\Delta$ Her head began to ache, and the lights on the altar swayed before her eyes. Empezoulle a doe-la cabeza, e a notar como as luces do altar oscilaban ante os seus ollos. [ESP (953)]

\section{CORPUS TÉCNICO DO GALEGO}

O Corpus Técnico do Galego (CTG) é unha colección de córpora do galego contemporáneo composta de textos monolingües especializados nos eidos do dereito, da informática, da economía, das ciencias ambientais, da socioloxía e da medicina, dispoñible desde 2006 para libre consulta no enderezo http://sli.uvigo.es/CTG/. Cunha extensión actual duns 12 millóns de palabras, o CTG está constituído polo Corpus Galex de textos xurídicoadministrativos en galego (2.516.846 palabras), o Corpus Xiga de textos de informática e telecomunicacións en galego (2.027.816 palabras), o Corpus Auga de textos de ecoloxía e ciencias ambientais en galego (2.349.362 palabras), o Corpus Achega de textos de economía en galego (2.055.837 palabras), o Corpus Sogal de textos de socioloxía en galego (2.442.765 palabras) e o Corpus Medigal de textos de medicina en galego (en fase de construción) (figura 2). 


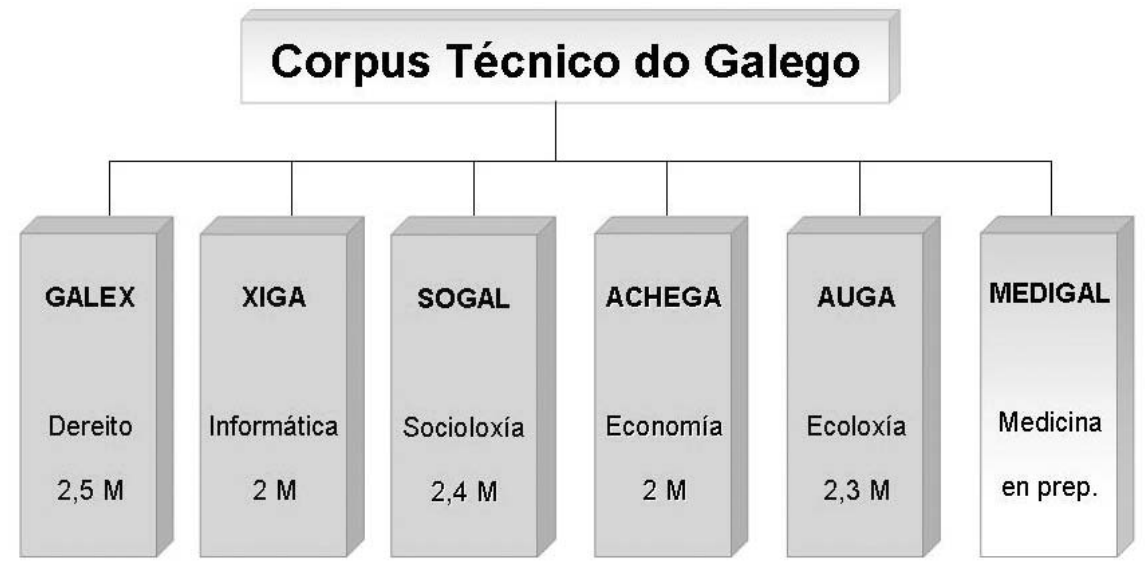

Figura 2. Composición do Corpus CTG

O corpus de dereito Galex recompila 72 textos lexislativos (leis, decretos, regulamentos) de ámbito autonómico, estatal e supraestatal, publicados entre 1998 e 2006. O corpus de informática Xiga contén 2450 textos sobre informática publicados entre 1997 e 2007, tirados de manuais, axudas, menús e mensaxes de programas (Proxecto Xis, Trasno, OpenOffice, Windows); de textos académicos e de divulgación (Galipedia, servizos informáticos universitarios, artigos en libros e revistas científicas); dos medios de comunicación especializados (Díxitos, Fwwwrando-Vieiros, Código Cero, Océano Internet-Galicia Hoxe), e de roldas, foros, grupos de novas e blogues. O corpus de economía Achega consta de 210 textos de economía publicados entre 2000 e 2007, tirados de convenios colectivos (banca, caixas de aforro, seguros), lexislación, libros, artigos (Revista Galega de Economía, Terra e Tempo), informes (Instituto Universitario de Estudos e Desenvolvemento de Galicia/IDEGA) e traballos académicos (teses de doutoramento, actas de congresos). O corpus Auga de ecoloxía e ciencias ambientais recolle 853 textos de ecoloxía publicados entre 1999 e 2007, e está formado por lexislación ambiental, libros, artigos, teses e traballos académicos, informes e guías, de fontes como a Federación Ecoloxista Galega, a Coordinadora para o Estudo dos Mamíferos Mariños/CEMMA, a Asociación para a Defensa Ecolóxica de Galiza/ADEGA, a Sociedade Galega de Historia Natural, a Consellaría de Medio Ambiente e a propia Universidade de Vigo. Por último, o corpus de socioloxía componse de 569 textos publicados entre 2000 e 2007 correspondentes a informes, artigos académicos e de opinión, e procedentes de diversas fontes, como a Xunta de Galicia, o Instituto Galego de Estatística, o Consello Económico e Social de Galicia, Altermundo.org, o Proxecto Galicia 2010, o Observatorio Galego dos Medios e a revista Andaina. 
O CTG está almacenado no formato XML, anotado con información bibliográfica e temática, e segmentado en frases. A aplicación desenvolvida en PHP que realiza as buscas no CTG a través da interface web pública permite facer consultas de palabras ou grupos de palabras, utilizar comodíns para efectuar buscas complexas, e especificar o subconxunto específico do corpus ao que se desexa cinguir a pescuda. Na actualidade, o CTG está a ser anotado con información sobre o lema e a categoría morfosintáctica das palabras. O conxunto de etiquetas utilizado para indicar as categorías das palabras baséase nas etiquetas propostas polo grupo Eagles (Leech / Wilson 1996) para a anotación morfosintáctica de léxicos e córpora para todas as linguas europeas. Velaquí, a xeito de exemplo, un fragmento tirado do CTG na súa versión anotada e sen anotar ${ }^{1}$ :

\footnotetext{
$<$ frase $>$ Galicia é a primeira Comunidade Autónoma pesqueira do Estado español, o sector pesqueiro representa o $8 \%$ do PIB e o $5 \%$ da poboación activa, estas cifras a pesar de estar en consonancia coa importancia do litoral a nivel mundial, o $40 \%$ da poboación do mundo vive nas zonas costeiras, presenta unhas cifras moi por enriba de calquera dos outros países comunitarios. $</$ frase $>$
}

\begin{abstract}
$<$ frase $>$ Galicia/Galicia_NP00000 é/ser_VIP3S00 a/o_AFS primeira/primeiro_NO0FS Comunidade/Comunidade_NCFS000 Autónoma/Autónomo_A0FS0 pesqueira/pesqueira_A0FS0 do/de_SPS00 /o_AMS Estado/estado_NCMS000 español/español_A0MS0 ,/,_Fc o/o_AMS sector/sector_NCMS000 pesqueiro/pesqueiro_A0MS0 representa/representar_VIP3S00 o/o_ AMS 8/8_Z\%/\%_Ft do/de_SPS00 /o_AMS PIB/PIB_NCMS000 e/e_CC o/o_AMS 5/5_Z $\% / \%$ $\%$ t da/de_SPS00 /O_AFS poboación/poboación_NCFS000 activa/activo_A0FS0 ,/,_FC estas/este_DFP0 cifras/cifra_NCFP000 a pesar de/a pesar de_CS estar/estar_VN00000 en consonancia/en consonancia_R0 coa/con_SPSO0 /O_AFS importancia/importancia_NCFS000 do/de_SPSO0 /O_AMS litoral/litoral_A0CS0 a/a_SPS00 nivel/nivel_NCMS000 mundial/ mundial_A0CS0,/,_Fc o/o_AMS 40/40_Z \%/\%_Ft da/de_SPS00 /o_AFS0 poboación/poboación_NCFS000 do/de_SPS00 /o_AMS mundo/mundo_NCMS000 vive/vivir_VIP3S00 nas/en_SPSO0 /o_AFP zonas/zona_NCFP000 costeiras/costeiro_A0FP0 ,/,_Fc presenta/ presentar_VIP3S00 unhas/un_IFP0 cifras/cifra_NCFP000 moi/moi_R0 por/por_SPS00 enriba/enriba_R0 de/de_SPS00 calquera/calquera_INS0 dos/de_SPS00 /o_AMP outros/outro_ IMP0 países/país_NCMP000 comunitarios/comunitario_A0MP0 ./._Fp $</$ frase $>$
\end{abstract}

\title{
5. BANCO DE DATOS TERMINOLÓXICO DA UNIVERSIDADE DE VIGO
}

O Banco de Datos Terminolóxico da Universidade de Vigo (TUVI) é unha base de datos terminolóxica baseada nos textos de especialidade mono-

1. Fragmento incluído na sección de ecoloxía e ciencias ambientais do CTG e pertencente á tese de doutoramento de Alfredo López Fernández, Estatus dos pequenos cetáceos da plataforma de Galicia, dirixida por Ángel Guerra Sierra e Graham J. Pierce, e presentada na Facultade de Bioloxía da Universidade de Santiago de Compostela en 2003. 
lingües e paralelos recompilados nos córpora da Universidade de Vigo, isto é, no Corpus Lingüístico da Universidade de Vigo (CLUVI) e no Corpus Técnico de Galego (CTG). Esta base de datos terminolóxica, de libre acceso na web no enderezo http://sli.uvigo.es/TUVI, está mantida polo Seminario de Lingüística Informática e polo Observatorio de Neoloxía da Universidade de Vigo e conta, na actualidade, con 5.625 termos documentados nos córpora CLUVI e CTG pertencentes aos ámbitos do dereito (1411 entradas bilingües e monolingües), da socioloxía (954 entradas tetralingües e monolingües), da economía (1163 entradas monolingües) e da ecoloxía (1324 entradas monolingües). Todos os termos incluídos no TUVI están documentados nos córpora, estando en fase de realización os inventarios terminolóxicos dos eidos da informática e da medicina. A figura 3 representa en forma gráfica o proceso de baleirado terminolóxico dos textos que se segue para a elaboración da base de datos terminolóxica a partir dos córpora da Universidade de Vigo utilizados como fonte.

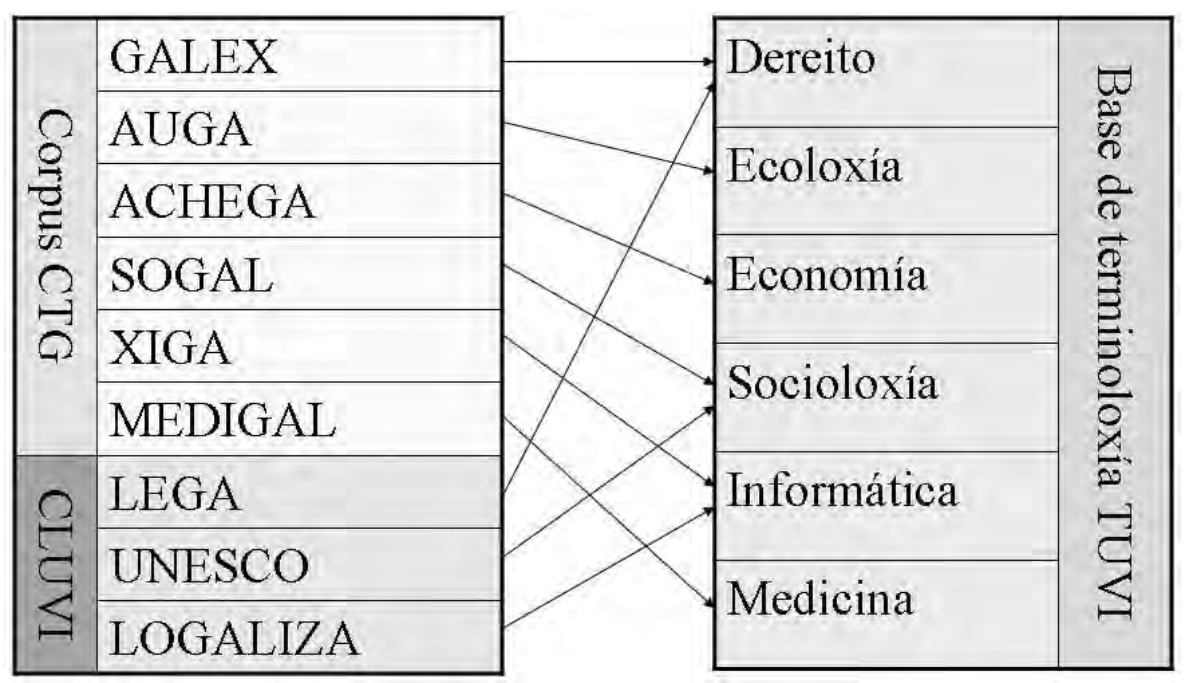

Figura 3. Fontes do Banco de Datos Terminolóxico TUVI.

Neste proceso de baleirado, a identificación no corpus das unidades terminolóxicas dun dominio realízase en dúas fases. Na primeira fase, analízanse as palabras e as secuencias de ata catro palabras máis frecuentes no corpus da especialidade. Mediante a revisión humana destas combinacións léxicas de maior frecuencia é posible identificar os termos máis prominentes nun ámbito. Por exemplo, analizando o Corpus Auga de ecoloxía e ciencias ambientais, pódense detectar termos frecuentes neste ámbito como residuos (5.900 veces no corpus), especies (2.464 veces), impacto ambiental (903 veces), avaliación ambiental (508 veces), calidade do aire (274 veces), plan de xestión (223 veces), organismos modificados xe- 
neticamente (214 veces), avaliación de impacto ambiental (247 veces) ou gases de efecto invernadoiro (220 veces). Nesta primeira fase de baleirado, ademais das listas das frecuencias absolutas no corpus das combinacións léxicas analizadas, analízanse tamén as atraccións léxicas mediante o sistema estatístico Senta de extracción de candidatos a termos pluriléxicos, que calcula o grao de asociación entre unidades textuais contigua mediante un modelo probabilístico coñecido como expectación mutua (Dias / Guilloré / Lopes 2000).

Os resultados revisados da extracción estatística complétanse, na segunda fase da identificación das unidades terminolóxicas, comprobando a existencia no corpus dos termos recompilados no material bibliográfico de referencia ausentes da lista elaborada durante a primeira fase. Deste xeito, a selección das entradas do TUVI inclúe, ao carón das unidades terminolóxicas máis frecuentes no corpus e das que presentan un maior grao de asociación, os termos que, malia teren unha escasa frecuencia no corpus e/ou un baixo índice de asociación, son considerados fundamentais polo feito de estaren censados nun traballo terminolóxico de referencia no ámbito de estudo.

No TUVI a información terminolóxica está estruturada ao redor dos conceptos. Cada ficha do TUVI inclúe toda a información relativa a un concepto, expresado cun termo galego do que se poden recoller tamén variantes, tanto intralingüísticas (termos sinónimos, variantes ortográficas ou variantes dialectais) coma interlingüísticas (traducións ou, con maior propiedade, equivalencias). A información recollida para cada variante (incluíndo a variante común ou non marcada) inclúe o lema do termo, a súa categoría gramatical, a súa definición e un contexto de uso documentado no corpus. As fichas ou conceptos da base de datos están agrupadas segundo o seu campo temático, dentro da póla correspondente dunha árbore conceptual xerarquizada da materia. Alén diso, os conceptos da base de datos constitúen unha rede léxico-semántica pola que se pode navegar, e onde os nós conceptuais interrelacionan entre si en función das relacións semánticas (antonimia, hiperonimia, holonimia, etc.) que se establecen entre eles.

Formalmente, o TUVI almacénase internamente nunha estrutura XML que se ilustra deseguido mediante un exemplo simplificado da ficha para o concepto que recolle os termos gas invernadoiro e gas de efecto invernadoiro: 
$<\mathrm{cc}>$

$<$ ic $>666406</$ ic $>$

$<$ rs tipo-rs="caus" $>66673</$ rs $>$

$<$ rs tipo-rs="hipo" $>666405</$ rs $>$

$<$ ct st="Text" $>$ AUGA.3.2.3.3</ct $>$

$<\lg$ xml:lang="gl">

$<$ var tipo $=$ "com">

$<$ lema $>$ gas de efecto invernadoiro $</$ lema $>$

$<$ cat valor $=$ "'m" $></$ cat $>$

$<\operatorname{ex}>$

<texto_ex>1) Tonelada equivalente de dióxido de carbono: unha tonelada métrica de dióxido de carbono (CO2) ou unha cantidade de calquera outro | gas de efecto invernadoiro\# recollido no anexo II cun potencial equivalente de quentamento do planeta. $</$ texto_ex $>$

$<$ fonte_ex $>$

$<$ obra $>$ A $1018</$ obra $>$

$<$ num $>50618</$ num $>$

$</$ fonte_ex $>$

$</$ ex $>$

$<$ frec $>$

$<$ fab $>5</$ fab $>$

< vcorpus $>20.09 .06</$ vcorpus $>$

$<$ palcorpus $>1604417</$ palcorpus $>$

$</$ frec $>$

$</ \operatorname{var}>$

$<$ var tipo="morf" $>$

$<$ lema $>$ gas invernadoiro $</$ lema $>$

$<$ cat valor $=$ "m" $></$ cat $>$

$<\operatorname{ex}>$

<texto_ex>O dióxido de carbono ( C O2) é o principal | gas invernadoiro\# e emítese, de forma inevitábel, ao queimarmos combustíbeis fóseis (carbón, petróleo e gas). $</$ texto_ex $>$

$<$ fonte_ex $>$

$<$ obra $>$ A $031</$ obra $>$

$<$ num $>477</$ num $>$

$</$ fonte_ex $>$

$</$ ex $>$

$<$ frec $>$

$<$ fab $>1</$ fab $>$

< vcorpus $>20.09 .06</$ vcorpus $>$

$<$ palcorpus $>1604417</$ palcorpus $>$

$</$ frec $>$

$</$ var $>$

$</ \lg >$

$</ \mathrm{cc}>$ 
Nesta estrutura de ficha terminolóxica, cada concepto (etiquetado como cc) está indexado mediante o seu índice conceptual (ic), un número único que identifica como un conxunto toda a información terminolóxica contida nunha ficha. No exemplo, o índice conceptual da ficha é o 666406. Un concepto pode establecer relacións semánticas ( $r s$ ) con outros conceptos da base de datos. No exemplo, o concepto correspondente a esta ficha establece unha relación de causa-efecto co concepto correspondente ao índice conceptual 66673 (o da ficha terminolóxica que recolle o concepto correspondente ao termo efecto invernadoiro) e unha relación de hiponimia co concepto 666405 (gas).Cada concepto está asignado a unha póla da árbore conceptual correspondente á súa especialidade. No exemplo, o concepto 666406 está asignado ao campo temático dos gases contaminantes, que comparte con conceptos relacionados cos termos monóxido de carbono e gas de vertedoiro, entre outros. A ficha para cada concepto pode conter información sobre un ou máis termos sinónimos, nunha soa lingua ou en máis dunha lingua. A información terminolóxica relativa a cada lingua está agrupada dentro da etiqueta lg especificada mediante un atributo xml:lang que adopta o valor do código ISO de dúas letras da lingua en cuestión. Cada un dos termos nunha lingua representa unha variante lingüística do concepto nesa lingua, podéndose tratar dunha variante común, dunha variante por sinonimia, dunha variante (orto)gráfica ou dunha variante dialectal. Toda a información relativa a unha variante está contida dentro da etiqueta var, especificada mediante un atributo tipo que adopta o valor correspondente ao tipo concreto de variante. No exemplo, a información relativa ao galego contén dúas variantes, a variante común e unha variante morfolóxica desta. Cada variante inclúe o lema para o termo, a súa categoría gramatical e un contexto de uso documentado no corpus. No exemplo, a primeira variante para o galego, que é de tipo sinonímico, é para o lema gas de efecto invernadoiro, de categoría $m$ (substantivo masculino). Os datos sobre o exemplo están separados en dúas partes: o (con)texto seleccionado (indicado coa etiqueta texto_ex) e a fonte do exemplo que, á súa vez, se divide en obra e número de frase. Os datos sobre a frecuencia de uso inclúen a frecuencia absoluta do termo (etiqueta fab) e a versión (vcorpus) e o tamaño (palcorpus) do corpus no momento do recoller esta información.

Como se explicou con anterioridade, este formato XML interno pódese converter a distintos formatos lexicográficos de presentación en función das necesidades. Así, na ferramenta de consulta na web, a base de datos terminolóxica é procesada por un programa informático en PHP que presenta os resultados da consulta en forma de táboa, como se mostra a continuación: 


\begin{tabular}{|c|c|}
\hline $\operatorname{Ref} . \underline{66406}$ & \\
\hline Campo temático: & $<$ AUGA.3.2.3.3/3.2.3.3. Gases contaminantes $>$ \\
\hline Relacións semánticas: & {$[$ caus $=>\underline{66673}][$ hipo $=>\underline{666405}]$} \\
\hline Termo GL: & gas de efecto invernadoiro \\
\hline Categoría: & $\mathrm{m}$ \\
\hline Variante: & com \\
\hline Frecuencia relativa: & 3.11639679709 \\
\hline Contexto de uso: & $\begin{array}{l}\text { 1) Tonelada equivalente de dióxido de carbono: unha tonelada métrica } \\
\text { de dióxido de carbono }\left(\mathrm{CO}^{2}\right) \text { ou unha cantidade de calquera outro gas } \\
\text { de efecto invernadoiro recollido no anexo II cun potencial equivalente de } \\
\text { quentamento do planeta. }[\underline{\mathrm{A} 1018}]\end{array}$ \\
\hline Ver contextos no CTG: & $\begin{array}{l}\text { Procurar máis exemplos (algún dos exemplos do termo no corpus poden } \\
\text { non corresponder ao concepto da ficha) }\end{array}$ \\
\hline Termo GL: & gas invernadoiro \\
\hline Categoría: & $\mathrm{m}$ \\
\hline Variante: & morf \\
\hline Frecuencia relativa: & 0.623279359418 \\
\hline Contexto de uso: & $\begin{array}{l}\text { O dióxido de carbono }\left(\mathrm{CO}^{2}\right) \text { é o principal gas invernadoiro e emítese, de } \\
\text { forma inevitábel, ao queimarmos combustíbeis fóseis (carbón, petróleo } \\
\text { e gas). [ } \underline{\mathrm{A} 031}]\end{array}$ \\
\hline Ver contextos no CTG: & $\begin{array}{l}\text { Procurar máis exemplos (algún dos exemplos do termo no corpus poden } \\
\text { non corresponder ao concepto da ficha) }\end{array}$ \\
\hline
\end{tabular}

As relacións semánticas entre termos codificados no TUVI son as de antonimia (esfera pública/esfera privada), hiponimia (educación primaria/educación), hiperonimia (explotación/escravitude), secuencialidade temporal anterior (adolescencia/xuventude), secuencialidade temporal posterior (eleccións/campaña electoral), axente (debedor/débeda), produto (emigración/emigrante), causa (medios de comunicación/comunicación), efecto (quecemento do planeta/contaminación), instrumento (lei/ xustiza), fin (saúde/medicina), meronimia (folklore/cultura) e holonimia (ideoloxía/crenza). A través dos enlaces da presentación web das fichas é posible percorrer os nodos conceptuais seguindo as relacións semánticas indicadas. O TUVI pode concibirse, logo, como unha rede léxico-semántica a dous niveis formada por nós conceptuais que interrelacionan entre si en función da súa clasificación temática e das súas relacións semánticas (figura 4). 


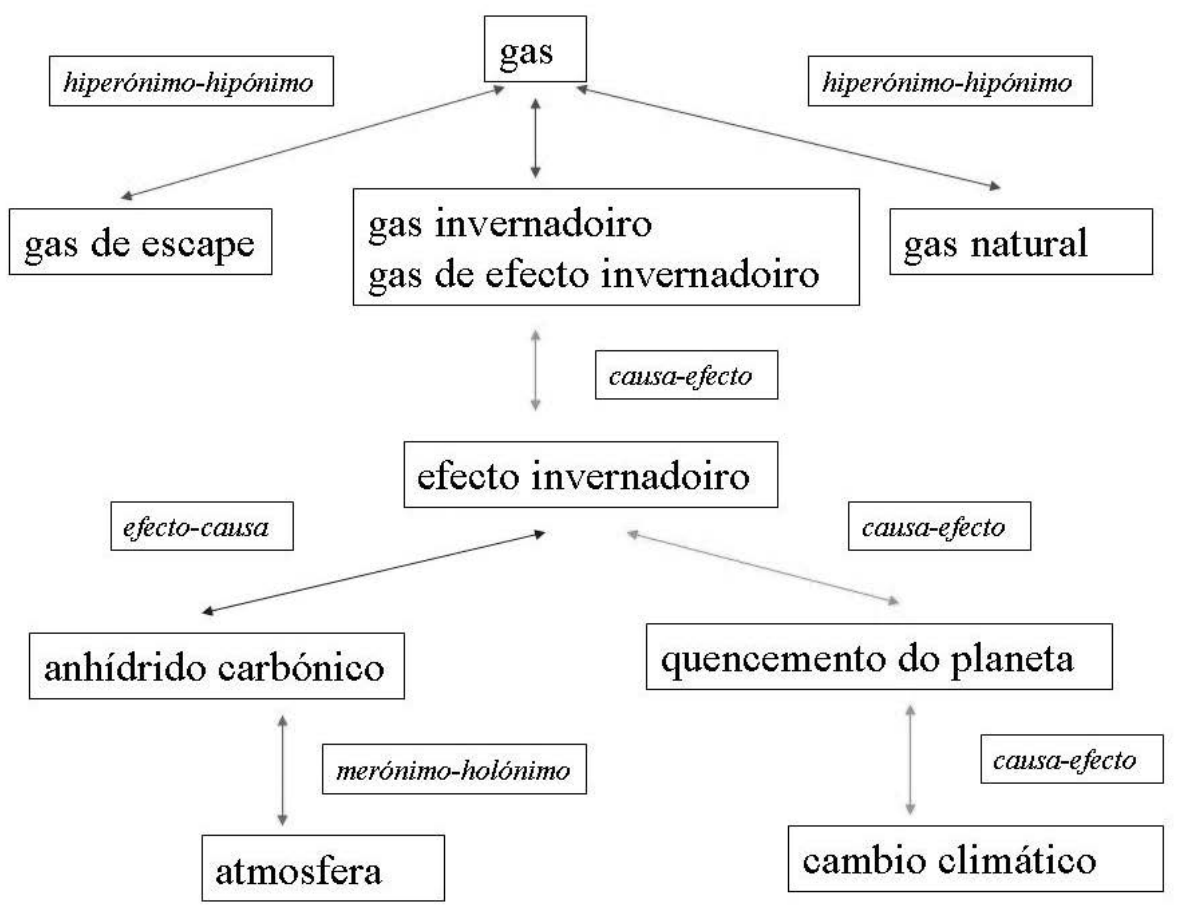

Figura 4. Relacións semánticas entre nós do TUVI

\section{PERSPECTIVAS}

Nestes momentos, os nosos esforzos de investigación no eido da lexicografía e a terminoloxía baseadas en córpora están centrados na ampliación dos córpora CLUVI e CTG (que supón a incorporación de novos textos, de novos campos especializados e de máis información lingüística), na segunda edición do Dicionario CLUVI Inglés-Galego, e na extensión da información terminolóxica do TUVI aos ámbitos da informática e da medicina.

Simultaneamente, estamos a traballar xunto co Instituto da Lingua Galega da Universidade de Santiago de Compostela no proxecto RILG (Recursos Integrados para o desenvolvemento de tecnoloxías da Lingua Galega), un proxecto encamiñado a ofrecer un portal web de servizos lingüísticos do galego desde o que se poida acceder de xeito conxunto aos bancos textuais e aos dicionarios desenvolvidos polo Seminario de Lingüística Informática e o Observatorio de Neoloxía da Universidade de Vigo e polo Instituto da Lingua Galega. Os recursos que se pretende integrar neste servizo inclúen o Tesouro Informatizado da Lingua Galega (TILG), o Tesouro Medieval Informatizado da Lingua Galega (TMILG), o Corpus CLUVI, o Corpus Técnico do Galego (CTG), o Dicionario de Dicionarios 
(DD) (Santamarina 2003b), o Dicionario de Dicionarios do Galego Medieval (DDGM) (González Seoane 2006), o Dicionario CLUVI Inglés-Galego (CLIG), o Banco de Datos Terminolóxico TUVI e a Neoloteca da Universidade de Vigo (Gómez Clemente / Rodríguez Guerra 2003b; López Fernández et al. 2005) (figura 5). Esperamos poder ofrecer os primeiros resultados deste importante proxecto durante o ano 2008.

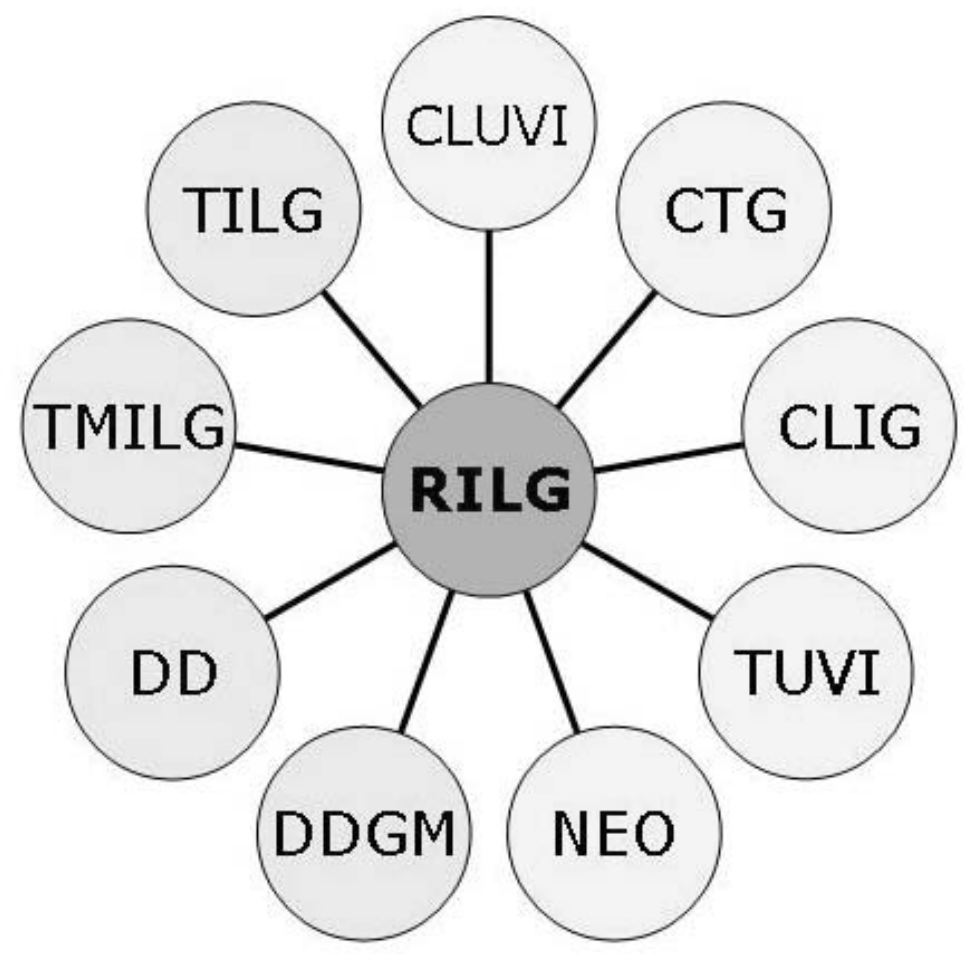

Figura 5. Integración de recursos no Proxecto RILG 


\title{
UN CORPUS PARA O ESTUDO DO GALEGO MEDIEVAL: O TMILG (TESOURO MEDIEVAL INFORMATIZADO DA LINGUA GALEGA)
}

\author{
Paulo Martínez Lema
}

Instituto da Lingua Galega. USC

\section{O TMILG COMO PROXECTO: OBXECTIVOS, PLANTEL E PREVISIÓNS DE FUTURO}

O TMILG (Tesouro Medieval Informatizado da Lingua Galega) constitúe hoxe por hoxe o único buscador on-line dispoñible para a lingua galega no seu estadio medieval, se ben debe enmarcarse dentro dun proxecto moito máis amplo e ambicioso, o Tesouro Medieval Galego-Portugués $(T M G P)$, que pretende pór a disposición do usuario a inmensa masa textual producida en Galiza e Portugal ao longo da Idade Media. Os criterios organizadores deste corpus son basicamente o glotolóxico e o xeográfico, e é a interacción dos mesmos a que nos permite establecer cinco subcórpora diferenciados: á marxe do TMILG propiamente dito, temos que falar do TMILC-G (textos galegos en lingua castelá, que nun futuro constituirán o Corpus Histórico do Castelán de Galicia ou CHCG), do TMILL-G (textos galegos en lingua latina), o TMILP (textos portugueses en lingua portuguesa) e finalmente o TMILL-P (textos portugueses en lingua latina). $O$ propio procesamento de textos para o TMILG, moitos dos cales están total ou parcialmente redactados en latín (no caso dos máis temperáns) e en castelán (nos dos máis serodios), permite ir construíndo de xeito progresivo e simultáneo estes córpora, dándolle sempre especial preeminencia ao TMILP por razóns lingüísticas e históricas evidentes. Neste sentido, están abertas senllas e frutíferas vías de colaboración cos equipos dos profesores portugueses Maria Francisca Xavier (Universidade Nova de Lisboa) e João Malaca Casteleiro (Academia das Ciências de Lisboa).

O TMILG naceu no seo do Instituto da Lingua Galega no ano 1992, se ben algúns dos membros do equipo inicial traballan hoxe noutras universidades galegas. $O$ desenvolvemento deste proxecto implica labores diversos que van do arrequentamento e diversificación do corpus (in- 
corporación de novas fontes) ao procesamento e revisión minuciosa dos textos de acordo cunhas pautas previamente establecidas e sometidas a unha constante actualización por parte do grupo. Tendo isto en conta, non debe estrañar que no TMILG participasen e participen persoas de extraccións e condicións diversas: bolseiros, contratados, investigadores da Universidade de Santiago de Compostela e mesmo voluntarios procedentes principalmente dos derradeiros cursos da titulación de Filoloxía Galega, así como dos distintos programas de doutoramento directa ou indirectamente relacionados coa lingua galega medieval.

O proxecto realízase desde as súas orixes baixo a dirección de Xavier Varela Barreiro, se ben na actualidade conta con dous bolseiros responsables de cadansúa sección: Ricardo Gutiérrez Pichel (fontes documentais e edición de textos) e Paulo Martínez Lema (codificación do corpus). Tamén figuran a día de hoxe como bolseiros Rocío Dourado Fernández, Lucía Doval, Iria Pérez Mariño e Iago Santiso Fernández, encargados principalmente da revisión e corrección das coleccións documentais asignadas en cada caso e en función das necesidades máis inmediatas do proxecto.

É xusto recoñecer que o TMILG non sería un proxecto posible nin viable sen o apoio de distintas institucións, entre as cales hai que salientar a propia Universidade de Santiago de Compostela, que xa desde as orixes cedeu un local de traballo axeitado no Instituto da Lingua Galega, así como o propio persoal investigador. A nivel estritamente económico cómpre destacar as achegas da Secretaría Xeral de Política Lingüística, que veu prestando apoio neste sentido tamén desde as fases máis embrionarias do TMILG.

O TMILG foi posto en rede por vez primeira no ano 2004 contando coa axuda técnica e informática do Centro Ramón Piñeiro (CIRP), que o tivo accesible no seu servidor até setembro do ano 2006. Ao longo dese período rexistráronse varios centos de usuarios regulares, concretándose máis de 23.000 consultas en pouco menos de 4.500 sesións, dato que deixa constancia do interese e utilidade (para investigadores principalmente, mais non só) dun produto coma o TMILG. En decembro de 2007 o buscador trasladouse á páxina web do ILG (http://ilg.usc.es/tmilg/), incorporando nesta nova versión novos modos de busca, de asociacións gráficas e de cálculo de estatísticas. Desde o mes de febreiro de 2008, esta nova versión do buscador vén funcionando de xeito ininterrompido e serviu xa para a realización dun elevado número de procuras, o cal dá boa conta da importancia que unha ferramenta deste tipo ten hoxe por hoxe para os investigadores.

As expectativas de futuro do TMILG son certamente prometedoras, sobre todo no tocante á multiplicidade de proxectos que, directa ou in- 
directamente, derivan del. No terreo estritamente lexicográfico botáronse a andar o Dicionario Histórico da Lingua Galega e mais o Dicionario Medieval Galego-Portugués, este último en colaboración con equipos da Universidade Nova de Lisboa. Tamén se está a traballar na Dialectoloxía Medieval Galego-Portuguesa, no Inventario Toponímico da Galiza Medieval (ITGM), que se pode consultar xa no seguinte enderezo web: http://ilg. usc.es/itgm/, na Gramática Histórica da Lingua Galega e na edición paleográfica de distintas obras medievais xa incorporadas ao TMILG, mais que nalgúns casos reclaman unha lectura máis actualizada ou, cando menos, máis axeitada ás esixencias que presentan actualmente os estudos de lingüística histórica. Algunhas desas obras, en fase avanzada de transcrición, son o Tratado de Albeitaria, os Miragres de Santiago e as Cantigas de Santa María. Todo isto sen esquecer que o TMILG, xunto co TILG, os dous Dicionarios de Dicionarios (o medieval e mais o moderno) e o Seminario de Lingüística Informática da Universidade de Vigo, participará na construción dunha plataforma de recursos informáticos para a investigación da lingua galega (RILG), co patrocinio do Ministerio de Educación e Ciencia e da Consellaría de Innovación e Industria da Xunta de Galicia.

\section{O CORPUS DO TMILG: ESTRUTURA E CARACTERÍSTICAS}

\subsection{Xéneros textuais}

O corpus do TMILG abrangue a día de hoxe uns 16.000 documentos, distribuídos á súa vez nun total de 82 obras e representativos das tres grandes categorías en que se articula a produción textual da Galiza medieval: a prosa notarial, a prosa non notarial e a poesía (verso). Mais, tal e como comprobamos nesta gráfica, o peso cuantitativo de cada unha delas é moi desigual: 


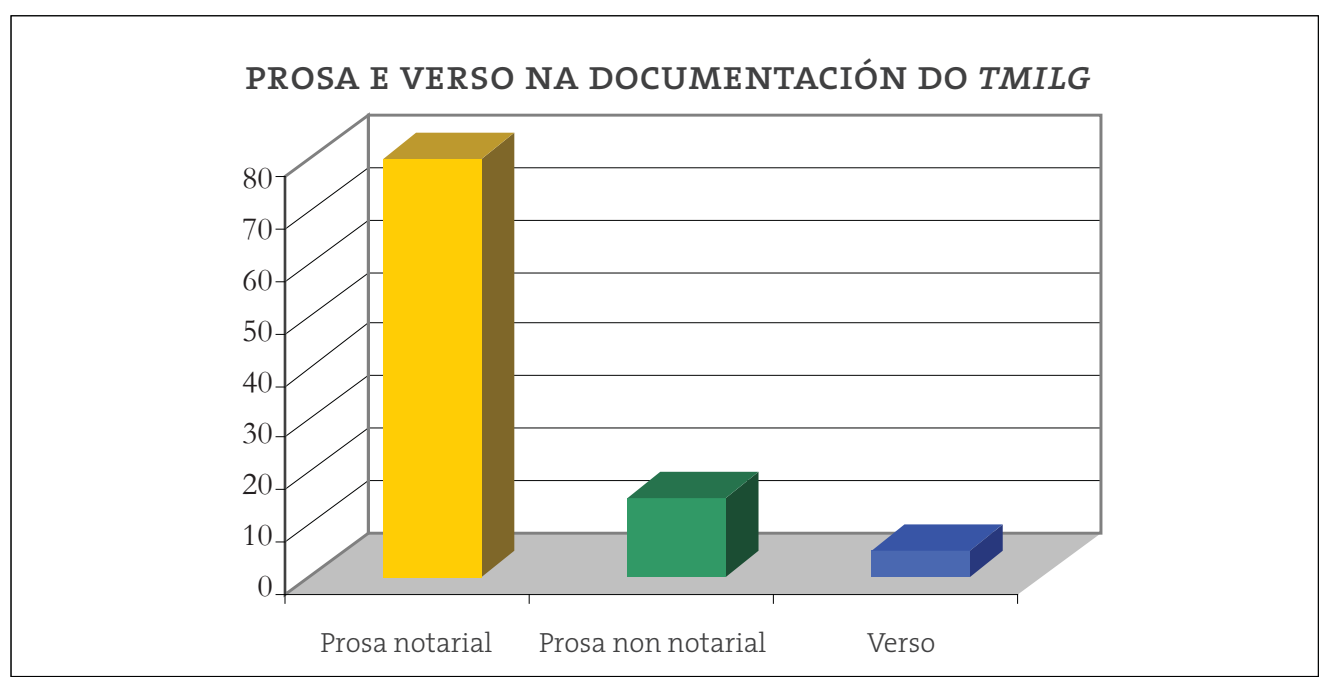

Dos tres grupos que vimos de mencionar, o que maior volume de texto achega é sen dúbida a prosa notarial, que constitúe por si soa case un $80 \%$ do total. Esta abundancia cuantitativa ten o seu correlato nunha grande riqueza de subtipos textuais, se ben esa diversidade pode reducirse en última instancia a cinco grandes grupos (Vázquez Bertomeu 2001). Eses grupos son os seguintes:

(a) documentos referentes á adquisición e xestión do patrimonio: neste grupo, quizais o máis amplo e variado, incluímos vendas, traspasamentos, desembargos, aforamentos, arrendamentos, alugueiros, nominacións, almoedas, doazóns, concambias... Cómpre lembrar que moitos destes tipos presentan á súa vez subtipos específicos, como ocorre p.ex. nos aforamentos ou contratos forais, categoría moi ampla que pode xebrarse en subconxuntos textuais máis reducidos como os traspasamentos de foro, o subaforamento ou a renovación de foro, entre outros;

(b) documentos relativos ao mundo mercantil e ás transaccións comerciais: gardas, peñoramentos, fianzas... formarían este segundo subconxunto textual;

(c) documentos administrativos: memoriais, inventarios de bens, apeos, relacións...

(d) documentos pertencentes ao ámbito familiar e doméstico: nesta categoría incluímos textos como as mandas, testamentos, codicilos, dotes...

(e) escritos de tipo xeral: testemuños, procurazóns, poderes, avinzas, sentenzas, renunciamentos e quitazóns, albalás, outorgamentos, demandas, frontas... 
A estas cinco categorías xerais podemos engadir aínda outras dúas representadas por documentos de características temáticas bastante peculiares, mais que veñen especificamente singularizados polo contexto institucional en que se xeraron. Referímonos, por un lado, aos documentos reais (privilexios, acoutamentos, mandatos, ordenanzas...), e, polo outro, aos documentos eclesiásticos e especialmente aos monásticos (cartas de irmandade, decretos de anexión, repartimentos, restauracións monásticas...).

Desde o punto de vista dos focos xeradores de documentación, o TMILG permítelle ao usuario acceder á documentación elaborada tanto nos núcleos eclesiásticos (catedrais, mosteiros, parroquias, sínodos) como nos civís (concellos, universidades, documentos de carácter privado e outros textos de natureza diversa). Porén, é o primeiro grupo, o da prosa notarial relixiosa e máis concretamente a redactada nos mosteiros, a que goza dunha maior presenza numérica dentro do corpus. Neste sentido, están xa incorporadas ao TMILG un total de 32 coleccións documentais procedentes de diversos mosteiros, dos cales 12 radican na provincia de Lugo, 9 na da Coruña, 7 na de Ourense e 4 na de Pontevedra. Ademais, están xa revisadas, preparadas e listas para a súa inminente inclusión varias coleccións diplomáticas de mosteiros pertencentes aos territorios galegófonos de Asturias, Zamora e León. Estas coleccións suman un total de 5 obras, o que converte a Galiza exterior nunha área xeográfica e lingüística xa notablemente representada no TMILG. Porén, o constante traballo de enriquecemento das fontes bibliográficas e de procesamento dos textos extraídos delas fai que estas cifras sexan sempre provisionais e susceptibles de actualizacións periódicas ${ }^{1}$.

\begin{tabular}{|l|l|l|}
\hline \multicolumn{1}{|c|}{ Mosteiro } & \multicolumn{1}{|c|}{ Concello } & \multicolumn{1}{c|}{ Provincia } \\
\hline San Antoniño de Toques & Toques & A Coruña \\
San Clodio do Ribeiro & Leiro & Ourense \\
San Martín de Castañeira & Puebla de Sanabria & Zamora \\
San Martiño de Vilourente & Mondoñedo & Lugo \\
San Miguel da Colleira & O Vicedo & Lugo \\
San Miguel de Bóveda & Amoeiro & Ourense \\
\hline
\end{tabular}

1. É necesario deixar clara esta circunstancia, pois, por poñer unicamente un exemplo, as cifras relativas á provincia da Coruña poderían engrosarse grazas aos textos procedentes de mosteiros como San Martiño de Cánduas (Ponteceso) ou San Cristovo de Dormeá (Boimorto), ou incluso con documentos serodios (finais do s. XV) que nos relatan procesos de reforma monástica que afectaron a cenobios como o de San Mamede de Seavia (Coristanco). Ao tratárense de obras aínda en proceso de revisión e conteren total ou maioritariamente textos en latín e/ou en castelán non foron tidas en conta neste cómputo. 


\begin{tabular}{|c|c|c|}
\hline Mosteiro & Emprazamento & Provincia \\
\hline San Paio de Antealtares & Santiago de Compostela & A Coruña \\
\hline San Pedro de Montes & Ponferrada & León \\
\hline San Pedro de Ramirás & Ramirás & Ourense \\
\hline San Pedro de Rocas & Esgos & Ourense \\
\hline San Pedro de Soandres & A Laracha & A Coruña \\
\hline San Pedro de Vilanova de Dozón & Dozón & Pontevedra \\
\hline San Salvador de Bergondo & Bergondo & A Coruña \\
\hline San Salvador de Celanova & Celanova & Ourense \\
\hline San Salvador de Lourenzá & Lourenzá & Lugo \\
\hline San Salvador de Pedroso & Narón & A Coruña \\
\hline San Salvador de Sobrado de Trives & Trives & Ourense \\
\hline San Salvador de Vilar de Donas & Palas de Rei & Lugo \\
\hline San Salvador e San Nicolás de Cins & Oza dos Ríos & A Coruña \\
\hline San Vicenzo de Pombeiro & Pantón & Lugo \\
\hline San Xoán de Caaveiro & A Capela & A Coruña \\
\hline San Xurxo de Codeseda & A Estrada & Pontevedra \\
\hline Santa Clara de Santiago & Santiago de Compostela & A Coruña \\
\hline Santa María de Belvís & Santiago de Compostela & A Coruña \\
\hline Santa María de Carracedo & Cacabelos & León \\
\hline Santa María de Castro de Rei de Lemos & Paradela & Lugo \\
\hline Santa María de Ferreira de Pallares & Guntín & Lugo \\
\hline Santa María de Ferreira de Pantón & Pantón & Lugo \\
\hline Santa María de Oseira & San Cristovo de Cea & Ourense \\
\hline Santa María de Valdeflores & Viveiro & Lugo \\
\hline Santa María de Vilanova dos Oscos & Vilanova dos Oscos & Asturias \\
\hline Santa María do Camiño & Pontevedra & Pontevedra \\
\hline Santiago de Ermelo & Bueu & Pontevedra \\
\hline Santiago de Mens & Malpica & A Coruña \\
\hline Santo Domingo de Viveiro & Viveiro & Lugo \\
\hline Santo Estevo de Chouzán & Carballedo & Lugo \\
\hline Santo Estevo de Ribas de Sil & Nogueira de Ramuín & Ourense \\
\hline Santos Xusto e Pastor de Toxos Outos & Lousame & A Coruña \\
\hline Veiga de Espiñareda & Veiga de Espiñareda & León \\
\hline
\end{tabular}


No seguinte gráfico podemos observar máis detalladamente a relación porcentual existente entre as distintas procedencias xeográficas da documentación cenobítica do TMILG, tomando como referencia o marco administrativo actual. Deste xeito podemos observar algúns datos bastante congruentes tanto co decorrer da historia medieval galega como, máis especificamente, coas tendencias xeográficas dos asentamentos monásticos no Noroeste peninsular: por exemplo, comprobamos que a provincia que maior cantidade de coleccións documentais achega é Lugo, e máis en concreto a súa área meridional, que, xunto cos territorios máis setentrionais da provincia de Ourense artellados ao redor do río Miño, constitúe unha área especialmente rica no que a institucións monásticas se refire: a Ribeira Sacra. Por outra banda, resulta cando menos rechamante a precariedade documental que presenta a provincia de Pontevedra (4 coleccións), superada de feito polos territorios galegófonos hoxe administrativamente asturianos e castelán-leoneses (5 coleccións). A provincia da Coruña, pola súa banda, proporciónalle ao TMILG 9 coleccións documentais, se ben hai que ter en conta o considerable peso cuantitativo e cualitativo que teñen os mosteiros radicados en Santiago de Compostela, capital eclesiástica de extraordinaria relevancia neste sentido.

COLECCIÓNS DOCUMENTAIS MONÁSTICAS NO TMILG

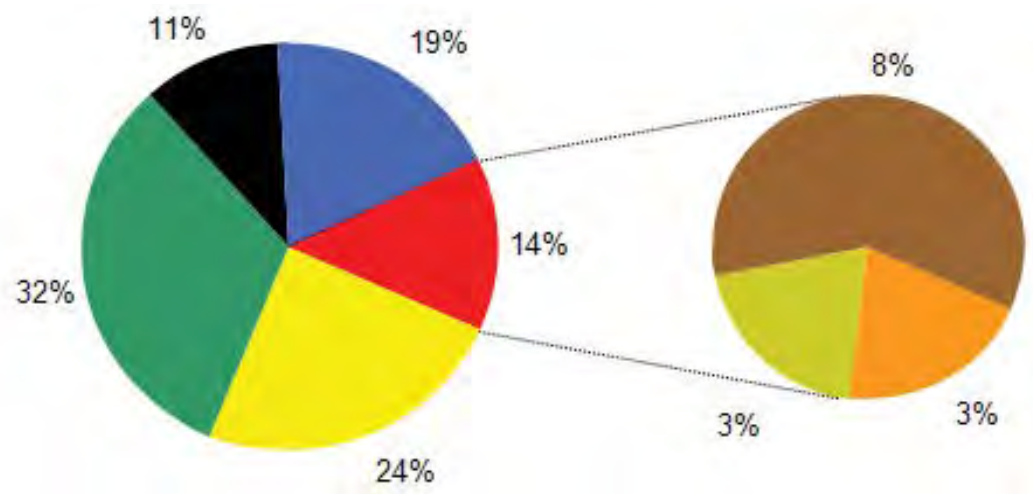

\begin{tabular}{|llll|}
\hline$\square$ A Coruña & $\square$ Lugc & $\square$ Pontevedra & $\square$ Ourense \\
$\square$ Exterior & $\square$ Asturias & $\square$ Zamora & $\square$ León \\
\hline
\end{tabular}

No que se refire ao outro grande bloque de prosa notarial, o constituído polos textos civís, domina claramente a documentación de tipo particular, sendo xa moito menos numerosa a procedente doutros ámbitos como o universitario e o municipal (soamente os concellos de Santiago, Noia, Pontevedra, Ourense e A Coruña achegan produción textual relevante ao TMILG). 
O segundo grupo en importancia cuantitativa é o da prosa non notarial, que comprende aproximadamente o $15 \%$ do total dos textos. A prosa non notarial está representada por obras ou fragmentos de obras pertencentes a cinco grandes bloques temáticos ben coñecidos e delimitados:

(a) prosa literaria: pertencen ao xénero da narrativa extensa a Crónica Troiana (CT), a Historia Troiana (HT) e mais o fragmento conservado do Livro de Tristan (LT);

(b) prosa histórica: como sabemos, a historiografía medieval coñecida en lingua galega nútrese exclusivamente de traducións de orixinais procedentes doutros ámbitos lingüísticos, nomeadamente o castelán. Soamente dispomos de tres textos que reúnan as características definitorias deste xénero: a Xeral Historia (XH), a Crónica Xeral e Crónica de Castela (TC) e mais a Crónica de Santa María de Iria (CI);

(c) prosa relixiosa: no TMILG rexístranse tan só dúas obras deste tipo, os Miragres de Santiago (MS) e un fragmento do tratado Sobre a simonía (SaS). Descoñecemos, cando menos a día de hoxe, obras prosísticas galegas medievais pertencentes ao xénero da haxiografía, a catequística ou o sermón, por exemplo;

(d) prosa técnica: no noso corpus inclúense dúas obras que, polo seu carácter descritivo e directivo, poden clasificarse sen maiores problemas dentro desta categoría, se ben cada unha delas desenvolve temáticas moi afastadas entre si. Por unha banda, a Arte de Trobar (AT) inscríbese dentro do ámbito da teoría poética e, a un nivel máis amplo, no mundo das ciencias sociais e humanas; en cambio, o Tratado de Albeitaria (TA) céntrase no terreo da veterinaria e, xa que logo, pode considerarse un manual de ciencias aplicadas, o único existente a día de hoxe na nosa tradición prosística medieval;

(e) prosa xurídica: aínda carecendo de tratados xurídicos propiamente ditos, a prosa galega medieval si conta cun amplo repertorio de ordenamentos e códigos legais, todos eles xa dispoñibles no TMILG: referímonos aos fragmentos conservados do Foro Xuzgo (FX), Flores de Dereito (FD), Foro Real (FR), Glosas de Textos Legais (GTL) e o Ordenamento de Alcalá de Henares (OA), así como a versión completa conservada dos Foros de Castelo Rodrigo (FCR). A todas estas obras hai que engadir aínda os distintos fragmentos das sete Partidas de Afonso X, na súa tradución ao galego. 
Finalmente, os textos en verso (todos eles pertencentes ao subxénero lírico nas súas distintas variantes), a pesar da súa innegable relevancia cualitativa dentro da produción escrita galega medieval, son os menos numerosos do noso corpus textual e supoñen aproximadamente un $5 \%$ do mesmo. Este conxunto pode dividirse á súa vez en dous grupos ben coñecidos e en cuxa caracterización interveñen o factor cronolóxico e a tradición estética na que se inscriben os textos:

(a) lírica trobadoresca, que abrangue grosso modo as derradeiras décadas do s. XII, a totalidade do s. XIII e a primeira metade do s. XIV. No TMILG podemos consultar os distintos subxéneros da vertente profana, maioritariamente agrupados baixo as siglas LP (Lírica Profana), con excepcións como o descort plurilingüe de Raimbaut de Vaqueiras (DPRV), xoia poética que inclúe unha estrofa en galego, ou o texto Us Castellans (UC) de Raimón Vidal de Besalú. Completan este inxente corpus poético as Cantigas de Santa María (CSM), tanto as narrativas como as propiamente líricas ou de loor, e mais a Cantiga de Valcavado (CV), as dúas únicas mostras poéticas de temática estritamente relixiosa con que conta a nosa tradición literaria medieval;

(b) lírica da decadencia (CGC), ou, atendendo á denominación máis comunmente aceptada e empregada, escola galego-castelá, que se desenvolve ao longo dos séculos XIV e XV.

Deste xeito, no TMILG encontramos perfectamente representadas as diversas parcelas textuais cultivadas na Galiza medieval, quer no terreo da prosa, quer no do verso. Con todo, e tal como pode observarse no cadro seguinte, (elaborado a partir do modelo de codificación do CORDE exposto en RAE 2001), non deixa de ser considerable o número de xéneros e subxéneros que non contaron co debido desenvolvemento e para os que, en consecuencia, carecemos de obras representativas. Mais esta situación está suxeita en todo caso ás alteracións que poderían derivar da descuberta e difusión de textos até o de agora inéditos. 


\begin{tabular}{|c|c|c|c|}
\hline \multicolumn{4}{|l|}{ PROSA } \\
\hline \multirow{2}{*}{\multicolumn{2}{|c|}{ Narrativa }} & \multicolumn{2}{|c|}{ Breve } \\
\hline & & \multicolumn{2}{|c|}{ Extensa $\rightarrow$ Novela $(\mathbf{C T}, \mathbf{H T}, \mathbf{F T})$} \\
\hline \multirow{2}{*}{\multicolumn{2}{|c|}{ Ciencia e técnica }} & \multirow{2}{*}{\multicolumn{2}{|c|}{$\begin{array}{l}\text { Ciencias sociais e humanas } \rightarrow \text { Literatura }(\mathbf{A T}) \\
\text { Ciencias aplicadas } \rightarrow \text { Veterinaria }(\mathbf{T A})\end{array}$}} \\
\hline & & & \\
\hline \multicolumn{4}{|l|}{ Sociedade } \\
\hline \multirow{6}{*}{\multicolumn{2}{|c|}{ Relixión }} & \multirow{5}{*}{\multicolumn{2}{|c|}{$\begin{array}{l}\text { Textos bíblicos e glosas } \\
\text { Haxiografía } \\
\text { Mística e ascética } \\
\text { Catequística } \\
\text { Sermóns }\end{array}$}} \\
\hline & & & \\
\hline & & & \\
\hline & & & \\
\hline & & & \\
\hline & & \multicolumn{2}{|c|}{ Outros (MS, SS) } \\
\hline \multirow{2}{*}{\multicolumn{2}{|c|}{ Historia }} & \multicolumn{2}{|c|}{ Historiografía (TC, GE, CI) } \\
\hline & & \multicolumn{2}{|c|}{ Biografía } \\
\hline \multirow{3}{*}{\multicolumn{2}{|c|}{ Dereito }} & \multicolumn{2}{|c|}{ Ordenamentos e códigos legais (FX, FD, FR, GTL, OA, Partidas) } \\
\hline & & \multicolumn{2}{|c|}{ Tratados xurídicos } \\
\hline & & \multicolumn{2}{|c|}{ Outros $\rightarrow$ Prosa notarial } \\
\hline \multicolumn{4}{|l|}{ Lírica } \\
\hline \multicolumn{4}{|l|}{ Teatro } \\
\hline \multicolumn{4}{|l|}{ Didáctica } \\
\hline \multicolumn{4}{|l|}{ VERSO } \\
\hline \multirow[t]{4}{*}{ Narrativa } & \multicolumn{3}{|c|}{ Tradicional } \\
\hline & \multirow{3}{*}{\multicolumn{2}{|c|}{ Culta }} & Épica \\
\hline & & & Relixiosa (CSM-cantigas narrativas) \\
\hline & & & Didáctica \\
\hline \multirow[t]{4}{*}{ Lírica } & \multicolumn{2}{|c|}{ Tradicional } & \\
\hline & \multirow{3}{*}{\multicolumn{2}{|c|}{ Culta }} & Individual (CSM-cantigas de loor) \\
\hline & & & Obras colectivas (LP, CGC, DPRV, UC) \\
\hline & & & Outros \\
\hline Dramática & & & \\
\hline
\end{tabular}

\subsection{Cronoloxía e glotoloxía dos textos}

Desde o punto de vista da cronoloxía, o corpus do TMILG cobre un período amplísimo como é o comprendido entre os séculos VIII (ano 700) e XVII (ano 1600). Neste sentido, o documento máis antigo co que contamos a día de hoxe no noso corpus é unha doazón procedente do mosteiro de Santa María de Sobrado dos Monxes, datada no ano 787 e editada por López Ferreiro no seu Galicia Histórica (capítulo 113) (López Ferreiro 1901: 
626-627). Aínda que no TMILG podemos encontrar representadas diversas linguas, o certo é que soamente o galego / galego-portugués, o latín e o castelán teñen verdadeira presenza como linguas vehiculares preferentes dos textos. Deste xeito, por volta de 9.000 dos documentos consultables (un 56\% do total) están escritos en idioma galego, fronte aos aproximadamente 4.500 (un 28\%) redactados en latín e os escasos 2.500 (o 15\% restante) para os que se escolleu a lingua latina.

\section{MICROESTRUTURA DO TMILG: O PROCESAMENTO DOS TEXTOS}

Unha das fases de maior relevancia do proceso de tratamento dos textos consiste na previa etiquetaxe dos mesmos, aplicándolles un encabezamento no que se fan constar distintos ítems informativos, como son:

(a) o rexesto: inclúese o rexesto literal redactado polo editor para cada documento, mais prescindindo de informacións complementarias como a cota arquivística ou os detalles codicolóxicos, por exemplo;

(b) o título da obra: como puidemos comprobar nas epígrafes precedentes, no TMILG combínase o título extenso da obra (regularizado e traducido sempre ao galego) cun título en clave formado xeralmente a partir das iniciais daquel (p.ex., Historia Xeral = HX);

(c) a información autorial, i. e., o nome do autor de cada documento: neste punto faise constar, en primeiro lugar, o nome do autor con todos os seus posíbeis atributos tal e como figuran no texto (p. ex., Johannes Petri, notarius concilii Noye juratus), mentres que nun segundo momento rexistramos unicamente a cadea antroponímica illada, sen ningún tipo de información complementaria (Johannes Petri). Contémplase tamén a posibilidade da autoría múltiple coas súas diversas variantes, entre as cales salientan como máis habituais a presenza dun notario e dun escribán ao seu servizo (caso no que figura sempre en primeiro lugar o nome do notario), a participación de varios notarios ao mesmo nivel na xénese do documento, etc. Todas estas opcións contan cun sistema de codificación específico dentro da etiqueta Autoría;

(d) información cronolóxica: sinálanse o século e o ano ou rango de anos concreto no que foi redactado cada documento. Tamén fixemos constar o ano no que o documento en cuestión foi copiado ou trasladado, información que explica moitas das distorsións léxicas, gráficas ou doutro tipo observables nos textos; 
(e) natureza do texto, i.e., se o documento en cuestión é un orixinal, unha copia, un traslado, un rexesto, unha tradución...

(f) información lingüística: indícase a lingua do texto mediante unha serie de claves numéricas específicas, e nos documentos traducidos exprésase ademais a lingua na que foi redactado o orixinal.

Na revisión do material textual ponse especial atención en illar, mediante os marcadores oportunamente establecidos, aqueles treitos, capítulos ou mesmo textos enteiros escritos en linguas distintas do galego. Deste xeito, o corpus do TMILG pode dividirse en varios subconxuntos desde o punto de vista glotolóxico, un dos cales é precisamente o dos documentos híbridos. O TMILG, como xa indicamos, abrangue desde textos moi temperáns, con fortísima presenza do latín, até textos moi serodios, nos que o castelán consegue hexemonizar xa a práctica escrita. Fica polo medio unha importante masa textual ao longo da cal imos asistindo á progresiva emerxencia e consolidación do romance galego-portugués como lingua escrita, sempre en tensión coa tradición escrituraria latina precedente e coa paulatina intromisión do castelán a partir do s. XIV. Xa que logo, a porcentaxe de textos híbridos resulta considerable, e o TMILG permitenos explotar as potencialidades que esta realidade lle ofrece ao investigador en eidos moi diversos que van desde a lexicografía á sociolingüística, pasando pola fraseoloxía ou a onomástica. Por exemplo, nun documento pertencente á colección da Casa de Altamira e datable nas primeiras décadas do s. XVI, Gutierre de Hevia, alcaide das fortalezas de Navia e Burón polo Conde de Altamira, quéixase do maltrato que recibe por parte do seu señor. A protesta formúlase nun perfecto castelán, mais nun determinado momento Gutierre de Hevia opta pola expresividade dun dito autóctono na lingua do país:

Por çierto no fuera mucho que onbre tan maltratado desesperara en algo de lo que arriba digo porque ay un enxenplo en Galizia que dize el can con rabia en seo dono traba.

Noutras ocasións, a irrupción do discurso oral nos documentos ilustra aspectos máis lúdicos da lingua da época. Nun requirimento feito pola abadesa de San Miguel de Bóveda en 1467 menciónase o xudeu Abraán de León, recadador dos Condes de Ribadavia, e dísenos que "quando se partira de ali que disera o dito judio: ¡como agora enganei a señora abadesa con un rabo de pescado!";

(g) información xeográfica: nesta etiqueta indícase a demarcación ou demarcacións onde exercía o seu labor o notario responsable da creación do documento. Cando se descoñece tal dato, figura tan só o lugar con- 
creto no que foi redactado o texto. Este apartado, como se comprenderá, resulta de especial interese para os historiadores e para os toponimistas, pois sempre se procura representar a forma lingüística exacta coa que aparece nomeada no documento esa referencia xeográfica concreta, así como, na medida do posible, contextualizala dentro dos parámetros administrativos que lle corresponderían na actualidade (provincia, concello, freguesía...). Por outra banda, cómpre lembrar que a vinculación dun notario cunha determinada xeografía ou xurisidición pode levar aparellado o emprego duns hábitos escriturais particulares a nivel léxico, gráfico e/ ou morfosintáctico. Por tanto, o estudo desas relacións pode ser de grande utilidade para ir artellando un modelo de dialectoloxía medieval do romance galego-portugués;

(h) tipoloxía documental do texto: sinálase se o documento en cuestión responde ás características temáticas e/ou estruturais dun contrato de aforamento, dunha doazón, dunha venda... Co fin de ir creando un repertorio amplo e representativo faise constar sempre o nome que se lle dá no texto á acción xurídica da que este emana, mais tamén as construcións sintácticas (moitas veces fosilizadas e convertidas en verdadeiras fórmulas ou lexías complexas asociadas a unha tipoloxía textual concreta) utilizadas para expresar a natureza da dita acción. Por exemplo, a tipoloxía doazón aparece representada nesta etiqueta por substantivos como doaçon, dationem, donationem, scripturam testamenti et donationis... e por frases verbais como dono et concedo, concedo et offero, do et offero, do et dono et offero... nas que se observan as distintas posibilidades combinatorias duns elementos léxicos máis ou menos constantes e recorrentes, e desde logo moi ligados semanticamente á acción que xera e xustifica o documento en cuestión. Neste sentido, tamén se observa unha notable riqueza nos testamentos e mandas testamentarias: substantivos transparentes como testamentum, mandatione, manda, ordinatione ou codeçilo (coas múltiples variantes gráficas existentes en cada caso) conviven no corpo do documento con fórmulas como uolo ut omnia mea ordinata remaneant, ordino et faço meu testamento, etc. En definitiva, este apartado do encabezamento ofrece unhas posibilidades nada desprezables no estudo do léxico medieval e da súa vinculación semántica máis ou menos sistemática a unhas determinadas accións xurídicas.

Por outra banda, no estado actual dos traballos do TMILG, a variedade documental novidosa en relación ás clasificacións canónicas de historiadores e paleógrafos é significativa, como tamén o é a nomenclatura empregada para identificar cada un deses tipos, unha nomenclatura que en galego é moitas veces debedora da tradición castelá. Deste xeito, o pro- 
cesamento de documentación para o TMILG permítenos rescatar termos até o de agora ausentes dos manuais e dicionarios ao uso, cando menos cos matices semánticos cos que concorren na nosa documentación medieval. Por exemplo, adoita denominarse deslinde ao documento no que se establecen os lindes dunha propiedade, herdade, freguesía ou couto. Tamén recibe este nome, mediante un proceso metonímico doadamente explicable, a propia marca ou sinal divisorio utilizado no deslindamento (GDXL, s.V. deslinde). Porén, nos textos medievais comparece un fermoso sinónimo de deslindar, como é devisar (coas súas múltiples variantes gráficas). Ramón Lorenzo (1968, s.v. deuisar) rexistra xa este verbo, nas súas formas participiais, en documentos da segunda metade do s. XIII: "assj como estam marcadas et deuisadas... assi como jaz deuisada" (1259), "per terminos deuissados" (1274). Na nosa lexicografía moderna, Eladio Rodríguez atesta as formas devisar e divisar co significado 'Divisar, señalar, referir, dividir', e non debemos esquecer que o portugués moderno conserva a forma devisar co significado 'Ordenar, planejar, construir de acordo com um plano' (Houaiss 2001, s.v. devisar). Porén, nin o galego nin o portugués pareceron conservar o derivado sufixal devisaçon, aínda recollido por Viterbo (1798-1799) coa variante divisaçom ('separação, divisa, termo, limite, partilha') nun documento bracarense de 1501 e relativamente abondosa nos nosos textos antigos: así, na colección do mosteiro de San Salvador de Celanova encontramos o termo devisaçiones xa nun documento en castelán con data de 1293 ("los marcos et las devisaçiones") 2, e nun texto algo posterior, concretamente de 1332, fálasenos da delimitación duns lugares "per marcos et deuisações çertas".

Aínda habería que engadir que o proceso de revisión de textos nos permite tamén identificar certos subtipos textuais caracterizados por matices xurídicos, estruturais e/ou mesmo lingüísticos que os diferencian do tipo textual máis xenérico no que se incardinan. Por exemplo, é ben coñecido o tipo textual foro/aforamento, mais na documentación do noso corpus poden recoñecerse subcategorías moi concretas e con entidade ben definida, como a cesión de foro, a confirmación de foro, a demisión de foro, a devolución de foro, o traspasamento de foro, o subaforo, o nomeamento de foreiros, etc. Nun documento procedente tamén do mosteiro de San Salvador de Celanova datado en 1426, un tal "Lourenço Miguelles, clerigo capellan do moesteiro de San Salvador d'Arnoya”, traspasa unhas herdades que el mesmo tiña aforadas polo devandito mosteiro, e exprésao nos

2. Curiosamente, o CORDE non dá ningunha ocorrencia do derivado devisaçion / divisaçion para o castelán, nin na época medieval nin na moderna, o que parece reafirmar máis aínda a singularidade desta forma. 
seguintes termos: "parto et demito et traspaso". Estas escollas léxicas entroncan o traspasamento de foro con outros tipos documentais profusamente representados no TMILG como son a demitizón ou a renuncia;

(i) información editorial: neste derradeiro apartado do encabezamento rexístrase a páxina da obra na que comeza o documento, así como o rango de páxinas que abrangue. Asemade, faise constar tamén o capítulo da edición co que se corresponde cada documento.

Este encabezamento veu funcionando, con certos reaxustes puntuais, ao longo destes case 20 anos de vida do TMILG, mais na actualidade o grupo de investigación está a desenvolver un novo e máis ambicioso etiquetario (DTD) mediante o que se recolla toda a información pertinente non só de cada documento en particular, senón tamén do conxunto da obra ou volume no que se recolle. Os ítems informativos contemplados nese novo encabezamento son esencialmente os mesmos aos que se veu recorrendo até o de agora, pero moito máis matizados e detallados. Ademais, incorporarase toda a información de tipo arquivístico e codicolóxico existente para cada documento e moitas veces accesible xa a través das propias edicións dos textos.

Xa dentro do documento en si, e nunha segunda e máis fonda fase de revisión, márcanse tamén, mediante os indicadores previamente convidos, todos e cada un dos elementos onomásticos: topónimos, antropónimos, títulos de obras, nomes de días e de meses, nomes de institucións... Esta práctica é a que permite desenvolver proxectos como o xa mencionado Inventario Toponímico da Galiza Medieval, que esixe un laborioso proceso previo de illamento, clasificación e identificación dos topónimos de cada documento que contribuíu a asentar unha metodoloxía de traballo xa ensaiada con éxito nalgúns traballos de doutoramento desenvolvidos por bolseiros do TMILG.

Como exemplo deste proceso de tratamento e etiquetaxe dos textos para o TMILG presentamos un documento pontevedrés do s. XV, pertencente a unha tipoloxía documental insólita até o de agora, o contrabto de perdon. O contido do escrito é certamente pintoresco, como tamén o son os termos e o léxico empregados: Pedro de Montes, natural do mosteiro de Aciveiro, comprométese a perdoar "todo mal, dano, pecado et copulaçon et adulterio" que a súa muller, Tareixa de Montes, cometera e puidera cometer até o 1 de abril seguinte, data na que ambos os dous deberían reencontrarse para "faser maridança segundo que manda Deus et Santa Iglesia". Xa que logo, o interese do documento desborda os aspectos meramente lingüísticos para converterse nunha peza de indubidable valor histórico e sociolóxico. 
[Rexesto do documento] [Pero de Montes, natural do mosteiro de Santa Maria de Acibeiro, perdoa á súa muller Teresa de Montes por ter abandonado o domicilio familiar e cometido adulterio, a condición que volte con el antes do próximo mes de abril]

[Acrónimo do título] [MNP]

[Título estandarizado] [Minutario Notarial de Pontevedra ${ }^{3}$ ]

[Volume] [-]

[Nome do autor (completo)] [Anónimo]

[Nome do autor (abreviado)] [Anónimo]

[Século] [15]

[Ano de redacción do documento] [1434]

[Ano de redacción do orixinal] [-]

[Mes de redacción do documento] [11 (= novembro)]>

[Orixinalidade] [O]

[Lingua do documento orixinal] [-]

[Lingua do documento] [1 (= galego) $]$

[Referencia xeográfica] [Pontevedra]

[Xeración trobadoresca] [-]

[Poesía / prosa $(1=$ prosa $)][1$ (= prosa $)]$

[Xénero] [15 (= prosa notaria)]

[Tipoloxía documental] [Perdón (“contrabto de perdón”)]

[Páxina de inicio] [150]

[Rango de páxinas] [150-151]

[Capítulo ou número de documento (na edición de referencia)] [110]

O primeiro dia do mes de novembro. Sabean todos que eu Pero de Montes, natural do moesteiro de Santa Maria d'Asiveiro que soo presente, quero et outorgo que por quanto vos Tareija de Montes mĩa moller, filla de Juan Branco et de Moor Gomes sua moller, que sodes absente, vos absentastes de mĩa casa et poder sen meu mandado et liçençia a outra parte a donde vos quisestes, por lo qual vos non queredes tornar a mia casa et poder, nen eso mesmo non ousades de andar seguramente por la terra donde sodes natural, nen paresçer ante mĩ nen lugar donde eu de vos aja notiçia et parte et vos posa costrenjer por rigor de dereito, reçeando vos que por lo dito absentamento que asy fezestes que eu vos queira demandar et acusar por rason que avedes cometido pecado de adulterio; por ende eu o dito Pero de Montes que asi soo presente, non costrengudo por força nen por engano rescebido, mas de mĩa livre et propia voontade et por lo amor de Deus, perdoo a vos a dita de Montes mĩa moller, que sodes absente asi como se fosedes presente, todo erro et mal et dano et interese que eu resçebese et ouvese por rason do dito absentamento que asi fezestes, et eso mesmo todo pecado de adulterio que vos fezesedes et cometesedes et fezestes et cometestes des lo tenpo que sodes mĩa moller et comigo casastes ata este presente dia et que fezerdes et cometerdes, o que Deus non queira, desde oje que esta carta he feita ata o primeiro dia do mes de abril primeiro que ven, que seera en este ano primeiro que verra de mill et quatroçentos et trinta et cinco anos, et qualquer copulaçon que fezesedes ou fezestes ou feserdes ata o dito

3. Rodríguez González / Armas Castro (1992). 
dia con qualquer persona en meu perjuiso. Et para esto asi seer mas firme, vos a dita Tareija de Montes ata o dito primeiro dia de abril avedes de vĩir aa iglesia de San Migell de Carvalleda, et desde que ende fordes fasermo a saber para que vos et eu falemos en hüu seguramente et conçertandonos para $<\mathbf{P} 151>$ que en hüun façamos nosa vivenda, asi como por Deus et por dereito somos obligados de nos faser maridança segundo que manda Deus et Santa Iglesia, et non nos et eu como dito he de boo vos perdoo et dou por livre et quita, para qui et por ante Deus, de todo mal, dano, pecado et copulaçon et adulterio que vos cometestes et fezestes et cometerdes et feserdes en meu perjuiso ata o dito primeiro dia de abril, et prometo et outorgo aa boa fe de Deus et sen mao engäno et por juramento que ende faço en este sinal de crus en lugar de santos avangeos, que eu que vos lo teña et conpra et agarde asi, et que en publico nen en scondido vos non beña nen pase, por min nen por outro, contra elo nen contra parte delo, et demais concertandonos ẽna dita vivenda que, sen enbargo do sobre dito, vos faça maridança do corpo et do aver ben et lealmente asi como marido a moller et por la via et forma que manda Deus et Santa Iglesia, et non no teendo et conprindo en todo asi et yndo et pasando contra elo, que eu seja enfames et fe perjuro, et me costamio de non ser de tal pecado asolto salvo por noso señor o papa; et demais que eu de et page por pena en nome de interese a vos a dita Maria de Montes dosentos froliins de ouro do cuño de Aragon, et apena pagada ou non que senpre este contrabto este firme, sobre lo qual renunçio as leis do dereito, dolo, engano, medo, força, endusimento et a todas las outras et dereitos canonicos et cevils et impereaas et reaas de que me eu ou outro por min pudeiramos ajudar para contra esto que dito he vĩir, que quero et outorgo que me non vallan nen sejamos sobrelo nen sobre parte dlelo oydos nen resçebidos en juiso nen fora del; et por que esto seja çerto outorgey ende este contrabto de perdon ante o notario et testemoyas de juso scriptas. Que foi outorgado na villa de Pontevedra, ano, dias, mes sobre ditos. Testemoyas que foron presentes, Afonso Soares caldeirerio morador ẽna dita villa et Garçia Corto et Gomes Ares moradores en Ribadavia et Gil Martines clérigo de San Justo de Avion et outros. $<P$ 152>

\section{ALGUNHAS CONCLUSIÓNS}

O TMILG, ao longo dos seus case catro anos en rede, converteuse nunha ferramenta indispensable para achegarse ás múltiples vertentes da cultura galega medieval, con especial relevancia das dimensións lingüística e histórica. Isto é así grazas ao abondoso material textual que constitúe o corpus base, mais tamén á súa diversidade xenérica e, en certo xeito, lingüística, o cal posibilita unha achega multidisciplinar a un período da nosa historia especialmente rico e aínda non totalmente explotado en todas as súas infinitas posibilidades. 



\title{
BUSCATERMOS: \\ BANCO DE DATOS TERMINOLÓXICO MULTILINGÜE
}

\author{
Xusto Rodríguez Río \\ Servizo de Normalización Lingüística \\ (Universidade de Santiago de Compostela)
}

Este traballo ten por obxecto presentar o bUSCatermos e mais o Banco de Datos Terminolóxico (BDT) do Servizo de Normalización Lingüística da USC, intentando destacar tamén algunhas das utilidades que pode ter para o traballo lexicográfico.

bUSCatermos non é máis ca a parte visible do BDT: unha interface que permite realizar consultas no corpus de información dese banco a través de Internet. Xa que logo, o verdadeiramente relevante é a cantidade e o tipo de información que se compila neste e a forma en que se organiza.

Actualmente, o BDT agrupa información procedente de tres tipos de fontes:

(1) A produción terminolóxica sistemática elaborada polo SNL.

Componse de tres tipos de repertorios: vocabularios (abranguen grandes áreas de especialidade e compilan un número de conceptos relativamente alto, normalmente entre 4.000 e 5.000), léxicos (atenden a ámbitos especializados máis restrinxidos, e oscilan entre os 1.000 e os 3.000 conceptos) e termos esenciais (produtos pensados especificamente para o alumnado que se limitan a recoller e divulgar terminoloxía relevante dentro dos plans de estudo de diferentes titulacións).

(2) A produción terminolóxica puntual desta mesma entidade.

Consta de varios milleiros de fichas en que se recolle e se xustifica a resposta a consultas formuladas sobre termos concretos das máis diversas áreas de especialidade. 
(3) Un conxunto de dicionarios e vocabularios técnicos ${ }^{1}$ que tratan áreas de interese para a comunidade da USC e que teñen o galego entre as súas linguas de traballo.

Todo este conxunto de materiais intégrase nunha base de datos, reelabórase, complétase e analízase desde o punto de vista da súa calidade lingüística, de tal forma que o produto resultante é cualitativamente diferente -pensamos que para mellor-á suma das partes que o compoñen. E sobre el é onde bUSCatermos realiza as consultas que lle formulan os usuarios.

O seguinte esquema reproduce de xeito visual o proceso que acabamos de describir:

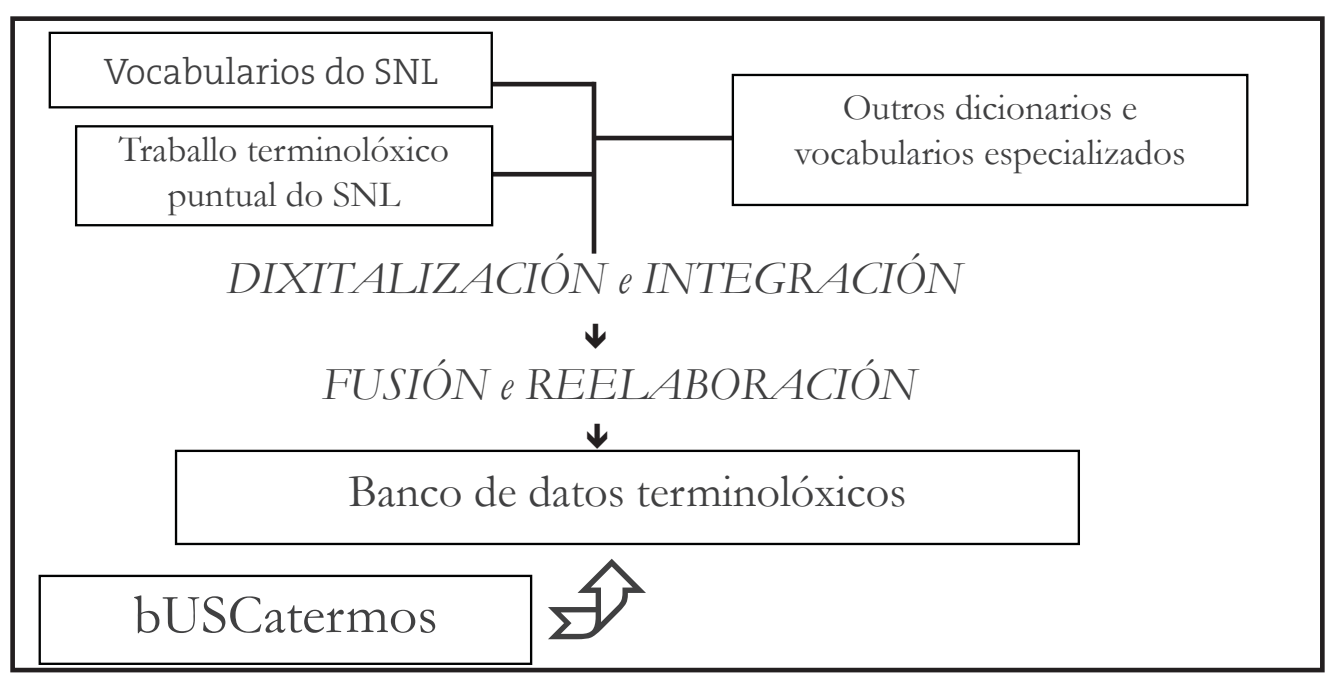

Olabor máis custoso² de toda esta secuencia é indubidablemente a reelaboración dos materiais, pero parecíanos evidente a necesidade de abordala, tendo en conta o obxectivo que pretendemos acadar. Se o que intentamos é proporcionarlles a todos os membros da comunidade da $\mathrm{USC}^{3}$ unha ferramenta que lles axude a mellorar a calidade dos textos técnicos que elaboran,

1. A escolla destes repertorios non se fai de xeito aleatorio, senón que previamente deben cumprir unha serie de condicións: (1) deben centrarse en áreas estudadas dentro dalgunha titulación impartida na USC; (2) deben acadar un grao de calidade mínimo que as faga aproveitables como fontes de consulta; (3) os autores deben autorizar explicitamente a súa utilización e inclusión no BDT, e (4) debe tratarse de produtos elaborados sen vocación comercial (que se distribuíron gratuitamente, que son accesibles de balde a través de Internet...) ou que xa remataron a súa "vida comercial útil" (traballos esgotados, de acceso moi difícil...).

2. Non só é custoso, senón que tamén se pode entender como "inacabable", xa que cada vez que se engade un novo repertorio ao Banco cumpriría reelaboralo tendo en conta as posibles coincidencias e contradicións con todo o material preexistente.

3. bUSCatermos é accesible desde calquera ordenador conectado á rede informática desta institución. 
facilitándolles a busca de terminoloxía precisa e adecuada e orientándoos sobre o seu emprego, tiñamos que ir máis alá da simple acumulación de materiais terminográficos. E tiñamos que facelo porque non é insólito que os diferentes dicionarios ou vocabularios recomenden solucións diferentes -ou aínda contraditorias- para a mesma cuestión terminolóxica; polo que esa vocación orientadora do uso non se podería desenvolver a través dunha compilación do tipo dun dicionario de dicionarios especializados.

Ese labor de reelaboración do material recollido concrétase fundamentalmente en tres accións:

(1) Reestrutúrase para intentar presentalo segundo un enfoque onomasiolóxico.

Os dicionarios que seguen pautas semasiolóxicas agrupan baixo unha mesma denominación (o lema) todos os conceptos que son representados por ela (as acepcións). Pero os traballos terminográficos deben tomar como unidade básica o concepto, vinculando a el todas as designacións que poida recibir nunha lingua.

Por exemplo, o Diccionario galego de termos médicos (DGTM) inclúe dentro da entrada "adaptación" oito acepcións diferentes:

\footnotetext{
adaptación s.f. 1. Acto ou efecto de adaptar. 2. Acomodación. 3. Adquisición das modificacións que permiten que un organismo viva nun novo ambiente ou en condicións novas. 4. Proceso dinámico no que os pensamentos, sentimentos, comportamento e mecanismos biofisiolóxicos cambian para axustarse ós cambios do ambiente. 5. Axuste da pupila do ollo ás variacións da intensidade da luz. 6. Inmunización. 7. En odontoloxía, axuste axeitado dunha dentadura, grao de proximidade e entrelazamento de material de restauración dunha preparación dental ou axuste exacto de bandas ós dentes. 8. Diminución da frecuencia de impulsos na actividade reflexa cando se repiten varias veces os estímulos sensoriais.
}

Trasladada esta información ao BDT, produce 6 fichas terminolóxicas: unha por cada un dos conceptos que describe cada acepción excluídas as dúas primeiras, que se poden entender como propias da linguaxe non especializada.

(2) Complétase a información obtida das fontes compiladas.

Normalmente, engádese aquilo que consideramos máis útil para quen consulta: denominacións equivalentes noutras linguas, denominacións inadecuadas de uso habitual, indicación da área temática, definicións...

(3) Analízase a denominación galega que se aconsellaba na fonte compilada.

Isto é especialmente importante nos casos en que varias fontes propoñen denominacións diferentes ou contraditorias para un mesmo con- 
cepto. Neses casos facemos unha valoración crítica -que pode levarnos a preferir unha delas, a incluílas todas como sinónimas ou a propor unha alternativa diferente-, xustificamos e argumentamos a decisión adoptada e outorgámoslles unha marca de valoración ${ }^{4}$.

Tendo en conta todo o devandito, é evidente que o lexicógrafo non pode recorrer ao bUSCatermos da mesma forma ca a un corpus -xa que a maior parte da información non procede de usos reais documentados senón de fontes secundarias-, a un dicionario de dicionarios -a información destas fontes secundarias non se conserva no seu estado orixinalou a un dicionario descritivo -existe unha vontade orientadora do uso explicitamente declarada.

Pero aínda así, pode ser un material interesante para tirar del información de cara a traballos de lexicografía especializada, ou para as entradas e acepcións especializadas presentes nas obras lexicográficas xerais.

Por exemplo, as máis de 50.000 definicións ${ }^{5}$ de conceptos pertencentes a ámbitos temáticos moi diversos poden ser útiles no proceso de elaboración de dicionarios monolingües, tanto xerais como especializados.

Para traballos lexicográficos bilingües ou multilingües poderíase tirar partido do feito de que para a maioría dos conceptos descritos se ofrezan denominacións en máis dun idioma. Así, existen equivalentes casteláns para preto de 70.000 deles, ingleses para máis de 30.000, portugueses para preto de 20.000 , franceses para case 13.000 , e cantidades menores para o alemán, o italiano ou o catalán.

Os autores de produtos con vocación correctiva (dicionarios de dúbidas, dicionarios que inclúen no corpus de entradas formas incorrectas...) poderían obter datos relevantes dos máis de 2.000 rexistros en que a información ofrecida para un concepto inclúe unha denominación problemática. Empregamos esta categoría para referirnos a aquelas que, sendo moi frecuentes no uso real, consideramos que deben evitarse por non seren adecuadas para designar ese concepto.

E finalmente, tamén poden ter interese os varios miles de propostas denominativas neolóxicas, realizadas polo persoal do SNL co fin de resolver as cuestións terminolóxicas que van xurdindo de forma puntual vinculadas ao labor de asesoramento lingüístico. En concreto, produtos

4. Esas marcas, que abranguen desde o grao 1 (termos normativos) ata o grao 5 (termos por resolver), asígnanse segundo uns criterios que se detallan en http://www4.usc.es/buscatermos/Caracteristicas.htm.

5. Estas definicións poden proceder dos traballos que se foron compilando ou ben ser elaboradas polo persoal do SNL ou polos especialistas da USC que colaboran con nós. 
como dicionarios descritivos, dicionarios de neoloxismos ou dicionarios de dúbidas poderían reutilizar con proveito eses materiais.

En resumo, aínda que a utilidade que para o traballo lexicográfico pode ter a parella bUSCatermos/BDT non pode compararse á de fontes documentais primarias, como os córpora, non deixa de ser un recurso interesante do que se podería tirar información relevante para a elaboración de diferentes produtos lexicográficos. Agardemos que nun futuro próximo un bUSCatermos aberto á consulta libre poida amosar na práctica estas potencialidades. 



\title{
O DICIONÁRIO DO PORTUGUÊS MEDIEVAL. FONTES, CONCEPÇÃO E METODOLOGIA
}

\author{
Maria Francisca Xavier \\ Centro de Linguística (Universidade Nova de Lisboa)
}

O projecto de construção de um Dicionário do Português Medieval (DPM) teve início há já alguns anos. Antes, porém, em 1992-93, um grupo de linguistas da Universidade Nova de Lisboa definiu como objectivo desenvolver estudos linguísticos diacrónicos, os quais dariam origem a uma Gramática, e viriam a ser complementados por um Dicionário, tendo por base textos dos primeiros tempos da história da língua portuguesa. Iniciou-se, então, a selecção e informatização de edições publicadas dos textos mais antigos representativos do português medieval-séculos XII a XVI-, sendo criado o Corpus Informatizado do Português Medieval (CIPM), parcialmente disponível na Internet (http://cipm.fcsh.unl.pt/) desde 2001. Aumentado sucessivamente, o corpus tem vindo a incorporar, para além de edições publicadas, também edições inéditas, algumas realizadas no âmbito de dissertações, diversas disponibilizadas para o CIPM pelos próprios editores já em formato digital.

Em 2003-04 foi concebido o primeiro esboço de projecto para um Dicionário do Português Medieval. A preparação deste projecto implicou, também, proceder a um novo levantamento de fontes primárias editadas, ainda não publicadas, tendo sido consultados para este efeito especialistas do período medieval português, de diferentes áreas, nomeadamente de linguística, literatura, cultura e história, o que permitiu tomar decisões sobre o alargamento do CIPM de forma a cobrir um maior número de temas diferenciados.

Para servir de fonte do dicionário foi, então, constituído um corpus que integra textos de diferentes tipos (documentos notariais e particulares, documentos régios, administrativos, textos didáctico-moralísticos, narrativos e poéticos) ${ }^{1}$. A diversidade tipológica dos textos seleccionados

1. A constituição do corpus textual é apresentada no final. 
vai permitir estudar e descrever uma quantidade significativa de vocabulário com vista à elaboração do primeiro dicionário. Este será ainda necessariamente pequeno, porque foi planeado para ser realizado no prazo apertado de cinco anos, por uma pequena equipa, integrando uma doutorada e cinco estudantes de pós-graduação em Linguística ${ }^{2}$.

Maria de Lourdes Crispim e eu própria, ambas do Centro de Linguística da Universidade Nova de Lisboa, em colaboração com o Prof. João Malaca Casteleiro, do Instituto de Lexicologia e Lexicografia da Academia de Ciências de Lisboa (ILL-ACL)³), estabelecemos os objectivos do projecto, a sua concepção e o manual de redacção, assegurando também o acompanhamento regular e a revisão do trabalho dos outros membros da equipa, bem como as reuniões com consultores do projecto.

Pretende-se com a realização deste dicionário cumprir três objectivos principais: contribuir para o preenchimento da lacuna da dicionarística portuguesa relativa ao período medieval, formar jovens investigadores que poderão vir a dar continuidade ao estudo da língua portuguesa histórica e à elaboração de outros dicionários e, ainda, facilitar a leitura dos textos daquele período a estudiosos de outras áreas e, em particular, a estudantes, tanto do ensino superior como do secundário.

O projecto de elaboração deste Dicionário do Português Medieval assenta numa concepção de carácter prospectivo, em que vai sendo descrita a história da origem e da evolução dos elementos lexicais atestados em corpora escritos ao longo dos primeiros séculos da história da língua, desde o século XII até final do século XV. Nesta perspectiva, são aplicados dois critérios que funcionam como pilares do processo de elaboração do DPM: exaustividade e sistematicidade.

A decisão sobre a adopção do critério de exaustividade é uma consequência da conjugação de duas outras decisões tomadas neste projecto -a constituição do corpus textual informatizado, o qual inclui exclusivamente fontes primárias, textos representativos de domínios sócio-culturais e históricos da época em estudo, e a acessibilidade ao corpus com o auxílio de ferramentas informáticas, permitindo e facilitando a extracção

2. A partir de finais de 2004, a equipa integra quatro bolseiros financiados directamente pela Fundação para a Ciência e a Tecnologia do Ministério da Ciência, Tecnologia e Ensino Superior, nomeadamente a doutora Maria Alexandra Fiéis, a mestre Maria de Fátima Martins e os mestrandos João Loureiro e Raquel Oliveira. Também alguns tarefeiros financiados pelo Centro de Linguística da UNL têm ocupado muitas horas com este trabalho, o mestre Miguel Gonçalves e, alternadamente, os mestrandos Sandro Dias e Ana Espírito Santo.

3. Através desta colaboração está prevista a integração do Dicionário do Português Medieval na triologia de dicionários do ILL-ACL. 
automática, contextualizada, quantificada e localizada de todas as formas/variantes dos vocábulos existentes nos textos.

Deste modo, o Dicionário do Português Medieval, elaborado a partir de um corpus informatizado de textos medievais de diferentes géneros e de diversas temáticas, comportará todos os vocábulos que ocorrem nesses textos. Será, então, um dicionário exaustivo não da língua portuguesa medieval, mas da língua que está documentada nas fontes textuais utilizadas.

O critério de sistematicidade na elaboração dos artigos do dicionário, constitui um requisito metodológico fundamental em todas as fases previstas para a progressão consistente do projecto, sendo este também facilitado pela possibilidade de utilização de ferramentas informáticas (lematizadores, sistemas de concordâncias, dicionários electrónicos e etiquetadores ou outros).

A elaboração do DPM segue de perto, embora com adaptações, a metodologia já utilizada no desenvolvimento do Dicionário de Verbos do Português Medieval (DVPM), concebido por uma equipa de linguistas, também do Centro de Linguística da Universidade Nova de Lisboa, constituída inicialmente por Maria Francisca Xavier, Maria da Graça Vicente, Maria de Lourdes Crispim, Maria Teresa Brocardo e António Emiliano, tendo os dois últimos colaborado até 1997. A equipa que realiza a investigação e as tarefas para o desenvolvimento do DVPM tem contado com a colaboração de diversos estudantes universitários dos três ciclos de formação, de diferentes áreas, nomeadamente Linguística, Clássicas, Estudos Portugueses e História.

Deste trabalho resultou uma primeira publicação, intitulada Dicionário de Verbos Portugueses do Século 13 (DVPM 1999), e uma segunda, publicada em papel e na Internet, o Dicionário de Verbos do Português Medieval. Séculos 12 e 13/14 (DVPM 2003), ambas organizadas por Maria Francisca Xavier, Maria da Graça Vicente e Maria de Lourdes Crispim.

Pretendeu-se com aquelas publicações mostrar o trabalho realizado e solicitar críticas, sugestões e colaborações que contribuíssem tanto para melhorar o que estava feito como para dar continuidade ao projecto.

As duas publicações referidas acima dão conta do trabalho desenvolvido em duas fases sucessivas, que correspondem ao tratamento lexical -morfológico, sintáctico e semântico- dos verbos atestados em dois corpora textuais complementares.

O corpus inicial que serviu de base ao DVPM era constituído pelo seguinte conjunto de textos não literários do século XIII: 


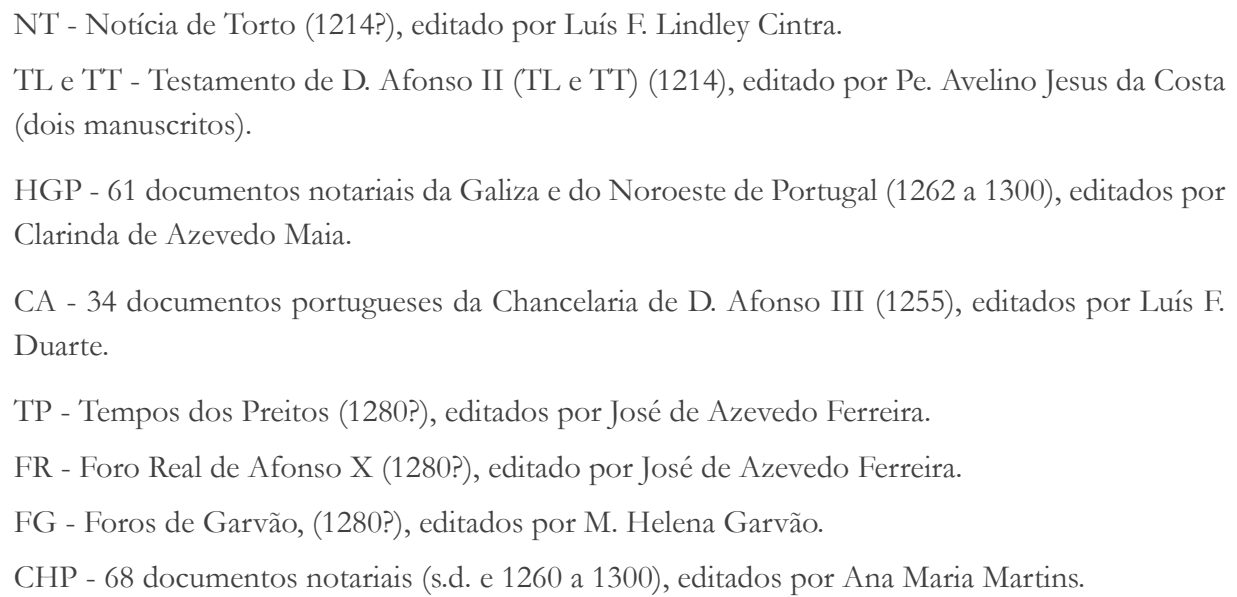

Neste corpus, perfazendo um total de 134.332 palavras, foram identificados, analisados e introduzidos na base de dados online do DVPM os 578 verbos que foram apresentados na publicação de 1999.

O corpus textual seguinte constituiu a segunda fonte do DVPM. Totalizando 171.000 palavras, o corpus incluiu, para além dos textos do corpus inicial, dois do século XII, mais alguns do século XIII e sete textos, de que não há certeza se são do século XIII ou do século XIV, editados a partir de cópias do século XV, como se indica na relação dos textos que se apresenta abaixo:

\footnotetext{
DN - 2 documentos notariais ( $2^{\mathrm{a}}$ metade do século XII), editados por Ana Maria Martins.

DN - 6 documentos notariais (s.d. ou datados entre 1243 a 1274), editados por Ana Maria Martins.

TOX - 23 documentos notariais (s.d. ou datados entre 1269 e 1300), editados por Stephen Parkinson.

TP - Tempos dos Preitos (1280?), editados por José de Azevedo Ferreira.

VS - 7 Vidas de Santos de um Manuscrito Alcobacense (século XIII ou XIV, cópias do século $\mathrm{XV}$ ), editados por Ivo Castro et alii.
}

No segundo corpus foram encontrados mais 212 verbos do que no anterior, totalizando 790 os verbos que constituíram o DVPM publicado em 2003.

Durante a segunda fase de desenvolvimento do Dicionário de Verbos, para além da elaboração das fichas daqueles 212 verbos, foram ainda revistos os verbos anteriormente estudados, tendo sido introduzida informação complementar nas entradas daqueles que se encontram atestados também nos textos que não faziam parte do corpus inicial -mais formas verbais (com variantes gráficas) e respectivas classificações morfológicas, mais acepções, mais contextos gramaticais e correspondentes abonações. 
Desde 2003, vão sendo publicadas na Internet as fichas criadas e as revisões das fichas dos verbos dos sucessivos corpora que vão sendo acrescentados como fontes para o DVPM.

Deste modo, a experiência de anos obtida no processo de desenvolvimento do Dicionário de Verbos permitiu consolidar a metodologia a seguir na elaboração do Dicionário do Português Medieval.

A partir do corpus textual total, foram constituidos dois corpora, um com textos dos séculos XII, XIII e XIII/XIV, o outro com os textos dos séculos XIV e XV. O estudo do léxico de um e de outro corpus corresponde a duas fases sequenciais do projecto, programadas para levar a cabo a elaboração das fichas do dicionário. A primeira fase teve início em finais de 2004 e terminou em finais de 2006, a segunda fase iniciou-se em princípios de 2007, estando previsto o seu término em finais de 2008.

Tratando-se de um projecto de dicionário exaustivo e sistemático, as duas fases do projecto compreendem passos idênticos, sendo que a segunda envolve ainda outros que complementam ou revêem os primeiros.

Ambas as fases têm em comum os seguintes passos:

(a) Preparação dos dados

- extracção da listagem automática das palavras do corpus

- lematização

- agrupamento das variantes gráficas

- extracção de concordâncias das formas gráficas atestadas no corpus

(b) Identificação das unidades lexicais

- selecção das vedetas dos artigos

- agrupamento das variantes gráficas e remissão para o artigo da cabeça

- inclusão da etimologia, origem das palavras e/ou sua formação

(c) Análise linguística das unidades lexicais

- classificação gramatical

- determinação e definição dos significados

- selecção das abonações 
No DPM, as fichas lexicográficas vão sendo criadas de acordo com a estrutura seguinte:

(i) A vedeta, ou cabeça do artigo, entendida como uma representação abstracta, corresponde a uma forma gráfica que obedece a critérios linguísticos e de funcionalidade tal como tem sido prática na elaboração dos artigos do Dicionário de Verbos. Assim, a vedeta deverá ter a forma gráfica mais próxima da forma ortográfica actual, quando esta exista, o que leva a aplicar, com frequência, as seguintes regras de supressão e de substituição de grafemas já utilizadas para as vedetas do DVPM:

- <h> com função de marcação de hiato é eliminado

- grafemas duplos, iniciais ou internos, com o mesmo valor fonético dos correspondentes simples $\rightarrow$ grafemas simples

- $\langle\mathrm{j}\rangle$ ou $\langle\mathrm{y}\rangle$ com valor de vogal ou semi-vogal $\rightarrow\langle\mathrm{i}\rangle$

- $\langle\mathrm{i}\rangle$, $\langle$ gi $\rangle$ ou $\langle\mathrm{y}\rangle$ com valor de sibilante vozeada palatal $\rightarrow\langle\mathrm{j}\rangle$

- $\langle\mathrm{U}\rangle$ com valor consonântico $\rightarrow\langle\mathrm{V}\rangle$

- $\langle$ ll $\rangle$ ou $\langle\mathrm{l}\rangle$ com valor de líquida palatal $\rightarrow\langle\mathrm{lh}\rangle$

- $\langle$ n $\rangle$ ou $\langle$ gn $\rangle$ com valor de nasal palatal $\rightarrow\langle$ nh $\rangle$

- 〈n> ou $\langle\sim>$ representando a nasalação da vogal antes de oclusiva labial $\rightarrow\langle\mathrm{m}\rangle$

- 〈 > representando a nasalação da vogal antes de consoante não labial $\rightarrow\langle n\rangle$

- $\langle$ ç $\rangle$ antes de $\langle\mathrm{e}\rangle$ ou $\langle\mathrm{i}\rangle \rightarrow\langle\mathrm{c}\rangle$

- 〈S $\rangle$ intervocálico com valor de surda $\rightarrow\langle$ SS $\rangle$

- 〈r $\rangle$ intervocálico com valor de múltipla $\rightarrow\langle$ rr $\rangle$

A aplicação destas regras e a decisão sobre qual deve ser a forma gráfica final das cabeças dos artigos têm de ser revistas à medida que mais variantes gráficas vão sendo registadas e a informação sobre as etimologias durante a segunda fase vai sendo validada.

(ii) A classificação gramatical das palavras do DPM. Os verbos são apresentados, como habitualmente, na forma de infinitivo e é indicada a subclasse a que pertencem. Os paradigmas flexionais verbais constarão de um anexo. Os nomes e os adjectivos são registados na forma masculina, seguida da flexão feminina. No plural são registadas unicamente as palavras que são sempre plural. Todas as palavras de todas as classes deverão ser classificadas de acordo com a terminologia corrente, as variáveis: verbos, nomes, adjectivos e pronomes, e as invariáveis: advérbios, conjunções, e preposições. 
(iii) A etimologia deverá indicar a origem das palavras, assim como os elementos da sua formação quando esta se verificou já no português.

(iv) As acepções que pode ter a entrada do dicionário serão dadas por um equivalente actual, quando este exista, e/ou por breves descrições dos significados da vedeta. As expressões multipalavra ou lexias complexas são incluídas nas entradas lexicais, seguidas do seu significado.

(v) As abonações são excertos extraídos das concordâncias, que ilustram as acepções das entradas lexicais, sendo sempre escolhida a abonação mais antiga e a última que se encontra atestada no corpus. Sempre que as abonações cronologicamente relevantes não são muito claras, acrescenta-se outra que possa contribuir para ilustrar a acepção. Estas estão identificadas com a data ou o século, quando a data é desconhecida, e também com a sigla do texto de onde foram extraídas.

(vi) As remissões entre vedetas correspondem a duas situações: (a) as cabeças morfológica e funcionalmente equivalentes correspondem a variantes gráficas que remetem para a cabeça da variante idêntica ou mais próxima da forma actual, sendo esta que contém a descrição das acepções e as abonações respectivas; (b) as cabeças morfológica e semanticamente semelhantes, cujas entradas lexicais apresentam acepções e descrições diferentes remetem umas para as outras, mas todas incluem a sua própria informação e as respectivas abonações.

Os artigos do dicionário vão sendo redigidos pelos membros da equipa a quem são distribuídos por letras. Em Janeiro de 2007, inicia-se o estudo do léxico do corpus constituído por textos dos séculos XIV e XV e todas as tarefas se desenvolvem pela ordem anteriormente definida. São então redigidos mais verbetes, assim como revista e complementada a informação daqueles que foram criados a partir do corpus anterior, sempre que sejam identificados dados a considerar. Vejam-se alguns exemplos de artigos do DPM:

abade s. m. (Do lat. ecl. abbate-). Abade, superior de um mosteiro ou abadia; sacerdote [séc. 12 DN002] Noticia de auer que deuen a dar a petro abade In palmazianos super uno casal de afonso rodrigiz: vij Morabetinos. [1500 HGP090] e nos, o dicto señor abbade \& prior \& côbento, obligamos os bens do dicto noso mosteyro de vos defenderemos a dereito cõ este dicto foro. (Var. abaade, abade, abate, abbade, abbas, abbat, habade). Fem. abadessa.

abarregado, a adj. (Do part. pas. de abarregar). Abarregado, que se amancebou [1489 TC] Item saiba da pessoa de que estado he se he casada se solteira se abarregada e eso mesmo per que mester viue.

homezio s. m. (Do lat. homicidiu-). Homicídio, morte de um ser humano por acção de outrem; assassinato [1214 NT] E super sa aiuda oue testifigo cũ Petro Gomez, omezio queli custou maes ka C morabitinos. (Var. homezio, omezio, umezio, omezyo, omizio, omizyo, oomezio, oomezyo). 
tafularia s. f. (De taful + -aria). 1. Vício ou prática do jogo [1264-1284 CSM214] Ca se Deus deu aas gentes jogos pera alegria / averen, todo o tornan elas en tafuraria, / e daquesta guisa queren gãar. 2. Casa de jogo [1264-1284 CSM174] E pois l' ouve dito, logo sayu da tafuraria / e fillouss' a chorar muito, [séc. 13 CEM251] Ainda eu outras manhas havia, / per que eu nom posso já muito valer: / nunca vos entro na tafularia / que lhi nom haja algum preit'a volver. / Porque hei eu pois em gram coita seer? / É fugir e guarir na putaria. (Var. tafularia, tafuraria).

Em 2009, deverá terminar a revisão final dos verbetes e das remissões internas ao dicionário, será preparado o anexo de morfologia verbal e finalizada a introdução. Sendo assim, em finais de 2009 deverá estar publicado este Dicionário do Português Medieval, procurando dar cumprimento aos objectivos formulados inicialmente. 


\section{APÉNDICE \\ O CORPUS INFORMATIZADO DO PORTUGUÊS MEDIEVAL (CIPM)}

Construído a partir de textos já editados, o corpus respeita os critérios de cada editor, embora, desde o início, tenha sido necessária uma adaptação das soluções gráficas das intervenções editoriais (itálicos, sublinhados, uso de parênteses ou barras) em função da necessidade de uniformização exigida pela utilização de diferentes suportes lógicos (DVPM 1999) e de coerência de notação interna do corpus.

\section{Século XII}

$\mathrm{DN}=2$ textos notariais ( $2^{\mathrm{a}}$ metade do século XII), in Ana Maria Martins

(ed.) (2000): Documentos notariais dos séculos XII a XVI. Edição digitalizada, cedida pela editora.

- "Finto" dos casais de Eligoo

- "Notícia de haver"

$\mathrm{DP}=4$ documentos privados ( $2^{\mathrm{a}}$ metade do século XII), in José António Souto Cabo (ed.) (2003): Nas origens da expressão escrita galego-portuguesa. Documentos do século XII. Braga: Universidade do Minho. Edição digitalizada, cedida pelo editor.

- Pacto de Gomes Pais e Ramiro Pais (ca.1173)

- Carta de foro da Benfeita

- Nomina de Pedro Viegas (1184)

- Escrito de Paio Soares

\section{Século XIII}

NT = Notícia de Torto (ca. 1214), in Luís Filipe Lindley Cintra (1990): “Sobre o mais antigo texto não-literário português: a Notícia de Torto (leitura crítica, data, redacção e comentário linguístico)", Boletim de Filologia 31, 21-77 (texto crítico, pp. 37-41). Edição digitalizada para o CIPM.

TL e TT = Testamento de D. Afonso II (1214), in Pe. Avelino Jesus da Costa (1979): "Os mais antigos documentos escritos em português", Revista Portuguesa de História 17, 307-321 (dois manuscritos: Lisboa e Toledo). Edição digitalizada para o CIPM.

$\mathrm{CA}=34$ documentos portugueses da Chancelaria de D. Afonso III (12551279), in Luiz Fagundes Duarte (1986): Os documentos em português da Chancelaria de D. Afonso III (Edição). Dissertação de Mestrado. Lisboa: FLUL, 68-295. Edição digitalizada para o CIPM. 
$\mathrm{DN}=73$ textos notariais (sem data ou datados entre 1214 e 1300), in Ana Maria Martins (ed.) (2000): Documentos notariais dos séculos XII a XVI. Edição digitalizada, cedida pela editora.

CHP $=2$ textos notariais (1275, 1278), in Ana Maria Martins (ed.) (1994): Clíticos na história do português. Apêndice documental.Vol. 2. Dissertação de Doutoramento, Lisboa. Edição digitalizada, cedida pela editora.

HGP = 61 textos notariais da Galiza e do Noroeste de Portugal (1262-1300), in Clarinda de Azevedo Maia (1986): História do galego-português. Coimbra: INIC, 19-295. Edição digitalizada para o CIPM.

FG = 6 foros de Garvão (1267-1280), in Maria Helena Garvão (ed.) (1992): Foros de Garvão. Edição e estudo linguístico. Dissertação de Mestrado. Lisboa: FLUL, 65-99. Edição digitalizada, cedida pela editora.

TOX = 21 textos notariais (sem data ou datados entre 1269 e 1300), in Stephen Parkinson (ed.): Arquivo de Textos Notariais em Português Antigo. Oxford. Edição digitalizada, cedida pelo editor.

FR = Foro Real (1280?), in José de Azevedo Ferreira (ed.) (1987): Afonso X. Foro Real. Lisboa: INIC, 125-309.

$\mathrm{TP}=$ Tempos dos Preitos (1280?), in José de Azevedo Ferreira (ed.), in Jean Roudil (1986): Summa de los Nueve Tiempos de los Pleitos. Édition et étude d'une variation sur un thème. Paris: Klincksieck, 151-169.

CS = 1 documento dos Costumes de Santarém (1294), in Maria Celeste Matias Rodrigues (1992): Dos costumes de Santarém. Dissertação de Mestrado. Lisboa: FLUL, 160-251. Edição digitalizada, cedida pela editora.

CAmi = 513 cantigas de amigo (sem data ou datados entre 1220-1300), in Rip Cohen (ed.) (2003): 500 cantigas de amigo. Porto: Campo das Letras. Edição digitalizada, cedida pelo editor.

CAmo = 517 cantigas de amor (sem data), in Mercedes Brea (coord.) (1996): Lírica profana galego-portuguesa. Santiago de Compostela: Centro Ramón Piñeiro. Edição digitalizada in Base de Datos en liña da Lírica Profana Galego-Portuguesa do Centro Ramón Piñeiro (www.cirp.es).

CSM = 419 cantigas de Santa Maria (datadas entre 1270 e 1282), in Walter Mettmann (ed.) (1981): Afonso X, o Sábio. Cantigas de Santa Maria. Vigo: Edicións Xerais de Galicia. Edição digitalizada cedida por Xavier Varela, Tesouro Medieval Informatizado da Lingua Galega.

$\mathrm{CEM}=403$ cantigas de escárnio e maldizer (sem data), in Graça Videira Lopes (2002): Cantigas de escárnio e maldizer dos trovadores e jograis galego-portugueses. Lisboa: Estampa. Edição digitalizada, cedida pela editora. 


\section{Séculos XIII/XIV}

CAmo = 159 cantigas de amor (sem data), in Mercedes Brea (coord.) (1996): Lírica profana galego-portuguesa. Santiago de Compostela: Centro Ramón Piñeiro. Edição digitalizada in Base de Datos en liña da Lírica Profana Galego-Portuguesa do Centro Ramón Piñeiro (www.cirp.es).

$\mathrm{CEM}=69$ cantigas de escárnio e maldizer, in Graça Videira Lopes (2002): Cantigas de escárnio e maldizer dos trovadores e jograis galego-portugueses. Lisboa: Estampa. Edição digitalizada, cedida pela editora.

$\mathrm{VS}=7$ vidas de santos de um manuscrito alcobacense (sem data; cópias do século XV), in Ivo Castro et alii (eds.) (1985): Vidas de santos de um manuscrito alcobacense (Cod. Alc. cclxvi / antt 2274). Lisboa: INIC, 16-52, 59-83. Edição digitalizada para o CIPM.

\section{Século XIV}

CAmo = 20 cantigas de amor (sem data), in Mercedes Brea (coord.) (1996): Lírica profana galego-portuguesa. Santiago de Compostela: Centro Ramón Piñeiro. Edição digitalizada in Base de Datos en liña da Lírica Profana Galego-Portuguesa do Centro Ramón Piñeiro (www.cirp.es).

CEM = 2 cantigas de escárnio e maldizer, in Graça Videira Lopes (2002): Cantigas de escárnio e maldizer dos trovadores e jograis galego-portugueses. Lisboa: Estampa. Edição digitalizada, cedida pela editora.

HGP = 62 textos notariais da Galiza e do Noroeste de Portugal (1301-1399), in Clarinda de Azevedo Maia (1986): História do galego-português. Coimbra: INIC, 19-295. Edição digitalizada para o CIPM.

$\mathrm{DN}=79$ textos notariais (sem data ou datados entre 1304 e 1397), in Ana Maria Martins (ed.) (2000): Documentos notariais dos séculos XII a XVI. Edição digitalizada, cedida pela editora.

TOX $=15$ textos notariais (sem data ou datados entre 1309 e 1336), in Stephen Parkinson (ed.): Arquivo de Textos Notariais em Português Antigo. Oxford. Edição digitalizada, cedida pelo editor.

CS = 3 documentos dos Costumes de Santarém ((1340-1360), in Maria Celeste Matias Rodrigues (1992): Dos costumes de Santarém. Dissertação de Mestrado. Lisboa: FLUL, 160-251. Edição digitalizada, cedida pela editora.

FG = 1 foro de Garvão (sem data), in Maria Helena Garvão (ed.) (1992): Foros de Garvão. Edição e estudo linguístico. Dissertação de Mestrado. Lisboa: FLUL, 65-99. Edição digitalizada, cedida pela editora. 
$\mathrm{PP}=$ Afonso X. Primeyra Partida (ca. 1350), in José de Azevedo Ferreira (1980): Alphonse X. Primeyra partida. Braga: INIC, 3-580. Edição digitalizada para o CIPM, financiada pelo editor.

CGE = Crónica Geral de Espanha de 1344 (sd), in Luís Filipe Lindley Cintra (ed.) (1951): Crónica geral de Espanha de 1344. Lisboa: INCM. Edição digitalizada para o CIPM.

CAXL = Crónica de Afonso X (manuscrito L) (sem data), in Luís Filipe Lindley Cintra (ed.) (1951): Crónica geral de Espanha de 1344. Lisboa: INCM. Edição digitalizada para o CIPM.

CAXP = Crónica de Afonso X (manuscrito P) (sem data), in Luís Filipe Lindley Cintra (ed.) (1951): Crónica geral de Espanha de 1344. Lisboa: INCM. Edição digitalizada para o CIPM.

$\mathrm{CDA}=$ Chancelarias Portuguesas de D. Afonso IV, vols. 1, 2 e 3 (30 Textos seleccionados), in João J. Alves Dias (ed.) (1990-1992): Chancelarias portuguesas de D. Afonso IV. Lisboa: INIC. Edição digitalizada, cedida pelo editor.

$\mathrm{AT}=$ Arte de Trovar (sem data), in Giuseppe Tavani (ed.) (1999): Arte de trovar do Cancioneiro da Biblioteca Nacional de Lisboa. Lisboa: Colibri. Edição digitalizada para o CIPM.

NLL = Narrativas dos Livros de Linhagens, in José Mattoso (1983): Narrativas dos Livros de linhagens. Lisboa: INCM. Edição digitalizada para o CIPM.

LM = Livro de Montaria de João I (sem data), in Adelino de Almeida Calado (ed.) (no prelo). Edição digitalizada, cedida pelo editor, através de Telmo Verdelho.

CI = Corte Imperial (anónima dos fins do séc. XIV), in Adelino de Almeida Calado (ed.) (2000): Corte enperial. Aveiro: Universidade. Edição digitalizada, cedida pelo editor, através de Telmo Verdelho.

\section{Século XV}

HGP = 42 textos notariais da Galiza e do Noroeste de Portugal (1401-1497), in Clarinda de Azevedo Maia (1986): História do galego-português. Coimbra: INIC, 19-295. Edição digitalizada para o CIPM.

$\mathrm{DN}=46$ textos notariais (sem data ou datados entre 1402 e 1499), in Ana Maria Martins (ed.) (2000): Documentos notariais dos séculos XII a XVI. Edição digitalizada, cedida pela editora.

LC = Leal Conselheiro (1437-38), in Joseph M. Piel (ed.) (1942): Leal Conselheiro. Lisboa: Livraria Bertrand. Edição digitalizada para o CIPM, revista por João Dionísio e Sandra Álvarez. 
LEBC = Livro da Ensinança de Bem Cavalgar Toda Sela (sem data), in Joseph M. Piel (ed.) (1944): Livro da ensinança de bem cavalgar toda sela. Lisboa: Livraria Bertrand. Edição digitalizada para o CIPM, revista por João Dionísio.

$\mathrm{CP}=$ Castelo Perigoso (sem data), in João António Santana Neto (ed.) (1997): Duas leituras do tratado ascético-místico Castelo Perigoso. Dissertação de Doutoramento. São Paulo: Faculdade de Filosofia, Letras e Ciências Humanas, USP. Edição digitalizada cedida pelo editor e revista por Irene Nunes.

DSG = Demanda do Santo Graal (sem data), in Irene Freire Nunes (2001): A demanda do Santo Graal. Edição digitalizada para o CIPM com base na edição publicada pela Imprensa Nacional-Casa da Moeda (Lisboa, 1995), revista pela editora.

LVT = Livro das Tres Vertudes (sem data), Maria de Lourdes Crispim (ed.).

Versão paradiplomática digitalizada, cedida pela editora.

$\mathrm{OE}=$ Orto do Esposo (sem data), in Bertil Maler (ed.) (1956): Orto do Esposo. Rio de Janeiro: Ministério da Educação e Cultura, Instituto Nacional do Livro. Edição digitalizada para o CIPM.

CPVC = Carta de Pêro Vaz de Caminha, in M. V. Guerreiro / E. B. Nunes (eds.) (1974): Carta a el-rey dom Manuel sobre o achamento do Brasil. Lisboa: INCM. Edição digitalizada para o CIPM.

HRP = História dos Reis de Portugal (sem data), in Luís Filipe Lindley Cintra (ed.) (1951): Crónica geral de Espanha de 1344. Lisboa: INCM. Edição digitalizada para o CIPM.

ZPM = Crónica do Conde D. Pedro de Meneses (sem data), in Maria Teresa Brocardo (ed.) (1994): Crónica do Conde D. Pedro de Meneses. Dissertação de Doutoramento. Lisboa: FCSH, 333-693. Edição digitalizada, cedida pela editora.

CDF = Crónica de D. Fernando, in Giuliano Macchi (ed.) (1975): Fernão Lopes. Cronica de D. Fernando. Lisboa: INCM. Edição digitalizada para o CIPM.

CDJI1 = Crónica de D. João I, parte 1, in Fernão Lopes (1945): Crónica de D. João I. Porto: Livraria Civilização (segundo o códice nº 352 do Arquivo Nacional da Torre do Tombo). Edição digitalizada para o CIPM.

CDJI2 = Crónica de D. João I, parte 2, in Fernão Lopes (1949): Crónica de D. João Primeiro. Porto: Livraria Civilização. Edição digitalizada para o CIPM.

CDPI = Crónica de D. Pedro I, in Damião Peres (ed.) (1965): Fernão Lopes. Crónica de D. Pedro I. Porto: Livraria Civilização. Edição digitalizada e revista por José Barbosa Machado, cedida pelo revisor. 
TC = Tratado da Confissom (1489), in José Barbosa Machado (ed.) (2003):

Tratado de Confissom. Vol I. Chaves: Universidade de Trás-os-Montes e Alto Douro. Edição digitalizada, cedida pelo editor.

PMP = Penitencial de Martim Pérez, in Mário Martins (ed.) (1957): Penitencial de Martim Pérez. Edição digitalizada e revista por José Barbosa Machado, cedida pelo revisor.

S = Sacramental, de Cremente Sanchez de Vercial (1488), in José Barbosa Machado (ed.) (2005): Clemente Sánchez de Vercial. Sacramental. Minho: Pena Perfeita. Edição digitalizada, cedida pelo editor.

VDT = Vida de D. Telo, in Aires Augusto Nascimento (ed.) (1998): Hagiografia de Santa Cruz de Coimbra. Lisboa: Colibri, 273-286. Edição digitalizada, cedida por José Barbosa Machado.

VST = Vida de São Teotónio, tradução quatrocentista da vida de S. Teotónio. Edição digitalizada e revista por Deolinda Rodrigues Cabrera, cedida por José Barbosa Machado.

LHB = Livro das Histórias da Bíblia (sem data), in J. Mendes de Castro (ed.) (1998): Bíblia de Lamego. Vol. I e II. Lamego. Edição digitalizada, cedida por José Barbosa Machado.

Cat = Catecismo (sem data), in Elsa Branco da Silva (ed.) (2001): O catecismo pequeno de Dom Diogo Ortiz. Lisboa: Colibri. Edição digitalizada, cedida pela editora. 
III. A LEXICOGRAFÍA ACADÉMICA 



\title{
O NOVO DICIONARIO DA REAL ACADEMIA GALEGA
}

\author{
Manuel González González \\ Real Academia Galega / Universidade de Santiago de Compostela
}

\section{INTRODUCIÓN}

Cando en 1905 a Asociación Iniciadora y Protectora de la Academia Gallega de La Habana impulsou a creación da RAG, encomendoulle como unha das principais tarefas a de realizar o dicionario da lingua galega. Neste momento xa se coñecían algúns dicionarios do galego, todos eles de carácter bilingüe, que no fondo tiñan sempre como punto de referencia o castelán. Pero nin o dicionario de F. J. Rodríguez (1863), nin o de Cuveiro (1876), nin o de Valladares (1884) podían considerarse obras de referencia nin sequera cos criterios lexicográficos pouco esixentes da época, aínda que hai que recoñecer que a obra de Valladares supuxo un adianto considerable con respecto ás dúas anteriores. En realidade, no único aspecto en que os lexicógrafos do XIX superaron o labor realizado no XVIII polos seus antecesores Sarmiento e Sobreira, foi en darlles ás súas obras un formato máis próximo ao que hoxe consideramos un dicionario. Coa vontade de dar un paso cualitativo dentro da lexicografía galega comezaron os traballos do Diccionario da RAG cun fervor realmente admirable. Para a súa realización pediuse a colaboración de todos os académicos da institución e daquelas persoas que naquel momento estaban en posesión dalgunha recolla léxica galega ou con ganas de levala a cabo. Desde aquela houbo diversas contribucións importantes no campo da lexicografía galega, que non é este o momento de examinar nin de valorar. Foi no 1990 cando se deron os pasos máis firmes no aspecto metodolóxico na lexicografía monolingüe, coa publicación por parte do Instituto da Lingua Galega e a Real Academia Galega do Diccionario da lingua galega (ILG/RAG 1990), Aínda que contaba só con 12.000 entradas, supuxo un avance decisivo en aspectos metodolóxicos tan importantes como: 
(a) o coidado na redacción das definicións, que se realizan facendo uso unicamente das palabras que figuran como entradas no propio dicionario, e que evitan en todo momento a circularidade, tan frecuente nalgúns traballos lexicográficos;

(b) a precisión nas indicacións categoriais, particularmente nos verbos, que se traduce non só nas anotacións de tipo gramatical, senón tamén na propia organización das definicións;

(c) a incorporación de exemplos a cada unha das acepcións recollidas;

(d) a indicación para cada unha das acepcións dos sinónimos, antónimos e palabras próximas semanticamente.

Probablemente a obra máis fiable e máis acabada de toda a historia da lexicografía galega, pese ao número relativamente reducido de entradas, xa que unicamente conta con 25.000 lemas, sexa o DRAG (1997). É un dicionario de uso, pero coa restrición do seu carácter normativo, o que explica que un número considerable de palabras empregadas habitualmente no galego non aparezan recollidas, por seren voces espurias innecesarias ou por teren un marcado carácter dialectal. Aínda así, pola alta frecuencia de uso que presentan, dáselles cabida a algunhas destas palabras non recomendables, pero van sempre precedidas dun asterisco, e desde elas remítese para a forma galega considerada máis correcta.

O carácter máis novidoso desta obra é a sistematicidade e modernidade da técnica lexicográfica na microestrutura das entradas. Cada artigo presenta unha información estruturada de tipo fonético (cando é pertinente), gramatical, léxico, nivel de lingua, ámbito de especialidade, etc. A incorporación do principio lexicográfico de que toda definición debe poder substituír o termo definido nun contexto dado levou a preocuparse de que a perífrase da definición teña unha forma tal que poida desempeñar a función sintáctica propia da palabra definida, así como á separación entre o núcleo e o contorno da definición. É esta a primeira obra de lexicografía galega en que se segue este principio de maneira sistemática. Cada unha das acepcións leva un ou varios exemplos de uso que, amais de proporcionar ao usuario un modelo de utilización concreta da palabra dentro dun enunciado, actúa tamén de elemento de contraste para someter a proba a corrección e adecuación da definición. Na selección de exemplos tívose especial coidado por evitar o clasismo, o sexismo e, en xeral, a transmisión de ideas non acordes cos principios de igualdade de todos os seres humanos, de convivencia democrática e de respecto pola natureza. O mesmo ca no dicionario de 1990, tamén neste se indica para cada acepción os sinónimos, antónimos e outros termos que presentan 
unha estreita afinidade semántica. Cada artigo cérrase coas locucións, frases feitas e modismos nos que aparece o lema da entrada como palabra base ${ }^{1}$. Neste momento a Real Academia Galega está traballando nun novo dicionario das mesmas características técnicas ca o anterior, pero de 50.000 entradas, e del é do que imos falar.

\section{O DRAG, DICIONARIO NORMATIVO}

Vimos xa que o primeiro encargo que se lle fixo á RAG foi a elaboración dun dicionario da lingua galega, que recolla a riqueza léxica da nosa lingua, aínda en boa parte non recompilada, pero tamén que sirva de orientación para a súa escrita. ODRAG debe ser, pois, un dicionario de lingua, no que se atope aquela parte do léxico que é común á maior parte dos falantes e que estes utilizan nas súas interrelacións habituais, pero tamén un dicionario normativo ao que o usuario poida acudir para saber se a forma, o contido, ou as características gramaticais dunha determinada voz pertencen ao que se considera bo galego ou non. Debe ser, pois, un dicionario que oriente sobre o uso correcto:

(a) na forma das palabras, tanto na súa vertente escrita (se unha palabra se escribe con $b$ ou $v$, con $h$ ou sen $h$, etc.), como na súa vertente oral (se unha palabra se pronuncia con $e$ aberto ou pechado, con $s$ ou con $x$, etc.). Por iso debe advertir, nos casos en que un grafema poida representar máis dun fonema, a cal dos fonemas representa en cada caso concreto;

(b) nos significados;

(c) nas características morfosintácticas;

(d) no rexistro.

\section{AS FONTES PARA A ELABORACIÓN DO DRAG}

Os primeiros dicionarios da lingua galega foron realizados por afeccionados que pacientemente ían apuntando as palabras que escoitaban no seu lugar de nacemento, no lugar onde vivían ou nos lugares que visitaban. Nalgúns casos incorporaron algúns datos extraídos de textos escritos, literarios ou non, pero en todo caso non se baseaban nun conxunto de textos orais ou escritos que puidesen ser considerados como represen-

1. Para a análise máis polo miúdo das características desta obra pode verse González González (1996). 
tativos do conxunto da realidade lingüística dun determinado momento. Hoxe non se entende a elaboración dun dicionario de lingua sen un corpus que lle sirva de base.

A información do $D R A G$ está elaborada a partir de tres tipos principais de fontes:

(a) Obras lexicográficas anteriores (dicionarios, vocabularios, léxicos...);

(b) Corpus representativo da lingua escrita do galego moderno;

(c) Corpus representativo da lingua oral do galego actual.

\subsection{Os dicionarios e obras lexicográficas anteriores}

Pódese dicir que dalgunha maneira o DRAG é debedor de todas cantas obras lexicográficas foron realizadas con anterioridade á súa elaboración, porque todas elas foron tidas en conta, mesmo en moitos casos para rexeitar a súa información. Pero permítaseme sinalar algunhas das obras históricas máis significativas: toda a información léxica contida nas obras de Sarmiento $(1970,1973,1975,1986,1999)$ e de Sobreira (cfr. Pensado 1974), a Traducción de algunas voces, frases y locuciones gallegas, especialmente de agricultura al castellano atribuída a Reguera y Pardiñas (18401858), os dicionarios e vocabularios de F. J. Rodríguez (1863), Juan Manuel Pintos (1865), Juan Cuveiro Piñol (1876), Marcial Valladares (1884) (cos suplementos de 1896 a 1902), Francisco Porto Rey (1900-1908), Leiras Pulpeiro (ca. 1906) (cfr. Pérez Pascual / Tato García 1986), Payzal (cfr. Ferreiro 1994), DRAG (1913-1928), X. F. Filgueira Valverde et alii (1926), Leandro Carré Alvarellos (1928-1931), Acevedo y Huelves / Fernández y Fernández (1932), Aníbal Otero (1949-1977, 1967, 1977), Eladio Rodríguez (1958-1961) (co apéndice), Franco Grande (1968), Ríos Panisse (1977, 1983), Elixio Rivas (1978, 1988, 1996, 1997a, 1997b, 1997c, 1998a, 1998b, 2003), Constantino García González (1974, 1985), Francisco Romero Lema (2000), etc.

Hoxe, a maioría destas obras están recollidas no Diccionario de diccionarios (Santamarina 2003b), que nos últimos anos nos facilitou moito o traballo, xa que permite unha consulta moito máis cómoda da información sobre unha palabra nos distintos dicionarios, facilita o seguimento histórico das voces nas obras lexicográficas (copias, malas lecturas, malas interpretacións...), e supón un aforro de tempo importantísimo para a consulta das fontes lexicográficas que incorpora. 


\subsection{O Tesouro Lexicográfico da Lingua Galega}

O Tesouro Lexicográfico da Lingua Galega é un amplo conxunto de fichas léxicas con voces recollidas especialmente da lingua oral, posto en marcha a finais dos anos sesenta por Constantino García no Departamento de Filoloxía Románica da Universidade de Santiago, e que despois, cando se creou o Instituto da Lingua Galega, pasou a esta institución. Este ficheiro contén voces procedentes de:

(a) teses de doutoramento e memorias de licenciatura realizadas sobre falas de distintos puntos de Galicia ou ben sobre elementos da cultura material ou espiritual de Galicia;

(b) enquisas realizadas por alumnos das materias que impartía o Departamento de Filoloxía Románica e por outros colaboradores que achegaban información máis ou menos ocasional;

(c) gravacións de textos orais.

Como cabería esperar pola formación dos seus recolectores, esta información non ofrece toda o mesmo nivel de fiabilidade. Non teñen o mesmo valor os datos proporcionados por un doutor, especialista en lingüistica, que os achegados por un alumno ou por un afeccionado que, aínda poñendo toda a súa mellor vontade, non sempre posúen a formación académica suficiente para transmitir con precisión aquilo que escoitaron ou coidaron escoitar. Esta é a razón que levou a clasificar a información do ficheiro en tres tipos de fichas, de distintas cores, segundo o nivel de confianza que ofrecesen:

(a) a información procedente de teses ou memorias de licenciatura ou de traballos contrastados cientificamente recóllese en fichas de cor branca;

(b) a procedente de enquisas de alumnos ou colaboradores, en fichas de cor amarela;

(c) a información procedente da transcrición de gravacións de textos orais, en fichas de cor azul.

O soporte desta información en fichas de papel limita o seu aproveitamento. Sería moi difícil, por exemplo, coñecer todos os sinónimos que aparecen para bidueiro, porque esixiría percorrer todas as fichas contidas en cada un dos centos de caixóns que integran o ficheiro. Por iso se intentou a informatización deste ficheiro nunha base de datos con nove campos: 

(a) forma dialectal
(b) forma normativa
(c) equivalencia en castelán
(d) categoría gramatical
(e) campo nocional
(f) exemplo
(g) lugar de recollida
(h) notas
(i) fonte

Para o campo nocional, deseñouse un modelo no que o universo se estrutura en dez campos; cada un destes subdívidese noutros dez, e cada un destes de novo noutros dez, etc.:

1. Ceo e atmosfera

2. Terra

3. Plantas

3.1. A vida vexetal en xeral

3.2. Árbores

3.2.1. Xeneralidades

3.2.2. Árbores madeirables

3.2.3. Árbores froiteiras

etc.

\subsection{O Tesouro Informatizado da Lingua Galega (TILG)}

É unha base de datos do léxico contido nun corpus do galego moderno. Trátase dun proxecto dirixido por Antón Santamarina, no Instituto da Lingua Galega, cunha finalidade principalmente lexicográfica. Contén ao redor de 11 millóns de rexistros, e abrangue o ámbito temporal comprendido entre o ano 1671 e a actualidade.

O corpus está integrado por:

- textos literarios

- textos xornalísticos

- textos de carácter técnico e científico

- textos de literatura oral

- textos orais sen carácter literario 
Coa finalidade de facilitar o seu tratamento, os textos foron sometidos a un proceso de normalización e uniformización ortográfica. Por exemplo:

(a) Reducíronse a $n h$ as diversas formas para representar a consoante nasal velar en posición intervocálica: unha, un-a, un-ha, umha > unha;

(b) Regularizouse o uso de $b$ e $v$, segundo os criterios ortográficos do galego actual: avó, abó > avó;

(c) Regularizouse o emprego de $h$, segundo a ortografía vixente na actualidade: hoso, óso > óso:

(d) Modificouse o uso do acento gráfico seguindo os criterios de acentuación das normas ortográficas actuais: cantéi, cantei > cantei; pèrtega, pértega > pértega.

O proceso de regularización do texto facilita o traballo de lematización, pero ten dous inconvenientes de certa importancia: non permite facer un seguimento da evolución da ortografía a través dos textos que contén, e esixe ter que acudir sistematicamente ás fontes para comprobar a ortografía cando se quere facer unha cita textual.

Esta base de datos ofrécenos para calquera voz as concordancias, o seu lema e a categoría gramatical á que pertence.

\subsection{Corpus de Referencia do Galego Actual (CORGA)}

O Corpus de Referencia do Galego Actual foi elaborado no Centro Ramón Piñéiro para a Investigación en Humanidades, e está dirixido por Guillermo Rojo.

O CORGA contén unha colección de documentos en formato electrónico, na que están representados os diferentes tipos de textos da lingua galega actual. Abrangue o ámbito cronolóxico comprendido entre o ano 1975 e a actualidade. Trátase, pois, dun corpus referido exclusivamente ao galego actual ou recente.

É un corpus que pretende ser equilibrado, con representación proporcional de textos de distintos xéneros, de distintas áreas temáticas e de distintos anos. As grandes áreas temáticas en que se clasifican os textos son:

- Economía e política

- Cultura e artes

- Ciencias sociais

- Ciencia e tecnoloxía 
- Ficción

- Outros

Na constitución temática do corpus tivéronse en conta non só as áreas temáticas, senón tamén as subáreas. Por exemplo, na área temática “Economía e política”, están representadas as subáreas de:

- Política

- Desenvolvemento e infraestruturas

- Emprego, traballo, industria

- Sector servizos

- Explotación primaria

- Economía, facenda, bolsa

- Ordenación sanitaria

- Xustiza, lexislación, dereito

- Asuntos sociais

- Ordenación académica

As buscas e concordancias pódense realizar sobre o conxunto do corpus, ou ben restrinxilas a unha ou varias áreas temáticas. O usuario pode seleccionar tamén o período cronolóxico que sexa do seu interese:

$-1975-1979$

$-1980-1984$

$-1985-1989$

- 1990-1994

- 1995-1999

- 2000-2004

Deste corpus existen dúas versións en liña. A primeira contén 17.5 millóns de formas, e está dispoñible no enderezo http://corpus.cirp.es/corga. A segunda, sobre a que aínda se está a traballar, contén neste momento 13.3 millóns de formas, e está dispoñible no enderezo http://corpus.cirp. es/corgaxml ${ }^{2}$.

A segunda versión en .xml creouse para posibilitar un sistema de recuperación de información máis flexible e efectivo, e obrigou a unha codificación e deseño dunha estrutura formal que dea conta da disposición 
interna característica de cada un dos grandes tipos de textos (xornalísticos, ensaio, novela...).

Estase ultimando unha ferramenta de análise gramatical automática e de desambiguación, que permitirá a lematización automática, a actualización da base cun custo económico baixo, e buscas secuenciais por categorías (por exemplo, verbo tirar + preposición).

\subsection{O Atlas Lingüístico Galego (ALGa)}

O Atlas Lingüístico Galego proporciona valiosísima información sobre a realidade léxica do galego actual, co valor engadido de que permite a súa localización xeográfica e examinar a extensión no territorio dunha voz cun significado determinado.

Neste momento lévanse publicados 5 volumes desta obra, pero para o DRAG fixéronse tamén con frecuencia consultas sobre os cadernos para documentar determinados significados de voces populares.

\subsection{O Arquivo do Galego Oral}

Outra fonte de procedencia oral con certo interese para o DRAG é o Arquivo do Galego Oral, proxecto dirixido por Francisco Fernández Rei, no ILG, e que contén gravacións de máis de 2.000 puntos de todo o territorio de fala galega. Neste momento aínda non está transcrito todo o material contido nas gravacións.

Aínda que a súa finalidade non é puramente lexicográfica, as súas concordancias son utilísimas para coñecer o uso das palabras, para examinar os contextos de utilización e para ver o seu valor real.

\subsection{O Tesouro Fraseolóxico Galego (TFG)}

Nos dicionarios actuais, cada vez se lle ofrece maior importancia á fraseoloxía, e para atender este aspecto resultou de axuda inestimable o proxecto, dirixido por Xesús Ferro Ruibal no Centro Ramón Piñeiro, que leva por título Tesouro Fraseolóxico Galego.

O TFG sobrepasa neste momento as trescentas mil entradas, con datos que van desde mediados do século XVIII ata hoxe, pero con predominio dos correspondentes aos últimos oitenta anos.

Por seren os fraseoloxismos unidades cunha estrutura máis ou menos fixada, cun significado que, na maior parte dos casos, non é a suma dos significados das palabras que as integran, enténdese facilmente que cada 
vez se lles dea unha maior importancia nos dicionarios modernos. Tense dito moitas veces que non se coñece en profundidade unha lingua ata que non se coñecen ben os seus fraseoloxismos. Pero, ademais, así como no léxico dunha lingua se reflicte dalgunha maneira a historia e as experiencias dos pobos, a fraseoloxía revélanos por veces dun xeito moi transparente a maneira particular de ver a realidade de cada sociedade ou de cada cultura.

\section{A MACROESTRUTURA DO DRAG}

\subsection{As entradas}

O Dicionario da Real Academia Galega contén ao redor de cincuenta mil artigos lexicográficos, e as súas entradas están baseadas no Vocabulario ortográfico da lingua galega (VOLG), con algúns engadidos:

(a) Considerouse conveniente completar algunha familia de palabras que no VOLG aparecía unicamente cos seus membros máis relevantes.

(b) Introducíronse algunhas voces non incluídas no VOLG, xeralmente pertencentes a linguas de especialidade, pero que presentan certo uso.

(c) Completouse algunha serie de palabras que constitúen un conxunto completo claramente delimitado, e que por algunha razón quedou incompleta no VOLG.

O VOLG é unha proposta de vocabulario normalizado da lingua galega. A primeira edición provisoria saíu no ano 1990, en edición non venal, e a primeira edición oficial é do ano 2004. Actualmente pódese consultar na páxina da RAG a versión en liña deste vocabulario (www.realacademiagalega.org). Esta versión en liña presenta xa algunhas correccións e novidades con respecto á editada en papel. A realización desta proposta de vocabulario normalizado da lingua galega esixiu realizar unha selección de formas dialectais dentro do propio galego, levar a cabo unha depuración de castelanismos e de voces espurias innecesarias, facer unha proposta de ortografía, acentuación e morfoloxía correctas, e, en certa medida, afrontar tamén o problema de actualización e modernización do léxico.

Foi necesario, en primeiro lugar, facer unha selección de formas dialectais. Por poñer un exemplo que sexa claramente comprensible, para designar a árbore betulla, de entre un gran número de formas existentes (bidueiro, bedueiro, bidoeiro, bidoeira, budueira, abedoeira, abedueiro..., bedugo, bedulo, 
dulo, bídalo, bido, budio...) foi necesario escoller unha delas, neste caso bidueiro, para a norma estándar. Evidentemente, as escollas non poden ser feitas de xeito arbitrario, senón seguindo unha serie de criterios da maneira máis coherente posible. Os principais criterios seguidos no VOLG para a selección dialectal foron: a autenticidade da forma, a extensión xeográfica, a tradición literaria e a coherencia interna dentro da mesma familia.

O VOLG significou un avance extraordinario tamén na depuración de castelanismos e voces espurias innecesarias. $O$ préstamo lingüístico pode ser necesario en certos casos, cando designa unha realidade nova, pero debe evitarse que unha voz foránea retire da circulación outra galega que designe o mesmo concepto. Por iso se excluíron castelanismos moi introducidos, como por exemplo abonar, para restituír no seu lugar a forma patrimonial galega aboar; ou lusismos con certa implantación literaria, como aceitona, anceio ou saudade, para darlles prioridade ás voces propiamente galegas oliva, ansia ou devezo, e soidade.

O VOLG é unha proposta de ortografía correcta para a lingua galega. Na tradición escrita do galego moderno existen tendencias gráficas alleas á historia e á evolución da propia lingua. Son frecuentes grafías debedoras do castelán como *acibro, ${ }^{*}$ trebo, ${ }^{*} b a r r e r$, e hai grafías que só se explican baixo a influencia do portugués, como por exemplo * povo. Todas elas foron restituídas á forma ortográfica máis acorde cos criterios gráficos do galego: acivro, trevo, varrer, pobo.

A presión do castelán, e a penetración dun gran número de cultismos a través desta lingua, introduciu nos falantes galegos un alto número de acentuacións antietimolóxicas, que foi necesario corrixir na proposta normativa do léxico galego: fronte ás realizacións populares, introducidas a través do castelán, do tipo *ósmose, ${ }^{*}$ diócese, ${ }^{*}$ atmósfera, ${ }^{*}$ isobara, ${ }^{*}$ fotolise, "monolito..., propuxéronse as formas con acentuación máis etimolóxica osmose, diocese, atmosfera, isóbara, fotólise, monólito...

No VOLG tamén se fai unha proposta de morfoloxía correcta para a lingua galega: indícase o xénero correcto de cada substantivo (condénanse, por exemplo, usos como ${ }^{*}$ fraude, ${ }^{*}$ sindrome, fronte ás formas recomendadas a fraude, a síndrome), indícase o réxime de cada verbo, do que aparecen usos incorrectos debidos á interferencia co castelán (quecer (i) / quentar, adormecer (i) / adormentar, amarelecer (i) / amarelar).

Naqueles casos en que a formación do feminino ou do plural pode ser problemática, tamén se informa sobre este particular: afgán /f: afgá, pero cachán / f: cachana.

Outra función que tivo que cumprir o VOLG é a de actualización e modernización do léxico. O galego, debido ás especiais circunstancias histó- 
ricas que lle tocou sufrir, quedando circunscrito practicamente ao mundo agrícola e mariñeiro, desenvolveu un léxico rico para estes ámbitos, pero non se adaptou lexicamente a aquelas áreas nas que non era lingua de uso habitual (ciencia, administración, tecnoloxía...). Foi necesario, xa que logo, facer un esforzo para capacitar a lingua para as novas necesidades da sociedade actual, actualizando o seu léxico mediante distintos procedementos:

(a) Préstamo doutra lingua: xenismos (khmer), préstamos integrados (bisté, chalé, estándar);

(b) Cultismo latino ou grego: elipse, metátese...;

(c) Revitalización de arcaísmos: ousia, doazón, xaxuar, taxa...;

(d) Calco: autoestrada, altofalante...;

(e) Creación autóctona: mostraxe, lastro, beirarrúa, rede de sumidoiros...

\subsection{Algúns problemas referidos á macroestrutura}

Os autores de calquera dicionario moderno, á hora de decidiren a súa macroestrutura, teñen que tomar unha serie de decisións sobre problemas como: qué unidades terminolóxicas introducir, o tratamento dos homónimos, o tratamento de formas morfoloxicamente irregulares, qué facer coas lexías compostas e as frases feitas, qué papel se lles vai dar ás palabras non normativas, etc. Vexamos cal é o comportamento do DRAG con respecto a estas cuestións.

\subsubsection{O tratamento da terminoloxía}

Dilucidar qué unidades terminolóxicas deben ser introducidas nun dicionario xeral dunha lingua é un asunto longamente discutido. Nunca coma hoxe houbo tanta osmose entre as linguas de especialidade e a lingua común, no que se refire ao léxico. Isto é unha consecuencia lóxica do aumento do nivel cultural das sociedades modernas e da democratización do coñecemento. Un termo coma o rato dun ordenador, que hai ben poucos anos pertencía á lingua de especialidade da informática, hoxe debe considerarse unha voz xa integrada na lingua habitual de calquera persoa. De maneira xeral, podemos dicir que nun dicionario de lingua deben ter cabida os termos, en canto unidades léxicas, que non pertenzan a un nivel altamente especializado.

Un problema especial preséntao o tratamento dos símbolos. Dentro das unidades de coñecemento especializado, temos unidades lin- 
güísticas (léxicas, fraseolóxicas e oracionais), pero encontramos tamén unidades non lingüísticas (símbolos, fórmulas, nomenclaturas, iconografía). Debemos preguntarnos, pois, qué facemos, por exemplo, cos símbolos químicos. Deben ter cabida no dicionario os símbolos $\mathrm{H}$ (que representa o hidróxeno) ou O (que representa o osíxeno)? En realidade, os símbolos son unidades non lingüísticas de coñecemento especializado, semellantes en certo modo ás iconas; pensemos por exemplo no que simboliza

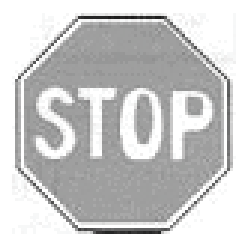

$\mathrm{E}$, se lle damos cabida no dicionario a $\mathrm{H}$ ou a $\mathrm{O}$, debemos preguntarnos tamén por qué non facemos o mesmo con, por exemplo, $\mathrm{H}_{2} \mathrm{SO}_{4}$, que representa o ácido sulfúrico.

O tratamento que os dicionarios lles dispensan aos símbolos químicos difire radicalmente duns a outros. Hai dicionarios que os acollen e outros que se negan a darlles cabida (por exemplo, un tan coñecido como - Vocabolario della lingua italiana de Zingarelli). No DRAG optamos por darlles cabida a algúns por razóns de tipo práctico, pero sen estarmos convencidos da súa inclusión desde un punto de vista teórico.

\subsubsection{Tratamento dos homónimos. O problema da homonimia e da po-} lisemia

En realidade, desde o punto de vista sincrónico, un signo lingüístico é unha unidade dotada dunha expresión fónica e un contido semántico. Deste xeito, cada acepción dunha voz (ou mellor, cada invariante significativa) constituiría un signo lingüístico distinto, e poderíase pensar nunha entrada distinta para cada relación significante-significado. Pero esta é unha práctica pouco seguida ata agora na lexicografía, por unha razón moi simple, porque todos temos conciencia de que diversos significados poden ser asignados a un mesmo significante, e de que entre estes significados existe moitas veces unha relación especial (de proximidade semántica, de derivación xenética entre un e outro, etc.).

Nas obras lexicográficas habitualmente véñense agrupando baixo un mesmo lema os casos de polisemia, e sepáranse en lemas distintos os casos de homonimia. O problema está daquela en distinguir entre homonimia e polisemia. As diferencias entre homonimia e polisemia non sempre 
están claras, e non todos os lingüistas seguen os mesmos criterios para diferenciar unha doutra. Os criterios máis frecuentes de distinción son:

(a) O etimolóxico: considéranse casos de polisemia aqueles en que os distintos significados que se asignan a un único significante derivan dun mesmo étimo; e considéranse casos de homonimia aqueles en que os distintos significados que se corresponden cun mesmo significante derivan de étimos distintos.

(b) Outras veces acódese á conciencia dos falantes, para dirimir se estamos ante un caso de homonimia ou de polisemia.

(c) Tamén con frecuencia se botou man de criterios semánticos, considerando, por exemplo, casos de polisemia aquelas acepcións que pertencen a un mesmo campo semántico, e casos de homonimia os demais.

No DRAG séguese un criterio historicista, baseado na etimoloxía:

\footnotetext{
sacha $^{1}$ s.f. Ferramenta agrícola utilizada para sachar, que varía de forma e de tamaño segundo os lugares. Colleu a sacha e foi cara á leira. SIN. sacho.

sacha $^{2}$ s.f. 1 . Acción de sachar. Xa logo empezaban coa sacha do millo. A sacha é un labor pesado. SIN. cava $^{1}$, sachada, sachadura. 2. Época en que se realiza este labor. Creo que ocorreu pola sacha das patacas. SIN. sachega.
}

No caso de sacha ${ }^{1}$ estamos ante unha formación a partir de sacho, que procede do lat. SARCULUM; en cambio, no caso de sacha ${ }^{2}$ encontrámonos diante dun substantivo deverbal, formado a partir do verbo sachar.

\subsubsection{Tratamento de formas morfoloxicamente irregulares}

Aínda que como cabeza de artigo lexicográfico figuran unicamente os lemas (as formas do masculino singular no caso dos substantivos e adxectivos, e o infinitivo no caso dos verbos), hai veces en que se incorporan como entradas tamén outras formas que son morfoloxicamente irregulares, co fin de facilitar o uso do dicionario a persoas que non teñen un coñecemento profundo da lingua. Nestes casos non se ofrece a información lexicográfica da voz, e remítese para o seu lema correspondente:

poetisa s.f. V. poeta.

poeta s.m. (f. poetisa) Persoa que escribe poesía. OBS. Tende a utilizarse a forma poeta como feminina, en lugar de poetisa. Curros Enríquez é un poeta do século XIX. A gran poetisa galega Rosalía de Castro. 
Esta práctica non se leva a cabo cando a forma irregular cadra xusto ao lado do lema, porque neste caso o usuario, ao buscar a forma irregular, encontra xa facilmente o lema correspondente. Isto ocorre, por exemplo, con actriz, que non figura como entrada porque caería xustamente despois de actor.

Hai un caso especial no que se lle dá cabida á forma morfoloxicamente irregular mesmo que alfabeticamente lle cadre xusto ao lado do seu lema: cando a forma do feminino ten algunha acepción distinta que non posúe a forma masculina:

\footnotetext{
duque $s . m$. (f. duquesa) Nobre do máis alto rango, despois do príncipe e inmediatamente superior ao marqués. Fomos visitar o pazo dos duques de Alba.

duquesa s.f. 1. V. duque. 2. Muller do duque. Acudiu a duquesa en representación do seu marido.
}

\subsubsection{O tratamento das locucións}

As lexías compostas e as locucións non figuran como entradas. Incorpóranse ao elemento constituínte que se considera máis importante semanticamente:

\footnotetext{
carrada s.f. 1. Carga que leva un carro dunha soa vez. Trouxeron unha carrada de toxo do monte. 2. Cada unha das viaxes que se fai cando se carrexa algo. De volta da segunda carrada foi montado no carro. 3. Gran cantidade ou gran número [de algo que se expresa]. A onde vas con esa carrada de libros? SIN. carrado, carretada. $\Delta$ A carradas. En gran abundancia. Había mazás a carradas.
}

Cando non existe un elemento semántico dominante, asígnase ao primeiro, e remítese desde o outro:

posesorio -a adx. Relativo ou pertencente á posesión. A lei esixía o transcurso dun prazo posesorio de dez. anos. $\Delta$ Xuízo posesorio. V. xuízo.

Pode darse o caso de que o elemento principal constitutivo da lexía composta ou da locución non figure como entrada do dicionario. Cando isto ocorre dáselle cabida como entrada á lexía composta ou locución. Por exemplo, a voz cabaleirola non figura como entrada do dicionario, porque non ten uso fóra da locución adverbial ás cabaleirolas, e por iso figura esta como entrada:

cabaleirolas, ás loc. adv. Escarranchado sobre os ombreiros ou o lombo. O máis pequeno levábao o pai ás cabaleirolas. SIN. a cabalo, ás cabaliñas, ao cabalete. CF. ao carrelo, ao lombo. 


\subsubsection{As palabras non normativas}

O DRAG debe ser e é un dicionario normativo, que orienta sobre o uso correcto do léxico do galego; por iso non deben figurar nel as voces non normativas. Pero debe ser tamén un dicionario didáctico, e que lle proporcione ao usuario a información que busca da maneira máis fácil posible. Esta é a razón que explica a presenza dalgunhas voces non normativas, pero que teñen certa vitalidade no uso. Dentro das voces non normativas, distínguense dous casos:

(a) O das formas das que non hai dúbida de que son galegas, pero que están marcadas cun forte carácter dialectal. Neste caso, despois da entrada, remítese para a forma máis recomendable, precedida do símbolo $\Rightarrow$ :

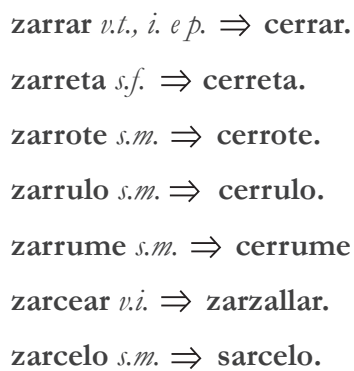

(b) O das formas que son incorrectas en galego, que van marcadas cun asterisco, e desde as cales se remite para a forma normativa galega:

\footnotetext{
*almidón s.m. amidón.
}

\section{A MICROESTRUTURA}

Que contén e como se organiza un artigo lexicográfico no DRAG? O $D R A G$ ofrece información sobre a forma gráfica do lema; información gramatical; información sobre a pronunciación (só nos casos conflitivos); información diastrática e diafásica; información tecnolectal; información sobre o carácter da acepción (fig., por ext.); a definición de cada acepción; observacións referidas á acepción; exemplos; sinónimos, antónimos e palabras próximas semanticamente; unidades pluriverbais nas que ocupa un lugar central a entrada, e observacións referidas ao enunciado. 


\subsection{O lema}

O lema é a forma non marcada: a do masculino singular, no caso dos substantivos e adxectivos; e a do infinitivo, no caso dos verbos. Encabeza sempre o artigo, e encabeza o parágrafo que contén este. Aparece sempre marcado tipograficamente dunha maneira que se faga máis visible e que destaque sobre o resto da información, para xebrar con claridade a información pertencente a un artigo da dos contiguos, e sobre todo, dado que os artigos están dispostos segundo a orde alfabética dos lemas que lle serven de entrada, para facilitarlle a busca ao usuario. No DRAG o lema aparece marcado tipograficamente en letra grosa.

\subsection{Información gramatical}

A información gramatical, deixando á parte a información implícita no sistema de definición de cada acepción, ofrécese por distintos procedementos:

(a) Un deles, sistemático, proporciona para cada lema información sobre a categoría gramatical, xénero, número, réxime verbal, etc. Esta información precede a definición de cada acepción, e vai sempre en caracteres itálicos, como se pode ver nos exemplos seguintes:

\footnotetext{
fachuzo s.m. Presa de palla atada que se acende para alumar. Levaban os fachuzos por se os collia a noite no camiño. SIN. facha ${ }^{1}$, fachico, facho, fachón, fachuco, palluzo.

azougar v.t. 1. Cubrir con azougue. Azougan o vidro pola súa cara posteriorpara convertelo en espello. // v.p. 2. Med. Contraer unha doenza caracterizada por un tremor continuo, causada pola absorción de vapores de azougue. Moitos mineiros azougábanse e morrían. 3. fig. Mostrarse moi inquieto e axitado ou estar en continuo movemento. Polas noites azougábase no leito por mor dos pesadelos.
}

(b) Información sobre a formación de femininos e plurais irregulares, que se ofrece entre parénteses, despois da categoría gramatical:

anorak $s . m$. ( $p l$. anoraks) Chaqueta impermeable con carapucha, que se usa para protexer do frío e da chuvia. Un anorak de plumas.

(c) Información gramatical complementaria, que vai introducida polo sinalizador OBS., onde poden encontrarse observacións de carácter gramatical de carácter moi variado: irregularidades na conxugación verbal, rexencias verbais, obrigatoriedade do uso do artigo, etc. 
- Información sobre as irregularidades verbais:

fuxir vi. 1. Afastarse rapidamente de algo ou alguén, polo xeral para evitar unha ameaza ou perigo. Nos tempos da guerra moitos fuxían para o monte. Os lobos foxen do lume. 2. Saír dun lugar onde se está preso por medios ilícitos. Onte á noite fuxiron varios presos. evadirse. OBS. Verbo con alternancia vocálica no pres. indic.: fuxo, foxes, foxe, fuximos, fuxides, foxen.

- Información sintagmática: obrigatoriedade de uso de artigo, rexencias verbais...:

\footnotetext{
ambos .as indef. Un e mais o outro, os dous. Hai só dúas solucións, ambas con poucas probabilidades de éxito. OBS. Cando vai modificando un substantivo, vai acompañado do artigo e pódese utilizar contraído coa segunda forma, dando como resultado as formas ámbolos e ámbalas. Ambas as partes estaban de acordo. Ámbalas partes estaban de acordo. $\Delta$ Ambos a dous. Os dous. Ambos a dous candidatos teñen as mesmas posibilidades. SIN. ambos os dous. / Ambos os dous. Ambos a dous. Ambos os dous merecian ganar.

tirar v.t. 14. Botar por terra [algo], facer caer ao chan. O temporal tirou o valado da horta. OBS. Emprégase tamén seguido da preposición con. Tirou con el do cabalo embaixo.
}

(d) Ás veces a información sintagmática sobre rexencia de certas preposicións vai indicada entre parénteses a continuación da entrada e co mesmo tipo de letra da entrada:

carecente (de) $a d x$. Que ten ou amosa algunha carencia. Carecente de estímulos e ilusións e invadida pola nostalxia decidiu regresar á súa vila natal. SIN. carecedor, carente.

\subsection{Información fonética}

No $D R A G$ non se ofrece a transcrición fonética de cada lema, pero si se proporciona información fonética sobre aqueles aspectos que poden ofrecer dificultade: a realización do timbre das vogais tónicas de grao medio $e, o$ (especialmente cando existen voces homógrafas que se distinguen unicamente polo timbre destas vogais), a pronunciación de grafemas que poden representar realidades fonolóxicas distintas, a pronunciación de estanxeirismos:

(a) Información sobre o timbre da vogal tónica cando é necesario:

pega ['peya] s.f. 1. Pau ou corda que se lles pon ás vacas, cabalos, etc. para que non fuxan cando están ceibos. Púxolle unha péga ao cabalo mentres pacía. SIN. cadarme, pexa, piega, solta, soltadoiro, traba. 2. fig. Cousa que impide o desenvolvemento normal ou a realización 
dunha acción. Non puxo ningunba péga polo cambio de día. SIN. dificultade, impedimento, inconveniente, obstáculo, pexa, traba.

(b) Pronunciación do grafema $x$ :

anorexia $[\mathrm{ks}]$ s.f. Med. Diminución ou perda do apetito. Pesa soamente trinta quilos porque sofre anorexia. CF. inapetencia. A Anorexia nerviosa. Psiq. Síndrome caracterizada pola redución voluntaria e extrema da alimentación acompañada de vómitos, que orixina adelgazamento e outras alteracións. A anorexia nerviosa é máis habitual en mulleres novas.

(c) Transcrición de estranxeirismos:

jeep [dzip] s.m.(pl. jeeps) Coche pequeno de orixe americana capaz de andar por terreos difíciles, orixinariamente utilizado polo exército. Alugamos un jeep para ir polo monte.

\subsection{Información diastrática, diafásica e diacrónica}

Dentro de calquera lingua existen variedades propias de distintos estratos sociais, de distintos rexistros, e mesmo usos que son considerados xa anticuados. Isto ocorre no plano fonético e no morfosintáctico, pero é especialmente visible no léxico. Por iso, con frecuencia, hai certas entradas ou determinadas acepcións do dicionario que van marcadas con etiquetas como: máis culto, menos culto, fam., pop, ant., etc.:

\footnotetext{
amolar v.p. 3. Sufrir molestia ou fastío. Que se amole e o faga aínda que non lle guste! SIN. amocar(se), enfastiar(se), foder(se) (vulg.).

ampola s.f. 1. Lesión cutánea producida por un levantamento da epiderme, que contén un líquido seroso. Os zapatos fixéronlle ampolas. SIN. bocha, bóchega, boza ${ }^{1}$, flictena (máis culto), vexiga, vincha, vinchoca.
}

\subsection{Información tecnolectal}

Tamén se ofrece información tecnolectal, na que se indica a lingua de especialidade á que pertence unha determinada voz ou unha acepción concreta desa voz. Esta información transmítese por medio de etiquetas, tales como Zool., Bot., Biol...., que van situadas en letra itálica inmediatamente antes da definición da acepción.

ampere s.m. Fís. Unidade de intensidade de corrente eléctrica do sistema internacional. O seu símbolo é $A$. $\Leftarrow$ amperio. Un limitador de 15 amperes.

anacruse s.f. 1. Lit. Na métrica clásica, sílaba que está diante da que inicia o primeiro pé completo. Na métrica grecolatina considérase que a sílaba en anacruse non forma parte do metro. 2 . Lit. Na métrica mo- 
derna, sílaba ou sílabas átonas que preceden o primeiro acento dun verso. Un verso con dúas sílabas en anacruse. 3. Mús. Nota ou grupo de notas dunha melodía que preceden o primeiro tempo forte. Unba melodía que comeza en anacruse.

\title{
5.6. Información sobre a natureza da acepción (ext., fig.)
}

\begin{abstract}
anaerobio -a $a d x$. 1. Biol. [Organismo] que é capaz de vivir sen a presenza de osíxeno no aire. Bacteria anaerobia. 2. Propio dos microorganismos anaerobios. Respiración anaerobia. 3. ext. [Motor, propulsor] que pode funcionar sen aire. Os propulsores anaerobios funcionan fóra da atmosfera. // s.m. 4. Biol. Microorganismo anaerobio. Unha infección producida por anaerobios. O xerme que produce o botulismo é un anaerobio. ANT. aerobio.
\end{abstract}

\begin{abstract}
anatematizar v.t. 1. Pronunciar ou lanzar un anatema unha autoridade eclesiástica contra [alguén]. Anatematizárono por herexe. CF. excomungar. 2. fig. Reprobar enerxicamente ou condenar moralmente. Anatematizou a súa ideoloxía e comportamento.

carburar vi. 3. fig. e pop. Funcionar. A televisión non carbura, non sei qué lle pasa. 4. fig. e pop. Razoar. Ti non carburas.
\end{abstract}

\subsection{A definición}

\subsubsection{Que é a definición?}

A definición consiste en facer corresponder unha unidade léxica, descoñecida ou mal coñecida, cunha serie de unidades pertencentes ao mesmo sistema lingüístico, organizadas segundo as estruturas sintagmáticas deste sistema, e que sexa capaz de remitir ao mesmo significado e de determinar no usuario do dicionario a elaboración conceptual deste significado.

\subsubsection{Definicións propias / definicións impropias}

É xa clásica a distinción entre definicións propias e definicións impropias, aínda que en realidade estas últimas non son verdadeiras definicións.

As definicións impropias están formuladas en metalingua de signo, e non se deixan someter á "lei da sinonimia". Non son verdadeiras definicións ("qué significa a palabra"), senón explicacións ("cómo e para qué se emprega a palabra"). As palabras ás que se aplica este tipo de definición -interxeccións e palabras gramaticais (preposicións, conxuncións, pronomes, artigos e certos adverbios, adxectivos e verbos)- son realmente indefinibles: 
lle, lles pron. pers. Formas átonas de terceira persoa singular e plural respectivamente, en función de complemento indirecto. Fixenlles pedir perdón. Non lles soubo contestar. OBS. lle e lles contraen cos pronomes persoais o, a, os, as e lo, la, los, las dando lugar ás formas Ilo, lla, llos, llas e llelo, llela, llelos, llelas, respectivamente.

As definicións propias son as verdadeiras definicións lexicográficas, están formuladas en metalingua de contido e nelas rexe o principio de substituibilidade entre definido e definidor (son as definicións que corresponden a todos os nomes e á inmensa maioría dos adxectivos, verbos e adverbios).

A lexicóloga e lexicógrafa J. Rey-Debove (1967), nunha das clasificacións máis aceptadas das definicións propias, distingue entre definición substancial e definición relacional. Na definición substancial a análise sémica incide na substancia do definido. A definición relacional incide na relación do definido con outra palabra do enunciado.

\subsection{A definición substancial}

Hai un caso, que podemos considerar "atípico", de definición substancial: é o dos enunciados definitorios ordinarios, sistema seguido por exemplo no Cobuild. É un tipo especial de definición que, baseándose en situacións comunicativas, exhibe unha serie de notas que permiten ao usuario do dicionario identificar a palabra cun significado determinado. Serían definicións do tipo:

\footnotetext{
chover: cando cae auga e imos co paraugas aberto, dicimos que chove.

preservar: se preservas algunha cousa, tomas medidas para conservala ou protexela para que non se estrague, non se perda ou non a rouben.
}

Este tipo de información é útil cando se trata de palabras referidas á esfera da vida da que o usuario ten experiencia, pero resulta pouco práctica ou inservible cando se refire a conceptos sobre os que o usuario non ten experiencia.

No DRAG seguimos outro tipo de definición substancial, máis coñecido e máis utilizado na tradición lexicográfica, que se basea na análise tradicional aristotélica do concepto do definido polo "xénero próximo" e a "diferenza específica". O xénero próximo denomínase incluínte. Corresponde co que Ignacio Bosque (1982) denomina "definición hiperonímica".

A definición substancial é unha resposta directa á pregunta: Que é o definido? Esta resposta preséntase conceptualmente baixo tres formas: 

(a) o definido é tal cousa
(b) o definido é non tal cousa
(c) o definido é o contrario ou a ausencia de tal cousa.

As tres formas de definición conceptual aparecen no noso dicionario. Por iso, aínda que sexa brevemente, imos ver algunha das características da inclusión, da exclusión e da inclusión negativa.

\section{a) A inclusión}

O incluínte é a expresión do concepto clasificador, e pertence á mesma categoría gramatical ca o definido. Semanticamente, todo o semema do incluínte está contido no definido, como por exemplo cabaleiro = 'home a cabalo'.

A maioría das definicións do DRAG presentan unha relación de inclusión:

\footnotetext{
$1 \mathbf{a}^{2}$ s.f. 1. Pelo da ovella ou do carneiro. Raparlles a la ás ovellas. 2. ext. Pelo dalgún outro animal, semellante á la. A la dos camelos. 3. Fío de la. Mercamos unhas madeixas de la para facerlle unha mantiña ao bebé. 4. Tecido de la. Un xersei de la. Un colchón de la. Un abrigo de la. $\Delta$ Baraza de la. V. baraza.
}

lacar v.t. Cubrir con laca [un moble ou outro obxecto]. Ela mesma lacou os mobles do salón.

b) A exclusión

O procedemento da exclusión consiste en definir unha palabra negando o seu oposto (por exemplo, abandonar = 'non continuar'). Neste caso non se trata dun estudo interno do semema do definido, senón dun estudo externo que supón a existencia e o coñecemento de parellas de contrarios. Isto é o que atopamos en definicións como as seguintes:

\footnotetext{
abandonar v.t. 3. Non continuar con [algo]. Abandonaron os seus plans de ataque. Os guerrilleiros abandonaron a loita. // v.p. 4 . Non coidar de si. Dun tempo para acá abandonouse de tal xeito que parece un farrapeiro. SIN. desleixarse.

lizquente $a d x$. Nin frío nin quente. Non me gusta o leite lizquente, quéroo fervendo. SIN. morno, temperado, tépedo.

amuar vi.i. 4. Non responder ao que preguntan, baixando a cabeza. Por máis que lle preguntaban, non conseguian nada, ela amuaba.
}

c) A inclusión negativa

Neste tipo de definición existe un incluínte que serve para negar o excluínte. Trátase, pois, dunha negación semántica, non dunha negación sintáctica. É o que aparece en: 
impericia s.f. Falta de pericia. A impericia da tripulación provocou o afundimento do barco. ANT. destreza, pericia. CF. inhabilidade.

avitaminose s.f. Med. Carencia ou deficiencia de vitaminas, que pode causar enfermidades. O escorbuto é unha das numerosas enfermidades provocadas por avitaminose.

\subsection{A definición relacional}

A definición relacional non envía só á substancia do definido, senón á relación entre o definido cualificador e outra palabra cualificada. Só concerne ao adxectivo e ao adverbio.

Para o adxectivo esta relación exprésase:

(a) por un relativo:

anoxadizo -a $a d x$. Que se anoxa facilmente. Éche moi anoxadizo pero axiña lle pasa. SIN. asañadizo.

(b) ou por unha preposición:

anfractuoso -a $a d x$. Con moitas irregularidades. Relevo anfractuoso.

Para o adverbio exprésase sempre por unha preposición:

atentamente $a d v$. 1. Con atención ou cortesía. Observaba atentamente os costumes dos habitantes da zona.

5.7.1.2. O principio de substituibilidade e a separación do núcleo e o contorno

Nas definicións do DRAG procurouse aplicar o principio de substituibilidade. Se o enunciado definidor pode substituír o termo definido nun enunciado de fala sen que se altere o sentido obxectivo deste, o enunciado definidor será válido. Isto implica que entre definido e definiente debe existir unha identidade categorial.

O principio de substituibilidade obrigou á separación do núcleo da definición do seu contorno. O contorno vai marcado entre corchetes, tal como pode verse nos seguintes artigos do DRAG:

anaerobio -a $a d x$. 1. Biol. [Organismo] que é capaz de vivir sen a presenza de osíxeno no aire. Bacteria anaerobia. 2. Propio dos microorganismos anaerobios. Respiración anaerobia. 3. ext. [Motor, 
propulsor] que pode funcionar sen aire. Os propulsores anaerobios funcionan fóra da atmosfera. ANT. aerobio.

ampolar v.t. 1. Producir unha ou máis ampolas en [unha parte do corpo]. Os zapatos novos ampoláronlle os pés. // v.p. 2. [Parte do corpo] sufrir a formación dunha ou máis ampolas. Ampoláronseme as mans de tanto traballar.

anatematizar v.t. 1. Pronunciar ou lanzar un anatema unha autoridade eclesiástica contra [alguén]. Anatematizárono por herexe. CF. excomungar. 2. fig. Reprobar enerxicamente ou condenar moralmente. Anatematizou a súa ideoloxía e comportamento.

\subsection{A ordenación das acepcións}

Existen tres criterios principais de ordenación das acepcións:

(a) lóxico: unha acepción debe anteceder a outra que deriva dela;

(b) histórico: a orde das acepcións segue a orde de documentación histórica;

(c) frecuencia: as acepcións deben ordenarse por frecuencia de uso.

No DRAG procurouse combinar a frecuencia de uso coa ordenación lóxica, pero estes criterios sempre se subordinan á clasificación por categoría gramatical, tal como se pode observar nos seguintes exemplos:

\footnotetext{
amarelo -a $a d x$. 1. Que ten a cor entre verde e laranxa, coma a do ouro, o limón maduro, etc. Mercou unha camisa amarela. Aos actores supersticiosos non lles gusta a cor amarela. 2. [persoa] Falto de cor. Atopeino amarelo, apoucado, fraco..., debe estar enfermo. SIN. esbrancuxado, pálido. // s.m. 3. A cor amarela. Pintaron o cuarto de amarelo. $\Delta$ Febre amarela. V. febre. / Raza amarela. V. raza. SIN. marelo.

amolar v.t. 1. Causar molestia ou fastío. Amólame ter que levantarme todos os días ás sete. SIN. amargar, molestar. Que perdeu o Celta, dis?, non me amoles! 2. Facer fío a [unha ferramenta]. Amolou os fouciños na moa. SIN. afiar, aguzar. // v.p. 3. Sufrir molestia ou fastío. Que se amole e o faga aínda que non lle guste! SIN. amocar(se), enfastiar(se), foder(se) (vulg.).
}

\subsection{Os exemplos}

Todas as acepcións levan un ou varios exemplos, que contribúan a:

(a) aclarar máis o significado, ofrecendo trazos do significado que non son substanciais, pero si habituais; 
(b) ilustrar sobre o uso;

(c) ver o comportamento sintagmático, e ofrecer as colocacións máis frecuentes;

(d) dar a coñecer aspectos da cultura propia, tal como se pode observar por exemplo en:

trasgar v.t. Colocarlle a trasga a [un animal]. Antes de muxir a vaca trásgaa para que non te manque.

noitevella s.f. Noite do trinta e un de decembro ao un de xaneiro. En noitevella moita xente sae despois de cear para celebrar a entrada do ano novo. SIN. fin de ano.

\subsection{A rede de relacións léxicas}

Cada acepción vai seguida dos sinónimos, antónimos e voces de sentido próximo, por esta orde. Os sinónimos van precedidos polo marcador SIN., os antónimos por ANT., e as voces de sentido próximo por CF.

\footnotetext{
atoar v.t. 1. Cerrar [un conduto] nalgún punto e impedir ou dificultar o paso dun fluído. O po atoon o tubo do gas. SIN. atascar, atrancar, obstruír, trancar. ANT. desatascar, desatoar. CF. cangar, tapar. 2. Cubrir de terra ou doutra cousa semellante. Atoou as brasas para que non prendesen lume. // v.p. 3. [Un conduto] quedar parcial ou totalmente cerrado por acumularse unha materia no seu interior. Atoouse a canle da anga. SIN. atascarse, atrancarse, obstruírse, trancarse. ANT. desatascarse, desatoarse, desatrancarse. 4. Quedar cuberto de terra ou doutra cousa semellante. Atoouse ata os xeonllos na neve. SIN. atuír(se). ANT. desatuír(se).
}

Como pode observarse tamén no exemplo anterior, cando un sinónimo ou antónimo o é de todas as acepcións, vai ao final de todo, precedido do símbolo

\subsection{As unidades pluriverbais}

As unidades pluriverbais (locucións e todo tipo de fraseoloxismos) van ao final do artigo, despois das acepcións, ordenadas alfabeticamente, co significado e exemplo. Van precedidas do símbolo $\boldsymbol{\Delta}$ :

pau s.m. 1. Calquera anaco de madeira longo e delgado. Cun pau e unha xesta fixo unha vasoira. Pau da luг: Pau do teléfono. 2. Mar. Poste de madeira ou de ferro, colocado en posición vertical nun barco, que sostén as velas e, nas embarcacións modernas, as antenas de radio, os focos, etc. O forte vento rompen 0 pan do veleiro. SIN. mastro. 3. Materia compacta e dura que está debaixo da casca das árbores e doutras plantas. Uns zocos con sola de pau. SIN. madeira ${ }^{1}$. 4. Cada unha das series de naipes que ten a baralla. Os paus da baralla son: ouros, copas, espadas e bastos. 5. Dep. Instrumento con que se golpea a pelota en determinados deportes, como o golf, o béisbol, etc. Xogaba ao golf cuns paus de seu avó. 6. Golpe dado cun pau ou con outro obxecto semellante. Como non cales, vas levar un pau. Ti o que estás buscando son uns 


\begin{abstract}
paus. 7. col. Desgraza ou suceso adverso. Para a familia foi un pau que a filla tivese que abandonar o país. 8. Trazo vertical ou case vertical, na escritura. Comezan por facer uns paus. O pau do 'd'. 9. Heráld. Peza que se coloca verticalmente na metade do escudo e que, cando é unha soa, ocupa a terceira parte deste. Destacaba a cor vermella do pau do escudo. $\mathbf{A}$ A darlle cun pau. En abundancia. Había peixe a darlle cun pau. / A paus. De maneira violenta. Remataron a discusión a paus. / Arado de pau. V. arado. / Culler de pau. V. culler. / Dar paus de cego. Facer algo de maneira irreflexiva e sen saber se se vai obter algún resultado. Vai pola vida dando paus de cego. / Pata de pau. V. pata. / Pau brasil. V. brasil ${ }^{2}$. / Pau de ferro. Pauferro. Fixeron un buraco na terra co pau de ferro para chantar as estacas. / Pau de San Gregorio. Arbusto ou árbore de pequeno tamaño da familia das rosáceas (Prunus padus), de tronco delgado, follas ovais, oblongas e lixeiramente dentadas, flores brancas moi aromáticas reunidas en acios e froito en drupa. O pau de San Gregorio cultivase como planta ornamental. / Pau maior. Mar. Pau máis alto dunha embarcación e que sostén a vela principal. O pau maior é paralelo ao trinquete. / Peixe pau. V. peixe. / Teso coma un pau. Cheo de arrogancia. Nin mirou para min, ía teso coma un pau.
\end{abstract}

\title{
6. RESPECTO AOS DEREITOS
}

Hai un aspecto non suficientemente traballado nos dicionarios, e particularmente nos dicionarios de institucións que teñen entre os seus cometidos o de orientar sobre o uso correcto do idioma, ou que posúen un forte ascendente social por gozaren dun alto prestixio. En todos os dicionarios, pero especialmente nos destas institucións, ha de procurarse non dar cabida ás definicións lexicográficas subxectivas, fomentar o respecto polos dereitos humanos, respectar escrupulosamente todos os pobos e culturas, e eliminar os elementos que impliquen manifestación sexista, directa ou indirecta. Nós procuramos camiñar por este sendeiro, aínda recoñecendo que é necesario seguir traballando para conseguir que o dicionario non só sexa un modelo de corrección lingüística, senón tamén, na medida do posible, de corrección social, e que os principios democráticos de respecto a todas as culturas e de igualdade entre todas as persoas se vexan plasmados nidiamente no contido da obra.

7. TIPOGRAFÍA, CONVENCIÓNS, SÍMBOLOS, ABREVIATURAS, ETC.

\subsection{A tipografía}

O coñecemento da tipografía e convencións son fundamentais para manexar o dicionario. A tipografía e as convencións son elementos significativos importantes que forman parte da metalingua das obras lexicográficas.

Respecto aos tipos de letra, a estrutura do dicionario é totalmente ríxida: a entrada vai sempre en letra grosa dun corpo lixeiramente maior ca 
o resto da información incluída no artigo lexicográfico, a categoría en cursiva, a definición da acepción en redonda, os exemplos en cursiva, as locucións e fraseoloxismos en grosa; os sinónimos, antónimos e voces relacionadas, en grosa itálica; e as observacións van cunha letra de corpo máis pequeno.

\subsection{Símbolos e marcas tipográficas}

// separa acepcións en que a entrada ten distinta categoría gramatical ou distinto xénero ou número;

I separa as locucións, frases feitas, expresións, sintagmas, etc.;

$\Rightarrow \quad$ marca que a palabra que vén a continuación se prefire á da entrada, sen ser esta incorrecta;

$\Leftarrow \quad$ marca que a palabra que vén a continuación é un sinónimo ou unha variante da entrada, que non se recomenda pero que se acepta;

* marca as formas que se consideran incorrectas;

- indica que a información que se ofrece a continuación é válida para todas as acepcións da entrada;

- introduce as locucións, frases feitas, expresións, etc.;

[ ] marcan o contorno da definición e a información fonética do lema;

() marcan rexencia de preposición, nome científico de animais e plantas, elementos opcionais da fraseoloxía;

1,2,3... empréganse para diferenciar as entradas nas palabras homógrafas;

1,2,3... empréganse para separar acepcións.

\subsection{Abreviaturas}

Non é necesario insistir na importancia que nunha obra como un dicionario ten a economía de espazo. Por iso, en poucas obras se fai un uso tan profuso das abreviaturas. A maioría delas están destinadas a facilitar información sobre o uso, información gramatical, información tecnolectal e información sobre as redes léxicas. Velaquí as máis utilizadas no $D R A G$ para cada un destes grupos. 
7.3.1. Información de uso (diafásica, diastrática, diacrónica)

$\begin{array}{ll}\text { ant. } & \text { anticuado ou antigo } \\ \text { col. } & \text { coloquial } \\ \text { desus. } & \text { desusado } \\ \text { fam. } & \text { familiar } \\ \text { lit. } & \text { literario } \\ \text { pex. } & \text { pexorativo } \\ \text { pop. } & \text { popular } \\ \text { prop. } & \text { propio } \\ \text { vulg. } & \text { vulgar }\end{array}$

7.3.2. Información gramatical

$\begin{array}{ll}\text { abs. } & \text { absoluto (verbo) } \\ \text { adv. } & \text { adverbio } \\ \text { adx. } & \text { adxectivo } \\ \text { art. } & \text { artigo } \\ \text { art. det. } & \text { artigo determinado } \\ \text { art. indet. } & \text { artigo indeterminado } \\ \text { contr. } & \text { contracción } \\ \text { conx. } & \text { conxunción } \\ \text { dem. } & \text { demostrativo } \\ \text { exclam. } & \text { exclamativo } \\ \text { f. } & \text { feminino } \\ \text { fut. } & \text { futuro } \\ \text { fut. pret. } & \text { futuro do pretérito } \\ \text { i. } & \text { intransitivo } \\ \text { imperat. } & \text { imperativo } \\ \text { imperf. } & \text { imperfecto } \\ \text { indef. } & \text { indefinido } \\ \text { indic. } & \text { indicativo } \\ \text { inf. } & \text { infinitivo } \\ \text { inf. conxug. } & \text { infinitivo conxugado } \\ \text { interrog. } & \text { interrogativo } \\ \text { interx. } & \text { interxección } \\ \text { irreg. } & \text { irregular } \\ \text { loc. } & \text { locución } \\ \text { loc. adv. } & \text { locución adverbial } \\ \text { loc. adx. } & \text { locución adxectiva }\end{array}$




\begin{tabular}{|c|c|}
\hline loc. $\operatorname{con} x$. & locución conxuntiva \\
\hline loc. lat. & locución latina \\
\hline loc. prep. & locución preposicional \\
\hline loc.s. & locución substantiva \\
\hline loc. s. lat. & locución substantiva latina \\
\hline$m$ & masculino \\
\hline$n$. & neutro \\
\hline num. & numeral \\
\hline num. card. & numeral cardinal \\
\hline num. ord. & numeral ordinal \\
\hline$p$ & pronominal \\
\hline part. & participio \\
\hline perf. & perfecto \\
\hline pl. & plural \\
\hline plusc. & pluscuamperfecto \\
\hline pos. & posesivo \\
\hline pref. & prefixo \\
\hline prep. & preposición \\
\hline pres. & presente \\
\hline pret. & pretérito \\
\hline pron. & pronome \\
\hline pron. pers. & pronome persoal \\
\hline rel. & relativo \\
\hline s. & substantivo \\
\hline sing. & singular \\
\hline subx. & subxuntivo \\
\hline$t$. & transitivo \\
\hline V. & verbo \\
\hline xer. & xerundio \\
\hline
\end{tabular}

\subsubsection{Tecnolectos}

$\begin{array}{ll}\text { Aeron. } & \text { Aeronáutica } \\ \text { Agr. } & \text { Agricultura } \\ \text { Anat. } & \text { Anatomía } \\ \text { Antig. } & \text { Antigüidade clásica } \\ \text { Antrop. } & \text { Antropoloxía } \\ \text { Arqueol. } & \text { Arqueoloxía } \\ \text { Arquit. } & \text { Arquitectura } \\ \text { Art. } & \text { Arte }\end{array}$




\begin{tabular}{|c|c|}
\hline Astrol. & Astroloxía \\
\hline Astron. & Astronomía \\
\hline Bibliol. & Bliblioloxía \\
\hline Biol. & Bioloxía \\
\hline Bioquím. & Bioquímica \\
\hline Bot. & Botánica \\
\hline Catol. & Catolicismo \\
\hline Cinem. & Cinematografía \\
\hline Cir. & Cirurxía \\
\hline Dep. & Deportes \\
\hline Der. & Dereito \\
\hline Econ. & Economía \\
\hline Electr. & Electricidade \\
\hline Electrón. & Electrónica \\
\hline Enxeñ. & Enxeñería \\
\hline Farm. & Farmacia \\
\hline Filos. & Filosofía \\
\hline Fis. & Física \\
\hline Fon. & Fonética e Fonoloxía \\
\hline Fot. & Fotografía \\
\hline Gram. & Gramática \\
\hline Heráld. & Heráldica \\
\hline Hist. & Historia \\
\hline Impr. & Imprenta \\
\hline Inform. & Informática \\
\hline Ling. & Lingüística \\
\hline Lit. & Literatura \\
\hline Mar. & Marítimo \\
\hline Mat. & Matemáticas \\
\hline Mec. & Mecánica \\
\hline Med. & Medicina \\
\hline Metal. & Metalurxia \\
\hline Meteor. & Meteoroloxía \\
\hline Métr. & Métrica \\
\hline Micol. & Micoloxía \\
\hline Mil. & Milicia \\
\hline Miner. & Mineraloxía \\
\hline Mit. & Mitoloxía \\
\hline Mús. & Música \\
\hline Ópt. & Óptica \\
\hline
\end{tabular}




$\begin{array}{ll}\text { Paleogr. } & \text { Paleografía } \\ \text { Petrogr. } & \text { Petrografía } \\ \text { Pint. } & \text { Pintura } \\ \text { Pol. } & \text { Política } \\ \text { Psic. } & \text { Psicoloxía } \\ \text { Psiq. } & \text { Psiquiatría } \\ \text { Quím. } & \text { Ouímica } \\ \text { Radiod. } & \text { Radiodifusión } \\ \text { Relix. } & \text { Relixión } \\ \text { Ret. } & \text { Retórica } \\ \text { Silv. } & \text { Silvicultura } \\ \text { Sociol. } & \text { Socioloxía } \\ \text { Taurom. } & \text { Tauromaquia } \\ \text { Telecom. } & \text { Telecomunicacións } \\ \text { Teol. } & \text { Teoloxía } \\ \text { Tip. } & \text { Tipografía } \\ \text { Top. } & \text { Topografía } \\ \text { Vet. } & \text { Veterinaria } \\ \text { Xenét. } & \text { Xenética } \\ \text { Xeogr. } & \text { Xeografía } \\ \text { Xeol. } & \text { Xeoloxía } \\ \text { Xeom. } & \text { Xeometría } \\ \text { Zool. } & \text { Zooloxía } \\ & \end{array}$

7.3.4. Rede léxica
ANT.
antónimo
CF.
compárese
SIN.
sinónimo

\subsubsection{Outras}

ac.

a. C.

d. C.

ex.

ext.

obs.

séc.

V. acepción

antes de Cristo

despois de Cristo

exemplo

extensión

observación

século

véxase 



\title{
LA ACTIVIDAD LEXICOGRÁFICA DEL INSTITUT D'ESTUDIS CATALANS. PASADO, PRESENTE Y FUTURO
}

\author{
Joaquim Rafel i Fontanals \\ Universitat de Barcelona / Institut d' Estudis Catalans
}

Comenzaré diciendo, para aquellos que no conozcan bien la naturaleza de esta institución, que el Institut d'Estudis Catalans es una corporación académica, científica y cultural que tiene por objeto la alta investigación científica, principalmente la de todos los aspectos de la cultura catalana. Fue creado en 1907 por un acuerdo de la Diputación Provincial de Barcelona, más tarde bajo la tutela de la Mancomunitat de Catalunya, y, después de un primer período floreciente y de una existencia agitada a merced de los avatares por los que ha pasado el país durante el segundo y tercer cuarto del siglo XX, actualmente su situación legal se basa en un Real Decreto del año 1976. De acuerdo con los estatutos vigentes sus finalidades son:

(a) ocuparse del estudio de la lengua catalana, establecer su normativa y velar para que su proceso de normalización sea coherente en todo su ámbito lingüístico;

(b) contribuir a la planificación, la coordinación, la realización y la difusión de la investigación en las distintas áreas de la ciencia y de la tecnología, y

(c) impulsar con las actividades que le son propias el progreso y el desarrollo de la sociedad y realizar, cuando corresponda, trabajos de asesoramiento de los poderes públicos y otras instituciones.

La corporación se halla estructurada en cinco secciones temáticas: la Histórico-Arqueológica, la de Ciencias Biológicas, la de Ciencias y Tecnología, la Filológica y la de Filosofía y Ciencias Sociales. La función normativa con relación a la lengua es competencia del conjunto de la institución, pero tanto esta función específica como el resto de trabajos relacionados con la lengua conciernen especialmente a su Sección Filológica. 
La idea del diccionario está vinculada a la Sección Filológica desde antes de su creación; en la memoria presentada a la Diputación de Barcelona para promover la ampliación del Institut d'Estudis Catalans con dos nuevas secciones, Enric Prat de la Riba menciona el diccionario como "la misión" de la propuesta Sección Filológica, a la cual denomina también Academia de la Lengua Catalana:

\footnotetext{
Perxò, al costat de la secció històrich-arqueològica ja existent y de la secció de ciencies, hauría de constituirse la secció filològica, és a dir, l'Academia de la Llengua Catalana. Els catalans que han fet de l'estudi d'aquesta llengua el centre de totes les seves activitats, s'uniríen als poetes y prosadors que ab la seva producció literaria l'han refeta y salvada. La seva missió sería fer el diccionari de la nostra llengua, magna empresa en que trobaríen la col-laboració entusiasta, amorosa, de tots els catalans, pera inventariar la llengua; de les altres seccions de l'Institut pera definicions, descripcions, historia de mots, gravats, etz. (Prat de la Riba 1910: 46).
}

Por otra parte, en el acuerdo de ampliación del Institut se menciona explícitamente la elaboración del diccionario como uno de los cometidos de la nueva sección:

\footnotetext{
La missió de la Secció Filològica o institut filològic, serà estudiar científicament la nostra llengua, inventariar el seu lèxic, fer-ne-l diccionari y fomentar el seu ús y imperi dins y fòra de la nostra terra (IEC 1911: 26).
}

Observemos que la misión encargada a la Sección Filológica no se limita sin embargo a la confección del diccionario de la lengua, sino que se extiende también a su estudio científico y a aspectos de carácter social, con lo cual esta institución queda configurada no como una academia que tiene estrictamente como objetivo fijar un modelo de lengua, sino que también le son encargados el estudio de la lengua y el fomento del uso lingüístico.

¿Cómo ha llevado a cabo la Sección Filológica del Institut d’Estudis Catalans esta misión, especialmente en el aspecto lexicográfico, que es el que nos interesa ahora? La actividad del Institut d'Estudis Catalans en sus distintos campos de actuación ha estado fuertemente condicionada a lo largo de su historia por diversos factores de naturaleza muy distinta, unos de orden externo y otros de orden interno. Con la denominación genérica de factores de orden externo me refiero a la situación política y social a lo largo del siglo XX, que, llegando al extremo de reducir la institución a la clandestinidad durante una buena parte de su existencia, ha impedido que cumpliera en el momento debido los principales objetivos para los que fue creada. Con la denominación de factores de orden interno me 
refiero a los inherentes a la mayor parte de las instituciones académicas, ligados a la dificultad para llegar a acuerdos -sobre todo a causa de las diferencias de criterios en algunas cuestiones fundamentales-o para planificar adecuadamente acciones coherentes y viables (Rafel 1996). La combinación de estos factores de naturaleza diversa permite distinguir diferentes períodos, condicionados por los acontecimientos y caracterizados por la naturaleza de las actividades llevadas a cabo.

Un breve período inicial, que podemos establecer entre 1911 y 1918, se caracteriza por una actividad importante en el seno de la Sección Filológica. Sabemos, sobre todo a través de las notas que Antoni M. Alcover publicaba en el Butlletí del Diccionari de la Llengua Catalana, que en las primeras reuniones de esta institución se discutieron los planes de actuación para alcanzar los objetivos fijados. Podemos deducir que las discusiones se centraron en el modelo de diccionario que hacía falta y, en definitiva, en el modelo de lengua que había de ser objeto de las deliberaciones y de la labor de la Sección. El resultado fue que, a parte de trazar un plan de publicaciones diversas, la Sección acordó adoptar el proyecto de diccionario que Alcover había promovido desde 1901, que menciona como "nuestro diccionario" y "el Diccionario gordo de nuestra lengua", y al mismo tiempo acuerda la publicación de un "diccionario catalán provisional", basado en la lengua escrita, dando escasa cabida a las variantes dialectales, el cual había de reflejar las palabras más obvias y corrientes de la lengua literaria; según Alcover, la dirección de este último diccionario había sido encargada a él mismo y a Pompeu Fabra. El texto publicado por Alcover contiene varios elementos que creo que son realmente significativos para comprender la problemática que nos ocupa:

\footnotetext{
També acordà la Secció Filològica publicar un Diccionari catalá provisional, propiament del llenguatge escrit, sense aficarse gayre dins les variedats i opulencia lexica dels diferents dialectes catalans, tant vitencs, gracies a Deu, a Catalunya espanyola i a Catalunya francesa, a les Balears i an el Reyne de Valencia, això es, un Diccionari aont s'incloguen gran part dels mots que surten per tot arreu dins els autors i demés monuments escrits antics i moderns i que no's troben desgraciadament dins cap dels Diccionaris catalans actuals. Naturalment això no ha d'esser el nostre Diccionari que tantes vegades hem promés, que fa tants d'anys que'l preparam, que'ns costa tants i tants i tants de sacrificis, per el qual ens han enviades milíes i milíes de cèdules qu'umplen tants de calaixos de la nostra Calaixera. El Diccionari així com el bosquetjárem dins la Lletra de convit, així com hem dit tantes de vegades que seria, així com el somiam des de l'any 1901, ha d'esser l'obra-capital de la Secció Filològica; an aqueixa obra estem abocats nosaltres i una partida d'amics fa tants d'anys, i hi seguirem abocats i s’hi abocarán tots els elements de la Secció Filològica i tots els que dita Secció puga moure i desxondir per tot arreu. Per aqueixa obra enviárem l'any 1908 a Alemanya els tres pensionats de la Diputació, En Griera, En Montoliu i En Barnils, que ja han fets an aquelles Universidats els estudis filológics qu'eren del cas, i ara se posaran a la tasca cent voltes gloriosa del Diccionari gros de la nostra llengua, aont s'ha d'aplegar tota la llengua catalana, l'antiga, la moderna,
} 


\footnotetext{
l'escrita i la vivent, les formes literáries i totes quantes formes dialectals se balluguin i poguem aglapir en tot Catalunya d'Espanya i de França, en tot el Reyne de Valencia, en totes les Balears, fins a Alguer de Sardenya. Pero com per enllestir tal Diccionari se necessitarán molts d'anys, i no es cosa d'estarmos sense un que duga almenys lo més obvi i corrent de la llengua literaria, per això la Secció Filològica acordá dins el juliol fer tal Diccionari català provisional, encarregantse'n principalment En Pompeu Fabra i Mn. Alcover (Alcover 1911: 369-370).
}

En estas decisiones hemos de ver probablemente una solución de compromiso, un intento de dar satisfacción a dos posiciones distintas representadas respectivamente por Alcover (diccionario que recoja las más diversas variantes de las palabras de la lengua) y por Fabra (diccionario de la unificación y de la purificación de la lengua).

A parte de estos dos proyectos, en el momento inicial la Sección Filológica trabaja también en la preparación y edición del inventario lexicográfico de Marià Aguiló, que el Institut había adquirido últimamente. Aguiló (1825-1897) fue un poeta, filólogo y bibliotecario que recopiló a lo largo de su vida un extenso repertorio de citas de textos medievales. La publicación de este repertorio, con el nombre de Diccionari Aguiló, se lleva a cabo, a cargo de Pompeu Fabra y de Manuel de Montoliu, en ocho volúmenes, entre 1915 y 1934 (Aguiló 1915-1934).

Sin embargo, la realización más emblemática de este período es el Diccionari Ortogràfic (Fabra 1917), que aparece el año 1917 "redactat sota la direcció de Pompeu Fabra". La publicación de esta obra es un hecho de gran trascendencia; por una parte representa la consolidación de las normas ortográficas que habían sido aprobadas y proclamadas en 1913, puesto que al principio del libro se publica por primera vez su versión definitiva, tal como hoy las conocemos; por otra parte, representa la fijación de la forma de las palabras consideradas más necesarias para la expresión corriente, puesto que responde a una clara voluntad normativa.

En 1918 se produce la ruptura de Antoni M. Alcover con el Institut. Alcover regresa a Mallorca llevando consigo el proyecto de diccionario comprensivo de toda la lengua, con los materiales recogidos hasta el momento, que años más tarde, entre 1926 y 1962, verán la luz de la mano de Francesc de Borja Moll en los diez volúmenes del Diccionari català-valencià-balear (DCVB).

El período que va de 1918 a 1923 se caracteriza por una gran actividad interna. Sabemos que durante estos años se llevaba a cabo un vaciado de textos antiguos que había de ser la base de un Diccionari del català antic. El resto de trabajos se agrupan en torno a dos objetivos bien diferentes que responden en cierta manera a los dos ideales contrapuestos a que hemos hecho ya referencia. Por una parte, continúa la recopilación de da- 
tos de la lengua viva iniciada en el período anterior; desde este punto de vista, dicha actividad puede ser considerada como la continuación de los ideales de Alcover, como él mismo reconoce en una de las crónicas que publicaba en el Butlletí del Diccionari de la Llengua Catalana:

\footnotetext{
El pla dels Drs. Barnils i Griera, que era el mateix pla meu, però renovellat, era com el meu, diametralment contrari an el Diccionari que aquells Caporals volíen, lo Diccionari exclusivament barceloní, de la llengua xinxoram de Barcelona, lo tema suprem i intangible d'En Fabra, que l'ha batejada ab lo pedantíssim i falsíssim nom de Català Normal o Llengua Literària (Alcover 1920: 165).
}

Por otra parte, se inician los trabajos de redacción de un diccionario de carácter normativo, dirigido por Pompeu Fabra, que se convierte en la labor primordial de la Sección Filológica de estos años durante una buena parte de sus sesiones. Este diccionario fue designado con diversos nombres, entre los cuales el que se usó con más frecuencia es el de Diccionari de la llengua literària. No llegó a ultimarse, pero estuvo a punto de iniciarse su publicación: se han conservado unas pruebas de los dos primeros pliegos impresos (hasta la palabra alabarda), y las galeradas corregidas correspondientes a dos pliegos más (hasta la palabra aquedar-se) (Rafel 1996: 230 n. 36).

En síntesis, por la información que poseemos de esta época, parece que los trabajos lexicográficos del Institut constituían un programa organizado que utilizó el nombre de Diccionari general de la llengua catalana para englobar diversas actividades destinadas a dar lugar a tres diccionarios distintos: el Diccionari del català antic, el Tresor de la llengua catalana o Diccionari dels dialectes y el Diccionari de la llengua literària, de carácter normativo.

En 1923, el advenimiento del directorio militar que dio lugar a la dictadura de Primo de Rivera altera profundamente el plan de trabajo establecido en el período anterior. Ignorado oficialmente el Institut y sin subvenciones, algunos de sus proyectos son asumidos por la Diputación de Barcelona, en un Servicio de Investigaciones Filológicas creado por dicha institución, y algunas publicaciones pasan al mecenazgo privado; los trabajos que continúan bajo la nueva organización oficial son sobre todo los correspondientes al Diccionari dels dialectes catalans y al Atlas lingüístic de Catalunya, controlados por A. Griera.

Al margen de la organización oficial promovida por el nuevo poder político, Pompeu Fabra inicia personalmente la redacción de un nuevo diccionario, siguiendo de cerca la parte redactada del Diccionari de la llengua literària y teniendo a la vista los materiales preparados para su redacción, especialmente los ficheros con el vaciado de los textos literarios. 
En el año 1932 se publica esta obra, con el título de Diccionari general de la llengua catalana $(D G L C)$ y con el nombre de Fabra como autor, por una editorial privada (López Llausàs, editor). Su aparición se produce, pues, al inicio de la época republicana, cuando se comienzan a recuperar las instituciones catalanas y cuando la lengua vuelve a ocupar el espacio social propio, unas circunstancias en las cuales el diccionario prestó un servicio muy importante a la sociedad y a la cultura catalanas. Entre el comienzo de la redacción (1923) y la publicación total de la obra (se había iniciado la aparición en fascículos en noviembre de 1931), transcurren nueve años; la dedicación preferente de Fabra a la redacción del diccionario, gracias al mecenazgo de Francesc Cambó, y el hecho de no tener que someterse al complejo trámite de la sanción académica permitieron la elaboración y la publicación de la obra en un plazo tan breve. A pesar de no tratarse propiamente del diccionario académico, por su naturaleza y por las circunstancias en que fue elaborada, esta obra ha sido considerada siempre por el Institut y por la población en general el diccionario de referencia normativa del catalán. Nos encontramos, pues, ante un fenómeno singular en que la labor individual de una persona se superpone a la labor colectiva de una institución y acaba siendo reconocida por esta como propia.

Después de la institución de la Generalitat de Catalunya (1931) y de la aprobación del Estatuto de Cataluña (1932), se inicia un período favorable al desarrollo de la lengua y de la cultura catalanas. En este nuevo contexto social, el Institut reanuda de manera progresiva sus actividades. La actividad lexicográfica de la institución no es, sin embargo, la que podríamos esperar en estas circunstancias, probablemente debido en gran parte a las diferencias de criterio y a las discrepancias ideológicas entre Pompeu Fabra por una parte y Antoni Griera y Manuel de Montoliu por otra.

Pasando por alto muchos detalles, podemos decir que no es hasta después de la expulsión de Griera del Institut (1935), como consecuencia de haber publicado por su cuenta el primer volumen del Tresor de la llengua, de les tradicions i de la cultura popular de Catalunya (Griera 1935-1947), utilizando los materiales reunidos en el Institut para el Diccionari dels dialectes, cuando Fabra presenta un plan de reestructuración de las Oficinas Lexicográficas "per a emprendre tan aviat com es pugui la reedició del Diccionari general de la llengua catalana". A partir de este momento son frecuentes en las actas las alusiones a los trabajos sobre el Diccionari general. Es justamente a partir de 1935 cuando podemos observar indicios de un plan para ejecutar un proyecto concreto de diccionario; así lo confirma una referencia de R. Aramon a esta época en que él mismo comenzaba a colaborar con el Institut: 


\begin{abstract}
Les Oficines Lexicogràfiques, que havien pogut continuar actives durant la Dictadura bé que sota un altre nom, com a servei de la Diputació, reprenen llur lligam amb la Secció Filològica i es veuen reforçades amb l'ingrés de nous colllaboradors, com Joan Coromines i el qui us parla, que vénen a fer costat als antics Manuel de Montoliu, Josep M. Casas i Homs i Francesc Torres, als quals s'uneix, ja començada la guerra, Josep Miracle. Tots plegats, sota la direcció de Fabra, intensifiquen la replega de materials, amb l'esperança de poder començar aviat la redacció del Diccionari de l'Institut (Aramon 1982: 36).
\end{abstract}

Pero la evolución de los acontecimientos políticos y el desarrollo y desenlace de la guerra civil interrumpieron las actividades del Institut d’Estudis Catalans. La conclusión que se impone después de un análisis detallado de los hechos (Rafel 1996) es que hasta el final de esta etapa y antes del largo período de clandestinidad que seguirá, la historia del Institut y de la Sección Filológica se ha caracterizado por diversos intentos de cumplir un mandato fundacional; estos intentos han resultado siempre frustrados en parte por la falta de unos objetivos claros, reconocidos institucionalmente y aceptados por todos sus miembros, y en parte por las circunstancias políticas desfavorables que han sacudido la sociedad catalana a lo largo del siglo XX.

A partir de 1939, el inicio de la dictadura franquista significa para el Institut el exilio de una parte importante de sus miembros más relevantes y la desaparición oficial de la institución; sólo algunos académicos que quedaron en el país se reunieron de manera clandestina y llevaron a cabo actividades resistenciales.

Por lo que respecta a la actividad lexicográfica, el hito más importante de todo este largo período es la publicación (1954) de la segunda edición del DGLC de Pompeu Fabra, revisada por la Sección Filológica, con un prólogo de Carles Riba, presidente de la Sección; en 1962 se reedita la obra y en años sucesivos irán apareciendo nuevas ediciones o reimpresiones. Por lo demás, durante la larga etapa de clandestinidad la actividad lexicográfica de la Sección Filológica se limita a la aprobación de algunas listas de palabras nuevas que se difunden de manera oficiosa hasta que van incorporándose al diccionario Fabra a partir de la cuarta edición (1966) y, en forma de apéndice, a partir de la quinta (1968).

En el año 1976, en plena transición política, un Real Decreto restablece la existencia oficial del Institut d'Estudis Catalans y aprueba unos nuevos estatutos para la entidad; el Institut deja de ser con ello una institución clandestina después de casi cuarenta años.

Al final de una fase de lenta recuperación de la normalidad corporativa -la sede social del Institut no podrá ser ocupada hasta en 1982-, el año 1983 la Sección Filológica se plantea la manera más adecuada de organizar la 
actividad lexicográfica después de un tiempo de interrupción tan dilatado y acuerda la realización de un proyecto basado en los principios metodológicos que la lexicografía moderna había propugnado en los últimos años. El proyecto, que recibió el nombre de Diccionari del català contemporani, pretendía asumir los avances producidos en la lingüística y aplicar las posibilidades de la tecnología moderna en el tratamiento de la información; su objetivo general era la redacción de un diccionario descriptivo del catalán sobre la base de un corpus textual suficientemente representativo de la lengua. De acuerdo con ello, el proyecto se estructuró en dos fases sucesivas: la constitución de un corpus textual informatizado y la redacción de un diccionario basado fundamentalmente en dicho corpus. Al margen de este proyecto concebido como una realización a término medio, la Sección Filológica se planteaba también cómo acometer las nuevas ediciones o actualizaciones del diccionario que tenía aún carácter normativo, pero que estaba claramente desfasado: el de Pompeu Fabra.

A partir de este momento podemos considerar que el Institut ha tenido una actividad importante en el campo lexicográfico. Si damos un rápido repaso a los principales acontecimientos posteriores, podemos destacar de una manera esquemática los siguientes hechos, por orden cronológico:

(a) El año 1985 el Institut se dota de una infraestructura informática adecuada y se inician los trabajos de constitución del Corpus Textual Informatitzat de la Llengua Catalana (CTILC).

(b) El año 1992 el Institut acuerda dar prioridad a la publicación con carácter urgente de un diccionario normativo elaborado sobre la base del Diccionari general de la llengua catalana de Pompeu Fabra debidamente actualizado.

(c) El año 1995 se publica el Diccionari de la llengua catalana, resultado de la ejecución del acuerdo anterior (DIEC).

(d) El año 1997 finalizan los trabajos de constitución del CTILC.

(e) El año 1997 se inicia la preparación de una segunda edición revisada y ampliada del Diccionari de la llengua catalana.

(f) El año 1998 se inician los trabajos del Diccionari descriptiu de la llengua catalana, segunda fase del proyecto Diccionari del català contemporani.

(g) El año 2001 se publica el Diccionari manual de la llengua catalana (IEC 2001).

(h) El año 2005 se pone a disposición del público por vía electrónica (Internet) la parte redactada del Diccionari descriptiu de la llengua catalana $(D D L C)$.

(i) El año 2007 se publica la segunda edición del Diccionari de la llengua catalana. 
El conjunto de estas actuaciones responde, en el ámbito del léxico, a dos de los objetivos estatutarios del Institut d'Estudis Catalans: el establecimiento de la normativa y el estudio de la lengua; con ellas la institución por una parte ejerce la estricta función de academia de la lengua, y por otra parte analiza las propiedades de las unidades léxicas a partir de su uso real. Voy a resumir brevemente las líneas generales de estas actuaciones.

\section{EL DICCIONARI DE LA LLENGUA CATALANA}

Esta obra responde a la constatación de que, una vez recuperada la normalidad de actuación de la institución académica, la sociedad reclamaba con urgencia un diccionario actualizado que sirviera de referencia normativa. La solución adoptada por el Institut fue la de elaborar un diccionario a partir del DGLC de Fabra (1932), sin alterar fundamentalmente los criterios lexicográficos ni la base léxica, pero ampliándolo y actualizándolo. Desde la publicación de esta obra las necesidades comunicativas habían cambiado mucho y se había dado lugar a un número importante de palabras o de acepciones nuevas, que en buena parte habían sido recogidas por los diccionarios publicados en los últimos años fuera del ámbito académico, sobre todo por el Diccionari de la llengua catalana de Enciclopèdia Catalana (DLC 1982), que recogía las aportaciones léxicas de la Gran Enciclopèdia Catalana (GEC 1969-1980). Ello dio lugar a un número importante de actuaciones en la nomenclatura del diccionario (adiciones, supresiones, modificaciones), que fueron objeto de publicación aparte por el mismo Institut (IEC 1997). En la confección de este nuevo diccionario fueron aplicados una serie de criterios previamente discutidos y aprobados por la Sección Filológica; estos criterios se refieren tanto a distintos aspectos de las entradas, como al contenido y estructura de los artículos, y fueron también dados a conocer públicamente (IEC 1996). La aplicación, sin embargo, de algunos de estos criterios, relativos sobre todo a la coherencia interna del diccionario y a ciertos aspectos de las definiciones, y una revisión sistemática y exhaustiva del léxico de especialidad, fueron dejados para una segunda edición, para no demorar demasiado la publicación de la obra. En cifras redondas, este diccionario contiene 67.000 entradas, 16.500 subentradas y 120.000 acepciones, lo cual representa, respecto del diccionario Fabra, un incremento de 17.000 entradas, 8.000 subentradas y 30.000 acepciones (Cabré / Bozzo / Santamaría 1996).

Después de la publicación del Diccionari de la llengua catalana, la Sección Filológica percibió la necesidad de publicar una obra no tan amplia 
como esta, centrada más en el léxico común, sin tantas palabras especializadas, destinado a un usuario con unas necesidades más elementales, útil para la escuela, etc.; así, el año 1997 tomó el acuerdo de publicar un diccionario abreviado con el nombre de Diccionari manual de la llengua catalana. Este diccionario, que aparece en el año 2001 (IEC 2001), no es, sin embargo, una mera versión abreviada del anterior, sino que en su elaboración se aplican una serie de acciones encaminadas a hacer de él una obra más manejable y comprensible para el público a que va destinada. Por otra parte, por el hecho de ser preparado cuando los trabajos de la segunda edición del diccionario normativo estaban ya bastante avanzados, se pudo beneficiar de las innovaciones que ya se habían introducido o que se había decidido introducir.

Por otra parte, recién terminada la primera edición del Diccionari de la llengua catalana, se comienza, de hecho, su revisión; sin embargo, los trabajos sistemáticos de preparación de la segunda edición de la obra no comienzan hasta 1997. El conjunto de actuaciones previstas se estructuró en cuatro grandes apartados:

(1) Aplicación de criterios lexicográficos.

(2) Revisión del léxico de especialidad:

(a) Revisión de la nomenclatura.

(b) Revisión de las definiciones.

(3) Tratamiento de las propuestas de enmienda.

(4) Revisión del léxico común.

Los criterios a los que se refiere el primer apartado son los siguientes:

(1) Numeración de las acepciones y de las subacepciones.

(2) Ordenación de las acepciones.

(3) Regularización de grupos semánticos y morfológicos.

(4) Supresión del punto y coma como separador de acepciones.

(5) Acepciones y subacepciones constituidas por ejemplos sin definición.

(6) Entrada de afijos.

(7) Entrada de gentilicios.

(8) Distribución de códigos de categoría gramatical.

(9) Tratamiento de los verbos pronominales.

(10) Modificación de definiciones impropias.

(11) Regularización de las remisiones.

(12) Tratamiento de las marcas valorativas.

(13) Marcaje de dialectalismos. 
Entre estos criterios hay algunos que ya estaba previsto aplicarlos en la primera edición del diccionario, pero de hecho no se aplicaron porque se dio prioridad a la publicación de la obra en un plazo determinado. El resto fueron discutidos y aprobados específicamente para la segunda edición.

El segundo apartado (Revisión del léxico de especialidad) es el más complejo, el que ha costado más esfuerzos y el que ha tenido un período de ejecución más largo. Esta complejidad y esta dificultad se deben a factores de naturaleza distinta; entre ellos podemos citar el gran número de términos a considerar, la dificultad de establecer el grado de especialización a la hora de seleccionar las entradas y las subentradas, la dificultad de encontrar el tipo de definición que satisfaga a la vez la exigencia científica del especialista y la claridad y simplicidad necesarias en un diccionario general, la coordinación entre áreas afines, la relación personal con los especialistas teniendo en cuenta la especificidad de cada área y de cada persona. Se han distinguido 76 áreas de especialidad y han intervenido en la revisión 120 especialistas. Por lo que respecta a los datos cuantitativos del léxico especializado, el examen de 43.356 entradas originarias ha dado lugar a 1.948 altas, 778 bajas y 218 cambios de grafía; el examen de 8.410 subentradas originarias ha dado lugar a 1.645 incorporaciones, 564 bajas y 706 modificaciones, y sobre las 61.262 acepciones de especialidad originarias se han añadido 2.652 y se han modificado 28.758. Además, se ha incorporado la marca de área temática a 5.000 acepciones que no la tenían y se ha suprimido esta marca en 2.000.

El tercer apartado (Tratamiento de las propuestas de enmienda) tuvo como objetivo analizar y dar solución a todas las sugerencias hechas directa o indirectamente, sea a través de publicaciones de diversa índole, especializadas o generales, sea a través de comunicaciones escritas o de manifestaciones verbales tanto de fuera de la institución como por parte de los académicos; también se recogen en él los resultados de una lectura sistemática de la obra que se llevó a cabo por parte del propio equipo de redactores inmediatamente después de la publicación de la primera edición. Dentro de este apartado se han analizado 6.941 propuestas de léxico común; de estas, 3.690 han dado lugar a algún tipo de modificación y las 3.251 restantes no han originado ninguna modificación.

El cuarto y último apartado se refiere a la Revisión del léxico común, que se dividió en dos subapartados: la revisión de la nomenclatura y la revisión del contenido de los artículos. Por lo que respecta a la nomenclatura, se estudiaron detenidamente 1.800 casos de propuestas de incorporación de nuevas entradas, y, después de un proceso complejo de estudio por la Comisión de Lexicografía y presentación y aprobación en el plenario de la Sección 
Filológica, fueron incorporadas 488 entradas y 84 subentradas nuevas; por otra parte, a partir del estudio y valoración de 153 casos de propuestas de supresión, fueron suprimidas 41 entradas. En cuanto a la revisión sistemática de los artículos de léxico común o con alguna acepción de léxico común, se llevó a cabo mediante una lectura por parte de personal competente; su objetivo ha sido la mejora de aquellos aspectos que escapaban a las actuaciones generales previstas, como pueden ser cuestiones relativas a la expresión de la categoría gramatical, la redacción de las definiciones, la naturaleza de los ejemplos, los casos de circularidad manifiestamente perturbadora y la coherencia general del diccionario. Hay que decir que con ello no se ha pretendido una reforma profunda de los materiales lexicográficos ni de la estructura del diccionario, en su mayor parte procedente del diccionario de Fabra y compartidos por muchos diccionarios, porque la labor habría superado la naturaleza de los objetivos establecidos en su momento para la preparación de esta segunda edición del diccionario normativo. Esta revisión ha dado lugar, con todo, a unas 7.000 intervenciones sobre un total de 31.762 artículos de léxico común o con alguna acepción de léxico común.

Después de todas las actuaciones previstas para esta segunda edición, las diferencias estadísticas generales son las siguientes:

\begin{tabular}{|l|c|c|c|}
\hline & Primera Edición & Segunda Edición & Diferencia \\
\hline Entradas & 67.566 & 69.988 & 2.422 \\
\hline Subentradas & 17.000 & 17.343 & 343 \\
\hline Acepciones & 103.000 & 115.117 & 12.117 \\
\hline Ejemplos & 44.000 & 50.064 & 6.064 \\
\hline
\end{tabular}

Una vez terminados los trabajos de revisión y actualización, la segunda edición del diccionario fue ratificada por la Sección Filológica en febrero de 2006 y en estos momentos ha pasado en el proceso de publicación. El libro vió la luz en 2007.

\section{EL DICCIONARI DEL CATALÀ CONTEMPORANI (DCC)}

Como ya he avanzado, con este nombre designamos un proyecto complejo que tiene su origen en el deseo de la Sección Filológica de que los trabajos que iba a emprender en un nuevo período de su historia no fueran insensibles a los avances científicos, metodológicos y tecnológicos que habían tenido lugar durante el largo tiempo de inactividad forzada. Este proyecto está estructurado en dos fases sucesivas: la primera corresponde 
a la creación de recursos lingüisticos y la segunda a la elaboración de un diccionario descriptivo, el $D D L C$, sobre la base de los recursos constituidos.

\subsection{Primera fase: Creación de recursos lingüísticos}

Aunque en un principio, en la primera fase del proyecto $D C C$, se había pretendido únicamente la constitución de un corpus textual, más tarde se vio la oportunidad de formar también un corpus con los diccionarios principales de la misma época que cubría el primero con el fin de poder obtener fácilmente la información contenida en ellos. Así pues, durante esta primera fase del proyecto, que se halla totalmente terminada, se ha constituido por una parte el Corpus Textual Informatitzat de la Llengua Catalana (CTILC) y por otra parte la Base de Dades Lexicogràfica (BDLex).

\subsubsection{Características principales del CTILC}

Desde el punto de vista cronológico, el CTILC se extiende desde 1832 hasta 1988; abarca, pues, textos de más de 150 años de la historia de la lengua catalana escrita entre los siglos XIX y XX. La fecha de origen viene determinada por el inicio de la recuperación del uso literario de la lengua en la época contemporánea y la fecha final por el momento en que se ultimó la selección de los textos que iban a formar parte del corpus. Desde el punto de vista tipológico, el CTILC incluye textos de carácter literario y textos de carácter no literario. Cada uno de estos dos tipos ha sido dividido en otros, que han permitido una selección equilibrada de los textos a tener en cuenta no sólo para cada tipo de lengua (literaria o no literaria), sino para cada subtipo (los cuatro géneros tradicionales: Narrativa, Poesía, Teatro y Ensayo, para la lengua literaria, y diez grupos temáticos o funcionales distintos para la lengua no literaria: Filosofía; Religión y Teología; Ciencias Sociales; Prensa; Ciencias Puras y Naturales; Ciencias Aplicadas; Bellas Artes, Ocio y Deportes; Lengua y Literatura; Historia y Geografía, y Correspondencia). La extensión total del corpus es de 52.371 .944 ocurrencias o palabras del texto, que se reparten en 23.105 .591 (44\%) correspondientes a la lengua literaria y 29.266 .353 (56\%) correspondientes a la lengua no literaria. En las figuras 1 y 2 puede verse la repartición del texto literario entre los cuatro grupos tipológicos considerados en la lengua literaria y los diez grupos tipológicos correspondientes a la lengua no literaria, respectivamente. El número de obras o textos distintos, de extensión muy diversa, que corresponden a este volumen de texto es de 3.299, de las cuales 1.011 corresponden a textos literarios y 2.288 a textos no literarios. 


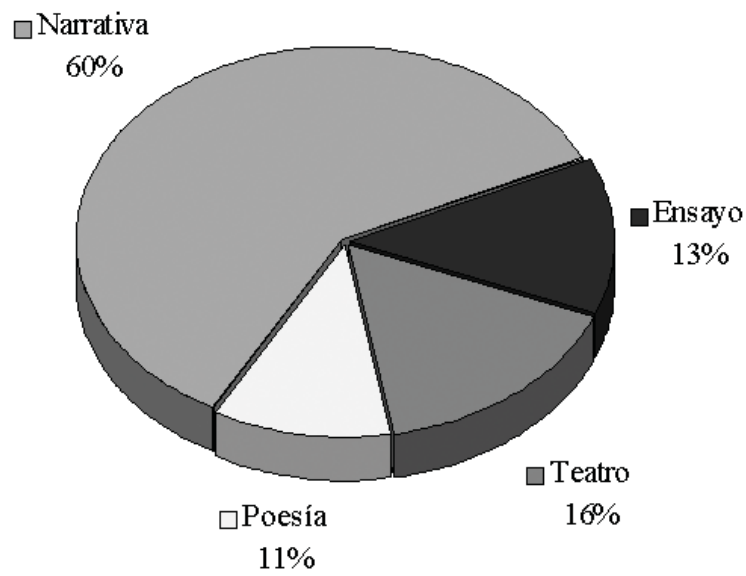

Figura 1. Repartición del texto literario entre sus cuatro grupos tipológicos

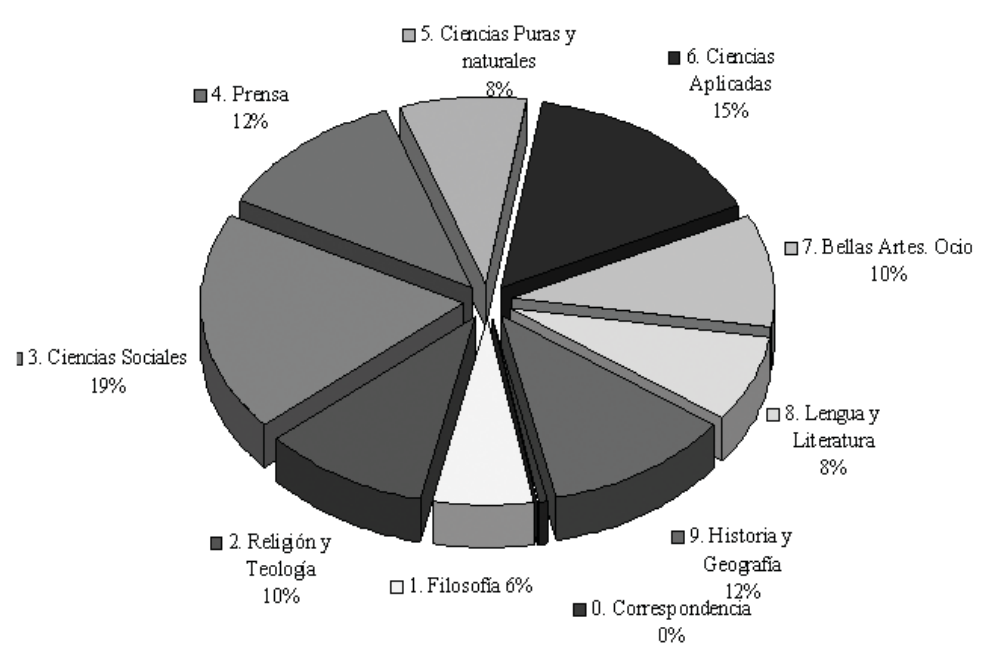

Figura 2. Repartición del texto no literario entre sus diez grupos tipológicos

Una de las preocupaciones principales a la hora de concebir el CTILC fue que tuviera la máxima representatividad, es decir, que el conjunto de textos tomados en consideración reflejara de la mejor manera posible la lengua escrita utilizada en el período de tiempo que abarca; para conseguir este objetivo, en el momento de la selección se puso especial empeño en lograr el máximo equilibrio entre los distintos tipos de texto que las necesidades de la comunicación escrita -estética o funcional- habían producido a lo largo del ámbito cronológico del CTILC. Para ello, además de la división tipológica a que me he referido hace un momento, se establecieron también unos grupos cronológicos que tienen una extensión de diez años en la parte más antigua (hasta 1913) y de cinco años a partir de 1914. Durante el proceso de selección de los textos se intentó que dentro de cada uno de los 23 grupos cronológicos que resultan de esta división se 
hallara representado cada uno de los subtipos establecidos de una manera aproximadamente proporcional al volumen de texto producido en aquel período. Hay que decir todavía que, por lo que se refiere a la lengua no literaria, la mayor parte de las áreas temáticas o funcionales han sido divididas en un número variable de subáreas, hasta un máximo de diez, y se han seleccionado textos de cada una de ellas; por lo que respecta a los textos literarios, sin necesidad de subdividir los géneros de una manera sistemática, se tuvieron en cuenta diferencias de carácter temático o de otra naturaleza (por ejemplo, narrativa imaginativa, libros de viajes, memorias; teatro costumbrista o clásico; poesía religiosa o profana, etc.). Con estas medidas se intentó lograr el máximo equilibrio entre las más variadas manifestaciones de la lengua escrita.

Una característica destacada del CTILC es que se trata de un corpus totalmente lematizado; en él se ha llevado a cabo una operación de análisis lingüístico en virtud de la cual se ha categorizado gramaticalmente cada una de las ocurrencias de cada forma gráfica y se ha asociado a una unidad léxica de referencia; con ello se cubren dos objetivos: por una parte se desambiguan formas gráficas que corresponden a formas gramaticales distintas (de una misma serie flexiva o de series flexivas correspondientes a lemas distintos) y por otra parte, como consecuencia de la misma operación, se relacionan entre ellas las distintas formas de una serie flexiva, las cuales quedan asociadas a un mismo lema. El CTILC, por el hecho de estar completamente lematizado, tiene un elevado nivel de funcionalidad; realizando una consulta a partir de un lema obtenemos información sobre todas las formas de flexión correspondientes, con las posibles variantes gráficas o formales que aparecen en textos de diferentes épocas, y también a las eventuales formas derivadas mediante afijos apreciativos o intensivos, para las cuales, siguiendo criterios lingüísticos, no se ha creado un lema propio, sino que se han asociado al lema correspondiente a su base léxica. El número de lemas a que ha dado lugar esta operación es de 149.185, que corresponden a 678.386 formas gramaticales y a 51.253 .680 ocurrencias del texto (el total de ocurrencias del corpus menos los nombres propios).

El CTILC fue constituido entre los años 1985 y 1997; podemos considerarlo, pues, un trabajo pionero en nuestras latitudes. Una vez terminado, dispone de un sistema de consulta y explotación concebido especialmente para su utilización con finalidades lexicográficas, pero que es también útil para cualquier tipo de estudio que se pretenda elaborar a partir de datos empíricos. En este momento el CTILC se puede consultar públicamente por Internet a través de la web del Institut d'Estudis Catalans; el procedimiento de consulta permite obtener una serie de contextos relativos 
a un lema determinado. Como actividad vinculada a la elaboración del CTILC, fue publicado entre los años 1996 y 1998 un diccionario de frecuencias en tres volúmenes impresos y dos CD-ROM, que incluye la totalidad de los datos léxicos y estadísticos del corpus (Rafel 1996-1998).

\subsubsection{Características principales de la BDLex}

La Base de Dades Lexicográfica (BDLex) contiene debidamente informatizados y cargados en una base de datos los 13 diccionarios catalanes que han sido considerados más significativos de los siglos XIX y XX; fue creada con el fin de facilitar el acceso rápido y sistemático a la información que contienen estas obras y obtener el máximo rendimiento de las consultas. Fue concebida, como ya he apuntado, como un recurso complementario dentro del proyecto general; más adelante concretaré cual es la utilización específica que se le da en la elaboración del diccionario descriptivo. Está formada por los diccionarios siguientes:

\section{CORPUS LEXICOGRÁFICO DE LA BDLEX}

$\begin{array}{ll}\text { DMFC } & \text { Febrer i Cardona, A.: “Diccionári menorquí españól francês y llatí”. [Manuscrito, } \\ & \text { principios siglo XIX] } \\ \text { DEBJ } & \text { Esteve, J. / J. Bellvitges / A. Juglà (1803-1805): Diccionario catalan-castellano-latino } \\ \text { DLCL } & \text { Labèrnia, P. (1839-1840): Diccionari de la llengua catalana: ab la correspondencia castellana } \\ & \text { yllatina } \\ \text { DMCF } & \text { Figuera, P. A. (1840): Diccionari mallorqui-castella } \\ \text { DVCE } & \text { Escrig, J. (1851): Diccionario valenciano-castellano } \\ \text { NDMA } & \text { Amengual, J. J. (1858): Nuevo diccionario mallorquin-castellano-latin } \\ D M C T & \text { [Tarongí i Cortès, J.] (1878): Diccionari mallorquí-castellá. [Inacabado] } \\ D G M G & \text { Martí i Gadea, J. (1891): Novisimo diccionario general valenciano-castellano } \\ D C V B & \text { Alcover, A. / F. de B. Moll (1926-1962): Diccionari Català-Valencià-Balear } \\ D P C V & \text { Vallès, E. [1927]: Pal-las: diccionari català-castellà-francès: amb vocabularis castellà-català } \\ D G E C & \text { francès-català }\end{array}$

La información que contienen estos diccionarios fue trasladada a soporte informático y el texto fue tratado de modo que permite la reproducción de los originales siguiendo los criterios tipográficos de cada uno. Los diferentes elementos que configuran la estructura de los distintos diccio- 
narios han sido identificados sistemáticamente y codificados de manera adecuada de tal forma que una vez incorporados a la base de datos pueden ser objeto de consultas orientadas selectivamente y pueden ser relacionados entre ellos. Otro aspecto importante del proceso de informatización ha sido lo que hemos llamado "normalización de las entradas", que, en síntesis, por una parte permite acceder a través de una forma normalizada a las variantes que contienen algunos de estos diccionarios, y por otra parte establece vínculos lógicos entre entradas que pueden considerarse variantes (generalmente gráficas) asociables entre ellas, pero que en el diccionario de que se trata aparecen sin ningún vínculo asociativo explícito.

\subsection{Segunda fase: Elaboración de un diccionario descriptivo}

El objetivo de la segunda fase del proyecto $D C C$, que se encuentra en proceso de realización, es la elaboración de un diccionario descriptivo de la lengua catalana contemporánea a partir, principalmente, del análisis y de la explotación de CTILC. Entendemos aquí por diccionario descriptivo aquella obra lexicográfica que tiene por objeto la definición de las unidades léxicas de la lengua desde el punto de vista de su contenido y de su utilización real, sin restricciones basadas en criterios prescriptivos.

Una de las justificaciones de la elaboración de un diccionario descriptivo de estas características por parte de una academia de la lengua es la creencia de que las prescripciones lingüísticas estarán tanto mejor fundamentadas cuanto mejor se conozca la lengua en su realidad fáctica; en el caso del Institut d'Estudis Catalans la justificación es doble por cuanto entre sus misiones estatutarias, como hemos visto, tiene no sólo el establecimiento de la normativa lingüística, sino también "ocuparse del estudio de la lengua". Con la elaboración de un diccionario descriptivo de estas características el Institut d'Estudis Catalans no sólo produce una obra concebida de acuerdo con los principios más generalmente asumidos por la lexicografía contemporánea, sino que se dota de un instrumento muy valioso a la hora de ejercer su actividad como institución académica encargada del establecimiento y de la actualización de la normativa de la lengua catalana.

\subsubsection{Características generales del DDLC}

Sin pretender ser un diccionario teórico, el Diccionari descriptiu de la llengua catalana comparte con estos alguna de sus características: no tiene un carácter pragmático ni una finalidad pedagógica, es concebido 
como el resultado de una investigación específica, su realización persigue el máximo rigor científico, su formulación aspira a un alto grado de explicitud y utiliza una cierta formalización en su lenguaje y en su presentación. Como consecuencia de ello, sus usuarios ideales son los profesionales de la lengua; sin embargo, esta obra lexicográfica no pretende dirigirse solamente a especialistas, sino que, además de ser útil para estos, aspira a estar al alcance de cualquier lector medianamente culto interesado por los problemas de la lengua en cuanto que usuario: se pretende, pues, presentar el contenido del diccionario combinando el rigor en el tratamiento de la información con la claridad expositiva y con la facilidad de interpretación.

La elaboración de un diccionario descriptivo por una academia de la lengua puede parecer una contradicción, puesto que este diccionario contiene palabras, acepciones o estructuras sintácticas que no son reconocidas por la normativa vigente, a pesar de encontrarse documentadas en los textos; por una parte, este diccionario puede ser considerado más científico que el normativo, porque intenta dar cuenta de una manera sistemática de la realidad de la lengua a partir de datos empíricos, pero por otra parte puede ser visto como un peligro para el uso lingüístico considerado correcto. En el caso que nos ocupa, este tema se debatió ampliamente en el seno de la Sección Filológica, la cual decidió que se identificara con una marca visible todos aquellos elementos (entrada, categoría, acepción, patrón sintáctico, etc.) que no gozaran de sanción normativa en el momento de divulgarlos.

En el aspecto material, tanto desde el punto de vista del proceso de redacción como en sus resultados finales, el proyecto de diccionario descriptivo, como ya he dicho, pretende incorporar los últimos avances metodológicos y tecnológicos que se han producido en el campo de la lexicografía. Como consecuencia de ello tiene las características de un diccionario electrónico, en forma de base de datos multifuncional que permite utilizaciones diversas, tanto relacionadas con la investigación como con la difusión de la obra; si nos centramos en la difusión, permite las más variadas posibilidades: por una parte, puede ser divulgado por vía electrónica a través de Internet y, por otra parte, puede servir de base para diversidad de publicaciones, sea en papel, sea en cualquiera de los soportes electrónicos disponibles.

Una de las características más destacadas del DDLC, que conforma todo el diccionario, es el hecho de utilizar el CTILC como base fundamental y fuente exclusiva; se trata, pues, en sentido estricto, de un diccionario basado en corpus. No es este el momento ni el lugar de detallar las venta- 
jas de este procedimiento; sólo destacaré el hecho de que de acuerdo con este principio metodológico, basado en datos empíricos, se establece no sólo la nomenclatura del diccionario, sino los significados de las unidades léxicas a partir del uso que realmente se ha hecho de ellas, en vez de utilizar métodos apriorísticos (basados en los diccionarios preexistentes) o intuitivos (basados en la conciencia lingüística del lexicógrafo); la aplicación de este método permite la utilización de datos de carácter estadístico que pueden llegar a tener una gran importancia tanto en la fijación de la nomenclatura como en aspectos internos de la estructura del diccionario; permite también la ejemplificación a través de testimonios de uso refrendados por una cita y una referencia concretas, con lo cual podemos, si es necesario, situar en el tiempo un determinado uso o significado. Como consecuencia de la utilización de un corpus como punto de referencia para su elaboración, el DDLC incluye una información exhaustiva y sistemática sobre las estructuras sintácticas de que pueden formar parte, en sus distintas acepciones, las unidades léxicas tratadas, y también sobre las coocurrencias más frecuentes.

Este método y este procedimiento, como a nadie se le oculta, tiene, sin embargo, sus detractores, que defienden otros modos de proceder en la práctica lexicográfica, temiendo que un sistema como este desvirtúe los logros de la lexicografía tradicional. Justamente, saliendo en cierto modo al paso de este tipo de objeción, el DDLC no sólo no deja de tener en cuenta lo que la tradición lexicográfica ha dado de sí en la lexicografía catalana, sino que incorpora todos los datos relativos al significado que aparecen en los principales diccionarios y que no se han verificado en el corpus; pero ello se hace fuera del cuerpo principal del artículo y dejando constancia de qué diccionario o qué diccionarios aportan la información correspondiente. No se entremezclan, pues, la información procedente del análisis del corpus, que determina el núcleo fundamental del artículo, con la que procede de los diccionarios y no tiene un reflejo en el corpus. No hace falta que haga notar que el hecho de contar con la BDLex, que he mencionado más arriba entre los recursos lingüísticos disponibles, facilita enormemente la inclusión de esta información.

Por lo que respecta a la nomenclatura, la del DDLC tiene un carácter complejo, en el sentido de que no todas las unidades léxicas que encabezan un artículo son descritas en él, sino en otro artículo encabezado por un elemento distinto. Así, pues, la nomenclatura del DDLC está formada por unos elementos de rango general (caracterizados por una descripción lexicográfica propiamente dicha) y por otros elementos de rango subsidiario (caracterizados por remitir a otros artículos); estos elementos sub- 
sidiarios, controlados sistemáticamente, corresponden a dos tipos: (a) los derivados formados a partir de alguno de los siete procesos de derivación sistemática establecidos en los criterios de redacción del diccionario, y (b) las variantes formales documentadas en el corpus que están asociadas a una forma léxica principal, sin ser meras variantes gráficas de ella. Contiene también el diccionario un tercer tipo de elementos vinculados a unas entradas determinadas, que se encuentran integrados en los artículos correspondientes a ellas y no dan lugar a entradas propias; se trata de los derivados apreciativos, de las variantes flexivas de la entrada no previstas en el modelo flexivo que la caracteriza y de las conversiones sintácticas, que están vinculadas a las acepciones correspondientes. Por último, las unidades léxicas plurinominales no constituyen tampoco entradas propias ni están vinculadas a acepciones o mezcladas con ellas, como ocurre en muchos diccionarios, sino que están agrupadas en una sección propia del artículo correspondiente a la entrada con la que se encuentran relacionadas de acuerdo con unos criterios explícitos.

El DDLC se organiza en artículos, que constituyen la unidad básica en que se estructura toda la información que contiene el diccionario. Los criterios para el establecimiento y la delimitación de los artículos se basan exclusivamente en principios de carácter formal y gramatical, y se aplican de una manera sistemática a lo largo de todo el diccionario sin ninguna excepción. Estos criterios consisten en la identidad o diferencia en cualquiera de las tres características que configuran la entrada: la grafía de la forma canónica, su categoría y sus propiedades flexivas. La diferencia en cualquiera de estas tres características determina la existencia de un artículo distinto; en caso contrario, toda la información se agrupa en un único artículo, independientemente de las diferencias de carácter meramente semántico o de consideraciones de carácter etimológico, que no intervienen como criterios diferenciadores de los artículos, contrariamente a lo que ocurre en la mayoría de los diccionarios tradicionales. En el $D D L C$ no existen, pues, dos entradas que coincidan en su forma gráfica, en su categoría y en su modelo de flexión.

Otra de las características del DDLC que merece ser mencionada es el sistema de ordenación de las acepciones, que se basa exclusivamente en una combinación de criterios frecuenciales y lógicos. Resumidamente diré que en un artículo que presenta varias acepciones puede ocurrir que estas tengan una afinidad semántica estrecha, en cuyo caso se aplica el criterio frecuencial: la acepción que se muestra más frecuente en el corpus aparece en primer lugar y el resto se ordenan por orden decreciente de frecuencia; si, en cambio, pueden establecerse varios grupos a partir 
del criterio de afinidad de significado, aparece en primer lugar el grupo que contiene la acepción más frecuente y el resto de grupos por orden decreciente de la acepción más frecuente del grupo. El sistema de ordenación presenta, pues, una jerarquía de dos niveles.

De acuerdo con lo dicho más arriba sobre el tipo de diccionario a que aspiramos, las definiciones del $D D L C$ evitan la información de carácter enciclopédico (basada en la descripción de la realidad) y se concentran en la información de carácter lingüístico (descripción del valor significativo, de las restricciones léxicas y de las propiedades sintácticas de las unidades). Desde el punto de vista del texto definidor, se tiene en cuenta la distinción entre los elementos propiamente definidores (constituyentes intrínsecos de la definición) y los que se refieren a condiciones o restricciones selectivas (constituyentes extrínsecos), codificándolos adecuadamente; estos conceptos (Rafel 1989) están en conexión con los de "entourage" de Rey-Debove y de "contorno" desarrollado por Seco (1979).

El DDLC contiene, para cada entrada, información de carácter cuantitativo relativa al uso observado en el corpus. Esta información aparece simplificada, con una representación gráfica, no numérica, que indica la pertenencia de la entrada a uno de los cinco rangos de uso establecidos. Para las entradas correspondientes a los tres primeros rangos de uso, el $D D L C$ contiene, además, información sobre la repartición porcentual de sus categorías morfológicas en el corpus.

\subsubsection{Contenido y estructura del DDLC}

Como ya hemos comentado, el DDLC consta de una serie de elementos estructurales organizados en forma de base de datos; cada uno de ellos está vinculado a un elemento de referencia, que es la entrada, lo cual permite configurarlos en forma de artículo de diccionario, que es la manera más común de presentarlos ante los usuarios, pero no la única posible; por otra parte, esta es la forma más práctica de referirse organizadamente a los distintos elementos que conforman la obra. En el esquema de la figura 3 pueden observarse los distintos elementos estructurales del diccionario y las relaciones entre ellos. Estos elementos tienen distintos grados de obligatoriedad y de dependencia unos de otros y, en consecuencia, puede haber artículos muy complejos -sobre todo si tenemos en cuenta la recurrencia potencial de algunos de sus componentes-y artículos muy simples. 


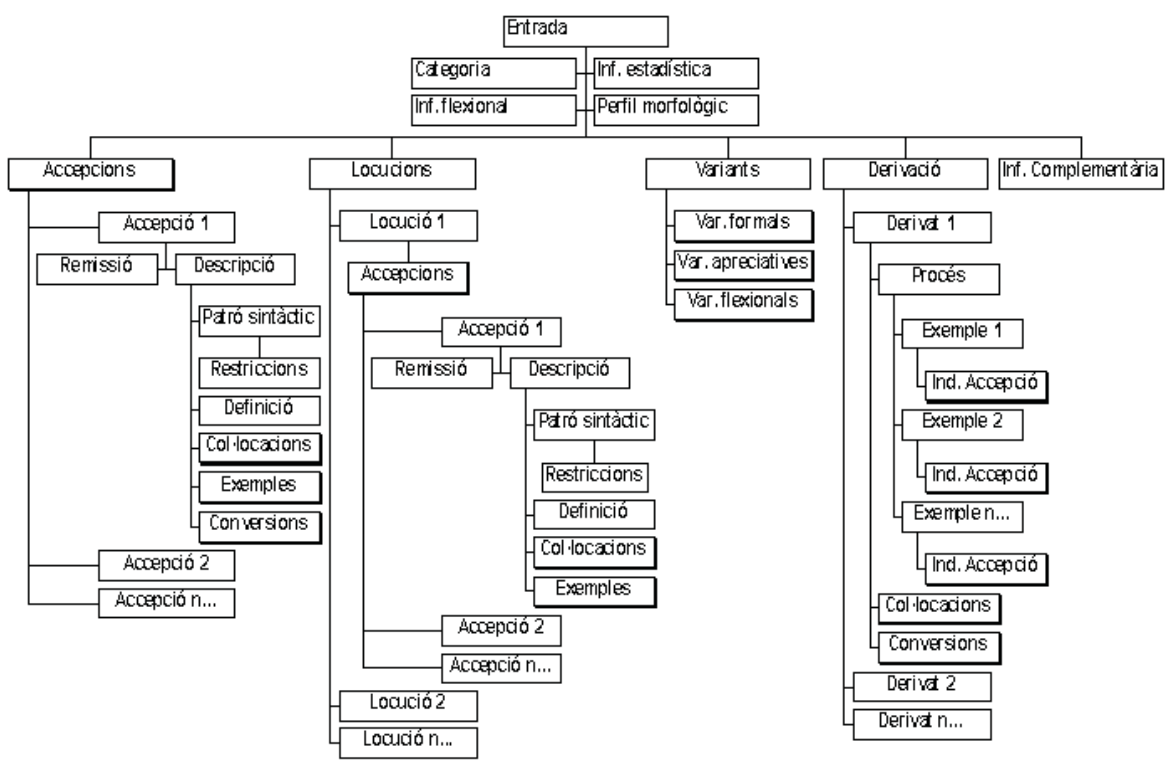

Figura 3. Estructura del artículo estándar del DDLC

No podemos entrar en este trabajo en el comentario detallado de cada uno de los elementos que constituyen la estructura de DDLC. Sólo recordaré que los ejemplos son citas extraídas del CTILC, que se reproducen sin ninguna adaptación ni modificación; la selección del ejemplo más adecuado para ilustrar una determinada acepción se hace teniendo en cuenta una serie compleja de criterios que ahora no podemos detallar; si la acepción tiene más de un patrón sintáctico, debe haber un ejemplo por cada patrón. Los ejemplos se identifican con una referencia simplificada que aporta una primera información sobre la procedencia de la cita; en la versión electrónica del $D D L C$ se pueden desarrollar interactivamente los elementos codificados de esta referencia simplificada y se puede acceder a la referencia bibliográfica completa de la obra en cuestión.

Señalaré también que el apartado de derivación incluye todos los derivados formados sobre la misma base que la entrada o sobre una base culta con cierta similitud formal y de sentido equivalente, cuyo sentido sea máximamente predictible, es decir, que sean el resultado de un proceso derivativo transparente a todos los niveles (semántico, morfosintáctico y fonológico). A fin de evitar decisiones subjetivas de los redactores, se han establecido y definido claramente siete procesos derivativos especificando los afijos que pueden actualizarlos, el tipo de transformación que suponen, la categoría y el significado del derivado en relación con los de la base a que está asociado y la definición formularia que le corresponde. Para cada derivado que se incluye en este apartado se indica el número del proceso derivativo a que corresponde y tantos ejemplos como acep- 
ciones de la entrada se encuentran actualizadas por este derivado en el corpus, indicando en cada ejemplo el número de la acepción de la entrada que actualiza.

\subsubsection{Ejecución y estado actual del DDLC}

La elaboración de $D D L C$ ha pasado desde su inicio por una serie de fases previas a la redacción, que resumidamente son las siguientes: (a) establecimiento de la nomenclatura del diccionario, (b) concreción de los criterios lexicográficos que se iban a aplicar en la redacción de la obra, (c) redacción de una serie de artículos de prueba, y (d) establecimiento de la estación de trabajo lexicográfica.

Desde 1999 la obra se halla en la fase de redacción sistemática. En relación con esta fase, que es de una complejidad notable, sólo destacaré que la redacción del DDLC no avanza siguiendo estrictamente el orden alfabético, sino que, a partir de una progresión alfabética básica, conjuntamente con el artículo de la palabra correspondiente al orden alfabético, se redactan también los artículos relativos a otras unidades léxicas que están relacionadas con ella por su forma o por una relación semántica o sistemática, sea cual sea la letra del alfabeto a que pertenecen; cada redactor elabora, pues, paralelamente, una serie más o menos larga de artículos cuyas entradas están relacionadas de acuerdo con estos criterios; con este procedimiento se intenta evitar en lo posible la falta de coherencia estructural y descriptiva que afecta, en algunos casos de manera grave, a la mayoría de diccionarios existentes.

Una acción importante en los trabajos de ejecución de la obra es lo que llamamos validación estructural. Se trata de una operación que se realiza sobre los artículos ya redactados y tiene como objeto el control sistemático de la aplicación rigurosa de los criterios de redacción y de la coherencia estructural de la obra.

Por lo que se refiere al estado actual de la redacción, hay que tener en cuenta que la extensión de la parte redactada del diccionario varía de día en día, porque se van sancionando los artículos a medida que se da por terminado su proceso de redacción. El volumen actual (en datos de 16 de noviembre de 2006) es de 32.241 artículos; por lo que respecta a la distribución alfabética, un poco menos de la tercera parte de este volumen $(9.433$ artículos) corresponde a la parte redactada según la progresión alfabética rigurosa, que alcanza hasta la entrada avançar v., mientras que los 22.808 artículos restantes (un poco más de las dos terceras partes) corresponden a entradas pertenecientes a otras letras del alfabeto, de acuerdo con 
el sistema particular de progresión en la redacción a que acabo de referirme. Este número de artículos redactados corresponde a un poco más de la tercera parte de la extensión prevista del diccionario. Como datos estadísticos que pueden ser de interés podemos decir que estos $32.241 \mathrm{ar}-$ tículos contienen 76.173 acepciones, 51.596 colocaciones, 119.099 ejemplos, 7.440 conversiones sintácticas, 6.651 locuciones, 10.510 variantes, 7.440 derivados y 21.720 unidades de información complementaria. El número de obras del corpus que han sido objeto de alguna cita en los ejemplos del diccionario es 3.191.

\subsubsection{Edición electrónica del DDLC}

Desde el mes de enero de 2005 el DDLC es consultable a través de Internet en forma de edición electrónica. Esta edición electrónica consta de un componente nuclear, constituido por el conjunto de artículos redactados, y de unos componentes accesorios, que son una Presentación, muy breve y sintética, y una Guía de utilización, más larga y compleja en la cual se encuentran explicados los distintos componentes del diccionario. Dado que las consultas se realizan directamente sobre la base de datos del diccionario, la edición electrónica está continuamente actualizada: por una parte, el número de artículos consultables va aumentando a medida que se da por terminado el proceso de redacción de cada grupo, y, por otra parte, se incorpora automáticamente cualquier modificación de que sea objeto la parte ya redactada.

Con esta edición electrónica, el $D D L C$ se pone a disposición del público mediante una estructura dinámica que permite la relación entre elementos de un mismo artículo o de distintos artículos del diccionario y también con elementos complementarios externos a los propios artículos a través de los vínculos activos adecuados.

\section{EL FUTURO INMEDIATO}

Con la finalidad de planificar las líneas generales de las actuaciones futuras y evitar en lo posible los pasos en falso y las decisiones precipitadas, el año 1996, recién publicada la primera edición del DIEC, la Sección Filológica y el Consejo Permanente del Institut d'Estudis Catalans aprueban un plan de actuación lexicográfica para los años posteriores. Dicho plan establece: 
(a) que se llevará a cabo una revisión sistemática y una cierta remodelación de este diccionario con el fin de publicar una segunda edición de la obra;

(b) que se iniciará la redacción de un diccionario de carácter descriptivo sobre la base del Corpus Textual Informatitzat de la Llengua Catalana, una vez finalizados los trabajos de constitución de este corpus, y

(c) que se emprenderá la elaboración de un diccionario normativo diseñado sobre unas nuevas bases establecidas a partir de un debate en la Sección Filológica.

El primero de estos objetivos se ha conseguido ya, como acabamos de ver, con la terminación de los trabajos de la segunda edición del Diccionari de la llengua catalana. Ha habido un notable retraso sobre las previsiones iniciales, pero finalmente la Sección Filológica ha sancionado la obra, que ya ha sido publicada. El segundo objetivo, el inicio de la redacción del Diccionari descriptiu de la llengua catalana, se cumplió en 1998, inmediatamente después de la conclusión de los trabajos del CTILC. Como hemos visto, los trabajos de este complejo proyecto están en marcha y el ritmo de redacción es altamente satisfactorio; actualmente se redactan más de 7.000 artículos por año, lo cual permite estimar la finalización de la redacción dentro de unos ocho años.

El único objetivo que queda todavía pendiente es, pues, la elaboración de un nuevo diccionario normativo que no sea la mera actualización del que se acaba de terminar. Ello supone un debate a fondo, por una parte, sobre cómo debe entenderse en el siglo XXI un diccionario de carácter prescriptivo, con todas sus implicaciones sociológicas, y, por otra parte, sobre la estructura y la naturaleza de este diccionario en sus múltiples aspectos. Este es, pues, el principal reto que tiene planteado en el momento actual la Sección Filológica del Institut d'Estudis Catalans por lo que respecta a su actividad lexicográfica. Llegar a conclusiones y a acuerdos sobre este punto requiere un debate complejo, puesto que entran en juego opiniones, criterios, sensibilidades y, en suma, ideologías distintas; debemos creer, con todo, que se abordarán con serenidad los variados aspectos de esta problemática y que el proyecto que resulte de las deliberaciones se llevará a buen término con la debida eficacia. 



\title{
ACTIVIDADES LEXICOGRÁFICAS DA ACADEMIA DAS CIÊNCIAS DE LISBOA
}

\author{
João Malaca Casteleiro \\ Universidade de Lisboa / Academia das Ciências de Lisboa
}

\section{NOTA INTRODUTÓRIA}

Uma das primeiras preocupações da Real Academia das Ciências, fundada em Dezembro de 1779, foi desde logo a elaboração de um grande dicionário da língua portuguesa. Neste empreendimento começaram a trabalhar, em meados do ano seguinte, os académicos Pedro José da Fonseca, Bartolomeu Inácio Jorge e Agostinho José da Costa de Macedo, os quais conseguiram, ao fim de treze anos de intenso labor, publicar, em 1793, o primeiro e único volume deste grande dicionário, mas circunscrito apenas à letra A (Academia das Ciências 1793).

Tomando como base de trabalho o Vocabulário Português e Latino, de Rafael Bluteau (1712-1728), publicado em 10 volumes, este primeiro Dicionário da Academia baseava-se na melhor metodologia lexicográfica da época, tanto portuguesa como europeia, e fundamentava-se em fontes documentais copiosas, que abrangiam cerca de quinhentas obras, de mais de duzentos autores diferentes. O Dicionário que então se arquitectava privilegiava, sobretudo, os séculos XVI e XVII, considerados como determinantes na refundação da língua portuguesa, graças à influência do Humanismo e do Renascimento e ao labor literário dos escritores clássicos, mas abrangia também o século XIV -um tempo de transição- e todo o período medieval. Tinha uma grande preocupação normativa, com um certo excesso purista, aliás próprio da época, mas visava essencialmente o objectivo patriótico de defesa da língua portuguesa, que estava a ser invadida por estrangeirismos, sobretudo de proveniência francesa, e começava a perder terreno no plano internacional.

O primeiro Dicionário da Academia, apesar de se quedar pela letra A, constitui um monumento lexicográfico, pela sua riqueza, pelo seu rigor, pela sua amplitude, assim como pela metodologia inovadora que consagra. 
Este primeiro projecto da Academia repousou na poeira dos arquivos por mais de século e meio. De facto, só no início da primeira metade do século XX ele foi retomado, graças à iniciativa de Jacinto do Prado Coelho, Luís Filipe Lindley Cintra, Joseph Piel e Inês Louro. Do labor destes académicos, sob a direcção de Jacinto do Prado Coelho, secundados por vários colaboradores externos, resultou em 1976 um novo primeiro volume (Academia das Ciências 1976), mas, mais uma vez, apenas para a letra A e incidindo, sobretudo, na língua portuguesa contemporânea. A metodologia lexicográfica foi renovada, com recurso à linguística moderna, nomeadamente à semântica estruturalista e ao que de melhor se fazia na lexicografia europeia.

Não foram, porém, dadas à Academia condições para dispor de colaboradores a tempo inteiro e novamente este primeiro volume não teve continuidade. Foi necessário esperar até 1988, ano em que arranca o projecto que dá origem à publicação, em 2001, pela Editorial Verbo, do Dicionário de Língua Portuguesa Contemporânea (Academia das Ciências 2001), o qual abrange essencialmente os séculos XIX e XX. Contribuíram financeiramente para a concretização deste projecto a Fundação Calouste Gulbenkian e o Ministério da Educação, além de outras instituições, como o Ministério da Cultura e o Instituto Camões, que deram apoios mais pontuais.

\section{CARACTERÍSTICAS ESSENCIAIS DO DICIONÁRIO DA LÍNGUA POR- TUGUESA CONTEMPORÂNEA}

Este novo Dicionário, que passo a designar como Dicionário da Academia ou, simplesmente, Dicionário, segue a linha dos seus predecessores -o primeiro, publicado em 1793, e o segundo em 1976- os quais, apesar de abrangerem apenas a letra A, estabeleceram, cada qual na sua época, uma metodologia lexicográfica rigorosa, inovadora, assente em fontes documentais muito ricas e variadas, modelar no quadro da lexicografia europeia.

Esta obra tem como objectivo essencial honrar o desígnio inicial da Academia, pondo à disposição do público português e agora, por extensão, de todos os povos que comunicam em língua portuguesa, um dicionário copioso, inovador, rigoroso e normalizador do uso vocabular.

O Dicionário da Academia regista sobretudo o léxico próprio da língua portuguesa contemporânea e actual -séculos XIX e XX-período em que o nosso idioma se enriqueceu com um vastíssimo número de novas palavras, quer construídas no seu interior por prefixação, sufixação, compo- 
sição e outros processos lexicais, quer importadas de outras línguas, com especial destaque para o francês e o inglês.

Trata-se de um Dicionário amplo, que regista cerca de 70.000 entradas lexicais, em ordem alfabética, e quase 170.000 acepções ou definições de significados.

As definições das palavras são acompanhadas de mais de 85.000 sinónimos e de cerca de 16.000 antónimos. No interior dos artigos do dicionário incluem-se mais de 22.000 combinatórias fixas, que se usam, de certo modo, como palavras compostas sem hífen, tais como água morta, corredor de fundo, sala de jantar, etc.

Os significados ou acepções das palavras são ilustrados com 33.000 abonações ou citações, provenientes de autores literários, tanto portugueses como brasileiros e africanos, e ainda de autores científicos e outros, nomeadamente de origem jornalística. Para ilustrar os significados das palavras foram ainda construídos ad hoc 90.000 exemplos de frases ou construções. As locuções e expressões idiomáticas diversas, registadas no Dicionário, totalizam cerca de 14.000 .

O léxico registado no Dicionário abrange, não apenas o vocabulário de uso geral, mas também cerca de 32.000 termos ou acepções das diferentes áreas científicas e técnicas, mais de 3.000 regionalismos portugueses e ainda os neologismos recentes e os vocábulos internacionais dos nossos dias, nomeadamente os das novas tecnologias. O Dicionário regista igualmente, na ordem alfabética, cerca de 700 elementos de formação (prefixos, sufixos e outros), gentílicos de uso mais geral, que se referem a continentes, países, estados brasileiros, cidades e outros, as siglas e os acrónimos de uso corrente, assim como as principais locuções latinas.

Como obra de amplitude lusófona, o Dicionário da Academia regista mais de 6.000 brasileirismos, cerca de um milhar de africanismos recentes e uma centena e meia de asiaticismos ainda actuais.

Como dicionário padrão da língua, a presente publicação constitui uma obra de natureza essencialmente descritiva, fundamentada no uso, embora tenha uma preocupação normalizadora em aspectos que se relacionam com a grafia, a fonética, o aportuguesamento de estrangeirismos ou a sua substituição por formas vernáculas, a hifenização de certos compostos, etc.

No que respeita aos estrangeirismos recentes, ou seja, vocábulos importados das línguas modernas, o Dicionário da Academia regista cerca de um milhar, dos quais $70 \%$ são de origem inglesa, sobretudo por via americana, $20 \%$ de origem francesa e $10 \%$ de outras proveniências. Destes, o Dicionário mantém, na sua forma de origem, aqueles que o uso nacional e internacional consagrou, como copyright, leasing, marketing, software, etc. 
Registou, com forma aportuguesada ou semiaportuguesada, palavras -algumas delas já consagradas pelo uso de certos autores- como ateliê (do fr. atelier), bibelô (do fr. bibelot), brifingue (do ingl. briefing), gangue (do ingl. gang), icebergue (do ingl. iceberg), lóbi (do ingl. lobby), motar (do fr. motard), raile (do ingl. rail), stresse (do ingl. stress), tróica (do russo troika), etc. Propôs formas vernáculas, por tradução, em casos como alta-fidelidade, em vez do ingl. hi-fi, assalto, em vez do ingl. round, empregado de bar, em vez do ingl. barman, churrasco, em vez do ingl. barbecue, correio electrónico, em vez do ingl. e-mail, registo de embarque/entrada, em vez do ingl. check-in, resultado, em vez do ingl. score, saber-fazer, em vez do ingl. know-how, etc.

No domínio dos estrangeirismos foi preocupação da Academia proteger de excessos a língua portuguesa, sem purismo excessivo, mas também sem a permissividade abusiva de certos media. O uso, por exemplo, de 2 ou 3\% num texto, de termos estrangeiros, na sua grafia de origem, não desvirtuará, com certeza, o espírito do idioma. O mesmo não acontecerá, porém, se no mesmo texto ocorrerem 10 ou 15\% de palavras estrangeiras, na sua forma de origem. Seguiu-se, aliás, no que concerne a este caso, a mesma preocupação dominante em outras línguas, como, por exemplo, o espanhol ou o francês.

Todas as entradas lexicais do Dicionário apresentam, além da classificação gramatical, a transcrição fonética da pronúncia, segundo a norma culta, aproximada, de Lisboa e Centro do país, excepto em abreviaturas, elementos de formação, locuções latinas e símbolos.

O Dicionário apresenta igualmente a etimologia das palavras, com excepção de certos compostos hifenizados (algodão-em-rama, fim-desemana, etc.), das contracções (à, deste, etc.), das locuções latinas (ad hoc, status quo, etc.) e dos símbolos ( $\mathrm{Ag}, \mathrm{NW}$, etc.).

O Dicionário da Academia constitui uma obra ímpar no panorama lexicográfico português, pela amplitude e variedade do léxico registado, pela riqueza das acepções ou significados que apresenta, pela quantidade de sinónimos e antónimos que acompanham as definições, pela cópia de abonações e exemplos que ilustram as acepções das palavras, pela forma inovadora como estrutura toda a informação lexical, pelo interesse da transcrição fonética da pronúncia das palavras. 


\section{VERSÃO PORTUGUESA DO DICIONÁRIO HOUAISS DA LÍNGUA PORTUGUESA}

Uma tarefa a que lançámos mãos na Academia, no seguimento da publicação do dicionário acima referido e em colaboração com o Instituto António Houaiss, do Rio de Janeiro, consistiu na elaboração da versão portuguesa do Dicionário Houaiss da Língua Portuguesa, entretanto publicado no Brasil (Houaiss 2001).

Esta tarefa, ou seja, a adaptação da versão brasileira deste dicionário à norma europeia do português, apresentou-se como um desafio lexicográfico muito interessante e que era difícil recusar, pelas seguintes razões:

(a) Era a primeira vez que se procedia à adaptação à norma europeia do português de um dicionário em versão brasileira, o que constituía, sem dúvida, uma experiência inovadora e de grande alcance para a Lexicografia Portuguesa.

(b) Este dicionário era a obra de uma vida de um dos mais eminentes filólogos brasileiros, como foi António Houaiss.

(c) Esta obra procurava abranger o vastíssimo domínio geográfico da Lusofonia, na medida em que inseria africanismos e asiaticismos dos países e territórios de língua portuguesa.

(d) Dava especial destaque à diversidade lexical do português, numa perspectiva comparativa, sem, contudo, prejudicar a unidade essencial da língua.

(e) Permitia desenvolver laços de uma eficaz cooperação lexicográfica entre a equipa portuguesa, que colaborou na conclusão do Dicionário da Academia, e a equipa brasileira do Dicionário Houaiss.

(f) Constituía para o mundo de língua portuguesa mais uma importante obra de referência lexicográfica.

O trabalho de adequação ao português europeu de um dicionário de tão grande envergadura, com cerca de 218.000 entradas lexicais, não devia limitar-se apenas às divergências ortográficas, como eventualmente poderia esperar-se, mas tinha de abarcar também vários domínios da gramática, como a ortoépia, igualmente com reflexos na ortografia, a morfologia, a sintaxe e a semântica. Assim, na versão portuguesa do Dicionário Houaiss tivemos necessidade de inserir variadíssimas alterações, umas relacionadas com a macroestrutura e outras respeitantes à redacção e estruturação dos próprios artigos. A elaboração da versão portuguesa do Dicionário Houaiss ocupou-nos cerca de dezoito meses. Este foi publicado pelo Círculo de Leitores, em seis volumes, em 2002-2003 (Houaiss 2002-2003). 


\section{ELABORAÇÃO DO NOVO DICIONÁRIO DA LÍNGUA PORTUGUESA}

Concluída a versão portuguesa do Dicionário Houaiss, começámos a dar corpo a um novo projecto, que consistia na elaboração de um novo dicionário de tipo escolar, que pudesse caber num único volume, mais manuseável, e satisfazer melhor às necessidades de aprendizagem e ensino da língua nas escolas, numa perspectiva de produção textual ou codificação e não apenas concebido na óptica da compreensão ou descodificação lexical. De facto, os dicionários de tipo escolar disponíveis satisfaziam mais a esta última perspectiva do que à primeira.

A nomenclatura do dicionário foi estabelecida progressivamente, com métodos inovadores baseados na investigação linguística e no uso de novas tecnologias. Assim, a estruturação inicial da nomenclatura, que constituiu o seu ponto de partida, alicerçou-se nas cerca de 2.200 palavras resultantes da investigação sobre o Português Fundamental pelo Centro de Linguística da Universidade de Lisboa (Bacelar do Nascimento et al 1987). A este primeiro acervo lexical foram sendo progressivamente acrescentadas entradas, como resultado de pesquisa e selecção a partir de corpora seleccionados, de comparação com outras obras da lexicografia portuguesa e brasileira e de pesquisa em motores de busca da Internet. À nomenclatura assim seleccionada foram ainda acrescentadas as entradas de programas escolares seleccionados do ensino básico e secundário e da Terminologia Linguística para o Ensino Básico e Secundário.

A nomenclatura deste dicionário é, por um lado, mais restrita, abrangendo apenas cerca de 53.700 palavras, em contraste com as cerca de 70.000 do Dicionário da Língua Portuguesa Contemporânea, já que se eliminaram, entre outros, os verbetes correspondentes a regionalismos, brasileirismos, africanismos e asiaticismos. Em contrapartida, nas cerca de 53.700 entradas lexicais entra um grande número de palavras novas não registadas no dicionário anterior. Este dicionário comporta cerca de 130.000 acepções, mais de 73.500 sinónimos e quase 13.000 antónimos e ainda aproximadamente 64.000 exemplos, ilustrativos do uso das palavras que constituem a nomenclatura do dicionário. Por motivos de natureza prática e de economia textual, não foram tidas em conta abonações ou citações literárias e outras.

A estrutura dos artigos ou verbetes do novo dicionário é diferente e inovadora quanto ao modelo lexicográfico adoptado. Assim, merecem destaque, como características inovadoras, entre outras, a divisão silábica para translineação das palavras, apresentada logo na entrada lexical; a classificação morfossintáctica dos verbos e respectiva exemplificação; os quadros de conjugação verbal; a junção, na mesma entrada lexical, de pa- 
lavras homónimas com idêntica etimologia mas classificação gramatical diferente.

A redacção dos verbetes teve claramente a intenção didáctica de explicitação do conhecimento da língua, aliada à necessidade de clareza e simplicidade das definições. Como trabalho prévio à redacção do dicionário, foi feita uma lista reduzida dos definidores a utilizar num dicionário de cariz didáctico. Para tal objectivo, foi estabelecido um conjunto de definições baseado num único núcleo de definição, funcionando a definição dos verbetes da mesma família com base na definição do verbo. Esta opção teve em conta, além de critérios de economia, a necessidade de os aprendentes da língua tomarem consciência da capacidade produtiva do português, através dos seus mecanismos regulares de flexão, de derivação, de composição e outros.

O Novo Dicionário da Língua Portuguesa contém uma classificação explícita de todas as regências verbais e respectiva exemplificação. Esta classificação segue a nomenclatura da Terminologia Linguística para o Ensino Básico e Secundário aprovada em Diário da República, em Dezembro de 2004.

$\mathrm{Na}$ elaboração dos verbetes respeitantes aos verbos foi dada informação quanto à conjugação verbal, o que levou à criação de 59 paradigmas verbais. A cada um dos 7.683 verbos incluídos na nomenclatura do dicionário foi atribuído o paradigma correspondente à sua flexão, com indicação da defectividade verbal.

Em suma, este Novo Dicionário apresenta-se como um instrumento de aprendizagem muito útil para o consulente que deseje esclarecer e compreender as suas dúvidas, adquirir conhecimentos e melhorar a utilização que faz do português, quer como língua materna, língua segunda ou língua estrangeira.

Infelizmente, este Dicionário, apesar de concluído em fins de 2005, ainda não está publicado.

\section{NOVAS TAREFAS LEXICOGRÁFICAS DA ACADEMIA}

Uma das tarefas mais importantes que estão em curso respeita à elaboração da segunda edição do Dicionário de Língua Portuguesa Contemporânea. O principal objectivo desta edição é o de corrigir as gralhas, erros e lacunas da primeira e aumentar a nomenclatura para cerca de 90.000 a 95.000 entradas. Outro objectivo, não menos importante, consiste na revisão das fontes documentais, assim como na sua ampliação, a fim de 
se incluírem autores de referência que não foram contemplados na primeira edição e alargar tal inclusão a novos escritores, entretanto surgidos e cuja qualidade literária seja reconhecida. Torna-se necessário também rever alguns modelos específicos dentro da elaboração dos artigos, visando uma maior sistematização e rigor lexicográficos. Encontra-se já revista e actualizada a maior parte da letra A, que inclui cerca de 2.400 artigos ou acepções novas e foi já efectuada a redacção, segundo o novo modelo da $2^{\mathrm{a}}$ edição, de aproximadamente 7.200 artigos ou acepções novas para as outras letras do dicionário.

O Dicionário da Língua Portuguesa Contemporânea, que abrange apenas os séculos XIX e XX, é o primeiro de uma trilogia que deve ser completada com um Dicionário da Língua Portuguesa Medieval, para os séculos XII a XV e um Dicionário da Língua Portuguesa Clássica, para os séculos XVI a XVIII.

O Dicionário da Língua Portuguesa Medieval encontra-se já em curso de elaboração, no âmbito de uma cooperação muito oportuna entre a Academia e o Centro de Linguística da Universidade Nova de Lisboa. Nesta tarefa colaboram também as Professoras Maria Francisca Xavier, Maria de Lurdes Crispim, a Doutora Alexandra Fiéis e outros colaboradores. Este projecto é apoiado financeiramente, nomeadamente através da concessão de algumas bolsas de investigação, pela Fundação para a Ciência e Tecnologia do Ministério da Ciência, Tecnologia e Ensino Superior. Sobre este projecto não adiantarei mais nada, uma vez que a Professora Maria Francisca Xavier o fai neste mesmo volume. 


\title{
PASADO, PRESENTE E FUTURO NOS TRABALLOS LEXICOGRÁFICOS DA REAL ACADEMIA ESPAÑOLA
}

\author{
Guillermo Rojo \\ Universidade de Santiago de Compostela / Real Academia Española
}

\section{INTRODUCIÓN}

Tratarei de esbozar as liñas xerais da lexicografía académica no pasado, as características básicas do que se está a facer na actualidade e os parámetros esenciais que, na miña opinión, van determinar a súa evolución no futuro inmediato.

\section{O PASADO}

Como é ben sabido, os primeiros Estatutos da Real Academia Española establecen con toda claridade as obrigas que os seus fundadores consideran inescusables na complicada etapa pola que pasaba o español no primeiro cuarto do século XVIII: publicación dos tres grandes códigos nos que, ao seu entender, estaba baseada a importancia e consistencia dunha lingua, isto é, un dicionario, unha gramática e unha ortografía. A esas tres grandes obras engadían outras como, por exemplo, unha historia da lingua e unha poética. As tres primeiras foron aparecendo no decurso do século e a primeira delas, o dicionario, foi, como tamén é ben coñecido, unha auténtica novidade nas obras lexicográficas. Resulta realmente asombroso que aqueles primeiros académicos, sen formación técnica ningunha, conseguiran en soamente 26 anos preparar os materiais, redactar e publicar a totalidade dunha obra que superaba, con bastante distancia, os estándares da época. O coñecido habitualmente como Diccionario de Autoridades segue a ter grande utilidade hoxe, e non unicamente no referente á historia da lexicografía.

Despois da publicación da primeira edición da Ortografía e en paralelo cos traballos de preparación da futura Gramática, acometeron a 
segunda edición da obra, na que pensaban aplicar numerosas melloras técnicas, incorporar un grande número de voces que non aparecen en $\mathrm{Au}$ toridades e tamén eliminar algunhas das que figuran na edición. $O$ ritmo foi xa bastante diferente e a obra non chegou a aparecer nunca. O primeiro tomo da segunda edición saíu en 1770 -co que temos a posibilidade de estudar as diferenzas de concepción entre as dúas- e pouco despois decidiron acometer os traballos de redución da obra, para facela máis accesible. O resultado desa decisión é o Diccionario de la lengua castellana compuesto por la Real Academia Española, reducido a un tomo para su más fácil uso, publicado en 1780 (RAE 1780). En realidade, non é unha obra distinta da anterior, senón o que queda dela despois de sérenlle retiradas as autoridades, os textos que aboan cada unha das palabras e acepcións mencionadas.

O proxecto do dicionario grande non é abandonado, seguen a traballar nel durante bastantes anos, pero son as sucesivas edicións do DRAE as que absorben a maior parte dos esforzos dos académicos da época. $O$ dicionario común emprende así, con este mal paso inicial, un camiño irregular, que agora podemos seguir con comodidade en todos os seus detalles grazas á existencia do Tesoro lexicográfico del español, a disposición dos interesados na páxina electrónica da Academia.

Non é posible, nin teño eu competencia para facelo, afondar aquí nos detalles da evolución experimentada por esta obra que, con todos os seus defectos, é a columna vertebral, a espiña da lexicografía hispánica. Moitas das edicións feitas nos case que douscentos cincuenta anos seguintes limítanse a facer algunhas adicións de palabras ou acepcións ou corrixir pequenos detalles nas definicións. Outras, en cambio, establecen fitos importantes polas adaptacións estruturais que supoñen ou ben, coma as de 1925 e 2001, pola atención especial prestada ás voces usadas en América.

En rápida síntese, as características básicas de toda a vida do DRAE anterior á edición de 2001 eran as seguintes:

(a) As edicións sucesivas ían retocando as anteriores na medida e direccións que en cada caso se consideraban axeitadas. Non se producía nunca unha reformulación radical do DRAE, polo que, mesmo aínda na versión actual, é posible localizar acepcións que teñen unha formulación non moi distinta da que aparece en Autoridades.

(b) Aínda que publicado pola Academia Española, o DRAE foi considerado sempre unha obra colectiva, na que a colaboración das Academias americanas era imprescindible. A Academia española favoreceu a creación de Academias nas vellas colonias americanas e tamén en Filipinas. 
As Academias americanas controlaban as propostas de modificación, que se publicaban no BRAE, e facían propostas de inclusión de voces específicas dos países respectivos. Dende a creación da Asociación de Academias de la Lengua Española, en 1951, hai unha Comisión permanente da Asociación, que, formada por representantes de diferentes Academias, traballa en Madrid durante cinco meses cada ano. Esa Comisión é a que se ocupa de tomar as decisións pertinentes sobre as voces americanas.

(c) A pesar da competencia dos técnicos e da boa disposición dos académicos, a documentación manexada habitualmente para o $D R A E$ resultaba escasa e, en moitos casos, deficiente. A decisión de prescindir das autoridades creou uns hábitos de traballo que en moitas ocasións levaron a reducir a documentación previa á que figuraba noutras obras lexicográficas (en moitos casos transmitida dunhas a outras) ou a basearse nas achegas persoais de académicos ou correspondentes. De aquí derivaba tamén unha dificilmente salvable descompensación de materiais (por citar un único factor, na edición actual hai 576 acepcións distribuídas en 526 entradas que levan a marca correspondente á provincia de Salamanca).

O DRAE é, sen dúbida ningunha, o elemento central da lexicografía académica, pero, como é ben sabido, non é o único. Flanquéano, por unha parte, o Diccionario manual (RAE 1927), que tivo varias edicións e ofrecía unha forma útil e cómoda de paliar os efectos negativos da ás veces excesiva distancia entre edicións sucesivas da obra de referencia e tamén un lugar no que formular propostas provisorias que non se consideraba axeitado introducir directamente no DRAE. Pola outra, o Diccionario histórico, que pretendía ser un dicionario integral do español de todas as épocas en todas as súas variedades. Tras do intento frustrado anterior á guerra civil (RAE 1933-1936), o proxecto de Casares, ben fundamentado nos presupostos metodolóxicos da época na que foi concibido, deu lugar a unha importante recolleita de material, estimado nuns doce millóns de papeletas, pero os atrasos producidos polo choque entre uns obxectivos excesivamente ambiciosos e a imposibilidade de manter os recursos humanos e materiais que precisarían levou a Academia a suspender o proxecto en 1996 para reenfocalo dende una perspectiva distinta.

A falla destes outros dous elementos do conxunto explica probablemente algunhas das características menos positivas do DRAE. Tiña que ser un rexistro do xa consolidado e bendicido polo uso culto en todo o mundo hispánico, pero tamén debía dar orientacións sobre formas que se estaban difundindo, co risco que iso supón. Tiña que ser un dicionario de uso do español actual, pero tamén tiña que axudar a quen necesitaba 
consultar formas ou expresións dos textos clásicos. Non é doado conxugar nunha obra única obxectivos tan discordantes entre si.

\section{O PRESENTE}

A actuación da Real Academia Española nos últimos anos está marcada pola intención de crear as condicións necesarias para remediar os defectos e inconsistencias da etapa anterior. En primeiro lugar, sen dúbida, a orientación panhispánica de todos os seus traballos. O obxectivo declarado, que é a consecución dunha norma culta unitaria que non negue as peculiaridades das normas nacionais ou areais non é, en definitiva, nada máis que o recoñecemento das características xeográficas, sociopolíticas e culturais do español no mundo actual. Existe unha estreita colaboración entre as 22 Academias que integran a Asociación, manifestada no feito de que as publicacións son conxuntas a partir da Ortografia, aparecida en 1999. E, por suposto, non se trata simplemente da publicación: o sistema de traballo adoptado habitualmente consiste na designación dun responsable de cada proxecto en todas as Academias e a constitución dunha comisión interacadémica, estruturada por áreas lingüísticas, que examina todos os materiais e valora as observacións formadas polas diferentes Academias.

Evidentemente, fixar como obxectivo un español xeral, relativamente unitario ao tempo que respectuoso coas características rexionais só é posible cun decidido investimento en infraestrutura documental. Esa é a intención coa que a RAE decidiu en 1995 emprender a confección do Corpus de referencia del español actual (CREA) e, poucos meses despois, como primeiro paso tamén para o novo proxecto de Diccionario histórico, do Corpus diacrónico del español (CORDE). Na actualidade (novembro de 2006), o CREA, a disposición pública dende 1998, consta duns 155 millóns de formas gráficas procedentes de textos dos mais diversos tipos e de todos os países hispánicos, producidos entre 1975 e 2004. Pola súa parte, o CORDE contén textos dende as orixes do idioma ata 1974 e consta actualmente de algo máis de 270 millóns de formas. En conxunto, pois, máis de 400 millóns de formas coas que os investigadores poden documentar e estudar o uso, a difusión, a frecuencia e máis a evolución de palabras e de expresións do español de todos os tempos. O Diccionario panhispánico de dudas (DPD), o Diccionario del Estudiante (RAE 2006) o Diccionario esencial (RAE 2005) e, naturalmente, a próxima edición do DRAE están construídos a partir destes dous enormes córpora textuais. 
A utilización de recursos electrónicos, non podía ser doutra forma, constitúe outra marca distintiva do traballo da RAE na actualidade. As técnicas da lingüística de corpus son, como acabo de sinalar, as utilizadas na recolleita do material no que se documenta e contrasta o contido das diversas obras lexicográficas e tamén a nova Gramática. Por outra parte, o $D R A E$ é xa realmente unha base de datos lexicográficos organizada para que poida conter non soamente a entrada tal e como é aprobada nas Comisións correspondentes, senón tamén toda a historia interna e o propio decurso ‘administrativo’ polo que pasa. Grazas ao seu carácter electrónico, é posible agora no DRAE realizar un auténtico control do dicionario (referencias internas, por exemplo), garantir a autocontención ou engadir estruturacións adicionais, como, por exemplo, a marcación temática acabada recentemente, que permitirá, por exemplo, acometer a revisión do $D R A E$ por áreas. Finalmente, os recursos electrónicos serven para a difusión da obra, que pode aparecer agora en formas ou presentacións imposibles sen eles. O DRAE, por exemplo, pon a disposición dos interesados a $22^{\mathrm{a}}$ edición, publicada en papel e CD, e tamén, como adianto da $23^{\mathrm{a}}$, as palabras ou acepcións xa aprobadas polas Academias para a súa inclusión. Facilítase desde xeito a consulta dunha obra permanentemente actualizada, algo imposible de conseguir polos procedementos tradicionais. Os dezaoito millóns de consultas que recibiu a versión electrónica do DRAE en setembro do 2006 son testemuña fiable da importancia adquirida por este recurso.

Todo o anterior, aínda que centrado no DRAE, aplícase tamén ás outras obras de carácter lexicográfico que as Academias publicaron recentemente e que, nunha consideración global, pretenden atender a obxectivos específicos e, por tanto, descargar o DRAE da necesidade de atendelos. O DPD pretende dar resposta ás dúbidas lingüísticas dos falantes do español, nesa perspectiva unitaria e diversa á que fixen referencia anteriormente, tratando de dar as razóns que avalan a(s) solución(s) ofrecida(s) en cada caso e actuando tamén como o instrumento no que as Academias fan as propostas que estiman máis aconsellables nos casos nos que se detecta vacilación. O Diccionario del estudiante reformula e adapta o contido do DRAE ás necesidades dos nosos estudantes do ensino medio. Por fin, o Diccionario esencial, que acaba de aparecer, selecciona do DRAE, mediante contraste cos datos do CREA, as palabras e acepcións correspondentes a ese español xeral que se busca e engádelle aquelas que están xa aprobadas para a próxima edición. 


\section{O FUTURO}

Esta é a liña básica na que a Academia pretende proseguir o seu traballo no futuro inmediato, unha liña marcada fundamentalmente pola colaboración intensa entre todas as Academias, a utilización en profundidade dos recursos electrónicos, a reestruturación do DRAE para adaptalo aos máis recentes avances da dicionarística e organización dos recursos existentes nun plan de lexicografía integrada que se manifeste en obras con obxectivos distintos, complementarias entre si.

Amais das citadas no parágrafo anterior, nesta nova xeira o DRAE estará acompañado doutras dúas obras que completarán o panorama da lexicografía do español. En primeiro termo, o Nuevo Diccionario histórico de la lengua española, que acaba de comezar unha nova formulación que nos permitirá dispor nun máximo de quince anos da historia dos 50.000 lemas centrais do español. En segundo lugar, o Diccionario académico de americanismos, que dará cumprimento a unha vella aspiración da Asociación de Academias.

Con todo isto, a próxima edición do DRAE, que podería aparecer no 2013, en conmemoración do terceiro centenario da creación da Real Academia Española, corresponderá a unha obra resituada en obxectivos e características. O DPD terá a misión de facer propostas en terreos nos que a norma non está aínda suficientemente ben establecida. O DH dará a historia dos significados e, naturalmente, conterá tamén as voces que xa non se utilizan e as acepcións desusadas. O DAA, pola súa parte, conterá os americanismos que non sexan de uso xeral. En consecuencia, o DRAE, desprendido destes compoñentes que o arredan do seu obxectivo central, quedará relevado desas obrigas secundarias que escurecen a súa finalidade fundamental e poderá ser sometido a esa revisión en profundidade que a longa historia da obra central da lexicografía hispánica está demandando en realidade desde a súa primeira edición. 


\title{
O TESORO DELLA LINGUA ITALIANA DELLE ORIGINI: O FUTURO DO ITALIANO ANTIGO?
}

\author{
Pär Larson \\ Opera del Vocabolario Italiano (CNR)
}

A Opera del Vocabolario Italiano (OVI) é un instituto de investigación no campo da lingüística que pertence ao Consiglio Nazionale delle Ricerche (CNR) - un organismo estatal análogo ao Consejo Superior de Investigaciones Científicas- e que ten a tarefa institucional de elaborar un vocabulario histórico da lingua italiana.

Dito desta maneira, soa moi ben, pero toda persoa que observe o substancial das cousas percibe rapidamente que se trata dun labor "ideal", unha empresa irrealizable se se consideran as posibilidades reais do OVI de hoxe, cos seus catorce traballadores. Por tanto, é lóxico que desde hai dez anos eu e os meus colegas nos esteamos ocupando dun labor, sempre vasto, pero máis reducido e por isto concretamente factible: a primeira tranche, a primeira sección do proxecto que mencionei anteriormente, é un vocabulario histórico do italiano antigo chamado Tesoro della Lingua Italiana delle Origini (TLIO). 


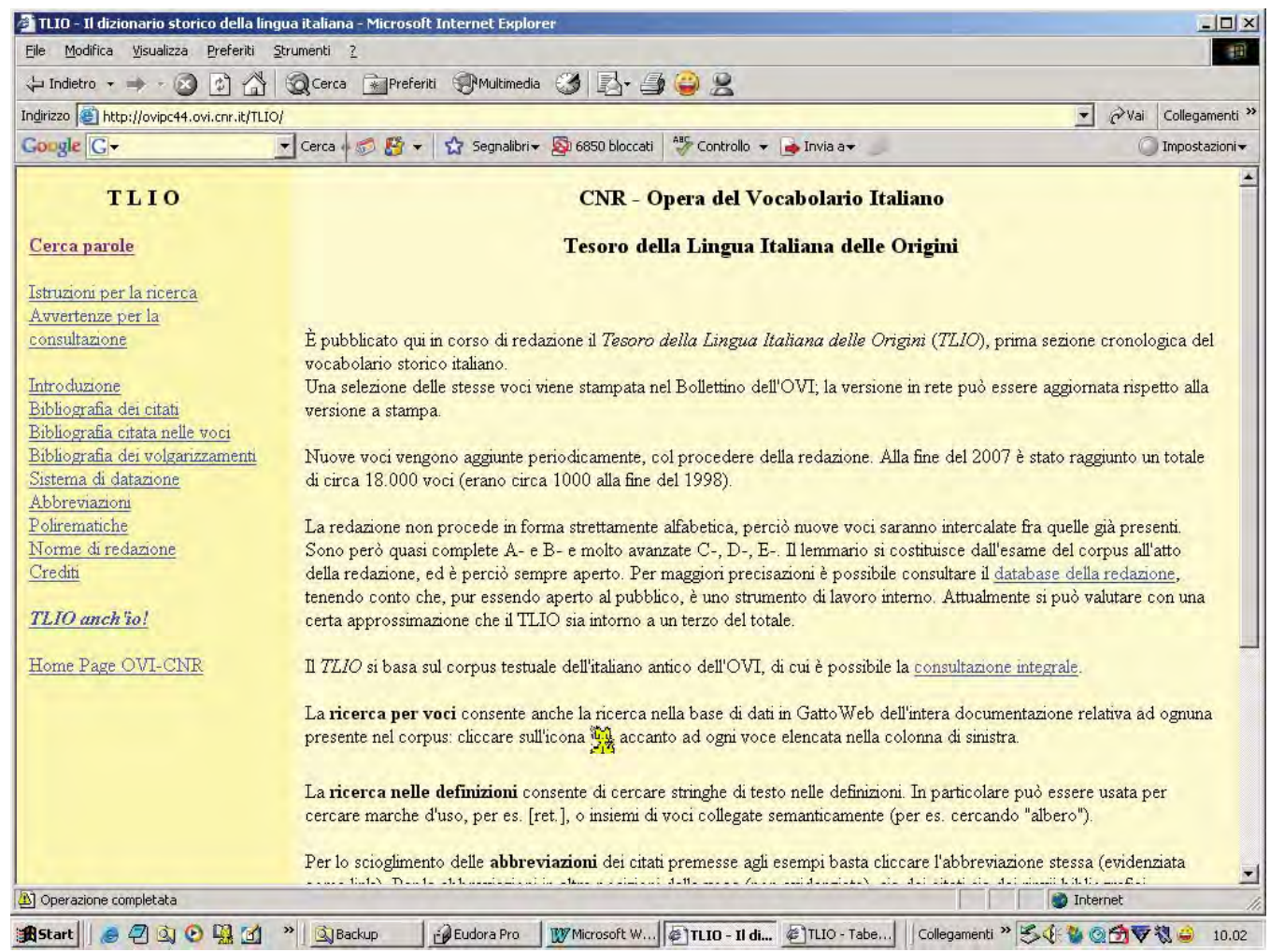

A actividade de redacción do TLIO, despois de tantos anos de traballos preparatorios ${ }^{1}$-que ás veces foron tamén dispersivos, debo admitilo- comezou a se concretar só nos anos noventa do século pasado, cando decidimos que a base de datos textual era o bastante grande para que se puidese iniciar a redacción das primeiras voces, que despois se publicaron directamente, no 1997, na nosa páxina web (http://www.vocabolario.org).

Mencionei a base de datos como cousa coñecida, mais creo que sería necesario explicar con maior detalle de que se trata, xa que é esta base de datos a que converte TLIO en algo completamente novo en Italia. De feito, as nosas voces de vocabulario redáctanse sobre materiais dun corpus informatizado e non reutilizando e reelaborando os traballos desenvolvidos polos lexicógrafos das xeracións precedentes, como ten acontecido sempre nalgunha medida cos grandes dicionarios italianos (e tamén en traballos semellantes noutros países), que debemos, non obstante, tomar sempre en consideración, xa que estou falando do glorioso -aínda que moi envellecido- Vocabolario della Crusca, do tamén glorioso Tommaseo / Bellini

1. O Tesoro, e o propio OVI, naceron no seo da Accademia della Crusca nos anos sesenta do pasado século: soamente nos comezos dos anos oitenta pasaron a ser xestionados polo CNR. Para termos unha idea do vasto proxecto inicial e do entusiasmo que o alentaba pode resultar interesante a lectura dunha serie de artigos do principal promotor do proxecto, o grande lingüista Giacomo Devoto (1969: esp. 136-171) (trátase de textos publicados no xornal florentino La Nazione entre 1964 e 1968). 
(1865-1879) e do recentemente finalizado Grande Dizionario della Lingua Italiana (GDLI). Todos estes dicionarios abranguen tamén a fase antiga da lingua, pero non se ocupan especificamente dela, e para a época antiga refírense ademais a un corpus moito máis pequeno e máis literario que o noso. Dicionarios tradicionais deste tipo tenden, pois, a falsear a visión da lingua antiga, dada a súa formulación 'teleolóxica', observando sempre o antigo a través do filtro do moderno, como algo que nos leva ao moderno.

Polo contrario, o Tesoro redáctase ex novo, así que, se tamén nós cometemos erros, polo menos os nosos son erros orixinais e non herdados dos nosos predecesores! O corpus está constituído idealmente ${ }^{2}$ por todos os textos en italiano antigo redactados nos primeiros séculos e editados dalgunha forma. O límite cronolóxico ante quem, nunha primeira fase dos traballos, fora fixado no ano 1375 -ano da morte de Giovanni Boccaccio, a última das chamadas "Tres Coroas" (Tre Corone) da literatura italiana3-, pero desde hai algúns anos desprazámolo ao ano 1400, onde permanecerá, aínda que este límite se supere nalgúns casos.

Podería ser útil subliñar un feito tan ben coñecido que frecuentemente o esquecemos: a lexicografía italiana nace, nun certo sentido, como lexicografía histórica. Os académicos da Crusca, a diferenza do que farían máis tarde os académicos de Francia e de España, codificando linguas orais xa existentes ${ }^{4}$, publicaron o seu primeiro Vocabolario no 1612 (os traballos preparatorios comezaran no 1591) para fornecer unha lingua literaria construída preferentemente na imitación da lingua dos escritores florentinos do secolo d'oro, o século XIV:

\footnotetext{
Nel compilare il presente Vocabolario [...] abbiamo stimato necessario di ricorrere all'autorità di quegli scrittori, che vissero, quando questo idioma principalmente fiorì, che fù da' tempi di Dante, o ver poco prima, sino ad alcuni anni, dopo la morte del Boccaccio. Il qual tempo, raccolto in una somma di tutto un secolo, potremo dir, che sia dall'anno del Signore 1300 al 1400 poco più, o poco meno [...] (Vocabolario della Crusca 1612: f. a3v -A' lettori-).
}

Os Cruscanti baseáronse só parcialmente nos usos da fala viva da época, para concentrarse nun canon de textos considerados como norma, elixido seguindo criterios de pureza lingüística aínda máis que de excelencia literaria. Deste punto de vista ideolóxico resultan interesantes as

2. Uso este termo porque, aínda sendo moi extenso, con 1.960 textos, 21.779 .246 ocorrencias, 442.770 formas distintas, 116.597 lemas, 3.576 .383 ocorrencias lematizadas, o corpus non está completo e continúa a crecer.

3. Trátase de Dante Alighieri (1265-1321), Francesco Petrarca (1304-1374) e Giovanni Boccaccio (1313-1375).

4. A primeira edición do Dictionnaire de l'Académie françoise data do ano 1694; a primeira do Diccionario de la Real Academia Española do 1780 
modificacións do mesmo título do vocabulario nos anos inmediatamente precedentes á sua publicación, coa referencia, máis política que lingüística, á "lingua toscana" e a mención, proposta para despois ser retirada a continuación, da lingua viva de Florencia:

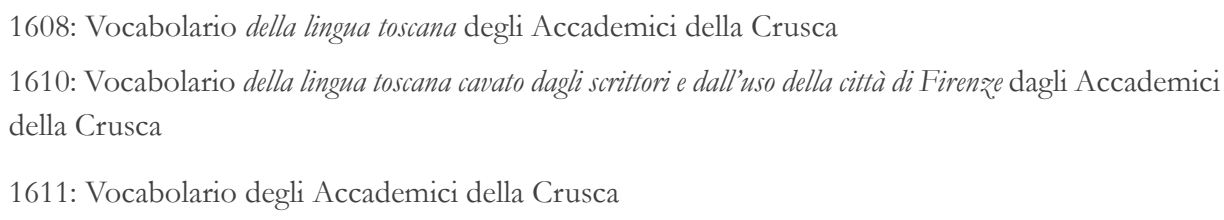

A base fonética e morfolóxica do italiano estándar moderno remonta así -cando menos nos seus trazos esenciais- á visión que da lingua florentina do século XIV tiñan os estudosos do tardío século XVI.

O TLIO é, pois, un vocabulario histórico do italiano antigo, desde os primeiros textos breves dos séculos IX e X despois de Cristo ata finais do século XIV. En verdade, falar de "lingua italiana" referíndose á época medieval é un anacronismo: só a partir do século XVI se pode comezar a falar dunha lingua italiana codificada non identificable con ningunha das variedades faladas daquela na península apenínica ${ }^{5}$. Ata o de agora os lexicógrafos e os lingüistas históricos ocupáronse do italiano antigo privilexiando a perspectiva de antecesor directo da lingua moderna, isto é, a antiga variedade da Toscana e sobre todo da cidade de Florencia (con algunha rara excepción en casos máis ou menos illados como o umbro da poesía relixiosa de Jacopone da Todi). Nun contexto rigorosamente lingüístico, no interior dun ambicioso proxecto recente no cal tiven unha pequena participación, a Grammatica dell'italiano antico dirixida por Giampaolo Salvi (Budapest) e Lorenzo Renzi (Padua) (Salvi / Renzi no prelo), o italiano antigo é identificado co florentino do século XIII, "a variedade que está na base do italiano literario e do italiano estándar moderno": e esta é sen dúbida unha definición aceptable, pero non é a nosa.

Se quixese ser preciso e inatacable debería ter dito que o TLIO é un "vocabulario histórico das antigas variedades italorromances", por máis que a cómoda expresión italiano antico encontre equivalentes perfectos noutras definicións lingüísticas análogas como old English, ancien français, Althochdeutsch e español antiguo, que definen tamén conxuntos dialectais heteroxéneos, coexistentes no mesmo continuum xeográfico e sen ningunha norma supradialectal.

5. A data tradicional é o ano 1525, no que se publica a primeira edición da Prose della volgar lingua de Pietro Bembo, onde se propón como norma literaria italiana o florentino do século XIV. 
No OVI adoptamos sistematicamente esta definición moi ampla da expresión italiano antico: e é este feito o que quixen sinalar co título do meu traballo. Ademais, non fixemos escollas entre os xéneros. Os vellos dicionarios, que, como dixen, querían proporcionar un modelo de lingua escrita para imitar, sempre consideraron case exclusivamente a lingua literaria e relegaron os outros rexistros; para nós, non obstante, valen o mesmo, e frecuentemente máis, os termos que aparecen en textos técnicos e lexislativos (onde ás veces é posible coñecer con maior precisión o seu valor semántico) que os usados polos grandes escritores. O feito de que o corpus se construíse como unha base de datos coloca todos os textos ao mesmo nivel, e o principal criterio de selección dos exemplos é o cronolóxico, xa non o do xénero do texto ou a súa orixe xeográfica.

Un pequeno excursus: entre as antigas variedades italorromances existen tamén variedades moi afastadas entre si, polo menos tanto como as variedades romances da península ibérica: abonda con comparar, por exemplo, un texto de Milán, un de Xénova, un de Perugia e un de Sicilia para comprendelo: as isoglosas que separan a Lombardía da Sicilia son probablemente máis numerosas que as que separan Cataluña de Castela e de Galicia. A pesar disto, a vontade dos escritores e dos gobernantes dos diversos estados italianos impediu que se formasen verdadeiras linguas autónomas, así que a escolla do modelo toscano non foi o resultado dunha imposición -Florencia non dominaba politicamente ningún territorio fóra da Toscana!- senón o resultado dunha imitación literaria voluntaria e gradual.

O corpus do TLIO foi creado a propósito para a redacción do vocabulario, pero é tamén un instrumento independente. Por esta razón decidimos facelo accesible a todos os usuarios, e debo dicir que fan un uso intenso $\mathrm{del}^{6}$. Desde hai varios anos o corpus é consultable a través do sitio ItalNet, creado e mantido por un consorcio formado polo OVI, dúas universidades estadounidenses (Chicago e Notre Dame) e unha universidade británica (Reading); no 2005 puxemos tamén na rede unha versión do noso software interno, o GATTO (do que non falarei agora, pois esixiría case unha conferencia completa), chamada GattoWeb, que permite a calquera usuario efectuar consultas no corpus, para integrar os datos proporcionados polo TLIO, ou para investigacións privadas de todo tipo.

Despois desta premisa extremadamente sumaria volvo falar do mesmo TLIO, cuxo lugar de publicación oficial e primaria é o noso sitio

6. Para demostrarlle ao Consiglio Nazionale delle Ricerche que merecemos existir (xa que hai que facelo!) recollemos no sitio web un elenco de traballos científicos que usan os nosos recursos. 
web (http://tlio.ovi.cnr.it/TLIO/). É verdade que unha selección de voces se imprime cada ano no noso anuario, o Bollettino dell'Opera del Vocabolario Italiano, pero trátase sempre dunha escolla representativa e non da produción anual total de dúas mil voces?. Son consciente de que esta última cifra redonda pode parecer estraña, pero xa que formamos parte dun organismo estatal que coordina institutos de investigación en moitos campos diversos -e pertencentes a maior parte ás chamadas "ciencias puras"- decidimos declarar como tarefa anual esta cifra redonda de voces (aos burócratas gústanlles as cifras exactas), aínda que todos nós sabemos que os números no noso campo non significan nada. Dicir "2.000 voces de vocabulario cada ano" é como dicir " 1.960 textos no corpus", xa que un texto pode ser unha inscrición de dúas liñas sobre un sarcófago do século XII, pero tamén poden ser os catorce mil hendecasílabos da Divina Commedia de Dante ou os cen relatos do Decamerone de Giovanni Boccaccio.

Actualmente temos en rede máis de 17.000 voces, que pertencen maioritariamente ás primeiras letras do alfabeto, aínda que tamén a outras, ás veces dunha maneira un pouco abrupta. Mais non tanto: e para ilustralo cun exemplo lóxico poñemos o caso da persoa que estea redactando a familia lexical de abbondare e abbondanza e decida engadir tamén os derivados prefixados sovrabbondanza, sovrabbondare e strabbondanza, ou o caso de que o redactor da voz asbergo (un tipo de coiraza medieval) considere tamén as variantes isbergo, osbergo, sbergo e usbergo (e máis tendo en conta que a forma usbergo é a única que se coñece un pouco hoxe, porque aparecía nas vellas edicións non filolóxicas da Divina Commedia -nas edicións actuais comparece asbergo- nunha expresión que se converteu logo en proverbial).

As voces do vocabulario redáctanse consultando o banco de datos coa axuda do mesmo software que se necesita para crear, corrixir, modificar e lematizar o corpus: como xa dixen chámase GATTO. Trátase dun zoónimo accidental, o acrónimo de Gestione degli Archivi Testuali del Tesoro delle Origini. GATTO foi producido para as nosas esixencias específicas polo meu colega Domenico Iorio-Fili e actualízase continuamente. Se alguén tivese interese en probalo para os propios traballos pode descargalo gratuitamente desde a nosa páxina web, xunto co manual de uso.

E agora entremos no TLIO. Escollín unha voz recente, errore s.m.

7. Ata hoxe publicáronse once tomos do Bollettino, imprimidos pola editorial Edizioni dell'Orso de Alessandria (http://www.ediorso.it) 


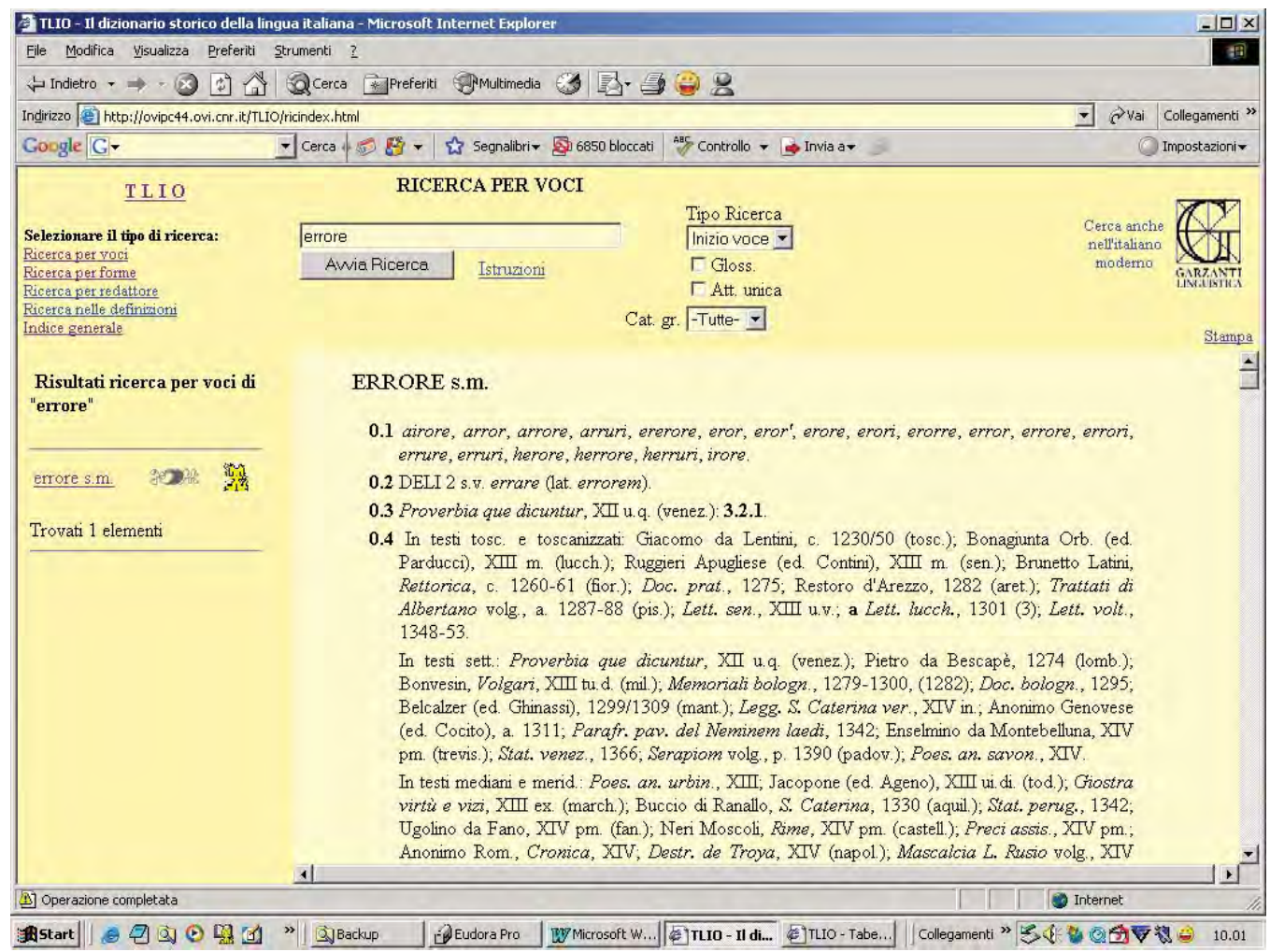

En primeiro lugar encontramos o lema en forma normalizada, seguido polas indicacións da categoría gramatical. O lema está na forma italiana moderna se o termo aínda existe; os lemas con grafía "dialectal"8 utilizanse exclusivamente para os termos testemuñados tan só nunha parte determinada do dominio italorromance, posto que a tentativa de italianizalo produciría un lema ficticio.

A continuación, o lema encontra un "parágrafo cero", composto por unha serie de subparágrafos numerados de 0.1 a 0.8 .

O punto 0.1 contén unha lista de todas as formas gráficas do lema presentes no corpus (nos casos de palabras -sobre todo verbos- rexistrados en moitas variedades lingüísticas diferentes, esta lista pode ser longuísima). Para reconstruír o material sobre o que foi redactada a voz a través desta lista chega con premer na icona co gatiño a carón do lema, na esquerda da pantalla: aparece unha páxina de consulta que leva ao contorno GattoWeb, onde se visualiza despois o resultado completo da búsqueda no corpus, é dicir, o mesmo material sobre o cal traballou o compilador da voz:

8. Pode que sexa mellor que explique rapidamente que as palabras italianas dialetto e dialettale se usan con maior liberdade que en España, onde son usados frecuentemente, se estou ben informado, para descualificar as realidades lingüísticas consideradas subalternas. 


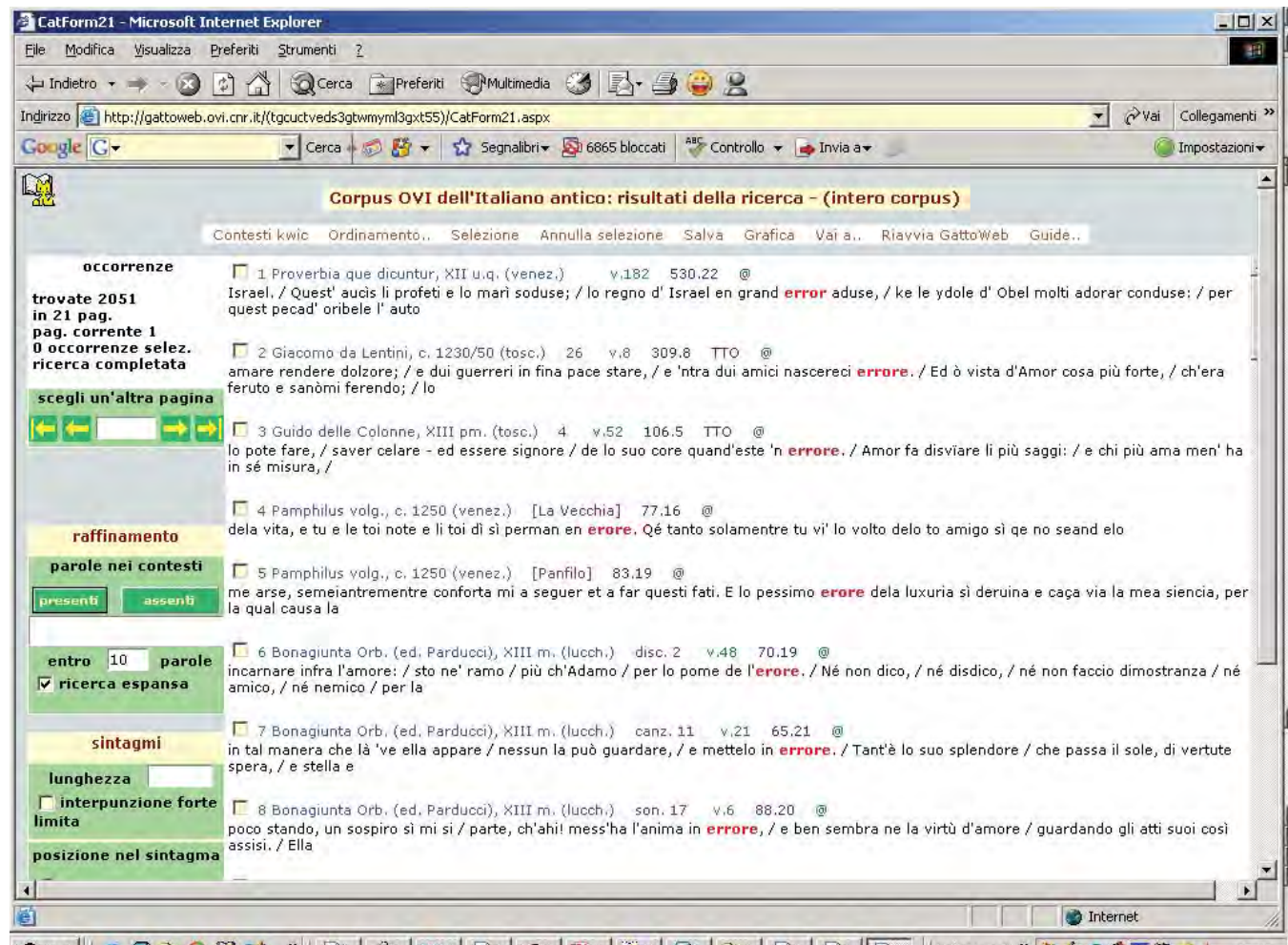

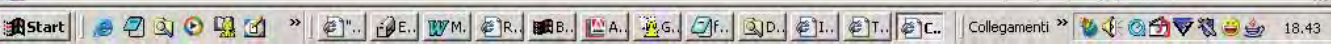

O punto 0.2 está dedicado á etimoloxía e serve simplemente para identificar o lema a respecto doutras formas homógrafas e homófonas: sempre que sexa posible limítase a un reenvío a un dos principais repertorios etimolóxicos, neste caso á segunda edición do Dizionario Etimologico della Lingua Italiana (Cortelazzo / Zolli 1999)9. Nalgúns casos, cando o redactor pode descartar as hipóteses etimolóxicas recoñecidas ou posúe materiais ou coñecementos que permiten precisar a orixe dunha palabra, o parágrafo 0.2 pode conter tamén unha discusión etimolóxica orixinal.

No punto 0.3 indícase o texto que contén o primeiro testemuño do lema e, para facilitar a "navegación" no interior da voz, tamén o número da acepción onde está situado este exemplo.

O punto 0.4 ilustra o tipo de atestación do lema: móstrase a distribución xeolingüística inventariando os primeiros testemuños de cada área lingüística, divididas por comodidade en catro grupos: (1) textos setentrionais, (2) textos toscanos e corsos, (3) textos meridionais e medianos (con mediani indícase tradicionalmente os dialectos da Umbria, das Marcas e do Lacio, contiguos ao grupo toscano e máis próximos a el que ás falas propiamente meridionais), (4) textos sicilianos. Sinálanse non só os primeiros

9. Para as palabras derivadas de étimos latinos pertencentes ás primeiras letras do alfabeto, recórrese sistematicamente ao LEI. 
testemuños absolutos de cada área, senón tamén (e esta é unha novidade nosa) os primeiros testemuños en textos lingüisticamente significativos. Estes textos, que están marcados na bibliografía e no corpus cun TS ("testo significativo"), son aqueles que consideramos homoxéneos e "sinceros", e por tanto representativos da variedade lingüística a que pertencen: trátase sobre todo de textos de carácter práctico como libros de contas, cartas privadas, etc., que teñen menor aspiración literaria e reflicten mellor a auténtica lingua do escriba do que as composicións puramente literarias. Poño un exemplo: o exemplo máis antigo nun texto de Boloña está nun poema copiado no 1282 nos rexistros do concello chamados Memoriali bolognesi, e citámolo no punto 0.4. Pero indicamos tamén o primeiro testemuño nun texto boloñés marcado con TS, un documento do 1295.

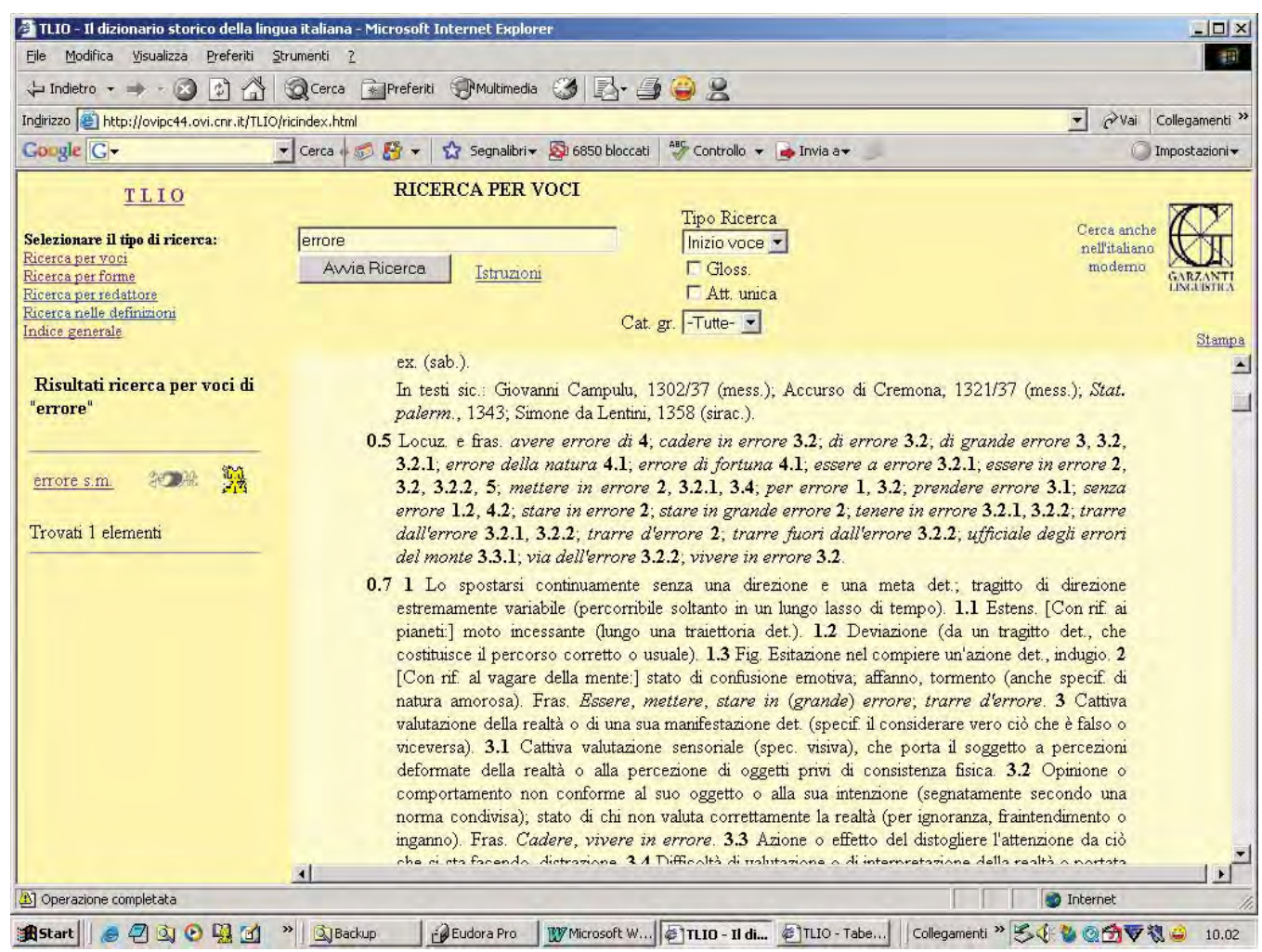

No punto 0.5 insírense eventuais observacións de carácter lingüístico sobre as construcións e sobre os usos sintácticos, e tamén informacións variadas que teñen que ver coa fonética, morfoloxía, etc. Aquí ten tamén o seu lugar o índice de locucións e da fraseoloxía rexistradas na voz (cando existen). Grazas a este índice é posible consultar as locucións en todo o vocabulario ata hoxe publicado. Na imaxe seguinte pódense ver os resultados dunha busca onde se visualizan todas as locucións que conteñen a palabra mano, e tamén as voces onde se encontran as locucións: 


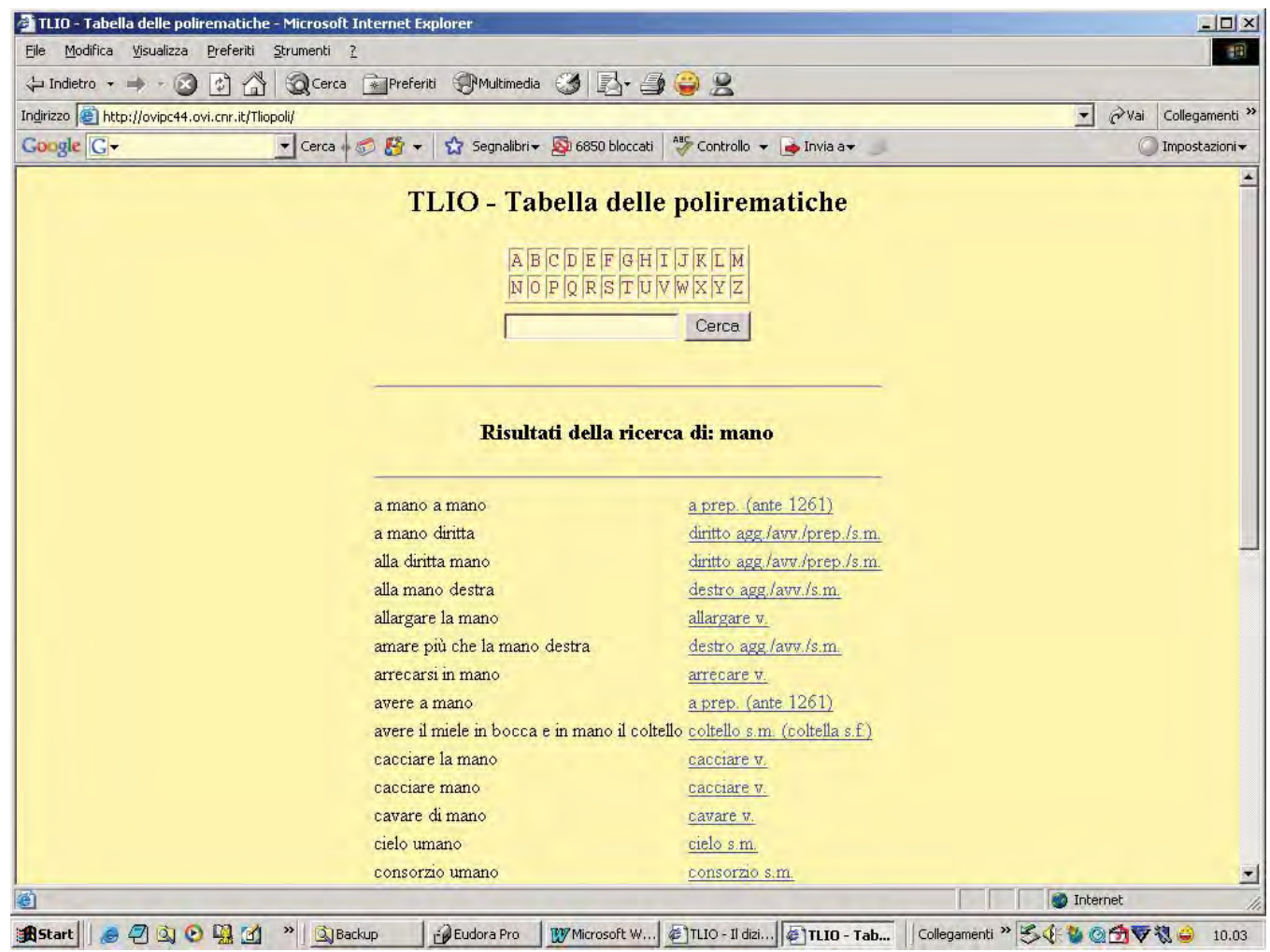

No punto 0.6 sitúanse anotacións de distinto tipo: sobre os usos do lema como nome de persoa ou de lugar, e tamén as ligazóns bibliográficas ou as ligazóns a outras voces do vocabulario.

No punto 0.7 fornécese un resumo da estrutura da voz, citando as definicións das acepcións únicas e subacepcións. Aínda que poida parecer unha cousa inútil, en moitos casos recorrer ao punto 0.7 pode ser suficiente para orientarse dentro do TLIO: o resumo corresponde realmente á lista das acepcións que se encontra nos dicionarios tradicionais que simplemente "ofrecen o significado das palabras".

0.7 1 Lo spostarsi continuamente senza una direzione e una meta det.; tragitto di direzione estremamente variabile (percorribile soltanto in un lungo lasso di tempo). 1.1 Estens. [Con rif. ai pianeti:] moto incessante (lungo una traiettoria det.). 1.2 Deviazione (da un tragitto det., che costituisce il percorso corretto o usuale). 1.3 Fig. Esitazione nel compiere un'azione det., indugio. 2 [Con rif. al vagare della mente:] stato di confusione emotiva; affanno, tormento (anche specif. di natura amorosa). Fras. Essere, mettere, stare in (grande) errore; trarre d'errore. 3 Cattiva valutazione della realtà o di una sua manifestazione det. (specif. il considerare vero ciò che è falso o viceversa). 3.1 Cattiva valutazione sensoriale (spec. visiva), che porta il soggetto a percezioni deformate della realtà o alla percezione di oggetti privi di consistenza fisica. 3.2 Opinione o comportamento non conforme al suo oggetto o alla sua intenzione (segnatamente secondo una norma condivisa); stato di chi non valuta correttamente la realtà (per ignoranza, fraintendimento o inganno). Fras. Cadere, vivere in errore 3.3 Azione o effetto del distogliere l'attenzione da ciò che si sta facendo, distrazione. 3.4 Difficoltà di valutazione o di interpretazione della realtà o portata di un oggetto o 
un'opinione, possibilità di dubbio o fraintendimento. Fras. Mettere in errore. 4 Stato di cose turbato, confuso, non conforme a giustezza. 4.1 Fras. Errore di fortuna, della natura: stato di cose non conforme a quanto costituisce la normalità (assunta a metro di giustezza), dovuto a fenomeni casuali. 4.2 Non conformità di un oggetto (prodotto da un'azione) alla sua intenzione o alla sua funzione, imperfezione, difetto. 5 Divergenza di opinioni circa la valutazione di un det. evento o oggetto (passibile di scatenare ostilità), malinteso, discordia. Fras. Essere in errore.

Finalmente, no punto 0.8 encóntrase a data de redacción e o nome do redactor. En caso de voces revisadas ou ampliadas, pódense engadir o nome do revisor e a data da revisión. As voces non asinadas, por tradición, fainas persoalmente o director. Tamén este punto é máis útil do que parece, porque os colaboradores vellos e novos son moitos (o número total, contando tamén as persoas que traballaron en colaboración con outros, e tamén persoas que fixeron só unha voz, é de 67 persoas), e tamén se procuramos uniformar o resultado dos seus esforzos poden quedar peculiaridades. Non obstante, a sinatura da voz serve sobre todo ao propio redactor, que está autorizado a citar a voz do vocabulario como obra súa e citala no seu currículo e na lista das súas publicacións.

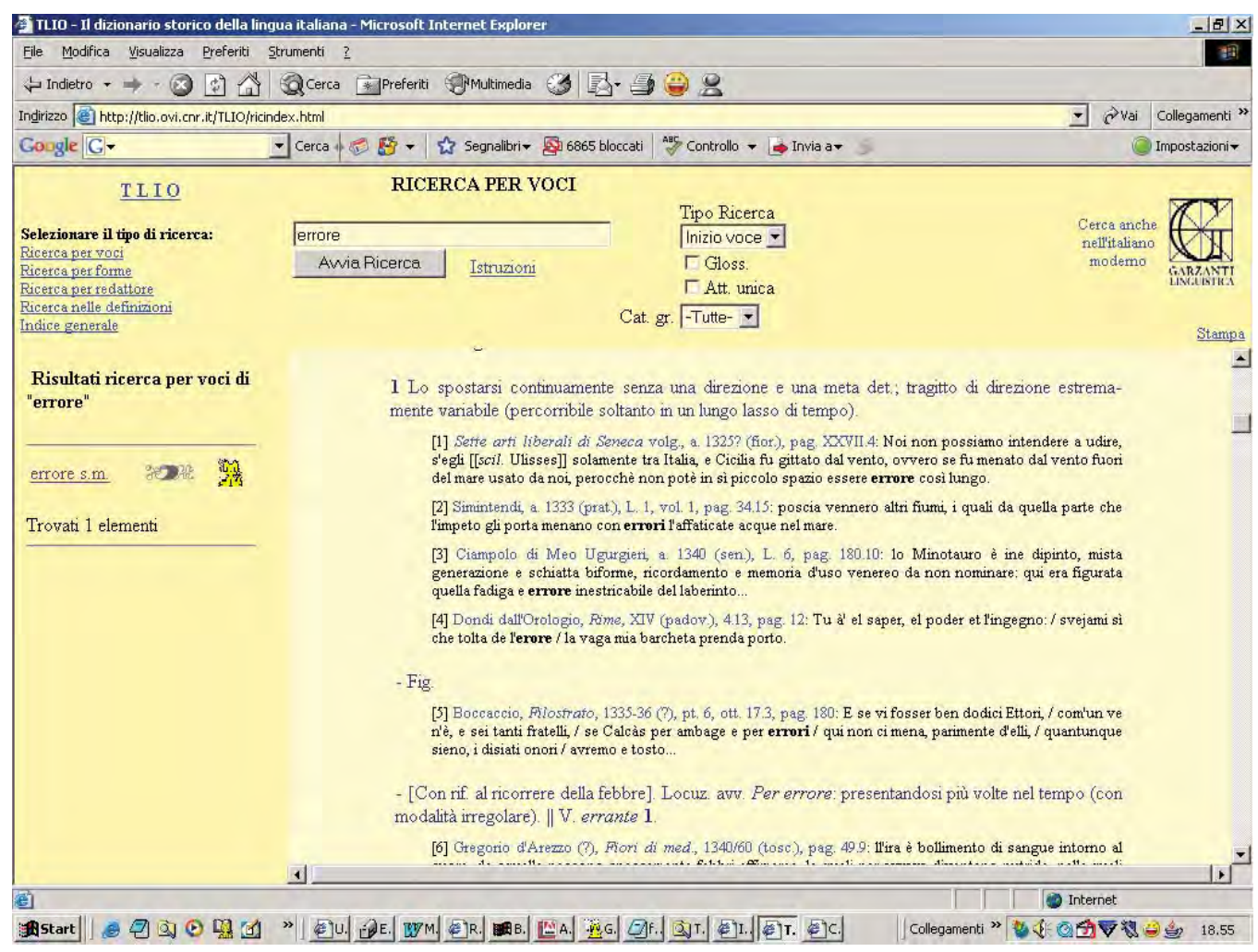

Se agora entramos na mesma voz, a primeira cousa que percibimos é que se citan moitos exemplos para cada acepción. Isto é unha consecuencia directa da 'ideoloxía' lingüística que expliquei antes: se por italiano antico entendemos, como dixen, o conxunto de todas as antigas varie- 
dades italorromances temos o deber de documentar a fondo a situación. Existen tipos lexicais semanticamente simples pero difundidos por todo o territorio italorromance, onde baixo unha soa acepción son citados corenta exemplos: por esta razón a lectura do TLIO pode resultar ás veces un pouquiño indixesta.

As diferenzas entre o TLIO e os outros dicionarios históricos italianos son, como se pode ver, numerosas; mais, alén das características que acabo de ilustrar, existen outras. Antes de concluír esta miña breve exposición mencionarei dous trazos do noso vocabulario que non están presentes noutros instrumentos lexicográficos análogos.

A primeira delas é a marca Glossa. Cando nun exemplo o lema tratado vén dalgún xeito explicado ou glosado -na mesma variedade lingüística do propio texto ou nunha outra- o exemplo vai precedido da abreviatura Gl. Isto sucede nos exemplos tirados de verdadeiros glosarios bilingües:

[5] G1 Gloss. prov.-it., XIV in. (it.sett./fior./eugub.), pag. 108.1: Aziman .i. calamita.

[3] G1 Senisio, Declarus, 1348 (sic.), 53v, pag. 65.4: Circopaticus a um, animal quoddam simile simie, sed caudatum, quod dicitur gactu maymuni.

[6] Gl Gloss. lat.-engub., XIV sm., pag. 87.2: Hic catus, ti et hic murilegus, hic pilax, cis id est lo gacto.

Mais tamén acontece noutras 'glosas' máis discursivas e casuais:

\footnotetext{
[4] G1 Serapiom volg., p. 1390 (padov.), Bestiario, cap. 27, pag. 433.9: E butage sovra de l'aqua da alto cum grande impeto, çoè remore, açò che la faça spuma, po muove questa soçura fortemente e arecogi questa spuma.

[1] Gl Francesco da Buti, Inf., 1385/95 (pis.), c. 21, 1-18, pag. 544.24: Et in-tende prima l'autore di trattare qui del peccato della baratteria, che per altro nome si chiama moccobellaria; e moccobellaria è vendimento, o vero comperamento di quello che l'uomo è tenuto di fare per suo uficio $\mathrm{o}$ in cose publiche o private, per danari o per cose equivalenti.
}

Os exemplos marcados deste xeito pódense procurar nas voces do TLIO a través da función de busca Gloss(ario).

A segunda característica do TLIO que me gustaría salientar refírese ás voces presentes en textos consistentes en traducións doutra lingua. No noso corpus existen, a carón de obras orixinais en verso ou en prosa, numerosos textos traducidos do latín, do francés antigo ou doutras linguas como o provenzal, e mesmo -caso único e extremadamente precoz-unha tradución do castelán, unha parte do Libro delle stelle fisse de Afonso o Sabio realizada contra 1341 por un florentino residente en Sevilla. 
Cando o redactor o considera útil, un exemplo tirado dunha tradución pode ir acompañado do fragmento correspondente do texto de procedencia:

[3] Bibbia (03), XIV-XV (tosc.), 2 Re 18, vol. 3, pag. 257.9: 6. E uscìo il popolo contra ad Israel, e fue fatta la battaglia nell'albareto di Efraim.|| Cfr. II $S_{m}$ 18, 5-8 «factum est proelium in saltu Ephraim».

[2] Bono Giamboni, Vegezio, a. 1292 (fior.), L. 1, cap. 1, pag. 6.25: In che modo la poca gente de' Romani contra la moltitudine de' Galli averebbe avuto potenza? Come la loro piccola statura contra la grandezza degli Alemanni avrebbe avuto ardimento? || Cfr. Veg. Mil. 1, 1: «Quid adversus Germanorum proceritatem brevitas potuisset audere?».

[1] Andrea da Grosseto (ed. Selmi), 1268 (tosc.), L. 4, cap. 16, pag. 329.10: Allegramente sono da amare le virtù, però che dice Augustino... || Cfr. Albertanus, De amore et dilectione Dei, L. IV, cap. 3: «Virtutes dixi vehementer esse diligendas»

[8] < Tesoro volg. (ed. Gaiter), XIII ex. (fior.)>, L. 7, cap. 17, vol. 3, pag. 281.15: ma guarda che tu per prestezza non perdi la perfezione di tua opera; chè 'l villano disse, cane frettoloso fa catelli ciechi. || Cfr. B. Latini, Tresor, II, 66, 5: «li vilains dist ke hastive lisse fet chiens avules».

Deste xeito resúltalle posible ao lector comprender o modo de traballar dos tradutores medievais e ter unha idea de como eran percibidas na época as linguas diferentes do italiano e, se cadra, mesmo comprender o proceso de xeración de certos latinismos ou estranxeirismos que sobreviviron na lingua. 



\title{
OS DICIONARIOS HISTÓRICOS. TRAZOS DUN DICIONARIO HISTÓRICO GALEGO E CONSIDERACIÓNS SOBRE A SÚA VIABILIDADE
}

\author{
Antón Santamarina
}

Instituto da Lingua Galega. USC

\section{OLLADA ÓS DICIONARIOS HISTÓRICOS}

Un dicionario é unha obra na que se lle mostra a alguén o uso e o valor das palabras ou calquera outra información sobre elas; daquela, o autor dun dicionario antes de acometer a súa obra imaxina un lector ideal e segundo as necesidades deste lector ideal fai un dicionario dun tipo ou doutro. Por iso hai moitos tipos de dicionario aínda que por antonomasia, cando dicimos dicionario, pensemos nos que se organizan alfabeticamente e se refiren ó uso actual dunha lingua. Que os lemas estean nunha lingua e as explicacións noutra ou noutras é un trazo engadido que ten outras explicacións, algunhas entendibles e outras non; por exemplo, que o Französisches etymologisches Wörterbuch (FEW) teña os lemas en francés e os testemuños sexan todos do francés e o occitano e os dialectos respectivos e en cambio estea redactado en alemán débese só a que Wartburg manexaba mellor o alemán có francés e a redacción dos artigos en alemán lle consumía menos tempo. A historia da lingua mesma explica, se é que nesa lingua os hai, tamén algúns trazos dos seus dicionarios. Por exemplo, no caso dos dicionarios galegos anteriores ós 80 a maior parte do léxico incluído era de procedencia popular; o lexicógrafo confundíase co dialectólogo; aínda polos anos 50 Aquilino Iglesia Avariño (que tamén papeletizaba autores) andaba co seu caderno na man á caza de palabras, mesmo nas tabernas de Santiago, das que era asiduo e onde o coñecían coa alcuña de "o home das palabras". Esa mesma historia externa explica bastantes trazos dos dicionarios aparecidos despois dos 80 na medida en que reciclan con maior ou menor filtrado (en xeral cun criterio normativista) os dicionarios "dialectolóxicos" anteriores.

Pois ben, entre a variada gama de dicionarios existente para o galego (lingua, dúbidas, sinónimos, rima, falas, nomenclaturas, terminoloxías, etc.) hai a lagoa dun dicionario histórico, ou sexa, un dicionario onde cada 
entrada conteña a biografía enteira da palabra. É verdade que o público destinatario deste tipo de dicionarios é restrinxido, como o é o de receptores dunha gramática histórica, que ten só unha clientela nos especialistas, nativos ou alleos, interesados pola historia da lingua. Con todo hai unha diferenza grande entre a gramática e os dicionarios; os procesos de palatalización de nexos consonánticos latinos en romance só interesan a un pequeno clan de historiadores da lingua; en cambio a historia de cada palabra é coma un pequeno fragmento da historia da cultura dun pobo; por iso un dicionario histórico ten un público que abarca, fóra dos lingüistas, especialistas en moitas outras materias (historiadores, etnógrafos, xuristas...) e lectores cultos curiosos aínda que non teñan intereses profesionais determinados.

Polas súas características os dicionarios históricos non adoitan ser obra de iniciativa privada, porque non son obras rendibles economicamente, senón de institucións académicas (Universidades ou Academias), aínda que hai excepcións.

Os dicionarios históricos teñen un antecedente nos dicionarios de autoridades. Entre os románicos está o Vocabolario della Crusca (1612), que non fai en realidade outra cousa que trasladar a un dicionario monolingüe romance o que xa se viña facendo cos grandes lexicóns das linguas clásicas desde o comezo do Renacemento, a saber, exemplificar con citas reais de escritores clásicos os varios sentidos dunha palabra. O Diccionario de Autoridades da Real Academia Española (1726-39) ou o Johnson (1755) e, despois deles, moitos outros seguen o exemplo do da Crusca. En linguas como o italiano ou o español, onde a distancia entre a lingua antiga e a moderna é escasa, os dicionarios de autoridades (porque as inclúen de toda a historia da lingua) funcionan como dicionarios históricos ou pouco lles falta; é o caso do Tommaseo / Bellini (1865-1879), ou o seu derivado na UTET de Salvatore Bataglia (1904-1971) / Giorgio Bàrberi Squarotti (1929-) (Bataglia 1961-2002). Con todo, os primeiros prototipos de dicionarios históricos só se idean e aparecen na segunda metade do século XIX, cando se aplica con rigor ós léxicos nacionais a mesma metodoloxía histórica que se aplicaba ás gramáticas. Non é así estraño que os que idearon o primeiro dicionario histórico dunha lingua moderna, o Deutsches Wörterbuch (DWB), (fosen filólogos de profesión como é talmente o caso dos irmáns Grimm -Jacob (1785-1863) e Wilhelm (1786-1859)-; os indoeuropeístas recordan o primeiro pola Deutsche Grammatik (J. Grimm 1819-1837), onde se formula por primeira vez a célebre lei da mutación consonántica; e os nenos de todo o mundo recordan a ambos polos contos populares. Ambos eran profesores e bibliotecarios e por razóns politicas foron apartados 
dos seus cargos (a Tommaseo, que tamén era folclorista e escritor -pero era xurista de profesión- pasoulle o mesmo varias veces en Italia). Cesantes ofrecéronse a un editor de Leipzig para facerlle un dicionario do alemán en 6 volumes que mellorase os de J. Ch. Adelung (1774-1786) e o de J. H. Campe (1807-1812). A idea dos Grimm era facer un dicionario que presentase o léxico alto-alemán conforme o testemuño dos escritos posteriores á segunda metade do século XV ata o momento actual. Excluíase, daquela, toda intención normativa e outorgábaselle valor primordial á cronoloxía e á forma da voz documentada para establecer a historia de cada palabra. Estaba previsto que a obra se acabase en 10 anos. Coa axuda de 80 colaboradores voluntarios comezaron o traballo en 1838 e no 52 apareceu o primeiro fascículo. Wilhelm morreu no 59 e foi responsable da redacción da letra D; Jacob morreu no 63; redactara as letras A B C E e estaba na palabra Frucht do F. Levaban un 25\% da obra feita. Erraran todas as contas porque a obra foi acabada moito despois e por outras persoas; non resultaron 6 volumes senón 32; e non foron 10 anos posto que a obra só rematou en 1961, 123 anos despois de comezada, 107 despois de aparecido o primeiro fascículo e 98 despois de desaparecido o último Grimm. Despois da morte dos Grimm pasou a responsabilidade do DWB a principios do XX á Academia dos Científicos de Prusia (Preußische Akademie der Wissenschaften) co taller en Göttingen, e en 1930 á Academia de Berlín. Desde 1957 (nunha cooperación entre as dúas Alemañas a través das universidades de Berlín e Götingen, que continúa despois de reunificado o país) trabállase na reelaboración das letras A-F; o primeiro fascículo apareceu en 1965 e está previsto rematar no ano de 2012. A duración do proxecto provocou unha muda de criterios editoriais (ademais do enriquecemento da documentación); así é que unha voz como essen redactada por Jacob en 1862 ten oito columnas, mentres que trinken redactada en 1950 ten trinta e sete ${ }^{1}$. Son moitas as ensinanzas que se poden extraer da obra do DWB. Metodoloxicamente puxo os fundamentos da lexicografía histórica que despois serían moi refinados pola obra do New English Dictionary on Historical Principles (NED) -Oxford English Dictionary (OED) desde 1895-, e de aquí exportados a outras obras semellantes (entre elas o propio DWB reelaborado). Pero igual de importante é salientar cómo a obra se fraguou co saber, o entusiasmo e a entrega dos dous autores e coa colaboración desinteresada de moitos patriotas amantes da lingua; cómo se continuou por varias xeracións de lexicógrafos, que seguen a chamarlle en honor dos iniciadores o Dicionario Grimm aínda que da pluma deles

1. Para este e outros pormenores véxase Osselton (2000). 
xa non queda case nada nos artigos do dicionario; e finalmente cómo o goberno acabou considerando ese dicionario un monumento á cultura da nación alemá e acabou apoiando economicamente o proxecto aínda que supoña un investimento do que non se pode esperar unha rendibilidade económica (a pesar de haber cerca de 100 millóns de xermanófonos posibles compradores). A primeira versión está dispoñible na rede (http:// germazope.uni-trier.de/Projects/DWB).

O seguinte gran fito na lexicografía histórica foi o dicionario do inglés, que xurdiu dunha iniciativa da Philological Society, unha entidade privada (unha especie de academia) fundada coa intención de promover os estudos sobre a estrutura, afinidades e historia das linguas. Fundouse en 1842. A finais dos 50 (1857) varios membros da sociedade comezaron a manifestarse sobre as deficiencias dos dicionarios dispoñibles na época e en 1858 puxeron en marcha a iniciativa dun dicionario histórico que tivo como primeiro editor (maio de 1860) a Herbert Coleridge (un neto do poeta), desaparecido ó pouco tempo (abril do 1861) vítima da tuberculose (contraída nunha reunión da PhilSoc á que asistiu coa roupa mollada); tiña 31 anos; deixaba 100.000 fichas. Entrou outro novo editor, Frederick Furnivall; puxo en marcha un exército de lectores voluntarios (ata 800) que reuniron unha cantidade enorme de fichas, almacenadas ata 1879, a maior parte no domicilio particular de Furnivall; outras nos domicilios de subeditores que as tiñan para ordenar (cando trataron de recuperalas a letra $\mathrm{H}$ estaba en Florencia na casa dun diplomático que as levara aló para traballar nelas). Na época de Furnivall unha boa parte das fichas volvéronse inservibles porque o tempo e os ratos as gastaran; outras foran convertidas en lixo; e outras (as de PA) foran usadas para acender o lume. En 1876 a PhilSoc tomou a determinación de nomear un novo responsable do dicionario e involucrar na empresa unha editorial que explotaría os beneficios da edición. Propúxose a James Murray (1837-1915), que daquela tiña 39 anos, para editor (que traballaría a tempo parcial) e á Clarendon Press da Universidade de Oxford como empresa editora. O dicionario levaría dez anos de traballo e tería 4 volumes de 2.600 páxinas cada un. Despois de moitas negociacións os delegados da Oxford University Press asinaron o contrato con Murray. O editor redactou un novo chamamento con instrucións precisas de cómo facer unha nova colleita de citas, publicouno na prensa e distribuíno por librerías e bibliotecas. Ó pouco tempo comezaron a chegar ó seu scriptorium unha media de 1.000 fichas por día; en 1882 tiña 3 millóns e medio, en cuxa ordenación colaborou moita xente, entre eles varios membros da súa propia familia, que era moi numerosa e traballadora. En 1884 apareceu o primeiro fascículo. No 1888 un dos 
asistentes de Murray, Henry Bradley (1845-1923), foi promovido a coeditor (traballou ata o 96 en Londres e despois en Oxford). A memoria foi inxusta con Bradley, porque nolo presenta coma unha sombra de Murray, pero o seu traballo no OED foi case tan importante coma o do fundador. Ningún dos dous editores chegou a ver a obra acabada; Murray morreu en 1915 despois de ter redactado as letras A-D, H-K, O-P e T; Bradley morreu en 1923, despois de facer as letras E-G, L-M, S-Sh, St e W-We. Antes diso xa se incorporaran outros dous editores, William Craigie (1867-1957) en 1901 (letras N, Q-R, Si-Sq, U-V e Wo-Wy), e Charles T. Onions (1873-1965), en 1914 (letras Su-Sz, Wh-Wo e X-Z). Ou sexa, que despois dun determinado momento funcionaban catro equipos redactores para acelerar o remate da obra, que cada vez se botaba máis fóra dos prazos previstos (13 anos, que en realidade foron 52), pois só o 19 de abril de 1928 saíu o último fascículo (desde Wise ata o final de W). Agora a obra era encadernable (e en realidade a partir de aí vendeuse encadernada); eran 10 volumes. No ano 1933 apareceu un suplemento e o dicionario foi reimpreso en 12 volumes. No 1957 nomeouse un novo editor, o neozelandés Robert Burchfield (1923-2004), que actualizou a obra con materiais especialmente do XX de todos os países angloparlantes. Cando foi nomeado pola editorial en 1957, encargóuselle un Suplemento que se prevía levaría sete anos e tería 1.275 páxinas; levoulle 29 anos, e foron 4 volumes cun total de 6.000 páxinas. Apareceron entre 1972 e 1986; daquela, nese ano o OED estaba en 16 volumes. A editorial tomou despois a determinación de integrar todos os engadidos nunha edición que apareceu en 1989 (20 volumes, 22.000 páxinas), así como de preparar unha edición electrónica que circula desde 1992 (hoxe están na versión 3.1).

Tamén no NED (OED) hai que destacar traballo dos voluntarios, algúns deles fornecedores de paquetes de ata 165.000 fichas $^{2}$ dos 5 millóns que chegou a ter o ficheiro de Murray; a xente comprendeu que se trataba dun "dictionary worthy of the great English nation" (The Times 1869) e prestouse a axudar desinteresadamente. Tal era o orgullo dos voluntarios que algún chegou mesmo a deixar mandas de 1.000 libras no seu testamento para Murray. O mesmo volveu manifestarse en resposta ó chamamento de Burchfield no ano 1957. Pero por encima de todo iso estivo o talento e a preparación de Murray así como a súa capacidade monstruosa de traballo. E todo sen apoio da coroa. Na célebre conferencia de Murray The evolution of English lexicography hai unha velada queixa disto cando se refire a como o goberno francés publica (1852) o Esclarcisemet de Palsgrave:

2. Thomas Austin Jr. levaba esa cifra en 1888. Cfr. Gilliver (2000). 
Entre os cambios de goberno que viu Francia nos últimos tempos, nunca esqueceu que a historia da lingua francesa [...] é parte da historia de Francia; o goberno británico non chegou aínda hoxe á situación de percibir isto (Murray 1900).

Hai moitos lugares onde se conta a historia desta obra monumental, "the greatest enterprise of its kind in history" (Winchester 2003: XV, que cita as palabras do Primeiro Ministro Baldwin o 6 de xuño de 1928 cando se fixo a festa de presentación do último volume); "the finest dictionary ever made in any language" (Winchester 2003: XXIII). Entre as moitas obras que falan do OED hai unha dunha neta do propio Murray (Murray 1977) e outra editada por Lynda Mugglestone (2000b) ${ }^{3}$.

As cualidades do OED mellor que dicilas é velas na realidade. É un dicionario rigorosamente histórico: cada palabra figura coas súas diferentes formas históricas e modernas e os significados están organizados tamén historicamente conforme van aparecendo e desaparecendo; en palabras de significación complexa os sentidos agrúpanse por bloques de afinidades, cada un deles dividido en subapartados xerárquicos necesarios, cos seus significados ben exemplificados e datados. Ademais das formas e os significados, cada palabra leva, se son necesarias, outras indicacións (área, rexistro, etc.). Neste sentido foi e segue a ser modelo para outras empresas e isto é algo que procede do modo en que foi concibido desde o principio. Por iso, ó contrario do que ocorreu co dicionario dos Grimm, que na redacción actual xa non ten practicamente nada do texto redactado polos dous irmáns, no OED todo o que redactaron Murray e os coeditores que traballaron con el e o sucederon segue a ter validez total; nas novas edicións non hai nada que quitar do que escribiron eles; engádense, iso si, novas palabras ou novos usos rexistrados ó longo do século XX ou póñense marcas de obsoletas a palabras ou acepcións que hoxe xa non circulan. Iso é o que xustifica que aumente de tamaño; de feito a primeira edición tiña 252.259 entradas, na segunda engadíronse 41.752 entradas novas e integrouse nova información en 27.620 (cfr. a introdución da versión electrónica). No OED resultan non só admirables todas esas cousas que dixemos tanto de Murray como dos outros colaboradores e do pobo británico en xeral, senón tamén o atrevemento dunha empresa privada (a OUP), que, non sen tensións entre os conselleiros da editorial (profesores da Universidade de Oxford), que non paraban de reclamar o remate da obra, e os traballadores do $O E D$, que non paraban de ampliar o produto e adiar o seu

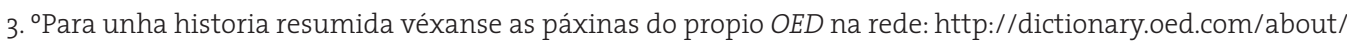
history.html e http://oed.hertford.ox.ac.uk/main/ 
remate, soubo apostar por unha obra que acabou converténdose nun dos principais monumentos da cultura mundial do século XX.

Á zaga do DWB e do OED foron construíndose monumentos semellantes para outras linguas europeas ó longo do século XX (algunhas iniciadas tamén no XIX), en especial en países de linguas xermánicas, promovidos polas academias e financiados con diñeiro dos orzamentos do estado. Todos teñen os trazos esenciais do OED ou, se non foron concibidos con eles, acabaron adoptándoos.

O primeiro e o Woordenboek der Nederlandsche Taal (WNT), que comezou a organizarse algo antes có OED. As súas orixes remóntanse a 1850, cando se constituíu unha comisión liderada por Matthias de Vries (18201892); no ano seguinte nun congreso presentou un plan para un dicionario holandés e nomeouse un comité editorial formado polo propio de Vries e por Lammert te Winkel (1806-1863); por certo, os dous son os reformadores da ortografía holandesa actual. O dicionario desde o principio foi froito dunha colaboración entre holandeses e flamengos; en 1852 comezou a recolleita de materiais. A empresa (como a alemá) comezou pola iniciativa privada dos promotores e dunha editorial; deu problemas ata que o goberno holandés se fixo cargo dos gastos despois da primeira guerra mundial. O plan do dicionario mudou a partir da década de 1880; en principio prevíase que fose un dicionario do holandés do século XIX; polo tanto non ía ser histórico (o modelo estaba máis no Littré ca nos Grimm); pero a medida que colleitaban documentación, por consello dos Grimm, foron recuando ata o 1500 e tomando tamén en consideración documentación non literaria (artes e ciencias), ademais dos dialectos, transformando así a idea do dicionario ó estilo do OED. O primeiro fascículo apareceu en $1883^{4}$ e o último en 1998 (684 fascículos, 40 volumes); o INL (Institut voor Nederlanse Lexikologie) está actualizando constantemente a obra, agora con procedementos novos. Pasaron cinco xeracións de lexicógrafos desde que se comezou (http://www.inl.nl/index.php?option=com_content\&task=v iew\&id=222\&Itemid=244).

Pero a lingua holandesa non dispón só do WNT, pois un dialecto moi importante dela e falado en Sudáfrica, o afrikaans, ten tamén o seu Woordeboek van die Afrikaanse Taal (WAT). O afrikaans é unha variante do holandés levado primeiro por colonias de protestantes no século XVII e despois por comerciantes e traficantes; hoxe é unha variante estandarizada como lingua á parte, falada como primeira ou segunda lingua por máis de 16 millóns (o holandés fálano uns 22 millóns). O WAT iniciouse 
nos anos 1920, comezouse a publicar en 1951 (volume I) e está en curso de publicación aínda; no 2005 apareceu o volume XII (letras P-Q). Naturalmente agora traballan con ferramentas electrónicas; pódese mercar en $\mathrm{CD}$ ata a letra $\mathrm{O}$; pero aínda non está dispoñible a súa consulta en rede (http://www.wat.co.za/).

Outro dicionario histórico xermánico é o Svenska Akademiens ordbok $(S A O B)$ tamén coñecido como Ordbok över svenska språket utgiven av Svenska Akademien. Aínda que está nos estatutos da Academia, de 1786, formar un dicionario similar ó doutras academias (particularmente ó da francesa), a obra do dicionario da Academia Sueca só se puxo en marcha cen anos despois (1883); Theodor Wisén (1835-1892) foi o responsable de facelo e naturalmente desde aquela tivo varias xeracións de redactores. Contén o vocabulario sueco desde 1521 á actualidade. Entre 1898 e 2007 fixeron os fascículos que van ata o número 363; a última entrega contén as letras TILL-TOJS (marzo de 2007); prevese que remate para o 2017; pode verse información na rede (http://www.saob.se/) e consultarse en liña (http://g3.spraakdata.gu.se/saob/). Ten unha novidade con respecto ó Grimm, ó OED e ó WNT en que rexistra nomes propios e topónimos (cousa que tamén veremos noutros dicionarios históricos ós que nos referiremos despois).

En Dinamarca hai o Ordbog over det danske sprog (ODS), iniciado en 1901 por Verner Dahlerup (1859-1938). Comezou sendo unha empresa privada, de Dahlerup e da súa muller, e acabou pasando a Sociedade Danesa de Lingua e Literatura. Comprende o vocabulario danés desde 1700 a 1955. Ten 28 volumes e publicouse entre 1919 a 1956; no 1992 actualizouse cun Supplement. Agora está dispoñible na Internet (http://ordnet.dk/ods/bogvaerket_html).

O máis asombroso de Dinamarca é que ademais teñen un Jysk Ordbog $(J O B)$, con datos dos dialectos iutos (jutish ou jutlandic), iniciado por Peter Skautrup (1896-1982), coñecido tamén por unha monumental historia da lingua danesa en catro volumes + índice (Skautrup 1944-1968); está na Universidade de Aarhus e é accesible en rede (http://www.jyskordbog.dk/ hjemmesider/index.html). Descoñezo o tamaño (non ten formato papel) pero debe ser grande porque en 1980 o ficheiro tiña 3.000.000 de fichas.

En Noruega o Norsk Ordbok (NOB) (do nynorsk) (http://no2014.uio. no/) comezou a compilarse en 1930. En 1950 apareceu o primeiro volume; no 2007 apareceu o vol VI ( $k$-kåvå); está previsto que acabe en 2014 con 12 volumes (de 800 páxinas). Abarca o noruegués desde 1650 ata a actualidade. Comezou sendo un corpus de fichas manuais; hoxe ten ademais un corpus informatizado de 25,6 millóns de rexistros. Neste momento, ade- 
mais da directora do proxecto (e outros responsables), ten seis grupos de redactores de catro persoas cada un na Universidade de Oslo5.

Para as linguas románicas hai poucos produtos equiparables o OED; os dicionarios de autoridades (tipo Battaglia) só son históricos en parte porque o material sobre o que traballan é exclusivamente literario.

Para o castelán houbo, como é sabido, dous intentos falidos. Un que partiu dunha iniciativa da Academia en 1914, deseguida desactivada, reiniciada nos anos 20 e que grazas en especial ó labor de académicos como García de Diego, Cotarelo e Casares logrou sacar en 1933 o primeiro volume (a letra A) e en 1935 o segundo (letra B e parte da C) (RAE 1933-1936). A guerra paralizou a obra e, máis grave aínda, un incendio queimou a Editorial Hernando, que almacenaba a edición case enteira. En realidade, o dicionario histórico de 1914 era histórico só no título, dado que na práctica era unha renovación do de Autoridades de 1726-1739, pero máis completo e actualizado. Despois da guerra volveuse a iniciar a obra do dicionario histórico. En 1946 creouse na Academia o Seminario de Lexicografía, que sería o encargado de levar adiante a obra do dicionario. En 1947 comezou de novo o traballo cun novo plan (desbotado o plan do 14, polas razóns ditas); o encargado de deseñalo era Casares e a nova iniciativa obrigaba a recompilar novos materiais porque os ficheiros da Academia (que almacenan fichas desde o Dicionario de Autoridades) contiñan un material tan anticuado e defectuoso (fichas baseadas en malas edicións e a maior parte das veces con mala localización), que fixo necesario comezar de novo. Fíxose un chamamento semellante ó de Murray pero apenas respondeu máis que un colaborador (o arcebispo galego Leopoldo Eijo Garay) ${ }^{6}$. Polo procedemento que fose, os ficheiros da Academia pasaron de 4 millóns de fichas en 1947 a 11 millóns en 1960. Neste ano apareceu o primeiro fascículo do novo dicionario histórico e en 1972 completouse o $1^{\circ}$ volume, que xa non puido ver Casares, que morera no 64; responsabilizáronse del despois,

5. Como se ve, as linguas nórdicas teñen todas unha aparición literaria tardía; algunhas teñen case como textos fundadores a tradución da Biblia, do XVI.

6. No seu informe de 1948 á RAE Casares insiste nesta posibilidade dado que "todos los grandes Diccionarios del siglo XX han tenido desde el primer momento la preocupación de imbuir en el ánimo de la opinión culta de sus respectivos países el convencimiento de que, tanto las entidades patrocinadoras de dichas obras -Academias, Sociedades, Congresos, etc.- como cuantas personas se ponían abnegadamente a su servicio, se arriesgaban en una empresa patriótica, cuya gloria, en caso de buen éxito, rebasaría ampliamente el círculo de los iniciadores y ejecutores, para extenderse a la nación entera, elevando el prestigio de la respectiva cultura ante el mundo civilizado. Artículos de prensa, folletos, circulares, conferencias, todo pareció poco para crear un clima favorable a la gestación de esos diccionarios, que habían de ofrecer a propios y extraños la riqueza, la vitalidad y la gracia de la lengua materna como el reflejo más auténtico y luminoso del verdadero genio nacional". 
sucesivamente, García de Diego, Lapesa e Seco. Dos seguintes volumes só hai outro completo, o volume II (fasc. 11-20, publicados entre 1974 e 1992); do volume III saíron dous fascículos en 1994 e 1996, e do IV só un fascículo en 1996. Aquí interrompeuse por varias razóns, entre elas a falta de financiamento e a imposibilidade de establecer un equipo estable de redactores. Hoxe aquel proxecto pode darse por definitivamente paralizado. Na actualidade está prevista unha nova acometida dunha empresa que probablemente se vai chamar Nuevo diccionario histórico de la lengua española (NDHLE), que nace con pretensións semellantes ó anterior de Casares, García de Diego e Lapesa, só que agora parece que hai garantido un financiamento estable por parte da administración, conforme se desprende das noticias de prensa segundo as cales o MEC financia a RAE con 1,2 millóns de euros ó ano, ó que se unirán as achegas de institucións e empresas (El País 25.01.2006). Sería bo que por fin unha lingua tan importante e defendida cunha política lingüistica máis retórica que eficaz contase cun instrumento así. Os córpora de que dispón o castelán (non só na Real Academia) proporcionan un material bruto moi abundante; con todo, os diferentes corpus parece que non satisfán os requisitos do editor (J. A. Pascual), e estase no seo da Academia a preparar un corpus electrónico ad hoc diferente do CORDE e do CREA. Mentres o dicionario histórico non aparece, o etimolóxico de Corominas cobre parcialmente a lagoa co esforzo persoal dunha soa persoa e con resultados forzosamente moi parciais (aínda así, un dicionario etimolóxico non é un dicionario histórico, por moito que en boa medida o presupoña).

Tampouco Francia ten un dicionario histórico semellante ó OED (ou o DHLE do castelán, abortado). Pero ten varios produtos que o suplen case totalmente. Un deles é o Trésor de la Langue Française (TLF), iniciado en 1957 pola sección de Nancy do CNRS baixo a dirección de Paul Imbs (despois substituído por Quemada e R. Martin). Foi o primeiro dicionario moderno que se compilou electronicamente (usando fichas perforadas). É un dicionario grande, con 23.000 páxinas, hoxe consultable gratuitamente en rede (http://atilf.atilf.fr/tlf.htm), e dispoñible en papel e CD. Non é un verdadeiro dicionario histórico, posto que só toma en consideración o francés escrito dos séculos XIX e XX; non comprende, daquela, ningunha palabra extinguida literariamente antes de 1800 nin palabras do francés dialectal antigo ou moderno; tampouco é histórico na medida en que prescinde da organización histórica das acepcións; en realidade foi concibido como unha parte dun dicionario histórico que terá (se se fan) cinco cortes sincrónicos da historia da lingua francesa. Aínda así, sendo só da última etapa, as palabras que perviven no francés literario moderno teñen ó final 
de cada artigo unha xenerosa nota etimolóxica e histórica que dan conta da evolución formal e semántica da palabra desde as orixes ata o francés actual (cfr. por exemplo a voz parole).

Tampouco é un dicionario histórico canónico (a pesar do seu nome), polos mesmas razóns de que os lemas son unicamente os do francés estándar de hoxe, o Dictionnaire Historique da la Langue Française (DHLF) da editorial Robert, dirixido por A. Rey; dá a etimoloxía, a cronoloxía das formas e as acepcións principais e secuencia en que se xeraron; pero non ten exemplos; tampouco ten entradas dialectais nin arcaicas. Os dous, o TLF e o DHLF, dan case un dicionario histórico; o que falta hai que suplilo con dicionarios etimolóxicos coma o de Wartburg (FEW) ou o de Baldinger (1974-2006) (para o occitano), ambos inacabados, que teñen abundante información histórica e dialectal. Para o francés hai, daquela, un substituto do dicionario histórico, aínda que sexa repartido en tres ou catro dicionarios diferentes; por iso, seguramente nunca se formulou a idea de fabricar para o francés nada semellante ó OED.

Para Italia xa vimos que o Battaglia (GDLI) era case un dicionario histórico; de feito é moito máis ca un dicionario da lingua toscana de todos os tempos, porque entran non só toscanismos (con tal de que tivesen uso literario). Tanto Salvatore Bataglia (1904-1971) como Giorgio Bàrberi Squarotti (1929-), que o dirixiron, teñen un mérito inmenso, como tamén a empresa privada que o financiou, a UTET (Unione Tipografico-Editrice Torinese), que xa antes financiara o Tommaseo / Bellini (1865-1879). Por parte da Crusca hai, desde hai moito, proxectado un Vocabolario storico della lingua italiana, nunca realizado. Parte deste dicionario da Accademia, o que se refire á lingua das orixes ata 1375, está sendo realizado agora polo CNR, o Tesoro della lingua italiana delle origini (TLIO), que concorre con outro Glossario degli antichi volgari italiani (GAVI) que se publica pola universidade de Helsinki desde 1983, ó coidado de Giorgio Colussi, e leva ata o momento 20 volumes aparecidos. Os dicionarios etimolóxicos, que para o italiano hai varios, e un especialmente monumental, o LEI de Pfister (agora na letra B), axudan a compoñer o perfil histórico do léxico italiano mentres non haxa o prometido da Crusca. En calquera caso, non hai nada en Italia (igual que en Francia) nunha obra única equiparable ó OED.

E isto é o que hai para as grandes linguas nacionais europeas occidentais (supoño que para o polaco, o ruso, o ucraíno, o checo ou o húngaro hai empresas históricas similares, pero bótanos máis lonxe e pertence a linguas menos accesibles). Pero quedan na Europa occidental linguas pequenas e mesmo dialectos sen vocación de lingua que teñen moito que ensinarnos en materia de lexicografía histórica. Entre estas linguas está 
en primeiro lugar a catalá, que dispón dun Diccionari català-valencià-balear (DCVB) completo desde o ano 1962. A historia do dicionario catalán é exemplar para nós (e para moitos outros) e foi contada en numerosos lugares, de maneira moi pormenorizada nas memorias de Moll, que son unha memoria do dicionario mesmo na medida en que o $D C V B$ foi a obra da súa vida. O dicionario catalán iniciouno, sen embargo, un manacorí, o cóengo Antoni $M^{a}$ Alcover ${ }^{7}$ (1862-1932). En 1901 lanzou Alcover (como a PhilSoc de Londres e máis tarde Murray e aínda despois Burchfield) unha Lletra de Convit a tots els amics de la llengua catalana para que colaborasen na súa recolleita; nos cinco primeiros anos apuntáronse 1.643 voluntarios (con rendementos moi dispares) que enviaron máis de 700.000 cédulas; para manter contacto cos entusiastas do seu convite iniciou o Bolletí del Diccionari de la Llengua Catalana (1901-1926), folleto mensual que funcionaba de crónica do dicionario, entre outras cousas. Pero Alcover era só un "aficionado", e ademais vía que el só ía ser incapaz de levar adiante a obra. En 1921 tomou como colaborador un mociño de 17 anos que se chamaba Francesc de Borja Moll (1903-1991), para quen procurou unha formación filolóxica sólida con mestres como Schädel e Meyer-Lübke. A historia do Diccionari foi moi azarosa. Unha das razóns foi o carácter "belicós", "rústic i agressiu" (en palabras de Moll) do "calonge", que entrou pronto en disputa co Institut d'Estudis Catalans, institución que patrocinaba o Diccionari, entre outras razóns porque Alcover quería facer un dicionario que fose á vez dialectal, histórico e literario e a maioría dos membros do IEC propoñían naquel momento a elaboración de tres dicionarios (un do catalán antigo, outro do moderno e outro dialectal); co IEC (e con Fabra persoalmente) mantivo discrepancias ortográficas. Isto motivou que Alcover rompese co IEC e que marchase en 1917 coa "calaixera" do dicionario para Mallorca, onde se ía facer de costas para o IEC; isto motivou tamén o cambio de nome da obra, que pasou a chamarse desde aquela Diccionari català-valencià-balear e non Diccionari de la llengua catalana. Outra dificultade foi a falta de medios, pois á parte dunha axuda que conseguiu Alcover do rei Afonso XIII, que durou só seis anos, e dalgunha institución, o diccionari estivo sempre ó borde da bancarrota. Aínda así, en xaneiro de 1924 comezou a redacción, con dous redactores (Alcover e Moll) e outros dous colaboradores fugaces; a finais do 1926 apareceu o primeiro fascículo; en 1930 estaba completo o primeiro volume. A recepción do dicionario foi pouco entusiasta (en especial no Principado, onde o catalanismo convertera a Alcover nunha especie de besta negra); isto repercutiu na falta 
de subscritores e de subvencións oficiais e motivou que Alcover comprometese a súa facenda e aínda a da familia; cando morreu en 1932 dun ataque de feridura (apoplexía) estaba completamente arruinado. En 1934, xa sen Alcover, completouse o volume segundo. A todas estas desgrazas hai que engadir a guerra civil; con ela o traballo do dicionario interrompeuse e Moll pasou a gañar a vida como impresor (na imprenta que o propio Alcover fundara para imprimir o dicionario) e como profesor de ensino medio. Moll continuou traballando só; desde 1943 a 1959 contou coa colaboración de Manuel Sanchis Guarner (1911-1981) e da súa filla Aina Moll; agora contaba coa subvención dun mecenas privado (o industrial barcelonés Enric Pérez i Capdevila) e cos fondos que recadaba das subscricións. En 1949 comezaron a saír de novo fascículos e grazas a unha campaña de márquetin moi ben organizada por simpatizantes do dicionario a obra puido concluírse sacando a razón de case un volume por ano (III, 1950; IV, 1951; V, 1953; VI, 1954; VII, 1955; VIII, 1957; IX, 1959; X, 1962). Nos anos seguintes reelaboráronse e reimprimíronse os dous primeiros volumes, e ademais prescindiuse neles da ortografía cismática de Alcover. O DCVB é unha obra extraordinaria tanto polo sacrificio con que foi levada a cabo como polo patriotismo dos seus iniciadores e redactores e mecenas, como polo contido mesmo, pois ten abundantísima documentación histórica, literaria e dialectal e está executada coa mellor técnica lexicográfica aínda que non siga rixidamente os principios históricos do OED; é en parte debedor do GPSR (do que imos falar), entre outras cousas, porque dá cabida a bastantes apelidos, que localiza nas áreas en que son orixinarios e abundan; en cambio, ó contrario do GPSR, non rexistra topónimos. En 1962, e aínda hoxe, ningunha lingua hispánica (incluídas as multimillonarias portuguesa e castelá) tiñan nada equiparable, nin de lonxe. Pode consultarse en rede (http://dcvb.iecat.net/).

Todas as linguas que vimos ata agora son linguas de estado. Algunhas delas teñen detrás un potencial demográfico enorme e todas elas teñen unha tradición literaria longa, de ata 12 séculos algunha. O caso do catalán é particular porque ten grande tradición literaria pero non ten estado, aínda que no Principado se ten manifestado suficiente vontade nacional como para telo. Pero dentro da tradición lexicográfica europea, próxima a nós, hai tamén casos de variedades rexionais sen vocación de lingua para as que se desenvolveron empresas lexicográficas de grande envergadura. Os dicionarios resultantes teñen moito parecido cos dicionarios históricos mencionados, coa diferenza de que nestes casos os testemuños literarios son moito máis escasos e os dialectais máis abundantes. Están neste apartado os catro grandes dicionarios realizados en Suíza para as catro variedades xermá- 
nica e románicas alí falados. Están todos auspiciados desde 1996 pola Academia Suíza de Ciencias Humanas e Sociais e na súa páxina poden verse as referencias (http://www.sagw.ch/frz/index.asp?pag=Kommissionen). Vou mencionalos porque son obras exemplares, honra do país que apoiou a súa elaboración e dos filólogos que os iniciaron e continuaron.

Comezo polo Glossaire des patois de la Suisse romande (GPSR), dicionario dialectal que rexistra todas as palabras patesas que estiveron ou están aínda en uso no interior dos límites da Suíza romanda; acolle tamén as palabras e usos particulares do francés suízo. Por riba o Glossaire reserva un lugar importante ós nomes de persoa e ós nomes de lugar romandos. Foi ideado arredor de 1890 por Louis Gauchat (1866-1942), unha especie de Leite de Vasconcelos suízo, mesmo celibatario como aquel. Gauchat soubo convencer as autoridades federais e cantonais para amparar economicamente a obra de recolleita dos patois franco-provenzais de Suíza; en 1899 a Comisión Administrativa (composta polos xefes de Instrución Pública dos cantóns francófonos) deu luz verde a un proxecto que aínda dura 107 anos despois; os tres primeiros redactores (que imprimiron carácter á obra) foron Gauchat, Jules Jeanjaquet (1866-1950) e Ernst Tappolet (1870-1939). As oficinas do GPSR estiveron primeiro en Berna, despois en Lausana (1956) e agora están en Neuchâtel (1972). Os tres redactores fixeron un número considerable de enquisas, algunhas delas en profundidade, ós mellores informantes; en trece anos xuntaron máis dun millón de fichas. Baleiraron tamén unha rica colleita de textos (moitos deles manuscritos cedidos polos herdeiros dos autores a arquivos e museos). E incorporaron o Ficheiro Muret (Ernest Muret) con máis de 150.000 topónimos. Naturalmente o GPSR non é un dicionario histórico ó estilo dos descritos, porque non se refire a unha lingua viva, senón a unha lingua de museo, recuperable só a través de textos e dos poucos falantes rurais sobreviventes a principios do XX; pero explica con pormenor semellante ós dicionarios históricos toda a riqueza de variantes formais e de contido dos diferentes lemas. Comezou a publicarse en $1924 \mathrm{e}$ na actualidade estanse redactando as letras F e $G^{8}$. Aínda que no seu sitio non dixemos de maneira clara se o DCVB ten un modelo, o máis próximo é o GPSR, e non os dicionarios históricos tipo OED ou DHLE. Na Internet hai información do Glossaire e ligazóns a outros sitios (http://www.gpsr.ch/)'.

8. O último fascículo aparecido é o 112 (2006), pertencente ao tomo VII, que abrangue o fragmento fragnatfripeur.

9. Para coñecer o estado de publicación da obra, véxase o catálogo da editorial Droz (https://www.droz.org). 
Unha historia moi parecida é a do Wörterbuch der schweizerdeutschen Sprache (WbsdS), ou Schweizerisches Idiotikon. Ainda que a idea dun dicionario suizo-alemán é máis antiga, os traballos para o WbsdS empezaron en 1862; en 1881 apareceu o primeiro fascículo. O WbsdS recolle o alemán de Suíza, tanto o escrito desde a Alta Idade Media como o dos dialectos modernos (tal como se recolleron principalmente na segunda metade do século XIX); sáese algo do territorio suízo na medida en que recolle tamén as penetracións alemánicas do norte de Italia (os Walser ou valeses que penetraron no XII e no XIV, e hoxe están esmorecentes). Aparece por fascículos encadernables; na actualidade está case completo o volume 16 (final de W); estará rematado para o 2020. Terá uns 130.000 rexistros ó remate. Igual que o GPSR ten un equipo de redactores e financiamento asegurado. Hai información na rede (http://www.sagw.ch/dt/kommissionen/woerterbuch/index.html).

É historia semellante, pero máis heroica aínda, a do dicionario romanche, o Dicziunari Rumantsch Grischun ( $D R G)$, tendo en conta que a poboación retorromanche é desde hai 150 anos só de 48.000 falantes. O dicionario foi ideado en 1904 pola Sociedade Retorromanche de Chur, liderada por Robert von Planta (1864-1937), coa intención de recoller todo o patrimonio lingüístico dos romanches. O material procede de 130 enquisas realizadas polo propio Planta (que elaborara un cuestionario de 10.000 palabras xa en 1898), Florian Melcher (?-1913), que foi o primeiro redactor, e Chasper Pult (1869-1939); e do baleirado de textos posteriores a 1560 (que é cando comeza a haber materiais escritos en romanche). Cada artigo é unha monografía da palabra (con formas, significado, frases, realidade material ou espiritual á que se refire, etimoloxía, etc.). En 1939 aparece o primeiro fascículo, que tivo como editor responsable a Andrea Schorta (1905-1990); a última entrega aparecida é o fascículo dobre 162/163 (manmancar) correspondente ó volume 12. Non dan un prazo para o remate, pero pode ser tamén pola década dos 2020. Igual cós outros dicionarios helvéticos, desde 1996 é a Academia Suíza de Ciencias Humanas a que prové os fondos para que a obra do $D R G$ se leve a cabo. Tamén neste caso existe información na rede (http://www.drg.ch/index.html e http:// www.drg.ch/downloads/100onnsDRG.pdf).

E o último grande dicionario suízo é o que corresponde á zona italiana, o Vocabolario dei dialetti della Svizzera italiana (VSI), comezado a publicar en 1952. O Vocabolario presenta os diversos matices de pronuncia e de significado, exemplificación de proverbios, modos de dicir e filastròcche, unha mole de documentación sobre as crenzas, as prácticas supersticiosas, a farmacopea e a medicina popular, os usos e as tradicións de todo 
o territorio da Suíza italiana. Unha voz é unha monografía da palabra e da cousa. Publícase por fascículos (dous por ano). En novembro de 2007 apareceu o fascículo 70, de cóbia a ccolár. A redacción hoxe diríxea Franco Lurà e traballan con el outras sete persoas. Existe información na rede (http://www.ti.ch/decs/dc/cde/temi/vocabolario.asp).

Menciono estes últimos catro glosarios, exemplares tanto polo seu valor científico como polo patriotismo con que foron acometidos e realizados.

\section{TRAZOS DUN DICIONARIO HISTÓRICO GALEGO}

A historia da nosa lingua explica unha parte do atraso da nosa lexicografía, que foi contada varias veces por nós mesmos e por outros. Como é ben sabido, aínda que houbo un rexurdimento vizoso, a forza da elite concienciada non foi capaz de contrarrestar a falta de estima e mesmo a hostilidade pola lingua do país. Nun clima así era pouco imaxinable unha empresa lexicografica de envergadura. A outra parte da historia dos dicionarios, como a da lingüística galega en xeral, explícase polo atraso da filoloxía no noso país; certamente, se o nivel cultural da Galicia de mediados do XIX, e aínda de mediados do XX, fose equiparable ó de Suíza (aínda no peor dos casos: que só se considerase o galego un dialecto sen vocación emancipadora) sería inconcibible que non aparecese algún von Planta ou algún Gauchat que, co apoio dos organismos oficiais competentes, intentase un Dizionar ou Glossaire. Isto non sucedeu. Pero aínda así, non se entenda que por atrasada lles damos pouco mérito ás pequenas empresas lexicográficas privadas que foron aparecendo; ó contrario, téñeno e moi grande, tanto polo valor das obras, como polo patriotismo dos autores. Pero non podemos estar cegos á realidade: a lingüística que se facía por Europa adiante a mediados do XIX só chegou a Galicia no último terzo do século XX; antes de 1963 contábanse cos dedos dunha man os galegos que sentiran falar de Saussure ou de Meillet, e con poucos máis dedos os que viran un Meyer-Lübke; o primeiro dicionario de Oxford que chegou á nosa Facultade debe ser dos anos setenta, nunha edición fotográfica. Así é que un intento de dicionario "histórico" (ou mellor pancrónico) como o da Academia pouco despois da súa fundación hai cen anos era unha empresa prematura. Non é mester que fagamos aquí unha análise desa obra abortada.

Pero hoxe quizais son chegados os tempos. En primeiro lugar porque a lingua mesma non está no estado de carencia en que estaba hai cento e pico de anos, cando Pintos ou Valladares facían os seus vocabularios. É probable 
que nalgúns aspectos esteamos peor hoxe; de feito, moitas voces vencelladas á cultura tradicional seguramente desapareceron antes de que fosen sometidas a unha recolleita tan sistemática como a que se fixo para os dialectos suízos; quen faga traballo dialectal hoxe sabe da dificultade que supón atopar un informante bo; con todo, aínda se chegou a tempo, polos anos setenta e oitenta, para facer un atlas e bastantes monografías que salvaron o esencial do naufraxio. En cambio, por outro lado, as cousas melloraron moito porque a lingua, especialmente despois do movemento das Irmandades, quedou rexistrada en escritos de temática cada vez máis variada. Dito doutra maneira: Valladares, aínda que quixese, apenas podía documentar palabras en textos; de feito a maior parte das ilustracións literarias que inclúe no seu dicionario son cantigas populares ou refráns e mesmo poemas propios; aínda don Eladio Rodríguez (1958-1961), polos anos 20, cando facía o seu Diccionario, andaba escaso de fontes. Hoxe para o galego moderno hai moitas fontes porque hai centenares de millóns de palabras fixadas en documentos escritos, de maneira que se perdemos algo por unha parte compensámolo con creces pola outra. É verdade que estas fontes están lexicograficamente algo descompensadas, porque hai campos nos que o galego ten pouco cultivo, pero aínda así hai moito material léxico que baleirar ou xa baleirado. Para o galego antigo tamén as cousas están nun bo momento, pois canto texto literario está descuberto conta con edicións boas; o mesmo sucede con moita documentación notarial, que aínda sendo algo monótona como material lexicográfico, é moi abondosa e está sendo transcrita e nalgúns casos provista de glosarios. E ademais hai moita xente no país que leu a Saussure e aínda a Coseriu. Por esta razón dicimos que o momento de comezar un dicionario histórico é propicio. E quizais son chegados os tempos tamén porque o galego adquiriu un grao de institucionalización considerable: é a lingua principal da administración autonómica e local; acabou tendo (mesmo para moitos que non o practican) un valor simbólico. Por ser lingua oficial require instrumentos que faciliten o seu acceso ós usuarios; e por ser simbólica necesita instrumentos que a canonicen, e entre eles están as gramáticas e os dicionarios, e entre estes un histórico. Unha lingua con estes instrumentos fai que os propios falantes se sintan orgullosos e que os de fóra nos respecten. De aí que a fabricación dun dicionario destas características sexa considerado en todos os sitios onde se acometeu un monumento á memoria cultural do pobo; por iso se implica nel o pobo mesmo (ou polo menos as súas elites máis sensibles) e as autoridades. As obras deste tipo, alí onde se acometeron, xustifícanse polas deficiencias das anteriores ${ }^{10}$. Pero as

10. On some Deficiencies in our English Dictionaries foi o manifesto que leu Richard Trench ante a PhilSoc o 5 de novembro de 1857 e disparou a obra do OED. 
deficiencias hai que miralas con perspectiva histórica, pois cada dicionario non é máis que o elo dunha cadea onde cada dicionario é unha peza necesaria para o que vén despois; o mesmo Murray matizou máis tarde as palabras de Trench recoñecendo que, sen unha cadea de dicionarios que empeza no XVII e vai desde Caudrey, Johnson, Bailey, Cocker, Webster e moitos outros, o OED sería inexplicable. E o mesmo acontecerá co galego se algún día se fai. Naturalmente, supoñendo que este dicionario se fixese, non suporía a desaparición dos outros dicionarios, porque cada destinatario necesita un tipo diferente de dicionario. O histórico é, dixemos, para especialistas e para xente cun nivel de curiosidade lingüistica moi especial; e por outra parte, podería ser a base doutros dicionarios. Na lingua inglesa o OED non anulou outras actividades lexicográficas, senón ó contrario.

Vexamos logo que entraría nese dicionario e como se mostraría a información. O que digamos non vai ter moita orixinalidade porque non se trata máis que de aplicar ó noso o que xa foi feito para outras linguas, conforme foi explicado nas introducións dos dicionarios, en informes previos presentados ás institucións que os promovían, ou en guías posteriores. Para moverse ben polo OED e entender ben o que ten dentro é moi útil ler a guía que escribiu Donna Lee Berg (1993) e mesmo o libro citado de Winchester (2003). En castelán hai informes de Julio Casares desde os anos 40, recollidos logo en libro (Casares 1950), que son de lectura moi proveitosa. Máis recentemente, José Antonio Pascual é coautor dun texto que en certa maneira adianta aspectos do que vai ser o NDHLE da RAE (Pascual / García 2007). Hai con todo que advertir que, como se trata dunha materia moi específica, a lexicografía histórica non adoita ser tratada nos manuais de lexicografía a non ser de maneira tanxencial. Daquela, o que digamos a seguir non é un blueprint ou manual do redactor do $D H G$, senón unha aproximación ó que esperamos que un lector poida atopar nel.

1. No noso caso, o primeiro que hai que dilucidar é cal é a profundidade (historical coverage) do corpus, ou sexa, ata onde recuamos na documentación, pois hai dúas posibilidades. Ou ben comezar a nosa historia en 1612, que é a data do primeiro texto galego coñecido despois da desaparición do galego como lingua da administración (os últimos documentos notariais son de 1530 ou por aí), ou ben remontarnos ás primeiras orixes. Ambas as opcións son defendibles; a primeira viría a coincidir coa postura adoptada polos dicionarios das linguas nórdicas, que comezan a súa documentación no século XVI, porque máis atrás desa época hai moi pouca documentación; no noso caso tería xustificación comezar no XVII, porque é cando o galego tomou a opción de seguir un camiño solitario 
despois dunha etapa común co portugués, despois varios séculos durante os cales a documentación escrita é moi escasa. En certa maneira esta solución resolvería moitas dificultades, entre elas a do volume e a do tempo, e por outra parte deixaría a etapa medieval para unha empresa diferente, que se podería facer a través dunha cooperación transfronteiriza, pois interesa tamén ó país veciño (ou a Galicia e a todos os países onde se fale portugués). Mesmo pensando na estratexia da fabricación do dicionario, podería facilitar as cousas afondar só ata o XVII dado que, ó termos unha lagoa de varios séculos sen documentación, a necesidade de aterse ó rigor de trazar historicamente a xenealoxía das diferentes acepcións de cada palabra patrimonial obviaría non poucos apuros insuperables; ter rota a cadea temporal obrigará a organizar as acepcións de maneira menos canónica (se cadra ó estilo do DCVB); pero isto de momento é unha conxectura que non se poderá comprobar ata que se fagan ensaios con palabras reais. De optarmos por facelo só do galego moderno, este dicionario sería equiparable (proporcións gardadas) ó TLF, que o é do francés dos dous últimos séculos; os séculos anteriores completaríanse con outros dicionarios (xa Sarmiento o quería facer así).

Pero aínda tendo en conta as vantaxes que suporía non ir máis aló do XVII, cremos que se debe tomar a historia do galego na súa integridade porque a decadencia (como en Inglaterra a etapa normanda) non representou a aparición dunha lingua nova senón unha lagoa que desembocou na rehabilitación literaria dunha lingua que, a nivel popular, mantivera sempre unha continuidade que só foi perturbada polas interferencias do bilingüismo e da diglosia. Lingüisticamente é, pois, máis defendible a postura da continuidade, porque nos dicionarios históricos está gardada non só a lingua senón en certa maneira tamén a historia cultural dun país, e no noso hai unha continuidade lingüística e cultural por riba de calquera decadencia. Así é que o noso dicionario histórico debería documentar o seu vocabulario desde as mesmas orixes do idioma e ás veces mesmo máis alá, pois nos textos latinos tardíos hai xa moitas voces romanceadas ou mesmo sen romancear que son a primeira documentación dunha serie que pode chegar ata hoxe; outros dicionarios históricos, como o OED ou o TLIO, recuperan constantemente voces anglosaxonas ou "italianas" dos documentos latinos.

2. Tendo optado pola solución larga, vaiamos ó contido. Un dicionario destas características ten que basearse principalmente no uso, ou sexa, debe rexistrar só palabras que algunha vez tiveron uso real nun texto escrito; a escritura era ata hai pouco a única maneira de darlle soporte per- 
manente á palabra e, aínda que hoxe hai outros medios de soporte, o escrito segue a ser insubstituíble porque é o único controlable. Dito doutra maneira máis sinxela: cada palabra ten que estar rexistrada nun discurso e ir ilustrada cun fragmento del e non con exemplos fabricados. Iso quere dicir que hai que facer un baleirado dun número representativo de textos. É sabido que nunca pode haber unha colleita exhaustiva, pois, por moi representativa que sexa a mostra, sempre vai faltar algunha palabra ou algunha acepción (se cadra algunha de certa frecuencia) que está fóra das fontes manexadas; e por outra parte o vocabulario está cambiando case cada día, cousa que se nota máis polas palabras que aparecen que non polas que pasan a obsoletas (porque alguén pode resucitalas nun momento dado). Pero, aínda así, é conveniente cerrar nun momento o corpus e gardar para futuras empresas os apéndices coas descubertas e novidades. Hoxe hai ese baleirado representativo tanto para o galego medieval, que conta cun corpus de case todo o editado, como para o moderno, que ten un corpus con testemuños ata o ano 2007, como xa se expuxo noutros capítulos deste volume.

Ademais das voces rexistradas en textos, os dicionarios históricos usan os dicionarios anteriores como corpus; nos dicionarios hai voces que nalgún (ou en moitos casos) non foron nunca usadas en texto ningún dos baleirados; carecen daquela de exemplos a non ser que o dicionarista que as rexistra inclúa unha ilustración. Tendo en conta que entre nós abundan dicionarios, vocabularios e nomenclaturas que se basean en enquisas dun determinado territorio, a posibilidade de que un localismo recollido, por exemplo, por Aníbal Otero ou por Elixio Rivas nunca fose usado en textos é bastante grande; polo tanto vai haber unha cantidade non desprezable de voces que só se teñan rexistrado en dicionarios.

Sobre a información dos dicionarios galegos hai que lembrar que cada un deles é un elo dunha cadea onde a información vai pasando unhas veces de maneira literal e outras filtrada. A información de carácter semántico en xeral é transmitida con bastante fidelidade (aínda que non faltan exemplos de terxiversacións graves); en cambio, outras informacións, como por exemplo a do lugar ou lugares en que se rexistra unha verba, adoitan desaparecer; paras as voces que se incorporaron nos dicionarios procedentes dos vocabularios de Sarmiento, Aníbal Otero ou Elixio Rivas prescindiuse sistematicamente de indicar a súa procedencia xeográfica, ademais doutras informacións. E é unha información non desdeñable mesmo para un dicionario de carácter xeral, dado que ese dato pode darnos unha idea da posible difusión da palabra; de feito, mesmo os dicionarios de uso ou prescritivos dunha lingua como o español nos informan 
constantemente de que unha palabra é propia só de Colombia ou de Álava ou de Extremadura; os galegos, mesmo os normativos recentes, non debían ocultar ese dato. En calquera caso, a distribución xeográfica dunha palabra é unha información da que non se pode prescindir nun dicionario histórico, sempre que se saiba; entre outras razóns, porque os dicionarios históricos son a base dos dicionarios etimolóxicos e a noticia sobre a vitalidade e dispersión dunha palabra é imprescindible; así é que no $D H G$ haberá que recuperar esta información dos dicionarios cando a dean.

E aínda unha nota marxinal máis: determinado tipo de voces (e mesmo procedementos lexicais) son comúns a moitas linguas. No OED non é raro ver como se cita moitas veces como fonte un dicionario dunha lingua estranxeira, que foi seguramente a primeira en poñer en circulación un neoloxismo. Obviamente, nun dicionario histórico coma o noso, recorrer a estes dicionarios para estas voces culturais vai ser non só conveniente, senón obrigatorio, pois o dato sobre a lingua en que se cuñou unha palabra e a lingua intermediaria entre aquela e a nosa non é superfluo. Os dicionarios enciclopédicos doutras linguas -que na nosa non os hai-terán que estar constantemente abertos na mesa do lexicógrafo; porque hai moitas cousas que se din en galego e non son só da cultura galega.

Non se esgotan niso seguramente as fontes do léxico galego, aínda que as mencionadas (textos galegos e dicionarios galegos) sexan as principais. Nos séculos chamados escuros producíronse moitos escritos en castelán, moitos deles inéditos, que están empedrados de palabras galegas ou ben porque o produtor do texto ten un coñecemento deficiente do castelán e intercala a palabra galega que lle é familiar ou ben porque a palabra se refire a un fenómeno da cultura galega que non ten tradución ó castelán e se cita por iso na lingua orixinaria. Calquera que repase documentos (escrituras, regulamentos de gremios como os dos mareantes, que rexistra moitos termos de pesca, etc.) dos séculos XVI-XIX encontrará a cada paso palabras en galego. Case toda esta documentación está aínda sen explorar, entre outras razóns porque esixe un baleirado manual, dos orixinais mesmo, porque hai poucos transcritos. Cómpre que quede constancia da lagoa.

Quédanos aínda unha pequena consideración referida á macroestrutura do dicionario. Está claro que sendo un dicionario da lingua galega o fondo esencial do seu contido (nomenclatura, lemario...) deben de ser as palabras galegas. Pero entre o que é galego e o que non é galego a raia non está clara ás veces, e especialmente se se opera co criterio do uso e non con criterios puristas. Todos os dicionarios teñen un problema cos estranxeirismos, pois entre os naturalizados e os ocasionais hai un continuo no que é difícil poñer límites. Entre nós as cousas complícanse por- 
que o bilingüismo facilita os intercambios (que poden ser conscientes ou inconscientes) e provoca as reaccións puristas consabidas, ás veces dexeneradas en hiperenxebrismo. En cada caso haberá que tomar unha determinación. O máis grave é que moitas veces seremos incapaces de saber (e isto xa se refire máis á etimoloxía que ó feito mesmo de excluír, incluír ou etiquetar a palabra) se esa palabra é préstamo, calco ou autóctona. Os catro séculos de silencio prívannos de poder aplicar o criterio cronolóxico para poder dilucidalo cando non vale o formal. Tamén vai ser dificultoso tomar a determinación de se se lles dá cabida no dicionario histórico ás palabras que pertencen ós verbos ou latíns (dos canteiros, etc.). En principio, un argot é unha lingua diferente, aínda que a súa morfoloxía e sintaxe sexan galegas; daquela, as palabras argóticas deberían de estar excluídas dos dicionarios históricos. Iso non quita que palabras da xiria non se poidan incorporar á lingua común. Antes de eu ter ningunha familiaridade co latín dos canteiros recollín de informantes meus da Fonsagrada baiorte 'viño', que puxen na miña memoria de licenciatura coma se fose unha palabra de Suarna; só despois aprendín de onde viña, o cal non me impediría seguramente tela rexistrado igual. Hai que ter en conta que algunhas destas palabras están bastante xeneralizadas, como é guiche, guicho ou a variante con gheada ghiche, ghicho, ghicha, ghichiño..., que está recollida unhas ducias de veces no TILG. E ás veces danse casos en que será imposible saber se unha palabra pasou do galego ó argot ou viceversa, como é o caso de baloca 'castaña' e 'pataca'. Como nos casos dos estranxeirismos, está pouco claro ás veces se unha voz argótica está "naturalizada" ou ten un uso ocasional. En calquera caso, o que parece claro é que non se poden incorporar en bruto os dicionarios do verbo ó dicionario histórico, pero tampouco se poden excluír de cheo; todos estamos fartos de ler en castelán palabras como gachí, parné, piltra, entre moitas outras, que o dicionario (aínda o de lingua, canto máis o histórico) ten que rexistrar. En caso de dúbida a filosofía debe ser varrer para dentro.

E aínda imos ter outro problema engadido, este máis grave cós anteriores, a saber, qué voces (tecnicismos) das falas especializadas admitir e cales non. O OED, que na actualidade ten 615.000 entradas, non dá cabida a todos cantos tecnicismos circulan pola lingua inglesa, que se contan seguramente por millóns. No noso caso hai tamén decenas de miles, como se pode ver no observatorio neolóxico de Vigo (que non ten representación de toda canta ciencia e técnica hai); haberá que estar atento a ese observatorio e establecer algún criterio para decidir que neoloxismos pasan e cales quedan. Na miña opinión estes termos teñen un interese secundario para o noso dicionario histórico, porque son en xeral interna- 
cionalismos que coinciden (sen adaptación ou con pouca adaptación) en todas as linguas. Moitos deles son de escasa duración ou de vida efémera. Por unha razón puramente económica (a de permitir que o dicionario teña un remate) hai que filtralos con parsimonia (tanto no sentido galego de 'coidado' como no inglés de 'aforro'), pero non excluílos de a feito entre outras razóns porque moitos deles teñen circulación moito máis alá da lingua especializada.

Tendo en conta todo anterior podemos concluír que o contido (os lemas) dun dicionario histórico son máis ou menos os dun dicionario de lingua, pero máis abundantes porque non se poñen restricións cronolóxicas, nin xeográficas, nin normativas; e por outra parte ése máis xeneroso con palabras xergais e tecnicismos. Os tipos de entrada ou lema (main entry) serían, daquela, as voces "normais" (patrimoniais, cultas, "algúns" estranxeirismos, "algúns" xergalismos, etc.) do vocabulario galego rexistradas conforme á súa forma canónica moderna (o antigo e moderno afiuzar prevalecerá sobre a variante antiga afeuzar e sobre a variante moderna afiunzar); no caso de palabras arcaicas hoxe fóra da circulación prevalecerá como vedette a forma máis típica (arrafeçar, refeçar, arrefeçar terán como entrada arrafeçar tendo en conta que deriva de rafez <ár. rafiz). Supoño que ha de haber moitos casos discutibles, pero o principio xeral debe ser este. Naturalmente esas formas secundarias teñen entrada, pero só a efectos de referencias cruzadas (para reenviar á entrada principal); encabezan, como se dixésemos, un artigo que non existe (polo menos nese lugar).

Ademais das palabras "normais" teñen entrada nos dicionarios (véxase Berg / 1993: 53 e ss.):

(a) As letras do alfabeto, que deben encabezar un artigo non (ou non só) polo valor do grafema, senón principalmente por outros valores que poidan ter, por exemplo, referidos á súa figura (unha curva en forma de $S$, ou facendo eses), posibilidade que ten de formar parte dunha seriación $(\mathrm{a}, \mathrm{b}, \mathrm{c})$, valores como símbolo $(\mathrm{K})$, abreviacións (por pudor pode escribirse c. ou $m$. en vez da palabra enteira), etc. Todas as letras deben ter entrada, mesmo algunhas que non se usan no alfabeto galego (como omega, que entra polo nome e non polo grafema, aínda que parte do contido do artigo teña que referirse a este último).

(b) Os acrónimos e as abreviacións. Os acrónimos corresponden a palabras que se forman coa letra (ás veces sílaba) inicial de cada elemento que compón o acrónimo (RAG, ORGA, ONU, SIDA...). Ás veces poden corresponder a palabras doutro idioma, como VIP, que por certo en inglés non se 
le vip senón vi-ai-pi. Non hai que confundir acrónimos con "inicialismos", do tipo OLP. A fronteira entre o acrónimo e o inicialismo non está clara moitas veces, e nós coñecemos mesmo mestura dos dous procedementos en casos como UPG ou ILG. Os acrónimos en xeral dan lugar a entradas; os inicialismos non: desenvólvense no artigo da letra correspondente. Pero a fronteira é ás veces tan borrosa que vai haber casos discutibles e polo tanto incongruencias. Por abreviacións referímonos ás palabras recortadas, tipo metro (que hoxe está tan lexicalizado que xa case ninguén se acorda da súa etimoloxía: (tren) metro(politano); outras veces, como no caso de bici, a etimoloxía é máis transparente aínda e neste caso a entrada terá o carácter só de referencia cruzada (a definición só incluirá os exemplos).

(c) Afixos e outras formas combinables (afíns ós afixos). Os dicionarios de lingua xa incorporan estes elementos como entradas; unhas veces son morfemas con escaso contido léxico, como ex-, anti-, auto-, -doiro, -izar, pero outras veces son elementos radicais, a maior parte das veces de grecismos, que se antepoñen ou pospoñen a outras raíces, igualmente gregas as máis das veces (pero que case nunca apareceron combinadas no grego clásico): referímonos a casos como cripto-, neo-, austro-, -cardia, -dinámico, -lecto... É conveniente que entren estes elementos nun dicionario histórico para ver a súa historia, pero non está claro ata qué punto a inclusión destas entradas libera de incluír tamén as palabras compostas nas que entra un deses elementos. Posiblemente moitos dos derivados formados con ex- non necesiten ter entrada, como moitos dos formados con auto-, e aquí o dicionarista poderase espraiar (cfr. o que fai o OED para pre-, con "mapa" e todo, ou para auto- sen "mapa"); en cambio todos os formados con -ectomía ou quiro- teñen que ter entrada no lugar que lles corresponda e entón o artigo poderá abreviarse. O galego non ten como o inglés a posibilidade de usar palabras patrimoniais como prefixos (tipo self: selfadhesive) ou sufixos (tipo man: spiderman), a non ser que consideremos latinismos como -forme (vermiforme) e outros como xa patrimoniais.

(d) Nomes propios e marcas rexistradas. Os nomes propios non entran nos dicionarios de lingua nin nos históricos. Hai, con todo, casos onde o nome propio de persoa ten os trazos dun apelativo: paio, xan, párkinson (que en realidade é unha elipse de enfermidade de Parkinson), e neste caso forman parte da macroestrutura do dicionario. O mesmo ocorre con algúns nomes xeográficos (ribeiro). Algúns deles están tan asimilados que xa se escriben con minúscula. Outras veces o nome propio figura como determinante ou atributivo doutro nome (baño (de) María, cruz de Caravaca); neste casos se o nome propio figura como entrada é só a efectos de referencia cruzada pois a locución irá explicada na palabra rexente. 
Hai casos, con todo, pouco claros. Relacionados cos nomes propios están os substantivos e adxectivos, e mesmo verbos e adverbios, derivados de nomes propios (gongorismo, gongorino, gongorizar; coruñesismo, coruñesista). Todos os dicionarios teñen un problema con estas entradas porque se trata dun sistema aberto que non se sabe moi ben onde cortar; no TILG aparecen esporadicamente verbos como despontevedrizar, que con certeza vai ser excluído do dicionario histórico. Murray era moi restritivo, ata o punto de que excluíu con algo de esaxero o adxectivo e substantivo African por ser de etimoloxía e valor obvios para calquera, a pesar de que hai datos del en inglés desde o ano 888. A importancia e a frecuencia destas voces é o criterio determinante. E relacionados cos nomes propios están os nomes comerciais, ás veces marcas rexistradas, de determinados produtos (do tipo Aspirina, Coca, Martini, Kleenex, tirita, maicena (<maizena) ou Ciprianillo). Lembremos que bolígrafo, plexiglás, celo e tergal, igual que as palabras anteriores, son marcas comerciais, algunhas rexistradas, e só os moi entendidos o saben ou sospeitan, a pesar de que algunhas teñen mesmo sitio na Internet (como www.tiritas.com, da casa Hartmann). A inclusión destas palabras dependerá do uso xenérico que se faga delas, cousa que non sempre é ben discernible.

(e) As palabras compostas teñen entrada nos dicionarios a través da súa forma gráfica soldada (abrecartas), aínda que a súa definición se aproxime moito á súa análise etimolóxica ('utensilio que serve para abrir cartas'). Pero hai casos en que entre a palabra composta e o sintagma libre hai límites borrosos porque aínda a morfoloxía non está fixada definitivamente: sapoconchos ou sapos conchos son posibles; mal non temos dúbida de que hai que escribilo xunto en maldicir, maldición, malbaratar, malbarate, pero xa non estamos tan seguros se debemos facer o mesmo en malcriado, malnacido ou maleducado porque mal- aínda esta moi ligado ó seu valor adverbial primitivo (de feito non se pode dicir *maleducación). Vexo difícil neste caso cómo se poden establecer criterios para decidir entre dar entrada á combinación ou ben remitir a súa inclusión a un dos elementos da combinación; hai que repasar neste caso a definición de palabra, tema do que xa se sabe que hai tratados enteiros. O editor terá que decidir co seu gusto sobre o grao de solidariedade; en calquera caso, estas combinacións teñen que ter un sitio no dicionario (ou ben como entrada ou ben como elementos polirremáticos dentro dunha entrada). E outra decisión similar haberá que adoptar con referencia ós derivados que son resultado dunha adición gramatical case mecánica; incluír como entradas todos os adverbios en -mente non ten sentido ningún, a non ser que queiramos por razóns comerciais de presumir de ter moitos lemas. 
O mesmo podemos dicir dos adxectivos en -ble, dos participios que se poden usar adxectivamente, etc. Naturalmente algúns destes derivados teñen que figurar, pero só aqueles que teñan algún matiz semántico engadido que non figuraba na base ou ben que teñan unha frecuencia moi elevada na lingua. Noutros casos inclúense baixo a palabra principal correspondente. Isto no noso caso (ó contrario do inglés) é moi frecuente, porque temos moitos diminutivos, aumentativos, etc.

(f) Palabras dubidosas ou claramente espurias. Nos textos, nunha parte moi considerable de casos as palabras falan por si soas, ou porque son moi coñecidas ou ben porque os contextos permiten verificar cal é o sentido exacto ou aproximado de cada palabra. Pero moitas veces as palabras poden estar referidas a cousas que xa descoñecemos porque pertencen a un mundo desaparecido e vai ser moi difícil de dilucidar o seu significado; outras veces poden deberse a erros dos autores ou mesmo a caprichos ós que a nosa literatura é (ou foi) bastante propicia; isto non é, aliás, un fenómeno só noso; entre a correspondencia de Murray hai moitas cartas dirixidas a autores vivos para preguntarlles qué querían dicir con tal palabra, cousa que ás veces nin os mesmos autores lograban esclarecer (cfr. Mugglestone 2000a: 17 e ss.). Debe ser un fenómeno universal; a nós mesmos tennos ocorrido máis dunha vez, aínda con escritores tan amigos da verdade filolóxica como Ferrín, que inclúe por exemplo a palabra sés nun contexto de Arraianos: "a donicela éche coma un rato; tenche sete sés de dentes afiados coma navalliñas" (p. 64). Este tipo de caprichos ou fantasías verbais (ou simplemente erros) teñen tamén entrada nos dicionarios históricos e sobre elas o lexicógrafo dirá o que saiba ou ben declarará que non sabe nada; en calquera caso, se fai unha conxectura que quede claro que o que propón é inseguro e provisional. Tamén entre os nosos dicionarios houbo unha tendencia a fabricar palabras (se o castelán cara é en galego face, daquela descarado é *desfazado, segundo Cuveiro (1876) e seguintes); como tamén houbo a tendencia a copiar palabras que proceden de lecturas erróneas doutras fontes escritas (a voz airoa 'anguía pequena' de Sarmiento foi mal lida por Rodríguez (1863), aixóa, e con esta forma foi transmitida despois a varios dicionarios); ou ben a facer pasar por galegas palabras que procedían doutras linguas (o grego ergaleion 'instrumento ou ferramenta dun artífice' nun texto de Sarmiento interprétase como galego e lese mal (ergaleirón) por De la Iglesia e así pasa a Rodríguez (1863) e a varios dicionarios posteriores. Ás veces algunhas destas palabras poden remanecer en escritos dalgún autor que acode ós dicionarios para enxebrizar o seu galego, de maneira que as fantasmas léxicas dos dicionarios poden retroalimentar a lingua literaria e lexitimar estas voces. Pero o nor- 
mal é que estas palabras carezan completamente de uso. Pois ben, mesmo estas voces dos dicionarios deberán de aparecer no DHG debidamente comentadas cando se saiban comentar. No OED estas formas espurias rexistranse como "erros" e explícanse cando se sabe; e se non preséntase como "explicada nos dicionarios como...", e dáse a cita. No OED as entradas espurias van entre corchetes (o artigo enteiro).

Non menciono agora outros pormenores da posible macroestrutura, entre eles o de se o dicionario ten que ser alfabético ou conceptual. A posibilidade (máis ben necesidade) de publicalo en formato electrónico permite que o traballo non sexa necesario acometelo por letras; o traballo pode render máis tratando acios de palabras que teñen unha afinidade semántica (voces que designan plantas, peixes, medo...) ou formal (un primitivo coa súa restra de derivados).

3. Pasamos agora a ver como sería a estrutura (microestrutura) dun verbete típico. Hai que ter en conta que as entradas son heteroxéneas e só en entradas moi complexas van ocorrer todos os trazos acumulados. Sérvenos de guía o OED.

Nos dicionarios históricos, coma nos dicionarios de lingua, hai dúas seccións; unha, a que comprende o verbete da entrada e toda a información que non é semántica: categoría gramatical, grafías, fonética, etimoloxía, frecuencia (que non aparece no OED pero si no TLF); a outra sección é a que se refire ó contido semántico do verbete, con todo o que leva aparellado: acepcións, exemplos, etiquetas de rexistro, combinacións, etc.

No $O E D$, para entradas que tiveron unha morfoloxía moi complicada (verbos como go), entre as dúas seccións, realmente na sección de contidos pero ó principio de todo, numerado sempre como letra A (inflexional forms), fronte a B (signification), clasifícanse todas as variantes morfolóxicas, por exemplo, no verbo por tempos e persoas (o noso verbo correspondente a go -ir-, e sen dúbida outros, necesitarán esa sección) ${ }^{11}$.

Esa distribución dalgúns dicionarios (primeiro as formas e etimoloxía e despois o contido) non ten por que ser necesariamente así nesa orde; noutros dicionarios, como o DCVB ou o TLF, a información sobre as variantes, pronunciación, morfoloxía, frecuencias e etimoloxía dáse ó final da entrada; cremos que a estratexia do OED é a máis acertada porque dis-

11. Non todos os dicionarios inclúen este apartado de inflexional forms, como ocorre no TLF, que promete un volume separado para as variantes flexionais; pero a maioría dos outros inclúen paradigmas históricos e dialectais. 
tingue ben as informacións relativas á forma (ó principio) das relativas ó contido (despois). Vaian onde queiran esas informacións, o único que non cambia de lugar é o lema (encabezado, cabeceira, rúbrica, verbete, mot vedette, headword) que encabeza o artigo lexicográfico, e a definición. Onde vai ir cada información haberá que decidilo cando se faga o blueprint definitivo.

Na sección do lema (ou se se quere no que non é sección do significado) aparecen obrigatoriamente a cabeceira (headword), a categoría gramatical e a etimoloxía; de ser necesario infórmase sobre o grao de integración da palabra (arcaísmo, estranxeirismo...), moitas veces simplemente mediante un signo non alfabético, o número de homónimo, etiqueta de campo, e variantes formais.

Non é necesario que nos deteñamos pormenorizadamente en cada un destes aspectos porque todos os dicionarios de lingua conteñen todas esas informacións e indicacións de navegación de maneira máis ou menos explícita. Pero hai algún que merece comentario porque non é habitual nos dicionarios de lingua:

(a) En primeiro lugar a fonética. En linguas cunha ortografía moi arbitraria, como é a do inglés ou a do francés, a pronunciación do lema (na súa forma non marcada) figura na maioría, ou nunha boa parte das entradas. Para dar un testemuño de como é a pronunciación do francés moderno Imbs e o seu equipo (TLF), á parte de acudir a libros como o de Quemada ou Martinet, fixeron enquisas cunha poboación de testemuñas (estudantes de enxeñeiros de París, procedentes de toda Francia, que serían o "corpo social representativo do noso tempo"). A grafía do galego fai previsible na maioría dos casos cal é a pronunciación. Por iso, fóra dos casos onde entren as vogais medias, o seseo, a gheada, o rotacismo e poucos outros fenómenos (coma o de inhibir), non será necesario facer constar cal é a pronuncia. Tendo en conta que non se vai tratar dun dicionario normativo (ó contrario do TLF ou mesmo do OED), no caso de que teñamos que dar a pronunciación, haberá que localizar a extensión de cada variante. Supoñendo que haxa consenso, poderá proporse unha das variantes como aspirante a normativa.

(b) As variantes (orto)gráficas tamén se deben de facer constar en caso de que as haxa, e non só as que se refiren ás diferentes formas de escribir palabras que teñen algún fonema con grafía arbitraria (como her$b a$, erba, herva, erva, que se pronuncia igual calquera que sexa a grafía), senón aquelas variantes en que a pronuncia motiva grafías diferentes, como vai ocorrer na entrada toupa, que será a que se escolla como ca- 
nónica para Talpa europaea, onde deberán figurar como variantes toupo, teipa, teipe, teupa, tiopa, tiopo, topia (pero non toupeira, aínda que é sinónimo nalgúns sitios, porque xa é máis que unha variante fonética); naturalmente todas elas terán entrada pero só a efecto de referencia cruzada contra toupa. Supoño que vai haber problemas máis dunha vez se é que a etimoloxía que vai seguir estas formas non o resolve; imaxinemos esta serie de nomes para a Digitalis purpurea (entre outros):

\footnotetext{
belitroque, bilicloques, bilicroque, bilitroque, milicrocas, milicroques, palitroques, cloques, croque, cróquel, croquetas, cuco, farricoque, trócoles, tróqueles, troques, estalote, estraladeira, estralante, estraloque, estroleque, estroqueiro.
}

Con esta restra imos ter dous problemas, que en realidade son un só: cál das formas dar como canónica, que é posterior a resolver se todos son variantes da mesma familia etimolóxica; e en segundo lugar, qué formas dar como variantes e cales como sinónimas. Nos dicionarios históricos, e no noso tamén, onde se van mesturar formas antigas e modernas, as variantes gráficas e fonéticas van ser numerosas. Imaxínese a cantidade delas que entrarán baixo o verbete escribir se a raíz no galego medieval pode ser (e)scre- ou (e)scri-; que o / $\boldsymbol{\beta} /$ do medio se pode escribir como $\langle\mathrm{v}\rangle$, $\langle\mathrm{u}\rangle,\langle\mathrm{pu}\rangle$ e $\langle\mathrm{b}\rangle$; que a desinencia pode ser -er, ou -ir; e calquera dos $/ \mathrm{i} / \mathrm{se}$ pode grafar $\langle i\rangle,\langle j\rangle$ ou $\langle\mathrm{y}\rangle$ (poderían ser mais de 100 variantes). Tendo en conta que estamos a falar dunha lingua de oito ou máis séculos é obvio que hai variantes gráficas propias dunha época, e así o haberá que facer constar; o mesmo acontece coa pronunciación que corresponda a estas grafías, que se rexistrará ou reconstruirá na medida do posible.

(c) Tocante á etimoloxía. Esta é unha información que se dá moi resumidamente, mesmo nos dicionarios de lingua (DRAE, Robert, Larousse, Webster, Houaiss...), e daquela non pode faltar nun dicionario histórico en tanto que a etimoloxía pertence á historia da palabra, polo menos na medida en que explica o seu nacemento. $O$ destinatario dun dicionario histórico é un profesional da lingüística ou unha persoa con curiosidades filolóxicas máis apuradas cás dun usuario que só quere comprobar un significado ou coñecer unha grafía correcta. Daquela, a nota etimolóxica dun dicionario histórico, sen chegar a ser un artigo de dicionario etimolóxico, ten que ser máis informativa cá dun simple dicionario de lingua. Nun dicionario destas características vai haber moitos tipos de etimoloxía. Por exemplo a dos internacionalismos formados con material grego e latino non necesitan máis indicación có étimo e o seu significado na lingua orixinal e, de ser o caso, a lingua intermediaria, se se sabe; 
o mesmo sucede cos estranxeirismos modernos, adoptados (tal cal) ou adaptados (ó sistema fonético e morfolóxico), tamén con indicación da lingua intermediaria; isto cabe nunha liña dunha columna. Tampouco as palabras patrimoniais derivadas ou compostas necesitan na maioría dos casos máis etimoloxía cá referencia cruzada ó primitivo ou a cada un dos elementos do composto. En cambio, as palabras patrimoniais primitivas deberán ser obxecto dun exame máis pormenorizado porque son o testemuño máis fiel do noso pasado cultural. Moitas destas palabras teñen cognados noutras linguas e xa foron tratadas en dicionarios etimolóxicos hispánicos e románicos; entre elas unha boa parte teñen etimoloxías que se poden admitir definitivamente como correctas porque cumpren todos os requisitos da fonética e da semántica. Outras son aínda obxecto de debate e non hai ningunha hipótese concluínte; neste caso haberá que mostrar as diferentes hipóteses, avalialas como mellor se poida e concluír que algunha delas é verosímil ou que ningunha o é e se deixa polo momento como de etimoloxía descoñecida. Outras serán palabras galegas para as que nunca se propuxo ningunha hipótese e entre elas haberaas tamén de dificultade moi variable, cunha porcentaxe considerable de orixe escura ou descoñecida. Sexa como sexa, os testemuños que vai dar un dicionario deste estilo van obrigar con certeza a revisar hipóteses doutros dicionarios hispánicos, porque os novos datos ofrecidos agora por primeira vez polo galego van validar ou invalidar etimoloxías máis ou menos aceptadas. A forma uesugo, documentada en textos latinos de Galicia en 1133 (en castelán ca. 1400), fai imposible a etimoloxía de Corominas (do occitano besuc 'birollo' < BIS-OCULU). Por outra parte, hai que ter en conta que o tramo de lingua que tratamos é de máis de oito séculos (en bastantes casos moitas palabras galegas xa están romanceadas en textos latinos de hai 1000 ou máis anos). Iso quere dicir que moitas veces a etimoloxía dunha palabra terá que facer referencia a transformacións (ramificacións de sentidos novos, perda doutros) operadas dentro da propia historia do galego. Desde a etimoloxía haberá que facer referencia a estas transformacións das que se dá conta na sección da definición. As reviravoltas da etimoloxía románica son ás veces insospeitadas, dado que a lingua nai conviviu coas linguas vulgares en contacto diglósico, de maneira que a derivación lineal esperada pode estar perturbada por préstamos semánticos de variado tipo. Imaxinemos voces como orde, arco, arte (vulgares pola fonética), ateigadas de acepcións cultas e de calcos doutras linguas. Nunha lingua como a nosa, que estivo case desde sempre en contacto desvantaxoso co castelán, os préstamos (conscientes ou non) e as reaccións de enxebrismo e mesmo hiperenxebrismo alteraron tamén a vida das palabras. De todo 
isto ten que dar conta a etimoloxía. Na sección de etimoloxía darase a bibliografía pertinente para cada palabra tratada, de habela. O OED con frecuencia engade á nota etimolóxica unha miscelánea de feitos enciclopédicos relacionados coa historia da palabra na cultura europea. Cfr. por ex. na palabra orange unha nota deste tipo; ou na palabra church (< ing.

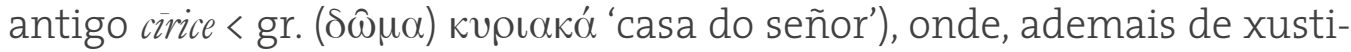
ficar este nome fonética e semanticamente, compara esta denominación

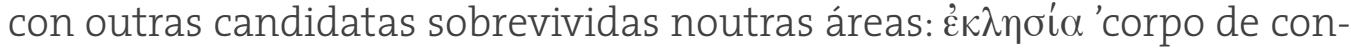
selleiros' (que vén a ser unha tradución do hebreo qāhāl 'congregación'),

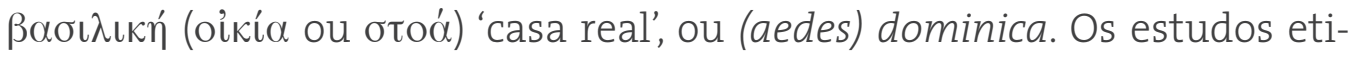
molóxicos sobre o galego non van permitir facer resumos etimolóxicos tan afinados como os do OED, pero non está mal poñermos unha meta parecida que xa se verá como se cumpre.

4. Entramos finalmente na parte máis importante de calquera dicionario: a que trata dos sentidos das entradas ou información lexicográfica propiamente dita. Cada entrada (a non ser as que sexan referencias cruzadas) terá que ter obrigatoriamente unha definición (como mínimo) e un ou máis exemplos. Ocasionalmente pode haber outras informacións, como son as referidas ó estatus da palabra (arcaísmo, forma non naturalizada), etiquetas de tipo gramatical (cando a palabra se usa cunha función que non é a esperada, por exemplo substantivos atributivos, adxectivos substantivados), rexistro (dialectal, vulgar, etc.) -asunto sobre o que hai moita literatura-, materia (Biol., Arquit., etc.), locucións e derivados (que non teñan entrada). Da maioría destes temas non imos ocuparnos; só diremos algo da definición e dos exemplos.

Pero antes convén facer unha advertencia. Cando se define o valor dunha palabra é sempre en relación co valor que outras palabras teñen nunha etapa da historia. Nunha historia de oito ou máis séculos a lingua produciu innumerables innovacións que alteraron o valor recíproco dunhas palabras coas outras. Isto engade unha dificultade metodolóxica ós dicionarios históricos, dado que na medida do posible teñen que dar conta das sucesivas sincronías (supoñendo que queiran respectar a dicotomía saussureana); como aliás o hai que ir facendo para os fenómenos gramaticais nunha gramática histórica (das do tipo da "economía dos cambios fonéticos"). Na práctica, facer isto, ou sexa trazar a historia da palabra en relación con todas as outras palabras do seu campo, sería enormemente laborioso e irrealizable para todo o léxico, pois equivalería a facer un estudo onomasiolóxico de todos os campos; cada palabra esixiría case unha tese de doutoramento. Ora, por experiencia sabemos que os sentidos cen- 
trais dunha palabra poden manterse estables ó longo do tempo. No OED unha acepción de church como 'conxunto dos clérigos dunha relixión ou un segmento dela' (do tipo a igrexa española) mostra exemplos desde o século X á actualidade. Outras veces as palabras cambian de significado; 0 fr. naïf pasou de 'nativo, natural' a 'falto de artificio' (e mesmo a 'inxenuo') e no TLF dáse a cadea de pasos pormenorizadamente. Pero nos dous casos non se fai referencia ás relacións paradigmáticas de church ou naï con outras palabras afíns; o mesmo que ocorre tamén nas gramáticas históricas (non estruturalistas) con fenómenos fonéticos e gramaticais. Desta maneira queda testemuño de como unha palabra existiu no discurso pero non no sistema. Tendo en conta que facer un dicionario respectando escrupulosamente os principios saussureanos indicando como cada palabra cambia segundo cambia o sistema é irrealizable, os lexicógrafos estruturalistas máis escrupulosos prefiren abordar a historia léxica dunha lingua a través dunha batería de dicionarios de épocas sucesivas (como e o caso de Imbs e o seu TLF). O malo é que esta solución ten dificultades prácticas, porque realizar unha batería de catro ou cinco dicionarios correspondentes a outros tantos cortes cronolóxicos é economicamente inviable. O mesmo Imbs e editores sucesivos, recoñecendo isto, engaden unha nota, como queda visto, ó final de cada entrada na que se xustifican historicamente os sentidos que ten unha palabra no francés moderno.

Pasando por alto esta eiva dos dicionarios históricos, imos logo ó núcleo esencial do dicionario: a análise sémica do vocabulario. Non imos expor aquí ningunha teoría nova, pois é o tema principal de calquera manual de lexicografía; hai mesmo libros enteiros dedicados ó problema da definición e da desambiguación da polisemia. Nos prólogos dos dicionarios hai tamén con máis ou menos pormenor ideas sobre a metodoloxía lexicográfica verbo disto. Cada lingua impón unhas certas estratexias, e a nosa pola súa historia tamén nos vai impoñer algunhas, pero hai principios de tipo xeral que podemos ir apuntando baseados na experiencia e na ensinanza allea.

Do vocabulario dunha lingua hai unha masa considerable que non ten grandes problemas lexicográficos: son as palabras monosémicas pertencentes ás nomenclaturas científicas, que crecen na medida en que nos distanciamos da lingua común; en xeral nos dicionarios bilingües teñen correspondencias exactas. En cambio, o núcleo fundamental do idioma está formado por uns cantos milleiros de palabras polisémicas que necesitan unha metodoloxía de análise porque son potencialmente portadoras dunha ambigüidade; naturalmente, para que un discurso sexa eficaz, a persoa que o produce, cando insire nel unha palabra polisémica e daquela 
ambigua, ten que fornecer ó mesmo tempo as claves necesarias para que o receptor da mensaxe (no noso caso o lector lexicógrafo, porque os textos que manexamos como córpora son só escritos) poida decodificala adecuadamente. As claves que se lle dan ó lector cando desambigua, ou ó lexicógrafo cando agrupa por afinidades semánticas as diferentes papeletas ou rexistros dunha palabra, son variadas (seguimos o esquema de Imbs no prólogo do TLF, pero é unha práctica experimentada en toda a lexicografía desde o Renacemento).

(a) A maioría das claves son de tipo contextual (colocacións) na medida en que pertencen a un uso habitual colectivamente memorizado. Estas claves ou auxiliares poden ser:

- O contexto inmediato, e desta maneira o adxuvante pode ser categorial (unha palabra cambia de sentido co cambio de categoría: pasaxeiro s. ou a.: un pasaxeiro, unha crise pasaxeira), de natureza sintáctica (unha palabra non significa o mesmo se só se usa en singular ou se se pode usar en singular e en plural: a luz é intensa, vexo dúas luces; ou se cambia de significado segundo a preposición que rexa: mirar algo, mirar por algo).

- O auxiliar dominio. É ben coñecido que moitas palabras teñen unha acepción diferente na lingua común ou cando son usadas nun dominio específico (unha ciencia, unha técnica, un oficio): mesa non é o mesmo na lingua común que cando se fala de carros do país; a silencio pásalle o mesmo segundo o usemos na lingua común ou falando de música (gardar silencio, un silencio de redonda).

- O auxiliar retórico (ás veces concomitante -redundantemente, porque a lingua é moitas veces redundante- co contexto inmediato). Referímonos con isto ó uso que se fai dos vocábulos co recurso da metáfora, da metonimia e da elipse, que nos dicionarios se inventarían tamén como acepcións dentro do campo sémico dunha palabra: a febre, que é unha alteración da temperatura corporal ( $a$ febre do cativo), pode por metáfora pasar a desexo incontrolado ( $a$ febre dos consumidores); mesa é un moble coñecido, e por metonimia mesa do leite ou Mesa pola Normalización Lingüística é un grupo de persoas, que se constitúen non necesariamente arredor dunha mesa, para reivindicar algo; vehículo automóbil incorpora os semas de 'vehículo' a automóbil cando vehículo desaparece por elipse. Hai que ter en conta que as relacións metonímicas e meta- 
fóricas teñen diferentes graos de transparencia, pero o que interesa aquí é chamar a atención sobre o procedemento.

- O auxiliar estilístico, que é diferente do retórico porque non se refire a figuras de pensamento senón a situacións nas que están involucrados o emisor e receptor (niveis de lingua) ou á intensidade expresiva ou afectiva que caracterizan o uso dunha palabra (rexistros). Sabido é que estas connotacións distinguen certas palabras dalgúns sinónimos semánticos (falador equivale a larapeteiro, pero dependendo só do rexistro) e, o que é máis importante aínda, interveñen na segmentación polisémica das palabras (por exemplo home ten a acepción de marido só nun contexto de lingua popular; finar pode significar morrer por razóns eufemísticas). Moitos destes sentidos dependen do sistema de valores de cada época e aínda de cada grupo, e daquela as connotacións poden cambiar segundo cambien as situacións socioculturais (cfr. palabras como aristócrata, burgués, fascista, clase, masa, segundo onde e por quen se digan; as regras de boa crianza fixeron que ó longo da historia bastantes palabras se tabuizasen).

- Os auxiliares demarcativos, que axudan tamén a desambiguar a polisemia, pois segundo as palabras do seu contorno unha palabra pode significar unha cousa ou outra; na maioría dos casos un verbo ten sentidos diferentes dependendo dos complementos (ou actantes) que teña; nos dicionarios distínguense tradicionalmente sentidos dos verbos segundo o carácter transitivo, intransitivo, pronominal, etc. (aproveitar/aproveitarse). Tamén as variacións na morfoloxía poden discriminar sentidos (fumes en plural é 'vaidade, arrogancia').

- As condicións semánticas son os auxiliares máis importantes para demarcar sentidos. Un verbo, por exemplo, pode ter sentidos diferentes segundo o suxeito sexa animado/inanimado, humano/ animal, persoa/cousa, abstracto/concreto (fulano corre, a auga corre, o día corre, o rumor corre; fulano quere a mengana, as plantas queren luz).

Todos estes coadxuvantes contextuais permiten desambiguar polisemias tanto se o dicionario é histórico como sincrónico; de feito, nos dicionarios históricos asúmese que un significante ten un significado constante durante un certo tempo e ten que dar noticia das mutacións formais como das perdas ou gaños no significado; mesmo en certos casos terá que asumir as estratexias dun dicionario bilingüe cando a palabra 
que se define con palabras de hoxe xa non teñen vixencia no vocabulario actual. Naturalmente, tamén ten que dar noticia dos cambios de valores que gobernan os rexistros: palabras que no galego medieval eran neutras hoxe son palabróns ou ó revés ${ }^{12}$.

(b) Por outra parte, hai que ter en conta que a polisemia e homonimia son dúas caras da mesma moeda. Para linguas como as europeas, onde hai dicionarios etimolóxicos, significantes idénticos adoitan darse como entradas diferentes sempre que a etimoloxía as retrotraia a étimos diferentes (golpe 'raposa' e golpe de golpear son dous lemas etimoloxicamente diferentes). Pero hai moitos casos para os que as etimoloxías son descoñecidas ou escuras e non sabemos se estamos ante voces homónimas ou polisémicas; hai mesmo casos nos que tratándose dunha palabra etimoloxicamente única as acepcións son tan diferentes que carecen de vínculo semántico ningún, ou sexa, carecen de semas comúns que permita unificalas como un significante único. Nestes casos os auxiliares demarcativos anteriores non son eficaces e é a análise distribucional a que pode dar indicios de se dous significados pertencen a un mesmo lema ou cada un a lemas diferentes: é o que ocorre hoxe con franquear unha porta ('abrila') / franquear unha carta ('selala'), que non teñen ningún sema en común nin calquera outro vínculo semántico; produciuse nelas o que se chama "rotura da unidade de campo" ou "homonimia interna". Nun dicionario de lingua (e mesmo nun dicionario histórico por etapas) franquear debería ter dous lemas homónimos. Con todo, non é este o caso dun dicionario histórico, que como o etimolóxico trata da historia das palabras; neste caso os dous franquear acabarían (histórica e etimoloxicamente) remontándose a un único franquear, cunha soa acepción ou con dúas, pero menos distanciadas e polo tanto de lema único.

(c) Con auxiliares contextuais ou sen eles, as palabras hai que analizalas componencialmente como acabamos de ver (nos casos de homonimia interna); desa maneira inventaríanse acepcións novas segundo se engadan ou muden semas: muller 'ser humano de sexo feminino', se ten engadido o sema de 'unida a un home por matrimonio' ten a acepción de esposa. A adición de semas, polo xeral, dá lugar a significados máis concretos; a falta deles dá lugar a significados máis abstractos ou xenéricos. $\mathrm{Na}$ análise componencial, como se sabe, os diferentes semas organízanse de modo xerárquico de maneira que un deles é o clasificador e os outros engaden diferenzas específicas. 
Todo isto é de manual. Pero despois a práctica lexicográfica admite moita flexibilidade porque, sexan polisémicas, sexan homonímicas, a lexicografía non deu definido aínda ata qué extremo se debe apurar a discriminación de sentidos. É un problema vello dos dicionarios e nos libros de lexicografía que tratan do tema sempre se chama a atención sobre como en dicionarios de alcance similar (polo tanto non é un problema de tamaño) a polisemia se trata de maneira moi diverxente, como se desprende do número de acepcións, poucas veces coincidente, que se dan da mesma palabra; porque entre os lexicógrafos hai dúas tendencias, a dos splitters e a dos lumpers (ou xebradores e agrupadores), segundo tendan, como os taxonomistas da bioloxía, a recoller os matices máis miúdos ou prefiran dar nunha única acepción varios sentidos algo diferentes pero con trazos comúns. Cítase como exemplo de splitter o dicionario da Crusca, que para luogo ten 172 parágrafos, en contraste co Littré, onde lieu ten só 24 (salvadas as diferenzas que poida haber de lingua a lingua, que son poucas (véxase Migliorini 1961: 46). Polo seu carácter, os dicionarios históricos pertencen todos á clase dos splitters. Así é que para entradas algo complexas, para que o lector non se perda, a entrada vén encabezada cun índice, que agora no $O E D$ electrónico se proporciona como un plano ou mapa da entrada (cfr. light a1).

5. Posterior á clasificación de acepcións dunha palabra (que xa se basea nunha análise sémica que en certa maneira supón unha definición) vén a definición mesma. A definición é a parte esencial dun dicionario (excepto dalgúns tipos de dicionarios moi especiais). Non nos imos deter agora nunha teoría da definición, porque a definición dun dicionario histórico non é diferente da definición de calquera dicionario de lingua e sobre ela hai literatura en todos os manuais, incluídos varios, excelentes, en castelán (como Lara 2004). Xa se sabe que unha definición correcta é aquela na que hai equivalencia semántica exacta entre o lema e a súa paráfrase ou o sinónimo que lle segue. Polo tanto, unha definición será boa se definiendum e definiens son reversibles. É verdade que hai palabras especiais (á parte das gramaticais) que non se poden definir por sinónimos nin polo procedemento aristotélico de genus proximum e differentiae specificae porque son primitivos semánticos, ou sexa, palabras que teñen un contido semántico que non ten genus proximum porque por riba do seu genus xa non hai nada; non son hipónimos de ninguén (ou non teñen hiperónimo, que é o mesmo); é o caso de facer, suceder, parte, dicir, grande, onde e unhas ducias máis (cfr. Wierzbicka 1996). O nome de "primitivos" xa vén de Arnauld (1662) (Wierzbicka 1996: 12); dito nas palabras de Wierzbicka (1996: 10), "os elementos que se usan para definir o significado 
de palabras (ou calquera outro significado) non poden ser eles mesmos definidos; máis ben deben de ser aceptados como indefinibilia". Por iso as definicións destas palabras ou son circulares ou son máis escuras cá palabra mesma pois non se pode cumprir o requisito de que a definición sexa construída con elementos máis simples e comprensibles cá palabra definida. Na lexicografía clásica xa se entendía así: "être 'exister' ne comporte pas définition analytique parce que il n'y a pas de terme ayant un contenu plus géneral que lui, faute de quoi on a recours à des définissants simplement synonymes et/ou à des definitions d'antonymie" (TLF).

Ademais da exactitude hai unha serie de notas engadidas que se lles adoita pedir ás definicións lexicográficas, entre elas, a brevidade e, de ser posible, a elegancia.

As definicións lexicográficas son, como é sabido, definición de palabras, e non de cousas (estas serían máis propias dun dicionario enciclopédico). Con todo, cando definimos unha palabra mostrando o seu xénero próximo (escano 'banco...') estamos orientando o lector cara a un referente extralingüístico, en certa maneira mostrándoo (función deíctica) e a través das diferenzas especificas ('corrido, fixo e con respaldo...') estamos mostrando os mobles que teñen características parecidas pero non idénticas.

Por iso, as definicións dos dicionarios históricos desenténdense bastante dos principios da reversibilidade e de que as definicións sexan definicións de palabras e non de cousas. Certamente un lector de dicionarios históricos (forzosamente un especialista ou un curioso moi motivado pola historia da lingua) prefire os pormenores enciclopédicos á definición do signo, ou mesmo a redundancia de informacións á reversibilidade. Tamén pola mesma razón de que un lector de dicionarios é unha persoa de certa cultura se preocupa menos cós lectores doutros dicionarios de que as palabras da definición sexan "menos escuras" cá entrada mesma, porque se entende que o seu posible lector domina un caudal léxico maior có dun lector normal.

No OED, por citar un clásico, abundan definicións como as seguintes:

\footnotetext{
place $(\mathrm{sb}) 1 \mathrm{~b}$.

In modern use, forming the second element in the name of a group of houses (and hence of a street) in a town or city, now or formerly possessing some of the characters (positive or negative) of a square, chiefly that of not being properly a street.

Often used in the name of a small area more or less built around, and lying aside from a street or thoroughfare, or of a short cul-de-sac or byway turning out of a main thoroughfare; also, more vaguely given to a short row or 'terrace' of houses, which originally stood by themselves on a suburban road; being in fact a ready denomination for any aggregation of houses which cannot be more particularly classed.
} 


\begin{abstract}
Employed in 16th c. to render F. place and its Italian, Spanish, and German cognates, in reference to foreign towns, whence introduced in English towns. (But in some cases the name 'Place' has arisen out of sense 4b, the site being that of a nobleman's or bishop's town-residence, which bore the name, e.g. Ely Place in London [A definición é de Murray].

square (sb) 12. a

An open space or area (approximately quadrilateral and rectangular) in a town or city, enclosed by buildings or dwelling-houses, esp. of a superior or residential kind, freq. containing a garden or laid out with trees, etc.; more generally, any open space resembling this, esp. one formed at the meeting or intersection of streets; also, the group of houses surrounding an area of this kind [A definición é de Craigie].
\end{abstract}

Murray e Craigie, de quen son as definicións anteriores, pertencen aínda á lexicografía clásica (aínda non naceran os Rey, Quemada, Hausmann, etc.). Pero cando Imbs (ou Quemada ou Martin) ou os seus axudantes escribiron estoutra definición para o TLF si que estaban xa a lexicoloxía e a lexicografía moito máis adiantadas, e en cambio seguen a dar definicións tan pouco reversibles coma esta, por moito que lle quitemos o "entorno":

PLACE, subst. fém.

\begin{abstract}
A. 1. Place publique et, p.ell., place. Dans une ville, une agglomération ou un village, lieu public consistant en un espace plus ou moins large, découvert et le plus souvent entouré de bâtiments publics, où aboutissent plusieurs rues ou avenues, et où ont lieu souvent des activités commerciales, festives ou publiques.
\end{abstract}

No caso do noso dicionario histórico galego, igual que ocorre nos glosarios suízos, ou no $D C V B$, na miña opinión, o principio das equivalencias sémicas non debe de ser unha camisa de forza, pois o usuario dun dicionario destas características, especialmente en palabras patrimoniais que teñen algo que ver coa vida espiritual ou material dos galegos ou en voces das nomenclaturas (partes do muíño, ferramentas, etc.), máis que a equivalencia exacta e a reversibilidade, agradecerá informacións enciclopédicas que vaian máis alá dos trazos esenciais; mesmo sería bo, se é do caso, mostralle os obxectos nun gráfico ou nunha imaxe.

Hai aínda pormenores referidos á definición, como son o nada sinxelo da xerarquización das acepcións. Nos dicionarios históricos a organización non pode ser senón cronolóxica. Na práctica, isto en moitas palabras é imposible, porque acepcións que foron orixe doutras poden estar documentadas despois das que derivan dela. Por iso, cada definición pide estratexias diferentes. No noso caso, que temos unha historia literaria interrompida, é probable que as rupturas cronolóxicas sexan frecuentes. En calquera caso, independentemente de que saibamos que rama vén antes 
ou vén despois, nestes dicionarios poden haber varios niveis de xerarquización, como se ve polos catro en que Onions dividiu os 12 sentidos da palabra whimsy (cfr. Berg 1993: 34) e casos parecidos a centos:

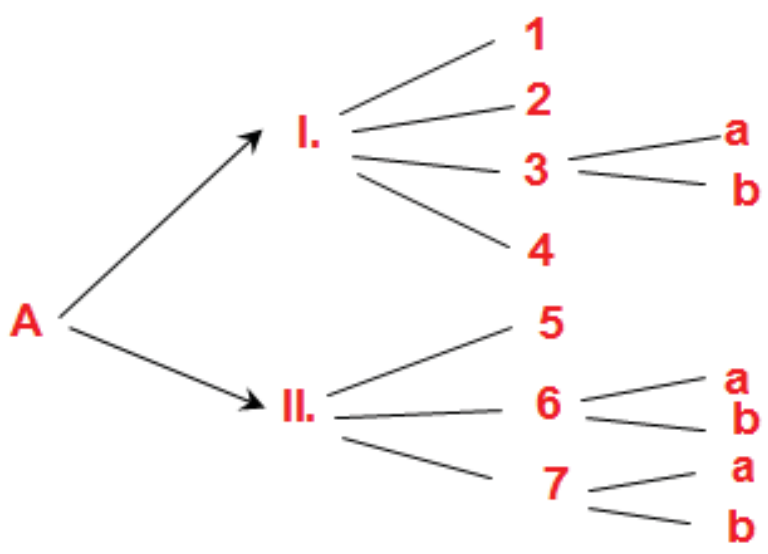

B

C

A outra parte importante da definición son os exemplos. Ilustrar con exemplos as definicións é unha práctica que se vén facendo desde o Renacemento para as linguas clásicas e xa desde o XVII para os dicionarios monolingües de linguas modernas. Aínda que Saussure cuñou a famosa frase de que un dictionnaire é un cemitière, a verdade é que isto é unha esaxeración, posto que é xusto nos dicionarios onde se ven claramente as dúas caras da súa dicotomía, por un lado a definición, que nos mostra cal é (ou foi no tempo) o nicho dunha palabra na langue, e por outro os exemplos, que son produtos reais onde se mostra a palabra funcionando na parole. Os exemplos veñen a ser para o lector como os testemuños de que a definición que elaborou o lexicógrafo responden a unha realidade non fabricada. Como di Imbs, nunha definición con exemplos o lector está á vez en presenza de esquemas abstractos e de modelos concretos, de maneira que en casos de dúbida pode ir dos esquemas ós modelos e confrontalos, e confrontalos aínda cos seus propios enunciados ou intuicións.

Canto ós exemplos cómpren tamén algunhas precisións. Nos baleirados manuais de textos os investigadores xa eran selectivos na recolla de datos, pois das palabras frecuentes non rexistraban senón mostras escolleitas; eran, en cambio, máis exhaustivos coas palabras de frecuencia menor ou obsoletas. Así quedaban os ficheiros desproporcionados (abundantes de palabras raras e escasos e palabras comúns). Os redactores do $O E D$, cando Murray se fixo cargo da redacción, tiveron que solicitar dos lectores que lles fichasen tamén as palabras frecuentes. Agora, cos balei- 
rados electrónicos, o vocabulario non leva filtros humanos (ou non leva máis filtros cós que lle queiramos impor á máquina) e poden aparecer todas as palabras dun corpus, cada unha coa súa frecuencia; iso quere dicir que palabras con moitas ocorrencias van ter moitas fichas e o problema convértese no contrario, ou sexa, nun exceso de documentación: palabras como ter, vir, haber..., e xa non digamos algunhas palabras gramaticais, que teñen decenas de millares de exemplos cada unha (polo menos para un corpus de cerca de 15 millóns, como é o noso moderno). Nestes casos o redactor do dicionario ten que operar só cunha mostra e aínda dela só lle pode trasladar ó lector un exemplario moi reducido.

Hai que ter en conta que os exemplos son os portadores dunha tradición e deben deixar ben manifesta a súa continuidade ou a súa ruptura. No OED insírense, ordenados cronoloxicamente, de dous a cinco exemplos por século. No DHLE danse tres ou catro por século e indícase que entre o século tal e cal hai máis de 124 fichas (ou as que sexan), para dar idea da frecuencia. Como o dicionario histórico debe dar conta da cronoloxía das palabras, é imprescindible que a primeira documentación sexa un dos exemplos.

Os textos ilustrativos, sempre que haxa abondos para escoller, deben mostrar a palabra en contextos sintagmáticos que permitan corroborar ben que a análise feita na definición é correcta (nunha entrada como ovo convén que entren exemplos que inclúan palabras como pita, poñer, niño, cesta, ducia, casca, xema, choco, cocido, estrelado, podre, goro...). Se por riba os exemplos ilustran as relacións paradigmáticas da palabra (sinónimos e antónimos), os dominios de uso ou os niveis de lingua, aínda mellor. Os textos en prosa sempre son preferibles ós textos en verso.

Para ser ben, os exemplos deben ser autenticamente históricos, ou sexa culturais, demostrativos de usos datados e vencellados ás condicións do medio (Imbs) de maneira que o dicionario de lingua se prolongue tanto como sexa posible nun dicionario de cousas, tanto da cultura material como espiritual. A lingua é un espello da cultura dun país e o dicionario a través das definicións e dos exemplos cumpre unha función antropolóxica (Lara 1990); iso é o que xustifica que poida haber, por exemplo, un Diccionario del español de México.

Nos dicionarios de autoridades os exemplos están escollidos cun criterio estético. De feito, quen non era bo escritor xa non era considerado "autoridade". O noso corpus non foi feito tomando como criterio a excelencia literaria dos testemuños. O corpus non é do galego literario (belles lettres), pois hai textos de moitos xéneros. Pero, aínda considerando textos que foron escritos con pretensións literarias, na escolla de 
autores para o corpus non fomos escrupulosos por razón de estética; consideramos que para dar testemuño da existencia dunha palabra tan bo era Xosé Baña Pose (=Pepe de Xan Baña) como Rosalía ou Cunqueiro. Con todo, habendo onde escoller (e sempre que outros criterios non o desaconsellen, por exemplo, a cronoloxía ou que o contexto sexa máis esclarecedor), será preferible dar exemplos de escritores bos, e non dos mediocres ou malos.

Sen dúbida o lemario do noso dicionario histórico vai ter un bo número de entradas que non proceden dun corpus, senón doutras obras lexicográficas anteriores (dicionarios, monografía, atlas, etc.). Na maioría dos casos -nunca no atlas- a palabra non está ilustrada con exemplo. Nestes casos o autor do dicionario poderá citar o exemplo do vocabulario orixinal se o ten, pero absterase de fabricar un exemplo. É ben sabido que entre os dicionarios de lingua hainos que optan por dar exemplos reais, pero outros prefiren fabricar os exemplos. Como un dicionario histórico non é un dicionario de lingua con vocación pedagóxica, limitarase a dar os feitos lexicográficos tal como os documenta.

Escusamos dicir que, calquera que sexa a calidade ou procedencia, as citas deben ir sempre coa referencia de fonte. As voces que procedan do ALGa ou doutro material dialectal deben indicar a localidade onde foron rexistradas.

Ademais da definición e dos exemplos (con outras informacións, rexistro dominio, etc.), dentro da sección semántica hai aínda outros apartados nos dicionarios históricos; é o ocupado polas locucións ([saber algo] polo libro 'con todos os pormenores'), combinacións frecuentes (libro do profesor, libro do alumno, libro de instrucións...) e derivados (libres$c o$ ). Non é este o lugar de discutir sobre o problema das locucións, senón sobre o lugar onde se colocan nun dicionario histórico. Como se sabe, non teñen entrada propia; dáselles entrada debaixo da palabra principal (ou de maior carga semántica) da locución. O OED agrúpaas todas despois da última acepción. Podería facerse seguramente doutra maneira (por exemplo, cada locución debaixo da acepción que correspondese), pero supoñemos que iso ten dificultades, porque ás veces non é doado decidir a que acepción corresponde a palabra nuclear da locución.

Ademais das locucións, e a seguir (no OED ou no DHLE), inclúense tamén frases proverbiais (do tipo [ser] antes o ovo ou a galiña para referirse a algo cuxa precedencia é dubidosa).

E finalmente poden (e algúns dicionarios fano) incluír unha serie de colocacións (ou expresións plurirremáticas). Nunha entrada como antena (na acepción de ‘aparello de telecomunicación’) deberán figurar antena 
de recepción, de emisión, parabólica, colectiva, individual, interior, telescópica, aínda que ningunha das expresións necesite definición, porque o seu significado vén cadrando co da suma dos dous elementos.

En canto ós derivados, como xa se dixo, algúns teñen entrada como lemas separados se teñen usos lexicalizados independentes (librillo ou librito ou mesmo libriño 'o de follas de papel de arroz para lear cigarros'). En cambio, lístanse dentro da entrada, sen definición ningunha, ordenados alfabeticamente e seguidos por unha lista de exemplos, naqueles casos en que o derivado se forma cun prefixo ou un sufixo produtivo e de significado transparente para un nativo; e aquí van todos os apreciativos (-iño, -azo...) e aínda outros do tipo -ble, -idade, -izar, des-, re- (educable, galeguidade, galeguizar, desensarillar, recolocar). Non está moi definido na práctica lexicográfica, con todo, qué derivados teñen entrada e cales se colocan como apéndice dunha entrada; se fosen todos sufixos non presentarían moitas dúbidas (entre outras razóns porque a súa colocación nun dicionario alfabético xa sería contigua á entrada); pero ó haber prefixos, que mandan os derivados a maior parte das veces moi lonxe dos primitivos, obriga a darlles entrada ós derivados aínda que só sexa como referencia cruzada. Nos próximos dicionarios de feitura electrónica este problema da colocación vai desaparecer e mesmo os derivados prefixados poden ter unha remisión interna doada.

Aínda nos queda outra observación que facer referente á parte dos contidos (ou sense section) do dicionario. Ata hai pouco o dicionario por antonomasia viña sendo unha obra en soporte papel que se organizaba en artigos encabezados por unha palabra que, entre outras funcións, tiña a de facilitar a busca nunha organización alfabética. Por iso, a gran maioría dos dicionarios eran semasiolóxicos, ou sexa, ían da palabra para o significado. Pero agora as ferramentas informáticas permiten recuperar a información de moitas outras maneiras. Para poñer un exemplo sinxelo, a palabra choco, que vimos antes no sintagma ovo choco, só se podía buscar en choco (claro que se podería buscar noutras partes do dicionario, pero sería obrigatorio ler o dicionario enteiro). Nun dicionario electrónico, supoñendo que se planifique ben e que se lle fabrique un motor de busca adecuado, poderiamos atopar a palabra choco en calquera outro lugar, e especialmente nas referencias paradigmáticas (hiperónimos, hipónimos, sinónimos, antónimos ou simplemente palabras de significado afín: goro, galeado, fecundo...) que se incluísen nas definicións; e tamén nas secuencias sintagmáticas que se usasen de ilustracións, como poden ser os exemplos incluídos en sintagmas tales coma pita, galiña, ovo, auga, caldo, campá, voz, lata, neboeiro... + choco/a. Un e outro tipo de relacións pode 
mostrarse simplemente nunha restra de colocacións como fai o TLF ${ }^{13}$, en vez de usar un exemplo para cada unha. O ordenador encargaríase de informarnos de que choco aparece nunha entrada, pero tamén nas entradas pita, ovo, auga, etc., formando sintagmas con elas; ou en goro, fecundo, etc., coas que forma un paradigma. Isto que xa se fai agora nas consultas complexas dos dicionarios electrónicos. Probablemente se podería completar con algún sistema que marcase o campo nocional a que pertence cada palabra (ou no seu caso cada acepción). Desta maneira podería facerse por exemplo unha busca de todos os lemas que incluísen na definición o hiperónimo "peixe”; sería cuestión de establecer unha arborización xerárquica de campos ou utilizar algunha xa fabricada, como a dos dicionarios ideolóxicos, ou o Begriffsystem de Hallig / Wartburg (1952), ou o wordnet, e usar definidores de maneira consistente. E así podería conseguirse unha explotación onomasiolóxica (da idea á palabra) do dicionario, útil entre outras cousas para facer etimoloxías.

6. E vén agora a parte máis delicada do dicionario (polo menos do noso), que é a súa fabricación e viabilidade.

Polo que dixemos nesta mesma contribución, o primeiro paso está dado: o material sobre o que facer o dicionario existe xa, pois co TMILG e co TILG, que xuntan entre os dous máis de 20 millóns de rexistros, hai un carozo máis que representativo para comezar. É verdade que hai outros córpora complementarios non integrables no mesmo ficheiro, como son o CORGA, os varios córpora da Universidade de Vigo ${ }^{14}$ e, ademais, o CODOLGA, e aínda probablemente outros que nin están situados en Galicia (especialmente para o galego antigo). A experiencia dirá cando o solapamento é total ou cando vai ser necesario botar man de datos alleos. Por outro lado, se consideramos os dicionarios como corpus, temos xa unha boa parte deles reunidos nos dous dicionarios de dicionarios, moderno e medieval (Santamarina 2003b e González Seoane 2006). Sería desexable que os diferentes córpora, tanto de textos como de dicionarios, se integrasen nunha única base de recursos, e iso é posible que suceda antes de dous anos. É verdade que hai dispersa outra documentación, ás veces dentro da mesma casa, como é a do ALGa ou do Arquivo Dialectal (que habería que pór en formato integrable ou polo menos manexable); outra veces o material está fóra do ILG e aínda non dispoñible de todo, como

13. Euf d'autruche, de cane, de merle, d'oie, de pigeon, de poule; pondre, couver un oeuf; couvaison, incubation, éclosion de l'oeuf... OEuffrais, gâté, pourri; oeuf du jour; blanc d'oeuf; jaune d'oeuf; gober un oeuf cru; mirer un oeuf; coquille d'oeuf (en parlant d'une couleur); boîte à oeufs.

14. Véxase, neste mesmo volume, o traballo de Gómez Guinovart. 
pode ser o procedente do refraneiro e do dicionario de fraseoloxía. E finalmente algunha información está aínda en fontes dispersas e difíciles de recoller, por exemplo a que figura en textos redactados en castelán, que insiren palabras referidas a institucións galegas que non teñen tradución ou que, se a teñen, lle era descoñecida ó usuario. É unha dispersión algo embarazosa, pero creo que as cousas hai que velas polo lado positivo e considerar como corpus básico o TILG e o TMILG e os dicionarios de dicionarios, e considerar os outros como contrapuntos que poden permitir unhas veces comprobacións e outras completar os datos propios. En calquera caso, os vimbios para facer o cesto xa están xuntos (ou case), non hai que ir ó monte por eles; a obra da cesta está nun estadio en que case se pode comezar a tecer.

Agora, podemos formular unha pequena batería de preguntas que non son doadas de responder. Entre elas as seguintes: (a) quén fai o dicionario histórico, (b) ónde se fai, (c) cánto vai levar facelo, (d) cánto vai custar facelo e tamén (e) cómo se fai.

(a) A primeira pregunta é quizais a máis doada de contestar porque hoxe son moitos os que neste país saben como se fai (e tamén como non se debe facer) un dicionario. En principio, parece que algunha responsabilidade deberían de ter os que se ocuparon previamente de organizar os córpora de base, pero non necesariamente só eles. O que está claro é que a duración da obra vai depender directamente do número e preparación e dedicación das persoas que traballen nela. Iso quere dicir que o razoable sería que houbese un equipo estable que, como pedía Julio Casares (desenganado de ver como os membros do seu equipo se ían marchando despois de estaren preparados), estea "decorosamente pagado". Hai que ter en conta, de todas maneiras, que agrupar por afinidades os diferentes valores dunha palabra e facer despois as súas definicións é un traballo delicado para o que non todos valen, e daquela a escolla dos membros do equipo debe efectuarse despois de avaliados adecuadamente os talentos de cada un. Entre os fabricantes do dicionario non esquezamos que hai unha parte informática que debe ocupar un profesional competente.

(b) A segunda pregunta (ónde se fai), no caso dunha lingua coma a nosa, hai que responder dicindo que no seo dunha institución académica. Un particular ou unha institución privada con ánimo de lucro nunca vai embarcarse nunha empresa destas características, porque é o mesmo que embarcarse nunha empresa de perdas millonarias; quen pense na posibilidade de que apareza un mecenas privado, sexa persoa ou fundación, disposto a perder cartos pola cultura do país está botando as contas da leiteira, 
porque esa é unha especie extinguida, ou, se a hai, é intereseira. Daquela quedan só dúas institucións que poidan facelo, ou a Universidade (enténdese universidades, que hai tres) ou a Academia, ou as dúas. Naturalmente, hai a posibilidade de que se faga só na Universidade de Santiago de Compostela, e máis concretamente no ILG, pois é en definitiva onde están os córpora principais. Isto ten inconvenientes insuperables por dous lados; en primeiro lugar, porque o ILG non é como o CSIC, onde pode haber un grupo de investigadores sen docencia a tempo completo dedicados exclusivamente a iso; ou sexa, é inviable que a USC (ou as tres universidades se algún día o ILG pasa a interuniversitario) poida convocar catro ou cinco prazas de lexicógrafo. Igualmente, a posibilidade dun proxecto de investigación dentro do ILG ou dun convenio tampouco é viable á vista de como está a política de investigación neste país, onde os convenios van de ano en ano e non se pode garantir unha estabilidade, e os proxectos competitivos a nivel autonómico ou estatal, aínda que poden ser por tres anos, non permitirían contratacións "decorosas" para persoas co nivel de preparación requirido por un proxecto deste tipo (á parte de que nos proxectos estatais están excluídos os dicionarios). Así é que, na miña opinión, de ser unha empresa realizable, só podería ser a través dunha colaboración entre a Academia e o ILG. A Academia ten entre os seus cometidos fundacionais a compilación dun dicionario. Claro que a Academia podería optar por facelo ela soa, e estaría no seu dereito, pero sería bastante absurdo que volvese a empezar de cero e empezase a compilar un corpus no que se leva máis de 20 anos traballando e que xa está feito. Poñéndonos no mellor dos casos, que entre a Academia e o ILG houbese un acordo de colaboración, o problema do financiamento persistiría porque a Academia tería que negociar á súa vez con outras institucións o financiamento. Iso vén a ser como pasarlle o morto a outro. De todas maneiras, cremos que a Academia está en mellor situación de conseguir un financiamento, pois, tendo en conta que as leis lle deron a potestade en materia lingüística, tamén deberían darlle os medios para que fabrique os recursos lingüísticos adecuados. Neste ano do centenario en que todos son a recoñecerlle unha autoridade ben ou mal gañada, sería esperable que lle recoñecesen tamén un orzamento axeitado. Lembrei antes que o Ministerio de Educación lle concedeu unha renda anual de 1.2 millóns de euros á RAE mentres duren os traballos do dicionario histórico do español (e non é unha cifra incompatible cos donativos de institucións privadas ou de mecenas individuais). No noso caso, por parte dos poderes públicos (galegos e estatais) a política é ter amarrada a Academia por convenios anuais en vez de asegurarlle unha cantidade anual fixa nos orzamentos da Comunidade Autónoma; pero iso é unha dinámica que conviría 
romper e asegurarlle á RAG por algún organismo da administración un financiamento de longa duración. En calquera caso, a RAG está en mellores condicións de conseguir ese financiamento do que o ILG. Pero así como case se pode garantir que a RAG diría si ó proxecto común, non está tan claro claro que as institucións autonómicas e estatais estean dispostas a concederlle un financiamento axeitado. No prólogo do WNT dicía Matthias deVries que "a lingua é a alma da nación; é a nación mesma" (apud Osselton 2000: 68). No noso caso, se se mira a lingua con tantas reticencias como a nación, a cousa pode ir para largo.

(c) Canto vai levar facelo? Pois depende de canta xente traballe, e á súa vez isto depende do financiamento que haxa, entre outras cousas máis. En xeral, estas obras nunca duran o que se calcula, entre outras razóns porque non se pode facer ben o cálculo mentres non se entre en materia, ou sexa, se saiba cantos lemas hai que definir e que cantidade media de lemas pode definir cada redactor por ano. Os calculadores sempre pecan de optimistas. Para que se vexa o enganosos que son os cálculos a priori vede na seguinte táboa a diferenza que houbo entre o tempo previsto e o tempo real das seguintes empresas:

\begin{tabular}{|l|l|l|c|c|c|}
\hline Dicionario & Comezo & Fin & Anos previstos & Anos reais & Veces o previsto \\
\hline DWB & 1838 & 1961 & 10 & 123 & 12,3 \\
OED & $1876(1858)$ & 1928 & 13 & 52 & 4 \\
WNT & 1852 & 1998 & 25 & 146 & 5,84 \\
SAOB & 1883 & 2017 & 12 & 166 & 13,8 \\
ODS & 1901 & 1956 & 12 & 55 & 4,5 \\
NO & 1930 & 2014 & $?$ & 84 & $?$ \\
DCVB & 1901 & 1962 & $?$ & 61 & $?$ \\
\hline
\end{tabular}

Outras empresas resultaron peor, como é o caso do DHLE, que dúas veces consecutivas non pasou do volume II.

Agora comprenderase por que o ILG ten difícil embarcarse só nunha empresa coma esta; aínda o ten difícil a Academia se vai negociar un convenio cunha Consellaría ou cun Ministerio se se presenta cunha memoria na que se inclúa a táboa anterior.

Con todo, cremos que o galego está nunha situación máis favorable cás linguas anteriores con vistas a facer un dicionario histórico en tempo breve, entre outras razóns porque non é unha lingua tan "copiosa" (non podemos fachendear diso) coma as dos arredores. A nosa literatura é pequena e lacunosa; as nomenclaturas de oficios son escasas, o uso do ga- 
lego nas ciencias foi cativo, así é que o número de lemas rexistrado nos nosos córpora vai ser bastante menor; menor incluso có do catalán. Iso pode poñernos no equivalente a cinco ou seis volumes do $D C V B$, supoñendo que se fixese en papel. Téñase en conta ademais que o noso corpus está feito; para os dicionarios da táboa anterior a data de inicio é a que corresponde á de comezo do baleirado de textos; tal como están as cousas nós poderiamos comezar xa os traballos de redacción en poucos meses. Por outra parte, habería que imitar máis ben ós que buliron que non ós que buliron pouco ou traballaron con interrupcións (a pesar deles). O TLF comezouse en 1957, apareceu o $1^{\circ}$ volume en 1971 e rematou en 1994 (47 anos); o GDLI empezou a publicarse en 1961 e rematou en 2002; o WAT (do afrikaans) vai ben de ritmo. Así é que, poñámonos no mellor dos casos, con cinco redactores full time máis os que xa gañen un soldo por outro lado (na universidade por exemplo) e poidan dar cheda na obra do dicionario, en 10 anos poderían ter redactado un bo carozo del. Dentro dun pouco diremos unhas palabras sobre como se fai e volveremos sobre isto. Sexa como for, o tempo que leve facelo vai depender da cantidade de xente que traballe e de que traballe coa dedicación esperada. O detallismo con que se faga tamén pode influír na duración; se cadra é mellor nunha primeira edición sacrificar algún pormenor secundario.

(d) Canto vai custar? Depende da cantidade de xente que traballe nel e do tempo que leve rematalo. Cos datos que dei antes pode calquera botar a conta: cinco lexicógrafos e un informático con dedicación exclusiva poden levantar un 300 mil euros ó ano. Se son 10 anos son 3 millóns de euros dos de hoxe. Dáse por sentado que os académicos ou membros da universidade que poidamos traballar niso sería a base de prestacións voluntarias. Na miña opinión, son cifras asumibles e quen se asuste dese monto ten que saber que é un traballo que se pagaría moi xenerosamente con que lle dedicasen unha cuarta parte do que se queima cada ano en fogos ó Apóstolo (e podería poñer moitos máis exemplos de foguetería similar que non dá proveito a ninguén ou dá un proveito ben escaso e efémero). Damos por suposto que o resultado vai ser consultable en principio só por Internet e daquela non haberá gastos adicionais en papel, impresión e encadernación.

(e) Como se fai? Contestar esta pregunta sería o mesmo que ter xa un manual de instrucións de como facelo, cousa que aínda non está pensada nos pormenores (que van ser moitos, e moitos deles só van xurdir e se poderán resolver cando se entre en materia). Non vou facer senón dúas observacións relacionadas coas tecnoloxías actuais e que poden facer máis viable o proxecto, adecuándoo en cada caso á dispoñibilidade de medios. 
En primeiro lugar, temos que asumir que o tempo dos dicionarios en papel pasou á historia; a nosa empresa non pode ser como a de a de Aguilar (DEA), ou a de UTET (GDLI), ou a da OUP (OED), que tentan sacar beneficio do moitísimo diñeiro investido; os resultados da nosa empresa serán de uso gratuíto como son as beirarrúas ou o paseo da Ferradura; o uso por Internet eliminará a carga de ter que facer un exemplar para cada contribuinte galego. É de supoñer, con todo, que vai haber fanáticos da letra impresa aínda por un tempo, e para estes haberá que facilitar ferramentas que lles permitan cargar e imprimir e encadernar pola súa conta parte da obra ou a obra enteira se queren.

Outra observación. Os dicionarios dos séculos XIX e XX (anteriores a 1961) había que facelos necesariamente en papel e ilos publicando por volumes ou por fascículos, e ademais seguindo a ordenación alfabética. Iso implicaba ter que redactar a entrada ábaco antes cá entrada abade (ou polo menos todas as palabras do fascículo I antes de entrar no II, pois había que imprimilos e encadernalos). O soporte electrónico vai permitir que a redacción se poida empezar por calquera sitio do alfabeto e seguindo a orde que sexa máis axeitada, se cadra unhas veces por campos léxicos e outras por familias de palabras, pero sempre guiados por criterios non alfabéticos. Iso vai permitir que nos centremos de entrada nas 20 ou 25 mil palabras patrimoniais, é dicir, aquelas palabras que se manifestan dentro de estruturas lexicais complexas, e que deixemos para o final a terminoloxía e as nomenclaturas (sempre cando non se refiran a realidades da cultura espiritual ou material galega). Noutras palabras, o usuario dun dicionario histórico galego vai estar sempre máis interesado en atopar nel palabras como abondo, acabar, anciño, afogar, alumar ou ali (e podemos incluír nesta lista tamén palabras do galego antigo xa desaparecidas como cócedra ou concambiar) do que palabras como abrasivo, acarofobia, acetileno, agaricáceas ou albuminasa. Todas as palabras do segundo grupo, que teñen interese por moitas outras razóns, son fabricacións máis ou menos antigas que se poden atopar nos dicionarios de calquera lingua e teñen unha definición que é traducible literalmente dunha lingua para outra. Por iso os primeiros dicionarios (Vocabolario della Crusca 1612, Dictionnaire de l'Académie Française 1694, Diccionario de Autoridades 1726) non incluían o vocabulario des arts e des métiers, e aínda hoxe son un problema para dicionarios con vocación exhaustiva como o OED ou o TLF, conforme vimos, porque universalismos destes hainos a millóns e naturalmente non se pode facer un dicionario dun millón de palabras. Desta maneira, podería ir montándose gradualmente un dicionario partindo do vocabulario máis representativo da etnicidade galega e ir engadíndolle materiais conforme se fose dispondo de medios. Propoño, como 
se ve, comezar polo máis urxente; se se procede así, forzosamente o noso dicionario histórico nun principio vaise parecer máis ós glosarios suízos ca ós dicionarios históricos das grandes linguas; pero a nosa aspiración deber ser que entre todo, tanto alumar como albuminasa.

Aínda quero engadir un comentario sobre a estratexia de fabricación do dicionario, e neste caso a inspiración debémoslla á intervención de Pär Larson. Como se dixo, debe de haber un equipo de redactores permanentes (catro ou cinco, podendo ser); estes redactores traballarían a tempo completo, como contratados pola institución que faga o dicionario, baixo a responsabilidade dun editor, que supervisaría o seu traballo e trataría de que fose o máis homoxéneo posible de acordo cos canones lexicographici previamente formulados polo editor ou editores. Cada entrada iría asinada polo seu redactor; en caso de que fose revisada por outra persoa que non sexa o editor (ou un dos editores) tamén constaría o seu nome; o visto e prace final para a inclusión dunha entrada definitivamente na base de datos debe dalo o editor (ou un dos editores, se hai máis de un).

Fóra dese núcleo reducido de redactores podería contarse tamén coa colaboración de redactores espontáneos; se se fai a través dunha colaboración entre o ILG e a Academia poderían ser académicos ou investigadores do ILG, pero non só; calquera filólogo onde queira que estea (dentro das universidades galegas ou fóra delas, ou mesmo no estranxeiro). A estes colaboradores internos e externos proporcionaríanselles as instrucións necesarias de cómo redactar unha voz, o acceso ás bases de datos e unha plataforma informática con folla de estilo, etc. na que introducir os datos. Igual que no caso dos redactores permanentes serían responsables da entrada e asinaríana (deixando tamén constancia do nome do revisor, se o houbo). Tamén coma no caso anterior un editor daría o visto e prace final para que a voz fose definitivamente engadida á base de datos definitiva.

Outras observacións sobre o "como" deixámolas para o manual de redacción se algún día se fai.

Con isto damos remate á esta contribución. Ó longo dela creo que demos noticia suficiente sobre a necesidade dun dicionario histórico, os materiais de que dispoñemos, os medios humanos e institucionais de que se dispón (ou que fan falta) e as dificultades que hai para inicialo e levalo a cabo. Demos tamén algunha noticia sobre a art and craft necesaria para facelo.

Como se pode ver, para esta obra non propoñemos ningunha innovación metodolóxica revolucionaria; no século XX e aínda no XIX xa se produciron moitos dicionarios que cumprían os requisitos de obras ben 
feitas e seguen a ter un valor insustituíble na actualidade. A pretensión dos galegos para o século XXI é ter por fin obras, e en concreto un dicionario histórico, que cumpra eses estándares e que se acabe antes de que se cumpra o primeiro cuarteirón do século. Nunca tan cerca se estivo de poder botalo a andar; esperemos que se poida facer. 


\section{BIBLIOGRAFÍA CITADA}

A.J. (1701): A compleat account of the Portugueze language, being a copious dictionary of English with Portugueze, and Portugueze with English. With an Easie And Unerring Method of its Pronunciation. London: R. Janeway [Edición facsimilar de R. C. Alston, Menston: Scolar Press, 1970].

Academia das Ciências (1793): Diccionario da lingoa portugueza / publicado pela Academia Real das Sciencias de Lisboa. Lisboa: Officina da mesma Academia. [Edición facsimilar de 1993].

Academia das Ciências (1940): Vocabulário Ortográfico da Língua Portuguesa. Lisboa: Imprensa Nacional.

Academia das Ciências (1947): Vocabulário ortográfico resumido da língua portuguesa. Lisboa: Imprensa Nacional.

Academia das Ciências (1970): Vocabulário ortográfico resumido da língua portuguesa. Lisboa: Imprensa Nacional.

Academia das Ciências (1976): Dicionário da Língua Portuguesa. Lisboa: Imprensa Nacional-Casa da Moeda.

Academia das Ciências (2001): Dicionário da Língua Portuguesa Contemporânea. 2 vols. Lisboa: Verbo.

Acevedo y Huelves, Bernardo / Marcelino Fernández y Fernández / Ignacio Aguilera (ed.) (1932): Vocabulario del bable de occidente. Madrid: Junta para Ampliación de Estudios e Investigaciones Científicas, Centro de Estudios Históricos. [Incluído en Santamarina (2003b)].

Acosta, Cristóbal (1578): Tractado Delas Drogas, y medicinas de las Indias Orientales, con sus Plantas debuxadas al biuo por Christóual Acosta médico y cirujano que las vio ocularmente. En el qual se verifica mucho de lo que escriuió el Doctor García de Orta. Burgos: Martín de Victoria.

Adamo, Giovanni / Valeria della Valle (2003): Neologismi quotidiani. Un dizionario a cavallo del millenio 1998-2003. Firenze: Olschki Editrice. 
Adelung, Johann Christoph (1774-1786): Grammatisch-kritisches Wörterbuch der hochdeutschen Mundart. 5 vols. Leipzig: Breitkopf \& Sohn; $1793-1802^{2}$ (4 vols.).

Adler, Ada (ed.) (1928-1938): Suidae Lexicon. 5 vols. Stuttgart: Verlag Teubner. Aguiló i Fuster, Marian (1915-1934): Diccionari Aguiló. Materials lexicografics aplegats per Marian Aguiló i Fuster, revisats y publicats sota la cura de Pompeu Fabra i Manuel de Montoliu. 8 vols. Barcelona: Institut d'Estudis Catalans.

Alcalá, Pedro de (1505): Vocabulista aráuigo en letra castellana. Granada: Juan Varela de Salamanca.

Alcover, Antoni Maria (1911): “Crònica de la Secció Filològica de l'Institut d'Estudis Catalans", Bolletí del Diccionari de la Llengua Catalana VI, 20, 368-372.

Alcover, Antoni Maria (1920): "Triunf definitiu, absolut i consumat de l'obra de Diccionari dins les Corts d'Espanya...", Bolletí del Diccionari de la Llengua Catalana 3, 65-180.

Aldrete, Bernardo de (1606): Del origen y principio de la lengva castellana o romance que oi se usa en España. Roma: Carlos Willeto. [Ed. facsimilar con estudo de Lidio Nieto, Madrid: CSIC, 1972].

Alewyn, Abraham / Joannes Collé (1714): Tesóuro dos Vocábulos Das dûas Línguas Portuguéza, e Bélgica; Em que circunstanteménte se demõstrão as sinificaçoës das Palávras Poruguézas segúndo a abundáncia da Belgica siéncia da Linguágem; Hüa óbra, geralménte, Péra tódos os amadóres das ámbas Linguas, e Principalménte Péra ós ensinadóres e discípúlos das mésmas grandeménte proveitósa. Amsterdam: Pieter vanden Berge.

Almeida, Átila (1988): Dicionários parentes e aderentes. Uma bibiliografia de dicionários, enciclopédias, glossários, vocabularios e livros afins em que entra a língua portuguesa. João Pessoa: FUNAPE/Nova Stela.

Alonso Ramos, Margarita (1994-1995): "Hacia una definición del concepto de colocación: de J. R. Firth a I. A. Mel'čuk”, Revista de Lexicografia 1, $9-28$.

Alonso y de los Ruizes de Fontecha, Juan (1606): Diez previlegios para las mujeres preñadas. Alcalá: Luys Martynez Grande.

Alonso, Amado (1951): Rec. de Gili Gaya (1947-1957), en NRFH V, 3, 324-328.

Alvar Ezquerra, Manuel (1992): "La Janua Linguarum de los jesuitas irlandeses de Salamanca”, en José Antonio Bartol Hernández / Juan Felipe García Santos / Javier de Santiago Guervós (eds.): Estudios filológicos en homenaje a Eugenio de Bustos Tovar. Vol. I. Salamanca: Universidad, 61-64.

Alvar Ezquerra, Manuel (1993): Lexicografía descriptiva. Barcelona: Biblograf. 
Alvar Ezquerra, Manuel (1996): “El Tesoro del andaluz”, en Ignacio Ahumada (ed.): Vocabularios dialectales. Revisión crítica y perspectivas. Jaén: Universidad, 43-58.

Alvar Ezquerra, Manuel (2000): Tesoro léxico de las hablas andaluzas. Madrid: Arco/Libros.

Alvar Ezquerra, Manuel (2002): "El diccionario de Richard Percyvall", en Carmen Saralegui Platero / Manuel Casado Velarde (eds.): Pulchre, bene, recte. Estudios en homenaje al Prof. Fernando González Ollé. Pamplona: Universidad de Navarra/Gobierno de Navarra, 49-71. [Recollido en De antiguos y nuevos diccionarios del español. Madrid: Arco/LibrosAgencia Española de Cooperación Internacional, 2002, 170-190].

Alvar Ezquerra, Manuel (2002-2004): "Léxico español en la Historia animalium de Conrad Gesner”, Archivo de Filología Aragonesa, 59-60, 149-167.

Alvar Ezquerra, Manuel (2003a): "Estado actual del Nuevo Tesoro Lexicográfico del Español (s. XIV-1726): repertorios posteriores a 1600", en María Antonia Martín Zorraquino / José Luis Aliaga Jiménez (eds.): La lexicografía hispánica ante el siglo XXI. Balance y perspectivas (Actas del Encuentro de Lexicógrafos celebrado en Zaragoza en el marco del Centenario María Moliner, los días 4 y 5 de noviembre de 2002). Zaragoza: Gobierno de Aragón-Institución “Fernando El Católico", 25-49.

Alvar Ezquerra, Manuel (2003b): "El Nuevo Tesoro Lexicográfico del Español (s. XIV-1726) y los diccionarios con las lenguas románicas", en Actas de la III Escuela Interlatina de Altos Estudios en Lingüistica Aplicada. La lexicografía plurilingüe en lenguas latinas: patrimonio, actualidad, perspectivas (San Millán de la Cogolla, 22-25 de octubre de 2003), no prelo.

Alvar Ezquerra, Manuel (2004): "El Nuevo Tesoro Lexicográfico del Español (s. XIV-1726): repertorios anteriores a 1600", en Paz Battaner / Janet DeCesaris (eds.): De Lexicografia. Actes del I Symposium Internacional de Lexicografia (Barcelona, 16-18 de maig de 2002). Barcelona: Universitat Pompeu Fabra, Institut Universitari de Lingüística Aplicada, 19-38.

Alvar Ezquerra, Manuel (2006a): “Un proyecto en marcha: el Nuevo Tesoro Lexicográfico del Español (s. XIV-1726)”, en Javier Rodríguez Molina / Daniel Sáez Rivera (coords.): Diacronía, Lengua Española y Lingüistica. Actas del IV Congreso Nacional de la Asociación de Jóvenes Investigadores de Historiografía e Historia de la Lengua Española (Madrid, 1, 2 y 3 de abril de 2004). Madrid: Síntesis, 43-61.

Alvar Ezquerra, Manuel (2006b): "Léxico del Tractado de las drogas y medicinas de las Indias Orientales de Cristóbal Acosta", Verba 33, 7-30.

Alvar Ezquerra, Manuel (2006c): "Cambios en el léxico español del Vocabulista de fray Pedro de Alcalá (1505)", en Actas del II Congreso Interna- 
cional de Lexicografía Hispánica. Alicante, 19-23 de septiembre de 2006, no prelo.

Alvar Ezquerra, Manuel / Lidio Nieto Jiménez (2003): "El español americano en A spanish and english dictionary de John Stevens", en Francisco Moreno Fernández / Francisco Gimeno Menéndez / José Antonio Samper / Ma Luz Gutiérrez Araus / María Vaquero / César Hernández (coords.): Lengua, variación y contexto. Estudios dedicados a Humberto López Morales. Vol. I. Madrid: Arco-Libros, 81-103.

Alvar Ezquerra, Manuel / Lidio Nieto Jiménez (2006): "La edición del Nuevo Tesoro Lexicográfico del Español (s. XIV-1726)", en Elisa Corino / Carla Marello / Cristina Onesti (eds.): Atti del XII Conreso Internazionale di Lessicografia. Torino, 6-9 settembre 2006. Proceedings XII Euralex International Congress. Torino, Italia, September 6th-9th, 2006. Alessandria: Edizioni dell'Orso, 365-370.

Amato Lusitano (1553): In Dioscoridis Anazarbei de medica materia libros quinque, Amati Lusitani, doctoris medici ad philosophi celeberrimi, enarrationes eruditissimae. Venecia: Gualterum Scotum.

Ameno, Francisco Luís (1781): Diccionário exegético. Lisboa: Offic. Patr. de Francisco de Luiz Ameno.

Angelis, Victoria de (1977-1980): Papiae Elementarium. 3 vols. Milán: Cisalpino Goliardica.

Anónimo (1554a): A very profitable boke to lerne the maner of redyng writyng \& speakyng english \& Spanish. Libro muy prouechoso para saber la manera de leer, y screuir, y hablar Angleis, y Español. Londres: John Kyngston \& Henry Sutton para John Wyght. [Ed. facsimilar en Menston: Scolar Press, 1971].

Anónimo (1554b): The boke of Englysche and Spanysche. Londres: Robert Wyer. [Ed. facsimilar en Menston: Scolar Press, 1971].

Aramon i Serra, Ramon (1982): "Pompeu Fabra i l'Institut d'Estudis Catalans", in Homenatge a Pompeu Fabra, President del Patronat de la Universitat Autónoma de Barcelona (1933-1939) en complir-se 50 anys de la publicació del Diccionari General de la Llengua Catalana i de les Normes de Castelló de la Plana (Acte inaugural del curs 1982-83). Barcelona: Universitat, 23-39.

Azorín Fernández, Dolores (2000): Los diccionarios del español en su perspectiva histórica. Alicante: Universidad.

Bacelar, Bernardo de Lima e Melo (1783): Diccionario da lingua portugueza. Lisboa: Of. de Jozé de Aquino Bulhoens.

Bacelar, Bernardo de Lima e Melo (1784): Arte, e diccionario do commercio, e economía portugueza. Lisboa: Of. de Domingos Gonsalves. 
Bacelar do Nascimento, Maria Fernanda et al. (1984): Português Fundamental. Vol. 1. Vocabulário e Gramática. Lisboa: INIC/Centro de Linguística da Universidade de Lisboa.

Bacelar do Nascimento, Maria Fernanda et al. (1987): Português Fundamental. Vol. 2. Métodos e documentos. Lisboa: INIC/Centro de Linguística da Universidade de Lisboa.

Balbus, Johannes (1286): Catholicon. Ed. incunabular en Maguncia (1460).

Baldinger, Kurt / Denis Gendron / Georges Staka (1974-2006): Dictionnaire étymologique de l'ancien français. Ouebec / Tübingen / Paris: Presses de l'Université Laval / Niemeyer / Klincksieck.

Barbosa, Jerónimo Soares (1822): Grammatica philosophica da lingua portugueza ou principios da grammatica geral aplicados à nossa linguagem. Lisboa: Academia Real das Sciencias.

Barreto, Manuel (1607): Vocabulario Lusitanico Latino composto na Provincia de Japão. 3 vols. manuscritos (Biblioteca da Academia das Ciências de Lisboa).

Berg, Donna Lee (1993): A Guide to de Oxford English Dictionary. The essential companion and user's guide. Oxford: Oxford University Press.

Blancas, Gerónimo de (1641): "Índice donde se declaran algunos vocablos aragoneses antiguos", en Coronaciones de los sereníssimos reyes de Aragón. Zaragoza: Diego Dormer.

Bluteau, Rafael (1712-1728): Vocabulario Portuguez e Latino, Aulico, Anatomico, Architectonico, Bellico, Botanico [...], autorizado com exemplos dos melhores escritores portuguezes, e latinos, e offerecido a ElRey de Portugal, D.Joaõ V pelo Padre D.Rafael Bluteau. Coimbra: Collegio das Artes da Companhia de Jesus / Lisboa: Joseph Antonio da Silva, 1712 (vols. I e II, A, B-C), 1713 (vols. III e IV, D-E, F-I), 1716 (vol. V, K-N), 1720 (vols. VI e VII, O-P, O-S), 1721 (vol. VIII, T-Z), 1727 (suplemento I), 1728 (suplemento II). [Reimpresión en Hildesheim: Georg Olms, 2002. Edición en CD-Rom da Academia Brasileira de Letras, 2003].

Bluteau, Rafael (1714/1728): Prosas portuguesas. 2 vols. Lisboa: José António da Silva.

Bosque, Ignacio (1982): “Sobre la teoría de la definición lexicográfica”, Verba 9, 105-123.

Bosque, Ignacio (2004): REDES. Diccionario combinatorio del español contemporáneo. Madrid: Ediciones SM.

Bosque, Ignacio (2006): "Una nota sobre la relevancia de la información sintáctica en el diccionario”, en Elisenda Bernal / Janet DeCesaris (eds.): Palabra por palabra. Estudios ofrecidos a Paz Battaner. Barcelona: Institut Universitari de Lingüística Aplicada, 47-53. 
Boulanger, Jean-Claude (1989): "L'évolution du concept de néologie de la linguistique aux industries de la langue", en Caroline de Schaetzen (ed.): Terminologie diachronique. Actes du Colloque organisé à Bruxelles les 25 et 26 mars 1988. Paris / Bruxelles: Conseil International de la Langue Française / Ministère de la Communauté Française de Belgique, 193-211. [Trad. ao galego como "A evolución do concepto de neoloxía: da lingüística ás industrias da lingua”, in Xosé María Gómez Clemente / Alexandre Rodríguez Guerra (coords.) (2003b), 32-48. Cítase pola versión galega].

Buescu, Maria Leonor Carvalhão (1983): O estudo das línguas exóticas no século XVI. Lisboa: ICALP.

Bugarín López, María Xesús (2007): O galego fundamental. Dicionario de frecuencias. A Coruña: Fundación Barrié.

bUSCatermos = Servizo de Normalización Lingüística: bUSCatermos. Universidade de Santiago de Compostela. 〈http://www4.usc.es/buscatermos/>

Cabral, Manuel de Pina (1780): Magnum lexicon latinum et lusitanum ex diuturnis celeberrimorum eruditissimorumque philologorum observationibus depromptum ad plenissimam scriptorum latinorum interpretationem accommodatum. Lisboa: Typii Regiae Officinae.

Cabré, M. Teresa (1993): La terminología. Teoría, métodos, aplicaciones. Barcelona: Antártida.

Cabré, M. Teresa (2000): "La neologia com a mesura de la vitalitat interna de les llengües", en M. Teresa Cabré / Judit Freixa / Elisabet Solé (eds.): La neologia en el tombant de segle. Barcelona: Universitat Pompeu Fabra, $85-108$.

Cabré, M. Teresa / María Bozzo / Carolina Santamaría (1996): "El Diccionari de la llengua catalana de l'Institut d'Estudis Catalans", Butlletí Intern del Departament de Presidència 11, 2-4.

Cabré, M. Teresa et al. (2004): "La lexicografia i la identificació automatitzada de neologia lèxica", en Paz Battaner / Janet DeCesaris (eds.): De Lexicografia. Actes del I Symposium Internacional de Lexicografia, Barcelona, 16-18 de maig de 2002. Barcelona: IULA, 287-294.

Calepino, Ambrosio (1502): Cornucopiae. Reggio.

Campe, Joachim Heinrich (1807-1812): Wörterbuch der deutschen Sprache. 5 vols. Braunschweig: Schulbuchhandlung.

Cândido Lusitano, v. Francisco José Freire.

Cannecatim, Bernardo Maria de (1804): Diccionario da lingua bunda ou angolense, explicada na portugueza, e latina. Lisboa: Impressão Regia.

Cannecatim, Bernardo Maria de (1805): Collecção de observações grammaticaes sobre a lingua bunda ou angolense, a que se ajunta um diccio- 
nario abbreviado da Lingua Congueza, ao qual accresce uma quarta columna, que contém os termos da lingua bunda, identicos ou similhantes á lingua congueza. Lisboa: Impressão Regia, 1859².

Cardoso, Jerónimo (1551): Hieronymi Cardosi Dictionarium Iuventuti studiosae admodum frugiferum. Coimbra: João de Barreira e João Álvares; Coimbra: João Álvares, 1562²; Coimbra: João de Barreira, 1587³.

Cardoso, Jerónimo (1562-1563): Hieronymi Cardosi Lamacensis Dictionarium ex lusitanico in latinum sermonem. Lisboa: João Álvares.

Carmelo, Luis do Monte (1767): Compêndio de orthografia, com sufficientes catalogos. Lisboa: Antonio Rodrigues Galhardo.

Carré Aldao, Uxío (1926): “Coleición de refrans de almanaque", Nós 35, 6-8; 36, 13-18.

Carré Alvarellos, Leandro (1928-1931): Diccionario galego-castelán e vocabulario castelán-galego. 2 vols. A Coruña: Lar; A Coruña: Impr. Zincke Hermanos, 1933²; A Coruña: Impr. Roel, 19513; A Coruña: Impr. Moret, 19724. [Incluído en Santamarina (2003b)].

Carter, Henry Hare (1953): "A Fourteenth-Century Latin-Old Portuguese Verb Dictionary", Romance Philology 6 (2/3), 71-105.

Carvalho, J. M. Teixeira de (1914): "Pedro de Mariz e a Livraria da Universidade de Coimbra", en Boletim Bibliográfico da Biblioteca da Universidade de Coimbra 1, 389-398, 438-446, 482-494, 533-542.

Carvalho, José Monteiro de (1765): Diccionario Portuguez das plantas, arbustos, matas, arvores, animaes quadrupedes, e reptis, aves, peixes, mariscos, insectos, gomas, metaes, pedras, terras, mineraes \&. Lisboa: Officina de Miguel Manescal da Costa.

Casares, Julio (1950): Introducción a la lexicografía moderna. Madrid: CSIC.

Casas, Cristóbal de las (1570): Vocabulario de las dos lenguas toscana y Castellana / de Christoual de las Casas; en que se contiene la declaracion de toscano en castellano, $y$ de castellano en toscano; en dos partes con una introduccion para leer y pronunciar en ambas lenguas. Sevilla: Alonso Escriuano. [Ed. facsimilar de Ediciones Istmo (Madrid) para Wareham Imprints (Wareham, Massachusetts), 1988].

Casteleiro, João Malaca (1993): "Introdução" a Academia das Ciências: Dicionário da Língua Portuguesa. Reprodução fac-similada da edição de 1793. Lisboa.

Chompré, Pierre / Pedro José da Fonseca (trad.) (1779): Diccionario abbreviado da fabula. Lisboa: Regia Officina Typografica.

$C I P M=$ Maria Francisca Xavier (dir.): Corpus Informatizado do Português Medieval. Centro de Lingüística da Universidade Nova de Lisboa. $<$ http://cipm.fcsh.unl.pt/> 
CLIG = Gómez Guinovart, Xavier (coord.) (2005): Dicionario CLUVI inglésgalego. Seminario de Lingüística Informática. Universidade de Vigo. 〈http://sli.uvigo.es/CLIG/>

CLP = Verdelho, Telmo (dir.): Corpus Lexicográfico do Portugués. Universidade de Aveiro. 〈http://clp.dlc.ua.pt/inicio.aspx>

CLUVI = Seminario de Lingüística Informática: Corpus Lingüístico da Universidade de Vigo. Vigo. Universidade. 〈http://sli.uvigo.es/ CLUVI/>

CODOLGA = López Pereira, José Eduardo: Corpus Documentale Latinum Gallaeciae. Centro Ramón Piñeiro para a Investigación en Humanidades. 〈http://corpus.cirp.es/codolga/>

Colón, Germán (1956): "A propos du Tesoro Lexicográfico de S. Gili Gaya", ZRPh 72, 379-386.

Constâncio, Francisco Solano (1836): Novo Diccionario crítico e etymologico da lingua portuguesa. Paris: Angelo Francisco Carneiro Junior Tip. de Casimir.

Corbeil, Jean-Claude (1971): “Aspects du problème néologique”, La Banque des Mots 2, 123-136.

CORDE = Real Academia Española: Corpus Diacrónico del Español. Real Academia Española. 〈http://corpus.rae.es/cordenet.html〉.

CORGA = Guillermo Rojo (dir.): Corpus de Referencia do Galego Actual. <http://corpus.cirp.es/corgaxml>.

Corominas, Joan (1954-1957): Diccionario crítico etimológico de la lengua castellana. Berna / Madrid: Francke / Gredos.

Cortelazzo, Manlio / Paolo Zolli (1999): Dizionario etimologico della lingua italiana. Bologna: Zanichelli, $1999^{2}$.

Cortesão, Armando (1978): A Suma Oriental de Tomé Pires e o Livro de Francisco Rodrigues, Coimbra: Universidade.

Coseriu, Eugenio (1977): Principios de semántica estructural. Madrid: Gredos.

Covarrubias Horozco, Sebastián (1611): Tesoro de la lengua castellana, o española. Madrid: Luis Sánchez. [Ed. de Martín de Riquer en Barcelona: Horta, 1943. Ed. de Ignacio Arellano / Rafael Zafra en Pamplona: Universidad de Navarra / Iberoamericana / Vervuert / Real Academia Española, 2006].

CREA = Real Academia Española: Corpus de Referencia del Español Actual. Real Academia Española. 〈http://corpus.rae.es/creanet.html〉

$C R P C=$ Nascimento, Maria Fernanda Bacelar do (dir.): Corpus de Referência do Português Contemporâneo. Centro de Linguística (Universidade de Lisboa). 〈http://www.clul.ul.pt/sectores/linguistica_de_corpus/ projecto_crpc.php>

CTG = Seminario de Lingüística Informática: Corpus Técnico do Galego . Vigo. Universidade. 〈http://sli.uvigo.es/CTG/> 
CTILC = Institut d'Estudis Catalans: Corpus Textual Informatitzat de la Llengua Catalana. Barcelona. Institut d'Estudis Catalans. 〈http://ctilc.iec.cat/>

Cunha, António Geraldo da (2002): Vocabulário histórico-cronológico do português medieval. Rio de Janeiro: Casa Ruy Barbosa.

Cuveiro Piñol, Juan (1876): Diccionario gallego. Barcelona: Tip. de Ramírez y Cía. [Incluído en Santamarina (2003b)].

Davies, Mark / Michael J. Ferreira (2006- ): Corpus do Portugués. <http:// www.corpusdoportugues.org>

$D C R$ = Cuervo, Rufino José: Diccionario de construcción y régimen de la lengua castellana / por RJ. Cuervo; continuado y editado por Instituto Caro y Cuervo. Barcelona: Herder, 1998.

DCVB = Alcover, Antoni M. / Francesc de Borja Moll (1926-1962). Diccionari català-valencià-balear. 10 vols. Palma de Mallorca: Moll. <http://dcvb. iecat.net/>

DDLC = Institut d'Estudis Catalans: Diccionari descriptiu de la llengua catalana. Barcelona. Institut d'Estudis Catalans. <http://dcc.iecat.net/ $\mathrm{ddlc} />$

De Bruyne, Jacques (1999): “Las preposiciones”, en Ignacio Bosque / Violeta Demonte (dirs.): Gramática descriptiva de la lengua española. Vol. I. Sintaxis básica de las clases de palabras. Madrid: Espasa, 657-703.

DEA = Seco, Manuel / Olimpia Andrés / Gabino Ramos (1999): Diccionario del español actual. Madrid: Aguilar.

DEA abreviado = Seco, Manuel / Olimpia Andrés / Gabino Ramos (2000): Diccionario abreviado del español actual. Madrid: Aguilar.

$D E B J$ = Esteve, J. / J. Bellvitges / A. Juglà (1803-1805): Diccionario catalancastellano-latino. 2 vols. Barcelona: Tecla Pla.

Deus, João de (1804): Diccionario historico, juridico, e theologico. Porto: Typ. de Antonio Alvarez Ribeiro.

Devoto, Giacomo (1969): Civiltà di parole/2. Firenze: Vallecchi Editore.

DGILE (1987)= Alvar Ezquerra, Manuel (dir.) (1987): Diccionario general ilustrado de la lengua española. Barcelona: Bibliograf.

DGLC = Fabra, Pompeu (1932): Diccionari general de la llengua catalana . Barcelona: Llibreria Catalònia.

DGMG = Martí i Gadea, Joaquim (1891): Novísimo diccionario general valenciano-castellano. València: Josep Canales Romà.

$D G P F=$ Ferrer Pastor, Francesc (1985): Diccionari General. València: Estel.

DGTM = Real Academia de Medicina e Cirurxía de Galicia (2002): Diccionario galego de térmos médicos. Santiago de Compostela: Dirección Xeral de Política Lingüística.

DHLE = Véxase RAE (1933-1936) e RAE (1960-1996). 
DHLF = Rey, Alain (dir.) (1992): Dictionnaire historique de la langue francaise; contenant les mots francais en usage et quelques autres delaisses. 2 vols. Paris: Dictionnaires Le Robert.

Dias, G. / S. Guilloré / J. G. P. Lopes (2000): "Extraction automatique d'associations textuelles à partir de corpora non traités", en M. Rajman / J.-C. Chappelier (2000): Proceedings of 5èmes journées internationales d'analyse statistique des données textuelles. Lausanne: EPFL, 213-221.

Diccionario abbreviado da Bíblia traduzido do francez. Lisboa: Antonio Rodrigues Galhardo, 1766, 1794².

Diccionario de Autoridades = Real Academia Española (1726-1739): Diccionario de la lengua castellana en que se explica el verdadero sentido de las voces, su naturaleza y calidad, con las phrases o modos de hablar, los proverbios o rephranes, y otras cosas convenientes al uso de la lengua [...] / Compuesto por la Real Academia Española. Madrid: Francisco del Hierro, $1770^{2}$.

Diccionario Geral (1818) = Diccionario Geral da Lingoa Portugueza de algibeira. por tres literatos nacionaes. Contem mais de vinte mil termos novos pertencentes a Artes, Officios, e Sciencias, todos tirados de Classicos Portuguezes, e ainda não incluidos em Diccionario algum até ao prezente publicado. Lisboa: Impressão Regia.

Diccionario Portuguez e Brasiliano. Obra necessária aos ministros do altar que empreenderam a conversão de tantos milhares de almas que ainda se acham dispersas, pelos vastos sertões do Brasil, sem o lume da fé, e batismo. Aos que paroqueiam missões antigas, pelo embaraço com que nelas se fala a língua portuguesa, para melhor poder conhecer o estado interior de suas consciências. A todos os que se empregarem no estudo da história natural da geografia daquele pais, pois conserva constantemente os seus nomes originais e primitivos. Lisboa: Oficina Patriarcal, 1795. [En 1934 foi feita unha reedición con adición da segunda parte: Dicionário Português-Brasiliano e Brasiliano-Português, ordenada e preparada por Plínio M. da Silva Ayrosa. São Paulo: Imprensa Oficial].

Diccionario Universal (1845) = Diccionario Universal da Lingua Portugueza, que abrange Todos os Vocabulos da Lingua Portugueza, antigos e modernos, suas accepções e sentido conforme as authoridades de nossos classicos, [...] por Uma Sociedade de Litteratos. Lisboa: Typographia de P.A. Borges.

Diccionario universal das moedas: assim metallicas, como ficticias, imaginarias, ou de conta, e das de fructos, conchas, \&c. que se conhecem na Europa, Asia, Africa, e América. A que se ajunta huma noticia das Moedas dos Judeos, Gregos, e Romanos; e dois Mappas dos pêzos das principaes 
Cidades de Commercio; das Medidas d'extensão reduzidas a palmos, covados, e varas; e das de capacidade, assim para secos como para molhados. Recopilado por**** Lisboa, of. de Simão Thaddeo Ferreira, 1793.

Dictionarivm latino lvsitanicvm, ac iaponicvm ex Ambrosii Calepini. Amacusa, 1595.

Dictionnaire de l'Académie Française. Paris: Coignard.

DIEC (1995) = Institut d'Estudis Catalans (1995): Diccionari de la Llengua Catalana. Barcelona / Palma / València: Enciclopèdia Catalana.

DLC (1982) = Diccionari de la llengua catalana . Barcelona: Enciclopèdia Catalana, 1982.

DLCL = Labèrnia, Pere (1839-1840): Diccionari de la llengua catalana ab la correspondencia castellana y llatina. 2 vols. Barcelona: V. Pla.

$D M C F=$ Figuera, Pere Antoni (1840): Diccionario mallorqui-castella. Palma: Esteve Trias.

DMCT = Tarongí i Cortès (1878): Diccionario mallorqui-castellá. [Obra inacabada].

$D M F C=$ Febrer i Cardona, A.: Diccionári menorquí, español, francês y llatí. Texto manuscrito de comezos do século XIX.

$D P C B=$ Vallès, Emili (1927): Pal•las diccionai català-castellà-francès, amb vocabularis castellà-català i francès-català. Barcelona: Pal-las.

$D P D=$ Real Academia Española / Asociación de Academias de la Lengua Española (2005): Diccionario panhispánico de dudas. Madrid: Santillana. <http://buscon.rae.es/dpdI/>

$D R A E=$ Real Academia Española (2001): Diccionario de la lengua española. Madrid: Espasa-Calpe, 200122. Edición en CD-ROM, Madrid: EspasaCalpe, 2003. 〈http://buscon.rae.es/draeI/>

DRAG (1913-1928) = Real Academia Gallega (1913-1928): Diccionario gallego-castellano. A Coruña: Imprenta Ferrer. [Incluído en Santamarina (2003b)].

DRAG (1997) = García, C. / Manuel González González (dirs.) (1997): Diccionario da Real Academia Galega. A Coruña: Galaxia / Xerais.

$D R G$ = Planta, Robert de / Florian Melcher / Chasper Pult et al. (1939- ): Dicziunari rumantsch grischun, publichà da la Società reto-rumantscha cul agüd da la Confederaziun, dal chantum Grischun e da la Lia rumantscha. 12 vols. (A-M). Cuoira: Bischofberger. <http://www.drg. ch/index.html>

DS = Gutiérrez Cuadrado, Juan (dir) (1996): Diccionario Salamanca de la lengua española. Madrid/Salamanca: Santillana/Universidad de Salamanca.

DUE = Moliner, María (1966): Diccionario de uso del español. Madrid: Gredos, 1998². [Ed. electrónica en 2001]. 
DVCE = Escrig, José (1851): Diccionario valenciano-castellano. València: Imprenta de J. Ferrer de Orga.

DVPM (1999) = Xavier, María Francisca / G. Vicente / M. L. Crispim (ed.) (1999): Dicionário de Verbos Portugueses do Século 13. Lisboa: Centro de Linguística da Universidade Nova de Lisboa.

DVPM (2003) = Xavier, Maria Francisca / G. Vicente / M. L. Crispim (ed.) (2003): Dicionário de Verbos do Português Medieval. Séculos 12 e 13/14. Lisboa: Centro de Linguística da Universidade Nova de Lisboa.

DWB = Grimm, Jacob / Grimm, Wilhelm (1854-1861): Deutsches Wörterbuch. 32 vols. Leipzig: S. Hirzel. <http://germazope.uni-trier.de/Projects/DWB>

Encyclopédie = Diderot, M. (1752): L'encyclopédie ou dictionnaire raisonné des sciences, des arts et des métiers [...]. Mis en ordre \& publié par M. Diderot [...]. Paris: Briasson / David / Le Breton / Durand, 1752 ss.

Estienne, Robert (1531): Thesaurus linguae latinae. Paris.

Estravís (1995) = Alonso Estravís, Isaac (dir.) (1995): Dicionário da língua galega. Santiago de Compostela: Sotelo Blanco.

Fabra, Pompeu (1917): Diccionari ortogràfic. Barcelona: Institut d'Estudis Catalans.

Faria, Eduardo de (1858-1859): Diccionario da lingua portugueza de Eduardo de Faria: quarta edição para uso dos portuguezes e brasileiros resumida correcta e augmentada com grande numero de termos antigos e modernos, por D. José Maria de Almeida e Araujo Corrêa de Lacerda, etc. Comprehendendo todos os vocabulos devidamente accentuados suas accepções e sentidos conforme a auctoridade dos nossos classicos. A etymologia de todos os termos radicaes, expondo o sentido rigoroso das raizes primitivas latinas, gregas, etc. A interpretação dos termos que usavam os antigos escriptores, e que se acham mal definidos nos Diccionarios até hoje publicados. Uma introducção grammatical a mais completa, e ao alcance de todas as intelligencias. Um vocabulario da lingua Tupy, chamada lingua geral dos indigenas do Brasil: seguido de um Diccionario de Synonymos com reflexões criticas. 2 vols. Lisboa: Imp. de Francisco Xavier de Sousa.

Faria, Eduardo de (1859): Novo Diccionario da Lingua Portugueza. O mais exacto e mais completo de todos os Diccionarios até hoje publicados. Quarta edição. Rio de Janeiro: Typ. Imperial e Constitucional de J. Villeneuve.

Fernández Rei, Francisco (2004a): "O Arquivo do Galego Oral do Instituto da Lingua Galega”, en C. Pujales Prats (ed.): Actas I, II e III Encontros 'O Son da Memoria'. Santiago de Compostela: Consello da Cultura Galega, 63-79. 
Fernández Rei, Francisco (2004b): "Andisías e rutías: mar de mar e mar de vento na Arousa e na Costa da Morte", Ardentía. Revista Galega de Cultura Marítima e Fluvial 1, 47-52.

Fernández Rei, Francisco (2005): “Cardumes, barrías e manchas de peixe en galego e portugués", en Ana I. Boullón Agrelo / Xosé Luís Couceiro Pérez / Francisco Fernández Rei: As tebras alumeadas. Estudos filolóxicos ofrecidos en homenaxe a Ramón Lorenzo. Santiago de Compostela: Universidade, 347-363.

Fernández Rei, Francisco (2007): "Unha vida entre peixe e salitre do mar da Arousa", Ardentía. Revista Galega de Cultura Marítima e Fluvial 4, 22-29.

Fernández Rei, Francisco / Carme Hermida Gulías (1996): A nosa fala. Bloques e áreas lingüisticas do galego. Santiago de Compostela: Consello da Cultura Galega, 2003². <www.consellodacultura.org/arquivos/asg/ anosafala.php>

Fernández Rei, Francisco / Carme Hermida Gulías / Fernando R. Tato Plaza (2004): "Historias de vida e léxico do Castiñeiriño (Santiago de Compostela)", en Rosario Álvarez / Antón Santamarina (eds.): (Dis)cursos da escrita. Estudos de filoloxía galega ofrecidos en memoria de Fernando R. Tato Plaza. A Coruña: Fundación Barrié, 141-182.

Ferreira, José de Azevedo (1980): Alphonse X. Primeyra Partida. Edition et Étude. Braga: INIC.

Ferreira, José de Azevedo (1987): Afonso X. Foro Real. Vol. 1. Edição e estudo linguistico. Lisboa: INIC.

Ferreiro, Manuel (1994): “Contribución á lexicografía histórica do galego: 0 vocabulario de Payzal", Cadernos de lingua 9, 55-88.

FEW = Wartburg, Walther von (1922- ): Französisches Etymologisches Wörterbuch. Eine Darstellung des galloromanischen Sprachschatzes. Bonn, 1922-1928, Leipzig, 1932-1940, Basel, 1944 e ss.

Feyjó, João de Moraes Madureyra (1781): Orthographia, ou arte de escrever, e pronunciar com acerto a lingua portugueza. $3^{\mathrm{a}}$ impr. Lisboa: Na Regia Officina Typografica.

Figueiredo, António Pereira de (1754): Colecção de palavras familiares assim portuguêsas como latinas. Lisboa: Miguel Rodrigues.

Figueiredo, António Pereira de (1760): Breve diccionario da latinidade pura e impura, com a significação portugueza. Lisboa: Of. Patr. de Francisco Luiz Ameno.

Filgueira Valverde, Xosé / L. Tobío Fernándes / A. Magariños Negreira / Cordal Carús (1926): Vocabulario popular castelán-galego. Vigo: El Pueblo Gallego. [Incluído en Santamarina (2003b)]. 
Folqman, Carlos (1755): Diccionario Portuguez e Latino, no qual as dicções e phrases da lingua portugueza [...] se acham clara e distinctamente vertidas na latina, e authorisadas com exemplos dos auctores classicos. [...] Compilado do Vocabulario do Reverendo Padre D. Rafael Bluteau, e dos melhores Diccionarios de varias linguas [...] offerecido ao Rei Fidelissimo Dom José I [...] por Carlos Folqman. Lisboa: Miguel Manescal da Costa.

Folqman, Carlos (1762): Nomenclatura portugueza, e latina [...] com hum pequeno vocabulario de verbos portuguezes. Lisboa: Miguel Rodrigues.

Fonseca, José da / José Inácio Roquete (1848a): Diccionario da Lingua Portugueza de José da Fonseca, feito inteiramente de novo e consideravelmente augmentado por José Inácio Roquete. París/Lisboa: Guillard/ Aillaud.

Fonseca, José da / José Inácio Roquete (1848b): Diccionario dos Synonimos, Poetico e de Epithethos da Lingua Portugueza. París: Aillaud.

Fonseca, Pedro José da (1762): Parvum lexicon latinum Lusitana interpretatione adjunta. Lisboa: Miguel Manescal da Costa.

Fonseca, Pedro José da (1771): Diccionario portuguez, e latino. Lisboa: Regia Officina Typografica.

Franco, António (1716): Indiculo universal: contém distinctos em suas classes os nomes de quasi todas as couzas que ha no mundo. Évora. [Reeds. en 1754, 1804].

Franco, Francisco Soares (1804-1806): Diccionario de agricultura. 5 vols. Coimbra: Real Imprensa da Universidade.

Franco Grande, Xosé Luís (1968): Diccionario galego-castelán e vocabulario castelán-galego. Vigo: Galaxia. [Incluído en Santamarina (2003b)].

Freire, Francisco José [Cândido Lusitano] (1765): Diccionario poetico. Lisboa: Officina Patriarcal de Francisco Luiz Ameno. [Reedicións en 1794, 1820].

Freire, Francisco José [Cândido Lusitano] (1842): Reflexões sobre a lingua portugueza. Lisboa: Typ. Soc. Propagadora dos Conhecimentos Uteis.

Freixa, Judit / Elisabet Solé (2003): "Neoloxismos para a actualización de gramáticas e diccionarios”, en Xosé María Gómez Clemente / Alexandre Rodríguez Guerra (coords.) (2003b), 179-190.

García de Palacio, Diego (1587): Instrvción návthica para el bven vso y regimiento de las naos, su traça y su gouierno conforme a la altura de México. México: Pedro Ocharte. [Ed. facsimilar en Madrid: Ediciones Cultura Hispánica, 1944].

García González, Constantino (1974): Léxico de la comarca compostelana. Santiago de Compostela: Universidade. 
García González, Constantino (1985): Glosario de voces galegas de hoxe. Santiago de Compostela: Universidade. [Incluído en Santamarina (2003b)].

García Macho, María Lourdes (1993): "Sobre los vocablos suprimidos en la edición de 1516 del Vocabulario español-latino de Nebrija", Anuario de Letras 30, 135-159.

García Macho, María Lourdes (1995): "Variantes léxicas y derivados en dos ediciones del Vocabulario español-latino de Elio Antonio de Nebrija", Cahiers de Linguistique Hispanique Médiévale 20, 187-208.

García Macho, María Lourdes (2005): "Actitud de Nebrija en las ediciones posteriores del Vocabulario español-latino", en Luis Santos Río (ed.): Palabra, norma, discurso. En memoria de Fernando Lázaro Carreter. Salamanca: Universidad, 537-558.

Gardin, B. et al. (1974): "À propos du 'sentiment néologique"', Langages 36, 45-72.

Garrett, João Baptista da Silva Leitão de Almeida (1966): Obras. Vol. II. Porto: Lello e Irmão.

GAVI = Colussi, Giorgio (1983-2006): Glossario degli antichi volgari italiani. 20 vols. Helsinki / Foligno: Helsinki University Press / Editoriale Umbra.

GDLE = Aquilino Sánchez (1985): Gran diccionario de la lengua española . Madrid: SGEL.

GDLI = Battaglia, Salvatore / Giorgio Bàrberi Squarotti (1961-2002): Grande dizionario della lingua italiana. 21 vols. Torino: UTET.

GDS XXI = Pena, X. A. (2005) Gran dicionario Século XXI da lingua galega. Vigo: Editorial Galaxia / Edicións do Cumio.

GDUEA = Aquilino Sánchez (dir.) (2001): Gran diccionario de uso del español actual. Madrid: SGEL.

GDXL (2000) = Carballeira Anxo, X. M. (coord.) (2000): Gran Diccionario Xerais da Lingua. Vigo: Xerais.

GEC (1969-1980) = Joan Carreras i Martí (1969-1980): Gran Enciclopèdia Catalana. Barcelona: Enciclopèdia Catalana.

Gesner, Conrad (1551-1587): Historiae animalium. Zürich: Christophorus Froschoverum, 1551 (I), 1554 (II), 1555 (III), IV (1558), 1587 (V).

Gestido de la Torre, Eloi / Xosé María Gómez Clemente (2003): "Neoloxía, neoloxismos e diccionarios", en María Álvarez de la Granja / Ernesto González Seoane (eds): A estandarización do léxico. Santiago: Consello da Cultura Galega, 475-498.

Gili Gaya, Samuel (1945): "Características de este diccionario", en Diccionario general ilustrado de la lengua española. Prólogo de D. Ramón Menéndez Pidal. Revisión de D. Samuel Gili Gaya. Barcelona: Spes; Barcelona: Bibliograf, $1971^{3}$. 
Gili Gaya, Samuel (1947-1957): Tesoro Lexicográfico del Español (1492-1726). Madrid: CSIC, 1947 (fasc. I, A), 1948 (fasc. II, B), 1952 (fasc. III, C-Ch), 1957 (fasc. IV, D); Madrid: CSIC, 1960 (vol. I, A-E).

Gilliver, Peter (2000): “Appendix II. OED Personalia”, en Lynda Mugglestone (2000b: 232-252).

Gómez Aguado, Enrique (ed.) (1992): Francisco del Rosal, Diccionario etimológico. Alfabeto primero de origen y etimología de todos los vocablos originales de la lengua castellana. Madrid: CSIC.

Gómez Clemente, Xosé María / Alexandre Rodríguez Guerra (2003a): "Neoloxismos na lingua xornalística galega", en Xosé María Gómez Clemente / Alexandre Rodríguez Guerra (coords.) (2003b), 95-168.

Gómez Clemente, Xosé María / Alexandre Rodríguez Guerra (coords.) (2003b): Neoloxía e lingua galega: teoría e práctica. Vigo: Universidade.

Gómez Guinovart, Xavier / E. Sacau Fontenla (2005): “Técnicas para o desenvolvemento de dicionarios de tradución a partir de córpora aplicadas na xeración do Dicionario CLUVI Inglés-Galego", Viceversa. Revista Galega de Traducción 11,159-171.

Gómez Pablos, Beatriz (2004): "Rafael Bluteau en el Diccionario de Autoridades", Revista de Filología de la Universidad de La Laguna 22, 67-78.

González González, Manuel (1996): "O Diccionario da lingua galega da Real Academia Galega”, en Actas do Simposio de Lexicografía actual: elaboración de diccionarios, organizado pola Real Academia Galega e o Centro de Investigacións Lingüísticas e Literarias "Ramón Piñeiro" (Santiago-A Coruña, 9-11 outubro de 1995). A Coruña: Real Academia Galega, 111-119.

González Seoane, Ernesto (dir.) / María Álvarez de la Granja / Ana Isabel Boullón Agrelo (2006): Dicionario de dicionarios do galego medieval. Santiago de Compostela: Universidade.

GPSR = Gauchat, Louis / Jules Jeanjaquet / Ernst Tappolet / E. Muret (1924- ): Glossaire des patois de la Suisse romande. 7 vols. (A-F). Neuchâtel / Paris: V. Attinger. 〈http://www.gpsr.ch/>

Griera, Antoni (1935-1947): Tresor de la llengua, de les tradicions i de la cultura popular de Catalunya. 14 vols. Barcelona: Eds. Catalunya.

Grimm, Jacob (1819-1837): Deutsche Grammatik. 4 vols. Göttingen: Dieterich'sche Buchhandlung. [Reimpresión en London: Routledge, 1999].

Guadix, Diego de [1593]: Recopilación de algunos nombres arábigos que los árabes pusieron a algunas ciudades y a otras muchas cosas. Manuscrito 59-I-24 da Biblioteca Colombina (Sevilla). [Existe unha edición de Elena Bajo Pérez / Felipe Maíllo Salgado, Gijón: Ediciones Trea, 2005]. 
Guardiola Savall, M. Isabel (2006): "El Tresor lexicogràfic valencià (15431880) (TLV)", en Actas del II Congreso Internacional de Lexicografía Hispánica. Alicante, 19-23 de septiembre de 2006, no prelo.

Guerra, Francisco (1982): El Tesoro de Medicinas de Gregorio López, 15421596. Estudio, texto y versión. Madrid: Ediciones Cultura Hispánica.

Guerreiro, Miguel do Couto (1784): Tratado da versificaçaõ portugueza [...] Diccionario de Consoantes. Lisboa: Of. Patr. de Francisco Luiz Ameno.

Guiter, Henri (1994): "Rang et dispersion des fréquences lexicales romanes", Revue de Linguistique Romane 58, 47-70.

Hallig, Rudolf / Walther von Wartburg (1952): Begriffssystem als Grundlage für die Lexikographie: Versuch eines Ordnungsschemas. Abhandlungen der Deutschen Akademie der Wissenschaften zu Berlin, Klasse für Sprachen, Literatur und Kunst 1952/4. Berlin: Akademie.

Houaiss, Antônio (2001): Dicionário Houaiss da Língua Portuguesa. Rio de Janeiro: Objetiva.

Houaiss, Antônio (2001): Dicionário Houaiss da Língua Portuguesa. 6 vols. Lisboa: Círculo de Leitores.

Ibáñez Fernández, José (1950): Diccionario galego da rima e galego-castelán. Madrid: Marsiega.

IEC (1911) = Institut d'Estudis Catalans (1911): Institut d'Estudis Catalans. Barcelona.

IEC (1996) = Institut d'Estudis Catalans (1996): "L'elaboració del Diccionari de la llengua catalana. Criteris aprovats per la Secció Filològica”, en Documents de la Secció Filològica. Vol. III. Barcelona: Institut d'Estudis Catalans, 11-53.

IEC (1997) = Institut d'Estudis Catalans (1997): "Diferències del DIEC respecte del DGLC quant a la representació de les entrades i la nomenclatura", en Institut d'Estudis Catalans: Documents normatius 1962-1996 (amb les novetats del diccionari). Barcelona: Institut d'Estudis Catalans, 45-228.

IEC (2001) = Institut d'Estudis Catalans (2001): Diccionari manual de la llengua catalana. Barcelona: Edicions 62 / Enciclopèdia Catalana / Institut d'Estudis Catalans.

ILG / RAG (1990) = Instituto da Lingua Galega / Real Academia Galega (1990): Diccionario da lingua galega. A Coruña: Real Academia Galega.

Ir Indo (2004)= Domínguez Dono, X. / A. X. Rajó Pazó / B. Varangas González. (coords.): Dicionario de galego. Vigo: Ir Indo.

Ivo, Miguel Tibério Pedegache Brandão (1778): Novo Diccionario francez e portuguez. Lisboa. [É a 4 a ed.; falta noticia das anteriores].

Ivo, Miguel Tibério Pedegache Brandão / Manuel Joaquim Henriques de Paiva (?) (17865): Novo Diccionario Francez e Portugues, composto se- 
gundo os mais célebres diccionarios e enriquecido de muitos termos de medicina, de anatomia, de cirurgia, de farmacia, de quimicia [sic], de historia natural, de botanica, de mathematica, de marinha, e de todas as outras artes e sciencias, notavelmente corrigido, emendado, e addicionado com hum sem numero de termos, e locuções, e algumas frazes em ambos os idiomas. Quinta Edição. Lisboa: Officina de Filipe da Silva e Azevedo; $1803^{7}$.

Janua linguarum (1611) = Janua linguarum, sive modvs maxime accomodatvs, qvo patefit aditvs ad omnes lingvas intelligendas. Salamanca: Francisco de Cea Tesa, 1611.

Jarava, Juan (1557): Historia de las yeruas y plantas, sacada de Dioscóride Anazarbeo y otros insignes autores, con los nombres griegos, latinos y españoles. Amberes: Herederos de Arnoldo Byrcman. [Ed. facsimilar de J. M. López Piñero / M. L. López Terrada / J. Pardo Tomás (1998): Historia de las yervas y plantas. Un tratado renacentista de materia médica. Barcelona: Juan de Serrallonga].

$J O B=$ Peter Skautrup: Jysk Ordbog. [en liña] <http://www.jyskordbog.dk/ hjemmesider/index.html>

Johnson, Samuel (1755): A Dictionary of the English Language: In which the Words are deduced from their Originals, and illustrated in their different significations by Examples from the best Writers To which are prefixed a History of the Language, and an English Grammar. 2 vols. London: Printed by W. Strahan for J. and P. Knapton; T. and T. Longemand; C. Hitch and L. Hawes; A. Millar; and R. and J. Dodsley.

Junius, Hadrianus [Adriaen de Jonghe] (1567): Nomenclator omnivm rervm propria nomina variis lingvis explicata indicans. Amberes: Cristóbal Plantino [Ed. facsimilar en Hildesheim-New York: Georg Olms, 1976].

Koike, Kazumi (2001): Colocaciones léxicas en el español actual. Análisis formal y léxico-semántico. Alcalá de Henares: Universidad de Alcalá/ Takushoku University.

Laguna, Andrés (1555): Acerca de la materia medicinal y de los venenos mortiferos. Amberes: Juan Latio. [Ed. facsmilar en Madrid: Consejería de Agricultura y Cooperación de la Comunidad de Madrid, 1991].

Lara, Luis Fernando (1990): "El diccionario, instrumento de la etnicidad", en Luis Fernando Lara: Dimensiones de la lexicografía. A propósito del Diccionario del español de México. México: El Colegio de México, pág. 39-50.

Lara, Luis Fernando (2004): De la definición lexicográfica. México: El Colegio de México. 
Laredo, Bernardino de (1527): Modus faciendi cum ordine medicandi. Sevilla: Jacobo Cromberger.

Laurenzi, Joseph (1640): Amalthea onomastica in qua voces universae, abstrusiores, sacrae, profanae, antiquae, antiquatae, usurpatae, usurpandae [...]. Basilea.

Leech, G. / A. Wilson (1996). Recommendations for the Morphosyntactic Annotation of Corpora. EAGLES Guidelines. [en liña] <http://www.ilc. cnr.it/EAGLES96/annotate/annotate.html>

LEI = Pfister, Max (1979- ): Lessico Etimologico Italiano. Wiesbaden: Reichert. Leiras Pulpeiro, Manuel (ca. 1906): Vocabulario. Texto manuscrito. Fundación Penzol. [Incluído en Santamarina (2003b)].

Lence Santar, Eduardo (1938-1941): Etnografía mindoniense. Ed. de Armando Requeixo. Santiago de Compostela: Follas Novas, 2000.

Llópiz Méndez, Vicente Luis (1954a): “Locuciones”, en Llópiz 1954a.

Llópiz Méndez, Vicente Luis (1954a): Refranero gallego. Inédito. Editorial de los Bibliófilos Gallegos. Museo de Pontevedra.

Llópiz Méndez, Vicente Luis (1956): "Paremias selectas. Un manuscrito bonaerense (1956) de Vicente Llópiz Méndez”, Cadernos de Fraseoloxía Galega 8 (2006), 265-316. [Edición de Xesús Ferro Ruibal e Cristina Veiga Novoa].

Lopes, David (1969): A expansão da língua portuguesa no Oriente nos séculos XVI, XVII e XVIII. $2^{\mathrm{a}}$ ed. revista, prefaciada e anotada por Luís de Matos. Porto: Ed. Portucalense. [A primeira edición é de 1936; reprod. facsimilar en Lisboa: Copipronto, 2000].

López, Gregorio (1672): Tesoro de medicinas para todas enfermedades. México: Francisco Rodríguez Lupercio.

López Fernández, S. et al. (2005): Novas palabras galegas. Repertorio de creacións léxicas rexistradas na prensa e en Internet. Vigo: Universidade.

López Ferreiro, Antonio (ed.) (1901): Galicia Histórica. Colección diplomática. Santiago: Tipografía Galaica.

Lorenzo, Ramón (ed.) (1968): Sobre cronologia do vocabulário galego-português (Anotações ao "Dicionario etimológico" de José Pedro Machado). Vigo: Galaxia.

Lorenzo, Ramón (ed.) (1988): Coloquio de lexicografía. Santiago de Compostela: Universidade.

Losada Soler, Elena (2006): "Los vocabularios del Roteiro da primeira viagem de Vasco da Gama y de la Relazione de Pigafetta: dos niveles de conciencia lingüística", en Maresia 1, 42-53.

Lucena, João de (1600): Historia da Vida do Padre Francisco Xavier. Lisboa:, Pedro Crasbeeck. [Ed. facsimilar en Lisboa, 1952]. 
Luz, Tomás da (1673): Amalthea, sive hortus onomasticus in gemina divisus florilegia, quorum quodlibet multigenas subdividitur in areolas, in quibus communiora nomina ad quotidianum linguæ Latialis usum, \& exercitation e spectantia continentur, cum indice totulorum ad limen apposito. Lisboa: Joannes a Costa.

Macdonald, Gerald J. (1981): Antonio de Nebrija, Vocabulario de romance en latín. Madrid: Cátedra.

Machado, Diogo Barbosa (1741-1758): Bibliotheca Lusitana, Historia, Critica e Chronologica, na qual se comprehende a noticia dos autores portuguezes, e das obras que compozeram desde o tempo da promulgação da Lei da Graça, até o tempo presente. Lisboa. [Cit. pola ed. de Coimbra, 1966].

Maia, Manuel Rodrigues (1790): Diccionário das elypses, que mais frequentemente se encontram nos auctores clássicos: interpretadas. Lisboa: Of. de António Gomes.

Mancho Duque, María Jesús (ed.) (2005): Juan Jarava, Historia de las yervas y plantas. Salamanca: Universidad.

Marcuello, Francisco (1617): Primera parte de la historia natvral y moral de las aves. Zaragoza: Juan de Lanaja y Ouartanet. [Ed. facsimilar en Madrid: ICONA, 1989].

Marques, José (1758-1764): Nouveau dictionnaire des langues françoise et portugaise: Novo diccionario das linguas portugueza e franceza, com os termos latinos, tirado dos melhores Authores, e do Vocabulario Portuguez, e Latino do P.D. Rafael Bluteau. Lisboa: Imp. de José da Costa Coimbra, 1758 (vol. I); Lisboa: Offic. Patriarcal de Francisco Luiz Ameno, 1764 (vol. II).

Marques, José (1775-1776?): Nouveau Dictionnaire des langues françoise et portugaise. Troisième edition. Lisboa: Imp. Royale.

Marques, José (ed.) (1999): Roteiro da primeira viagem da Vasco da Gama à Índia / Álvaro Velho. Porto: Faculdade de Letras.

Maunory, Monsieur de (1701): Grammaire et dictionnaire françois et espagnol. París: Veuve de Claude Barbin.

Messner, Dieter (1994- ): Dicionário dos dicionários portugueses: Salzburg: Universität/Institut für Romanistik. [Da obra, en curso de publicación, saíron a lume os seguintes volumes: I, ABA-ABC (1994); II, ABD-ABU (1994); III, AC (1996); IV, ADA-AFU (1996); V, AGA-AJU (1995); VI, ALA-ALG (1997); VII, ALHALZ (1998); VIII, AM (1998); IX, AN-AO (2003); X, APA-APU (2005); XI, AQ-ARL, (2005); XII ARM- ARRI (2005); XIII, ARRO-ATELI (2006); XIV, ATEM-AZU; H (2005); K (2002); NA-NI (1999); NO-NU (2001); O (2002); U (1997)].

Messner, Dieter (1998): "Postscriptum: Vasco da Gama und ein Tabu in der portugiesischen Lexikologie", in Mitteilungen des Deutscher Lusitanisten-Verband 10, 45-46. 
Messner, Dieter (2007a): "Os dicionários portugueses, devedores da lexicografia espanhola”, Península. Revista de Estudos Ibéricos 4, 15-20.

Messner, Dieter (2007b): "Las relaciones lexicográficas hispano-lusas", en Ángel Marcos de Dios: Aula ibérica. Actas de los congresos de Évora y Salamanca. Salamanca: Universidad, 317-322.

Migliorini Bruno (19613): Che cos'è un vocabolario. Firenze: F. Le Monnier.

Minsheu, John (1599): A Dictionarie in Spanish and English, first published into the English tongue by Ric. Perciuale [...] Hereunto for the further profite and pleasure of the learner or delighted this tongue, is annexed an ample English Dictionarie. Londres: Edm. Bollifant. [Ed. facsimilar en Málaga: Universidad, 2000].

Minsheu, John (1617): Ductor in Linguas, The Gvide Into tongves. Londres: Iohannis Minsheu.

Miranda Menéndez, Fernanda (2004): “Dimensões 'meta' nos textos jurídicos medievais", en Ana Maria Brito / Olívia Figueiredo / Clara Barros (eds.): Linguística histórica e história da língua portuguesa. Actas do Encontro de Homenagem a Maria Helena Paiva. Porto: Faculdade de Letras, 227-237.

Morais Silva, António de (1789): Diccionario da lingua portugueza / composto pelo padre D. Rafael Bluteau; reformado e accrescentado por Antonio de Moraes Silva. 2 vols. Lisboa: Of. de Simão Thaddeo Ferreira; $1813^{2} ; 1823^{3} ; 1831^{4} ; 1844^{5}$; Lisboa: Typ. de Antonio José da Rocha, 1858 ; $1877-1878^{7} ; 1889^{8} ; 1891^{9}$.

Morais Silva, António de (1949-1959): Grande dicionário da língua portuguesa. Ed. revista, corrigida, muito aumentada e actualizada segundo as regras do acordo ortográfico luso-brasileiro de 10 de Agosto de 1945 por Augusto Moreno, Cardoso Júnior e José Pedro Machado. 12 vols. Lisboa: Editorial Confluência 1949-1959 ${ }^{10}$.

Mugglestone, Lynda (2000a): "'Pioneers in the Untrodden Forest': The New English Dictionary", en Lynda Mugglestone (2000b), 1-22.

Mugglestone, Lynda (ed.) (2000b): Lexicography and the OED. Pioneers in the Untrodden Forest. Oxford: Oxford University Press.

Murray, James Augustus Henry (1900): The evolution of English lexicography. Oxford: Clarendon Press; London: Henry Frowde.

Murray, K. M. Elisabeth (1977): Caught in the Web of Words. James Murray and the 'Oxford English Dictionary'. New Haven / London: Yale University Press.

NDMA = Amengual, Josep J. (1858): Nuevo diccionario mallorquin-castellano-latin. Palma: J. Colomar. 
Nebrija, Elio Antonio de (1481): Introductiones latinæ. Salamanca. [Ed. facsimilar en Salamanca: Universidad, 1981].

Nebrija, Elio Antonio de (1492): Lexicon hoc est dictionarium ex sermone latino in hispaniense. Salamanca. [Ed. facsimilar de Germán Colón / Amadeu-J. Soberanas, Barcelona: Puvill, 1979].

Nebrija, Elio Antonio de (1495?): Dictionarium ex hispaniense in latinum sermonem. Salamanca. [Ed. facsimilar da Real Academia Española (Madrid, 1989), que reproduce a edición facsimilar anterior de 1951].

Nebrija, Elio Antonio de (1518): "Lexicon illorum vocum quae as medicamentariam arte pertinerent", en Pedacij dioscoridis anazarbei de medicinali materia liber primus. Alcalá: Arnaldo Guillermo de Brocar.

Nebrija, Elio Antonio de (1545): Dictionarium Aelij Antonij Nebrissensis iam denuo innumeris dictionibus locupletatum. Amberes: Iohannis Steelsij.

$N E D=$ Véxase $O E D$.

Nieto Jiménez, Lidio (2002): Tesoro lexicográfico del español marinero anterior a 1726. Madrid: Arco/Libros.

Nieto Jiménez, Lidio / Manuel Alvar Ezquerra (2002): "Apuntes para la historia de la lexicografía hispano-inglesa", Revista de Filología Española 82, 319-343.

Nieto Jiménez, Lidio / Manuel Alvar Ezquerra (2004): "El Nuevo Tesoro Lexicográfico del Español (s. XIV-1726)", en Actas del I Congreso Internacional de Lexicografía Hispánica, La Coruña, 14-18 de septiembre de 2004, no prelo.

Nieto Jiménez, Lidio / Manuel Alvar Ezquerra (2006): “Nebrija en la lexicografía hispano-inglesa anterior al Diccionario de Autoridades, según los datos del NTLE", en Antonio Roldán Pérez / Ricardo Escavy Zamora / Eulalia Hernández Sánchez / José Miguel Hernández Terrés / Mª Isabel López Martínez (eds.): Caminos Actuales de la Historiografía Lingüistica. Actas del V Congreso Internacional de la Sociedad Española de Historiografia Lingüística. Murcia, 7-11 de noviembre de 2005. Murcia: Universidad, vol. I, 133-153.

$N O B=$ Norsk Ordbok. 6 vols. (A-K). Oslo: Det norske Samlaget, 1950-2002. 〈http://no2014.uio.no/>

Novo diccionario (1806) = Novo Diccionario da Lingua Portugueza, composto sobre os que até ao presente se tem dado ao prelo, e Accrescentado de varios vocabulos extrahidos dos Classicos Antigos, e dos Modernos de melhor nota, que se achaõ universalmente recibidos. Lisboa: Typografia Rollandiana, 1806.

NTLE = Nieto Jiménez, Lidio / Manuel Alvar Ezquerra (2007): Nuevo tesoro lexicográfico del español (s. XIV-1726). 11 vols. Madrid: Arco/Libros. 
Observatori de Neologia (1998): Diccionari de paraules noves. Barcelona: Enciclopèdia Catalana.

Och, F. J. / H. Ney (2003): “A Systematic Comparison of Various Statistical Alignment Models", Computational Linguistics 29 (1), 19-51.

ODS = Dahlerup, Verner (1919-1956): Ordbog over det danske sprog. 28 vols. Copenhague: Gyldendal. 〈http://ordnet.dk/ods/bogvaerket_html〉 OED = Murray, James Augustus Henry / Henry Bradley / W. A. Craigie / C. T. Onions (1928): Oxford English Dictionary. Oxford: Clarendon Press; $1989^{2}$ (20 vols.); $2000^{3}$ (en liña). [Publicado inicialmente en 128 fascículos entre 1884 e 1928. Ata 1895 leva por título A new English dictionary on historical principles founded mainly on the materials collected by the Philological Society].

Oliveira: Alberto de (s.d.): Eça de Queiroz. Páginas de memorias. Lisboa: Portugal-Brasil.

Orta, Garcia da (1563): Coloquio dos simples e drogas he cousas mediçinais da India e assim dalgu[m]as frutas achadas nella onde se tratam algu[m] as cousas tocantes amediçina, [sic] pratica e outras cousas boas pera saber / cõpostos pello Doutor Garçia Dorta, fisico del Rey nosso senhor, vistos pello muyto Reuerendo senhor, ho liçenciado Alex Diaz Falcam, desembargador da casa da supricaçã inquisidor nestas partes. Goa: Ioannes de Endem. [Reprod. facsimilar s.d. (1963?)].

Ortigão, José Duarte Ramalho (1943/1945): Figuras e questões literarias. 2 vols. Lisboa: Livraria Clássica Editora, 1943 (vol. I), 1945 (vol. II).

Osselton, Noel (2000): "Murray and his European Counterparts", en Lynda Mugglestone (2000b: 59-76).

Otero Álvarez, Aníbal (1949-1977): "Hipótesis etimológicas referentes al gallego-portugués [I]-(XXV)", Cuadernos de Estudios Gallegos IV/13 (1949), 171-200; VI/18 (1951), 83-114; VIII/24 (1953), 87-119; IX/28 (1954), 273-292; X/32 (1955), 405-427; XI/33 (1956), 117-139; XI/34 (1956), 245-269; XII/36 (1957), 107-125; XII/37 (1957), 213-227; XIII/39 (1958), 77-94; XIV/43 (1959), 87-105; XIV/44 (1959), 331-348; XV/45 (1960), 89-104; XVI/49 (1961), 159-175; XVII/53 (1962), 329-347; XVIII/54 (1963), 16-34; XIX/58 (1964), 141-160; XX/60 (1965), 12-30; XX/62 (1965), 330-349; XXI/64 (1966), 170188; XXII/67 (1967), 165-182; XXIII/69 (1968), 70-88; XXV/75 (1970), 70-88; XXVI/80 (1971), 287-306; XXX/90-91-92 (1976-77): 137-155. [Incluído en Santamarina (2003b)].

Otero Álvarez, Aníbal (1967): Contribución al diccionario gallego. Vigo: Galaxia. [Incluido en Santamarina (2003b)].

Otero Álvarez, Aníbal (1977): Vocabulario de San Jorge de Piquín. Santiago de Compostela: Universidade de Santiago. [Incluído en Santamarina (2003b)]. 
Owen, Lewis (1605): The Key of the Spanish Tongve. Londres: T. C. for W. Welby. Palencia, Alfonso de (1490): Universal vocabulario en latín y en romance o Universale compendium vocabulorum cum vulgare expositione. Sevilla: Paulus de Colonia.

Palmireno, Juan Lorenzo (1569): Vocabulario del humanista [...] donde se trata aues, peces, quadrúpedos, con sus vocablos de caçar, y pescar, yeruas, metales, monedas, piedras preciosas, gomas, drogas, olores, y otras cosas que el estudioso en letras humanas ha menester. Valencia: Pedro de Huete. [Ed. facsimilar en Valencia: F. Domenech, 1978].

Papias (ca. 1050): Elementarium doctrinae erudimentum. Eds. incunabulares en Milán (1476) e Venecia (1485, 1491 e 1496).

Pascual Rodríguez, José Antonio / Rafael García Pérez (2007): Límites y horizontes en un diccionario histórico. Salamanca: Diputación.

Peiris, Edmund (1943): "Sinhalese Christian Literature of the XVIIth and XVIIIth Centuries", en Journal of the Royal Asiatic Society C.B., 35, 96, 163-181.

Pensado Tomé, José Luis (1974): Opúsculos lingüísticos gallegos del siglo XVIII. Vigo: Galaxia.

Pereira, Bento (1634): Prosodia in Vocabularium Trilingue, Latinum, Lusitanicum, \& Hispanicum digesta, in qua dictionum significatio, et sylabarum quantitas expenditur. Évora. [Reeds. en Lisboa, 1653, 1661, 1669, 1674, 1683].

Pereira, Bento (1647): Thesouro da Lingoa Portuguesa. Lisboa.

Pereira, Bento (1655): Florilegio dos modos de fallar, e adagios da lingoa portuguesa: dividido em duas partes, em a primeira das quaes se poem pella ordem do Alphabeto as Frases Portuguesas, a que correspondem as mais puras, \& elegantes Latinas: na segunda se poem os principaes adagios Portugueses, com seu Latim proverbial correspondente. Pera se ajuntar a Prosodia, \& Thesouro Portugues, como appendiz, ou complemento. Lisboa.

Pereira, Bento (1697): Tertia pars selectissimarum descriptionum, quas idem auctor vel olim á se compositas, vel à probatissimis scriptoribus emendicatas alphabetico ordine digessit. Ubi quae sine ullo auctore proponuntur, auctor ipse Florilegii composuit, reliquas collegit. Évora. [Reeds. en Évora, 1710, 1723, 1732, 1741, 1750].

Pereira, Bento (1697): Thesouro da Lingoa Portugueza, en Prosodia in Vocabularium Bilingue, Latinum, et Lusitanum digesta, [...] auctore Doctore P.Benedicto Pereyra S.J. [...], Septima Editio. Evora: Typographia Academiae.

Pereira, Bento / Matias de S. Germano (1750): Prosodia in vocabularium bilingue, Latinum, et Lusitanum digesta. Évora: Typographia Academiae. 
Pereira, Isaías da Rosa (1964-1966): "A livraria da Universidade de Lisboa, no início do século XVI”, en Arquivo de bibliografia portuguesa 37/48, 155-170.

Pérez Pascual, Ignacio / Cleofé Tato García (1986): "O vocabulario de Leiras Pulpeiro (I)", Verba 13, 237-267.

Pinto, Luís Álvares (1784): Diccionario pueril para uso dos meninos. Lisboa: Offic. Patr. de Francisco Luiz Ameno.

Pintos, Juan Manuel (1865): Vocabulario gallego-castellano. Ed. de M. Neira e X. Riveiro. Anexo 5 de Cadernos de lingua. A Coruña: RAG, 2000. [Incluído en Santamarina (2003b)].

Pomey, Francisco / Antonio Franco (1754): Indiculo universal: contém distinctos em suas classes os nomes de quasi todas as couzas que ha no mundo. Évora: Off. da Universidade.

Pomey, Francisco / Manuel de Azevedo (1736): Pomarium latinitatis elegantiori consitum cultu, longeque paritiori descriptum manu in quo locutiones synonymae bene multae...editio postrema ac nova lusitano ordine translata. Coimbra.

Porto Dapena, José Álvaro (1997): “Algunas observaciones sobre el contorno de la definición lexicográfica", en M. Almeida / J. Dorta (eds.): Contribuciones al estudio de la lingüística hispánica. Homenaje al profesor Ramón Trujillo. Vol. II. Santa Cruz de Tenerife: Montesinos, 211-226.

Porto Dapena, José Álvaro (2000-2001): “Las letras como entradas del diccionario", Revista de Lexicografía 7, 125-154.

Porto Dapena, José Álvaro (2002a): Manual de técnica lexicográfica. Madrid: Arco/Libros.

Porto Dapena, José Álvaro (2002b): "La estructura actancial como criterio separador de acepciones en el artículo lexicográfico”, en José Ignacio Pérez Pascual / Mar Campos Souto (eds.): Cuestiones de lexicografía. Lugo: Tris Tram, 171-190.

Porto Dapena, José Álvaro (2003-2004): “La lematización de los pronombres en los diccionarios actuales", Revista de Lexicografía, 10, 139-182.

Porto Rey, Francisco (1900-1908): Diccionario gallego-castellano. Edición de María Xesús Bugarín López e Begoña González Rei. A Coruña: Real Academia Galega, 2000.

Pottier, Bernard (1962): Rec. de Gili Gaya (1947-1957), Bulletin Hispanique 64, 143-144.

Prat de la Riba, E. (1910): Memòria endreçada a la Diputació de Barcelona pel seu President. Barcelona.

Quilis, Antonio (1982): “Diccionarios de pronunciación”, LEA 4/2, 325-332.

Quinque linguarum (1526) = Quinque linguarum vtilissimus uocabulista Latine. Tusche. Galliche. Hyspane. \& Alemanice. Ualde necessarius per 
mundum versari cupientibus. Nouiter per Franciscum Garonus maxima diligentia in lucem elaboratus. Venecia: Franciscum Garonus, 1526.

Quinque linguarum (1534) = Qvinqve lingvarvn, Latinae, Theutonicae, Gallicae, Hispanicae, Italicae, dilucidissimus dictionarius. Amberes: Ioannes Steelsius, 1534.

RAE (1780) = Real Academia Española (1780): Diccionario de la lengua castellana compuesto por la Real Academia Española, reduicido á un tomo para su mas fácil uso. Madrid: Joaquín Ibarra.

RAE (1927) = Real Academia Española (1927): Diccionario manual e ilustrado de la lengua española. Madrid: Espasa-Calpe.

RAE (1933-1936): Real Academia Española (1933-1936): Diccionario histórico de la lengua española. Madrid: Imprenta de Librería y Casa Editorial Hernando, 1933 (vol. I, A), 1936 (vol. II, B-Cevilla).

RAE (1960-1996): Diccionario histórico de la lengua española. Madrid: Imp. Silverio Aguirre Torre.

RAE (2000) = Real Academia Española (2000): Ortografía española. Madrid: Espasa-Calpe.

RAE (2001) = Corpus Diacrónico del Español. Prontuario de marcación SGML. Madrid.

RAE (2005) = Real Academia Española (2005): Diccionario del estudiante. Madrid: Santillana.

RAE (2006) = Real Academia Española / Asociación de Academias de la Lengua Española (2006): Diccionario esencial de la lengua española. Madrid: Espasa-Calpe.

Rafel, Joaquim (1989): "Sobre la normalització dels diccionaris catalans: els elements intrínsecs i extrínsecs en les definicions lexicogràfiques”, en La corona d'Aragó i les llengües romàniques. Miscel•lània d'homenatge per a Germà Colon. Tübingen: Gunter Narr Verlag, 441-452.

Rafel, Joaquim (1996): "El diccionari de l'Institut i el Diccionari Fabra", en Estudis de Lingüística i Filologia oferts a Antoni M. Badia i Margarit. Vol. 3. Barcelona: Publicacions de l'Abadia de Montserrat i Departament de Filologia Catalana, 217-269.

Rafel, Joaquim (dir.) (1996-1998): Diccionari de freqüències. 3 vols + 2 CDROM. Barcelona: Institut d'Estudis Catalans.

Rafel, Joaquim (2006): "Els elements extrínsecs en les definicions lexicogràfiques: teoria i aplicació”, en Elisenda Bernal / Janet DeCesaris (ed.): Palabra por palabra. Estudios ofrecidos a Paz Battaner. Barcelona: Institut Universitari de Lingüística Aplicada, 201-217.

Rafel, Joaquim (2007): "Prescripción y descripción en la actividad académica: el Diccionari descriptiu de la llengua catalana”, en Mar Campos et 
al.: Reflexiones sobre el diccionario. Actas del I Congreso Internacional de Lexicografía Hispánica (A Coruña, septiembre de 2004). A Coruña: Universidade, 9-33.

Ramos, Vítor (1972): A edição portuguesa em França (1800-1850). Repertório geral dos títulos publicados e ensaio crítico. Paris: Fundação Calouste Gulbenkian.

Reguera y Pardiñas, E. (1840-1858): Traducción de algunas voces, frases y locuciones gallegas, especialmente de agricultura, al castellano (1840-1858). Ed. e estudo de J. L. Pensado. A Coruña: Real Academia Galega, 1995.

Rey, Alain (1976): “Le néologisme: un pseudoconcept?", Cahiers de Lexicologie 28, 3-17.

Rey-Debove, J. (1967): “La définition lexicographique: bases d'une typologie formelle", Travaux de Linguistique et de Littérature V, 1, 141-161.

Ribeiro, Diogo (1626): Vocabulario da lingoa canarina. Lisboa: Junta de Investigação do Ultramar, 1973. [Reprod. facsimilar do manuscrito, con nota introdutoria de Justino Mendes de Almeida].

Rico, Alberto / Joan Solà (1995): Gramatica i Lexicografia catalanes: sintesi històrica. València: Universitat.

Ríos Panisse, María do Carme (1977): Nomenclatura de la flora y fauna maritimas de Galicia. I. Invertebrados y peces. Santiago: Universidade. [Incluído en Santamarina (2003b)].

Ríos Panisse, María do Carme (1983): Nomenclatura de la flora y fauna maritimas de Galicia. II: Mamíferos, aves y algas. Santiago: Universidade. [Incluído en Santamarina (2003b)].

Rivas Quintas, Eligio (1978): Frampas. Contribución al vocabulario gallego. Salamanca: Ceme. [Incluído en (Santamarina 2003b)].

Rivas Quintas, Elixio (1988): Frampas II. Contribución al diccionario gallego. Lugo: Alvarellos. [Incluído en (Santamarina 2003b)].

Rivas Quintas, Elixio (1996): Millo e Hórreo, Legumia e Cesto. Santiago de Compostela: Laiovento.

Rivas Quintas, Elixio (1997a): O muíño. Ourense: Grafo Dos.

Rivas Quintas, Elixio (1997b): Ferramenta e labranza manual, Ourense: Grafo Dos.

Rivas Quintas, Elixio (1997c): O castiñeiro e as castañas. Ourense: Grafo Dos. Rivas Quintas, Elixio (1998a): O forno de pan. Ourense: Grafo Dos. Rivas Quintas, Elixio (1998b): O tear e o tecido. Ourense: Grafo Dos. Rivas Quintas, Elixio (2003): Frampas III. Contribución al diccionario gallego, en Santamarina (2003b).

Rodrigues, Francisco (1917): A formação intelectual do Jesuita. Porto: Liv. Magalhães \& Moniz. 
Rodrigues Tçuzu, João et al. (1603-1604): Vocabulario da lingoa de Iapam com a declaração em Portugues, feito por alguns padres e irmãos da Companhia de Iesu. Nagasaki: Tipografia do Colégio.

Rodríguez, Francisco Javier (1855): Diccionario gallego-castellano. Texto manuscrito. Real Academia Galega. [Incluído en Santamarina (2003b)].

Rodríguez, Francisco Javier (1863): Diccionario gallego-castellano. A Coruña. [Incluído en Santamarina (2003b)].

Rodríguez González, Ángel / José Armas Castro (1992): Minutario Notarial de Pontevedra (1433-1435). Santiago de Compostela: Consello da Cultura Galega.

Rodríguez González, Eladio (1958-1961): Diccionario enciclopédico gallegocastellano. 3 vols. Vigo: Galaxia. [Incluído en Santamarina (2003b)].

Rodríguez Río, Xusto A. (1998): "O tratamento dos préstamos na norma léxica do galego", Verba 25, 293-322.

Rodríguez Río, Xusto A. (2003): Metodoloxía do traballo terminolóxico puntual en lingua galega. Santiago: Consello da Cultura Galega.

Romero Lema, F. (2000): Vocabulario de Soneira. Ed. de X. M. Rei Lema. A Coruña: Real Academia Galega.

Rosal, Francisco del [1601]): Origen y etimología de todos los vocablos originales de la lengua castellana. Manuscrito 6929-T.127 da Biblioteca Nacional (Madrid).

Rosário, Joaquim do (1794): Compendio do Diccionario dos Casos de Consciencia de Pontas. 8 vols. Lisboa: Simão Thaddeo Ferreira.

Sá, Joaquim José da Costa e (1773-1774): Diccionario italiano e portuguez. 2 vols. Lisboa: Régia Oficina Tipográfica.

Sá, Joaquim José da Costa e (1794): Diccionario portuguez-francez-e-latino. 2 vols. Lisboa: Officina de Simão Thaddeo Ferreira.

Salas Quesada, Pilar (2003): "Los comienzos de la lexicografía bilingüe con el español y el portugués. El Dicionário Castelhano-Portuguéz de Raphael Bluteau", Res Diachronicae 2, 343-351.

Salvi, Giampaolo / Lorenzo Renzi (dirs.) (no prelo): Grammatica dell'italiano antico. Bologna: Il Mulino [Versión provisoria en <http://www.geocities.com/gpsalvi/konyv/>].

Santamarina, Antón (2003a): “O VOLG: criterios de elaboración”, en María Álvarez de la Granja / Ernesto González Seoane (eds.): A estandarización do léxico. Santiago de Compostela: Instituto da Lingua Galega / Consello da Cultura Galega, 53-92.

Santamarina, Antón (2003b): Diccionario de diccionarios. Versión 3. A Coruña: Fundación Pedro Barrié de la Maza. 
Santamarina, Antón (2003c): "Diccionario", en Gran Enciclopedia Galega 14. Lugo: El Progreso / Diario de Pontevedra, 26-35.

$S A O B=$ Ordbok över svenska språket utgiven av Svenska Akademien [= Svenska Akademiens ordbok]. Lund: Gleerupska univ.-bokh., 1898-2008 (A-T). 〈http://g3.spraakdata.gu.se/saob/>

Sarmento, Francisco de Jesus Maria (1785): Thesouro biblico ou diccionario historico, e etymologico dos nomes proprios. Lisboa: Off. de Simão Thaddeo Ferreira.

Sarmento, Pedro de Mariz de Sousa (1788): Elementos de construcção e diccionario francez e portuguez de todas as pessas de... navios... Lisboa: Of. Patr. de Francisco Luiz Ameno.

Sarmento, Pedro de Mariz de Sousa (1789): Preceitos de construcção de navios e da sua mastrição e nomenclatura portugueza dos termos technicos da mastrição e diccionario delles em francez e portuguez. Lisboa: Of. de António Rodrigues Galhardo.

Sarmiento, Martín (1970): Colección de voces y frases gallegas. Ed. y estudio de J. L. Pensado Tomé. Salamanca: Universidad.

Sarmiento, Martín (1973): Catálogo de voces y frases de la lengua gallega. Ed. y estudio de J. L. Pensado Tomé. Salamanca: Universidad.

Sarmiento, Martín (1975): Viaje a Galicia (1745). Ed. de J. L. Pensado Tomé. Salamanca: Universidad.

Sarmiento, Martín (1986): Catálogo de voces vulgares y en especial de voces gallegas de diferentes vegetables. Ed. y estudio de J. L. Pensado Tomé. Salamanca: Universidad.

Sarmiento, Martín (1999): Onomástico etimológico de la lengua gallega. Ed. y estudio de J. L. Pensado Tomé. A Coruña: Fundación Barrié.

Savourel, Y. (ed.) (2005): TMX 1.4b Specification. Localisation Industry Standards Association. [en liña] <http://www.lisa.org/standards/tmx/ specification.html> [Consulta: 7 novembro 2007]

Seco, Manuel (1979): "El contorno en la definición lexicográfica", en Homenaje a Samuel Gili Gaya (in memoriam). Barcelona: Vox, 183-191; reproducido en Manuel Seco (1987): Estudios de lexicografía española. Madrid: Paraninfo, 35-45.

Shaw, Jean Florence (1997): Contributions to a study of the printed dictionary in France before 1539. Toronto: Edicta.

Silva, Bartolomeu Alvares da (1764): Collecção da palavras familiares portuguezas, francezas, latinas e britanicas. Coimbra: Real Officina da Universidade.

Silva, Innocencio Francisco da (1858-1958): Diccionario bibliographico portuguez. Lisboa: Impr. Nacional. 
Silvestre, João Paulo Martins (2004): Rafael Bluteau e o Vocabulario Portuguez, e Latino: teoria metalexicográfica, fontes e recepção. Tese de doutoramento. Universidade de Aveiro.

Simões, A. M. / J. J. Almeida (2003): "NATools: A Statistical Word Aligner Workbench", Procesamiento del Lenguaje Natural 31, 217-224.

Skautrup, Peter (1944-1968): Det danske sprogs historie. 4 vols. Copenhague: Gyldendalske boghandel.

Sobreira = Sobreira, Juan: Papeletas de un diccionario gallego. Edición y estudio crítico de José Luis Pensado Tomé. Ourense: Instituto de Estudios Orensanos "Padre Feijoo", 1979. [Incluído, xunto con outros textos de Sobreira, en Santamarina (2003b)].

Sousa, João de (1789): Vestigios da lingua arabica em Portugal, ou lexicon etymologico das palavras, e nomes portuguezes, que tem origem arabica. Lisboa: Na Officina da Academia Real das Sciencias.

Sousa, João de / José de Santo António Moura (1830): Vestigios da Lingoa Arabica em Portugal, ou Lexicon etymologico das palavras, e nomes portuguezes, que tem origem arabica, composto por ordem da Academia Real das Sciencias de Lisboa por Fr. João de Sousa, [...], e augmentado e annotado por Fr. Joze de Santo Antonio Moura. Lisboa: Na Typographia da mesma Academia.

Sousa, Manuel de / Joaquim José da Costa e Sá (1784-1786): Nouveau dictionnaire François-Portugais. 2 vols. Lisboa: Simão Thadeo Ferreira.

Teixeira, António José (trad.) (1780): Noticia da mythologia. Lisboa: Typ. Rollandiana. [Reed. en 1803].

Teixeira, Vicente de Bastos (1779): Dictionnaire moderne françois expliqué en portugais. Tome premier ( $A-C)$. Lisboa: Imp. Louisiane.

Terreros y Pando, Esteban de (1786): Diccionario castellano con las voces de ciencias y artes y sus correspondientes en las tres lenguas Francesa, Latina é Italiana. Madrid: Viuda de Ibarra, Hijos y Compañía. [Edición facsimilar en Madrid: Arco/Libros, 1987].

Tiedemann, J. (2003): Recycling Translations - Extraction of Lexical Data from Parallel Corpora and their Application in Natural Language Processing. Upssala: Acta Universitatis Upsaliensis.

TILG = Santamarina, A. (dir.): Tesouro Informatizado da Lingua Galega . Santiago de Compostela: Instituto da Lingua Galega. <http://www. ti.usc.es/TILG>

TILIO = Opera del Vocabolario Italiano: Tesoro della Lingua Italiana delle Origini. Consiglio Nazionale delle Ricerche. 〈http://tlio.ovi.cnr.it/TLIO/>

TLF = Imbs, Paul et al. (dir.) (1971-1994): Trésor de la langue française. Dictionnaire de la langue du XIX et du XX siècle (1789-1960). 16 volumes. 
Paris: Centre National de la Recherche Scientifique. [Ed. en CD-ROM en Paris: CNRS, 2004]. 〈http://atilf.atilf.fr/tlf.htm>

TMILG = Varela Barreiro, Xavier (dir.) (2004- ): Tesouro Medieval Informatizado da Lingua Galega. Santiago de Compostela: Instituto da Lingua Galega. 〈http://ilg.usc.es./tmilg/>

Tommaseo, Niccolò / Bernardo Bellini (1865-1879): Dizionario della lingua italiana. 4 vols. Torino: UTET.

Transtagano, Antonio Vieira (1773): A Dictionary of the Portuguese and English Languages in two parts, Portuguese and English and English and Portuguese [...] By Anthony Vieyra Transtagano. Londres: J. Nourse; $1794^{2}$.

TUVI = Seminario de Lingüística Informática: Banco de Datos Terminolóxico da Universidade de Vigo. Vigo. Universidade. <http://sli.uvigo. es/ TUVI/>

Urrea, Miguel de (1582): M. Vitrvvio Pollion De Architectura, dividido en diez libros, traduzidos de latín en castellano por [...]. Alcalá de Henares: Juan Gracián. [Ed. facsimilar en Valencia, Albatros Ediciones, 1978].

Valladares Núñez, Marcial (1884): Diccionario gallego-castellano. Santiago de Compostela: Tipografía del Seminario Conciliar Central. [Incluído en Santamarina (2003b)].

Valladares Núñez, Marcial (1896): Nuevo suplemento al Diccionario gallegocastellano, publicado en 1884 por D. Marcial Valladares Núñez [1893-1896]. Edición e estudio de Mari Carme Garcia Ares. Santiago de Compostela: Real Academia Galega, 2000. [Incluído en Santamarina (2003b)].

Valverde y Gandía, Bartolomé (1760?): Tractado de Etymologías de voces castellanas en otras lenguas, castellana, hebrea, griega, árabe. Manuscrito LI.2 da Biblioteca del Monasterio de El Escorial..

Vandelli, Domingos (1788): Diccionario dos termos technicos de Historia Natural extrahidos das obras de Linnéo. Coimbra: Real Of. da Universidade.

Vázquez Bertomeu, Mercedes (2001): Notarios, notarías y documentos en Santiago y su tierra en el siglo XV. Sada: Ediciós do Castro.

Vázquez Saco, Francisco (1962): Refraneiro galego e outros materiais de tradición oral [= Cadernos de Fraseoloxía Galega 5]. Edición de Josefa Beloso Gómez, Patricia Buján Otero, Xesús Ferro Ruibal e $M^{a}$ Carmen Paz Roca.

Velez, António (1599): Index totius artis (Emmanuelis Aluari e Societate Iesu De institutione grammatica libri tres). Évora.

Verdelho, Telmo (1982): "Historiografia linguística e reforma do ensino. A propósito de três centenários: Manuel Álvares, Bento Pereira e Marquês de Pombal", en Brigantia 2,4, 347-356. 
Verdelho, Telmo (1995): As origens da gramaticografia e da lexicografia latino-portuguesas. Aveiro: INIC..

Verdelho, Telmo (1999-2000): “O Calepino em Portugal e a obra lexicográfica de Amaro Reboredo", en Revista Portuguesa de Filologia 23, 125-149.

Verdelho, Telmo (2002): "O dicionário de Morais Silva e o início da lexicografia moderna", in Brian Head et al. (eds.): História da língua e história da gramática. Actas do encontro. Braga: Universidade do Minho, Centro de Estudos Humanísticos, 473-490.

Verdelho, Telmo (2006): “A Amalthea (1673) de Tomás da Luz", Beihefte zu Lusorama 11, 93-118.

Verdelho, Telmo / João Paulo Silvestre (eds.) (2007): Dicionarística portuguesa: inventariação e estudo do patrimómio lexicográfico. Aveiro: Universidade.

Vieira, Domingos (1871-1874): Grande Diccionario Portuguez ou Thesouro da Lingua Portugueza. 5 vols. Porto: Cahrdron e Bartholomeu H. de Moraes.

Viterbo, Joaquim de Santa Rosa de (1798-1799): Elucidario das Palavras, Termos, e Frases, que em Portugal antigamente se usarão e que hoje regularmente se ignorão. 2 vols. Lisboa: Of. de Simão Thaddeo Ferreira. [Reedicións en 1865 e 1966].

Vocabolario della Crusca = Accademia della Crusca (1612):Vocabolario degli Accademici della Crusca. Venezia: Appresso Giovanni Alberti, 1612; Firenze: Tipografia Galileiana, 1863-1923 [5ª impresión, que inclúe ata a palabra ozono; a última edición completa é a cuarta, dos anos 1729-1738].

Vocabulario de seis linguaies (1541) = Vocabulario de seis linguaies, latín, francés, espagniol, italián, englese y alemana. Venecia: Marchio Sessa, 1541.

VOLG (1989) = Instituto da Lingua Galega / Real Academia Galega (1989): Vocabulario Ortográfico da Lingua Galega. Versión provisional. Santiago: ILG / RAG.

VOLG (2004) = Santamarina, Antón / Manuel González González (2004): Vocabulario Ortográfico da Lingua Galega. A Coruña: Real Academia Galega / Instituto da Lingua Galega. <http://www.realacademiagalega.org/volga>

VSI = Spiess, Federico / Rosanna Zeli / Franco Lurà (1952- ): Vocabolario dei dialetti della Svizzera italiana. Lugano: Fotocomposizione Taiana.

WAT = Schoonees, Pieter Cornelis et al. (1950-): Woordeboek van die Afrikaanse Taal. 12 vols (A-O). Pretoria: Staatsdrukker. 〈http://www.wat.co.za/〉

WbsdS = Staub, Friedrich / Ludwig Tobler / Albert Bachmann (1881- ): Schweizerisches Idiotikon. Wörterbuch der schweizerdeutschen Sprache. 
Gesammelt auf Veranstaltung der Antiquarischen Gesellschaft in Zürich unter Beihülfe aus allen Kreisen des Schweizervolkes. Frauenfeld: Huber.

Wierzbicka, Anna (1996): Semantics. Primes and Universals. Oxford: Oxford University Press.

Winchester, Simon (2003): The Meaning of Everything. The Story of the 'Oxford English Dictionary'. Oxford: Oxford University Press.

$W N T=$ Vries, Matthias de / Lammert A. Te Winkel et al. (1882-1998): Woordenboek der Nederlandsche Taal. 40 vols. 'S-Gravenhage, [etc.]: M. Nijhoff, [etc.]. [Ed. en CD-ROM en Rotterdam: AND Publishers, 2000. <http://www.wnt.inl.nl/>

Wolf, Elena (1971): Dicionário inverso da língua portuguesa. Moscova: Nanka.

Wooldridge, Terence Russon (1977): Les débuts de la lexicographie française. Toronto: University of Toronto Press.

Ximenez Arias, Diego (1566): Lexicon ecclesiaticum latinohispanicum, ex sacris Biblijs, Concilijs, Pontificum ac Theologorum Decretis. Salamanca.

Zabía Lasala, Ma Purificación (1999): Diccionario de Juan Alonso y de los Ruyzes de Fontecha. Madrid: Arco/Libros.

Zamora Mosquera, Federico (1972): Refráns e ditos populares galegos. Vigo: Galaxia. 


